\title{
PRODUCTION AND CHARACTERIZATION OF NANOCELLULAR POLYMERS BASED ON NANOSTRUCTURED PMMA BLENDS AND PMMA NANOCOMPOSITES
}

Presentada por Victoria Bernardo García para optar al grado de Doctora por la Universidad de Valladolid

Dirigida por:

Prof. Dr. Miguel Ángel Rodríguez Pérez 

A Miguel Ángel.

A mis padres y a Cris.

Y para Antonio, siempre. 

Desde el día que empecé a trabajar en la tesis he estado pensando sin parar en este instante: el día en que al fin sintiera que era el momento de dar las gracias. Y hoy, que me enfrento al papel en blanco por fin, siento de pronto mucho miedo. No por quedarme sin palabras. Tampoco por no saber qué escribir. Simplemente, es que tengo la sensación de que, diga lo que diga, nunca será suficiente, porque tengo tanto y tanto que agradecer que me parece que no hay forma de expresarlo. Pero lo voy a intentar.

Quiero dar las gracias para empezar a mi director de tesis, al profesor Miguel Ángel Rodríguez Pérez. Primero, por ser uno de los mejores profesores que he tenido nunca, por dar las clases con tanto entusiasmo que hiciste que me interesara de verdad y quisiera seguir aprendiendo de ti. Después, cuando ya entré en el laboratorio, por animarme y darme la oportunidad para hacer esta tesis. Sin ese apoyo jamás me hubiera lanzado a realizar este proyecto por el que hoy me siento tan feliz. Así que gracias. Y gracias por cada momento de la tesis, por enseñarme y aconsejarme, por dejarme equivocarme también y luego mostrarme el buen camino, por contagiarme tu entusiasmo y ser siempre, ante todo, el magnífico docente que eres. Si hoy soy un poco mejor investigadora que hace unos años es gracias a ti.

Hoy me tengo que acordar también del profesor José Antonio de Saja, que nos dejó hace ya un tiempo pero con quien tuve la suerte de convivir en mis primeros años en CellMat. Como su "nieta científica" tengo que agradecerle que creara nuestro grupo y nuestra forma de trabajar.

Ahora tengo que agradecerle todo a la segunda mitad de esta tesis, la futura doctora Judith Martín de León. Sin su ayuda para realizar los experimentos, sin su capacidad para resolver problemas, sin sus consejos para pensar y seguir adelante, sin sus correcciones y críticas constructivas, en fin, sin ella, esta tesis no sería ni la mitad de lo que es. Así que solo puedo decir: gracias. Gracias por ser la mejor compañera de tesis que nadie pueda desear. Pero por encima de todo, gracias por ser mi mejor amiga. Gracias por quererme como soy, por ser siempre mi apoyo, por decirme a la cara lo que nadie más se atreve. Te quiero muchísimo y este camino no hubiera sido tan maravilloso si no hubieras estado a mi lado a cada paso.

Me gustaría agradecer al Dr. Norman Fleck de la Universidad de Cambridge por acogerme en su laboratorio durante el verano de 2017 y por la ayuda prestada para la realización e interpretación de los ensayos mecánicos de esta tesis. Gracias también a los compañeros de allí por hacerme la estancia tan agradable. A Joe, a Philipp, a Graham en el laboratorio, por supuesto a mi amigo Adam, y a todos los demás, muchas gracias. Y finalmente, gracias al prácticamente doctor Frederik Van Loock por ayudarme tanto con todo durante el tiempo que estuve allí y ser mi guía y mi amigo en Cambridge. También por las fructíferas discusiones sobre espumas y por todo el trabajo en común.

Me toca ahora agradecer al Dr. Javier Pinto, de quien heredé la mitad de los temas de esta tesis y quien me ha ayudado mucho a interpretar los resultados. También te quiero dar las gracias por enseñarme a pensar de otra manera y también ayudarme a mejorar mis artículos. Finalmente, gracias a ti y a las personas del IIT por las imágenes de TEM y las otras colaboraciones que hemos podido compartir. 
Quiero agradecer al Dr. Alberto López, que fue uno de mis primeros tutores cuando llegué a CellMat. Mil gracias por ser siempre tan natural y cercano, por hacerme sentir a gusto desde el primer momento y por enseñarme tanto. Siguiendo con los doctores, me gustaría agradecer a la Dra. Leandra Salmazo, ya que cuando hemos trabajo juntas siempre ha sido de gran ayuda. Y finalmente, gracias a la Dra. Suset Barroso, aunque aún no hayamos trabajado juntas, por ser parte de nuestro grupo y ayudarme también cuando lo he necesitado.

Entre las personas que me han ayudado con los experimentos de esta tesis tengo que destacar a los técnicos de nuestro laboratorio. A Puri Niño, siempre dispuesta a echar una mano. A Javi, no solo por su ayuda, también por las risas que hemos compartido estos años. A Pablo, por las preciosas fotos de SEM y ser un encanto. A Patri, por llenar nuestro cuarto de cosas de Disney y ser tan buena.

A la Dra. Blanca Calvo. Blanca, me has enseñado muchísimo estos años, pero todavía me gusta escucharte enseñar cuando vienen los alumnos de visita. Gracias por compartir todo lo que sabes, por tu cariño y tu ayuda. A Emy Andrés. Gracias porque sin ti no hubiera hecho ni un papel bien, por tu paciencia infinita con mis errores y tu gran ayuda. Y gracias también por tu cariño, por escucharme y enseñarme de la vida. Por hacerme sentir en casa estando en el trabajo.

A Laura Izaguirre. Gracias por estar siempre disponible, por dejar lo que estuvieras haciendo para ayudarme. También por tu cariño y compresión, por saber escuchar y saber qué decir. Gracias de verdad, eres una persona maravillosa y a tu lado siempre me he sentido a gusto y querida.

A la Dra. Cristina Saiz. Cris, gracias por darme siempre un buen consejo cuando me he atascado. Como científica eres increíble, gracias por tu ayuda y tus enseñanzas. Pero sobre todo, gracias por ser como eres, por luchar por lo que quieres y nunca rendirte. Gracias por dejarme acercarme a ti, por regalarme tu amistad y por tantos buenos ratos de sobremesa.

A la Dra. Ester Laguna. Qué te voy a decir a estas alturas. Entré de tu mano en el grupo y gracias a ti he ido avanzando y progresando. Me enseñaste lo primero que aprendí sobre investigación y aún hoy me sigues enseñando. Gracias por ser mi amiga, por ser tan dulce y hacer que el trabajo contigo sea menos trabajo.

A Mikel. Mi primer verano de verdad en CellMat lo pasé contigo en la extrusora y eso une más que nada. Gracias por tantos buenos ratos, por ayudarme siempre y por ser tan genial como profesional y como amigo. A Dani. Gracias también por tu ayuda y por todo lo que hemos trabajado y trabajaremos juntos. Pero gracias especialmente por ser así de bueno, porque tu simpatía calma los días más agobiantes. A los dos, y a Patri y a Judith: gracias por crear un pequeño hogar en nuestro cuarto.

Al resto de mis compañeros de CellMat, que no son pocos. Gracias a los futuros doctores Mercedes Santiago y Eduardo López, con quien he compartido esta aventura de la tesis desde el principio, por ser estupendos científicos y mejores personas. Al ya Dr. Saúl Pérez, que me ayudó como compañero de cuarto en mis primeros días oficiales en CellMat. A Josías, que me ha ayudado un montón en mil cosas. A Santi, por nuestro trabajo juntos en la campaña y su ayuda con todo. A Alberto, por estar también siempre dispuesto a ayudarme. A Paula, no solo por el trabajo compartido, sino por recomendarme tan buenos libros. Y por supuesto a Bea, tan divertida y buena, por su amistad y por traer tanta alegría y entusiasmo al grupo. 
Me gustaría dedicar una última línea en general a todo CellMat, incluyendo a los que han pasado por el grupo estos años. Hemos creado una gran familia y para mí es un placer ir al laboratorio y compartir tiempo con vosotros. Gracias por las cenas de grupo, los cumpleaños, por la cercanía y la familiaridad que hemos creado. Porque con buen rollo se trabaja mejor.

Ahora me toca la otra parte de mi vida, porque sí, hay vida más allá de la tesis. Empiezo agradeciendo a mis amigos, y primero, a mis compañeros de clase, los frikifísicos. Son ellos los causantes de que me gustara más la carrera de lo que yo pensaba. Gracias por la motivación, siempre. Gracias a mis amigos de Palencia también. A todo mi grupo, por los viajes, las fiestas, las risas y las confidencias. A Leo y a Cris Masa, por escucharme tanto y apoyarme. Y por supuesto a Dafne, a Marcos, a Edu, a Cris García: cada uno a vuestra manera me habéis ayudado a seguir adelante. Os quiero chicos.

Por último, gracias a mi familia. A la más lejana, y a la más cercana. A mis primas y a mi tía Marisa, por el apoyo y el amor. A mi tío Félix, a quien echamos de menos. A mi abuela, por su cariño incondicional. A mi hermana. Cris, tú me has enseñado que es verdad que un hermano es un amigo que te da la naturaleza. Gracias por ser mi hermana y mi amiga, por estar siempre de mi lado. Te quiero y te admiro más de lo que te digo. Estar contigo es estar en familia y eso lo es todo.

A mis padres. Sin vosotros yo no sería la persona que soy hoy. Gracias por hacerme fuerte, por darme seguridad en mí misma, por demostrarme cada día vuestro amor. Por apoyarme en el camino, pero enseñarme a ver las piedras. Por levantarme para sortearlas. Por sujetarme si me caigo. Porque pase lo que pase, sois vosotros. Sin vosotros, ni esta tesis, ni nada, tendría sentido.

A Antonio. El amor es algo complicado de describir en unas líneas. Pero para mí el amor eres tú. Es mirarte y pensar que quiero estar a tu lado cada día. Gracias por tu apoyo constante estos once años, gracias por hacerme tan inmensamente feliz. Me falla la voz, o las teclas, para agradecerte tanto y tanto, tanto cariño, tanto apoyo, tantísimo amor. Por estar a mi lado en cada batalla, por compartir cada ilusión. Solo puedo soñar que esto dure para siempre. Te quiero.

No sé si habré conseguido transmitir mínimamente lo que siento en estas líneas. Pero por si no queda claro, GRACIAS. Porque este trabajo está formado por muchas pequeñas cosas que sin vosotros no hubieran sido posibles. GRACIAS :-; 



\section{FINANCIACIÓN}

Se agradece al Ministerio de Educación, Cultura y Deporte por el apoyo económico aportado para la realización de esta tesis doctoral a través de un contrato de Formación del Personal Universitario (FPU14/02050). Además quiero agradecer la financiación recibida por el grupo CellMat, proveniente de los siguientes proyectos de investigación:

- DESARROLLO Y FABRICACION EN CONTINUO DE AISLANTES TERMICOS AVANZADOS BASADOS EN POLIMEROS NANOCELULARES (MAT2015-69234-R). Financiado por MINECO, FEDER, UE, Programa Estatal de I+D+i Orientada a los Retos de la Sociedad.

- SENSORES BASAdOS EN POLÍMEROS NANOCELULARES PARA EL ANÁLISIS DE POLIFENOLES DE INTERÉS EN ALIMENTACIÓN (VA011U16). Financiado por la Junta de Castilla y León

- NUEVAS ESTRATEGÍAS PARA EL DISEÑO DE SENSORES Y BIOSENSORES PARA LA DETECCIÓN DE POLIFENOLES Y AZÚCARES BASADOS EN POLÍMEROS TUBULARES (VA275P18). Financiado por la Junta de Castilla y León

- desarRollo de plasticos SUb-MiCROCELULARES Y NANOCELULARES: FABriCACION, ESTRUCTURA, PROPIEDADES Y POTENCIALES APLICACIONES (MAT2012-34901). Financiado por Proyecto Plan Nacionales de Materiales.

- DESARROLlo de UNA NUEVA GENERACIÓN DE AISLANTES TÉRMICOS AVANZADOS BASADOS EN LA OBTENCIÓN DE ESTRUCTURAS POROSAS NANOCELULARES (VA035U13). Financiado por la Junta de Castilla y León.

\section{FUNDING}

Financial support from the FPU contract (FPU14/02050) from the Spanish Ministry of Education is gratefully acknowledged. In addition, financial assistance by CellMat group provided by the following research projects is also acknowledged:

- DESARROLLO Y FABRICACION EN CONTINUO DE AISLANTES TERMICOS AVANZADOS BASADOS EN POLIMEROS NANOCELULARES (MAT2015-69234-R). Funded by MINECO, FEDER, UE, Programa Estatal de I+D+i Orientada a los Retos de la Sociedad.

- SENSORES basAdos EN POLímEROS NANOCELULARES PARA EL ANÁLISIS DE POLIFENOLES DE INTERÉS EN ALIMENTACIÓN (VA011U16). Funded by Junta de Castilla y León

- NUEVAS ESTRATEgÍAs PARA El DISEÑo de SENSORES Y BIOSENSORES PARA LA DETECCIÓN DE POLIFENOLES Y AZÚCARES BASADOS EN POLÍMEROS TUBULARES (VA275P18). Funded by Junta de Castilla y León

- DESARROLLO DE PLASTICOS SUB-MICROCELULARES Y NANOCELULARES: FABRICACION, ESTRUCTURA, PROPIEDADES Y POTENCIALES APLICACIONES (MAT2012-34901). Funded by Proyecto Plan Nacionales de Materiales.

- DESARROLLO DE UNA NUEVA GENERACIÓN DE AISLANTES TÉRMICOS AVANZADOS BASADOS EN LA OBTENCIÓN DE ESTRUCTURAS POROSAS NANOCELULARES (VA035U13). Funded by Junta de Castilla y León. 



$$
-1
$$





\section{Contents}

\begin{tabular}{|c|c|}
\hline I. & 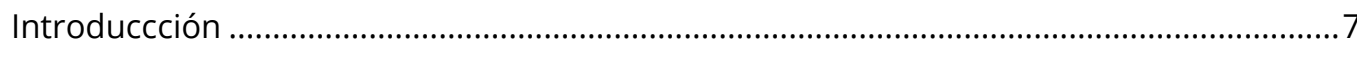 \\
\hline II. & Marco de la tesis \\
\hline III. & 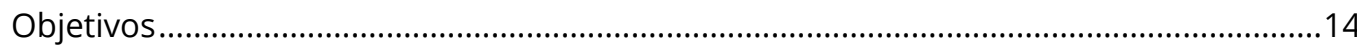 \\
\hline IV. & Estructura de la tesis ......................................... \\
\hline V. & Publicaciones, conferencias y cursos.................. \\
\hline VI. & 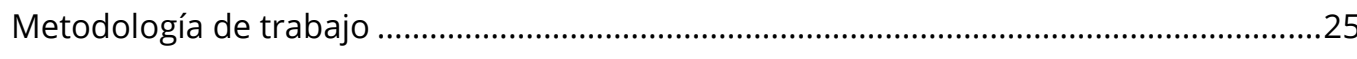 \\
\hline VII. & Principales resultados y conclusiones \\
\hline VIII. & Referencias. \\
\hline
\end{tabular}

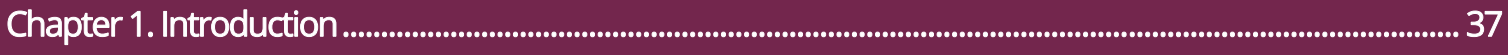

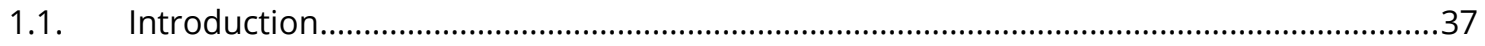

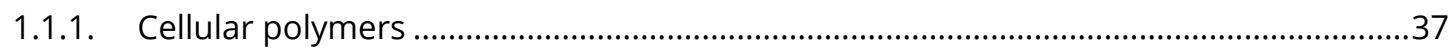

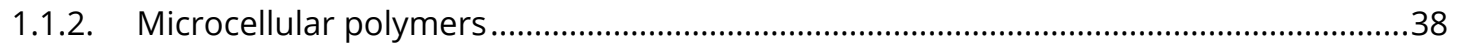

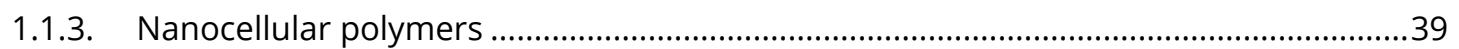

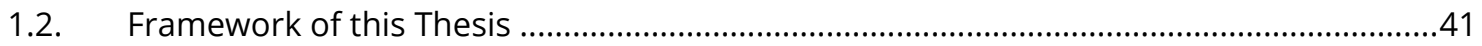

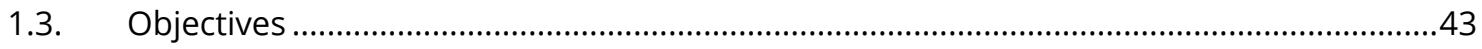

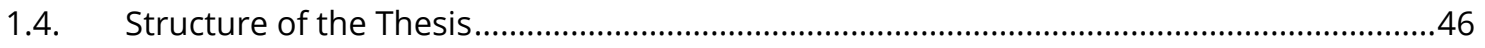

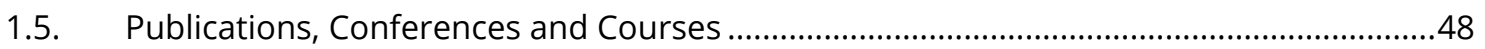

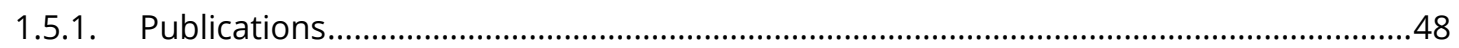

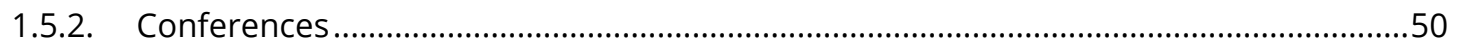

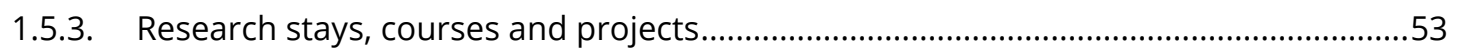

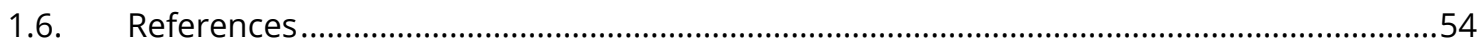

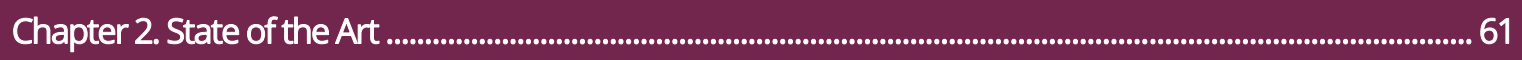

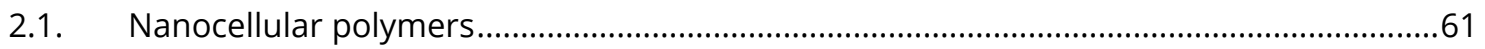

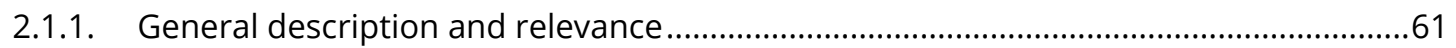

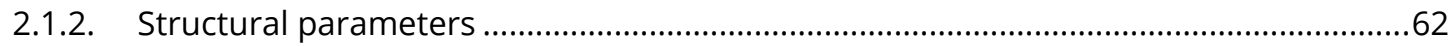

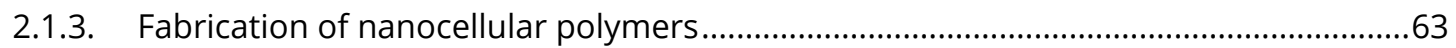

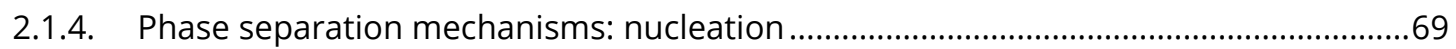




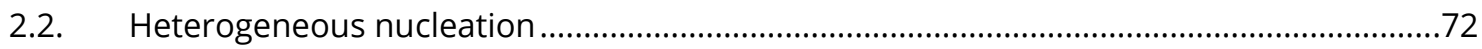

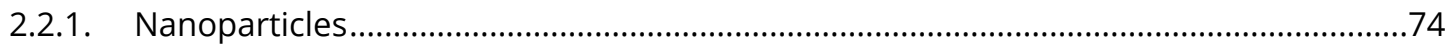

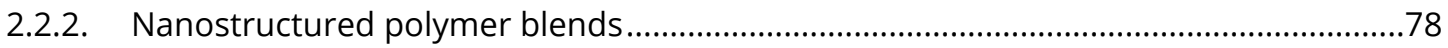

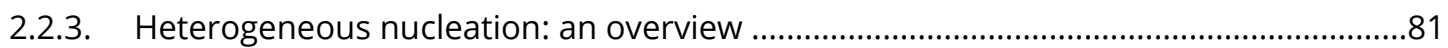

2.3. Limits and challenges in the production of nanocellular polymers.................................83

2.3.1. Heterogeneous nucleation versus homogeneous nucleation ......................................83

2.3.2. Production conditions to obtain nanocellular polymers.................................................84

2.3.3. Current challenges and limiting mechanisms ...........................................................90

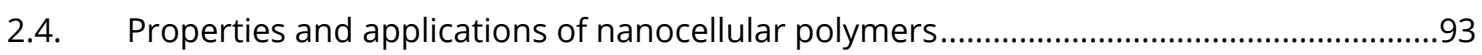

2.4.1. Thermal conductivity: Knudsen effect .......................................................................93

2.4.2. Mechanical properties: confinement effect of the solid polymer................................97

2.4.3. Other properties and potential applications: transparency and surface area .............98

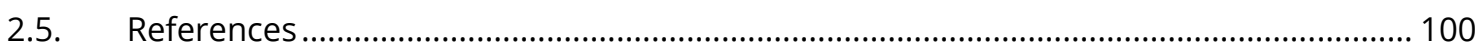

Chapter 3. Materials and Methods ........................................................................................................................... 111

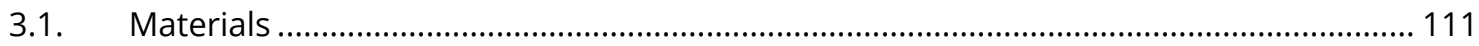

3.1.1. Poly(methyl methacrylate) (PMMA) ..................................................................... 111

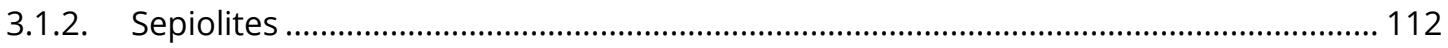

3.1.3. Tri-block copolymers (MAM) ............................................................................... 113

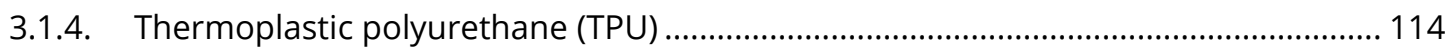

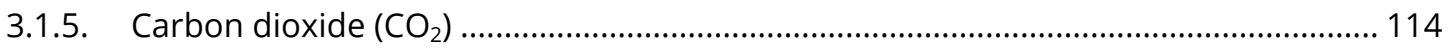

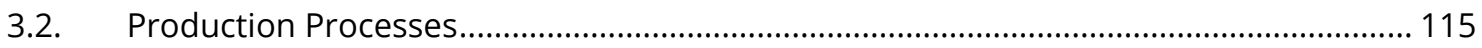

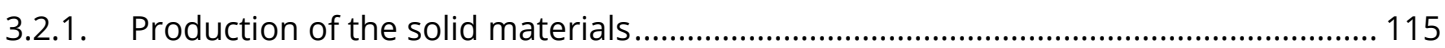

3.2.2. Production of the cellular materials .................................................................... 117

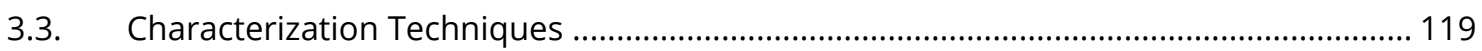

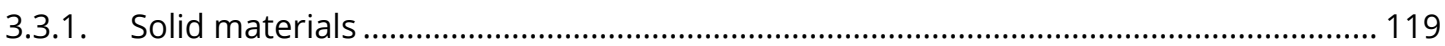

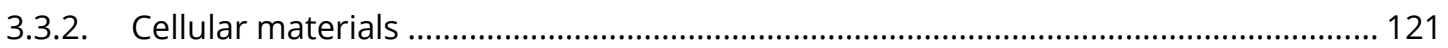

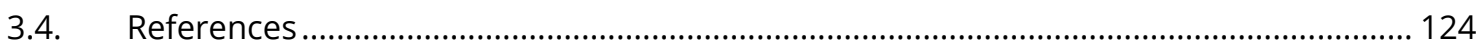

Chapter 4. Fabrication of Nanocellular Polymers based on PMMA filled with Sepiolite Nanoparticles...... 129

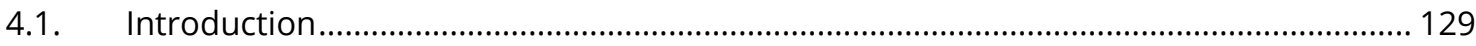

4.2. $\quad P M M A$-sepiolite nanocomposites as new promising materials for the production of

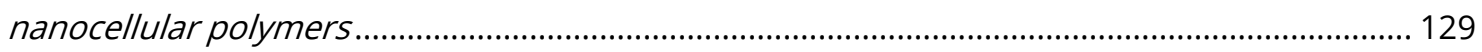

4.3. Anisotropy in nanocellular polymers promoted by the addition of needle-like sepiolites..157 
5.1. Introduction.

5.2. Understanding the role of MAM molecular weight on the production of PMMAMMAM nanocellular polymers.

5.3. Low-density PMMA/MAM nanocellular polymers using low MAM contents: production and characterization 207

5.4. Nanocellular polymers based on PMMAVTPU blends by gas dissolution foaming...... 235

Chapter 6. Other Fabrication Strategies Based on Heterogeneous Nucleation .

6.1. Introduction. 255

6.2. Highly anisotropic nanocellular polymers based on tri-phasic blends of PMMA with two nucleating agents.

6.3. Production of PMMA-based nanocellular polymers using low demanding saturation conditions.

Chapter 7. Properties of Nanocellular Polymers Produced by Heterogeneous Nucleation ...

7.1. Introduction.

7.2. Mechanical properties of PMMA-sepiolite nanocellular materials with a bimodal cellular structure.

7.3. Modeling the heat transfer by conduction of nanocellular polymers with bimodal cellular structures 309

Chapter 8. Conclusions and Future Work ........................................................................................................... 339

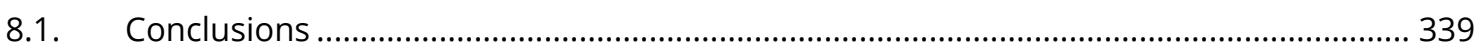

8.1.1. Fabrication of PMMA/Sepiolites nanocellular polymers ............................................... 339

8.1.2. Fabrication of PMMA/MAM nanocellular polymers..................................................... 341

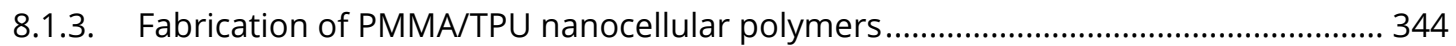

8.1.4. Fabrication of PMMA/MAM/Sepiolites nanocellular polymers ................................... 346

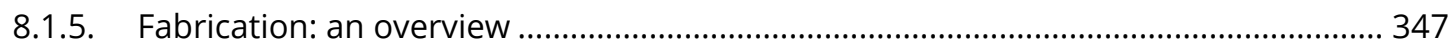

8.1.6. Properties of nanocellular polymers ........................................................................... 348

8.1.7. The last objective: understanding the heterogeneous nucleation mechanisms, advantages, and limitations ........................................................................................................ 349

8.2. Fabrication of nanocellular polymers: state of the art after this thesis ........................... 351

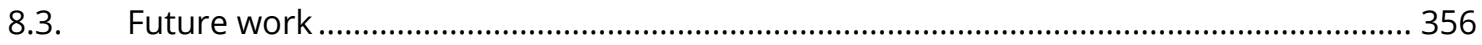



Resumen en Español 



\section{Resumen en Español}

\section{Introduccción}

\section{I.1. Polímeros celulares}

Los polímeros celulares son sistemas bifásicos formados por una fase gaseosa dispersada en una matriz polimérica sólida continua. El uso de los polímeros celulares (o espumas poliméricas) está extendido en prácticamente todos los sectores de la industria, tales como el sector deportivo, la automoción y la aeronáutica, el ocio y el embalaje [1]. La Figura R.1 muestra algunos ejemplos de materiales celulares basados en distintas matrices poliméricas utilizados en diferentes aplicaciones.
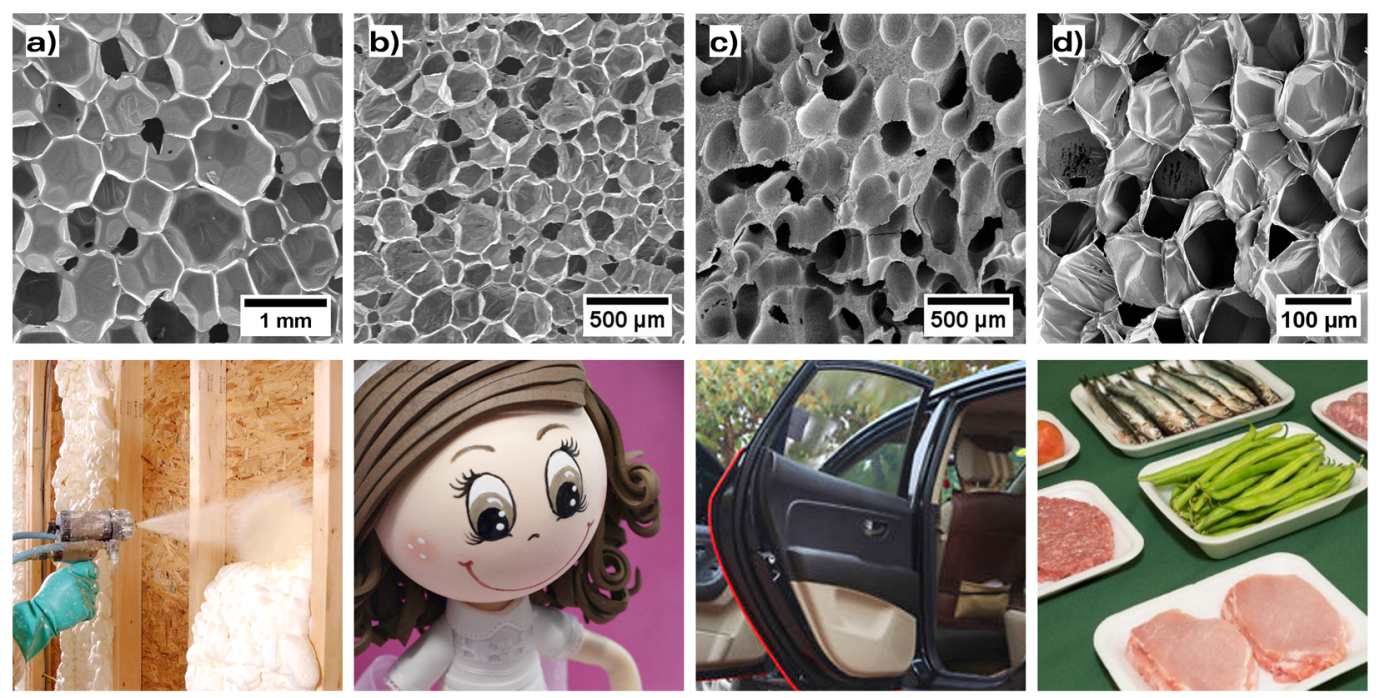

Figura R.1. Polímeros celulares basados en diferentes polímeros y algunas de sus aplicaciones: a) poliuretano (PU) para aislamiento térmico en edificios, b) etilvinilacetato (EVA) en juguetes, c) polipropileno (PP) en piezas de coches, y d) poliestireno (PS) en embalajes para alimentación.

Los materiales celulares naturales (como la madera de balsa o el corcho) se conocen desde hace cientos de años. Sin embargo, hasta la década de 1930 no se inició el desarrollo de polímeros celulares producidos por el hombre. Este inicio puede datarse con la primera patente publicada sobre poliestireno celular [2]. Desde entonces, el uso de estos materiales ha crecido rápidamente, y todavía continúa creciendo a un ritmo elevado. De hecho, el mercado de polímeros celulares era de casi 90 billones de dólares es 2016, y se estima que alcance los 126 billones de dólares en 2022, con un crecimiento anual del 5.86\% entre 2017 y 2022 [3].

Las razones que justifican el uso extendido de estos materiales se relacionan con las mejoras y nuevas propiedades que se pueden añadir a un polímero al introducirle una fase gaseosa en una estructura celular. Algunas de estas propiedades son la ligereza, el excelente balance entre resistencia y peso, las capacidades aislantes superiores y el buen comportamiento frente a absorción de impactos, entre otras [4]. Además, las propiedades de los polímeros celulares se 
pueden diseñar para dar respuesta a los requerimientos de una aplicación específica, modificando la matriz polimérica, la estructura celular o incluyendo aditivos.

El diseño de polímeros celulares con propiedades mejoradas es uno de los temas de mayor relevancia en el desarrollo de este campo. En particular, el descubrimiento de nuevas tecnologías de espumado suele fomentar la aparición de nuevas estructuras o propiedades que amplían el rango de aplicación de los polímeros celulares. Por ejemplo, la introducción de las tecnologías de extrusión (ya conocidas en el área del mezclado y la producción de piezas sólidas) para producir polímeros celulares en la década de los cuarenta permitió la producción en continuo de piezas espumadas [5,6]. Otro ejemplo de tecnología de espumado es el llamado proceso de bead foaming (primer uso aproximadamente en 1950), que permite obtener piezas con características similares a los materiales extruidos, pero con geometrías complejas gracias a la versatilidad de los beads o perlitas espumadas [7]. Más recientemente, en la década de 1980, apareció una nueva clase de materiales celulares con el desarrollo de los polímeros microcelulares (y más adelante los submicrocelulares y nanocelulares) por medio de la tecnología de espumado por disolución de gas [810].

\section{I.2. Polímeros microcelulares}

La idea de fabricar polímeros microcelulares (es decir, polímeros celulares con poros en el rango de las decenas de micras) surgió en el Instituto Tecnológico de Massachusetts (MIT) en la década de los ochenta, como respuesta a la necesidad de reducir la cantidad de material utilizada en la industria del envasado sin disminuir las propiedades mecánicas [1]. En aquel momento, algunas aplicaciones utilizaban láminas sólidas delgadas, por lo que disminuir la densidad mediante las tecnologías de espumado convencionales, que daban lugar a celdas de más de 100 micras, no era viable debido a la pérdida de propiedades. Entonces, se pensó en una solución: si el tamaño de celda se reducía lo suficiente, era posible obtener suficientes celdas a lo largo del espesor para conseguir un comportamiento mecánico razonable para estas aplicaciones. Este fue el nacimiento de los polímeros microcelulares, con las tesis de máster de Waldman [8] y Martini [10] y su patente común (junto con el Profesor Suh) sobre el proceso de producción de estos nuevos materiales [9].

Las tecnologías de espumado convencionales no permitían crear la gran densidad de celdas $\left(10^{9}\right.$ celdas $/ \mathrm{cm}^{3}$ ) necesarias para reducir el tamaño de celda por debajo de 100 micras. Además, el espumado en el estado fundido complicaba la estabilización de celdas muy pequeñas. El desarrollo de un nuevo sistema de espumado, el llamado espumado en estado sólido, consiguió superar estas dificultades. Las claves del éxito de este método para producir estructuras microcelulares estables radican en la disolución del agente espumante en estado sólido, induciendo luego una gran inestabilidad termodinámica [11]. Desde entonces, el método de espumado en estado sólido (o espumado por disolución de gas) se ha utilizado para producir polímeros microcelulares [12-18] que se utilizan hoy en día en múltiples aplicaciones debido a sus mejores propiedades mecánicas en comparación con polímeros celulares convencionales de la misma densidad [19-21]. La Figura R.2 muestra algunos ejemplos de polímeros microcelulares y sus aplicaciones. Otro aspecto interesante de los polímeros microcelulares es la posibilidad de producir piezas de bajo espesor 
sin reducir las propiedades mecánicas, lo que abre el campo de aplicaciones al sector de láminas delgadas y films.

La investigación y los avances en el área de los polímeros microcelulares permitieron la producción de materiales con tamaños de celda aún más bajos, alcanzando tamaños de una micra y menores. El progreso en la tecnología de espumado, junto con las interesantes propiedades de los polímeros microcelulares, desencadenó el salto hacia la nueva generación de materiales celulares a principios de los años 2000 [2]: el desarrollo de los polímeros nanocelulares.
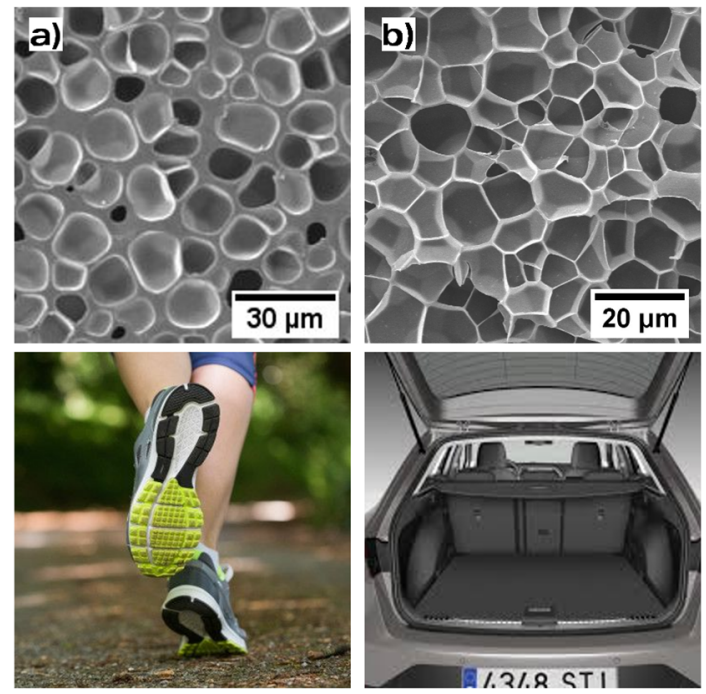

Figura R.2. Materiales microcelulares basados en diferentes polímeros y sus aplicaciones: a) poliuretano termoplástico (TPU) en el sector deportivo, y b) PP expandido en automoción.

\section{I.3. Polímeros nanocelulares}

Tras el desarrollo de los polímeros microcelulares, el siguiente paso natural era la reducción del tamaño de celda a la escala nanométrica. A la vista de las mejoras significativas alcanzadas en aquellos sistemas, era de esperar que una reducción del tamaño de celda aún mayor consiguiera alcanzar propiedades todavía mejores. La producción de polímeros nanocelulares implica un desafío mucho más complejo desde el punto de vista tecnológico: la densidad de celdas tiene que incrementarse desde $10^{9}$ celdas $/ \mathrm{cm}^{3}$ hasta $10^{13}$ celdas $/ \mathrm{cm}^{3}$ para alcanzar una estructura nanocellular. La Figura R.3 muestra dos ejemplos del cambio de escala entre estructuras micro y nanocelulares.

En una estructura nanocellular, las dos fases (gas y sólido) se encuentran confinadas: por un lado, el gas está confinado en las pequeñas celdas y, por otra parte, el polímero está restringido a ocupar el espacio en las estrechas paredes celulares. Como consecuencia de estos efectos, se esperan nuevas propiedades que no se observan en polímeros celulares convencionales o microcelulares [22]. Por ejemplo, se sabe que cuando un gas está confinado en un volumen de tamaño similar al recorrido libre medio de las moléculas del gas (aproximadamente $70 \mathrm{~nm}$ para el aire en condiciones normales), aparece el denominado efecto Knudsen $[23,24]$ y la conducción térmica a través de la fase gaseosa se reduce drásticamente. Esto se cumple en el caso de los polímeros nanocelulares, y por tanto, estos materiales tienen el potencial de ser súper-aislantes térmicos [25,26]. Al mismo 
tiempo, el polímero está estirado en las paredes celulares, que son de menor tamaño que la longitud típica de las macromoléculas del polímero (20-30 nm versus $100 \mathrm{~nm}$ ), lo cual causa, entre otros efectos, un incremento de la temperatura de transición vítrea del polímero [27] y una mejora en las propiedades mecánicas [28]. Además, la reducción del tamaño de celda a la escala nanométrica tiene otras consecuencias interesantes. Una de las propiedades más relevantes que ha sido probada recientemente es que los polímeros nanocelulares tienen el potencial de ser parcialmente transparentes debido al tamaño de celda [29,30]. Esta propiedad, combinada con la capacidad súper-aislante, convierte a los polímeros nanocelulares en excelentes candidatos para aplicaciones que requieran aislantes térmicos transparentes. Además, los polímeros nanocelulares tienen diferentes propiedades acústicas y eléctricas comparadas con los polímeros microcelulares [31,32]. Por otra parte, el tamaño de celda nanométrico y la gran área específica asociada a esta estructura abren la posibilidad de utilizar estos materiales en aplicaciones como la producción de membranas, filtros o catálisis [33-35].

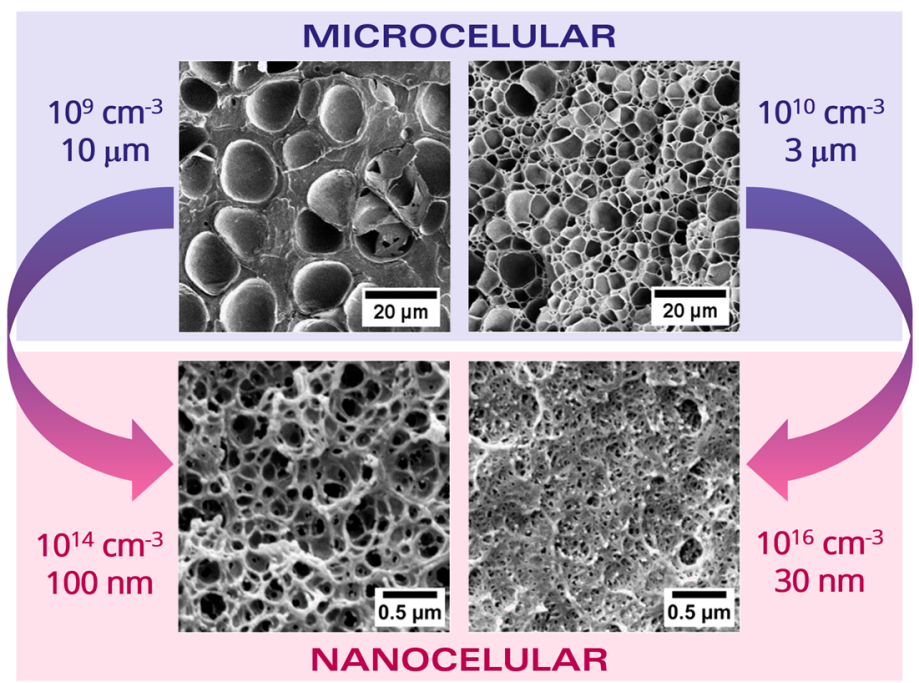

Figura R.3. Ejemplos de transición de una estructura microcelular a una nanocelular (reducción del tamaño de celda en un factor 100).

Los polímeros nanocelulares han suscitado gran atención en la comunidad científica debido a sus interesantes propiedades. Durante las últimas dos décadas, compañías internacionales importantes y laboratorios de investigación de primer nivel alrededor del mundo han iniciado líneas de investigación en esta área. Además, la Unión Europea (UE) también ha previsto el potencial de los polímeros nanocelulares, y los ha incluido como objetivos de investigación en el programa "Horizon 2020" (Horizon 2020, the EU Research and Innovation program for the period 2014-2020 [36,37]). Una de las prioridades de este programa era "La producción y control de materiales nanoporosos". La UE mencionaba que existe "un interés en constante crecimiento sobre los materiales porosos nanoestructurados, gracias a las múltiples aplicaciones que se pueden beneficiar de una porosidad controlada en la nanoescala".

La investigación sobre polímeros nanocelulares ha aumentado constantemente durante los últimos años [38-41], pero todavía es un área de estudio relativamente nueva, y quedan muchas cuestiones sin resolver, especialmente sobre el proceso de producción. La mayoría de los polímeros nanocelulares se producen utilizando el método de espumado por disolución de gas con 
$\mathrm{CO}_{2}$ como el agente espumante, pero esta tecnología y los materiales utilizados hasta la fecha no han permitido un control fino de las estructuras para obtener las propiedades deseadas [38]. Además, la producción de estos materiales a gran escala todavía no es una realidad. Como ya se ha mencionado, se requiere crear una densidad de celdas extremadamente elevada para obtener un polímero nanocelular, y la estructura nanocelular necesita estabilizarse manteniendo los poros en la nanoescala. Para conseguir la alta densidad de nucleación, se necesitan condiciones de procesado extremas durante el proceso de espumado por disolución de gas para promover la creación de suficientes núcleos [42,43]. La mayor parte de los polímeros nanocelulares desarrollados hasta la fecha se han producido utilizando condiciones de procesado exigentes, tales como altas presiones (30-33 MPa) [43,44] o muy bajas temperaturas (por debajo de $0^{\circ} \mathrm{C}$ ) $[42,45]$. Sin embargo, y a pesar de los buenos resultados conseguidos con este método desde un punto de vista académico, el uso de tales condiciones de producción complica la transferencia de esta tecnología a la industria.

Por otro lado, se puede favorecer la nucleación añadiendo un agente nucleante. Esta alternativa permite generar polímeros nanocelulares utilizando condiciones de procesado poco exigentes, ya que el agente nucleante controla el proceso de nucleación. Desde un punto de vista tecnológico, el uso de especies nucleantes parece ser la ruta apropiada para pasar a la producción en masa a escala industrial. Sin embargo, aún hay algunas limitaciones en el uso de esta estrategia. Las estructuras tipo plantilla o template como las mezclas de polímeros nanoestructuradas parecen limitar la expansión [38,44], mientras que el uso de nanopartículas no se ha explotado por completo aún.

Además, existe una limitación en la producción de materiales nanocelulares de muy baja densidad con el tamaño de celda deseado, y este tipo de estructura es necesaria para poder aprovechar al máximo las propiedades de estos materiales, como su baja conductividad térmica [2].

Podemos concluir que los polímeros nanocelulares son materiales prometedores para muchas aplicaciones, pero aún se requiere más investigación para seguir desarrollando este campo. En concreto, es imprescindible llegar a comprender profundamente los mecanismos físicos implicados en la formación de la estructura (nucleación y crecimiento) para poder controlar completamente la producción de estos materiales. Solamente a través de la investigación y el conocimiento se puede conseguir que estos materiales dejen los laboratorios para llegar a la industria en forma de materiales nuevos y avanzados. La Figura R.4 muestra un esquema de las aplicaciones de los polímeros nanocelulares y los desafíos a los que se van a enfrentar en los próximos años los científicos investigando en esta área. 


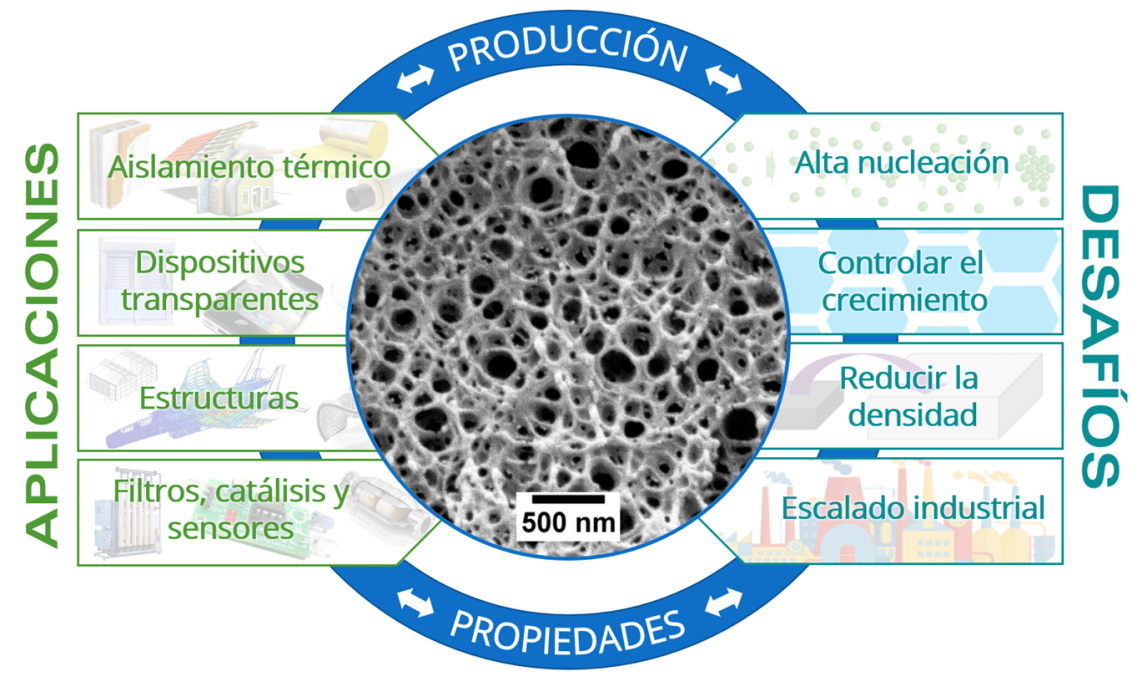

Figura R.4. Aplicaciones de los polímeros nanocelulares y desafíos en su producción.

\section{Marco de la tesis}

La presente tesis es parte de las actividades de investigación desarrolladas en el Laboratorio CellMat del Departamento de Física de la Materia Condensada de la Universidad de Valladolid [45], y ha sido supervisada por el Prof. Dr. Miguel Ángel Rodríguez-Pérez, director de este laboratorio.

El Laboratorio CellMat fue fundado en 1999 por el Prof. Dr. José Antonio de Saja y el Prof. Dr. Miguel Ángel Rodríguez-Pérez. Desde aquel momento, el laboratorio ha crecido tanto en personal y equipamiento como en variedad de las actividades de investigación y su impacto en la comunidad investigadora sobre polímeros celulares. A día de hoy, el Laboratorio CellMat es una referencia en el estudio y desarrollo de materiales celulares, con más de 190 publicaciones en JCR y 25 tesis doctorales defendidas.

Las investigaciones del Laboratorio CellMat se iniciaron con la caracterización de materiales celulares basados en poliolefinas [46-49]. En aquellos primeros años, se utilizaron técnicas tanto microscópicas como macroscópicas para caracterizar por completo espumas poliméricas comerciales. Con la experiencia adquirida, en 2005 CellMat dio un paso adelante en sus investigaciones, adquiriendo equipamiento para producir sus propios materiales celulares. A partir de entonces, CellMat comenzó a investigar las relaciones entre la composición química, el procesado, la estructura celular y las propiedades físicas [50-53], una investigación que continúa a día de hoy y que define la metodología del Laboratorio CellMat.

De hecho, la base de CellMat es el tetraedro de los materiales celulares (Figura R.5): establecer una relación entre la producción, la estructura y las propiedades de los materiales celulares, con el objetivo final de evaluar las posibles aplicaciones, ya que uno de los principios del Laboratorio CellMat es la transferencia de conocimiento y tecnología entre la Universidad y la industria, como un factor clave del desarrollo industrial. 

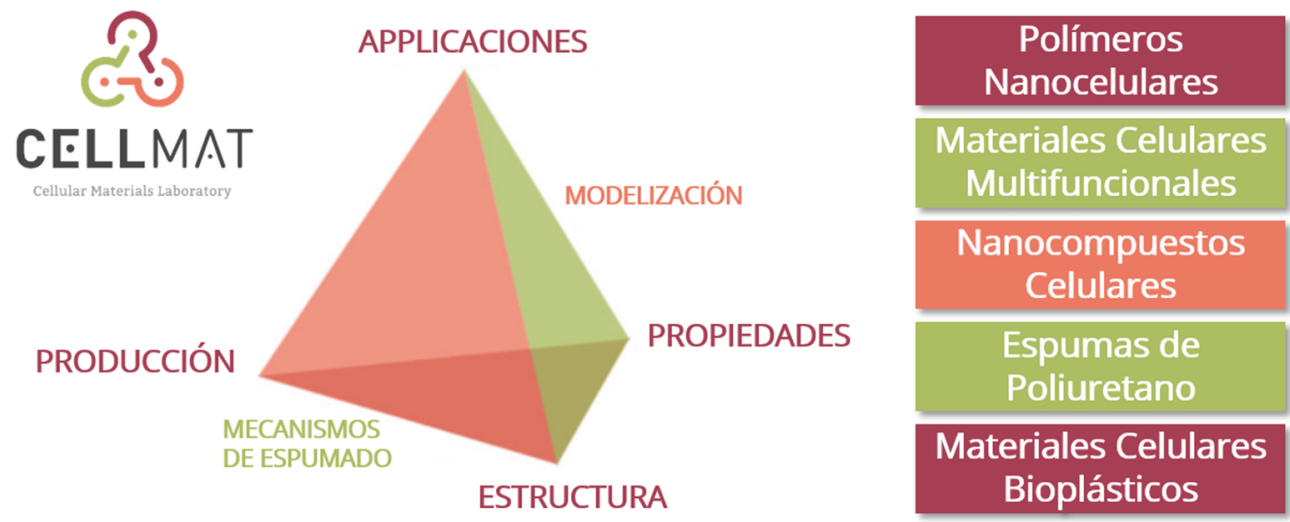

Figura R.5. Base de las investigaciones del Laboratorio CellMat (el tetraedro de los materiales celulares), y líneas de investigación en la actualidad.

Actualmente, CellMat mantiene cinco líneas de investigación principales (Figura R.5): polímeros nanocelulares [54,55], materiales celulares multifuncionales [29,56], nanocompuestos celulares $[52,57]$, espumas de poliuretano $[56,58]$ y materiales celulares bioplásticos [59,60]. La experiencia de CellMat en todos estos campos, y los esfuerzos continuos para generar nuevo conocimiento sobre diferentes temas (tales como los mecanismos y las tecnologías de espumado, la caracterización de la estructura celular, la relación estructura propiedades, etc.) han convertido al Laboratorio CellMat en un referente internacional en el área de los polímeros celulares.

La presente tesis pertenece al área de investigación de Polímeros Nanocelulares, la línea de investigación más reciente de CellMat [45]. Esta línea se empezó a desarrollar en CellMat con la tesis doctoral del Dr. Javier Pinto en 2014 [54], cotutelada por el Prof. Dr. Miguel Ángel RodríguezPérez y el Prof. Dr. Michel Dumon del Laboratoire de Chimie des Polymères Organiques (LCPO, University of Bordeaux 1, France). De esta tesis, CellMat adquirió conocimiento sobre la producción de materiales nanocelulares y mezclas de polímeros nanoestructuradas [34,61-63], y también sobre el gran interés de esta nueva clase de materiales. Por esta razón, se inició una nueva línea de investigación sobre polímeros nanocelulares, que fue continuada por la tesis doctoral de la Dr. Belén Notario [55], supervisada por el Dr. Javier Pinto y el Prof. Dr. Miguel Ángel Rodríguez-Pérez. En esta tesis, se evaluaron varias propiedades mecánicas sobre polímeros nanocelulares $[22,25,28,31,32]$. Con las investigaciones llevadas a cabo durante los últimos años, el Laboratorio CellMat se ha convertido en una referencia en el campo de los polímeros nanocelulares. En particular, CellMat tiene el crédito de haber probado por primera vez la presencia de efecto Knudsen en este tipo de materiales [25], de haber demostrado la posibilidad de producir espumas transparentes [30], y también de haber comprobado las propiedades mecánicas mejoradas de estos materiales [28].

Partiendo de estos precedentes, el siguiente paso en esta línea de investigación es continuar investigando sobre la producción, comprendiendo los mecanismos de espumado y siendo capaces de controlar la estructura celular. Para alcanzar estos objetivos, dos tesis doctorales comenzaron simultáneamente en CellMat en 2014. La primera de ellas, desarrollada en paralelo a esta tesis, estaba mayoritariamente centrada en analizar los efectos de los parámetros de proceso en la producción de polímeros nanocelulares utilizando sistemas homogéneos. De esta investigación ya 
se han obtenido algunos resultados prometedores [30,64]. La segunda tesis, esta, tenía como objetivo investigar los efectos de diferentes tipos de nucleantes (nanopartículas y mezclas de polímeros nanoestructuradas) en la producción de polímeros nanocelulares, con el objetivo final de encontrar nuevos sistemas y rutas de producción que permitan obtener estos materiales y que puedan ser fácilmente escalables a la industria.

\section{Objetivos}

Esta investigación tiene un objetivo fundamental y dos objetivos secundarios (Figura R.6). El objetivo principal es la producción y caracterización de polímeros nanocelulares aprovechando el mecanismo de nucleación heterogénea, utilizando tanto nanopartículas como polímeros nanoestructurados. Tras la producción, esta investigación aspira a comprender los mecanismos físicos implicados en la formación de estos materiales. Finalmente, esta tesis intenta encontrar soluciones que permitan reducir la densidad de los materiales tanto como sea posible, manteniendo al mismo tiempo parámetros de proceso poco exigentes que permitan la futura implementación de estas estrategias a escala industrial.

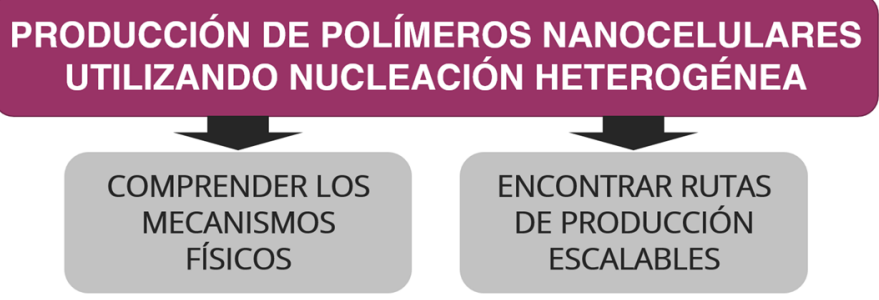

Figura S6. Objetivos generales de esta tesis.

Cuando se añade una segunda fase a una matriz polimérica, por ejemplo, un agente nucleante, durante el proceso de espumado aparecen varios efectos que deben tenerse en cuenta (Figura R.7). (Una explicación más detallada sobre la nucleación heterogénea y el proceso de espumado por disolución de gas puede encontrarse en el Capítulo 2). Para empezar, el agente nucleante puede modificar el proceso de nucleación en comparación con el polímero puro. En la mayoría de los casos, la adición de una segunda fase reduce la barrera energética para la formación de núcleos, promoviendo una mayor nucleación [65]. Simultáneamente, el agente nucleante modifica el comportamiento reológico del polímero. Esto puede tener varias consecuencias. Por un lado, la viscosidad del polímero se ve alterada, y esto puede modificar la tensión superficial y afectar a la nucleación. Además, la viscosidad extensional también se ve alterada, lo cual puede influenciar la capacidad de expandir de la mezcla. Todos estos efectos dependen fuertemente del tipo de agente nucleante, la concentración añadida, y el modo en el que el agente nucleante está distribuido en la matriz polimérica. Además, la morfología del agente nucleante (tamaño y geometría) puede ser un factor. Por otro lado, los parámetros de proceso también juegan un papel en la estructura celular resultante. Los parámetros de proceso en la etapa de saturación (es decir, mientras se absorbe el gas) pueden afectar a la eficiencia de la nucleación, es decir, para algunas condiciones, la nucleación en la segunda fase puede no ser favorable comparada con la nucleación homogénea. Además, las condiciones de saturación determinan la cantidad de gas absorbida en la muestra (aunque el 
agente nucleante también puede modificar este parámetro si su absorción es diferente a la de matriz). La cantidad de gas absorbida también altera la reología de la mezcla, y determina la plastificación de la matriz, y estos efectos combinados con las condiciones de espumado (tiempo y temperatura) afectan al crecimiento celular y a la expansión. En conclusión, durante el proceso de espumado por disolución de gas hay múltiples parámetros involucrados que varían simultáneamente, y comprender el efecto del agente nucleante en cada uno de ellos es fundamental para producir estructuras celulares controladas.

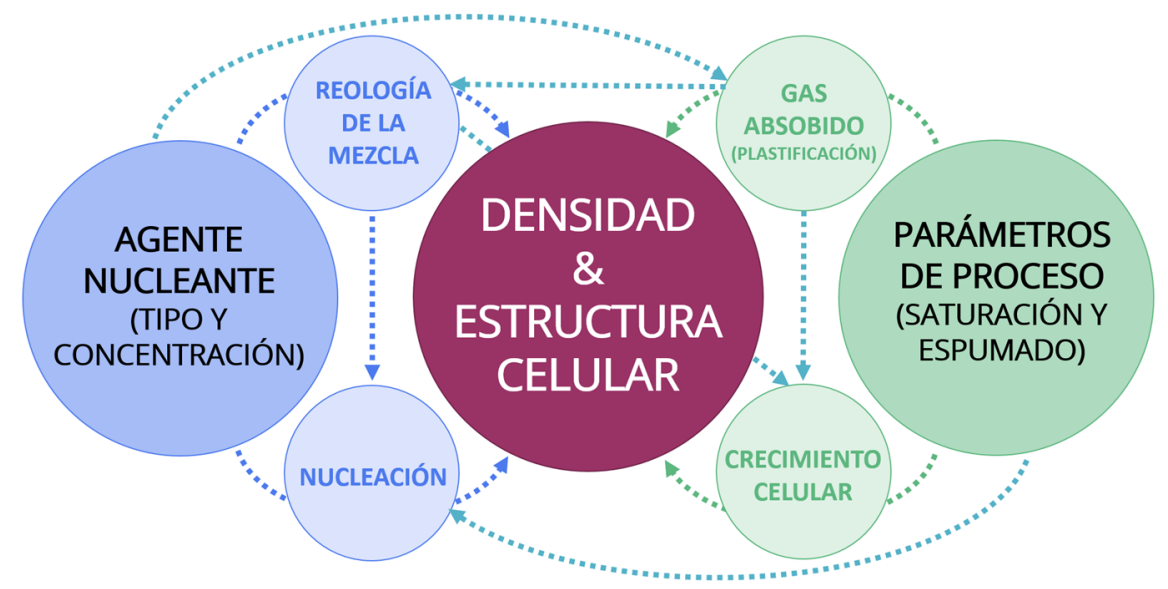

Figura R.7. Esquema de algunos de los efectos que se deben tener en cuenta en la producción de polímeros nanocelulares utilizando un agente nucleante y las interrelaciones entre ellos.

Como se ha mencionado anteriormente, uno de los mayores desafíos en la producción de polímeros nanocelulares es la compresión total de los mecanismos implicados durante su producción. Además, proporcionar estrategias que puedan ser fácilmente transferibles a la industria es también crucial para el futuro desarrollo y utilización de los polímeros nanocelulares. Por esta razón, en esta tesis se establecen los siguientes objetivos específicos:

- Evaluar el efecto nucleante de varios agentes nucleantes para producir polímeros nanocelulares.

- Investigar el efecto de las condiciones de proceso en aspectos tales como la eficiencia de la nucleación y el crecimiento celular.

- Optimizar la estructura celular de los sistemas producidos con diferentes agentes nucleantes, en términos de tamaño de celda y densidad.

- Encontrar la ventana de procesado para la producción de estos materiales, intentando utilizar condiciones de fabricación tan poco exigentes como sea posible, manteniendo al mismo tiempo baja densidad y tamaño de celda nanométrico.

- Correlacionar todos los parámetros previamente mencionados para cada sistema, con el objetivo de alcanzar una comprensión profunda de los mecanismos implicados en la formación de la estructura celular, y evaluar los materiales más prometedores para la posible producción futura a escala industrial.

Para alcanzar estos objetivos, los efectos de varios agente nucleantes en el espumado de una matriz polimérica serán investigados. La matriz polimérica elegida es polimetilmetacrilato (PMMA) debido a que en las dos tesis doctorales previamente desarrolladas en CellMat se demostró el buen 
comportamiento de este polímero para producir polímeros nanocelulares $[54,55]$. Con respecto a los agentes nucleantes, se han seleccionado tres tipos:

1) Sepiolitas: Estas nanopartículas inorgánicas con morfología en forma de aguja se utilizan en muchas aplicaciones [66], incluyendo la nucleación de polímeros celulares convencionales y microcelulares $[67,68]$. Sin embargo, no existen trabajos sobre el uso de estas nanopartículas en la producción de polímeros nanocelulares. En esta tesis, se ha investigado por primera vez el efecto nucleante de las sepiolitas en una matriz de PMMA para obtener celdas nanométricas. Varias sepiolitas con diferentes tratamientos superficiales se han utilizado para indagar sobre el efecto de la modificación superficial. También se estudiarán otros efectos, tales como la concentración de sepiolitas y la influencia de las condiciones de proceso. Además, como las sepiolitas presentan una estructura anisotrópica, se evaluará la posibilidad de producir polímeros nanocelulares con un elevado ratio de anisotropía. Finalmente, se medirán las propiedades mecánicas de estos materiales. Los objetivos específicos para los sistemas basados en PMMA/Sepiolitas se resumen en la Figura R.8, mientras que los resultados de esta investigación se encuentran en el Capítulo 4, el Capítulo 6 y el Capítulo 7.

2) MAM: MAM es un copolímero tribloque con una estructura tipo PMMA-PBA-PMMA (PBA: polibutilacrilato). Al mezclarse con PMMA, se puede auto-ensamblar formando micelas nanométricas. El Laboratorio CellMat fue pionero en el uso de MAM para producir polímeros nanocelulares durante la tesis del Dr. Pinto [54]. La presente tesis tiene como objetivo dar un paso más en el análisis de este material como un agente nucleante prometedor. En particular, en esta tesis se han utilizado tres grados de MAM con diferentes pesos moleculares. El mayor desafío con estos sistemas es superar la actual limitación asociada al uso de estas estructuras tipo plantilla (como la nanoestructuración de las micelas de MAM) para obtener polímeros nanocelulares de densidad reducida. Además, sería interesante producir estos materiales utilizando el menor contenido de MAM posible y también utilizando bajas presiones de saturación. Los objetivos específicos para los sistemas PMMA/MAM están enumerados en la Figura R.7, y los resultados están recogidos en el Capítulo 5 y el Capítulo 6.

3) TPU: El poliuretano termoplástico (TPU) es un elastómero lineal termoplástico. Recientemente, se ha demostrado que puede ser un candidato adecuado para nuclear PMMA, ya que la mezcla inmiscible PMMA/TPU resulta en dominios de TPU nanométricos que pueden favorecer la nucleación [69]. Sin embargo, solamente existe un trabajo en la literatura sobre la producción de polímeros nanocelulares utilizando TPU. Por esta razón, en esta tesis se pretende ampliar el conocimiento sobre este nuevo sistema, evaluando su efecto nucleante y la influencia de los parámetros de procesado (los objetivos están resumidos en la Figura R.8). Los resultados de esta investigación están en el Capítulo 5.

El efecto combinado de dos de estos agentes nucleantes también será evaluando mediante la producción de mezclas trifásicas PMMA/MAM/Sepiolitas. Hasta nuestro conocimiento, esta es la primera vez que se combinan las dos estrategias de nucleación (nanopartículas y polímeros nanoestructurados). Los objetivos específicos de esta investigación se encuentran en la Figura R.8, mientras que los resultados se incluyen en el Capítulo 6.

Finalmente, una de las propiedades más interesantes de los polímeros nanocelulares es la conductividad térmica reducida a lo largo de la fase gaseosa. Sin embargo, en ocasiones aparecen 
estructuras bimodales con poros nanométricos, y es necesario tener un modelo que prediga la conductividad térmica de una estructura bimodal. Por tanto, en esta tesis se pretende desarrollar un modelo para describir la conducción térmica de polímeros nanocelulares con una estructura bimodal y correlacionar el modelo con los resultados experimentales de materiales bimodales reales (Figura R.8). Los resultados de esta investigación se presentan en el Capítulo 7.

Capítulos 4,6,7

1) PMMA/sepiolitas

Investigar los efectos de:

- La modificación superficial

- La concentración de sepiolitas

- La presión de saturación en la eficiencia de la nucleación

- La temperatura de espumado

- Las sepiolitas en las propiedades mecánicas

Desafíos:

- Posibilidad de producir estructuras anisotrópicas
Capítulos 5,6

2) PMMAVMAM

Investigar los efectos de:

- El peso molecular del MAM

- La concentración de MAM

- La presión de saturación en la eficiencia de la nucleación

- La temperatura de espumado

Desafíos:

- Estructuras nanocelulares con bajos contenidos de MAM

- Reducir la densidad utilizando esta estrategia
Capítulo 5

\begin{tabular}{|l|}
\hline \multicolumn{1}{|c|}{ 3) PMMA/TPU } \\
\hline Investigar los efectos de: \\
- La adicción de TPU \\
- La presión de saturación en la \\
eficiencia de la nucleación \\
- La temperatura y el tiempo de \\
espumado \\
Desafíos: \\
- Aprender sobre esta nueva \\
aproximación \\
- Producir materiales \\
nanocelulares de baja densidad
\end{tabular}

\section{4) PMMA/MAM/sepiolitas}

Investigar los efectos de:

- La concentración de MAM

- La adicción de sepiolitas

- El proceso de nucleación en cada nucleante

Desafíos:

- Producir estructuras anisotrópicas

Capítulo 6

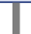

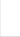

Figura R.8. Objetivos específicos de esta tesis para los diferentes sistemas que se han investigado, y capítulos donde se explican los resultados obtenidos.

\section{Estructura de la tesis}

Esta tesis se ha escrito como compendio de publicaciones. Se incluyen nueve publicaciones enviadas a revistas internacionales. De estos trabajos, seis de ellos ya han sido publicados, mientras que los otro tres están aún pendientes de aceptación. Las publicaciones se han incluido en los Capítulos 4, Capítulo 5, Capítulo 6 y Capítulo 7. Además, esta tesis reúne los requerimientos para ser acreditada con Mención Internacional. La estructura de la tesis con las correspondientes publicaciones científicas está esquemáticamente resumida en la Figura R.9.

La tesis se divide en ocho capítulos con la siguiente información:

El Capítulo 1 presenta el marco de la tesis, con una breve introducción al tema de investigación y su relevancia en el Laboratorio CellMat, los objetivos y un esquema de la estructura. Además, se enumeran los artículos científicos, conferencias y otros trabajos relevantes derivados de la tesis. 


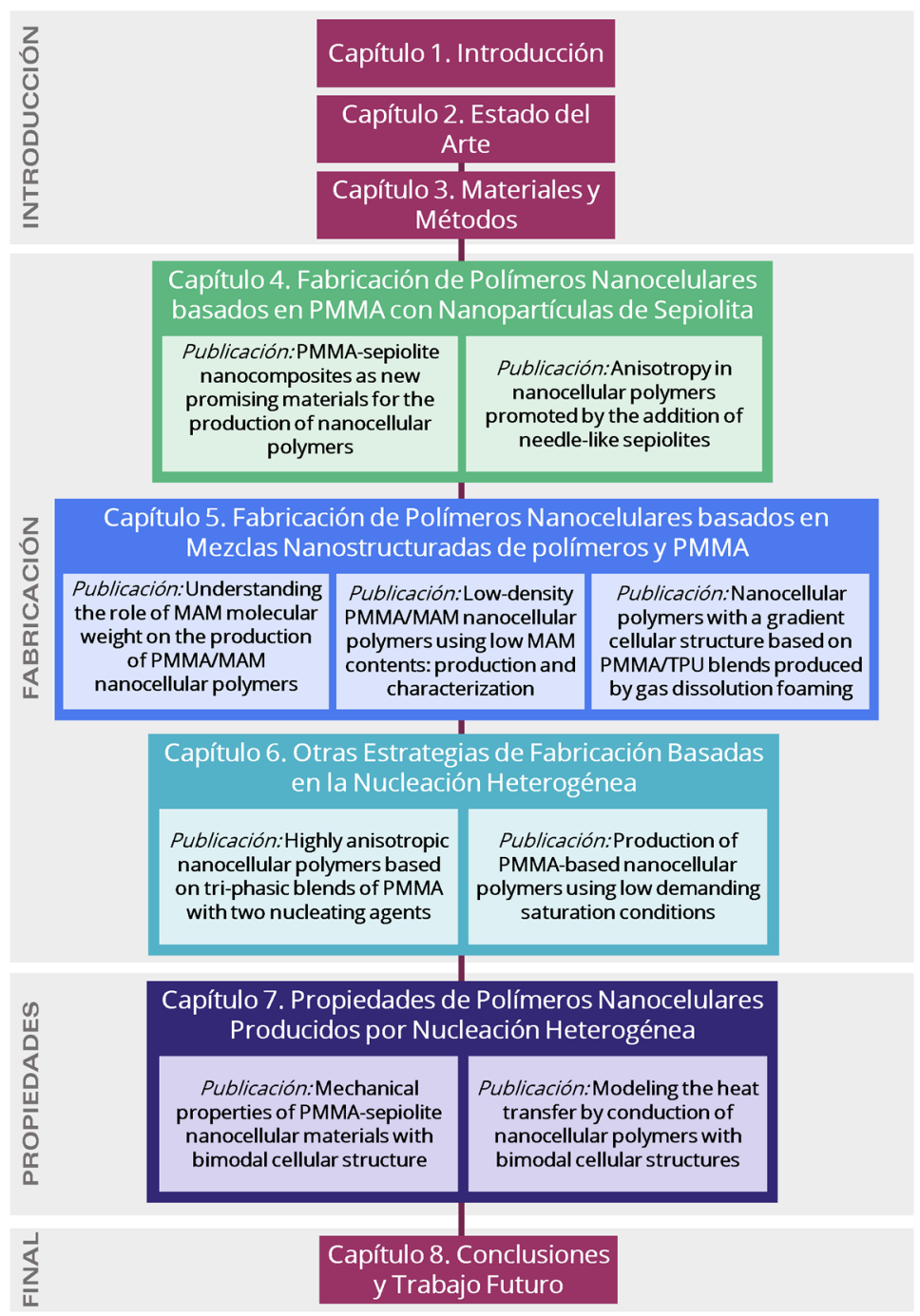

Figura R.9. Esquema de los capítulos y las publicaciones científicas.

El Capítulo 2 muestra un análisis detallado del estado del arte sobre la producción y propiedades de polímeros nanocelulares. Se presentan datos de los trabajos más relevantes de la literatura en varios mapas comparativos.

El Capítulo 3 describe los materiales de partida utilizados en esta investigación y las diversas técnicas utilizadas para producir y caracterizar los polímeros nanocelulares obtenidos.

El Capítulo 4 presenta los resultados obtenidos con las mezclas basadas en PMMA con sepiolitas nanométricas. Se incluyen dos publicaciones científicas. Se analizan varios efectos: la influencia de la modificación superficial de las partículas, su concentración en la mezcla y el efecto de los parámetros de proceso en la estructura. Además, se obtienen polímeros nanocelulares anisotrópicos. Se discuten los mecanismos de nucleación involucrados en la formación de estos polímeros nanocelulares basados en PMMA con sepiolitas.

El Capítulo 5 contiene los resultados relativos al uso de mezclas de polímeros nanoestructuradas. Este capítulo incluye tres publicaciones. Dos de ellas se relacionan con las mezclas PMMA/MAM. En estos trabajos, se investigan los efectos del peso molecular del MAM y su concentración. Se analizan en detalle los mecanismos físicos relacionados con la formación de estas estructuras. La tercera 
publicación trata sobre el uso de TPU como agente nucleante para la producción de polímeros nanocelulares.

El Capítulo 6 relaciona algunos de los resultados de los dos capítulos previos con otras rutas de fabricación. Este capítulo incluye dos comunicaciones cortas. La primera trata sobre mezclas trifásicas, combinando sepiolitas y MAM y analizando las estructuras obtenidas. La segunda comunicación está relacionada con la producción de polímeros nanocelulares utilizando bajas presiones y temperatura ambiente como condiciones de espumado, tanto para PMMA/Sepiolitas como para PMMA/MAM.

El Capítulo 7 incluye dos publicaciones más relacionadas con algunas propiedades de los materiales obtenidos en los capítulos previos. En la primera publicación, se investigan las propiedades mecánicas de polímeros nanocelulares basados en PMMA/Sepiolitas (este estudio se desarrolló en colaboración con la Universidad de Cambridge durante una estancia de investigación internacional). El segundo trabajo presenta un modelo para caracterizar la conductividad térmica por conducción de polímeros nanocelulares con estructura bimodal, y el modelo es validado utilizando sistemas bimodales reales basados tanto en mezclas PMMA/Sepiolitas como en sistemas PMMA/MAM.

El Capítulo 8 presenta las principales conclusiones de esta investigación. Además, los resultados de esta tesis se comparan con los de la literatura en varios mapas comparativos. Finalmente, se enumeran algunas guías para el trabajo futuro.

\section{Publicaciones, conferencias y cursos}

\section{V.1. Publicaciones}

Las publicaciones científicas en revistas internacionales generadas durante el desarrollo de esta tesis están recogidas en la Tabla S.1. Las publicaciones se han incluido en el capítulo correspondiente (Figura R.9).

Tabla S.1. Publicaciones en revistas internacionales incluidas en esta tesis.

V. Bernardo, J. Martin-de Leon, E. Laguna-Gutierrez, M. A. Rodriguez-Perez

PMMA-sepiolite nanocomposites as new promising materials for the production of nanocellular polymers

European Polymer Journal 2017, 96, 10-26

V. Bernardo, J. Martin-de León, M. A. Rodriguez-Perez

Anisotropy in nanocellular polymers promoted by the addition of needle-like sepiolites

Polymer International 2019, 68, 1204-1214

V. Bernardo, J. Martin-de Leon, E. Laguna-Gutierrez, T. Catelani, J. Pinto, A. Athanassiou,

M. A. Rodriguez-Perez

Understanding the role of MAM molecular weight on the production of PMMA/MAM 
V. Bernardo, J. Martin-de Leon, J. Pinto, T. Catelani, A. Athanassiou, M. A. Rodriguez-

Perez

Low-density PMMA/MAM nanocellular polymers using low MAM contents: production and characterization

Polymer 2019, 163, 115-124

V. Bernardo, J. Martin-de Leon, I. Sanchez-Calderon, E. Laguna-Gutierrez, M. A.

Rodriguez-Perez

Nanocellular polymers with a gradient cellular structure based on PMMATPU blends

by gas dissolution foaming

Submitted

V. Bernardo, J. Martin-de Leon, M. A. Rodriguez-Perez

Highly anisotropic nanocellular polymers based on tri-phasic blends of PMMA with two nucleating agents

Submitted

V. Bernardo, J. Martin-de Leon, M. A. Rodriguez-Perez

Production of PMMA-based nanocellular polymers using low demanding saturation

conditions

Submitted

V.Bernardo, F. Van Loock, J. Martin-de Leon, N. A. Fleck, M. A. Rodriguez-Perez.

Mechanical properties of PMMA-sepiolite nanocellular materials with a bimodal cellular structure.

Macromolecular Materials and Engineering 2019, 1900041, 1-12

V. Bernardo, J. Martin-de Leon, J. Pinto, R. Verdejo, M. A. Rodriguez-Perez.

Modeling the heat transfer by conduction of nanocellular polymers with bimodal

cellular structures

Polymer 2019, 160, 126-137

Además de las publicaciones previas, la Tabla S.2 presenta otros trabajos publicados durante la tesis doctoral que están relacionados con la producción de polímeros nanocelulares. Finalmente, la Tabla S.3 incluye otros trabajos no relacionados directamente con la fabricación de polímeros nanocelulares, pero que pertenecen al área de polímeros celulares.

Tabla S.2. Otras publicaciones relacionadas con la producción de polímeros nanocelulares.

Referencia de la publicación

J. Martin-de Leon, V. Bernardo, P. Cimavilla-Román, S. Pérez-Tamarit, M. A. Rodriguez-Perez

Overcoming the Challenge of Producing Large and Flat Nanocellular Polymers: A Study with PMMA

Advanced Engineering Materials 2019, 1900148, 1-8

J. Martin-de Leon, V. Bernardo, M. A. Rodriguez-Perez

Nanocellular polymers: the challenge of creating cells in the nanoscale

Materials 2019, 12, 797

J. Martin-de Leon, V. Bernardo, M. A. Rodriguez-Perez

Transparent Nanocellular PMMA: Characterization and Modeling of the Optical Properties

Polymer 2019, 170, 16-23

J. Martin-de Leon, V. Bernardo, M. A. Rodriguez-Perez

Key Production Parameters to Obtain Transparent Nanocellular PMMA

Macromolecular Materials and Engineering 2017, 1700343(1)-1700343(5)

J. Pinto, D. Morselli, V. Bernardo, B. Notario, D. Fragouli, M. A. Rodriguez-Perez, A. Athanassiou 
Nanoporous PMMA foams with templated pore size obtained by localized in situ synthesis of nanoparticles and $\mathrm{CO}_{2}$ foaming

Polymer 2017, 124, 176-185

J. Martin-de Leon, V. Bernardo, M. A. Rodriguez-Perez

Low Density Nanocellular Polymers Based on PMMA Produced by Gas Dissolution Foaming:

Fabrication and Cellular Structure Characterization

Polymers 2016, 8, 1-16

V. Bernardo, J. Martin-de Leon, M. A. Rodriguez-Perez

Production and characterization of nanocellular polyphenylsulfone foams

Materials Letters 2016, 178, 155-158

Tabla S.3. Otras publicaciones en el área de polímeros celulares.

\section{Referencia de la publicación}

V. Bernardo, E. Laguna-Gutierrez, A. Lopez-Gil, M. A. Rodriguez-Perez

Highly anisotropic crosslinked HDPE foams with a controlled anisotropy ratio: Production and characterization of the cellular structure and mechanical properties

Materials and Design 2016, 114, 83-91

\section{V.2. Conferencias}

Los resultados de esta tesis se han presentado en varias conferencias internaciones y nacionales (Tabla S.4). Además, algunos de estos trabajos fueron premiados durante la conferencia.

Tabla S.4. Contribuciones a conferencias nacionales e internacionales y premios recibidos.

\section{Contribución a conferencia}

V. Bernardo, J. Martín-de León, I. Sánchez-Calderón, E. Laguna-Gutiérrez, M. Á. Rodríguez-Pérez Fabrication of low-density nanocellular polymers using PMMATPU blends CelIMAT 2018, Bad Staffelstein, Alemania, Octubre 2018, Comunicación oral

V. Bernardo, J. Martín-de León, F. Van Loock, N. Fleck, P. Cimavilla-Roman, S. Perez-Tamarit, M. Á. Rodríguez-Pérez

Nanocellular polymers based on PMMA/sepiolite nanocomposites: characterization of the mechanical behaviour

CellMAT 2018, Bad Staffelstein, Alemania, Octubre 2018, Póster

M.A. Rodríguez Pérez, J. Pinto, V. Bernardo, J. Martin-de Leon

Nanocellular polymers. Novel approaches to produce these materials using gas dissolution foaming

CellMAT 2018, Bad Staffelstein, Alemania, Octubre 2018, Keynote lecture (Comunicación oral)

J. Martín-de León, V. Bernardo, J. L. Pura, M. Á. Rodríguez-Pérez

Nanocellular polymers based on PMMA: Recent approaches to produce these materials with improved cellular structures and properties

FOAMS2018, Montreal, Canadá, Septiembre 2018, Comunicación oral

V. Bernardo, J. Martín-De León, J. Pinto, T. Catelani, M. A. Rodríguez-Pérez

Effect of the Amount of Block-Copolymer on the Density and Cellular Structure of Nanocellular Polymers Based on PMMA/MAM Blends

FOAMS2017, Bayreuth, Alemania, Octubre 2017, Póster

Premio: Michael Reedy Student Scholarship 2017

J. Martín-De León, V. Bernardo, S. Perez-Tamarit, M. A. Rodríguez-Pérez 
Production and properties of low density nanocellular PMMA with controlled density and cellular structure

Poly-Foam 2017 Conference, Hilton Main, Alemania, Abril 2017, Comunicación oral

V. Bernardo, J. Martín-De León, M. A. Rodríguez-Pérez, J. Pinto, S. Barroso, T. Catelani, D. Fragouli,

A. Athanassiou

Nanocellular polymers based on PMMA/MAM blends: effect of the copolymer chemistry on the nanostructuration and the cellular structure

FOAMS2016, Seattle, USA, Septiembre 2016, Póster

Premio: Poster Second Place winner

V. Bernardo, J. Martín-De León, M. A. Rodríguez-Pérez

Needle-like nanoparticles as a new nucleating agent in CO2-foaming of nanocellular PMMA

FOAMS2016, Seattle, USA, Septiembre 2016, Póster

Premio: Michael Reedy Student Scholarship 2016

J. Martín-De León, V. Bernardo, S. Perez-Tamarit, M. A. Rodríguez-Pérez

Low density nanocellular foams based on PMMA: production, structure and properties

FOAMS2016, Seattle, USA, Septiembre 2016, Comunicación oral

V. Bernardo, J. Martín-De León, M. A. Rodríguez-Pérez

Production of nanocellular materials from nanostructured polymers based on PMMA/MAM blends: influence of the polymer morphology on the cellular structure

XIV Reunión del GEP de la RSEQ y RSEF, Burgos, España, Septiembre 2016, Comunicación oral

M. A. Rodríguez-Pérez, B. Notario, J. Pinto, V. Bernardo, J. Martín-de León

Nanocellular polymers: a new class of materials with enhanced properties

XIV Reunión del GEP de la RSEQ y RSEF, Burgos, España, Septiembre 2016, Plenary talk,

(Comunicación oral)

V. Bernardo, J. Martín-De León, M. A. Rodríguez-Pérez

Sepiolites as nucleating agent in PMMA nanofoams

EsMolNa 2015, Paris, Francia, Octubre 2015, Comunicación oral

V. Bernardo, J. Martín-De León, S. Pérez-Tamarit, E. Solórzano, M. A. Rodríguez-Pérez

Cellular Structure, Properties and Applications of Nanoporous Materials

Metfoam 2015, Barcelona, España, Agosto 2015, Póster

V. Bernardo, J. Martín-De León, J. Pinto, M. A. Rodríguez-Pérez

Nanostructured materials and nanoporous foams

XVI Escuela Nacional de Materiales Moleculares, Santa Pola, España, Febrero 2015, Comunicación

oral

Además, la Tabla S.5 resume otras contribuciones a conferencias nacionales e internacionales que no están relacionadas con los resultados en esta tesis.

Tabla S.5. Otras contribuciones a conferencias nacionales e internacionales.

Contribución a conferencia

J. Martín-de León, V. Bernardo, J. L. Pura, M. Á. Rodríguez-Pérez

Understanding the behaviour of semi-transparent nanocellular PMMA: study of the transmittance and modelling

CellMAT 2018, Bad Staffelstein, Alemania, Octubre 2018, Comunicación oral

J. Pinto, D. Morselli, V. Bernardo, B. Notario, D. Fragouli, A. Athanassiou, M.A. Rodríguez Pérez

Localized in situ synthesis of nanoparticles as a promising route for the development of templated

PMMA foams by gas dissolution foaming

CellMAT 2018, Bad Staffelstein, Alemania, Octubre 2018, Comunicación oral

M. Mugica, V. Bernardo, J. Martin-de Leon, C. Saiz-Arroyo, M.A. Rodríguez Pérez

Production of microcellular PMMA using the bead foaming technology 
CellMAT 2018, Bad Staffelstein, Alemania, Octubre 2018, Póster

J. Martin-de Leon, V. Bernardo, M.A. Rodríguez Pérez

Nanocellular PMMA with tunable cellular structure by changing the rheological behaviour of the polymer matrix

CellMAT 2018, Bad Staffelstein, Alemania, Octubre 2018, Póster

M. Santiago-Calvo, H. Naji, V. Bernardo, J. Martín de León, A. Saiani, F. Villafañe, M.A. Rodríguez

Pérez

Production of thermoplastic polyurethane foams synthesized with different contents of hard segment and graphene nanoplatelets by the gas dissolution foaming process

CellMAT 2018, Bad Staffelstein, Alemania, Octubre 2018, Póster

E. López-González, S. Muñoz-Pascual, V. Bernardo, E. Laguna-Gutiérrez, J. Martin-de-Leon, S.

Perez-Tamarit, J. Pinto, M.A. Rodriguez-Perez

Evolution of the practical training in materials physics: from a constrained research in the polymer science field to a multidisciplinary methodology

10th EDULEARN, Palma, España, Julio 2018, Comunicación oral

S. Perez-Tamarit, J. Martin-de-Leon, V. Bernardo, E. López-González, S. Muñoz-Pascual, J. Pinto, E. Laguna-Gutiérrez, M.A. Rodriguez-Perez

Transferring knowledge from the university to the industry: internships at the university of Valladolid

10th EDULEARN, Palma, España, Julio 2018, Comunicación oral

M. Santiago-Calvo, H. Naji, V. Bernardo, J. Martín-de León, A. Saiani, F. Villafañe, M. A. Rodríguez-

Pérez

Synthesis, characterization and foaming of thermoplastic polyurethane synthesized with different soft/hard segment ratio and graphene nanoplatelet contents

Polymers: Design, Function and Application 2018, Barcelona, España, Marzo 2018, Comunicación oral

J. Martín-De León, V. Bernardo, S. Pérez-Tamarit, M. A. Rodríguez-Pérez

Semi-Transparent Nanocellular Polymers Based on PMMA: Production and Characterization

FOAMS2017, Bayreuth, Alemania, Octubre 2017, Comunicación oral

J. Martín-De León, V. Bernardo, M. A. Rodríguez-Pérez

Controlled Foaming in a Hot Press of Flat and Large Parts of Nanocellular PMMA

FOAMS2017, Bayreuth, Alemania, Octubre 2017,, Póster

J. Martín-De León, V. Bernardo, M. A. Rodríguez-Pérez

Description of the process parameters for the production of PPSU nanocellular materials

FOAMS2016, Seattle, USA, Septiembre 2016, Póster

J. Martín-De León, V. Bernardo, M. A. Rodríguez-Pérez

Understanding the mechanisms that allow reducing density in PMMA nanocellular polymers

FOAMS2016, Seattle, USA, Septiembre 2016, Póster

J. Martín-De León, V. Bernardo, M. A. Rodríguez-Pérez

Influence of the process parameters in the cellular structure of low density PMMA nanocellular

polymers produced by the gas dissolution foaming route

XIV Reunión del GEP de la RSEQ y RSEF, Burgos, España, Septiembre 2016, Comunicación oral

J. Martín-De León, V. Bernardo, M. A. Rodríguez-Pérez

Higher nucleation efficiency in polymer foams by improving gas dissolution method

EsMolNa 2015, Paris, Francia, Octubre 2015, Comunicación oral

J. Martín-De León, V. Bernardo, S. Pérez-Tamarit, E. Solórzano, M. A. Rodríguez-Pérez Nanocellular Foams Fabrication Methods by Gas Dissolution Process

Metfoam 2015, Barcelona, España, Agosto 2015, Póster

S. Pérez-Tamarit, V. Bernardo, E. Solórzano, J. Martín-De León, M. A. Rodríguez-Pérez

Characterization of the Solid Phase of Cellular Materials by means of X-Ray microCT

Metfoam 2015, Barcelona, España, Agosto 2015, Póster 
J. Martín-De León, V. Bernardo, M. A. Rodríguez-Pérez Influencia de la temperatura en la absorción de $\mathrm{CO} 2$ en espumas nanocelulares XVI Escuela Nacional de Materiales Moleculares, Santa Pola, España, Febrero 2015, Comunicación oral

\section{V.3. Estancias de investigación, cursos y proyectos}

La Tabla S.6 resume las estancias de investigación en otras instituciones durante el desarrollo de esta tesis. La estancia en el Departamento de Ingeniería de la Universidad de Cambridge, bajo la supervisión del Prof. Dr. Norman Fleck, duró tres meses. Durante este tiempo, se realizaron algunos de los experimentos incluidos en el Capítulo 7, resultando en una publicación (Tabla S.1). Las otras estancias fueron en instalaciones de sincrotrón para investigar diferentes aspectos. Por ejemplo, las primeras tomografías de polímeros nanocelulares hechas con la suficiente resolución se realizaron en la campaña en el sincrotrón Diamond Light Source. Además, las primeras medidas experimentales del coeficiente de extinción de polímeros nanocelulares se llevaron a cabo recientemente en el sincrotrón Bessy II.

Tabla S.6. Estancias de investigación en otras instituciones.

\section{Localización, fecha y tema}

Synchrotron Bessy II, Helmholtz Zentrum Berlin (Alemania) - Abril 2019

Tema: Medida del coeficiente de extinción en polímeros nanocelulares

Synchrotron Diamond Light Source (UK) - Febrero 2019

Tema: Ptycotomografía de polímeros microcelulares y sub-microcelulares

University of Cambridge (UK) - Junio 2017 - Septiembre 2017

Tema: Caracterización mecánica de polímeros nanocelulares

Synchrotron Bessy II, Helmholtz Zentrum Berlin (Alemania) - Octubre 2016

Tema: Experimentos in-situ de intercalación de nanopartículas

Como parte de la formación, durante la tesis se asistió a varios cursos sobre diferentes temas (aislamiento, embalaje, reología, etc.) (Tabla S.7).

Tabla S.7. Cursos que se han realizado durante la tesis.

Título, organizador, localización y fecha

Jornadas Profesor Antonio de Saja “Envases Plásticos: Fundamentos, Normativa y Tendencias"

Leical, CellMat Technologies - Valladolid, España, Febrero 2018

Jornada "Caracterización de Materiales Poliméricos"

Leical, CellMat Technologies - Valladolid, España, Diciembre 2016

36th Berlin School on Neutron Scattering

Helmholtz Zentrum Berlin - Berlin, Alemania, Marzo 2016

Jornada "Aislamiento térmico en edificación"

Leical, CellMat Technologies - Valladolid, España, Diciembre 2014

Curso teórico-práctico de reología

TA Instruments -Waters Cromatografía, S.A - Madrid, España, Junio 2015

Workshop on X-RAY radioscopy and tomography

Technical University of Berlin - Berlin, Alemania, Noviembre 2014 
Finalmente, la estudiante de doctorado estuvo involucrada en actividades de investigación relacionadas con los siguientes proyectos (Tabla S.8).

Tabla S.8. Participación en otros proyectos con financiación.

FINANCIACIÓN PÚBLICA
DESARROLLO Y FABRICACION EN CONTINUO DE AISLANTES TERMICOS AVANZADOS BASADOS EN
POLIMEROS NANOCELULARES
Programa Estatal de I+D+i Orientada a los Retos de la Sociedad - 2016-2019
DESARROLLO DE PLASTICOS SUB-MICROCELULARES Y NANOCELULARES: FABRICACION,
ESTRUCTURA, PROPIEDADES Y POTENCIALES APLICACIONES. MAT2012-34901
ProYeCto Plan Nacionales de Materiales - 2013-2015
DESARROLLO DE UNA NUEVA GENERACIÓN DE AISLANTES TÉRMICOS AVANZADOS BASADOS EN LA
OBTENCIÓN DE ESTRUCTURAS POROSAS NANOCELULARES. VA035U13
JUnta de CaStilla Y LeÓn - 2013-2015
FINANCIACIÓN PRIVADA
DESARROLLO DE MATERIALES CELULARES LIGEROS Y RESISTENTES MEDIANTE EL CONTROL DE LA
COMPOSICIÓN QUÍMICA Y ESTRUCTURA CELULAR: MATERIALES MICRO Y NANOCELULARES
CELLMAT TECHNOLOGIES SL - 2013-2016
DESARROLLO DE POLÍMEROS NANOCELULARES AVANZADOS
CELLMAT TECHNOLOGIES SL and SABIC - 2014-2016
DESARROLLO DE ESTRATEGÍAS PARA FABRICAR POLÍMEROS NANOCELULARES EN PROCESOS
INDUSTRIALES: EXTRUSIÓN Y PERLITAS EXPANDIDAS
CELLMAT TECHNOLOGIES SL - 2015-2017
DESARROLLO DE NUEVOS MATERIALES CELULARES POLIMÉRICOS
TECHNOFORM BAUTEC - 2013-2016

VI. Metodología de trabajo

\section{Vl.1. Materiales y producción}

A lo largo de la presente tesis doctoral se ha trabajo con distintos materiales:

- Polimetilmetacrilato (PMMA): Este polímero, amorfo y transparente, se ha utilizado como matriz para fabricar todos los materiales compuestos que se han desarrollado a lo largo de la tesis. Se ha seleccionado debido a su alta afinidad por el $\mathrm{CO}_{2}$ [70], lo que lo convierte en un material óptimo para el espumado por disolución de gas [71-75]. En esta tesis se han empleado dos grados de PMMA comerciales con diferente viscosidad.

- Sepiolitas: Son nanopartículas de silicatos de magnesio con forma de aguja [66], con diámetro entre 20 y $50 \mathrm{~nm}$ y longitud entre 1 y 5 micras [76]. Se utilizan para múltiples aplicaciones, incluida la producción de nanocompuestos poliméricos y materiales celulares [68,77-79]. Para esta investigación se ha trabajado con cuatro sepiolitas con diferentes tratamientos superficiales, proporcionadas por Tolsa (Madrid, España).

- Copolímeros tri-bloque (MAM): Este copolímero tiene una composición química polimetilmetacrilato-polibutilacrilato-polimetilmetacrilato. El bloque central de PBA presenta alta afinidad por el $\mathrm{CO}_{2}$, y cuando se mezcla con PMMA el MAM pueden formar micelas nanométricas [61]. Para esta tesis se han utilizado tres grados de MAM con diferente peso molecular y contenido fijo de PBA, suministrados por Arkema (Francia). 
- TPU: Es un polímero lineal elastomérico inmiscible en PMMA, por lo que al formar compuestos con estos dos materiales se forma una nanoestructura formada por dominios de TPU [69]. Para esta tesis se empleó un único grado de TPU comercial.

- Dióxido de carbono $\left(\mathrm{CO}_{2}\right)$ : Para producir los materiales celulares se utilizó $\mathrm{CO}_{2}$ (grado médico, 99\% pureza). El dióxido de carbono es un gas que se considera respetuoso con el medio ambiente en comparación con otros gases empleados como agente espumante [80].

Se fabricaron mayoritariamente mezclas binarias, utilizando PMMA como matriz y las sepiolitas, el MAM o el TPU como aditivos, en distintas proporciones. En un trabajo concreto se fabricaron también mezclas ternarias de PMMA/MAM/Sepiolitas (Capítulo 6).

Con respecto a la producción de las mezclas, se puede considerar que el proceso de producción cuenta de varias etapas, como se muestra esquemáticamente en la Figura R.10. Los materiales se mezclaron en las proporciones deseadas por extrusión utilizando una extrusora de doble husillo. Después del primer ciclo de extrusión, todas las formulaciones fueron procesadas de nuevo para asegurar la homogeneidad en la dispersión de los agentes nucleantes. De la extrusión se obtuvieron o bien pellets, utilizados para producir láminas sólidas mediante moldeo por compresión, o bien filamentos que se utilizaron directamente como precursores en el proceso de espumado. A continuación, se produjeron los materiales celulares, utilizando para ello el llamado proceso de espumado por disolución de gas en dos etapas: saturación (disolución del $\mathrm{CO}_{2}$ en lámina o el filamento sólido a unas ciertas condiciones de presión y temperatura) y espumado (en un baño termostático a una temperatura prefijada durante un tiempo determinado).

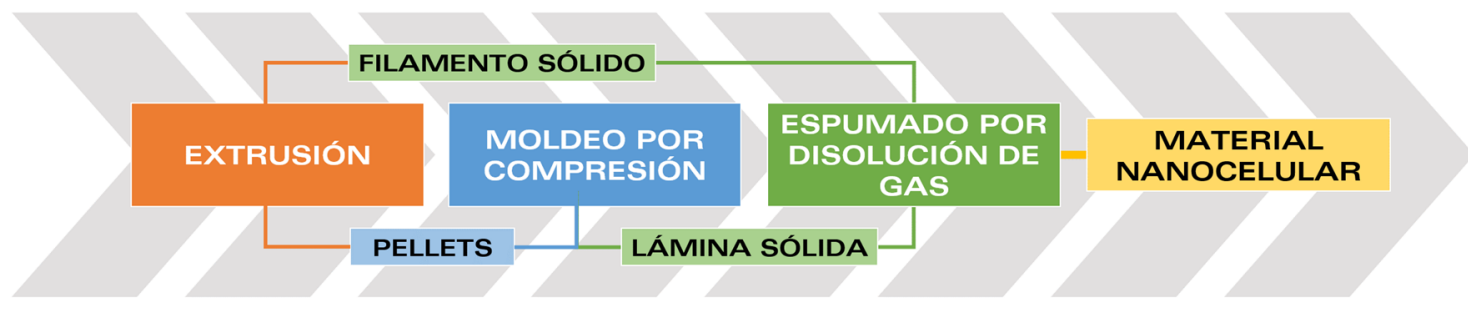

Figura R.10. Vista esquemática de las etapas del proceso de producción.

\section{VI.2. Caracterización}

Las técnicas de caracterización pueden dividirse en dos grandes grupos: las empleadas para los sólidos y las utilizadas para los materiales celulares (Figura R.11).

- Sólidos: Todos los compuestos sólidos se caracterizaron utilizando microscopía, bien electrónica de barrido (SEM) o de transmisión (TEM) para investigar la morfología resultante y la dispersión del agente nucleante en la matriz de PMMA. Además se midió la densidad mediante picnometría de gases. En algunos estudios, se determinó también la solubilidad del material y se midieron las propiedades reológicas de las mezclas.

- Materiales celulares: La caracterización básica de estos materiales fue medir su densidad y analizar en detalle la estructura celular mediante SEM, calculando los parámetros más relevantes como el tamaño de celda y la densidad de puntos de nucleación. Además, en 
algunos casos se estudió el contenido de celda abierta, y se midieron propiedades tales como la conductividad térmica o algunas propiedades mecánicas.
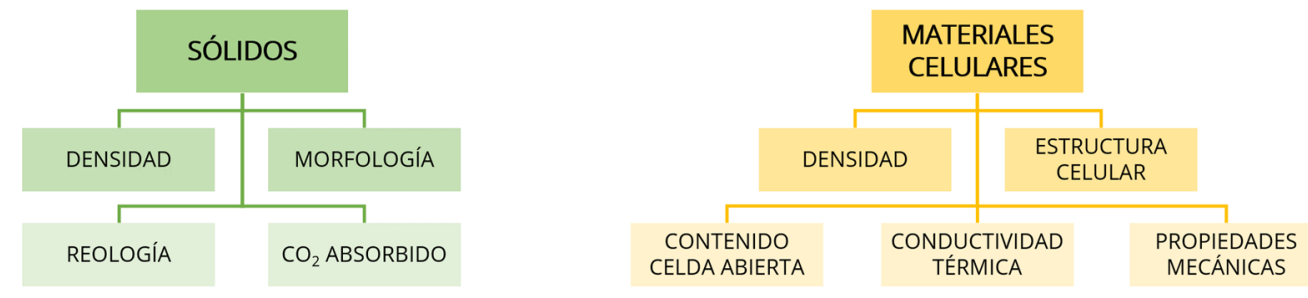

Figura R.11. Vista esquemática de las propiedades analizadas durante la caracterización de los sólidos y los materiales celulares. Primera fila: caracterización básica realizada para todos los materiales. Segunda fila: técnicas específicas utilizadas para algunos estudios.

\section{Principales resultados y conclusiones}

\section{VII.1. Fabricación de polímeros nanocelulares utilizando distintos agentes nucleantes}

Todos los materiales producidos a lo largo de esta tesis doctoral se encuentran recopilados en los mapas de la Figura R.12, donde pueden observarse el tamaño de celda en función de la densidad relativa (Figura R.12.a) y la densidad de nucleación en función de la densidad relativa (Figura R.12.b) para los distintos sistemas investigados en este trabajo (Capítulo 4, Capítulo 5, Capítulo 6 y Capítulo 7). Se ha incluido la sección del capítulo en la que aparecen los distintos materiales.

Las diferentes estrategias empleadas han permitido cubrir un amplio rango de materiales, con tamaños de celda entre 100 y $800 \mathrm{~nm}$, densidades de nucleación desde $10^{13}$ a $10^{15}$ núcleos $/ \mathrm{cm}^{3}$ y densidades relativas entre 0.15 y 0.6. Los sistemas basados en PMMA/MAM permiten obtener los menores tamaños de celda con las mayores densidades de nucleación. Las mezclas PMMA/TPU presentan, por otra parte, las menores densidades relativas. Por otro lado, los sistemas en base PMMA/Sepiolitas producen estructuras bimodales y en algunos casos estructuras muy anisotrópicas.

Es importante mencionar que estos materiales pueden producirse a bajas presiones (10 MPa) y temperatura ambiente como condiciones de saturación. Además, la mayor parte de ellos (excepto aquellos basados en PMMA/TPU) se pueden producir a una muy baja presión (6 MPa), que es la presión de la botella de gas. Es decir, la mayor parte de los polímeros nanocelulares de esta investigación se pueden fabricar sin requerir el uso de una bomba de presión o un sistema de calentamiento o enfriamiento durante la etapa de saturación. 

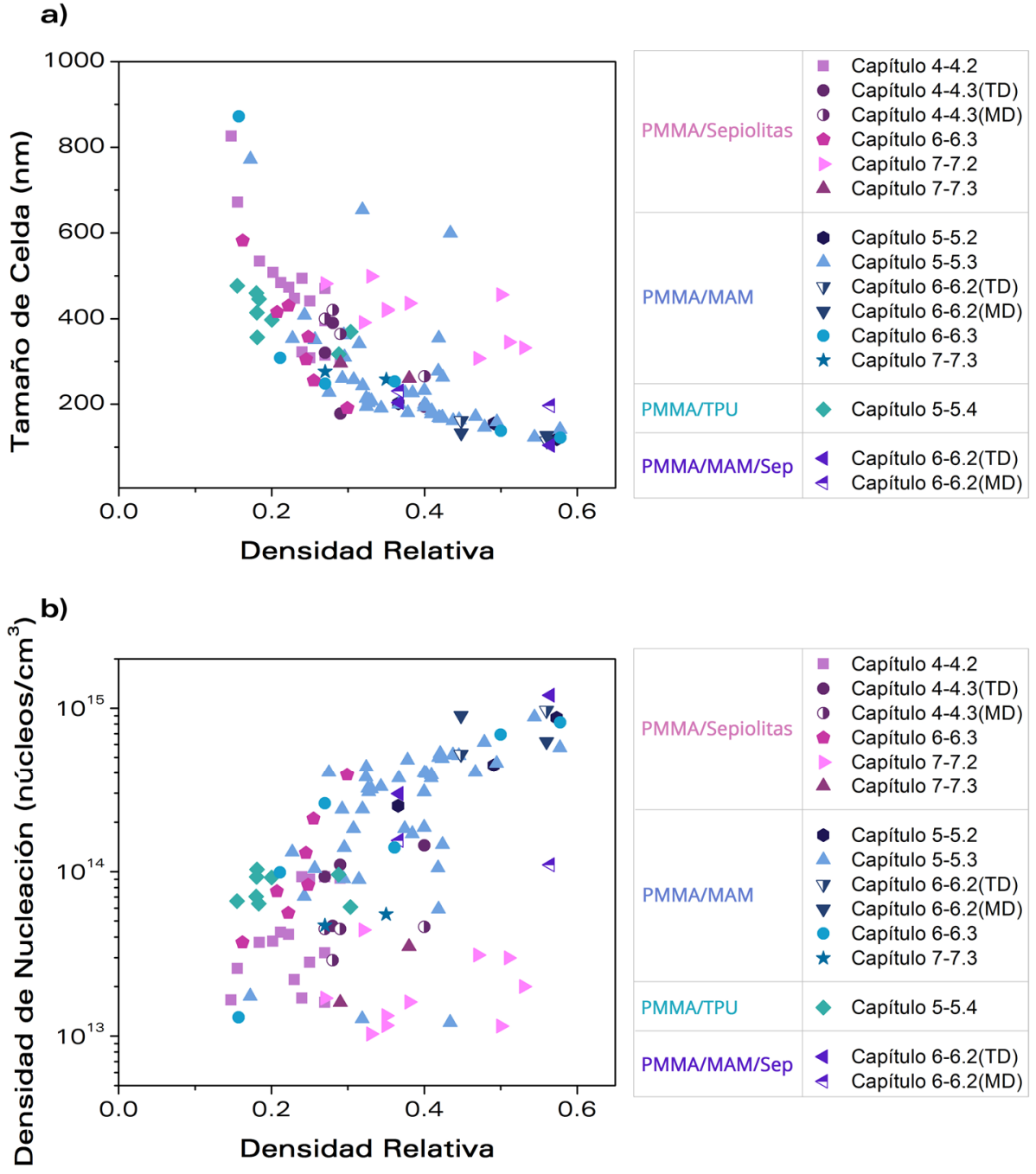

Figura R.12. a) Tamaño de celda en función de la densidad relativa y b) densidad de nucleación en función de la densidad relativa para todos los materiales producidos en esta tesis. Para aquellos materiales con una estructura bimodal, el tamaño de celda (Figura R.12.a) corresponde al tamaño

en la zona nanocelular. En los sistemas con estructuras anisotrópicas, se ha presentado la estructura de ambos planos (anisotropía, dirección de la máquina (MD) y dirección transversal

(TD)). En los sistemas con estructura tipo gradiente, los parámetros corresponden al core nanocelular homogéneo.

\section{VII.2. Propiedades de polímeros nanocelulares fabricados mediante nucleación heterogénea}

De los análisis de propiedades efectuados en algunos de los sistemas recopilados en la Figura R.12 se ha concluido lo siguiente (Capítulo 7):

- La adición de sepiolitas mejora el comportamiento a compresión de los nanocompuestos sólidos, pero empeora la tenacidad a fractura. Sin embargo, en los polímeros nanocelulares con estructura bimodal basados en estos materiales se observa una ligera mejora del módulo elástico relativo, mientras que la tenacidad a fractura relativa aumenta 
notablemente. Estas mejoras se relacionan con los agregados micrométricos. En los materiales celulares se ha comprobado una mejor dispersión de los mismos, y también se observa que se sitúan dentro de los poros micrométricos, por lo que su efecto negativo en las propiedades se ve compensado.

- Los materiales bimodales con estructura nanocelular precisan un modelo concreto para predecir su conductividad térmica. En concreto, en esta tesis se ha demostrado que se requiere un modelo que tenga en cuenta la fracción ocupada por las celdas micrométricas. El modelo desarrollado en esta tesis supone diferente comportamiento para la conducción del calor a través de las celdas micrométricas con respecto a las nanométricas. Estas últimas contribuyen con otro factor, en el que se tiene en cuenta el efecto Knudsen y también la modificación de la conducción de la fase sólida. El modelo se ha validado con materiales bimodales reales basados tanto en PMMA/MAM como en PMMA/Sepiolitas.

\section{VII.3. Principales conclusiones}

Uno de los principales objetivos de este trabajo era "alcanzar una comprensión profunda de los mecanismos implicados en la formación de la estructura celular". Esto es, aprender sobre la física implicada en la formación de polímeros nanocelulares a través de un proceso de nucleación heterogénea, con el objetivo de ser capaces de controlar el proceso e identificar sus principales ventajas y limitaciones. De los trabajos obtenidos a lo largo de esta tesis, se pueden extraer las siguientes conclusiones generales sobre el espumado de estos sistemas:

* La adición de sepiolitas con forma de aguja es una estrategia prometedora para producir polímeros nanocelulares. La dispersión de las partículas en la matriz, junto con el tratamiento superficial de la nanoarcilla, son aspectos clave que controlan la eficiencia de la nucleación. La presencia de agregados micrométricos produce que las estructuras resultantes sean bimodales, con poros micrométricos dispersos en la estructura nanocelular. Si se consiguiesen dispersar las partículas de un modo ideal, se podrían llegar a producir polímeros nanocelulares con una estructura homogénea y altas densidades de nucleación utilizando un bajo contenido de partículas. La nucleación en las sepiolitas es predominante en un amplio rango de presiones.

- Sin embargo, el carácter rígido de este aditivo, combinado con su forma acimutal, provoca coalescencia de las paredes celulares en la interfaz del polímero con la partícula a altas expansiones. No obstante, se puede explotar este efecto alineando las partículas en una cierta dirección, seleccionando así la dirección de la coalescencia. Como resultado, se pueden obtener estructuras celulares muy anisotrópicas gracias a las sepiolitas.

* El peso molecular del MAM es una herramienta que permite controlar la nanoestructuración de la mezcla PMMA/MAM, y por tanto controlar la estructura celular. La nucleación en el MAM es también predominante en un amplio rango de presiones.

* La presencia de las micelas nanométricas es un factor limitante en la expansión debido a la organización de las moléculas alrededor de la micela y la geometría esférica impuesta por las mismas. Sin embargo, una vez que se ha identificado esta limitación, se puede superar cambiando la nucleación de las micelas a regiones ricas en MAM, pero sin 
estructura. Esto puede lograrse reduciendo la concentración de MAM, de forma que no llegan a formarse micelas, pero el MAM está presente, fomentando la nucleación. Esto permite reducir la densidad, ya que las celdas tienen libertad para crecer y rellenar el espacio en cualquier configuración.

- Las mezclas inmiscibles de PMMA/TPU son nuevos materiales prometedores para obtener materiales nanocelulares de baja densidad. No obstante, la nucleación en la fase de TPU no predomina a todas las presiones. Utilizar un grado de PMMA de baja viscosidad para la matriz parece ser adecuado, pero también restringe el rango de condiciones de espumado, que afectan de un modo más significativo a la estructura celular. Por todo esto, este sistema resulta más complejo, debido a que pequeñas variaciones de las condiciones de procesado modifican la estructura celular. Además, las muestras obtenidas presentan una estructura de tipo gradiente, siendo solamente la región central nanocelular.

* Combinar dos agentes nucleantes, tales como el MAM y las sepiolitas, puede llevar a estructuras intermedias para bajos contenidos de los dos nucleantes. Sin embargo, cuando el contenido de MAM es alto, la nucleación viene dada por la fase de MAM. Combinando los dos nucleantes y promoviendo la coalescencia asociada a cada uno de ellos en una única dirección, se pueden conseguir estructuras de alta anisotropía.

Es evidente que el uso de la nucleación heterogénea para producir polímeros nanocelulares presenta varios puntos fuertes en comparación con la aproximación homogénea. En particular, algunas de las ventajas más relevantes del mecanismo de nucleación heterogénea que se han identificado a lo largo de esta tesis son:

$\checkmark$ Se pueden producir polímeros nanocelulares utilizando condiciones de proceso suaves o poco exigentes (saturación a temperatura ambiente $\left(25^{\circ} \mathrm{C}\right)$ y bajas/medias presiones (a partir de $6 \mathrm{MPa})$ ).

$\checkmark$ La ventana de proceso para la obtención de estos materiales es, en general, bastante amplia, debido a que el agente nucleante controla la nucleación, y por tanto variaciones en las condiciones de saturación no afectan a las estructuras obtenidas. Esto quiere decir que el proceso de producción es más robusto y reproducible.

$\checkmark$ El agente nucleante controla la estructura celular, por lo que se pueden obtener una amplia variedad de morfologías a las mismas condiciones de proceso simplemente modificando la cantidad o el tipo de agente nucleante.

$\checkmark$ La adición de nanopartículas o la obtención de mezclas de polímeros nanoestructuradas pueden llevar a mejoras en los materiales nanocelulares, tales como propiedades mecánicas mejoradas.

Sin embargo, esta estrategia también presenta algunos inconvenientes, al menos con los materiales y tecnologías disponibles a día de hoy. Algunas de las limitaciones actuales de la aproximación de la nucleación heterogénea son:

* Obtener tamaños de celda muy reducidos (por debajo de $50 \mathrm{~nm}$ ) parece ser complicado debido al tamaño de los nucleantes en ese mismo orden de magnitud. 
* Incluso aunque pudieran obtenerse tamaños de celda tan pequeños, podría ser que el material resultante no presentase transparencia, debido a que la presencia del agente nucleante puede dispersar parcialmente la luz, evitando la transparencia.

* La presencia de aditivos también puede afectar negativamente a algunas propiedades (por ejemplo, algunas nanopartículas aumentan la conductividad térmica).

A pesar de los inconvenientes mencionados, la estrategia de nucleación heterogénea continúa siendo, a día de hoy, una de las rutas más prometedoras para la producción de materiales nanocelulares a escala industrial. La posibilidad de utilizar condiciones de procesado no exigentes es el aspecto clave que convierte a los sistemas heterogéneos en los candidatos más probables para el futuro escalado industrial del proceso de espumado por disolución de gas. Estrategias de producción en continuo, tales como la extrusión, también serán más fácilmente implementadas en sistemas heterogéneos. Por todas estas razones, el desarrollo de polímeros nanocelulares con esta estrategia seguirá estando en el centro de atención durante los próximos años.

\section{Referencias}

[1] D. Eaves, Handbook of Polymer Foams, Rapra Technology, United Kingdom, 2004.

[2] C. Okolieocha, D. Raps, K. Subramaniam, V. Altstädt, Microcellular to nanocellular polymer foams: Progress (2004-2015) and future directions - A review, Eur. Polym. J. 73 (2015) 500-519. doi:10.1016/j.eurpolymj.2015.11.001.

[3] Marketsandmarkets.com, http://www.marketsandmarkets.com/Market-Reports/foams-market-1011.html, Accesed April 2019. (n.d.).

[4] D. Klempner, K.C. Frisch, Handbook of Polymeric Foams and Foam Technology, 1991.

[5] S.T. Lee, Foam extrusion: principles and practice, CRC Press, 100AD.

[6] M. Sauceau, J. Fages, A. Common, C. Nikitine, E. Rodier, New challenges in polymer foaming: A review of extrusion processes assisted by supercritical carbon dioxide, Prog. Polym. Sci. 36 (2011) 749-766. doi:10.1016/j.progpolymsci.2010.12.004.

[7] D. Raps, N. Hossieny, C.B. Park, V. Altstädt, Past and present developments in polymer bead foams and bead foaming technology, Polymer (Guildf). 56 (2015) 5-19. doi:10.1016/j.polymer.2014.10.078.

[8] F.A. Waldman, The processing of microcellular foam, Massachusetts Institute of Technology, 1980.

[9] J.E. Martini-Vvedensky, N.P. Suh, F.A. Waldman, United States Patent - MICROCELLULAR CLOSED CELL FOAMS AND THEIR METHOD OF MANUFACTURE, 4,473,665, 1984.

[10] J.E. Martini, The production and analysis of microcellular foam, Massachusetts Institute of Technology, 1981.

[11] N.P. Suh, Impact of Microcellular Plastics on Industrial Practice and Academic Research, Macromol. Symp. 201 (2003) 187-201. doi:10.1002/masy.200351122.

[12] V. Kumar, N.P. Suh, A process for making microcellular parts, Polym. Eng. Sci. 30 (1990) 1323-1329. doi:https://doi.org/10.1002/pen.760302010.

[13] V. Kumar, J. Weller, Production of Microcellular Polycarbonate Using Carbon Dioxide for Bubble Nucleation, J. Eng. Ind. 116 (1994) 413-420. doi:10.1115/1.2902122.

[14] K. Nadella, S. Powers, T. Malone, United States Patent - METHODS AND PRESSURE VESSELS FOR SOLID-STATE MICROCELLULAR PROCESSING OF THERMOPLASTIC ROLLS OR SHEETS, US 8,080,194 B2, 2011.

[15] J.A. Reglero Ruiz, C. Saiz-Arroyo, M. Dumon, M.A. Rodríguez-Perez, L. Gonzalez, Production, cellular structure and thermal conductivity of microcellular (methyl methacrylate)-(butyl acrylate)-(methyl methacrylate) triblock copolymers, Polym. Int. 60 (2011) 146-152. doi:10.1002/pi.2931.

[16] X. Han, K.W. Koelling, D.L. Tomasko, Continuous Microcellular Polystyrene Foam Extrusion With Supercritical CO2, Polym. 42 (2002) 2094-2106. doi:10.1002/pen.11100. 
[17] S.K. Goel, E.J. Beckman, Generation of Microcellular Polymeric Foams Using Supercritical Carbon Dioxide. I: Effect of Pressure and Temperature on Nucleation, Polym. Eng. Sci. 34 (1994) 1137-1147. doi:10.1002/pen.760341407.

[18] M.R. Holl, J.L. Garbini, W.R. Murray, V. Kumar, A steady-state mass balance model of the polycarbonate-CO2 system reveals a self-regulating cell growth mechanism in the solid-state microcellular process, J. Polym. Sci. Part B Polym. Phys. 39 (2001) 868-880. doi:10.1002/polb.1061.

[19] J.E. Weller, V. Kumar, Solid-State Microcellular Polycarbonate Foams II. The Effect of Cell Size on Tensile Properties, Polym. Eng. Sci. 50 (2010) 2170-2175. doi:10.1002/pen.

[20] V. Kumar, M. Vanderwel, J. Weller, K.A. Seeler, Experimental Characterization of the Tensile Behavior of Microcellular Polycarbonate Foams, J. Eng. Mater. Technol. 116 (1994) 439-445. doi:10.1115/1.2904310.

[21] J. Fu, C. Jo, H.E. Naguib, Effect of Processing Parameters on Cellular Structures and Mechanical Properties of PMMA Microcellular Foams, Cell. Polym. 24 (2005) 177-195. doi:10.1177/026248930502400401.

[22] B. Notario, J. Pinto, M.A. Rodriguez-Perez, Nanoporous polymeric materials: A new class of materials with enhanced properties, Prog. Polym. Sci. 78-79 (2016) 93-139. doi:10.1016/j.pmatsci.2016.02.002.

[23] M. Knudsen, The Kinetic Theory of Gases, Methuen, London, 1934.

[24] S. Song, M.M. Yovanovich, F.O. Goodman, Thermal Gap Conductance of Conforming Surfaces in Contact, J. Heat Transfer. 115 (1993) 533-540. doi:10.1115/1.2910719.

[25] B. Notario, J. Pinto, E. Solorzano, J.A. de Saja, M. Dumon, M.A. Rodriguez-Perez, Experimental validation of the Knudsen effect in nanocellular polymeric foams, Polymer (Guildf). 56 (2015) 57-67. doi:10.1016/j.polymer.2014.10.006.

[26] S. Liu, J. Duvigneau, G.J. Vancso, Nanocellular polymer foams as promising high performance thermal insulation materials, Eur. Polym. J. 65 (2015) 33-45. doi:10.1016/j.eurpolymj.2015.01.039.

[27] J. Pinto, B. Notario, R. Verdejo, M. Dumon, S. Costeux, M.A. Rodriguez-perez, Molecular confinement of solid and gaseous phases of self-standing bulk nanoporous polymers inducing enhanced and unexpected physical properties, Polymer (Guildf). 113 (2017) 27-33. doi:10.1016/j.polymer.2017.02.046.

[28] B. Notario, J. Pinto, M.A. Rodríguez-Perez, Towards a new generation of polymeric foams: PMMA nanocellular foams with enhanced physical properties, Polymer (Guildf). 63 (2015) 116-126. doi:10.1016/j.polymer.2015.03.003.

[29] S. Perez-Tamarit, B. Notario, E. Solorzano, M.A. Rodriguez-Perez, Light transmission in nanocellular polymers: are semi-transparent cellular polymers possible?, Mater. Lett. 210 (2017) 39-41. doi:10.1016/j.matlet.2017.08.109.

[30] J. Martin-de Leon, V. Bernardo, M.A. Rodriguez-Perez, Key Production Parameters to Obtain Transparent Nanocellular PMMA, Macromol. Mater. Eng. 1700343 (2017) 1-5. doi:10.1002/mame.201700343.

[31] B. Notario, A. Ballesteros, J. Pinto, M.A. Rodriguez-Perez, Nanoporous PMMA: A novel system with different acoustic properties, Mater. Lett. 168 (2016) 76-79. doi:10.1016/j.matlet.2016.01.037.

[32] B. Notario, J. Pinto, R. Verdejo, M.A. Rodríguez-Pérez, Dielectric behavior of porous PMMA: From the micrometer to the nanometer scale, Polymer (Guildf). $107 \quad$ (2016) 302-305. doi:10.1016/j.polymer.2016.11.030.

[33] L. Li, L. Schulte, L.D. Clausen, K.M. Hansen, G.E. Jonsson, S. Ndoni, Gyroid nanoporous membranes with tunable permeability, ACS Nano. 5 (2011) 7754-7766. doi:10.1021/nn200610r.

[34] J. Pinto, M. Dumon, M.A. Rodriguez-Perez, R. Garcia, C. Dietz, Block Copolymers Self-Assembly Allows Obtaining Tunable Micro or Nanoporous Membranes or Depth Filters Based on PMMA; Fabrication Method and Nanostructures, J. Phys. Chem. C. 118 (2014) 4656-4663. doi:10.1021/jp409803u.

[35] G.Q. Lu, X.S. Zhao, Nanoporous Materials - An Overview, in: Nanoporous Mater. Sci. Eng., Imperial Collegue Press, London, 2004. doi:10.1142/9781860946561_0001.

[36] European Commission, Horizon 2020 Work Programme 2014 - 2015 Science with and for Society, 2015. https://ec.europa.eu/research/participants/data/ref/h2020/wp/2014_2015/main/h2020-wp1415swfs_en.pdf.

[37] European Commission, Horizon 2020 Work Programme 2018 - 2020: 10. Secure, Clean and Efficient Energy, 2017. https://ec.europa.eu/programmes/horizon2020/en/h2020-section/secure-clean-and-efficient-energy.

[38] S. Costeux, CO2-blown nanocellular foams, J. Appl. Polym. Sci. 131 (2014) 41293(1)-41293(16). doi:10.1002/app.41293. 
[39] C. Forest, P. Chaumont, P. Cassagnau, B. Swoboda, P. Sonntag, Polymer nano-foams for insulating applications prepared from CO 2 foaming, Prog. Polym. Sci. 41 (2015) 122-145. doi:10.1016/j.progpolymsci.2014.07.001.

[40] D. Miller, P. Chatchaisucha, V. Kumar, Microcellular and nanocellular solid-state polyetherimide ( PEI ) foams using sub-critical carbon dioxide I. Processing and structure, Polymer (Guildf). 50 (2009) 5576-5584. doi:10.1016/j.polymer.2009.09.020.

[41] H. Guo, Solid-state Polymer Nanofoams, University of Washington, 2015.

[42] H. Guo, V. Kumar, Some thermodynamic and kinetic low-temperature properties of the PC-CO2 system and morphological characteristics of solid-state PC nanofoams produced with liquid CO2, Polymer (Guildf). 56 (2015) 46-56. doi:10.1016/j.polymer.2014.09.061.

[43] S. Costeux, S.P. Bunker, Homogeneous nanocellular foams from styrenic-acrylic polymer blends, J. Mater. Res. 17 (2013) 2351. doi:10.1557/jmr.2013.100.

[44] J. Pinto, M. Dumon, M.A. Rodriguez-Perez, Nanoporous Polymer Foams from Nanostructured Polymer Blends: Preparation, Characterization, and Properties, in: P.. Visakh, G. Markovic, D. Pasquini (Eds.), Recent Dev. Polym. Macro, Micro Nano Blends, Woodhead Publishing in Materials, 2016: pp. 237-288.

[45] CellMat Laboratory Webpage, Accesed April 2019. (n.d.). http://cellmat.es/.

[46] M.Á. Rodríguez-Pérez, PROPIEDADES TÉRMICAS Y MECÁNICAS DE ESPUMAS DE POLIOLEFINAS, University of Valladolid, 1998.

[47] O. Almanza, Caracterización y Modelización de las Propiedades Térmicas y Mecánicas de Espumas con Base Polietileno, University of Valladolid, 2000.

[48] J.I. Velasco, A.B. Martínez, D. Arencón, M.A. Rodríguez-Pérez, J.A. De Saja, Application of instrumented falling dart impact to the mechanical characterization of thermoplastic foams, J. Mater. Sci. 34 (1999) 431-438. doi:10.1023/A:1004565822502.

[49] M.A. Rodriguez-Perez, J.A. de Saja, The effect of blending on the physical properties of crosslinked closed cell polyethylene foams, Cell. Polym. 18 (1999) 1-20.

[50] C. Saiz-Arroyo, Fabricación de Materiales Celulares Mejorados Basados en Poliolefinas. Relación ProcesadoComposición-Estructura-Propiedades, University of Valladolid, 2002.

[51] C. Saiz-Arroyo, M.A. Rodriguez-Perez, J. Tirado, A. López-Gil, J.A. de Saja, Structure-property relationships of medium-density polypropylene foams, Polym. Int. 62 (2013) 1324-1333. doi:10.1002/pi.4424.

[52] J.E. Arconada, Polyolefin Based Cellular Materials . Development of New Production Routes and Optimization of Barrier and Mechanical Properties By the Addition of Nanoclays, University of Valladolid, 2015.

[53] E. Laguna-Gutiérrez, Understanding the Foamability of Complex Polymeric Systems By Using Extensional Rheology, University of Valladolid, 2016.

[54] J. Pinto, Fabrication and Characterization of Nanocellular Polymeric Materials from Nanostructured Polymers, University of Valladolid, 2014.

[55] B. Notario, Fabrication and Characterization of the Physical Properties of Nanocellular Polymers: the Transition from the Micro to the Nanoscale., University of Valladolid, 2016.

[56] S. Pardo Alonso, X-Ray Imaging Applied to the Characterization of Polymer Foams' Cellular Structure and Its Evolution, University of Valladolid, 2014.

[57] E. Laguna-Gutierrez, C. Saiz-Arroyo, J.I. Velasco, M.A. Rodriguez-Perez, Low density polyethylene/silica nanocomposite foams. Relationship between chemical composition, particle dispersion, cellular structure and physical properties, Eur. Polym. J. 81 (2016) 173-185. doi:10.1016/j.eurpolymj.2016.06.001.

[58] S. Estravís, J. Tirado-Mediavilla, M. Santiago-Calvo, J.L. Ruiz-Herrero, F. Villafañe, M.Á. Rodríguez-Pérez, Rigid polyurethane foams with infused nanoclays: Relationship between cellular structure and thermal conductivity, Eur. Polym. J. 80 (2016) 1-15. doi:10.1016/j.eurpolymj.2016.04.026.

[59] H. Ventura, Development of New Composites Reinforced Lightweight Green Structures of Flax With Nonwoven Fibres, Universitat Politècnica de Catalunya, 2017.

[60] A. López Gil, Development of Environmentally Friendly Cellular Polymers for Packaging and Structural Applications. Study of the Relationship Cellular Structure-Mechanical Properties, University of Valladolid, 2016.

[61] J. Pinto, M. Dumon, M. Pedros, J. Reglero, M.A. Rodriguez-Perez, Nanocellular CO2 foaming of PMMA assisted 
by block copolymer nanostructuration, Chem. Eng. J. 243 (2014) 428-435. doi:10.1016/j.cej.2014.01.021.

[62] J. Pinto, S. Pardo, E. Solórzano, M.A. Rodríguez-Pérez, M. Dumon, J.A. de Saja, Solid Skin Characterization of PMMA/MAM Foams Fabricated by Gas Dissolution Foaming over a Range of Pressures, Defect Diffus. Forum. 326-328 (2012) 434-439. doi:10.4028/www.scientific.net/DDF.326-328.434.

[63] J. Pinto, J.A. Reglero-Ruiz, M. Dumon, M.A. Rodriguez-Perez, Temperature influence and CO2 transport in foaming processes of poly(methyl methacrylate)-block copolymer nanocellular and microcellular foams, J. Supercrit. Fluids. 94 (2014) 198-205. doi:10.1016/j.supflu.2014.07.021.

[64] J. Martin de-Leon, V. Bernardo, M.A. Rodriguez-Perez, Low Density Nanocellular Polymers Based on PMMA Produced by Gas Dissolution Foaming: Fabrication and Cellular Structure Characterization, Polymers (Basel). 8 (2016) 1-16. doi:10.3390/polym8070265.

[65] V.I. Kalikmanov, Nucleation Theory, Springer, 2013.

[66] A. Alvarez, J. Santaren, A. Esteban-Cubillo, P. Aparicio, Development in Palygorskite-Sepiolite Research, Elsevier, 2011.

[67] D. Killeen, M. Frydrych, B. Chen, Porous poly (vinyl alcohol)/ sepiolite bone scaffolds: Preparation, structure and mechanical properties, Mater. Sci. Eng. C. 32 (2012) 749-757. doi:10.1016/j.msec.2012.01.019.

[68] J. Santaren, A. Alvarez, A. Esteban-Cubillo, B. Notario, D. Velasco, M.A. Rodriguez-Perez, Improving the Cellular Structure and Thermal Conductivity of PS Foams by Using Sepiolites, in: Foams2012, 2012: pp. 1-5.

[69] G. Wang, J. Zhao, L.H. Mark, G. Wang, K. Yu, C. Wang, C.B. Park, G. Zhao, Ultra-tough and super thermalinsulation nanocellular PMMA/TPU, Chem. Eng. J. 325 (2017) 632-646. doi:10.1016/j.cej.2017.05.116.

[70] H. Guo, V. Kumar, Solid-state poly(methyl methacrylate) (PMMA) nanofoams. Part I: Low-temperature CO2 sorption, diffusion, and the depression in PMMA glass transition, Polymer (Guildf). 57 (2015) 157-163. doi:10.1016/j.polymer.2014.12.029.

[71] C. Okolieocha, F. Beckert, M. Herling, J. Breu, R. Mülhaupt, V. Altstädt, Preparation of microcellular low-density PMMA nanocomposite foams: Influence of different fillers on the mechanical, rheological and cell morphological properties, Compos. Sci. Technol. 118 (2015) 108-116. doi:10.1016/j.compscitech.2015.08.016.

[72] K. Nadella, V. Kumar, W. Li, Constrained solid-state foaming of microcellular panels, Cell. Polym. 24 (2005) $71-$ 90. doi:10.1177/026248930502400202.

[73] S. Siripurapu, J. a. Coughlan, R.J. Spontak, S. a. Khan, Surface-Constrained Foaming of Polymer Thin Films with Supercritical Carbon Dioxide, Macromolecules. 37 (2004) 9872-9879. doi:10.1021/ma0484983.

[74] J. Fu, H.E. Naguib, Effect of Nanoclay on the Mechanical Properties of PMMA/Clay Nanocomposite Foams, J. Cell. Plast. 42 (2006) 325-342. doi:10.1177/0021955X06063517.

[75] F. Zhang, D. Lee, T.J. Pinnavaia, PMMA - mesocellular foam silica nanocomposites prepared through batch emulsion polymerization and compression molding, Polymer (Guildf). 50 (2009) 4768-4774. doi:10.1016/j.polymer.2009.08.007.

[76] D. Garcia-Lopez, J.F. Fernandez, J.C. Merino, J. Santaren, J.M. Pastor, Effect of organic modification of sepiolite for PA 6 polymer/organoclay nanocomposites, Compos. Sci. Technol. 70 (2010) 1429-1436. doi:10.1016/j.compscitech.2010.05.020.

[77] J. Ma, J.A. Darr, Preparation of polypropylene/sepiolite nanocomposites using supercritical CO2 assisted mixing, Eur. Polym. J. 43 (2007) 4931-4939. doi:10.1016/j.eurpolymj.2007.09.010.

[78] P. Lu, The Effects of Different Grafted Clays on Thermal Properties of Their PMMA Composites, Polym. Plast. Technol. Eng. 50 (2011) 1541-1545. doi:10.1080/03602559.2011.603780.

[79] Y. Zheng, Y. Zheng, Study on Sepiolite-Reinforced Polymeric Nanocomposites, J. Appl. Polym. Sci. 99 (2006) 2163-2166. doi:10.1002/app.22337.

[80] L.J.M. Jacobs, M.F. Kemmere, J.T.F. Keurentjes, Sustainable polymer foaming using high pressure carbon dioxide: A review on fundamentals, processes and applications, Green Chem. 10 (2008) 731-738. doi:10.1039/b801895b. 
Chapter 1.

Introduction 



\section{Chapter 1. Introduction}

\subsection{Introduction}

\subsubsection{Cellular polymers}

Cellular polymers are two-phase systems in which one phase is a gas that is dispersed in a continuous polymer matrix. The use of cellular polymers (or polymer foams) is extremely widespread in almost every industry sector, such as sports, automotive, aircraft, leisure, or packing [1]. Figure 1.1 shows some examples of cellular polymers based on various polymer matrices used for different applications.
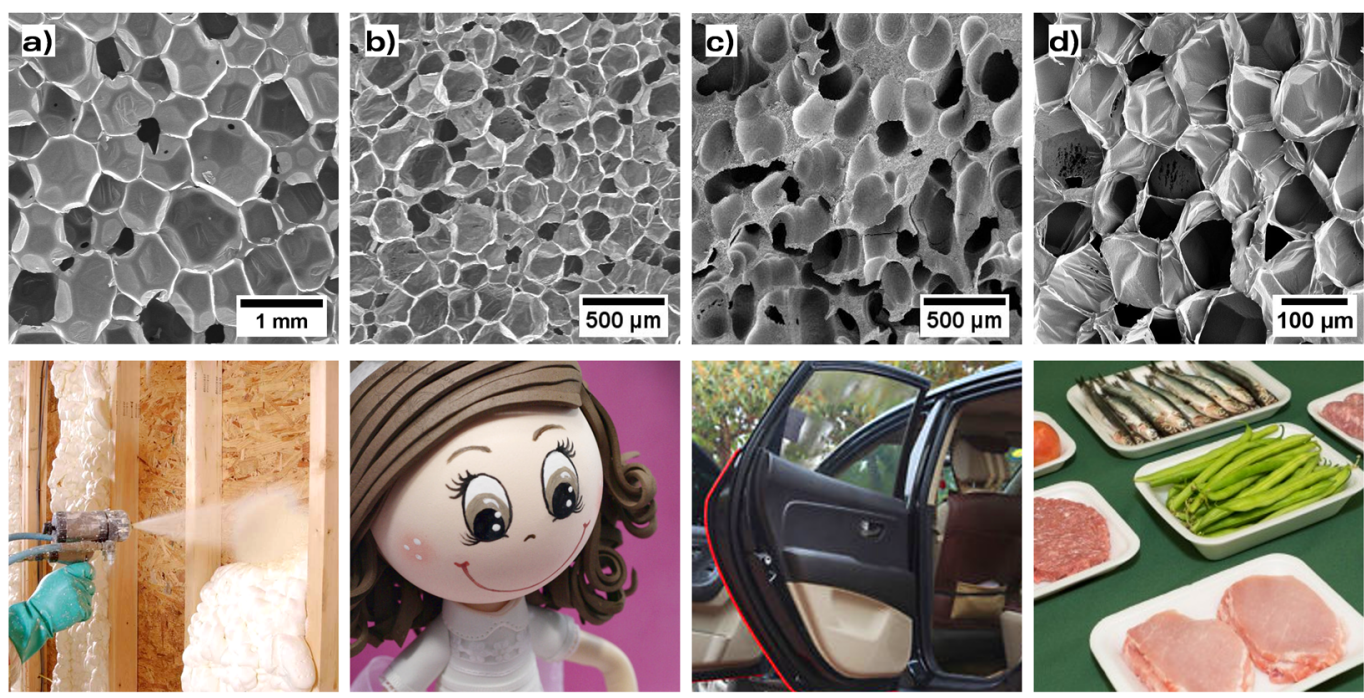

Figure 1.1. Cellular materials based on various polymers and some of their applications: a) polyurethane (PU) for thermal insulation in buildings, b) ethyl(vinyl acetate) (EVA) in toys, c) polypropylene (PP) in car parts and d) polystyrene (PS) in food packaging.

Although natural cellular materials (such as balsa wood or cork) have been known for many years, it was not until the 1930s when the development of manufactured cellular polymers started with the first patent in cellular polystyrene [2]. The use of this class of materials has grown rapidly in less than a century, and it continues to grow at a high pace. In fact, the market size of cellular polymers was $\$ 89.62$ billion in 2016 and is estimated to reach $\$ 126.08$ billion by 2022, at an annual growth rate of $5.86 \%$ between 2017 and 2022 [3].

The reasons underlying the worldwide use of these materials are related to the improvements and also to the new properties that can be added to a polymer by introducing a gas phase in a cellular structure. Some of these properties are the light-weight, the excellent strength/weight ratio, the superior insulation ability, and the energy absorbing performance, among others [4]. Also, the properties of cellular polymers can be tailored to address the requirements of a specific application, by modifying the polymer matrix, the density, the cellular structure, or by including additives. 
The design of cellular polymers with enhanced properties is an issue of great importance in the development of this field. In particular, the discovery of new foaming technologies usually paves the way for the appearance of new structures or properties that widen the range of applications of cellular polymers. For instance, the introduction of extrusion technologies (well-known for mixing and producing solid elements) to fabricate cellular polymers in the 1940s allowed the continuous production of foamed parts [5,6]. Another example of foaming technology is the bead foaming process (first use around 1950) that led to pieces with similar characteristics as the extruded materials but with complex geometries thanks to the versatility of the small beads [7]. More recently, in the 1980s, a new class of cellular materials appeared with the development of microcellular polymers (and later sub-micro and nanocellular polymers) via the use of a gas dissolution foaming approach [8-10].

\subsubsection{Microcellular polymers}

The idea of producing microcellular polymers (that is, cellular materials with pores in the range of tens of microns) was born in the Massachusetts Institute of Technology (MIT) in the 1980s as a response to the need of reducing the amount of material in the packaging industry without decreasing the mechanical performance [1]. Some of the applications under study at that moment were thin solid sheets, so decreasing the density with the traditional foaming technologies that produced cells higher than 100 microns was not feasible due to the loss of strength. Then, they came up with a solution: if the cell sizes were reduced enough, it would be possible to obtain enough cells in thickness to reach reasonable mechanical properties for the intended applications. This was the born of microcellular polymers with the master thesis of Waldman [8] and Martini [10] and their joint patent with Professor Suh on the process to produce this new class of materials [9].

Conventional foaming technologies did not permit to create the high density of cells $\left(10^{9} \mathrm{cells} / \mathrm{cm}^{3}\right)$ required to reduce the cell size under 100 microns. In addition, foaming in the molten state complicated the stabilization of very small cells. The development of a new foaming process, the so-called solid-state foaming, overcame these difficulties. Dissolving the blowing agent in the solid state and inducing a large thermodynamic instability were the keys to produce stable microcellular structures [11]. Since then, the solid-state foaming (or gas dissolution foaming) technique has been used extensively to produce microcellular polymers [12-18] that are nowadays used in multiple applications because of their enhanced mechanical properties compared to conventional cellular polymers with the same density [19-21]. Figure 1.2 shows some examples of microcellular polymers and their applications. Another interesting aspect of microcellular polymers is the possibility of producing them in a reduced thickness without losing mechanical strength, which opened the field of applications of cellular polymers to the thin-layers and films sectors.

Further research and advances in the production of these materials allowed the generation of microcellular polymers with even smaller cell sizes, reaching cell sizes of 1 micron and less. The progress in the foaming technology together with the interesting properties of microcellular polymers triggered the leap to the next generation of cellular materials in the early 2000s [2]: the development of nanocellular polymers. 

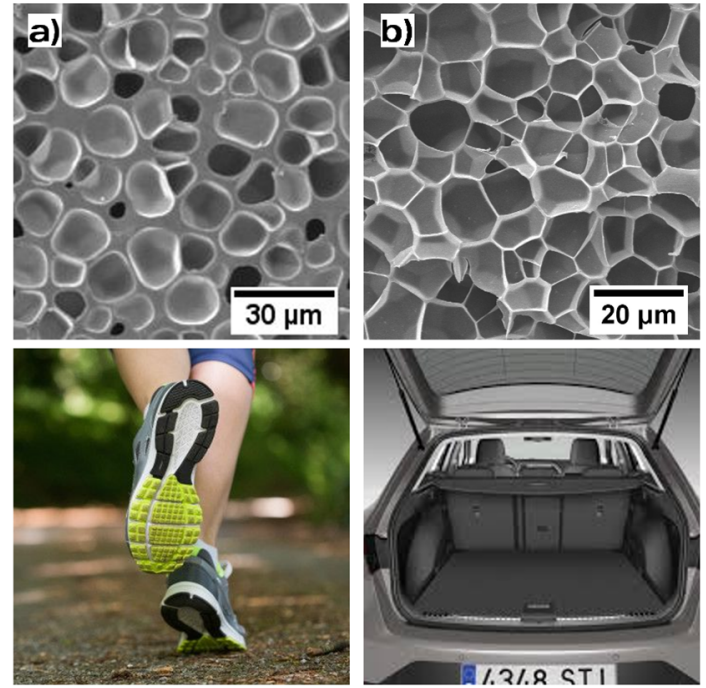

Figure 1.2. Microcellular materials based on various polymers and some of their applications: a) thermoplastic polyurethane (TPU) for sports applications, and b) expanded PP in car parts.

\subsubsection{Nanocellular polymers}

The reduction of the cell size to the nanometric scale was the natural step forward after the development of microcellular polymers. In light of the significant improvements achieved in those systems, it was expectable that a further decrease in the cell size would lead to even better properties. The production of nanocellular polymers implies a significantly harder challenge from a technological point of view: the cell density should be increased from $10^{9} \mathrm{cells} / \mathrm{cm}^{3}$ to $10^{13}$ cells $/ \mathrm{cm}^{3}$ to reach a nanometric cellular structure. Figure 1.3 presents two examples of the change of scale from micro to nanocellular structures.

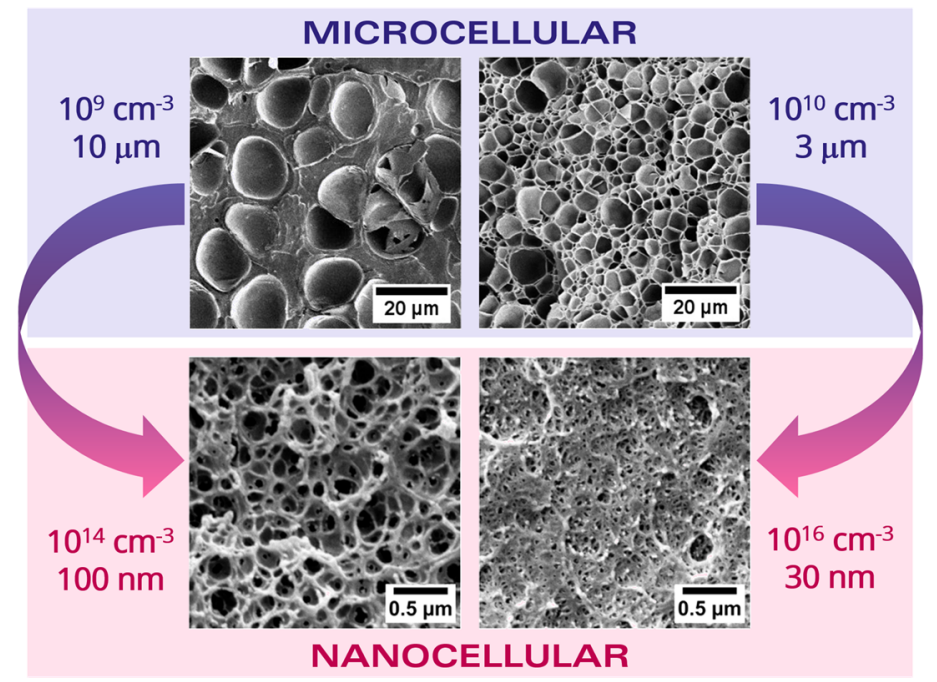

Figure 1.3. Examples of transition from a microcellular to a nanocellular structure (reduction of the cell size in a factor of 100).

In a nanocellular structure, the two phases (gas and solid) are confined: one the one hand, the gas is confined in small cells, and on the other hand, the polymer is restricted to be in very thin cell 
walls. As a consequence of these effects, new properties never observed in conventional or microcellular polymers are expected [22]. For instance, it is known that when a gas is confined in a volume of similar size as the mean free path of the gas molecules (around $70 \mathrm{~nm}$ for air in standard conditions), Knudsen effect appears [23,24] and the conduction through the gas is drastically reduced. This is precisely the case in nanocellular polymers, and for this reason, these materials have the potential of being super-thermal insulators $[25,26]$. Simultaneously, the polymer is stretched in cell walls smaller than the typical length of the polymer macromolecules (20-30 nm versus $100 \mathrm{~nm}$ ), leading to a confinement effect of the solid phase that can produce, among other effects, an increase of the glass transition temperature of the polymer [27] and an enhancement of the mechanical properties [28]. Also, the reduction of the cell size to the nanoscale has other interesting consequences. One of the most outstanding properties that has been recently proved is that nanocellular polymers have the potential of being partially transparent due to their nanometric cell size $[29,30]$. This property, combined with the super-insulator capacity of nanocellular polymers, makes them suitable for producing advanced transparent insulators for many applications. Further, nanocellular polymers present different acoustic and dielectric properties compared to microcellular polymers [31,32]. Moreover, the nanometric cell size and the high surface area associated to it open the possibility of using these materials in some applications such as the production of membranes, filters, sensors and supports for catalysis [33-35].

Due to the interesting combination of properties of nanocellular polymers, they have aroused great attention, and during the last two decades, important international companies and first level research laboratories all around the world have started investigation lines about this topic. In addition, the European Union (EU) also foresaw the potential of nanocellular polymers and included them in the research objectives of the program "Horizon 2020" (Horizon 2020, the EU Research and Innovation program for the period 2014-2020 [36,37]). One of the priorities of this program was the "Manufacturing and control of nanoporous materials". EU refers to "a constantly growing interest in nanostructured porous materials, thanks to the many applications that can benefit from controlled porosity at the nanoscale".

The research about nanocellular polymers has been continually growing during the last years [3841], but it is still a new area of study, and many questions remain unsolved, especially about the production processes. Most nanocellular polymers are produced using a gas dissolution foaming approach with $\mathrm{CO}_{2}$ as the blowing agent, but this technology and the materials used up to date have not allowed fine control of the cellular structures to obtain the desired properties [38]. In addition, the production of these materials on a large scale is not yet a reality. As aforementioned, extremely high cell densities must be created to produce a nanocellular polymer, and the cellular structure needs to be stabilized with pores in the nanoscale. To achieve high cell densities, extreme processing conditions are required during the gas dissolution foaming process to promote the creation of enough nuclei [42,43]. Most of the nanocellular polymers developed so far are produced using demanding processing conditions, such as high pressures (30-33 MPa) $[43,44]$ or extremely low temperatures (under $0^{\circ} \mathrm{C}$ ) [42,45]. However, and although this approach provides interesting results from an academic point of view, the use of such production conditions complicates the transfer to industrial scale. 
Otherwise, nucleation can be favored by adding a nucleating agent. This alternative allows generating nanocellular polymers using mild processing conditions since the nucleating agent controls the nucleation process. From a technological point of view, the use of nucleating species seems to be the appropriate way towards mass-scale production. Nonetheless, there are still some limitations in the use of this strategy. Template structures, such as nanostructured polymer blends, seem to limit the expansion $[38,46]$, and the potential of using nanoparticles is still not fully exploited.

Moreover, there is a general limitation in the production of low-density nanocellular materials with the desired cell size, and such materials would be needed to take advantage of some of the properties of nanocellular polymers, such as the reduced thermal conductivity [2].

It can be concluded that nanocellular polymers are promising and interesting materials for many applications, but further research is needed to continue the development of this field. In particular, a deep understanding of the mechanisms implied in the formation of the nanocellular structure (nucleation, cell growth, and stabilization) would be mandatory to achieve complete control in the production of these materials. Only through research and knowledge can these materials leave the laboratories and reach the industry to produce new and advanced products. Figure 1.4 shows a schematic overview of the potential applications of nanocellular polymers already identified, and the challenges that the scientists working in this area are facing nowadays and in the coming years.

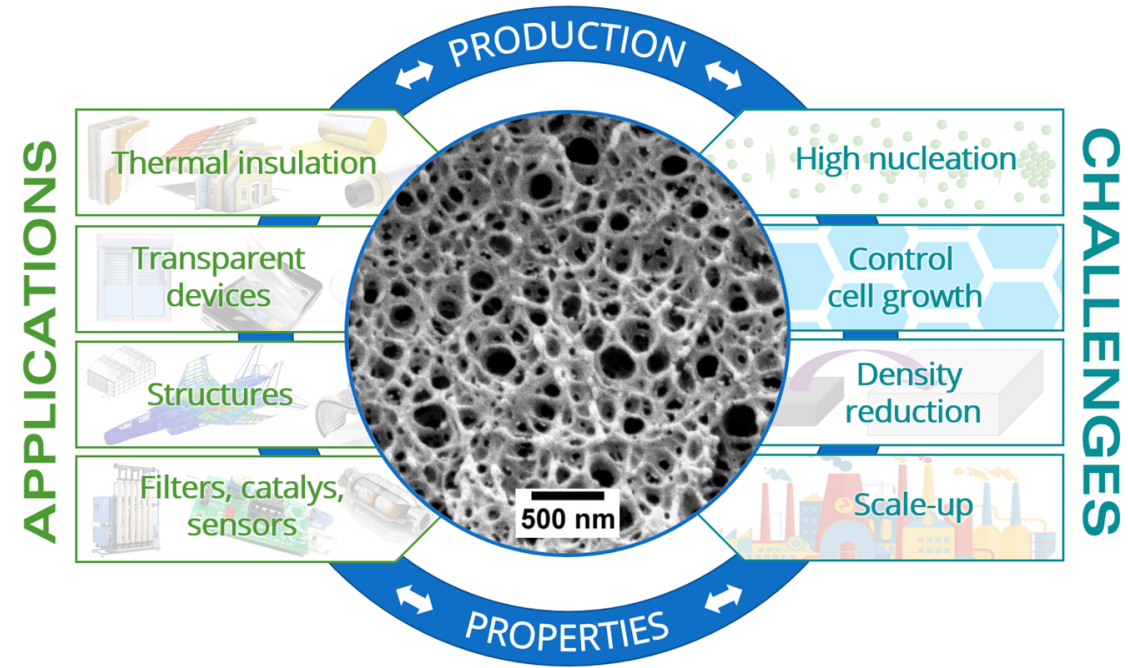

Figure 1.4. Potential applications of nanocellular polymers and challenges in their production.

\subsection{Framework of this Thesis}

This investigation is part of the research activities of CellMat Laboratory in the Condensed Matter Physics Department of the University of Valladolid [47] and was supervised by Prof. Dr. Miguel Ángel Rodríguez-Pérez, head of the laboratory.

CellMat Laboratory was founded in 1999 by Prof. Dr. José Antonio de Saja and Prof. Dr. Miguel Ángel Rodríguez-Pérez. From then on, the lab has continued to grow just as much in staff and facilities as in the variety of research activities and their impact on the cellular materials scientific community. 
Today, CellMat Laboratory is a reference in the study and development of cellular materials, with more than 200 publications in JCR and 25 Ph.D. thesis defended.

The activities of CellMat Laboratory started with the characterization of cellular materials based on polyolefins [48-51]. Microscopic and macroscopic techniques were used to fully characterized commercial polymer foams. With the expertise gain during these first years, in 2005 CellMat took a step forward and acquired facilities to produce their own cellular materials. From that moment, CellMat started to investigate the relationships between chemical composition, processing, cellular structure and physical properties [52-55], a research that continues nowadays and that defines the methodology of CellMat Laboratory.

Indeed, the basis of CellMat is the cellular materials tetrahedron (Figure 1.5): establishing a relationship between the production, the structure, and the properties of the cellular materials. The final goal is evaluating the possible applications, as one of the main principles of CellMat Laboratory is the transfer of knowledge and technology between the University and the industry, as a critical factor for the industrial development.
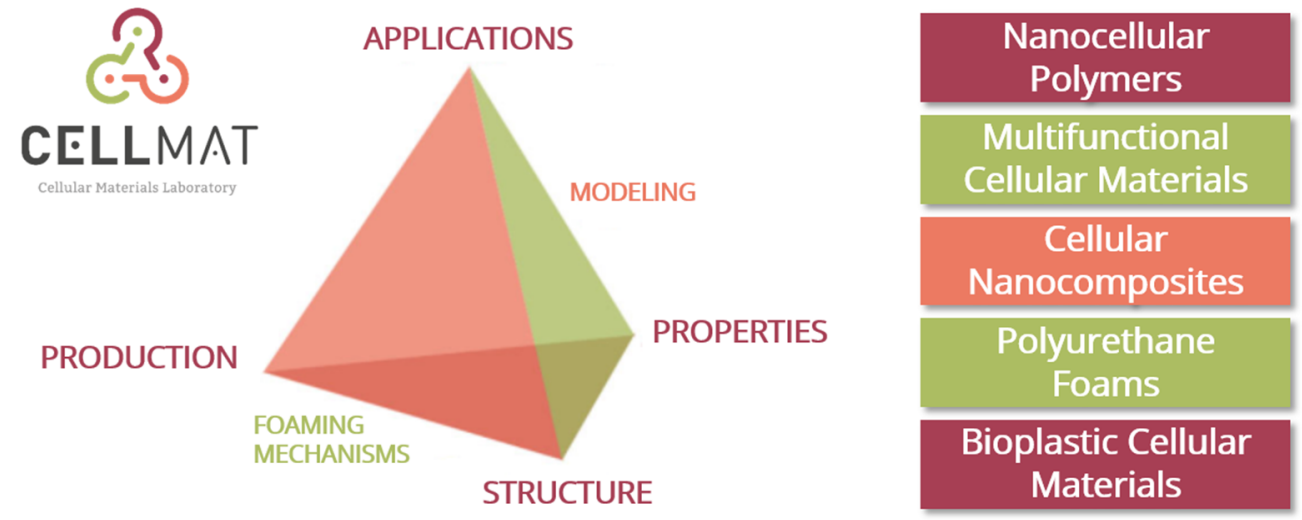

Figure 1.5. The basis of the investigations of CellMat Laboratory (the cellular materials tetrahedron), and current research lines.

Nowadays, CellMat sustains five main research lines (Figure 1.5): nanocellular polymers [56,57], multifunctional cellular materials $[29,58]$, cellular nanocomposites [54,59], polyurethane foams $[58,60]$ and bioplastic cellular materials $[61,62]$. The expertise of CellMat in all these fields, and the continuous efforts to generate knowledge about different topics (such as foaming mechanisms and production technologies, characterization of cellular materials, structure-properties relationship, etc.) have made CellMat Laboratory an international reference in the area of cellular polymers.

The present thesis belongs to the research topic in Nanocellular Polymers, the most recent line in CellMat Laboratory [47]. This research was firstly developed at CellMat by Dr. Javier Pinto with his Ph.D. thesis in 2014 [56], supervised by Prof. Dr. Miguel Ángel Rodríguez-Pérez and Prof. Dr. Michel Dumon from the Laboratoire de Chimie des Polymères Organiques (LCPO, University of Bordeaux 1, France). From this thesis, CellMat gained knowledge about the production of nanocellular materials using pure polymers and nanostructured polymer blends [34,63-65], and also about the great interest of this new class of materials. For this reason, a new research line about these materials started in CellMat Laboratory, and it was continued with the Ph.D. thesis of Dr. Belén 
Notario [57], supervised by Dr. Javier Pinto and Prof. Dr. Miguel Ángel Rodríguez-Pérez. In this thesis, several properties of nanocellular polymers were evaluated [22,25,28,31,32]. With the research carried out during these last years, CellMat Laboratory has become a reference in the field of nanocellular polymers. In particular, CellMat has the credit of having proved, for the first time, the presence of the Knudsen effect in this type of materials [25], to evidence the possibility of producing transparent cellular polymers [30] and to prove the improved mechanical properties of these novel materials [28].

From these precedents, the next step in this research line is to investigate the production of cellular materials further, understanding the foaming mechanisms and being able to control the cellular structure. To achieve these goals, two theses started simultaneously at CellMat in 2014. The first one, developed parallel to this thesis, was mainly focused on analyzing the effects of the processing parameters on the production of nanocellular polymers using homogeneous systems. Some promising results have already been obtained in this research [30,44]. The second thesis, the present one, aimed at investigating the effects of different nucleating agents (nanoparticles and nanostructured polymer blends) on the production of nanocellular polymers, with the goal of finding new systems and production routes that allow obtaining these materials and that could be easily scaled-up to the industry.

\subsection{Objectives}

This investigation has one primary objective and two secondary goals (Figure 1.6). The main objective is the production and characterization of nanocellular polymers taking advantage of the heterogeneous nucleation mechanism, using both nanoparticles and nanostructured polymer blends. After the production, this research aims at understanding the physical mechanisms involved in the formation of these materials. Finally, this thesis attempts to find approaches that could reduce the density of the materials as much as possible, keeping at the same time not very demanding processing conditions that could facilitate a future scaling up of the developed approaches.

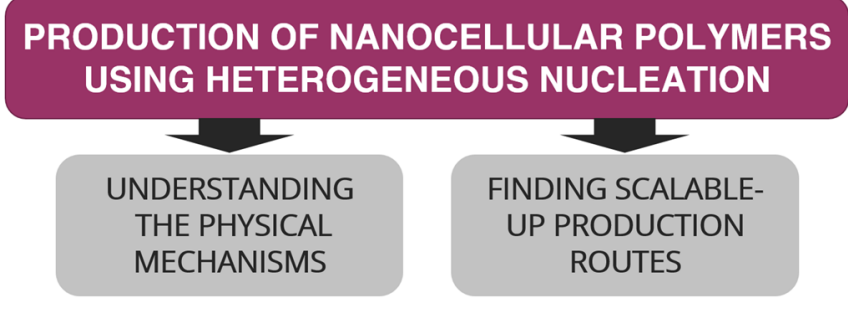

Figure 1.6. General objectives of this thesis.

When a second phase, such as a nucleating agent, is added to a polymer matrix, several effects must be taken into account during the foaming process (Figure 1.7). (A more detailed theoretical background about heterogeneous nucleation and the gas dissolution foaming process can be found in Chapter 2). To begin with, the nucleating agent might modify the nucleation with respect to the pure polymer. In most cases, the addition of a second phase reduces the energy barrier for nucleus formation, promoting higher nucleation [66]. Simultaneously, the nucleating agent is altering the rheological behavior of the polymer. This can have several consequences. First, the 
viscosity of the polymer is affected, and this can tune the surface tension and alter the nucleation. Second, the extensional viscosity is also modified, which can influence the expansion capability of the blend. All these effects would strongly depend on the type of nucleating agent, the concentration added, and the way the nucleating agent is distributed in the matrix. Also, the morphology of the nucleating agent (size and geometry) and its interaction with the gas phase could have an influence. On the other hand, the processing parameters play a role in the resultant cellular material as well. The processing parameters during the saturation stage (that is, while the gas is being absorbed) can affect the nucleation efficiency, that is, for some conditions, the nucleation in the second phase could not be favored compared to the homogeneous nucleation. Further, the saturation conditions determine the amount of gas absorbed in the sample (although the nucleating agent can also affect this parameter if it absorbs more or less gas than the matrix). The amount of gas absorbed also influences the rheology of the blend, and determines the plasticization of the matrix, and these two effects combined with the foaming conditions (temperature and time) affect the cell growth and the expansion. In short, many parameters are varying at the same time during the gas dissolution foaming process, and understanding the effect of the nucleating agent in each of them is mandatory for being able to produce controlled structures.

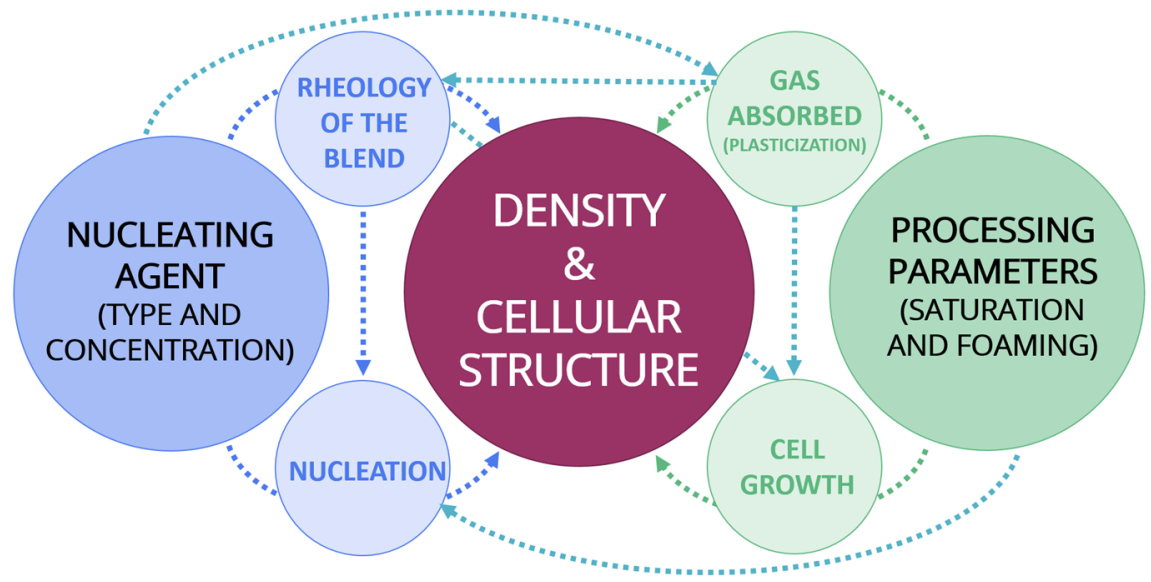

Figure 1.7. Scheme of some of the effects that should be taken into account in the production of a nanocellular polymer using a nucleating agent and the interconnections among them.

As aforementioned, one of the key challenges in the production of nanocellular polymers is to understand the mechanisms implied in their generation fully. Also, providing approaches that could be easily be transferred to the industrial scale is also crucial for the future development and use of nanocellular polymers. For this reason, in this thesis, the following specific objectives are set:

- Evaluate the nucleation effect of various nucleating agents to produce nanocellular polymers.

- Investigate the effect of the processing conditions on aspects such as the nucleation efficiency and the cell growth.

- Optimize the cellular structure of the systems produced with different nucleating agents, regarding the cell size and the density. 
- Find the processing window for the production of these materials, trying to use the fabrication conditions as less demanding as possible while keeping a reduced density and a nanometric cell size.

- Correlate all the previously mentioned parameters for each system, to achieve a deep understanding of the mechanisms involved in the formation of the cellular structure, and evaluate the most promising materials for the possible future industrial production.

To achieve these goals, the effects of different nucleating agents in the foaming behavior of a polymer matrix will be investigated. The polymer matrix chosen is poly(methyl methacrylate) (PMMA) because from the two previous theses carried out at CellMat (and others in the current literature) there was plenty of evidence about the good performance of this polymer to produce nanocellular structures $[56,57]$. Regarding the nucleating agents, three nucleating agents have been selected:

1) Sepiolites: These inorganic nanoclays with a needle-like morphology are used in several applications [67], including nucleation of conventional and microcellular polymers [68,69]. However, there were no previous works about the use of these particles in the production of nanocellular polymers. In this thesis, the nucleating effect of sepiolites in PMMA to achieve nanometric cells is investigated for the first time. Several sepiolites with different surface treatments have been considered. Other effects, such as the concentration of sepiolites and the influence of the processing conditions will also be analyzed. Further, as the sepiolites present an anisotropic structure, the possibility of producing anisotropic nanocellular materials will be evaluated. Finally, the mechanical properties of the cellular materials will be tested. The specific objectives for the PMMA/Sepiolites systems are summarized in Figure 1.8, whereas the results of this research are collected in Chapter 4, Chapter 6 and Chapter 7.

2) MAM: MAM is a tri-block copolymer with structure PMMA-PBA-PMMA (PBA: poly(butyl acrylate). It can self-assembly and form nanometric micelles when blended with PMMA. CellMat Laboratory was a pioneer in the use of MAM to produce nanocellular polymers in the Ph.D. of Dr. Pinto [56]. The present thesis aims at going a step forward in the analysis of this material as a promising nucleating agent. In particular, three MAM grades with different molecular weights will be used. The main challenge is to overcome the current limitation associated with the use of template structures (such as the MAM micelle nanostructuration) to produce nanocellular materials with reduced density. Also, it would be interesting to produce nanocellular polymers with as low MAM content as possible and also using a low saturation pressure. The specific goals for the PMMA/MAM systems are listed in Figure 1.8, and the results can be found in Chapter 5 and Chapter 6 .

3) TPU: Thermoplastic polyurethane (TPU) is a linear thermoplastic elastomer. It has been recently proved to be a suitable nucleating agent for PMMA since the immiscible PMMA/TPU blend results in nanometric TPU domains that can favor the nucleation process [70]. However, at the moment this thesis is written, there is only one paper dealing with the production of nanocellular polymers using TPU as nucleating phase. For this reason, in this thesis, we aim at gaining knowledge about this new nucleating agent, by evaluating the effect of the addition of TPU and the influence of the processing parameters. These objectives are summarized in Figure 1.8. The results from this research are also included in Chapter 5. 
The combined effect of two of these nucleating agents will also be evaluated by producing tri-phasic PMMA/MAM/sepiolites blends. To our knowledge, this is the first time that two different nucleation strategies (nanoparticles and nanostructured polymer blends) are combined. The specific goals of this research can be found in Figure 1.8, while the results are included in Chapter 6 .

Finally, one of the most interesting properties of nanocellular polymers is the reduced thermal conduction through the gas phase. However, sometimes bimodal structures combining micrometric and nanometric pores appear, and it is necessary to provide a model to understand the thermal conductivity of the bimodal structure. Therefore, in this thesis, we aim at developing a new model to describe the thermal conduction of nanocellular polymers with a bimodal cellular structure and to correlate the model with experimental data of real bimodal systems (Figure 1.8). The results of this research are presented in Chapter 7.

\begin{tabular}{|c|c|c|c|}
\hline Chapters 4,6,7 & \multicolumn{2}{|l|}{ Chapter 5,6 } & Chapter 5 \\
\hline 1) PMMA/sepiolites & \multicolumn{2}{|c|}{ 2) PMMA/MAM } & 3) PMMA/TPU \\
\hline $\begin{array}{l}\text { Investigate the effects of: } \\
\text { - The surface modification } \\
\text { - The sepiolite concentration } \\
\text { nucleation efficiency } \\
\text { - The foaming temperature } \\
\text { - The sepiolites on the mechanical } \\
\text { properties } \\
\text { Challenges: } \\
\text { - Possibility of producing } \\
\text { anisotropic structures }\end{array}$ & \multicolumn{2}{|c|}{$\begin{array}{l}\text { Investigate the effects of: } \\
\text { - The molecular weight of MAM } \\
\text { - The concentration of MAM } \\
\text { - The saturation pressure in the } \\
\text { nucleation efficiency } \\
\text { - The foaming temperature } \\
\text { Challenges: } \\
\text { - Nanocellular structures with low } \\
\text { MAM contents } \\
\text { - Reduce the density using this } \\
\text { strategy }\end{array}$} & $\begin{array}{l}\text { Investigate the effects of: } \\
\text { - The addition of TPU } \\
\text { - The saturation pressure in the } \\
\text { nucleation efficiency } \\
\text { - The foaming temperature and } \\
\text { time } \\
\text { Challenges: } \\
\text { - Gain knowledge about this new } \\
\text { approach } \\
\text { - Produce low-density } \\
\text { nanocellular materials }\end{array}$ \\
\hline \multicolumn{2}{|c|}{ 4) PMMA/MAM/sepiolites } & \multicolumn{2}{|c|}{$\begin{array}{l}\text { Bimodal systems based on } \\
\text { PMMA/MAM and PMMA/sepiolites }\end{array}$} \\
\hline \multicolumn{2}{|c|}{$\begin{array}{l}\text { Investigate the effects of: } \\
\text { - The concentration of MAM } \\
\text { - The addition of sepiolite } \\
\text { - The nucleation process in each nucleating agent } \\
\text { Challenges: } \\
\text { - Possibility of producing anisotropic structures }\end{array}$} & \multicolumn{2}{|c|}{$\begin{array}{l}\text { - Determine the thermal conductivity of nanocellular } \\
\text { polymers with bimodal cellular structures } \\
\text { Challenges: } \\
\text { - Model the heat transfer by conduction in bimodal } \\
\text { structures } \\
\text { - Correlate the model and the experiments }\end{array}$} \\
\hline
\end{tabular}

Figure 1.8. Specific objectives of this thesis for the different systems investigated and the chapters in which these studies are explained.

\subsection{Structure of the Thesis}

This thesis is written as a compendium of publications. Nine papers sent to international journals are included in this work. From these papers, six of them have already been published, while the other three are still pending of acceptance. These papers are included in Chapter 4, Chapter 5, Chapter 6 and Chapter 7. Moreover, this thesis fulfills the requirements to be accredited with the International Mention. The structure of the chapters with their corresponding scientific publications is schematically presented in Figure 1.9. 


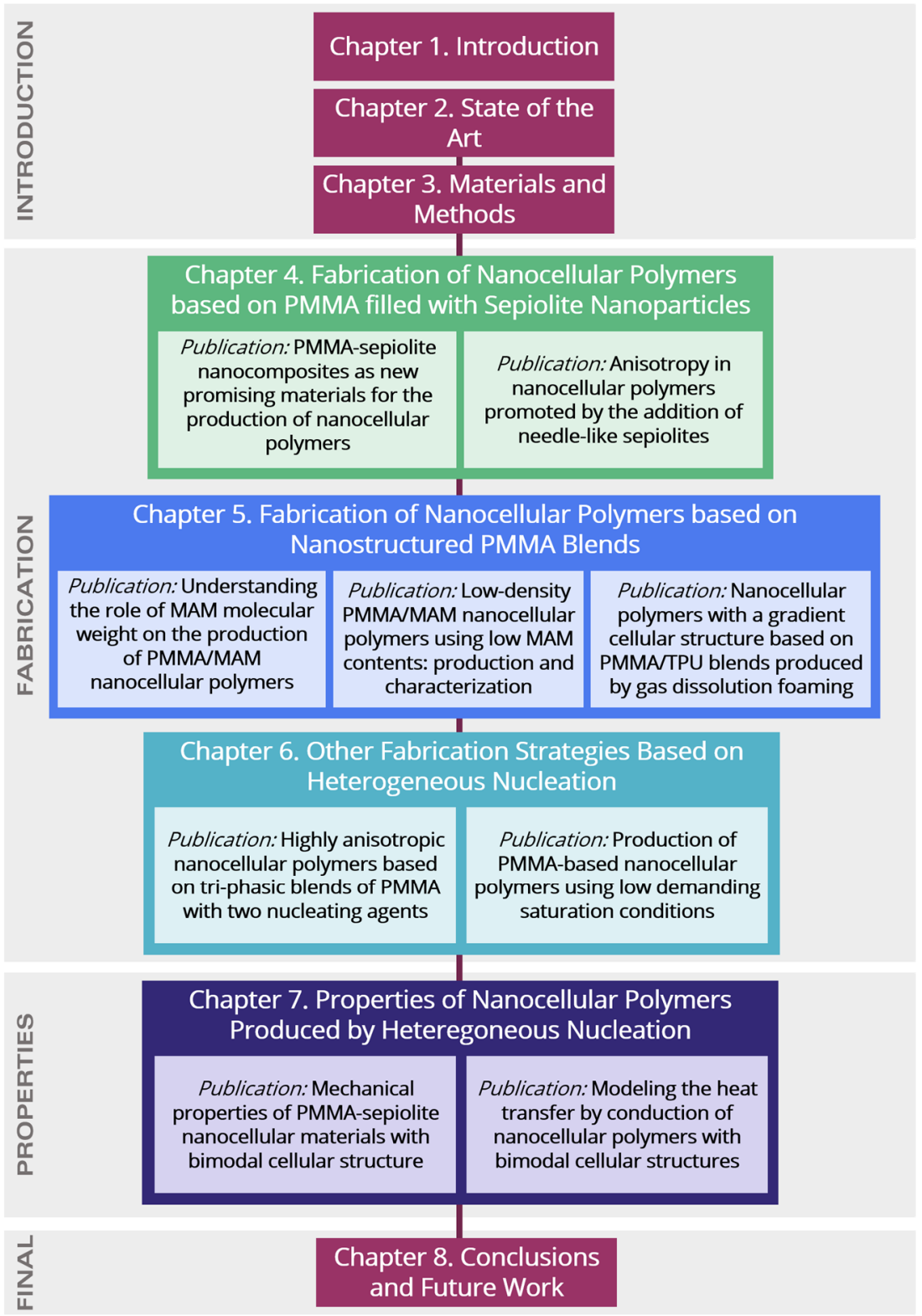

Figure 1.9. Overview of the chapters and scientific publications.

The thesis is divided into eight chapters containing the following information:

Chapter 1 presents the framework of this thesis, with a brief introduction to the research topic and its relevance in CellMat Laboratory, the objectives and a schematic view of the structure of the thesis. Also, the scientific articles, conferences and other relevant works derived from this research are listed.

Chapter 2 shows a detailed analysis of the state of the art about the production and properties of nanocellular polymers. Data from the most relevant literature in this field is presented in several comparative maps.

Chapter 3 describes the raw materials used in this research and the different techniques used to produce and characterize the nanocellular materials produced. 
Chapter 4 presents the results obtained with the blends based on PMMA with nanometric sepiolites. Two scientific publications are included. Several effects are analyzed: the influence of the surface modification of the sepiolites, the concentration of sepiolite, and also the effect of the processing conditions in the structure. Besides, anisotropic nanocellular polymers are produced. The nucleation mechanisms involved in the formation of these PMMA/Sepiolites nanocellular polymers are discussed.

Chapter 5 contains the results concerning the use of nanostructured polymer blends. This chapter includes three publications. Two of them are related to PMMA/MAM blends. In these papers, the effects of the MAM molecular weight and concentration are investigated. The physical mechanisms related to the formation of the structures are analyzed in detail. Further, the third paper is about the use of TPU as a nucleating agent for the production of nanocellular polymers.

Chapter 6 merges some of the results of two previous chapters with other fabrication routes. This chapter includes two short communications. The first one is about tri-phasic blends, combining sepiolites and MAM and analyzing the structures obtained with these systems. The second one deals with the production of nanocellular polymers using low pressures.

Chapter 7 includes two more papers related to some properties of the materials obtained in the previous chapters. In one paper, the mechanical properties of PMMA/Sepiolites nanocellular systems are investigated (this research was carried out in collaboration with the University of Cambridge during an international research stay). The second paper presents a model to characterize the thermal conductivity by conduction of bimodal nanocellular polymers, a model that is validated using real bimodal systems based on PMMA/Sepiolites and PMMA/MAM blends.

Chapter 8 presents the main conclusions of this research. Moreover, the results of this thesis are compared with the literature in various comparative maps. Finally, some guidelines for future work are listed at the end of this thesis.

\subsection{Publications, Conferences and Courses}

\subsubsection{Publications}

The scientific publications generated during the development of this thesis are summarized in Table

1.1. These publications are included in the corresponding chapter (Figure 1.9).

Table 1.1. Publications in international journals included in this thesis.

V. Bernardo, J. Martin-de Leon, E. Laguna-Gutierrez, M. A. Rodriguez-Perez

PMMA-sepiolite nanocomposites as new promising materials for the production of nanocellular polymers

European Polymer Journal 2017, 96, 10-26

V. Bernardo, J. Martin-de León, M. A. Rodriguez-Perez

Anisotropy in nanocellular polymers promoted by the addition of needle-like sepiolites

Polymer International 2019, 68, 1204-1214 


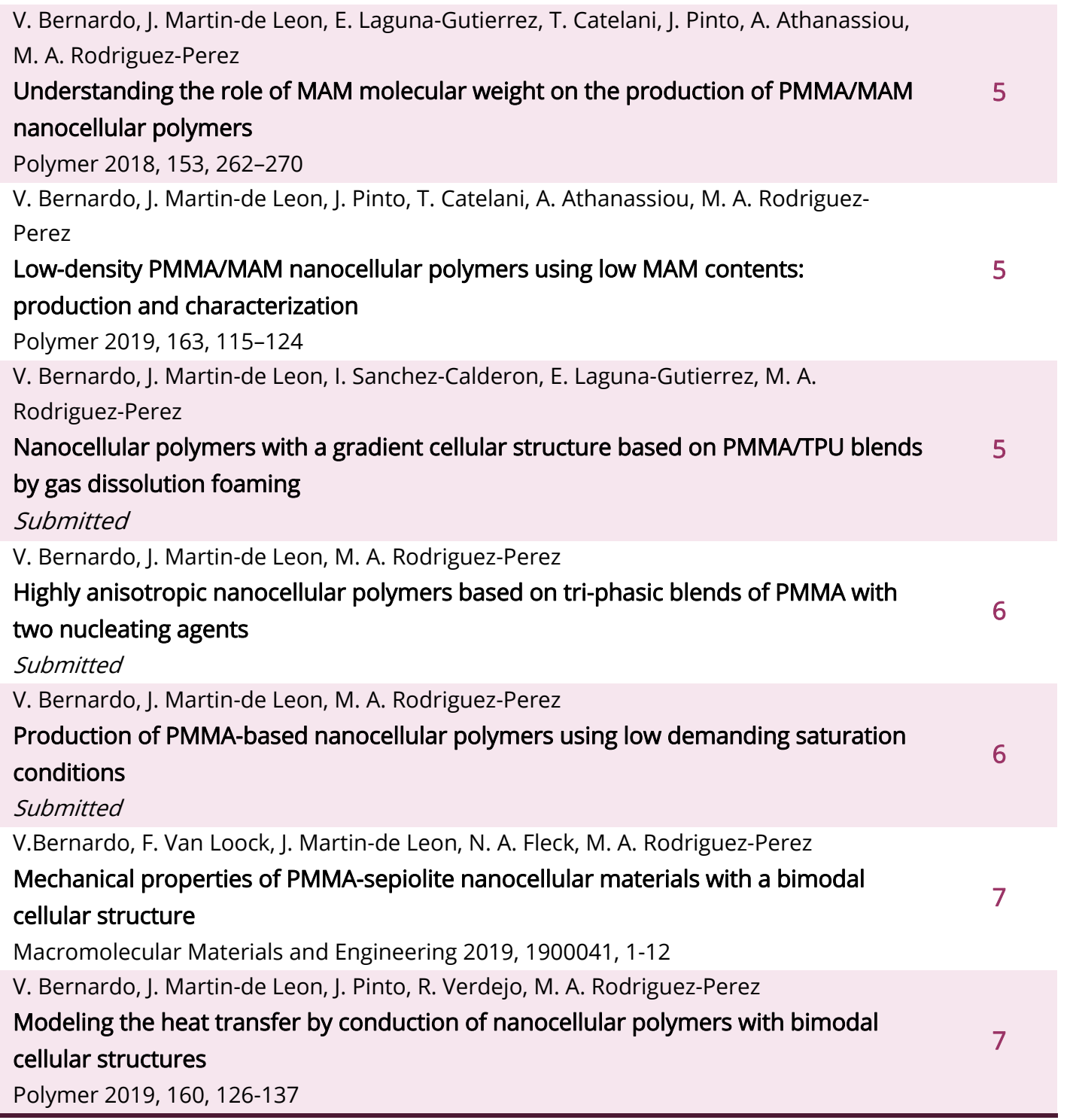

In addition to the previous publications, Table 1.2 collects other scientific publications published during the development of this thesis that are related to the production of nanocellular polymers and in which the author of this thesis has collaborated. Moreover, Table 1.3 includes another work not directly related to the fabrication of nanocellular polymers, but that belongs to the field of cellular polymers and in which the author of this thesis is the first author.

Table 1.2. Other publications related to the production of nanocellular polymers.

Publication reference

J. Martin-de Leon, V. Bernardo, P. Cimavilla-Román, S. Pérez-Tamarit, M. A. Rodriguez-Perez

Overcoming the Challenge of Producing Large and Flat Nanocellular Polymers: A Study with PMMA

Advanced Engineering Materials 2019, 1900148, 1-8

J. Martin-de Leon, V. Bernardo, M. A. Rodriguez-Perez

Nanocellular polymers: the challenge of creating cells in the nanoscale

Materials 2019, 12, 797

J. Martin-de Leon, V. Bernardo, M. A. Rodriguez-Perez

Transparent Nanocellular PMMA: Characterization and Modeling of the Optical Properties

Polymer 2019, 170, 16-23 
J. Martin-de Leon, V. Bernardo, M. A. Rodriguez-Perez

Key Production Parameters to Obtain Transparent Nanocellular PMMA

Macromolecular Materials and Engineering 2017, 1700343(1)-1700343(5)

J. Pinto, D. Morselli, V. Bernardo, B. Notario, D. Fragouli, M. A. Rodriguez-Perez, A. Athanassiou

Nanoporous PMMA foams with templated pore size obtained by localized in situ synthesis of nanoparticles and $\mathrm{CO}_{2}$ foaming

Polymer 2017, 124, 176-185

J. Martin-de Leon, V. Bernardo, M. A. Rodriguez-Perez

Low Density Nanocellular Polymers Based on PMMA Produced by Gas Dissolution Foaming:

Fabrication and Cellular Structure Characterization

Polymers 2016, 8, 1-16

V. Bernardo, J. Martin-de Leon, M. A. Rodriguez-Perez

Production and characterization of nanocellular polyphenylsulfone foams

Materials Letters 2016, 178, 155-158

Table 1.3. Other publications in the field of cellular polymers.

\section{Publication reference}

V. Bernardo, E. Laguna-Gutierrez, A. Lopez-Gil, M. A. Rodriguez-Perez

Highly anisotropic crosslinked HDPE foams with a controlled anisotropy ratio: Production and characterization of the cellular structure and mechanical properties

Materials and Design 2016, 114, 83-91

\subsubsection{Conferences}

The results of this thesis have been presented in several international and national conferences (Table 1.4). In addition, some of these works were awarded during the conference.

Table 1.4. Contributions to international and national conferences and awards received.

\section{Conference contributions}

V. Bernardo, J. Martín-de León, I. Sánchez-Calderón, E. Laguna-Gutiérrez, M. Á. Rodríguez-Pérez. Fabrication of low-density nanocellular polymers using PMMA/TPU blends. CellMAT 2018, Bad Staffelstein, Germany, October 2018, Oral communication

V. Bernardo, J. Martín-de León, F. Van Loock, N. Fleck, P. Cimavilla-Roman, S. Perez-Tamarit, M. Á. Rodríguez-Pérez

Nanocellular polymers based on PMMA/sepiolite nanocomposites: characterization of the mechanical behaviour

CellMAT 2018, Bad Staffelstein, Germany, October 2018, Poster

M.A. Rodríguez Pérez, J. Pinto, V. Bernardo, J. Martin-de Leon

Nanocellular polymers. Novel approaches to produce these materials using gas dissolution foaming

CellMAT 2018, Bad Staffelstein, Germany, October 2018, Key note lecture

J. Martín-de León, V. Bernardo, J. L. Pura, M. Á. Rodríguez-Pérez

Nanocellular polymers based on PMMA: Recent approaches to produce these materials with improved cellular structures and properties

FOAMS2018, Montreal, Canada, September 2018, Oral communication

V. Bernardo, J. Martín-De León, J. Pinto, T. Catelani, M. A. Rodríguez-Pérez

Effect of the Amount of Block-Copolymer on the Density and Cellular Structure of Nanocellular

Polymers Based on PMMA/MAM Blends 
FOAMS2017, Bayreuth, Germany, October 2017, Poster

Award: Michael Reedy Student Scholarship 2017

J. Martín-De León, V. Bernardo, S. Perez-Tamarit, M. A. Rodríguez-Pérez

Production and properties of low density nanocellular PMMA with controlled density and cellular structure

Poly-Foam 2017 Conference, Hilton Main, Germany, April 2017, Oral communication

V. Bernardo, J. Martín-De León, M. A. Rodríguez-Pérez, J. Pinto, S. Barroso, T. Catelani, D. Fragouli,

A. Athanassiou

Nanocellular polymers based on PMMA/MAM blends: effect of the copolymer chemistry on the nanostructuration and the cellular structure

FOAMS2016, Seattle, USA, September 2016, Poster

Award: Poster Second Place winner

V. Bernardo, J. Martín-De León, M. A. Rodríguez-Pérez

Needle-like nanoparticles as a new nucleating agent in CO2-foaming of nanocellular PMMA

FOAMS2016, Seattle, USA, September 2016, Poster

\section{Award: Michael Reedy Student Scholarship 2016}

J. Martín-De León, V. Bernardo, S. Perez-Tamarit, M. A. Rodríguez-Pérez

Low density nanocellular foams based on PMMA: production, structure and properties

FOAMS2016, Seattle, USA, September 2016, Oral communication

V. Bernardo, J. Martín-De León, M. A. Rodríguez-Pérez

Production of nanocellular materials from nanostructured polymers based on PMMA/MAM blends: influence of the polymer morphology on the cellular structure

XIV Reunión del GEP de la RSEQ y RSEF, Burgos, Spain, September 2016, Oral communication

M. A. Rodríguez-Pérez, B. Notario, J. Pinto, V. Bernardo, J. Martín-de León

Nanocellular polymers: a new class of materials with enhanced properties

XIV Reunión del GEP de la RSEQ y RSEF, Burgos, Spain, September 2016, Plenary talk

V. Bernardo, J. Martín-De León, M. A. Rodríguez-Pérez

Sepiolites as nucleating agent in PMMA nanofoams

EsMolNa 2015, Paris, France, October 2015, Oral communication

V. Bernardo, J. Martín-De León, S. Pérez-Tamarit, E. Solórzano, M. A. Rodríguez-Pérez

Cellular Structure, Properties and Applications of Nanoporous Materials

Metfoam 2015, Barcelona, Spain, August 2015, Poster

V. Bernardo, J. Martín-De León, J. Pinto, M. A. Rodríguez-Pérez

Nanostructured materials and nanoporous foams

XVI Escuela Nacional de Materiales Moleculares, Santa Pola, Spain, February 2015, Oral

communication

Moreover, Table 1.5 summarizes other contributions to international and national conferences non-related to the results of this thesis in which the author of this thesis has contributed.

Table 1.5. Other contributions to international and national conferences.

\section{Conference contributions}

J. Martín-de León, V. Bernardo, J. L. Pura, M. Á. Rodríguez-Pérez

Understanding the behaviour of semi-transparent nanocellular PMMA: study of the transmittance and modelling

CellMAT 2018, Bad Staffelstein, Germany, October 2018, Oral communication

J. Pinto, D. Morselli, V. Bernardo, B. Notario, D. Fragouli, A. Athanassiou, M.A. Rodríguez Pérez Localized in situ synthesis of nanoparticles as a promising route for the development of templated PMMA foams by gas dissolution foaming

CellMAT 2018, Bad Staffelstein, Germany, October 2018, Oral communication 
M. Mugica, V. Bernardo, J. Martin-de Leon, C. Saiz-Arroyo, M.A. Rodríguez Pérez

Production of microcellular PMMA using the bead foaming technology

CellMAT 2018, Bad Staffelstein, Germany, October 2018, Poster

J. Martin-de Leon, V. Bernardo, M.A. Rodríguez Pérez

Nanocellular PMMA with tunable cellular structure by changing the rheological behaviour of the

polymer matrix

CellMAT 2018, Bad Staffelstein, Germany, October 2018, Poster

M. Santiago-Calvo, H. Naji, V. Bernardo, J. Martín de León, A. Saiani, F. Villafañe, M.A. Rodríguez

Pérez

Production of thermoplastic polyurethane foams synthesized with different contents of hard segment and graphene nanoplatelets by the gas dissolution foaming process

CellMAT 2018, Bad Staffelstein, Germany, October 2018, Poster

E. López-González, S. Muñoz-Pascual, V. Bernardo, E. Laguna-Gutiérrez, J. Martin-de-Leon, S.

Perez-Tamarit, J. Pinto, M.A. Rodriguez-Perez

Evolution of the practical training in materials physics: from a constrained research in the polymer science field to a multidisciplinary methodology

10th EDULEARN, Palma, Spain, July 2018, Oral communication

S. Perez-Tamarit, J. Martin-de-Leon, V. Bernardo, E. López-González, S. Muñoz-Pascual, J. Pinto, E. Laguna-Gutiérrez, M.A. Rodriguez-Perez

Transferring knowledge from the university to the industry: internships at the university of Valladolid

10th EDULEARN, Palma, Spain, July 2018, Oral communication

M. Santiago-Calvo, H. Naji, V. Bernardo, J. Martín-de León, A. Saiani, F. Villafañe, M. A. Rodríguez-

Pérez

Synthesis, characterization and foaming of thermoplastic polyurethane synthesized with different soft/hard segment ratio and graphene nanoplatelet contents

Polymers: Design, Function and Application 2018, Barcelona, Spain, March 2018, Oral

communication

J. Martín-De León, V. Bernardo, S. Pérez-Tamarit, M. A. Rodríguez-Pérez

Semi-Transparent Nanocellular Polymers Based on PMMA: Production and Characterization

FOAMS2017, Bayreuth, Germany, October 2017, Oral communication

J. Martín-De León, V. Bernardo, M. A. Rodríguez-Pérez

Controlled Foaming in a Hot Press of Flat and Large Parts of Nanocellular PMMA

FOAMS2017, Bayreuth, Germany, October 2017, Poster

J. Martín-De León, V. Bernardo, M. A. Rodríguez-Pérez

Description of the process parameters for the production of PPSU nanocellular materials FOAMS2016, Seattle, USA, September 2016, Poster

J. Martín-De León, V. Bernardo, M. A. Rodríguez-Pérez

Understanding the mechanisms that allow reducing density in PMMA nanocellular polymers FOAMS2016, Seattle, USA, September 2016, Poster

J. Martín-De León, V. Bernardo, M. A. Rodríguez-Pérez

Influence of the process parameters in the cellular structure of low density PMMA nanocellular polymers produced by the gas dissolution foaming route

XIV Reunión del GEP de la RSEQ y RSEF, Burgos, Spain, September 2016, Oral communication

J. Martín-De León, V. Bernardo, M. A. Rodríguez-Pérez

Higher nucleation efficiency in polymer foams by improving gas dissolution method

EsMolNa 2015, Paris, France, October 2015, Oral communication

J. Martín-De León, V. Bernardo, S. Pérez-Tamarit, E. Solórzano, M. A. Rodríguez-Pérez

Nanocellular Foams Fabrication Methods by Gas Dissolution Process

Metfoam 2015, Barcelona, Spain, August 2015, Poster

S. Pérez-Tamarit, V. Bernardo, E. Solórzano, J. Martín-De León, M. A. Rodríguez-Pérez

Characterization of the Solid Phase of Cellular Materials by means of X-Ray microCT 
Metfoam 2015, Barcelona, Spain, August 2015, Poster

J. Martín-De León, V. Bernardo, M. A. Rodríguez-Pérez Influencia de la temperatura en la absorción de $\mathrm{CO} 2$ en espumas nanocelulares XVI Escuela Nacional de Materiales Moleculares, Santa Pola, Spain, February 2015, Oral communication

\subsubsection{Research stays, courses and projects}

Table 1.6 summarizes the research stays in other institutions during the development of this thesis. The research stay in the Engineering Department at the University of Cambridge, under the supervision of Prof. Dr. Norman Fleck, lasted three months. During this time, some of the experiments included in Chapter 7 were conducted, resulting in one publication (Table 1.1). The other research stays were in synchrotron facilities to investigate several topics. For instance, the first tomographies of nanocellular polymers with enough resolution were performed during the campaign on the Synchrotron Diamond Light Source. In addition, the first experimental measurements of the extinction coefficient of nanocellular polymers were recently performed at the synchrotron Bessy II.

Table 1.6. Research stays in other institutions.

\section{Location, time and topic}

Synchrotron Bessy II, Helmholtz Zentrum Berlin (Germany) - April 2019

Topic: Measurement of the extinction coefficient of nanocellular polymers

Synchrotron Diamond Light Source (UK) - February 2019

Topic: Ptychotomography of microcellular and sub-microcellular polymers

University of Cambridge (UK) - June 2017 - September 2017

Topic: Mechanical characterization of nanocellular polymers

Synchrotron Bessy II, Helmholtz Zentrum Berlin (Germany) - October 2016

Topic: In-situ experiments of nanoclay intercalation

Several courses on different topics (insulation, packaging, rheology, among others) were attended as part of the training (Table 1.7).

Table 1.7. Attended courses during this thesis.

\section{Title, organizer, location and time}

Jornadas Profesor Antonio de Saja “Envases Plásticos: Fundamentos, Normativa y Tendencias”
Leical, CellMat Technologies - Valladolid, Spain, February 2018
Jornada “Caracterización de Materiales Poliméricos”
Leical, CellMat Technologies - Valladolid, Spain, December 2016
36th Berlin School on Neutron Scattering
Helmholtz Zentrum Berlin - Berlin, Germany, March 2016
Jornada “Aislamiento térmico en edificación”
Leical, Cel/Mat Technologies - Valladolid, Spain, December 2014
Curso teórico-práctico de reología
TA Instruments -Waters Cromatografía, S.A - Madrid, Spain, June 2015
Workshop on X-RAY radioscopy and tomography
Technical University of Berlin - Berlin, Germany, November 2014


Finally, the Ph.D. student was involved in the research activities of the following projects (Table 1.8).

Table 1.8. Participation in other research funded projects.

PUBLIC FUNDING
DESARROLLO Y FABRICACION EN CONTINUO DE AISLANTES TERMICOS AVANZADOS BASADOS EN
POLIMEROS NANOCELULARES
Programa Estatal de I+D+i Orientada a los Retos de la Sociedad - 2016-2019
DESARROLLO DE PLASTICOS SUB-MICROCELULARES Y NANOCELULARES: FABRICACION,
ESTRUCTURA, PROPIEDADES Y POTENCIALES APLICACIONES. MAT2012-34901
ProyeCto Plan Nacionales de Materiales - 2013-2015
DESARROLLO DE UNA NUEVA GENERACIÓN DE AISLANTES TÉRMICOS AVANZADOS BASADOS EN LA
OBTENCIÓN DE ESTRUCTURAS POROSAS NANOCELULARES. VA035U13
JUnta de CaStilla Y LeÓn - 2013-2015
PRIVATE FUNDING
DESARROLLO DE MATERIALES CELULARES LIGEROS Y RESISTENTES MEDIANTE EL CONTROL DE LA
COMPOSICIÓN QUÍMICA Y ESTRUCTURA CELULAR: MATERIALES MICRO Y NANOCELULARES
CELLMAT TECHNOLOGIES SL - 2013-2016
DESARROLLO DE POLÍMEROS NANOCELULARES AVANZADOS
CELLMAT TECHNOLOGIES SL and SABIC - 2014-2016
DESARROLLO DE ESTRATEGÍAS PARA FABRICAR POLÍMEROS NANOCELULARES EN PROCESOS
INDUSTRIALES: EXTRUSIÓN Y PERLITAS EXPANDIDAS
CELLMAT TECHNOLOGIES SL - 2015-2017
DESARROLLO DE NUEVOS MATERIALES CELULARES POLIMÉRICOS
TECHNOFORM BAUTEC - 2013-2016

\subsection{References}

[1] D. Eaves, Handbook of Polymer Foams, Rapra Technology, United Kingdom, 2004.

[2] C. Okolieocha, D. Raps, K. Subramaniam, V. Altstädt, Microcellular to nanocellular polymer foams: Progress (2004-2015) and future directions - A review, Eur. Polym. J. 73 (2015) 500-519. doi:10.1016/j.eurpolymj.2015.11.001.

[3] Marketsandmarkets.com, http://www.marketsandmarkets.com/Market-Reports/foams-market-1011.html, Accesed April 2019. (n.d.).

[4] D. Klempner, K.C. Frisch, Handbook of Polymeric Foams and Foam Technology, 1991.

[5] S.T. Lee, Foam extrusion: principles and practice, CRC Press, 100AD.

[6] M. Sauceau, J. Fages, A. Common, C. Nikitine, E. Rodier, New challenges in polymer foaming: A review of extrusion processes assisted by supercritical carbon dioxide, Prog. Polym. Sci. 36 (2011) 749-766. doi:10.1016/j.progpolymsci.2010.12.004.

[7] D. Raps, N. Hossieny, C.B. Park, V. Altstädt, Past and present developments in polymer bead foams and bead foaming technology, Polymer (Guildf). 56 (2015) 5-19. doi:10.1016/j.polymer.2014.10.078.

[8] F.A. Waldman, The processing of microcellular foam, Massachusetts Institute of Technology, 1980.

[9] J.E. Martini-Vvedensky, N.P. Suh, F.A. Waldman, United States Patent - MICROCELLULAR CLOSED CELL FOAMS AND THEIR METHOD OF MANUFACTURE, 4,473,665, 1984.

[10] J.E. Martini, The production and analysis of microcellular foam, Massachusetts Institute of Technology, 1981.

[11] N.P. Suh, Impact of Microcellular Plastics on Industrial Practice and Academic Research, Macromol. Symp. 
201 (2003) 187-201. doi:10.1002/masy.200351122.

[12] V. Kumar, N.P. Suh, A process for making microcellular parts, Polym. Eng. Sci. 30 (1990) 1323-1329. doi:https://doi.org/10.1002/pen.760302010.

[13] V. Kumar, J. Weller, Production of Microcellular Polycarbonate Using Carbon Dioxide for Bubble Nucleation, J. Eng. Ind. 116 (1994) 413-420. doi:10.1115/1.2902122.

[14] K. Nadella, S. Powers, T. Malone, United States Patent - METHODS AND PRESSURE VESSELS FOR SOLID-STATE MICROCELLULAR PROCESSING OF THERMOPLASTIC ROLLS OR SHEETS, US 8,080,194 B2, 2011.

[15] J.A. Reglero Ruiz, C. Saiz-Arroyo, M. Dumon, M.A. Rodríguez-Perez, L. Gonzalez, Production, cellular structure and thermal conductivity of microcellular (methyl methacrylate)-(butyl acrylate)-(methyl methacrylate) triblock copolymers, Polym. Int. 60 (2011) 146-152. doi:10.1002/pi.2931.

[16] X. Han, K.W. Koelling, D.L. Tomasko, Continuous Microcellular Polystyrene Foam Extrusion With Supercritical CO2, Polym. 42 (2002) 2094-2106. doi:10.1002/pen.11100.

[17] S.K. Goel, E.J. Beckman, Generation of Microcellular Polymeric Foams Using Supercritical Carbon Dioxide. I: Effect of Pressure and Temperature on Nucleation, Polym. Eng. Sci. 34 (1994) 1137-1147. doi:10.1002/pen.760341407.

[18] M.R. Holl, J.L. Garbini, W.R. Murray, V. Kumar, A steady-state mass balance model of the polycarbonate-CO2 system reveals a self-regulating cell growth mechanism in the solid-state microcellular process, J. Polym. Sci. Part B Polym. Phys. 39 (2001) 868-880. doi:10.1002/polb.1061.

[19] J.E. Weller, V. Kumar, Solid-State Microcellular Polycarbonate Foams II. The Effect of Cell Size on Tensile Properties, Polym. Eng. Sci. 50 (2010) 2170-2175. doi:10.1002/pen.

[20] V. Kumar, M. Vanderwel, J. Weller, K.A. Seeler, Experimental Characterization of the Tensile Behavior of Microcellular Polycarbonate Foams, J. Eng. Mater. Technol. 116 (1994) 439-445. doi:10.1115/1.2904310.

[21] J. Fu, C. Jo, H.E. Naguib, Effect of Processing Parameters on Cellular Structures and Mechanical Properties of PMMA Microcellular Foams, Cell. Polym. 24 (2005) 177-195. doi:10.1177/026248930502400401.

[22] B. Notario, J. Pinto, M.A. Rodriguez-Perez, Nanoporous polymeric materials: A new class of materials with enhanced properties, Prog. Polym. Sci. 78-79 (2016) 93-139. doi:10.1016/j.pmatsci.2016.02.002.

[23] M. Knudsen, The Kinetic Theory of Gases, Methuen, London, 1934.

[24] S. Song, M.M. Yovanovich, F.O. Goodman, Thermal Gap Conductance of Conforming Surfaces in Contact, J. Heat Transfer. 115 (1993) 533-540. doi:10.1115/1.2910719.

[25] B. Notario, J. Pinto, E. Solorzano, J.A. de Saja, M. Dumon, M.A. Rodriguez-Perez, Experimental validation of the Knudsen effect in nanocellular polymeric foams, Polymer (Guildf). 56 (2015) 57-67. doi:10.1016/j.polymer.2014.10.006.

[26] S. Liu, J. Duvigneau, G.J. Vancso, Nanocellular polymer foams as promising high performance thermal insulation materials, Eur. Polym. J. 65 (2015) 33-45. doi:10.1016/j.eurpolymj.2015.01.039.

[27] J. Pinto, B. Notario, R. Verdejo, M. Dumon, S. Costeux, M.A. Rodriguez-perez, Molecular confinement of solid and gaseous phases of self-standing bulk nanoporous polymers inducing enhanced and unexpected physical properties, Polymer (Guildf). 113 (2017) 27-33. doi:10.1016/j.polymer.2017.02.046.

[28] B. Notario, J. Pinto, M.A. Rodríguez-Perez, Towards a new generation of polymeric foams: PMMA nanocellular foams with enhanced physical properties, Polymer (Guildf). 63 (2015) 116-126. doi:10.1016/j.polymer.2015.03.003.

[29] S. Perez-Tamarit, B. Notario, E. Solorzano, M.A. Rodriguez-Perez, Light transmission in nanocellular polymers: are semi-transparent cellular polymers possible?, Mater. Lett. $210 \quad$ (2017) 39-41. doi:10.1016/j.matlet.2017.08.109.

[30] J. Martin-de Leon, V. Bernardo, M.A. Rodriguez-Perez, Key Production Parameters to Obtain Transparent Nanocellular PMMA, Macromol. Mater. Eng. 1700343 (2017) 1-5. doi:10.1002/mame.201700343.

[31] B. Notario, A. Ballesteros, J. Pinto, M.A. Rodriguez-Perez, Nanoporous PMMA: A novel system with different acoustic properties, Mater. Lett. 168 (2016) 76-79. doi:10.1016/j.matlet.2016.01.037.

[32] B. Notario, J. Pinto, R. Verdejo, M.A. Rodríguez-Pérez, Dielectric behavior of porous PMMA: From the micrometer to the nanometer scale, Polymer (Guildf). 107 (2016) 302-305. doi:10.1016/j.polymer.2016.11.030.

[33] L. Li, L. Schulte, L.D. Clausen, K.M. Hansen, G.E. Jonsson, S. Ndoni, Gyroid nanoporous membranes with 
tunable permeability, ACS Nano. 5 (2011) 7754-7766. doi:10.1021/nn200610r.

[34] J. Pinto, M. Dumon, M.A. Rodriguez-Perez, R. Garcia, C. Dietz, Block Copolymers Self-Assembly Allows Obtaining Tunable Micro or Nanoporous Membranes or Depth Filters Based on PMMA; Fabrication Method and Nanostructures, J. Phys. Chem. C. 118 (2014) 4656-4663. doi:10.1021/jp409803u.

[35] G.Q. Lu, X.S. Zhao, Nanoporous Materials - An Overview, in: Nanoporous Mater. Sci. Eng., Imperial Collegue Press, London, 2004. doi:10.1142/9781860946561_0001.

[36] European Commission, Horizon 2020 Work Programme 2014 - 2015 Science with and for Society, 2015. https://ec.europa.eu/research/participants/data/ref/h2020/wp/2014_2015/main/h2020-wp1415swfs_en.pdf.

[37] European Commission, Horizon 2020 Work Programme 2018 - 2020: 10. Secure, Clean and Efficient Energy, 2017. https://ec.europa.eu/programmes/horizon2020/en/h2020-section/secure-clean-and-efficient-energy.

[38] S. Costeux, CO2-blown nanocellular foams, J. Appl. Polym. Sci. 131 (2014) 41293(1)-41293(16). doi:10.1002/app.41293.

[39] C. Forest, P. Chaumont, P. Cassagnau, B. Swoboda, P. Sonntag, Polymer nano-foams for insulating applications prepared from CO 2 foaming, Prog. Polym. Sci. 41 (2015) 122-145. doi:10.1016/j.progpolymsci.2014.07.001.

[40] D. Miller, P. Chatchaisucha, V. Kumar, Microcellular and nanocellular solid-state polyetherimide ( PEI ) foams using sub-critical carbon dioxide I. Processing and structure, Polymer (Guildf). 50 (2009) 5576-5584. doi:10.1016/j.polymer.2009.09.020.

[41] H. Guo, Solid-state Polymer Nanofoams, University of Washington, 2015.

[42] H. Guo, V. Kumar, Some thermodynamic and kinetic low-temperature properties of the PC-CO2 system and morphological characteristics of solid-state PC nanofoams produced with liquid CO2, Polymer (Guildf). 56 (2015) 46-56. doi:10.1016/j.polymer.2014.09.061.

[43] S. Costeux, I. Khan, S.P. Bunker, H.K. Jeon, Experimental study and modeling of nanofoams formation from single phase acrylic copolymers, J. Cell. Plast. 51 (2015) 197-221. doi:10.1177/0021955X14531972.

[44] J. Martin de-Leon, V. Bernardo, M.A. Rodriguez-Perez, Low Density Nanocellular Polymers Based on PMMA Produced by Gas Dissolution Foaming: Fabrication and Cellular Structure Characterization, Polymers (Basel). 8 (2016) 1-16. doi:10.3390/polym8070265.

[45] H. Guo, A. Nicolae, V. Kumar, Solid-State Microcellular and Nanocellular Polysulfone Foams, J. Polym. Sci. Part B Polym. Phys. 53 (2015) 975-985. doi:10.1002/polb.23719.

[46] J. Pinto, M. Dumon, M.A. Rodriguez-Perez, Nanoporous Polymer Foams from Nanostructured Polymer Blends: Preparation, Characterization, and Properties, in: P.. Visakh, G. Markovic, D. Pasquini (Eds.), Recent Dev. Polym. Macro, Micro Nano Blends, Woodhead Publishing in Materials, 2016: pp. 237-288.

[47] CellMat Laboratory Webpage, Accesed April 2019. (n.d.). http://cellmat.es/.

[48] M.Á. Rodríguez-Pérez, PROPIEDADES TÉRMICAS Y MECÁNICAS DE ESPUMAS DE POLIOLEFINAS, University of Valladolid, 1998.

[49] O. Almanza, Caracterización y Modelización de las Propiedades Térmicas y Mecánicas de Espumas con Base Polietileno, University of Valladolid, 2000.

[50] J.I. Velasco, A.B. Martínez, D. Arencón, M.A. Rodríguez-Pérez, J.A. De Saja, Application of instrumented falling dart impact to the mechanical characterization of thermoplastic foams, J. Mater. Sci. 34 (1999) 431-438. doi:10.1023/A:1004565822502.

[51] M.A. Rodriguez-Perez, J.A. de Saja, The effect of blending on the physical properties of crosslinked closed cell polyethylene foams, Cell. Polym. 18 (1999) 1-20.

[52] C. Saiz-Arroyo, Fabricación de Materiales Celulares Mejorados Basados en Poliolefinas. Relación ProcesadoComposición-Estructura-Propiedades, University of Valladolid, 2002.

[53] C. Saiz-Arroyo, M.A. Rodriguez-Perez, J. Tirado, A. López-Gil, J.A. de Saja, Structure-property relationships of medium-density polypropylene foams, Polym. Int. 62 (2013) 1324-1333. doi:10.1002/pi.4424.

[54] J.E. Arconada, Polyolefin Based Cellular Materials . Development of New Production Routes and Optimization of Barrier and Mechanical Properties By the Addition of Nanoclays, University of Valladolid, 2015.

[55] E. Laguna-Gutiérrez, Understanding the Foamability of Complex Polymeric Systems By Using Extensional Rheology, University of Valladolid, 2016. 
[56] J. Pinto, Fabrication and Characterization of Nanocellular Polymeric Materials from Nanostructured Polymers, University of Valladolid, 2014.

[57] B. Notario, Fabrication and Characterization of the Physical Properties of Nanocellular Polymers: the Transition from the Micro to the Nanoscale., University of Valladolid, 2016.

[58] S. Pardo Alonso, X-Ray Imaging Applied to the Characterization of Polymer Foams' Cellular Structure and Its Evolution, University of Valladolid, 2014.

[59] E. Laguna-Gutierrez, C. Saiz-Arroyo, J.I. Velasco, M.A. Rodriguez-Perez, Low density polyethylene/silica nanocomposite foams. Relationship between chemical composition, particle dispersion, cellular structure and physical properties, Eur. Polym. J. 81 (2016) 173-185. doi:10.1016/j.eurpolymj.2016.06.001.

[60] S. Estravís, J. Tirado-Mediavilla, M. Santiago-Calvo, J.L. Ruiz-Herrero, F. Villafañe, M.Á. Rodríguez-Pérez, Rigid polyurethane foams with infused nanoclays: Relationship between cellular structure and thermal conductivity, Eur. Polym. J. 80 (2016) 1-15. doi:10.1016/j.eurpolymj.2016.04.026.

[61] H. Ventura, Development of New Composites Reinforced Lightweight Green Structures of Flax With Nonwoven Fibres, Universitat Politècnica de Catalunya, 2017.

[62] A. López Gil, Development of Environmentally Friendly Cellular Polymers for Packaging and Structural Applications. Study of the Relationship Cellular Structure-Mechanical Properties, University of Valladolid, 2016.

[63] J. Pinto, M. Dumon, M. Pedros, J. Reglero, M.A. Rodriguez-Perez, Nanocellular CO2 foaming of PMMA assisted by block copolymer nanostructuration, Chem. Eng. J. 243 (2014) 428-435. doi:10.1016/j.cej.2014.01.021.

[64] J. Pinto, S. Pardo, E. Solórzano, M.A. Rodríguez-Pérez, M. Dumon, J.A. de Saja, Solid Skin Characterization of PMMA/MAM Foams Fabricated by Gas Dissolution Foaming over a Range of Pressures, Defect Diffus. Forum. 326-328 (2012) 434-439. doi:10.4028/www.scientific.net/DDF.326-328.434.

[65] J. Pinto, J.A. Reglero-Ruiz, M. Dumon, M.A. Rodriguez-Perez, Temperature influence and CO2 transport in foaming processes of poly(methyl methacrylate)-block copolymer nanocellular and microcellular foams, J. Supercrit. Fluids. 94 (2014) 198-205. doi:10.1016/j.supflu.2014.07.021.

[66] V.I. Kalikmanov, Nucleation Theory, Springer, 2013.

[67] A. Alvarez, J. Santaren, A. Esteban-Cubillo, P. Aparicio, Development in Palygorskite-Sepiolite Research, Elsevier, 2011.

[68] D. Killeen, M. Frydrych, B. Chen, Porous poly (vinyl alcohol)/ sepiolite bone scaffolds: Preparation, structure and mechanical properties, Mater. Sci. Eng. C. 32 (2012) 749-757. doi:10.1016/j.msec.2012.01.019.

[69] J. Santaren, A. Alvarez, A. Esteban-Cubillo, B. Notario, D. Velasco, M.A. Rodriguez-Perez, Improving the Cellular Structure and Thermal Conductivity of PS Foams by Using Sepiolites, in: Foams2012, 2012: pp. 1-5.

[70] G. Wang, J. Zhao, L.H. Mark, G. Wang, K. Yu, C. Wang, C.B. Park, G. Zhao, Ultra-tough and super thermalinsulation nanocellular PMMA/TPU, Chem. Eng. J. 325 (2017) 632-646. doi:10.1016/j.cej.2017.05.116. 

Chapter 2.

State of the Art 



\section{Chapter 2. State of the Art}

\subsection{Nanocellular polymers}

\subsubsection{General description and relevance}

Nanocellular polymers are a new generation of cellular materials characterized by cell sizes in the nanometric range. These materials have aroused great interest in the Material Science research community due to their outstanding and promising combination of properties [1]. Figure 2.1 shows examples of the typical microscopic structures of various nanocellular polymers.
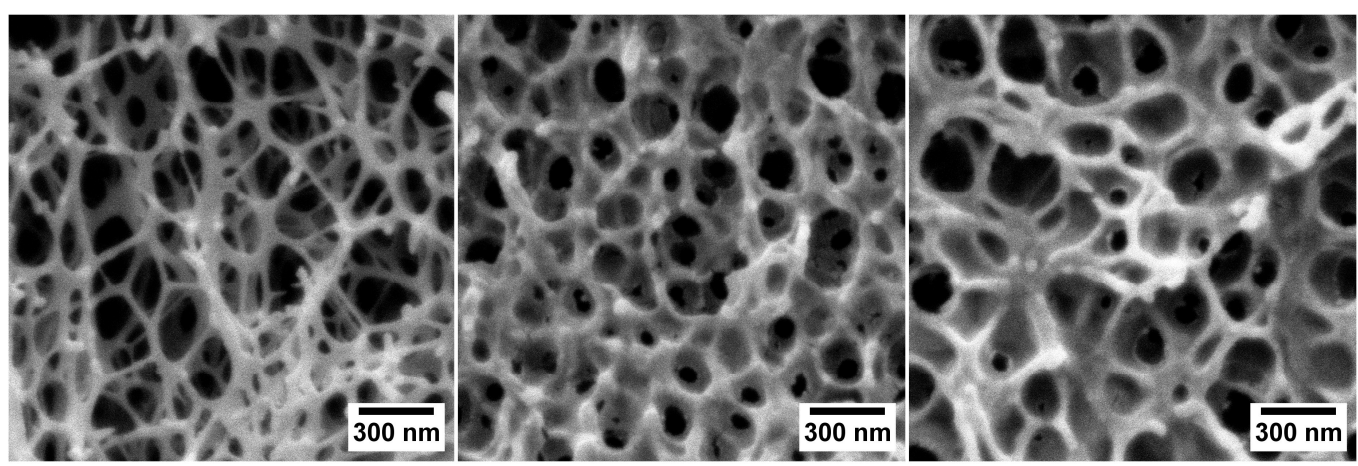

Figure 2.1. Examples of micrographs of three different nanocellular polymers.

The reduction of the cell size to the nanometric range implies a double confinement effect. On the one hand, the polymer chains are confined in very thin cell walls, smaller than $100 \mathrm{~nm}$. Typical cell wall thicknesses of nanocellular materials are in the range from 20 to $60 \mathrm{~nm}[2,3]$. That is, the polymer macromolecules are stretched in regions of a size smaller than their length. As a consequence of this confinement effect of the solid phase, new and unexpected effects appear in nanocellular polymers. On the one hand, it has been observed that the glass transition temperature increases in nanocellular polymers as a result of the reduced mobility of the polymer chains [2,4]. Also, the dielectric behavior of nanocellular polymers is significantly different from that of microcellular materials due to the confinement effect [5]. Finally, the mechanical behavior of nanocellular polymers can be affected as well by the reduction of the cell wall thickness to the nanometric range [3].

On the other hand, the gas inside the cells is also confined in nanometric voids. In a nanocellular polymer, the mean free path of the gas molecules is comparable to the cell size, and thus new effects appear. In particular, the Knudsen effect is well-known to take place in nanocellular polymers, resulting in a drastic reduction of the thermal conductivity [6-8].

Another interesting effect related to the presence of nanometric cells is the possibility of obtaining transparent cellular materials when the cell size becomes much smaller than the wavelength of the visible light $[9,10]$. Moreover, the nanometric cell size involves a very high surface area, and due to this, nanocellular polymers could be used in some specific applications such as catalysis and sensors [11,12]. Finally, open nanocellular structures could be employed as membranes for micro and ultrafiltration [13]. 
The criterion to determine when a cellular material can be considered as nanocellular is still not overall established and varies among authors. However, it should be related to the effects associated with the change of scale to the nanometric range, so the criteria to speak about a nanocellular material should differ for the different properties of these materials. For instance, thermal conductivity starts to significantly decrease from cell sizes of $500 \mathrm{~nm}[6,14]$, whereas to obtain semi-transparent nanocellular polymers cell sizes as low as $50 \mathrm{~nm}$ are required $[2,10]$. Therefore, nanocellular polymers can be applied in various applications depending on their cell size (Figure 2.2).

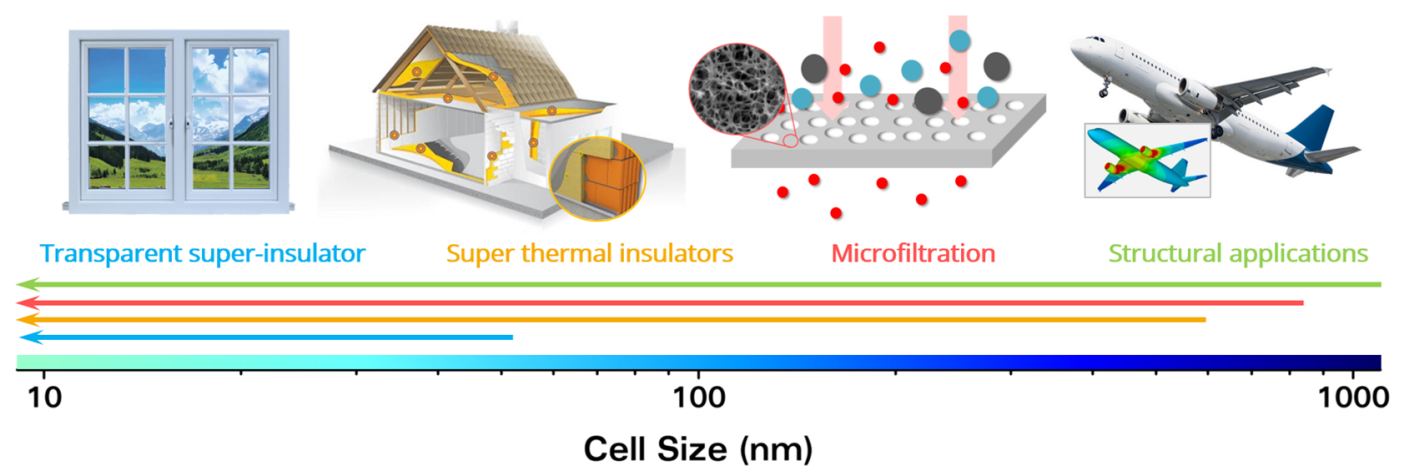

Figure 2.2. Scheme of some potential applications of nanocellular polymers and cell sizes in which these materials provide improved properties in comparison with cellular materials with larger cell sizes.

\subsubsection{Structural parameters}

The main parameter describing any cellular polymer is its relative density, $\rho_{r}$, defined as the ratio between the density of the cellular material, $\rho$, and the density of the solid precursor, $\rho_{s}$ (equation (2.1)):

$$
\rho_{r}=\frac{\rho}{\rho_{s}}
$$

The relative density of a nanocellular polymer can determine its range of application. For instance, high-density materials (relative density above 0.7 ) are suitable for structural applications, whereas low-density nanocellular polymers (relative density below 0.2 ) would behave as very efficient thermal insulators.

Another crucial descriptor in a nanocellular structure is the cell nucleation density, that is, the number of nucleation points in the solid material. Assuming that every nucleus in the solid material results in a cell, the cell nucleation density, $N_{0}$, can be calculated from the cell density, $N_{v}$ (number of cells per unit of volume of the cellular material) according to equation (2.2):

$$
N_{0}=\frac{N_{v}}{\rho_{r}}
$$

In order to obtain a nanocellular polymer, the cell nucleation density should be of the order of $10^{13}$. $10^{15}$ nuclei/cm ${ }^{3}$ or even higher. In conventional cellular polymers, this parameter usually takes values around $10^{6}$ nuclei $/ \mathrm{cm}^{3}$, whereas to obtain microcellular polymers cell nucleation densities 
higher than $10^{8}-10^{9}$ nuclei $/ \mathrm{cm}^{3}$ are needed. This means that the production of nanocellular polymers requires a considerable evolution from the previous materials, by increasing the cell nucleation density in several orders of magnitude.

Another relevant parameter in the characterization of a nanocellular polymer is the cell size. As aforementioned, the cell size of a nanocellular polymer is, in many cases, connected with their properties and possible applications. Both the cell size and the cell nucleation density can be calculated from image analysis of micrographs [15]. Note that the real cell size is a threedimensional value, and to calculate the real cell size from two-dimensional images, a correction factor must be applied.

The three quantities previously described (relative density, cell nucleation density, and cell size) are theoretically correlated according to equation (2.3) [16], where $\phi$ is the cell size. This relation implies that, for obtaining nanocellular polymers with very low relative densities, extremely high cell nucleation densities are required. For instance, to produce a nanocellular material with $100 \mathrm{~nm}$ of cell size and relative density of 0.1 , the cell nucleation density should be of the order of $10^{16}$ nuclei $/ \mathrm{cm}^{3}$. That is, the challenge of producing nanocellular polymers becomes even more complicated in the range of low relative densities.

$$
N_{0}=\frac{6}{\pi \phi^{3}}\left(\frac{1}{\rho_{r}}-1\right)
$$

Other standard descriptors of cellular materials, such as the cell wall thickness, the open cell content, the anisotropy ratio or the fraction of mass in the struts, can also be measured for nanocellular polymers and will impact in some extend their physical properties [2]. Details about the definition, methods of measurement and effect on the physical properties in conventional cellular polymers can be found extensively explained elsewhere [17-19].

\subsubsection{Fabrication of nanocellular polymers}

The production of nanocellular polymers requires technologies able to create a high density of nuclei that could, later on, grow into nanometric cells. In addition, the resultant structure must be stabilized to avoid further undesired growth or the degeneration of the structure. As a consequence of the significant challenges associated with the production of nanocellular polymers, its development is relatively recent in comparison with that of conventional cellular polymers. In fact, it was not until a few years ago when the technology allowed manufacturing these materials with enough dimensions to test and verify their properties [14].

Nowadays, there are several approaches to fabricate nanocellular polymers. They can be divided into three broad groups: phase separation techniques, imprinting or templating approaches, and foaming methods $[14,20]$.

The phase separation methods are based on the use of two or more polymer-based components that are immiscible, leading to the formation of a porous structure when one of the components solidifies [20-23]. The phase separation can be induced chemically, thermally, or using an immersion technique. 
Regarding the imprinting or templating techniques, they rely on a nanometric pattern in which the polymer should be arranged. For this purpose, ordered self-organized media such as block copolymers can be used as a template to obtain the nanoporous polymer [24,25]. After polymerization, the template is removed to leave a nanoporous structure.

These first two approaches are mainly restricted to the fabrication of thin films, which is a limitation to the potential future applications of nanocellular polymers. Moreover, they usually require the use of organic solvents, which should be removed after the structure is obtained and could be potentially hazardous for the environment. For all these reasons, the last method, that is, the using of a foaming approach is nowadays the most promising strategy to produce bulk nanocellular polymers using a scalable and environmentally friendly production route.

In particular, the gas dissolution foaming process using carbon dioxide $\left(\mathrm{CO}_{2}\right)$ as the physical blowing agent has been successfully used to obtain polymer-based nanocellular structures using a wide variety of polymer matrices [2,26-33]. The selection of $\mathrm{CO}_{2}$ as the blowing agent is related to its excellent diffusion properties, especially in the supercritical state that can be easily reached at mild processing conditions $\left(7.3 \mathrm{MPa}\right.$ and $\left.31^{\circ} \mathrm{C}\right)$. Furthermore, this gas can be considered as a green solvent that can be removed without using any pollutant compound, and that could be recycled in an industrial process [34]. In fact, $\mathrm{CO}_{2}$ is considered today as a sustainable alternative to other blowing agents used in the production of cellular polymers [35].

\subsubsection{Gas dissolution foaming}

The foaming methods used for the production of nanocellular polymers were firstly developed in the Massachusetts Institute of Technology (MIT) in the 80s for the fabrication of microcellular parts $[36,37]$. After an extensive study of the promising properties of microcellular polymers $[16,38,39]$, it was only a matter of time to move towards the next step, that is, reducing the cell size to the nano-scale. The technologies used for the fabrication of microcellular polymers were found to be also suitable for the production of nanometric cellular structures, once the processing parameters and/or formulations are adequately tuned $[40,41]$.

The equipment used in the gas dissolution foaming technology is schematized in Figure 2.3. The set-up comprises a pressure vessel or an autoclave, together with a pressure controller connected to a $\mathrm{CO}_{2}$ supply to keep the pressure to the desired value. Besides, the temperature can be adjusted via a heating or cooling system surrounding the pressure vessel. To release the pressure, the vessel should be equipped with a depressurization valve. In the ideal situation, all the parameters involved in the process (pressure, temperature, and pressure drop rate) are automatically monitored and registered. Depending on the initial conditions and the polymer matrix used, in some cases, an additional external heating system, such as a thermal bath, is required to heat the samples for a foaming or post-foaming step. Finally, an external cooling system (for instance, a thermal bath with water at room temperature) is also necessary to quench the cellular structure. 


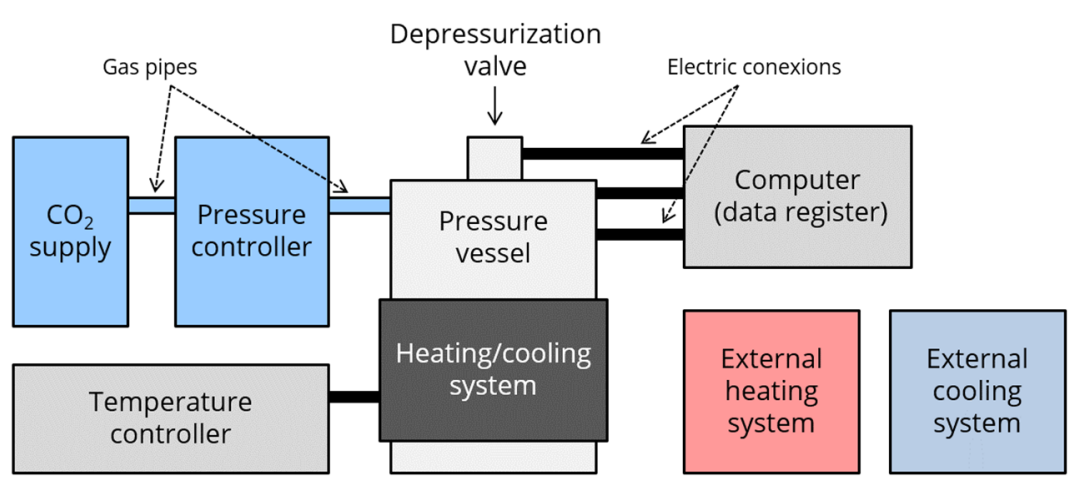

Figure 2.3. Scheme of the equipment used in the gas dissolution foaming process.

The gas dissolution foaming process consists of several stages (Figure 2.4): saturation, pressure release, foaming, and stabilization of the structure. There are two possible routes. If the pressure release and the foaming take place simultaneously (this might occur depending on the conditions and the materials used) the process is called batch foaming or one-step gas dissolution foaming (Figure 2.4, left route). If during the pressure release the sample does not expand, and an additional foaming step is required to achieve a cellular structure, then the process is called solid-state foaming or two-step gas dissolution foaming (Figure 2.4, right route). In the next paragraphs, the physical phenomena occurring in each stage of the process are explained in detail.

1) Saturation. The first stage is related to the absorption of the $\mathrm{CO}_{2}$. Firstly, the sample is introduced in the pressure vessel under certain conditions of gas pressure and temperature. Then, due to a concentration gradient, the diffusion process starts, that is, the gas starts to diffuse into the sample. For every pair of pressure-temperature conditions and every polymer matrix, there is a maximum amount of $\mathrm{CO}_{2}$ that can be absorbed by the polymer, and that is called solubility. The time required to achieve this solubility limit is related to both the polymer nature and the processing conditions, and it is controlled by the diffusivity constant or diffusion coefficient [4244]. In the gas dissolution foaming process, this time is called saturation time. The diffusion process is governed by diffusion equations such as the Fick's law. For instance, the basic mass transfer equation for a plane sheet and assuming a diffusion coefficient independent of the gas concentration is given by equation (2.4) [45]:

$$
\frac{\partial C}{\partial t}=D \frac{\partial^{2} C}{\partial x^{2}}
$$

Where $C$ is the concentration and $D$ is the diffusivity. Assuming one-dimensional diffusion along the thickness $L$, an analytical solution for long sorption time can be found (equation (2.5)):

$$
C=1-\frac{8}{\pi^{2}} \exp \left(-\frac{D \pi^{2} t}{L^{2}}\right)
$$

Regarding solubility, it is established that it increases with the saturation pressure. However, the dependency of the solubility with the pressure might vary among different materials. Three situations are possible. Both quantities can be correlated linearly (Henry's law), potentially (Langmuir's model) or using a dual model which considers both contributions [46]. On the other hand, solubility $(S)$ decreases exponentially with temperature following an Arrhenius equation [47] 
for systems in which the sorption of gas is an exothermic process. Equation (2.6) is governing the solubility dependence with temperature, where $\Delta H_{s}$ is the enthalpy exchange, $T$ is the temperature, $R$ is the gas constant and $S_{0}$ is a pre-exponential constant.

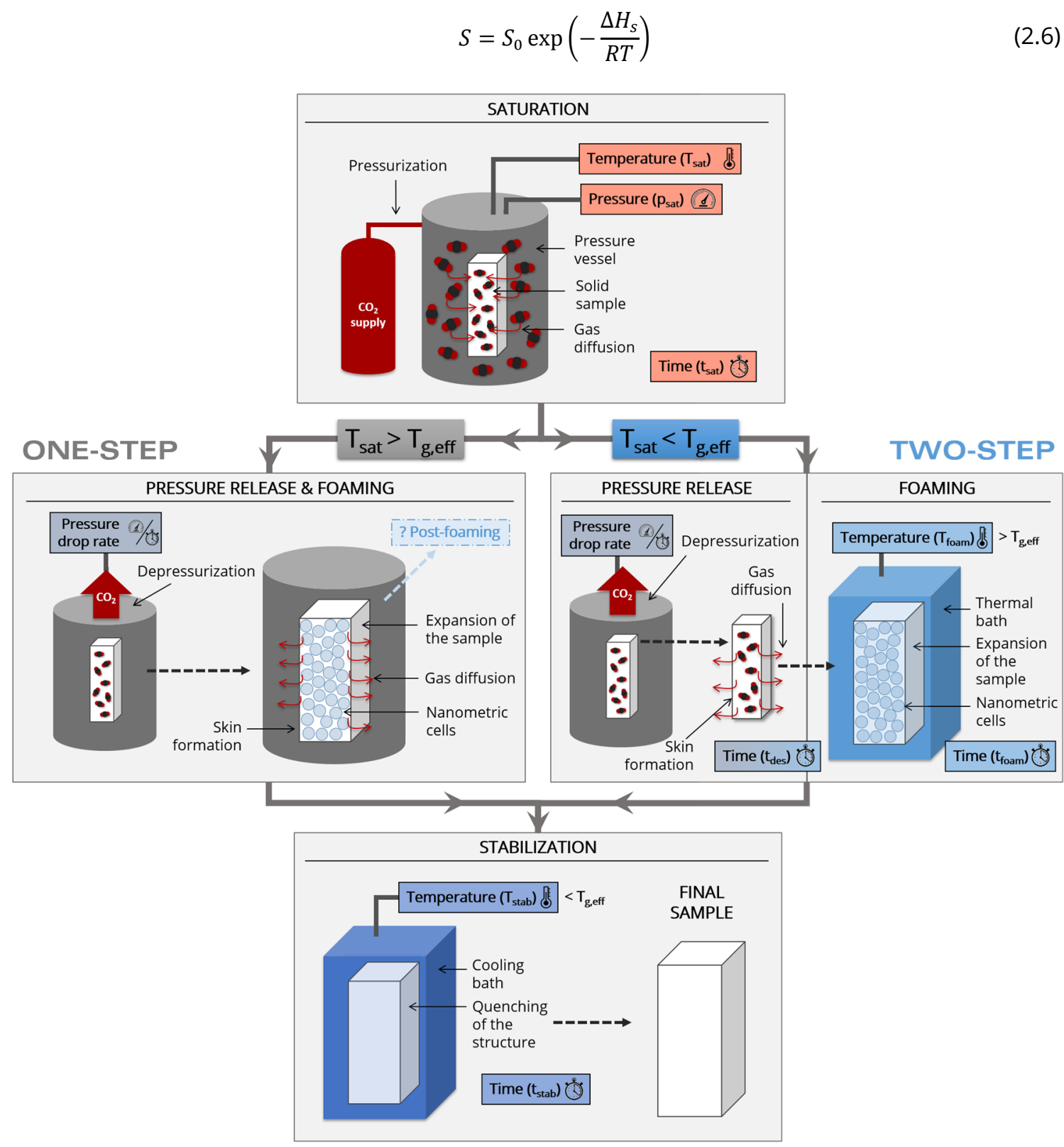

Figure 2.4. Scheme of the stages of the gas dissolution foaming process and the two possible routes: left: one-step gas dissolution foaming and right: two-steps gas dissolution foaming.

Last but not least, during the saturation process another relevant physical effect occurs: the plasticization effect of the polymer due to the $\mathrm{CO}_{2}$ absorption. When a gas dissolves into a polymer, it weakens the attraction between the polymer molecules and changes the entanglement, making the molecular movements more active. As a consequence, the characteristic temperatures of the polymer, such as the glass transition $\left(T_{g}\right)$ and the melting temperature $\left(T_{m}\right)$ decrease. In a semicrystalline polymer, only the amorphous parts can absorb gas, and then the solubility is usually not so high, so this plasticization effect becomes more relevant in amorphous polymers. Therefore, when a gas diffuses into an amorphous polymer, the glass transition temperature drops [48-51]. 
The polymer is now characterized by its effective glass transition temperature, $T_{\text {g,eff. }}$. This effect is of high relevance in the gas dissolution foaming process because the temperature required to induce the growth of the cells would now depend on this new $T_{g, \text { eff, }}$ as it is explained later on.

2) Pressure release. Once saturation is achieved, the pressure is released. Then, the sample is extracted from the pressure vessel. The pressure drop rate, that is, the velocity at which the gas leaves the pressure vessel, is a critical factor that might affect the later foaming structure. This is because the sudden decrease in pressure generates a thermodynamic instability that can result in a nucleation process. However, up to date, it has not been established without question at which point of the process the nucleation happens, as the later foaming under a certain temperature also leads to a thermodynamic instability. For this reason, at this stage, it can only be claimed that the pressure is released and not that the nucleation of the cells is happening.

When the pressure is released, the contrary diffusion process starts to take place, that is, the gas from the surface diffuses out of the sample. As a result, the surface and some region near the surface do not have any gas or the amount of gas is smaller than the critical value needed to create a cell. Then, a solid skin without any pores appears on the surface of the sample, as well as a transition region (with a variable amount of gas dissolved) from the solid skin to the homogeneous foamed core [52,53]. Once again, the diffusion velocity is controlled by a diffusion coefficient, and in this case, it is called the desorption diffusion coefficient [54]. The sorption and desorption diffusion coefficients are in principle different, due to, among other effects, the different state of the polymer before and after the gas sorption.

If the saturation temperature is higher than the effective glass transition temperature of the polymer after the $\mathrm{CO}_{2}$ absorption, then the sample is in the rubber state and has enough mobility, so it would expand and foam immediately after the pressure release given that the depressurization does not induce an excessive cooling of the sample. This is called one-step gas dissolution foaming or batch foaming [55] (Figure 2.4, left). In these conditions, as the foaming takes place without any time delay, the solid skin should have a minimum thickness, and it is plausible to assume that the transition region between the core and the surface would also be small if the pressure drop rate is high enough.

3) Foaming. If the saturation temperature is smaller than the $T_{g, \text { eff, }}$ or the depressurization induced cooling of the samples under the $T_{\text {g,eff, }}$ then the sample is in the glassy state and an additional foaming step is required to expand the sample (two-steps gas dissolution foaming). Samples are introduced in a thermal bath (or any other heating system such as a hot plate press [38]) at a temperature (foaming temperature, $T_{\text {foam }}$ ) higher than the $T_{\text {g,eff }}$ during a certain time $\left(t_{\text {foam }}\right)$ for the foaming step (Figure 2.4, right). The polymer chains acquire enough mobility, the gas diffuses from the nuclei to the cells and the expansion takes place. Both foaming temperature and foaming time must be controlled to ensure that the sample reaches the temperature homogeneously through all the volume and also to avoid undesired degeneration mechanisms or excessive growth of the cells. The time between the release of the pressure and the foaming step (so-called desorption time, $t_{\text {des }}$ ) is an important parameter, because during this time the gas is diffusing out of the sample, causing a gas concentration gradient inside the material and also a gradient of the effective glass transition temperature that can result in heterogeneous structures. 
In a batch foaming procedure, in which foaming occurs in the second stage, an additional foaming step (called in this case post-foaming) can be done to tune the cellular structure or increase the homogeneity of the cellular structure [56].

4) Stabilization: Once the cellular structure is formed, the sample is introduced in a cool bath (that is, at a temperature $T_{\text {sta }}$ smaller than the $T_{\text {g,eff }}$ after the foaming) to stabilize the structure. During foaming and stabilization, the material is losing gas due to the pressure gradient with the ambient, and thus the $T_{g, \text { eff }}$ is rising again. The gas dissolution foaming process occurs mainly in a rubber state (very close to the glass transition region) in which the polymer has a high viscosity. Thus, the cellular structures obtained via this method tend to be more stable than those produced using other foaming technologies (extrusion, injection molding, etc.) in which higher temperatures are used and the polymer has a much lower viscosity. However, quenching the structure after the foaming is a necessary step to freeze the structure and avoid a possible degeneration. Also, the viscosity of the polymer matrix and its extensional behavior [57] can determine how stable the structure can be, and also some additives, such as micron-sized aggregates, can affect negatively to the stabilization of the structure [58].

Table 2.1 summarizes all the main parameters involved in the different stages of the gas dissolution foaming process.

Table 2.1. Key parameters in the gas dissolution foaming process, their effects, and the relationships among them.

\begin{tabular}{|c|c|c|}
\hline & Parameter & Effects \\
\hline \multirow{6}{*}{ 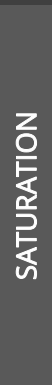 } & Saturation pressure $\left(p_{\text {sat }}\right)$ & $\begin{array}{l}\text { Determines the solubility (together with } \mathrm{T}_{\text {sat }} \text { ) and affects } \\
\text { the pressure drop rate }\end{array}$ \\
\hline & Saturation temperature ( $\left.\mathrm{T}_{\text {sat }}\right)$ & Determines the solubility (together with $\mathrm{p}_{\text {sat }}$ ) \\
\hline & Sorption diffusivity $\left(D_{s}\right)$ & Depends on $\mathrm{T}_{\text {sat }}$ and $\mathrm{p}_{\text {sat }}$, determines $\mathrm{t}_{\text {sat }}$ \\
\hline & Saturation time $\left(\mathrm{t}_{\mathrm{sat}}\right)$ & Depends on $\mathrm{D}_{\mathrm{s}}$ and precursor dimensions \\
\hline & Solubility & Amount of gas available for nucleation and/or foaming \\
\hline & Effective glass transition ( $\left.T_{g, e f f}\right)$ & $\begin{array}{l}\text { Plasticization of the polymer, depends on solubility and } \\
\text { the polymer used }\end{array}$ \\
\hline \multirow{4}{*}{ 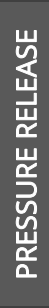 } & Pressure drop rate & $\begin{array}{l}\text { Instability: affects nucleation and the cooling of the } \\
\text { pressure vessel during pressure release }\end{array}$ \\
\hline & Desorption diffusivity $\left(D_{d}\right)$ & $\begin{array}{l}\text { Causes gas loss, affects the skin thickness, depends on } \\
\text { solubility and temperature }\end{array}$ \\
\hline & Cooling during pressure release & Modifies $D_{d}$, reduces the temperature of the sample \\
\hline & Desorption time $\left(t_{d}\right)$ & $\begin{array}{l}\text { Gradient of gas concentration and } T_{g, \text { eff, }} \text { skin and } \\
\text { transition zone formation }\end{array}$ \\
\hline \multirow{5}{*}{$\frac{\text { U }}{\sum}$} & Viscosity of the polymer $(\eta)$ & Nucleation (surface tension) and foaming (extensional) \\
\hline & Foaming temperature $\left(T_{\text {foam }}\right)$ & Instability: affects nucleation, $T_{\text {foam }}-T_{\text {g.eff }}$ affects $\eta$ \\
\hline & Foaming time ( $\left.\mathrm{t}_{\text {foam }}\right)$ & Cell growth \\
\hline & Gas diffusion out during foaming & Might limit the expansion \\
\hline & Solid skin & Might limit the expansion \\
\hline \multirow{3}{*}{$\begin{array}{l}\text { I } \\
\text { z } \\
\text { 岂 } \\
\text { Ơ }\end{array}$} & Stabilization temperature $\left(\mathrm{T}_{\text {sta }}\right)$ & Avoid degeneration and undesired cell growth \\
\hline & Stabilization time $\left(\mathrm{t}_{\mathrm{sta}}\right)$ & Depends on sample size \\
\hline & Gas diffusion during stabilization & Might provoke defects \\
\hline
\end{tabular}


Each of the parameters listed in Table 2.1 needs to be controlled and specified in the production of nanocellular polymers using this route. Although the process might look simple at a first look, the possibilities to tune it are multiple, so it is a versatile production method able to generate different types of structures. However, to reach a fine control of the process, every condition must be strictly adjusted and controlled.

\subsubsection{Phase separation mechanisms: nucleation}

In the previous sections, we have intentionally not deepened into the phase separation mechanisms that take place during the gas dissolution foaming process. After the saturation stage, once the pressure is released, the polymer/gas mixture is in a supersaturated state. Then, a sudden thermodynamic instability (such as a pressure change or a temperature increase) occurs, and subsequent phase separation takes place. The homogeneous polymer/gas mixture is now separated in its two components. Phase separation is known to happen via two primary mechanisms: spinodal decomposition and nucleation and growth, the latter being considered usually as the main mechanism in most of the foaming processes [59] (Figure 2.5).

Spinodal decomposition takes place at high supersaturations, at which the mixture is unstable [60]. The polymer/gas mixture undergoes spontaneous phase separation without the appearance of nucleation points [61]. This phenomenon is characterized by the vanishing of the energy barrier of nucleus formation [62], and so gas molecules immediately start to form clusters, which rapidly grow and coalesce. The result of the spinodal decomposition is a single gas phase, or in other words, an interconnected or co-continuous cellular structure [27,32,63-65]. Although it is not the most common mechanism for the production of nanocellular polymers, some works have reported spinodal decomposition as responsible for the appearance of co-continuous structures.

However, the principal mechanism that is believed to control phase separation in the gas dissolution foaming process is nucleation. Nucleation consists on the appearance of small clusters or aggregates of gas (nuclei) in a polymer/gas mixture after a sudden change in the thermodynamic conditions [60,62]. Then, gas in the polymer/gas system diffuses to the newly created nuclei. The nuclei grow as a result of the gas coming into them, and the pores or cells appear. As opposed to spinodal decomposition, nucleation implies an energy barrier that must be overcome in order to create a nucleus.

When in the polymer/gas mixture there are not any active nucleating agents, that is, the polymer is homogenous or it contains additives that are not contributing to the nucleation process, nucleation is said to be homogeneous. The equations governing the nucleation process were stated in the Classical Nucleation Theory (CNT). According to CNT, the Gibbs free energy barrier $\left(\Delta G_{\text {hom }}\right)$ that a nucleous should overcome to grow into a bubble is given by equation (2.7), where $\gamma$ is the surface tension between the gas and the polymer phase and $\Delta p$ is the pressure difference between gas and solid:

$$
\Delta G_{\text {hom }}=\frac{16 \pi \gamma^{3}}{3 \Delta p^{2}}
$$

The critical value of the nuclei radius, $r_{c}$ (equation (2.8)) can be computed from the previous equation [66-68]. The cluster of gas molecules should be larger than the critical radius in order to 
survive and grow. Those clusters with a size smaller than $r_{c}$ will not be stable. The critical radius can be estimated theoretically using the surface tension and the pressure gradient, though this calculation is not straightforward due to the complication of determining the surface tension of the polymer/gas mixture. For instance, for poly(methyl methacrylate) (PMMA) it was estimated to be around $2 \mathrm{~nm}$ in the range from 30 to $35 \mathrm{MPa}$ [56]. In other work, it was estimated to vary between $2.5 \mathrm{~nm}$ to $8 \mathrm{~nm}$ for saturation pressures from 10 to $30 \mathrm{MPa}$, also for PMMA [69]. In polystyrene at 3.5 $\mathrm{MPa}$, the critical radius was found to be of $20 \mathrm{~nm}[70]$.

$$
r_{c}=\frac{2 \gamma}{\Delta p}
$$

The CNT also predicts the homogeneous nucleation rate $N$, that is, the number of nuclei formed per unit of volume and unit of time. It is given by equation (2.9), where $C_{0}$ is the initial concentration of gas in the polymer, $f_{0}$ is the frequency factor of gas molecules joining the nucleus, $k_{B}$ is the Boltzmann constant and $T$ is the temperature $[66,71]$ :

$$
N=f_{0} C_{0} \exp \left(-\frac{\Delta G_{\text {hom }}}{k_{B} T}\right)
$$

Although it has been established that this CNT model severally under-predicts the nucleation rate for homogeneous nucleation [67], this theory provides a useful insight into the parameters involved in the nucleation process, and it correctly predicts some trends with the processing parameters [59]. For instance, according to equation (2.9), the nucleation increases as the gas concentration or solubility increases. This relation between the concentration of gas and the cell density has been found experimentally in numerous studies about nanocellular polymers based on pure polymers $[27,28,31,32,69]$. Therefore, one strategy to achieve high nucleation ratios is to maximize the solubility. This can be done by increasing pressure or reducing temperature, as stated in the previous section. On the other hand, temperature and pressure gradient also play a role in the nucleation process according to CNT equations. Higher temperatures will lead to higher nucleation ratios [2], whereas a higher pressure gradient will also induce larger nucleation [72]. Moreover, the interfacial surface tension also affects the Gibbs free energy barrier and the nucleation [59]. The surface tension is related to the viscosity of the polymer. For instance, according to the model proposed by Schonhorn [73], the surface tension and the viscosity $\eta_{l}$ of a liquid are related by equation (2.10):

$$
\gamma=A \exp \left(\frac{-B}{\eta_{l}-\eta_{v}}\right)
$$

Where $\eta_{v}$ is the vapour viscosity, $A$ is the surface tension when the viscosity is infinite and $B$ is a positive constant. According to this equation, an increase in the viscosity increases the surface tension, and as a result, the Gibbs free energy barrier would increase, so the nucleation rate would be reduced. Moreover, the surface tension might also depend on temperature [70].

After nucleation, the gas diffuses from the polymer/gas mixture to the newly created nuclei, causing the cell growth and the resultant expansion of the structure. Equation (2.11) provides a simplified equation governing cell growth, where $R$ is the radius of the cell, $t$ is the time and $\eta$ is the viscosity of the gas/polymer mixture $[59,67]$. Note that the solution of this equation is not trivial since the 
pressure gradient $\Delta p$, the viscosity and the surface tension might vary with time as gas is diffusing to the cells and out of the sample.

$$
\frac{d R}{d t}=\frac{\Delta p}{4 \eta}-\frac{\gamma}{2 \eta}
$$

Equation (2.7) to (2.11) provide the theoretical insights to understand the effect of the different processing parameters in the nucleation and growth processes of a homogeneous system. If the homogeneous system is altered by the addition of a second species, such as a nucleating agent, nucleation can be non-homogeneous, but heterogeneous. Then, the previous equations must be modified to take into account the presence and the effect of the second phase, as it is explained in the next section.

A summary of the different phase separation mechanisms, together with some examples of structures resultant of the various processes, is schematized in Figure 2.5.

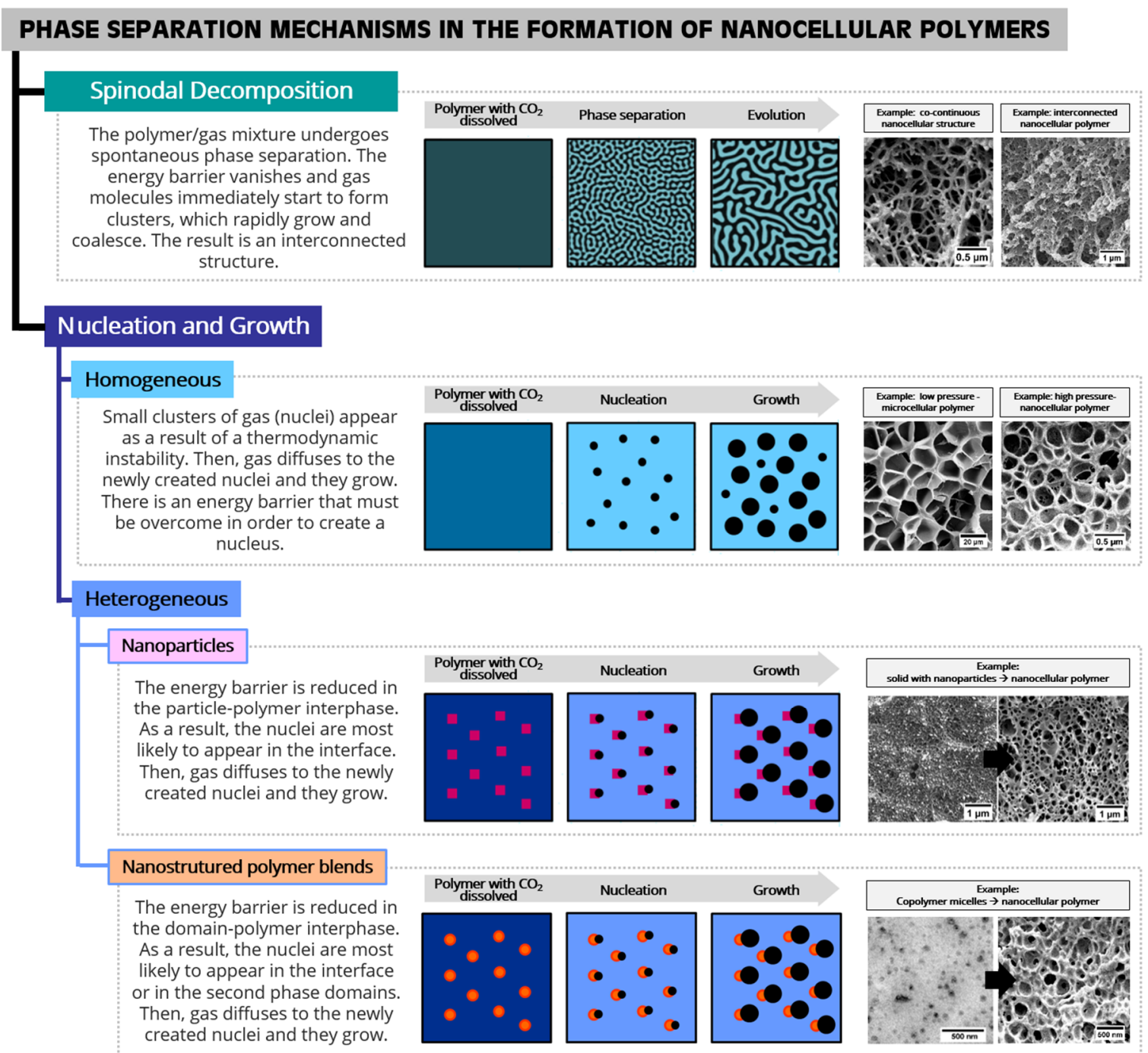

Figure 2.5. Phase separation mechanisms in the formation of nanocellular polymers via a gas dissolution foaming process.

As seen in the previous paragraphs, the processing parameters play a key role in the nucleation process of homogeneous systems. Then, to tune nucleation and achieve nanometric cell sizes, one 
possible strategy is to adjust the processing parameters to control the nucleation in a homogeneous system. This is the approach that has been successfully used by several authors in the last few years with very promising results. For instance, Guo and coworkers have used a lowtemperature (and low pressure (5 $\mathrm{MPa})$ ) approach to produce nanocellular polymers of various polymer matrices. PMMA [28,64], polycarbonate (PC) [27], polyphenylsulfone (PPSU) [30] and polysulfone (PSU) [32] were used to produce materials with very low cell sizes (under $100 \mathrm{~nm}$ ). These materials were produced using extremely low temperatures, between $0{ }^{\circ} \mathrm{C}$ and $-30^{\circ} \mathrm{C}$. The works of Liao et al. [74,75] and Martin-de Leon et al. [9] also supported that nanocellular PMMA can be produced at low temperatures and medium/low pressures (from 6 to $20 \mathrm{MPa}$ ). Costeux et al. [59] showed that acrylic copolymers based on methyl methacrylate (MMA) could be used to produce nanocellular polymers at high ( $>30 \mathrm{MPa}$ ) saturation pressures without the need of reducing the temperature. High pressures (30-31 MPa) were also employed in the works of Martinde Leon and coworkers [2] and Pinto and coworkers [69] to obtain nanocellular PMMA with saturation at room temperature. Other polymers, such as polyetherimide (PEI), do not require such extreme processing conditions and can lead to nanocellular structures at low pressures (5-8 MPa) and room temperature, as it was proved by Miller et al. [65] and later by Zhou and coworkers [76]. Bernardo et al. [31] also reported that nanocellular PPSU could be obtained from $15 \mathrm{MPa}$ using room temperature for the saturation stage. Homogeneous nucleation also takes place in polymer blends as long as the two polymers are miscible and form a single phase, such as in the work of Krause et al. [77] in PSU/PI (polyimide) nanocellular materials.

\subsection{Heterogeneous nucleation}

The addition of a second component to the polymer/gas mixture might affect the surface tension in comparison to that of the pure polymer. Depending on the nature of the second phase, the new system can present higher or smaller surface tension, and thus the Gibbs free energy can be increased or reduced. A simple way to estimate the surface tension of a two-phase system is given by equation (2.12), where $\gamma_{s p}, \gamma_{p}$ and $\gamma_{s}$ are the surface tensions of the second phase and the polymer, the gas-polymer and the gas-second phase, respectively, and $\theta$ is the wetting angle of the interface [78]:

$$
\gamma_{s p}=\gamma_{p}+\gamma_{s} \cos \theta
$$

In general terms, the addition of a second phase creates interfaces in the polymer/gas mixture, and these surfaces induce wetting, that is, gas molecules have a tendency to aggregate at the foreign surface [79]. Then, the nucleation process tends to take place in these pre-existing surfaces. Also, nucleation can occur within the second phase in specific systems where the second phase is organic. This process is called heterogeneous nucleation. As in the case of homogeneous nucleation, the heterogeneous nucleation rate is determined by an energy barrier, $\Delta G_{\text {het }}$. The energy for forming a critical nucleus in a heterogeneous system, $\Delta G_{\text {het }}$, is proportional to the energy barrier in a homogeneous system, $\Delta G_{\text {hom }}$, by a factor $S(\theta)$ depending on the wetting/contact angle of the polymer-additive-gas interface [71]: 


$$
\Delta G_{h e t}=\Delta G_{h o m} S(\theta)=\frac{16 \pi \gamma^{3}}{3 \Delta p^{2}} S(\theta)
$$

This function $S(\theta)$ is always less than or equal to one [62], that is, the Gibbs free energy barrier for heterogeneous nucleation is lowered, so nucleation is enhanced compared to the homogeneous situation. The function $S(\theta)$ can be written in terms of the contact angle $\theta$ of the polymer-additivegas interface [71]:

$$
S(\theta)=\frac{1}{4}(2+\cos \theta)(1-\cos \theta)^{2}
$$

The nucleation rate for heterogeneous nucleation, $N_{\text {het }}$, is given by equation (2.14), where $C_{1}$ is the initial concentration of gas in the polymer and $f_{1}$ is the frequency factor of gas molecules joining the nucleus.

$$
N_{\text {het }}=f_{1} C_{1} \exp \left(-\frac{\Delta G_{\text {hom }}}{k_{B} T}\right)
$$

One important consideration about the heterogeneous nucleation mechanism is that the critical radius is not affected by the presence of a second phase, that is, if we compute the critical radius in this situation, we recover the result of equation (2.8).

For critical nuclei, that is, for clusters of molecules with the size of the critical radius, the reduction of the energy barrier due to the presence of a second phase can be written in terms of a new function $f(m, n)$ (equation (2.16)) that takes into account not only the wetting angle, but the particle of the second phase curvature, assuming that they are spheres.

$$
\Delta G_{\text {het }}=\Delta G_{\text {hom }} f(m, n)=\frac{16 \pi \gamma^{3}}{3 \Delta p^{2}} f(m, n)
$$

This function varies between 0 and 1, and it is known as the Fletcher factor [80] (equation (2.17)):

$$
f(m, n)=\frac{1}{2}+\frac{1}{2}\left(\frac{1-m n}{g}\right)^{3}+\frac{n^{3}}{2}\left[2-3\left(\frac{n-m}{g}\right)+\left(\frac{n-m}{g}\right)^{3}\right]+\frac{3}{2} m n^{2}\left(\frac{n-m}{g}-1\right)
$$

Where $m$ is related with the contact angle (equation (2.18)) and $n$ is a ratio of the radius of the second phase, $R$, and the critical radius (equation (2.19)). Meanwhile, $g$ is a function of both parameters (equation (2.20)).

$$
\begin{gathered}
m=\cos \theta \\
n=R / r_{c} \\
g=\left(1+n^{2}-2 m n\right)^{1 / 2}
\end{gathered}
$$

The influence of the particle geometry can be evaluated in the extreme situation of a flat surface, $n \gg 1$. In this case, $f(m, n)$ takes its minimum value, and any other surface increases $f(m, n)$. The size of the particle compared to the critical radius $(n)$ is then crucial to investigate the potential nucleating effect of a nucleating agent. Note that the derivation of equation (2.17) is only valid for critical nuclei, so it cannot be applied for any arbitrary nucleus. However, equation (2.17) has been proved to be useful to estimate the reduction of the free energy when a second species is added. For instance, the addition of particles can reduce the energy barrier in a factor of a thousand [81]. 
Not all the nucleants would have the same effect when added to a polymer matrix. Their surface characteristics, their affinity with the blowing agent, their ability to be dispersed in the polymer, would affect their performance in the nucleation process. In fact, the ideal nucleants would have the following four qualities [70]:

1. Heterogeneous nucleation at the interface or in the nucleant should be energetically favorable relative to homogeneous nucleation. Weak interactions between the nucleant and the polymer usually lead to low energy barriers. However, this can depend on the processing conditions, that is, for some processing parameters heterogeneous nucleation might dominate, while for other conditions homogeneous nucleation is controlling the process.

2. Uniform size and surface properties to assure that all the interfaces act as a nucleation point at the same time. Otherwise, non-uniform or bimodal structures can appear.

3. The nucleants must be easily dispersed in the polymer matrix, without aggregation. If the dispersion is poor, the effective number of available nucleation points would be reduced compared to the theoretical estimation, and also non-uniform structures can result from a heterogeneous dispersion of the nucleants.

4. The volumetric density of nucleants is enough to achieve the nucleation ratios desired, and of course, higher than the estimated homogeneous nucleation at the processing conditions used.

Once these requirements are fulfilled, at least to the best possible, the addition of a second phase provides heterogeneous surfaces on which the nucleation energy barrier is lowered, and heterogeneous nucleation starts to play an essential role during the process. Two types of additives can be used as nucleating species in a general foaming process: particles and nanostructured polymers. In the case of the production of nanocellular polymers, the requirements for the nucleating species are more demanding, since the number of nuclei needed to obtain a nanocellular polymers is huge $\left(\sim 10^{14}\right.$ nuclei/ $\left./ \mathrm{cm}^{3}\right)$ compared to the nucleation in conventional cellular materials $\left(\sim 10^{6}\right.$ nuclei $\left./ \mathrm{cm}^{3}\right)$. Thus, a high volumetric density of nano-sized domains is necessary (but not sufficient) to produce nanocellular polymers using a heterogeneous nucleation approach.

One of the advantages of using a heterogeneous nucleation strategy is that it allows obtaining high nucleation densities without the need of using extreme processing conditions, as required in the homogeneous nucleation approach. This is due to the fact that in this case a high solubility is not required because the nucleating agent would provide the high number of nucleation sites. The volumetric density of interfaces of the second phase would be the parameter controlling the nucleation ratio as long as nucleation is favored in the interface or the second phase at the processing conditions used.

\subsubsection{Nanoparticles}

The high nucleation densities that must be achieved for the production of nanocellular polymers imply that micrometric nanoparticles cannot be used as efficient nucleating agents. The maximum nucleation density that can be achieved with spherical particles can be estimated theoretically from 
equation (2.21) $[70,81]$, where $\omega_{p}$ is the particle content, $\rho_{c}$ is the density of the composite (the polymer blended with the particles), $\rho_{p}$ is the density of the particles and $V_{p}$ is the volume of one individual particle.

$$
\frac{\text { Nucleants }}{c m^{3}}=\frac{\omega_{p} \rho_{c}}{\rho_{p} V_{p}}
$$

Assuming spherical particles of radius 0.5 microns with density of $2 \mathrm{~g} / \mathrm{cm}^{3}$ dispersed in a PMMA matrix (density: $1.19 \mathrm{~g} / \mathrm{cm}^{3}$ ), the maximum theoretical density of nucleants is of the order of $10^{12}$ nucleants $/ \mathrm{cm}^{3}$, and that value is obtained for unrealistic contents of particles in a real material, higher than a $90 \%$ in volume. However, for radii of $50 \mathrm{~nm}$ or smaller, nucleants densities higher than $10^{14}$ nucleants $/ \mathrm{cm}^{3}$ can be achieved for concentrations of particles of $10 \%$ and less.

Also, in order to promote the growth of stable nuclei, the particle size should be at least of the same size as the critical nucleus diameter but smaller than the desired cell size [56]. Finally, the nanoparticles should be smaller than the cell wall thickness in the nanocellular polymer (in the range of 20-30 $\mathrm{nm}$ [2]) to prevent cell wall rupture and degeneration mechanisms.

Therefore, nanometric particles are required to produce nanocellular polymers. Inorganic particles are considered as nanoparticles when at least one dimension of the dispersed particles is in the nanometer range [82]. Three different geometries are possible, depending on how many dimensions are in the nano-scale: sheets of few nanometers in thickness and hundreds to thousands nanometers in extent, such as clay platelets [83] or graphene [84], needle-like particles, with two dimensions within the nanometric range and variable length, for instance nanotubes [85] or nanofibers [86], and spheres, in which all the dimensions are in the nanoscale, like silica particles [87].

The addition of particles to cellular polymers is a common strategy to improve the properties of the cellular material. In particular, the high surface to volume ratio of nanoparticles leads to a higher reinforcement efficiency compared with micron-sized particles [82]. For this reason, many works are dealing with the effects on the properties associated with the addition of nanoparticles, such as the improvement in mechanical behavior $[83,88,89]$. The properties of the cellular nanocomposite would depend not only on the properties of the particles and the polymer matrix but also on the morphology formed during the blending of the two components. It is well-known that the degree of dispersion enhances the benefits associated with the presence of the particles, whereas large particle aggregates can lead to a reduction of the mechanical response. As a result, there is a vast literature about how nanoparticles can be dispersed in different polymer matrices $[90,91]$.

Moreover, nanoparticles have been proved to be very efficient nucleating agents in the production of microcellular polymers using a wide variety of foaming processes, and in particular with the gas dissolution foaming approach. For instance, Janani et al. [92] showed that the addition of only 0.1 wt\% of nanosilicas in polystyrene (PS) promote an increase of the cell nucleation density of two orders of magnitude compared to the neat polymer (from $10^{9}$ to $10^{11} \mathrm{cells} / \mathrm{cm}^{3}$ ). In the work of Siripurapu [93], ultraporous PMMA films were produced using silica particles. A $12 \mathrm{wt} \%$ of particles led to a reduction in the cell size from 10 to almost $1 \mu \mathrm{m}$. Santaren and coworkers [94] showed that 
the addition of $5 \mathrm{wt} \%$ of sepiolites induced a reduction of the cell size from 70 to $10 \mu \mathrm{m}$ in a PS matrix.

Recently, nanoparticles have shown their potential as nucleating agents also in the production of nanocellular polymers. Table 2.2 summarizes some of the most relevant works in the literature related to the use of nanoparticles in the production of nanocellular polymers, with different polymer matrices and types of nanoparticles. The range of cell sizes $(\phi)$, relative densities $\left(\rho_{r}\right)$ and cell nucleation densities $\left(N_{0}\right)$ achieved in each work are also included in Table 2.2, together with the saturation pressure $\left(p_{s a t}\right)$ and the saturation temperature $\left(T_{\text {sat }}\right)$ used to produce those materials. All the cellular structure parameters included in Table 2.2 have been taken directly from the respective papers. In this summary, only foaming approaches have been considered for the sake of comparison. The main results of the works included in Table 2.2 have been plotted in the cell size-relative density map of Figure 2.6 .

Table 2.2. State of the art of the production of nanocellular polymers using nanoparticles as a nucleating agent. List of abbreviations is available at the end of this chapter.

\begin{tabular}{|c|c|c|c|c|c|c|c|c|}
\hline Ref & Authors & $\begin{array}{c}\text { Polymer } \\
\text { matrix }\end{array}$ & Nanoparticles & $\phi(n m)$ & $\rho_{r}$ & $N_{0}\left(\text { nuclei } / \mathrm{cm}^{3}\right)^{*}$ & $p_{\text {sat }}(\mathrm{MPa})$ & $T_{\text {sat }}\left({ }^{\circ} \mathrm{C}\right)$ \\
\hline$[40]$ & Fujimoto & PLA & O-MMT & 360 & 0.46 & $3 \times 10^{14}$ * & 10 & $140-165$ \\
\hline [95] & Ema & PLA & O-MMT & $170-200$ & $0.86-0.91$ & $2 \times 10^{13}$ & $24-28$ & 110 \\
\hline [96] & Lee & HDPE & O-MMT & $200-800$ & $0.83-0.85$ & $4 \times 10^{12}-3 \times 10^{13}$ * & 8.3 & 50 \\
\hline [97] & Ameli & PP & MWCNT & $75-210$ & $0.62-0.81$ & $8 \times 10^{13}-2 \times 10^{14}$ * & 30 & $142-145$ \\
\hline [81] & Zhai & PC & $\mathrm{SiO}_{2}$ & $450-750$ & 0.83 & $4 \times 10^{12}-6 \times 10^{12}$ * & 20 & 50 \\
\hline [98] & Ito & PC & $\mathrm{O}-\mathrm{FH}$ & $330-850$ & $0.50-0.74$ & $2 \times 10^{12}-2 \times 10^{13}$ & $18-22$ & 80 \\
\hline$[56]$ & Costeux & PMMA & $\mathrm{SiO}_{2}$ & $95-280$ & $0.18-0.23$ & $3 \times 10^{14}-9 \times 10^{15}$ & $30-33$ & $40-60$ \\
\hline$[56]$ & Costeux & PMMA & POSS & $65-120$ & $0.15-0.26$ & $6 \times 10^{15}-2 \times 10^{16}$ & 33 & $35-50$ \\
\hline$[56]$ & Costeux & SAN & POSS & 200 & 0.3 & $6 \times 10^{14}$ & 33 & 30 \\
\hline [99] & Urbanczyk & SAN & O-MMT & $300-500$ & $0.50-0.67$ & $4 \times 10^{13}-8 \times 10^{13}$ & 30 & 100 \\
\hline$[100]$ & Pinto & PMMA & $\mathrm{ZnO}$ & 530 & 0.84 & $2 \times 10^{12}$ & 20 & 60 \\
\hline [101] & Liu & PMMA & $\mathrm{SiO}_{2}$ & $400-810$ & $0.24-0.32$ & $2 \times 10^{12}-1 \times 10^{13} *$ & 5.5 & RT \\
\hline [101] & Liu & PS & $\mathrm{SiO}_{2}$ & $440-640$ & $0.30-0.34$ & $3 \times 10^{12}-2 \times 10^{13}$ & 5.5 & $\mathrm{RT}$ \\
\hline$[102]$ & Yang & PMMA & OMS & 660 & 0.44 & $8 \times 10^{12}$ & 13.8 & 80 \\
\hline [103] & $\mathrm{Yu}$ & PEI & POSS & $66-905$ & $0.32-0.90$ & $4 \times 10^{11}-7 \times 10^{15}$ & $6-40$ & 40 \\
\hline [104] & Realinho & PMMA & O-MMT & $310-450$ & $0.60-0.63$ & $9 \times 10^{12}-3 \times 10^{13}$ & 20 & 70 \\
\hline [105] & Monnereau & PC & MWCNT & 600 & 0.54 & $5 \times 10^{11}$ * & 10 & 100 \\
\hline
\end{tabular}

*Note that some of the data do not fulfill the theoretical equation (2.3) relating $\phi, \rho_{r}$ and $N_{0}$. When the difference between the theoretical $N_{0}$ and the data provided is of one order of magnitude or more, such papers have been marked with *. This discrepancy might be due to an incorrect determination of the cell size (in 2D instead of in 3D) or a wrong measurement of $N_{0}$ or $\rho_{r}$. However, we decided to leave the original data from the papers.

It is necessary to remark that, in every work, the authors might have followed different approximations to determine these parameters. For instance, some works measure the density and the cell size and calculate the nucleation theoretically (for instance in the works of Ema [95] and Ito [98]) whereas others calculate each parameter independently, such as in the papers of Lee [96] and Ameli [97]. Also, note that the cell size data collected in Table 2.2 corresponds directly to the data provided in the respective paper, and it might not be the three-dimensional cell size, but the two-dimensional value calculated directly from the image analysis. To convert a $2 \mathrm{D}$ cell size to 
the correct 3D value, a correction must be applied (multiplying by 1.273 [15]). Some works do not specify how they calculate the cell size (such as those of Liu et al. [101] and Monnereau et al. [105]), while others, like the paper of Costeux et al. [56] claim that the cell size is calculated as a 2D value. These differences should be taken into consideration when comparing these results.

Semicrystalline polymers, such as poly(lactic acid) (PLA) [40,95], high-density polyethylene (HDPE) [96], or polypropylene (PP) [97] have been used to produce nanocellular materials with this approach. The works reported in Table 2.2 use clay platelets or needle-like particles such as carbon nanotubes. In these semicrystalline systems, the presence of nanoparticles to promote nucleation is key to achieve the nucleation densities required, as the solubility of gases in semicrystalline polymers below their melting temperature is usually low and not sufficient to induce the formation of a large density of nucleation points. High saturation temperatures are needed in most cases to have the crystals melted and enhance the gas absorption and the foaming, but when the polymer is melted it is complicated to prevent excessive growth of the cells and maintain the nanocellular structure. Therefore, the relative densities obtained with these materials are usually high. For all these reasons, most of the works about the production of nanocellular polymers are focused on amorphous polymers.

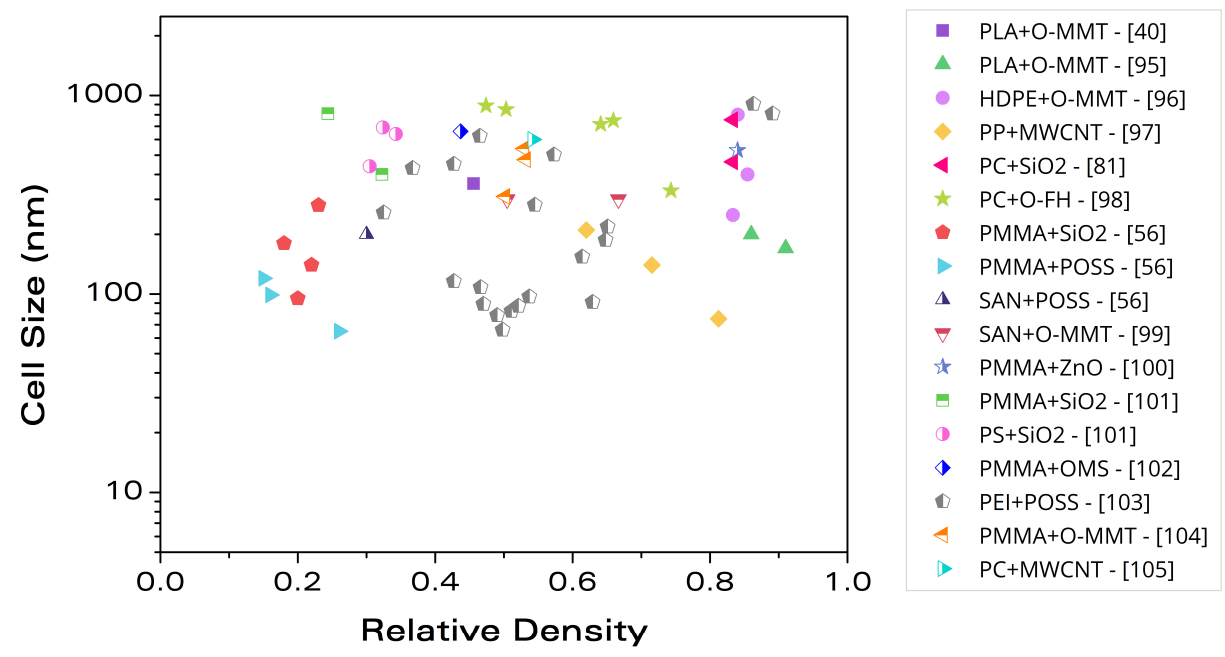

Figure 2.6. Cell size - relative density map summarizing the main results of the production of nanocellular polymers using nanoparticles as a nucleating agent (works included in Table 2.2).

The most promising results regarding a combination of low cell sizes and a wide range of densities are found for amorphous polymers, such as PC $[81,98]$, PS and PS copolymers $[56,99,101]$ and PMMA [56,100-102]. All these works use spherical nanoparticles such as nanosilica particles. The work of Costeux [56] with PMMA is extremely interesting, since it provides a route to produce lowdensity nanocellular polymers (relative density of 0.15$)$ together with a very small cell size $(120 \mathrm{~nm})$, and, up to date, it is still one of the best results that can be found in the literature. However, to produce such materials, very high pressures (ranging 30-33 MPa) are required. Other works, like the paper of Liu et al. with PMMA and PS [101] show the possibility of using mild processing conditions once nanoparticles are added (5.5 MPa and room temperature), to obtain low-middle density nanocellular materials (relative densities ranging 0.24-0.34). However, the cell sizes obtained were high (above $400 \mathrm{~nm}$ ). 
In short, the addition of nanoparticles is a powerful strategy to obtain nanocellular materials using different polymers (both semicrystalline and amorphous) and particles (with various geometries and chemical structures). The use of amorphous polymers is promising, but few works are using this approach. Besides, all the works with amorphous polymers so far use spherical particles. Thus, there is a need for further research in this line, using new nanoparticles with different geometries, such as needle-like particles, that could lead to different effects and structures. Also, the use of nanoparticles could provide enhanced properties to the resultant nanocellular material, as already demonstrated for microcellular polymers, although the literature on this aspect is still very scarce.

\subsubsection{Nanostructured polymer blends}

The same principles explained for nanoparticles can be applied in the case of polymer blends. It is necessary that the blending results in the formation of nanometric domains with sufficiently small sizes and in a volumetric density high enough $\left(>10^{13}-10^{14}\right.$ domains $\left./ \mathrm{cm}^{3}\right)$ to produce nanocellular polymers.

One example of a nanostructured polymer blend is the micelle nanostructuration that can be obtained using block copolymers dispersed in a continuous polymer matrix of the same composition of one of the blocks of the copolymer. The simplest case would be a binary blend of a di-block copolymer A-B in an A matrix. In this case, the copolymer can form disordered micelles, with the incompatible blocks (B) forming the micelle core and the compatible block $A$ forming the corona that extends into the A matrix. A micelle is a supramolecular structure that results from the self-assembly or self-organization of the copolymer molecules, and it is usually spherical, and its size is on the nanometric scale. The self-assembly process is a function of the processing parameters, being possible to obtain a micelle nanostructuration under equilibrium but also in nonequilibrium conditions. The maximum number of micelles per unit of volume $\left(n_{\max }\right)$ is given by equation (2.22), and it is estimated by assuming all the copolymer blocks resides in the micelles [70]:

$$
n_{\max }=\frac{w N_{a v}}{M_{n} N_{c}}
$$

Where $w$ is the amount of copolymer, $N_{a v}$ is the Avogadro's number, $M_{n}$ is the molecular weight of the copolymer, and $N_{c}$ is the aggregation number, defined as the number of copolymer molecules in one micelle. Also, there is a minimum amount of block copolymer needed to obtain micelles, the critical micelle concentration (cmc) [106]. A good strategy to produce nanocellular materials with nanostructured block copolymers is the use of materials with $\mathrm{CO}_{2}$-philic blocks, which enhance the gas absorption and also promote that the gas molecules are most likely to be placed close to the $\mathrm{CO}_{2}$-philic block $[107,108]$. In this particular case, not only do the micelles work as interfaces to promote nucleation, but also as $\mathrm{CO}_{2}$ reservoirs, enhancing solubility and promoting the foaming process. In this case, nucleation can take place within the micelle itself. Due to the ability of block copolymers to self-assembly, they can also produce nanostructures and lead to nano-scale cellular materials without the need of a polymer matrix [107].

Another approach to obtain a nanostructured polymer blend is the use of immiscible (or heterogeneous) polymer blends. When two immiscible polymers are melt blended in specific 
proportions, phase separation occurs due to the incompatibility, and the minor component is dispersed in small domains, which can be in the nanometric scale. The study of these solid nanostructured polymer blends is also interesting since they can present enhanced thermal and mechanical properties [109], and the properties can be tuned by modifying the morphology of the blend. The size of the domains is determined by several factors, such as the relative viscosities of the polymers and the processing conditions. For instance, according to the model proposed by Wu for an extrusion process [110], the size of the dispersed domains $(d)$ is given by equation (2.23), where $\eta_{d}$ is the viscosity of the dispersed polymer, $\eta_{m}$ is the viscosity of the matrix, $\sigma$ is the interface surface tension and $\dot{\gamma}$ is the shear velocity of the extruder screw. This equation has two branches, valid for viscosities of the dispersed polymer higher or smaller than the viscosity of the matrix, respectively, and it reaches a minimum (that is, the minimum domain size) when the two viscosities are equal. Therefore, to obtain domain sizes as small as possible, using polymers with similar viscosity is a good strategy. Another approach is to increase the shear velocity in the extruded screw.

$$
d=\frac{4 \sigma}{\eta_{m} \dot{\gamma}}\left(\frac{\eta_{d}}{\eta_{m}}\right)^{ \pm 0.84} \quad\left\{\begin{array}{l}
+ \text { if } \eta_{d} / \eta_{m}>1 \\
- \text { if } \eta_{d} / \eta_{m}<1
\end{array}\right.
$$

Regarding the use of these systems for the production of nanocellular polymers, the interface between the dispersed domains (or polymer nanoparticles) and the polymer matrix produces the same effects explained for inorganic nanoparticles and block copolymer micelles. Also, the difference in solubility between the polymers of the blend can also induce changes in the solubility and the foaming of these materials.

Table 2.3 summarizes some of the most relevant works about the production of nanocellular polymers using nanostructured polymer blends, both with block copolymers and with immiscible polymer blends. All the cellular structure parameters included in Table 2.3 have been taken directly from the respective papers. In this summary, only foaming approaches have been considered for the sake of comparison. The main results of the works included in Table 2.3 have been plotted in the cell size-relative density map of Figure 2.7. Once again, the cell sizes collected in Table 2.3 are the data extracted from the papers, that are in most cases only a $2 \mathrm{D}$ estimation of the real threedimensional cell size.

Table 2.3. State of the art of the production of nanocellular polymers using nanostructured polymer blends as a nucleating agent. List of abbreviations is available at the end of this chapter.

\begin{tabular}{|cccccccccc}
\hline Ref & Authors & $\begin{array}{c}\text { Polymer } \\
\text { matrix }\end{array}$ & $\begin{array}{c}\text { Dispersed } \\
\text { polymer }\end{array}$ & $\phi(\mathrm{nm})$ & $\rho_{r}$ & $N_{0}$ (nuclei/cm $\left.{ }^{3}\right)$ & $\boldsymbol{p}_{\text {sat }}(\mathrm{MPa})$ & $T_{\text {sat }}\left({ }^{\circ} \mathrm{C}\right)$ \\
\hline$[111]$ & Yokoyama & PS-PFMA & - & $10-30$ & - & $1 \times 10^{16}-4 \times 10^{16}$ & $7.5-30$ & 60 \\
\hline$[107]$ & Yokoyama & PS-PFS & - & $20-40$ & - & $5 \times 10^{15}$ & 30 & 60 \\
\hline$[108]$ & Reglero & PS-PFDA & - & 100 & 0.7 & $1 \times 10^{15}$ & 30 & 0 \\
\hline$[112]$ & Dutriez & PMMA-PFMA & - & $15-40$ & $0.75-0.95$ & $1 \times 10^{15}$ & $8-30$ & 45 \\
\hline$[69]$ & Pinto & PMMA & MAM & $150-180$ & $0.43-0.58$ & $4 \times 10^{14}$ & $10-30$ & RT \\
\hline$[113]$ & Pinto & PMMA & MAM & $180-950$ & $0.36-0.44$ & $4 \times 10^{12}-4 \times 10^{14}$ & 30 & RT-70 \\
\hline$[113]$ & Pinto & MAM & - & 129.5 & 0.45 & $1 \times 10^{15}$ & 30 & RT \\
\hline$[12]$ & Pinto & PMMA & MAM & $95-230$ & $0.41-0.56$ & $2 \times 10^{14}-3 \times 10^{15}$ & 30 & RT-50 \\
\hline$[41]$ & Reglero & PMMA & MAM & $200-300$ & $0.4-0.7$ & $7 \times 10^{13}-1 \times 10^{15} *$ & $10-30$ & 20 \\
\hline
\end{tabular}




\begin{tabular}{|c|c|c|c|c|c|c|c|c|}
\hline [114] & Nawaby & ABS & - & 470 & 0.90 & $3 \times 10^{12}$ & 3.4 & 0 \\
\hline [115] & Otsuka & PS & PMMA & $35-120$ & - & $1 \times 10^{14}-9 \times 10^{14}$ & 8.6 & $20-40$ \\
\hline$[116]$ & Nemoto & PEEK & PEI & $80-150$ & $0.7-0.8$ & - & 20 & 40 \\
\hline [117] & Bao & PC & PLA & $100-140$ & - & $5 \times 10^{13}-1 \times 10^{14}$ & 21 & 110 \\
\hline [118] & Nemoto & PP & TPS & $250-800$ & - & $6 \times 10^{13}-8 \times 10^{13}$ & 20 & 25 \\
\hline [119] & Nemoto & PP & PER & 500 & - & $1 \times 10^{12}$ & 20 & 25 \\
\hline [120] & Sharudin & PP & SEBS & 250 & - & $7 \times 10^{13}$ & 20 & 25 \\
\hline [121] & Wang & PMMA & TPU & $170-940$ & $0.13-0.48$ & $3 \times 10^{12}-2 \times 10^{14}$ * & $6.9-27.6$ & 25 \\
\hline$[26]$ & Forest & PMMA & MAM & $70-700$ & $0.23-0.65$ & $2 \times 10^{13}-1 \times 10^{15}$ * & 3.2 & 0 \\
\hline [57] & Forest & PMMA & MAM & $60-110$ & $0.3-0.56$ & $3 \times 10^{14}-1 \times 10^{15}$ * & 3.2 & 0 \\
\hline
\end{tabular}

"Note that some of the data do not fulfill the theoretical equation (2.3) relating $\phi, \rho_{r}$ and $N_{0}$. When the difference between the theoretical $N_{0}$ and the data provided is of one order of magnitude or more, such papers have been marked with *. This discrepancy might be due to an incorrect determination of the cell size (in $2 D$ instead of in $3 D$ ) or a wrong measurement of $N_{0}$ or $\rho_{r}$. However, we decided to leave the original data from the papers.

Note that some of the relative density data are missing in Table 2.3 due to the lack of experimental determination of this parameter in the corresponding work. In most cases, such as the works of Yokoyama and coworkers [107,111] or Dutriez et al. [112], the solid precursors were thin films in which determining the density is not an easy task. In other studies, like those of Nemoto et al. $[118,119]$, the density was determined from the cellular structure analysis and not from a bulk measurement. In any case, all the works listed in Table 2.3 in which the density is not specified present very high relative densities (or very low expansion ratios), as it can be extracted from the corresponding SEM images in the papers, or in some cases the low cell nucleation densities (smaller than $10^{13}$ nuclei $/ \mathrm{cm}^{3}$ ). The results of these works are not plotted in the comparative map of Figure 2.7.

One of the most promising systems for the production of nanocellular polymers taking advantage of a polymer nanostructuration is the use of a tri-block copolymer MAM (poly(methyl methacrylate)poly(butyl acrylate)-poly(methyl methacrylate)) blended with PMMA. This copolymer can selfassemble in nanometric core-shell micelles that act as preferable nucleating sites, because of the interface and because the poly(butyl acrylate) (PBA) block presents a higher affinity to $\mathrm{CO}_{2}$ compared to PMMA. Interesting results have been obtained by Reglero et al. [41] and later by Pinto and coworkers $[12,69,113]$, with cell sizes ranging from 100 to $300 \mathrm{~nm}$ and relative densities from 0.36 to 0.8 . Also, they showed that these materials could be produced under a wide range of both saturation pressures and saturation temperatures. Forest et al. [26,57] continued developing these PMMA+MAM blends, and they were able to produce nanocellular structures with a more extensive range of densities and cell sizes by modifying the amount of copolymer and the viscoelasticity of the PMMA matrix. Although the promising results obtained so far with this PMMA+MAM system, some questions remain still unsolved. For instance, there is a lack of knowledge about the influence of the molecular weight of the MAM in the nanostructuration and the cellular structure. Also, it would be interesting to optimize the amount of MAM needed to obtain a nanocellular polymer. Finally, the use of a MAM micellar nanostructuration seems to limit the expansion, so it is necessary to overcome this issue.

Regarding the low-density/low-cell size region, the recent work of Wang et al. [121] has established the current best results, with PMMA+TPU blends that presented cell sizes around 200 and cell 
densities under 0.15. Despite the good results, up to the moment this thesis is written, this is the only work that can be found in the literature using PMMA+TPU blends. Therefore, it would be interesting to explore this system further as a new material to produce low-density nanocellular polymers.

In short, the use block copolymers with $\mathrm{CO}_{2}$-philic blocks (both individually or blended with homopolymers) and nanostructured polymer blends is another strategy suitable to produce nanocellular polymers, that can be obtained with different polymer matrices and in a wide range of densities and cell sizes, as displayed in Figure 2.7. However, there is a need for further research in the most interesting systems, such as PMMA+MAM and PMMA+TPU.

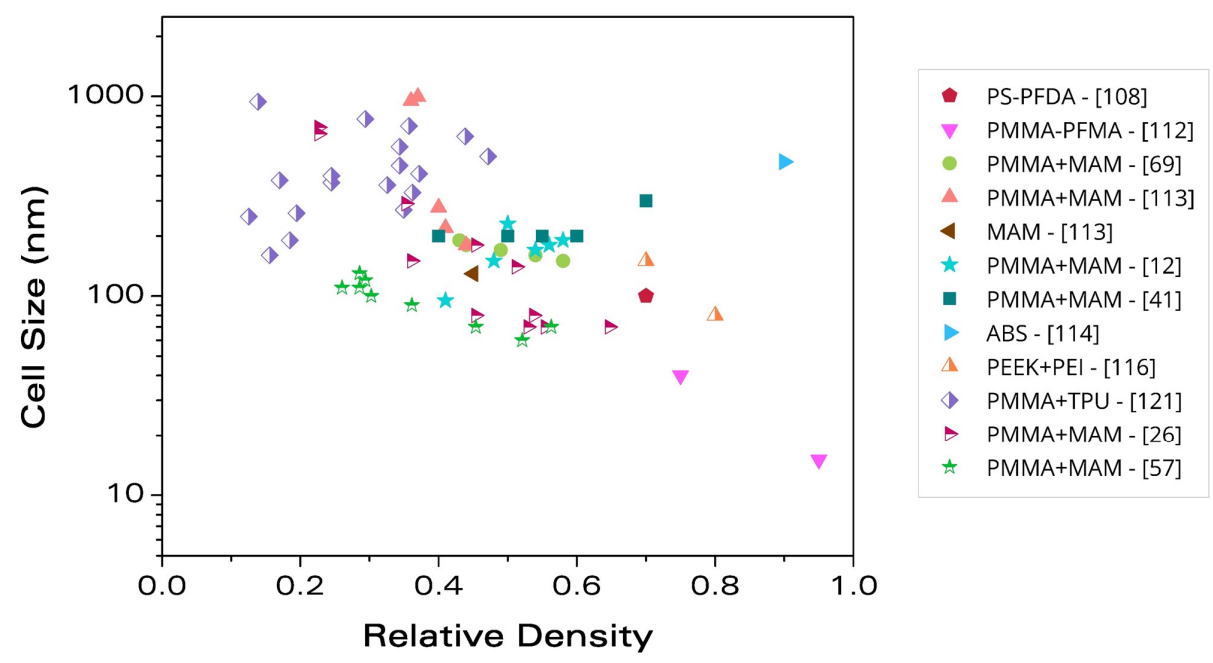

Figure 2.7. Cell size - relative density map summarizing the main results of the production of nanocellular polymers using nanostructured polymer blends as nucleating agent (works included in Table 2.3).

\subsubsection{Heterogeneous nucleation: an overview}

All the results of Figure 2.6 and Figure 2.7 are plotted together in Figure 2.8 as an overview of the state of the art of the production of nanocellular polymers produced using the heterogeneous nucleation methodology. Curves of constant cell nucleation density (predicted theoretically using equation (2.3)) are added to this figure as guidelines for the discussion. Almost all the materials in Figure 2.8 lie between the lines of cell nucleation density equal to $10^{13}$ nuclei/ $\mathrm{cm}^{3}$ and $10^{16}$ nuclei/ $\mathrm{cm}^{3}$, confirming that at least $10^{13}$ nuclei/ $\mathrm{cm}^{3}$ are necessary to move from the micro to the nano-scale. Another essential remark from this graph is that there are no data points in the region of very low cell sizes (under $50 \mathrm{~nm}$ ) combined with a medium or low relative density. This result might be a limitation of the heterogeneous nucleation approach since the nanoparticles and the polymer nano-domains used for the nucleation process are usually around $50 \mathrm{~nm}$ (or more) in size. In Figure 2.8, it is also found that nanostructured polymer blends with micelles (such as PMMA+MAM blends) present higher densities than other nanostructured polymer blends like PMMA+TPU and also than systems with nanoparticles. This is a usual limitation of the use of nanometric micelles or template structures: the molecular organization of the macromolecules around the micelle acts as a limitation of the expansion of the cellular material (see Chapter 5 for 
more details about this topic). The main conclusion of this graph is that the greatest part of the most promising and best results are obtained with amorphous polymers, especially with PMMA. This is not a surprise since PMMA presents a high affinity to $\mathrm{CO}_{2}$, and this property makes it one of the most suitable candidates for the production of nanocellular polymers via gas dissolution foaming with $\mathrm{CO}_{2}$ as the blowing agent.
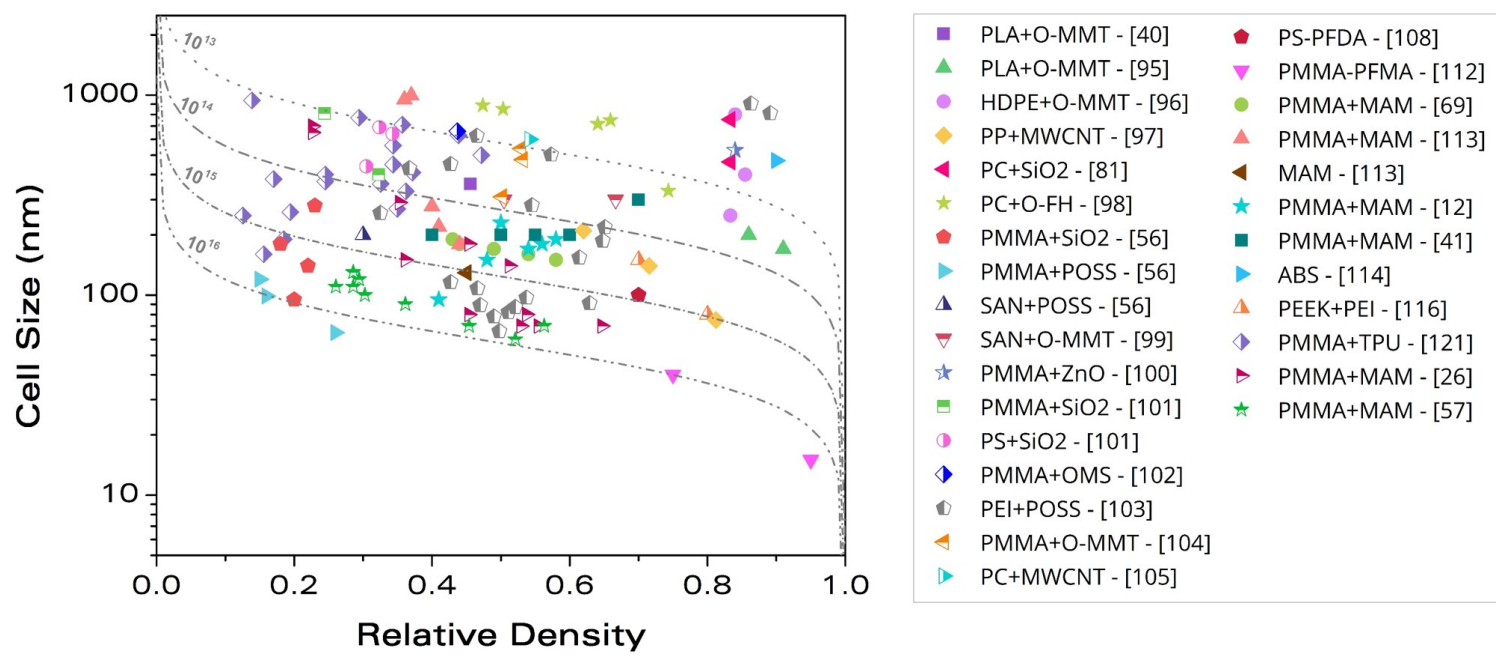

Figure 2.8. Cell size - relative density map summarizing the main results of the production of nanocellular polymers using a heterogeneous nucleation approach (works included in Table 2.2 and Table 2.3). Discontinuous lines represent curves of constant cell nucleation density (from $10^{13}$ to $10^{16}$ nuclei/ $/ \mathrm{cm}^{3}$ ) according to the theoretical prediction of equation (2.3).

To analyze in more detail these results, Figure 2.9.a shows an overview of the cell sizes and relative densities than can be obtained with the different approaches (nanoparticles and nanostructured polymer blends). In addition, Figure 2.9.b shows a schematic overview of the results obtained for various systems.

a)

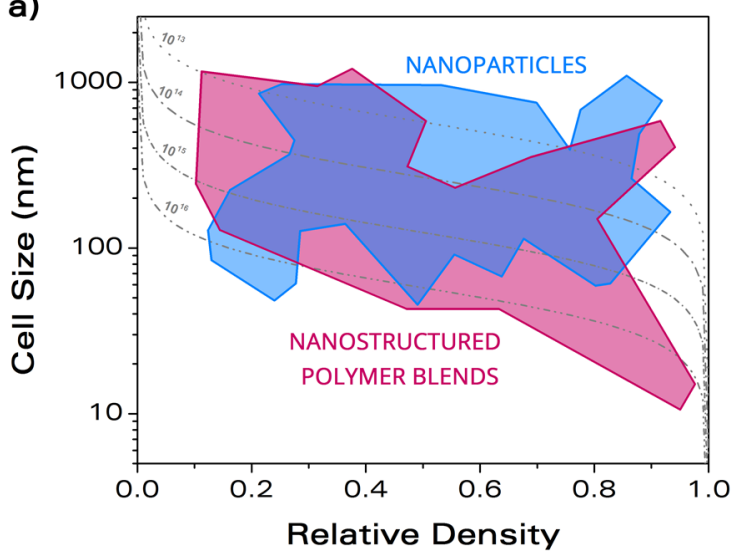

b)

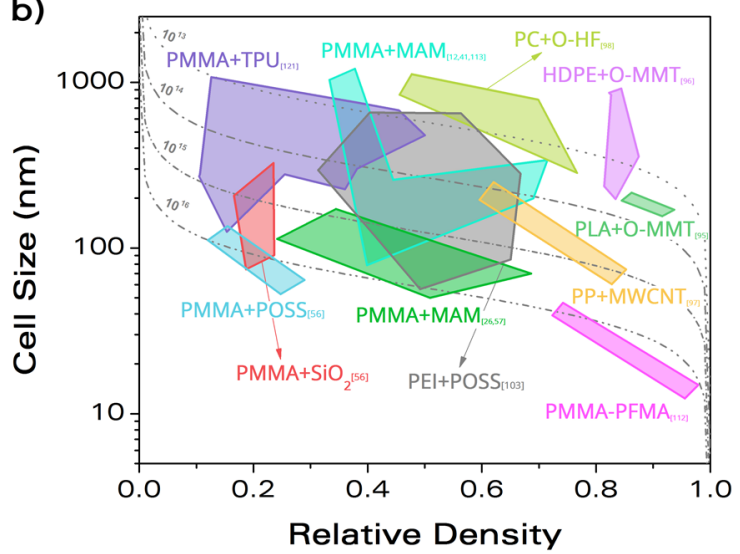

Figure 2.9. a) Overview of cell sizes and relative density of nanocellular polymers produced with nanoparticles and nanostructured polymer blends and b) schematic view for some particular systems. Discontinuous lines represent curves of constant cell nucleation density (from $10^{13}$ to $10^{16}$ nuclei $/ \mathrm{cm}^{3}$ ) according to the theoretical prediction of equation (2.3).

As aforementioned, PMMA is set as the most promising polymer matrix to produce nanocellular polymers using nanoparticles and nanostructured polymer blends. However, as previously 
commented, some lacks of knowledge are identified in the current state of the art of the production of nanocellular polymers using PMMA and a heterogeneous nucleation approach:

- The use of nanoparticles as nucleating species in amorphous polymers is still not fully exploit. All the papers in the literature are based in spherical-shaped nanoparticles. Thus, there is a need for more investigations using particles with different geometries.

- Although PMMA+MAM systems have proved their potential, some issues need still to be solved. First, the difficulty of producing low-density materials with this approach should be investigated. Second, the amount of copolymer needed to produce the nanocellular polymer must be optimized. Moreover, it would be interesting to evaluate the influence of MAM chemistry in the obtained materials.

- TPU seems to be an appropriate candidate for the production of low-density nanocellular polymers, but the literature about PMMA+TPU blends is still very scarce. More works dealing with the production of PMMA+TPU nanocellular polymers are needed.

- Up to date, there are no works combining both strategies, the use of nanoparticles and nanostructured polymer blends. Thus, there is also a lack of knowledge the use of tri-phasic blends with two nucleating agents.

- Currently, there are no reports of highly anisotropic nanocellular polymers, that could present enhanced performance for many applications.

Given the above limitations and unsolved issues, this research aims at facing these problems in the use of nanoparticles and nanostructured polymer blends for the production of nanocellular polymers based on PMMA, with the aim of contributing to the state of the art with relevant and new research.

\subsection{Limits and challenges in the production of nanocellular polymers}

\subsubsection{Heterogeneous nucleation versus homogeneous nucleation}

The previous results already showed that the production of nanocellular polymers is still a challenging task. Different materials and strategies are needed to obtain these materials with the desired cell size and density, and moreover, some particular structures, such as those with lowdensity and very small cell size, are still difficult to obtain. In that sense, the use of the homogeneous nucleation mechanism broads the range of nanocellular materials that can be obtained with the heterogeneous nucleation approach. Figure 2.10.a shows some of the most relevant results that have been achieved using the homogeneous nucleation approach (references [2,9,27,28,30$32,59,65,122,123])$, whereas Figure $2.10 . \mathrm{b}$ presents a qualitative comparison between the materials that have been produced with the two strategies (homogenous and heterogeneous nucleation) up to date. This figure shows that the use of homogeneous systems, such as pure polymers or miscible polymer blends, allows obtaining materials with small cell sizes (under $50 \mathrm{~nm}$ ) at medium relative densities (0.3-0.7). 


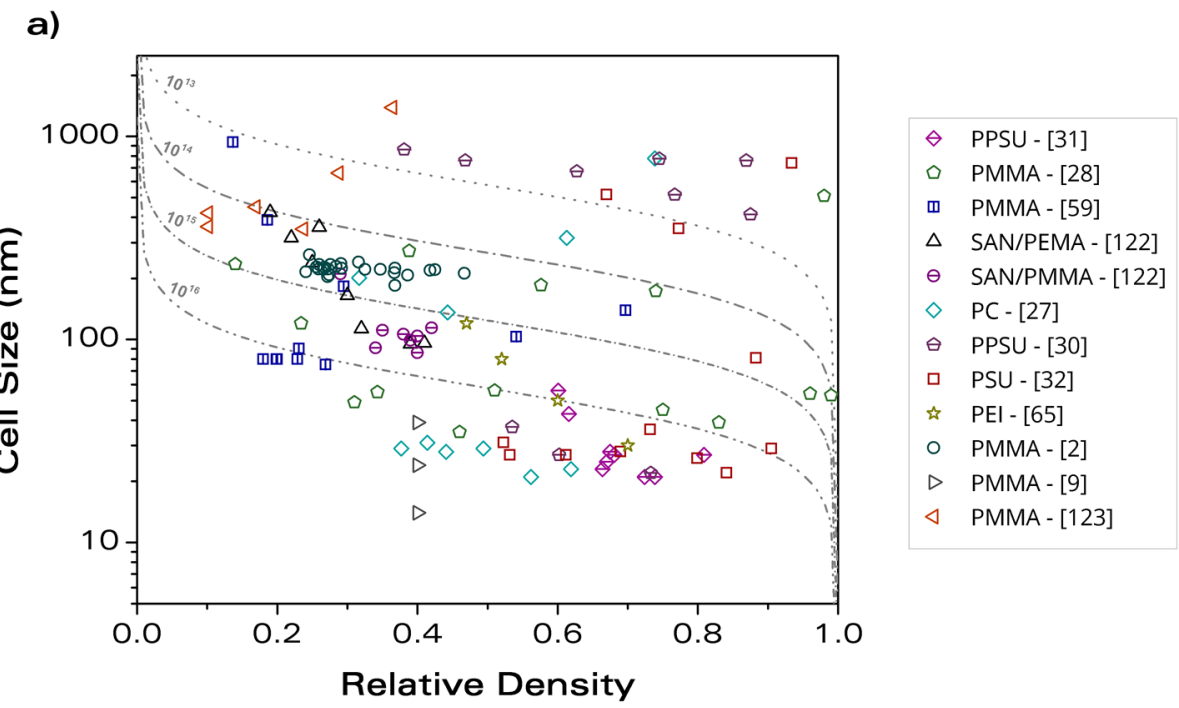

b)

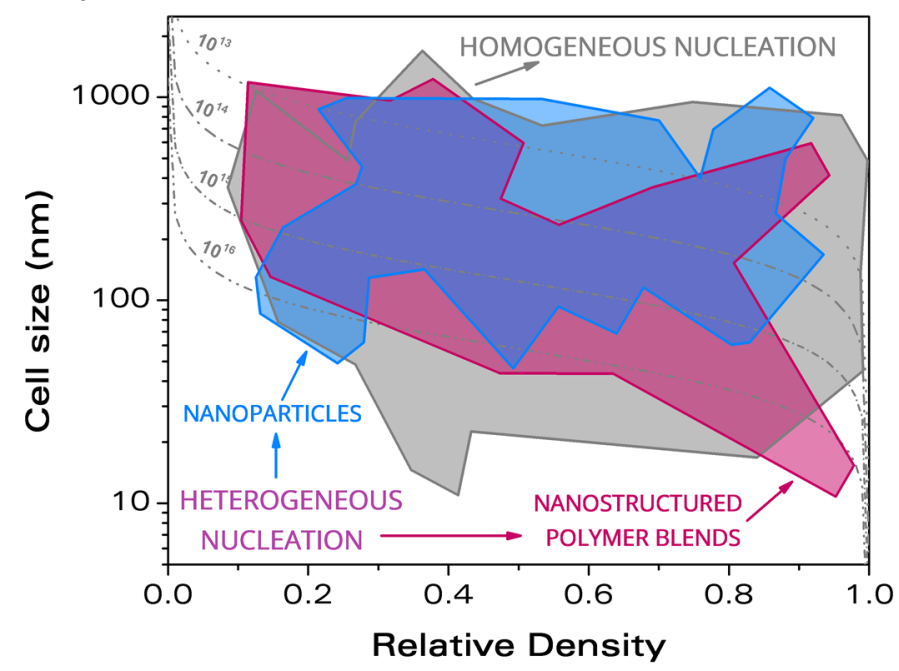

Figure 2.10. a) Cell size - relative density map summarizing the main results of the production of nanocellular polymers using a homogeneous nucleation approach (list of abbreviations is available at the end of this chapter); b) Comparison between the materials that have been produced taking advantage of homogeneous and heterogeneous nucleation.

\subsubsection{Production conditions to obtain nanocellular polymers}

Although the good results obtained using homogeneous systems, this production route presents a main disadvantage. To produce nanocellular materials with this approach, extreme processing conditions are usually required. Figure 2.11.a shows a comparative three-dimensional plot of the different cell sizes that have been obtained as a function of both the saturation pressure and saturation temperature. (Note that the data points corresponding to the homogeneous systems are open symbols with thick edges, whereas the heterogeneous materials are represented with fill or semi-filled symbols). To help to visualize the results of Figure 2.11.a, additional plots with the information of the different planes are also presented: saturation temperature vs. saturation pressure (Figure 2.11.b and Figure 2.11.c, same figure with regions delimiting the ranges of each strategy), cell size vs. saturation pressure (Figure 2.11.d) and cell size vs. saturation temperature 
(Figure 2.11.e). The representation of Figure 2.11.b and Figure 2.11.c is especially enlightening to understand the main difference between the two strategies. Whereas the use of a homogeneous nucleation approach is restricted to some specific processing conditions, the heterogeneous nucleation strategy can be used in a much more extensive range of saturation parameters. The use of heterogeneous systems is, therefore, key to the future industrial scale production of nanocellular polymers, since homogeneous systems sometimes require very specific and demanding processing conditions. Some of the most interesting results observed in the map of Figure 2.10.a were obtained at high saturation pressure, like the works of Costeux et al. [59,123] and Martin-de Leon et al. [2] (Figure 2.11.d), while extremely low temperatures $\left(0{ }^{\circ} \mathrm{C}\right.$ and less) were used in the works of Handa et al. [122], Martin-de Leon and coworkers [9] and Guo et al. [27,28,30,32] (Figure 2.11.e). In contrast, many heterogeneous systems were produced at medium pressures (5-20 MPa) and temperatures from room temperature to $40-50^{\circ} \mathrm{C}$ (Figure 2.11.b and Figure 2.11.c).

However, establishing a general comparison among all the systems is difficult, since each polymer matrix requires specific processing conditions. For instance, semi-crystalline polymers might require high processing temperatures to be above or close to the melting point of the polymer, like in the work of Ameli and coworkers [97] with PP and carbon nanotubes. Another example is PPSU that allows obtaining nanocellular structures using medium pressure (15 $\mathrm{MPa})$ and room temperature as saturation conditions [31].

Thus, to make a fair comparison and better understand and visualize the effects of the saturation parameters, the plots of Figure 2.11 is reproduced with only the works that use the same polymer matrix. Throughout the last years, PMMA has been shown to be the most promising candidate for the production of nanocellular polymers. In addition, the materials used in this thesis are based on PMMA blends. Therefore, all the data points from the different works about PMMA are collected in Figure 2.12. As in the previous analysis, five different plots are presented. First, Figure 2.12.a shows a 3D graph of the cell size as a function of the saturation pressure and the saturation temperature. Then, 2D plots are prepared from this figure for clarification. Figure 2.12.b shows a saturation temperature - saturation pressure graph, and Figure 2.12.c shows the same plot but with regions corresponding to the homogeneous and heterogeneous nucleation approaches. Figure 2.12.d presents the cell size vs. the saturation pressure, whereas Figure 2.12.e shows the cell size vs. the saturation temperature. Figure 2.12.b and Figure 2.12.c prove that for producing nanocellular PMMA without any nucleating species, high pressures (30-33 MPa) or low temperatures (from $0{ }^{\circ} \mathrm{C}$ to $-32^{\circ} \mathrm{C}$ ) are needed. This is also observed in Figure 2.12.d and Figure 2.12.e (note that the points at low pressure in Figure 2.12.d correspond to the low-temperature data points in Figure 2.12.e). In contrast, the processing window for producing nanocellular polymer following a heterogeneous nucleation approach is much wider: saturation pressures from 5 to $35 \mathrm{MPa}$ and saturation temperatures from room temperature to almost $80^{\circ} \mathrm{C}$ can be used (Figure 2.12.b and Figure 2.12.c). 


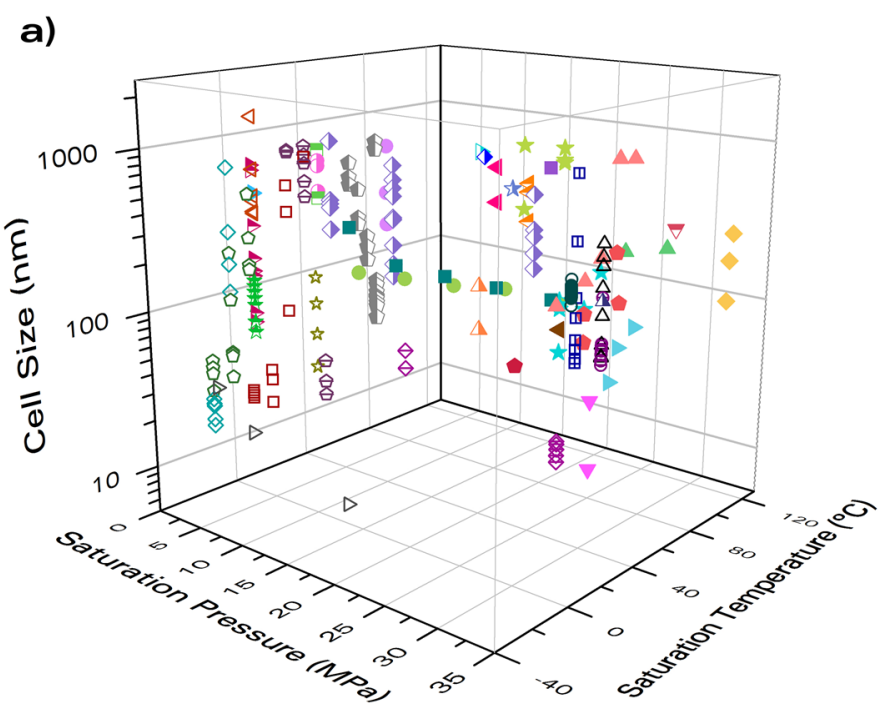

- PS-PFDA-[108] $\quad \nabla \quad$ SAN+O-MMT - [99]

- PMMA-PFMA-[112] \& PMMA+ZnO-[100]

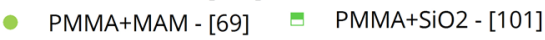

A PMMA+MAM - [113] PS+SiO2 - [101]

4 MAM-[113] PMMA+OMS-[102]

$\star$ PMMA+MAM - [12] PEI+POSS - [103]

- PMMA+MAM - [41] $\rightarrow$ PMMA+O-MMT-[104]

$\rightarrow$ ABS-[114] D PC+MWCNT-[105]

$\triangle$ PEEK+PEI-[116] $\diamond \quad$ PPSU - [31]

4PMMA+TPU - [121] $\triangle$ PMMA - [28]

$\rightarrow$ PMMA+MAM - [26] $\square$ PMMA - [59]

¿ PMMA+MAM - [57] $\triangle$ SAN/PEMA - [122]

- PLA+O-MMT - [40] $\ominus$ SAN/PMMA - [122]

$\triangle$ PLA+O-MMT-[95] $\diamond \quad P C-[27]$

- HDPE+O-MMT - [96] $\ominus$ PPSU - [30]

- PP+MWCNT - [97] $\square$ PSU - [32]

$4 \mathrm{PC}+\mathrm{SiO} 2-[81]$ के $\mathrm{PEI}-[65]$

* $\mathrm{PC}+\mathrm{O}-\mathrm{FH}-[98] \quad 0 \quad \mathrm{PMMA}-[2]$

- PMMA+SiO2-[56] D PMMA - [9]

D PMMA+POSS - [56] $\triangleleft$ PMMA-[123]

4. SAN+POSS - [56]

b)

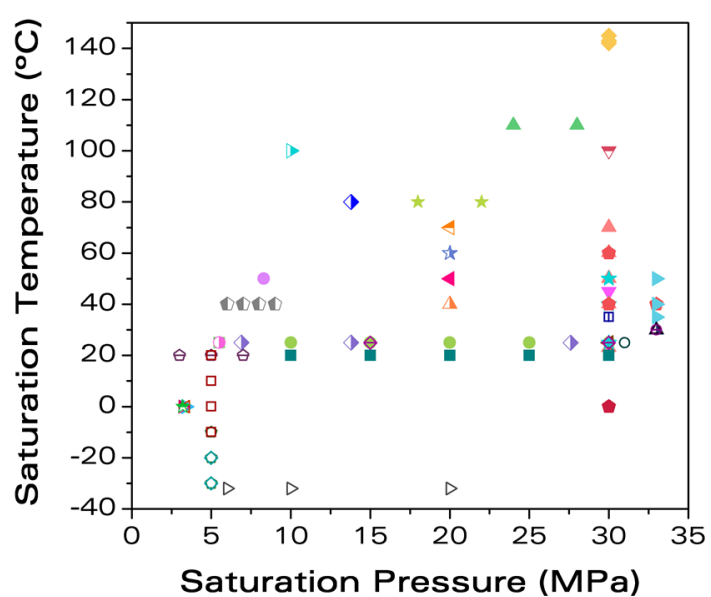

d)

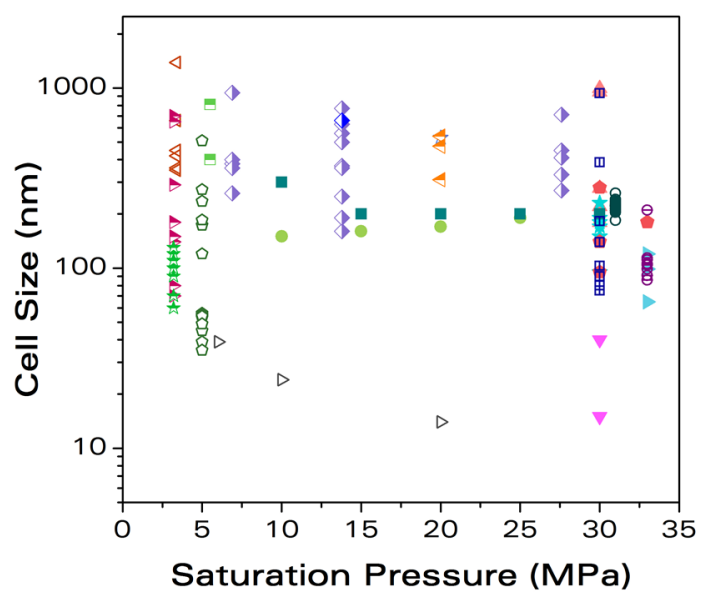

c)

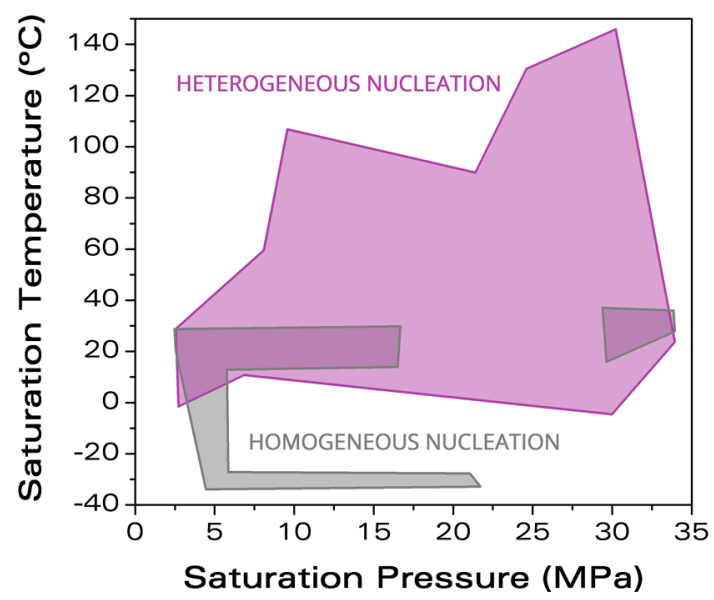

e)

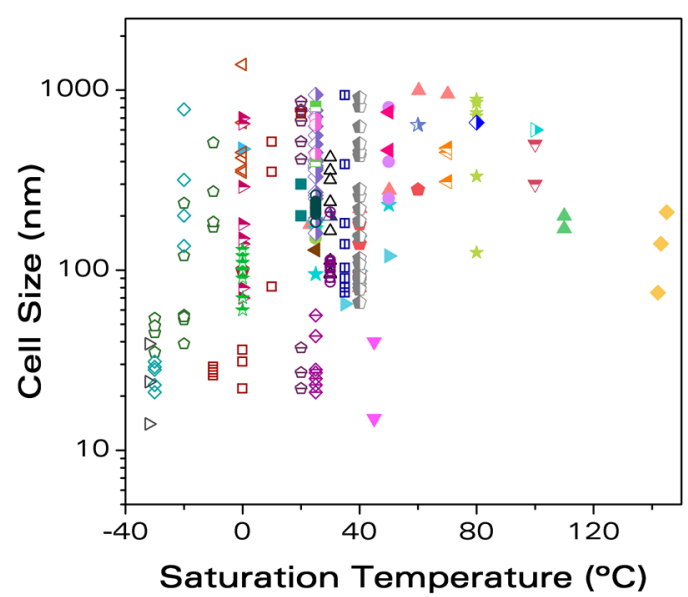

Figure 2.11. a) Cell size - saturation temperature - saturation pressure 3D map for different systems, and 2D projections: b) saturation temperature - saturation pressure, c) saturation temperature - saturation pressure (with regions for the homogeneous and the heterogeneous systems), d) cell size - saturation pressure, and d) cell size - saturation temperature. 
a)

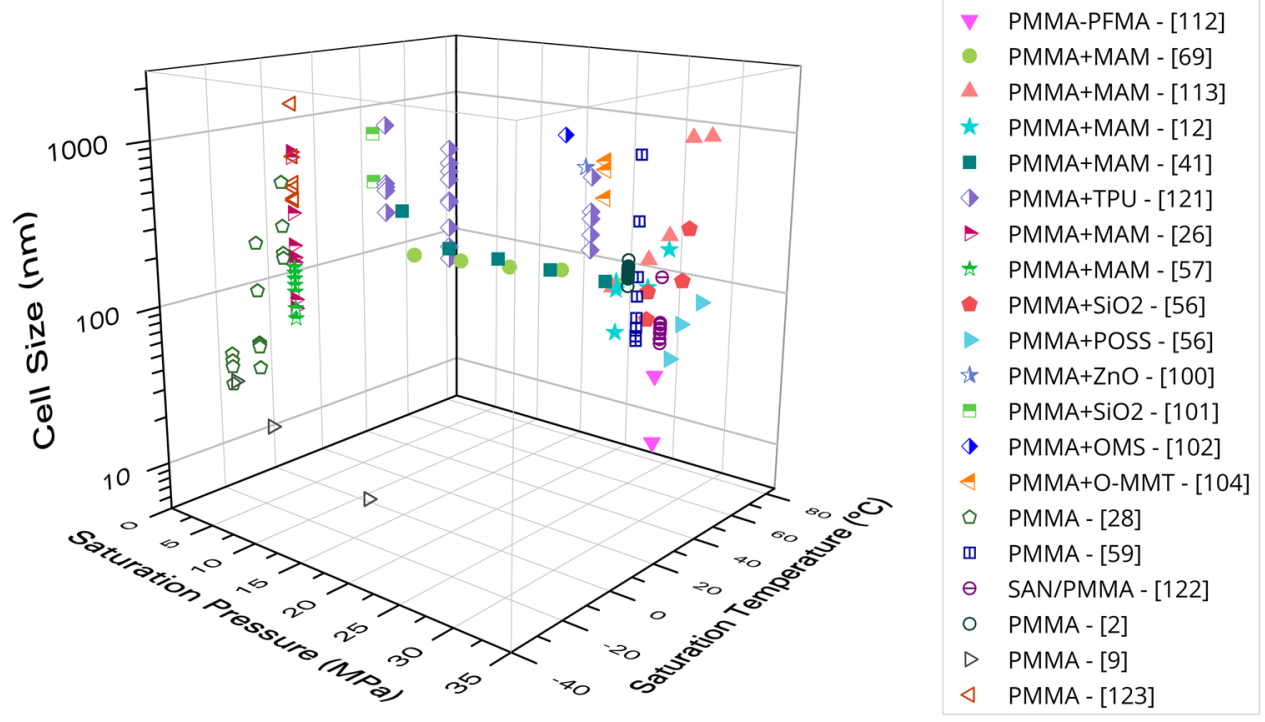

b)

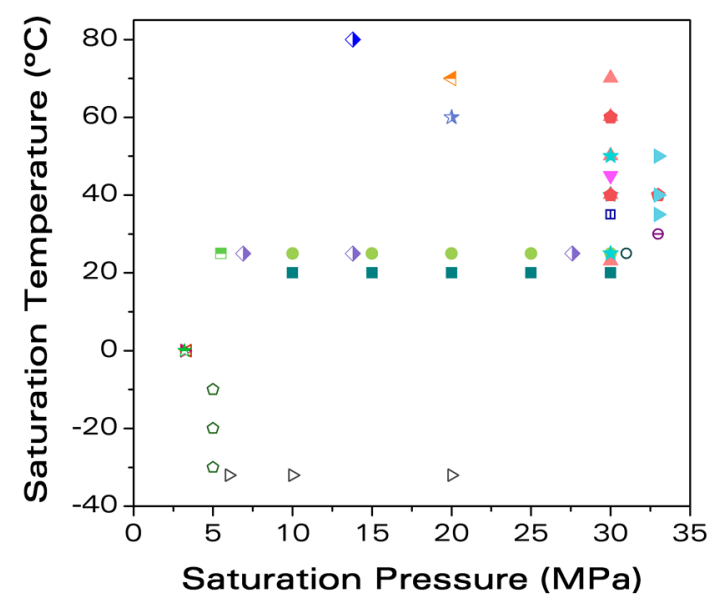

d)

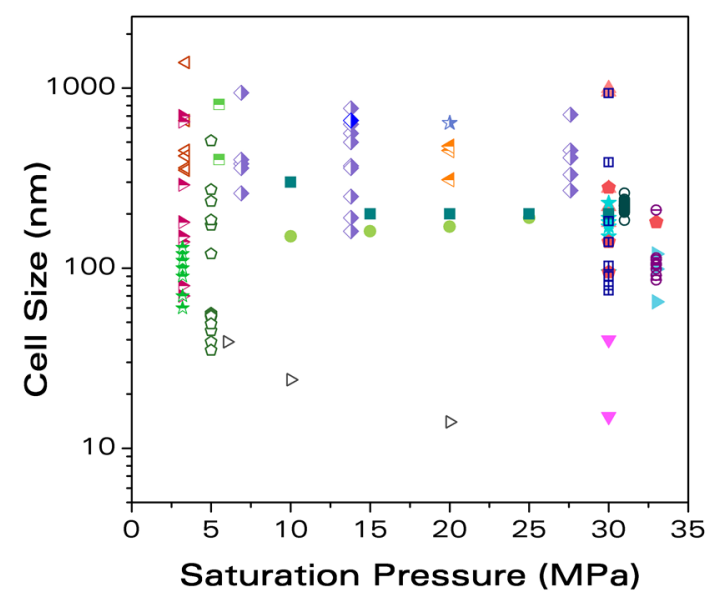

c)

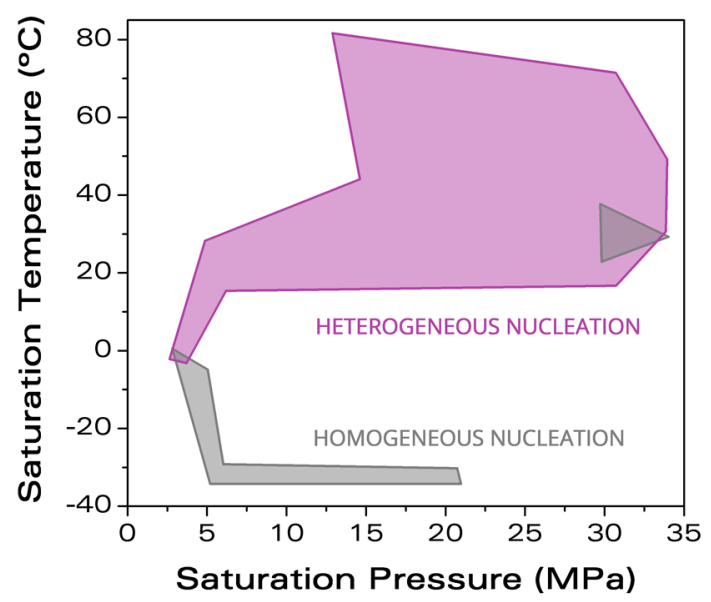

e)

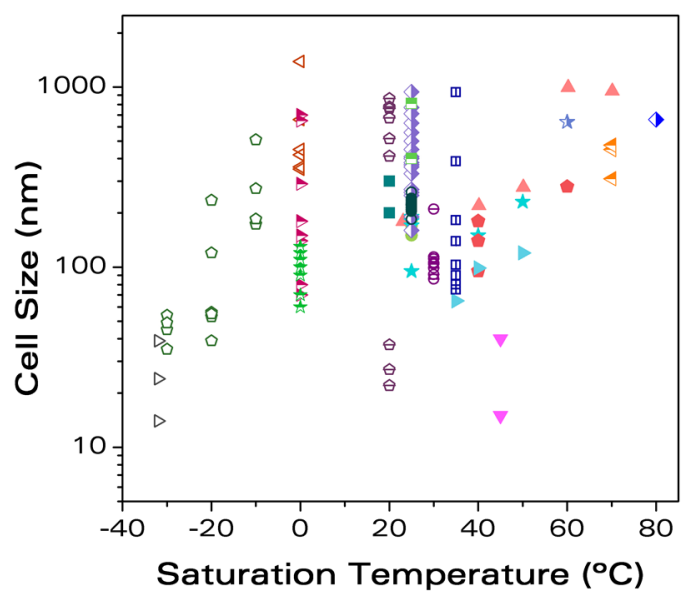

Figure 2.12. a) Cell size - saturation temperature - saturation pressure 3D map for PMMA-based systems, and 2D projections: b) saturation temperature - saturation pressure, c) saturation temperature - saturation pressure (with regions for the homogeneous and the heterogeneous systems), d) cell size - saturation pressure, and d) cell size - saturation temperature. 
The saturation conditions (pressure and temperature) determine the amount of $\mathrm{CO}_{2}$ that the polymer can absorb, that is, the solubility. Therefore, solubility can be used as a parameter to take into account pressure and temperature at the same time. Thus, it can be assumed that the higher the solubility, the more demanding the saturation conditions. With this idea, in Figure 2.13.a, a 3D plot of the cell size, the relative density and the solubility for the different PMMA-based systems is presented. For simplicity, all the systems based on the same approach (homogeneous nucleation, addition of nanoparticles and nanostructured polymer blends) have been plotted together. The solubility data were extracted from the respective paper when specified. Otherwise, it was interpolated from other available data in the literature. Once again, additional 2D plots are presented with the 3D graph for clarification: Figure 2.13.b and Figure 2.13.c show the relative density and the cell size as a function of the amount of gas uptake, respectively, while Figure 2.13.d presents a cell size - relative density map. For the majority of the homogeneous systems (open symbols with thick edges), the amount of gas uptake needs to be at least $30 \mathrm{wt} \%$ or higher for being able to obtain a nanocellular polymer. This is, of course, a limitation when scaling up the production of these materials. The homogeneous data points with solubilities between $25 \mathrm{wt} \%$ and $30 \mathrm{wt} \%$ correspond to SAN/PMMA blend because the solubility of SAN was smaller than that of PMMA (22 wt $\%$ vs $37 \mathrm{wt} \%$ ), but these materials were produced at high pressure (33 MPa). On the other hand, a solubility around $20 \mathrm{wt} \%$ is enough to achieve nanocellular polymers using a heterogeneous nucleation approach (filled and semi-filled symbols).

Nonetheless, one crucial remark about all the maps that have been presented so far is not related with the materials that have been achieved up to now, but with the systems that are still not been produced. In particular, in the region of low cell sizes (less than $100 \mathrm{~nm}$ ) and low relative densities (under 0.2 ), there are not yet any data points, that is, with the technology and materials available nowadays it has not been possible to produce such structures.

From the analysis of the previous maps, the following main conclusions about the state of the art of nanocellular polymers can be extracted:

- Heterogeneous nucleation allows producing nanocellular polymers via gas dissolution foaming at mild processing conditions, that is, using low/medium pressure and room temperature. The amount of gas that needs to be dissolved in the sample is smaller than in the homogeneous case.

- From a technological point of view, the use of nucleating species seems to be the most appropriate strategy to generate nanocellular polymers using scalable-up production routes.

Therefore, this research also aims at finding production routes that could be easily transferred to the industry, keeping the processing conditions as less demanding as possible, using the heterogeneous nucleation strategy. 
a)

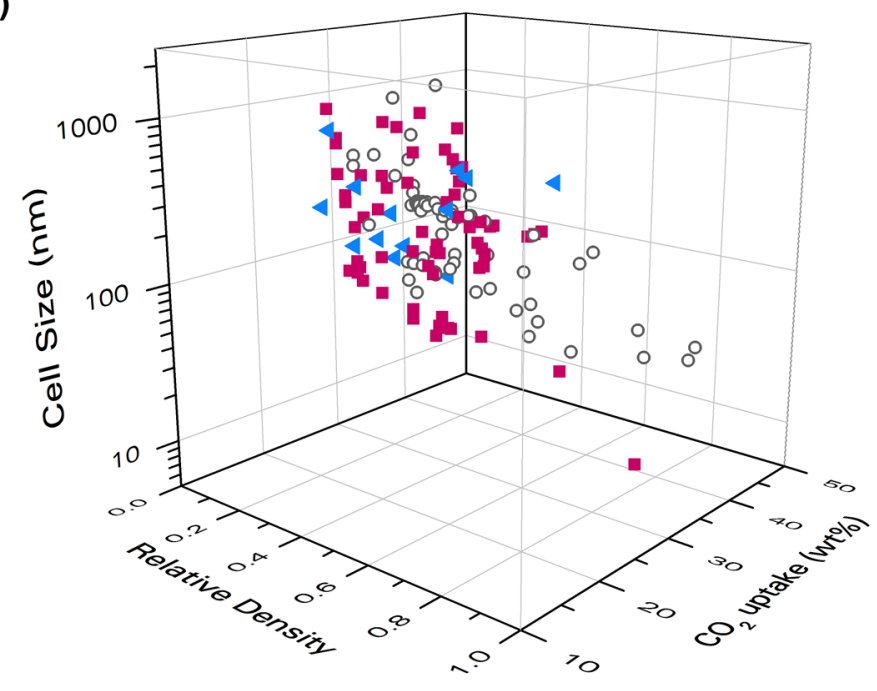

4 PMMA/nanoparticles nanocomposites

- PMMA-based nanostructured polymer blends

- Homogeneous PMMA-based systems

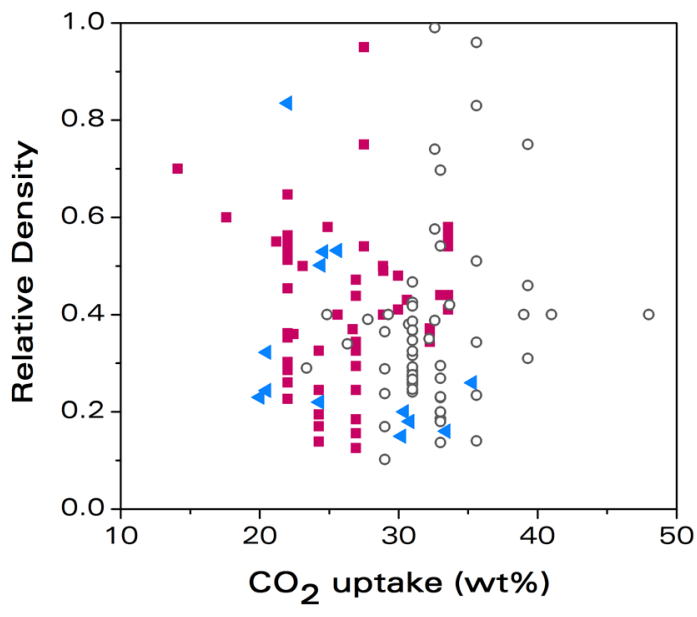

d) c)

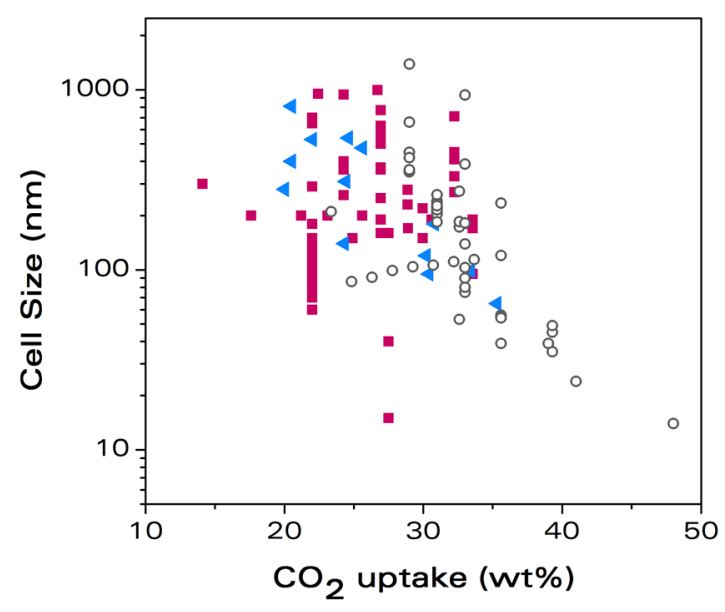

e)

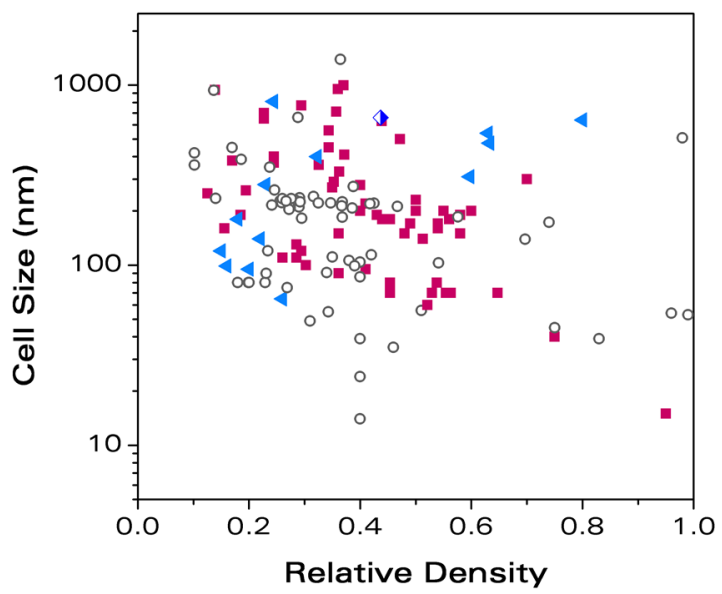

Figure 2.13. a) Cell size - relative density - $\mathrm{CO}_{2}$ uptake 3D map for PMMA-based systems, and $2 \mathrm{D}$ projections: b) relative density $-\mathrm{CO}_{2}$ uptake, c) cell size $-\mathrm{CO}_{2}$ uptake, and d) cell size - relative density. 


\subsubsection{Current challenges and limiting mechanisms}

The reasons under the limitations in the production of nanocellular polymers are related to several aspects of the physical mechanisms implied in the formation of these structures. Figure 2.14 schematically presents the evolution of the expansion ratio (that is, the inverse of the relative density) as a function of foaming time for a nanocellular material. The challenges and the key aspects to take into account in every step of the process are also included in Figure 2.14. In the next paragraphs, each of the parameters that influence the generation of a nanocellular polymer is discussed.

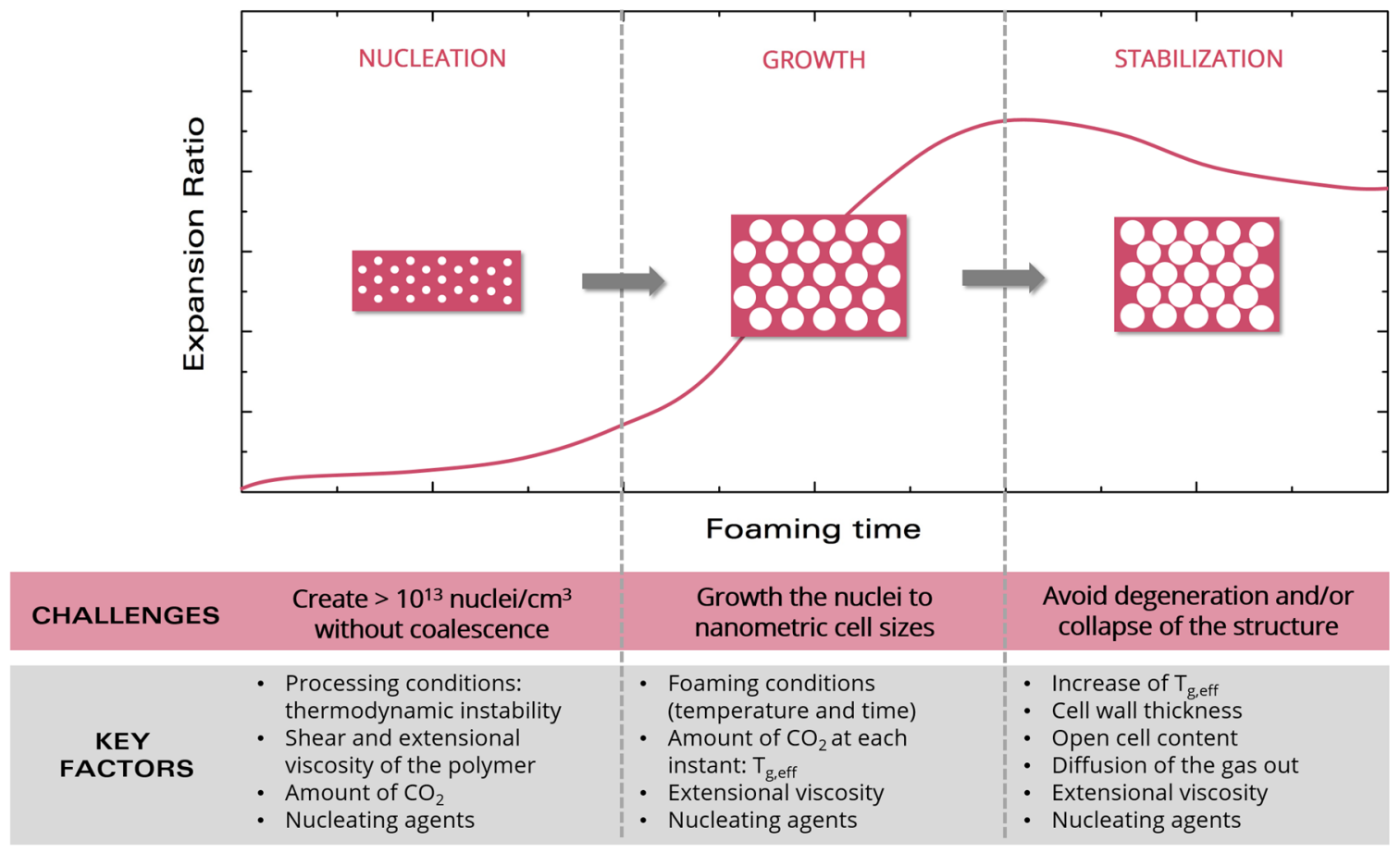

Figure 2.14. Schematic evolution of the expansion ratio in a nanocellular material as a function of the foaming time, challenges and key factors that influence each of the stages of the process.

To begin with, the viscosity of the polymer matrix plays a significant role during the whole process. Two types of viscosity need to be considered: shear and extensional, both crucial during the foaming process. In particular, both affect the first stage of the process, the nucleation (Figure 2.14). On the one hand, the shear viscosity is related to the surface tension, as reported in equation (2.10), so it affects directly to the nucleation process (equation (2.7)). On the other hand, the extensional viscosity is a factor that influences the formation of nuclei as well as the growth and the stabilization process. At low strains, the polymer should have a viscosity that allows the formation of nuclei (or very small cells), but also that prevents the coalescence of the newly formed pores. If the polymer is too viscous at low strains, it could occur that the clusters of gas molecules are not able to expand the polymer and create a new cell. On the contrary, a too low extensional viscosity can favor the coalescence of nuclei that are close to each other, reducing the effective nucleation density. In the second and third steps of the process (growth and stabilization, Figure 2.14), the extensional viscosity of the polymer is still an important factor (equation (2.11)). At medium strains, the polymer should present low viscosity to allow the growth of the cells, but at high strains, it should be viscous enough to prevent degeneration of the structure. Then, when choosing a polymer matrix, the 
viscosity (that depends on several factors such as the chemical structure and the molecular weight) needs to be considered. Besides the complexity already mentioned, note that the viscosity of the polymer is not constant during the process. First, it depends on the amount of $\mathrm{CO}_{2}$ dissolved, and as the gas is diffusing out during the process, the viscosity varies with time accordingly. Second, the foaming temperature also affects the viscosity, and in particular with respect to the effective glass transition temperature (that is also modified as the gas leaves the sample). Finally, when a nucleating agent is added (heterogeneous nucleation), the rheology of the systems can be modified entirely, and both shear and extensional viscosities might be significantly altered. For instance, it is known that high particle contents can reduce the expansion, and also copolymer micelles are known to be a limiting factor in the expansion due to the molecular organization of the micelle. In short, we can conclude that viscosity is one of the main factors in the production of a nanocellular polymer throughout all the stages of the process. There should be an optimum viscosity that allows maximizing the nucleation, but at the same time, lets achieve a high expansion ratio, i.e., a low density. However, optimizing this parameter is not a trivial task. Some works $[57,59,75]$ have proved that reducing the viscosity allows reaching lower densities, but with higher cell sizes. Therefore, more research is needed to correlate the rheological behavior with the production of nanocellular polymers.

The amount of gas in the sample is also a controlling parameter of the process (Figure 2.14). In the nucleation stage, it can affect the nucleation (if there are not any active nucleating agents). In the next stages, the amount of gas dissolved determines the plasticization of the polymer, that is, the effective glass transition temperature. As the gas is diffusing out during the process, the $T_{g \text {,eff }}$ is necessarily being modified along the foaming. In fact, the stabilization of the structure is related to this change in the $T_{\text {g,eff. }}$ The growth of the cells can occur as long as the temperature is higher than $T_{g, \text { eff. }}$ During the foaming process, the gas diffused from the polymer to the cells, and also out of the sample, so the $T_{\text {g,eff }}$ in the polymer is constantly increasing. When the sample reaches a temperature equal or higher than $T_{g, e f f}$, the polymer is again in a glassy state and the structure becomes stable.

Another aspect that needs to be considered is the thickness of the cell walls. In a microcellular polymer, the cell walls can have several hundreds of nanometers in thickness, whereas in a nanocellular polymer the cell walls are reduced under $100 \mathrm{~nm}$, with typical values around 20-60 nm $[2,3]$. Given the very small cell wall thickness, it is plausible to assume that the gas diffusion from the walls to the inside of the cells will be much faster than in a microcellular polymer. Thus, the raise in the $T_{\text {g,eff }}$ is set to take place quicker in a nanocellular polymer, and therefore, the time available for the cell growth might be restricted.

In addition, the very small cell wall thickness (tens of nanometers) implies that the polymer chains are stretched and confined in a very thin volume (of the same order of magnitude than the macromolecules dimensions), and this can affect in the properties of the solid. However, one can guess that the cell wall thickness cannot be as thin as desired, that is, it should exist a minimum cell wall thickness that can be achieved for every system. The minimum cell wall thickness could be a function of the molecular weight of the polymer, among other possible factors. This limitation in the cell wall thickness can somehow constrict the structures that can be achieved with a particular polymer, since the cell size, the relative density, and the cell wall thickness are intrinsically 
correlated [17]. For instance, it has been established that the cell wall thickness $(\xi)$, the cell size $(\phi)$, the fraction of material in the struts $\left(\mathrm{f}_{\mathrm{s}}\right)$ and the relative density $\left(\rho_{r}\right)$ of closed cell foams are related according to equation (2.24), where $C$ is a constant that takes a value of 3.46 for pentagonal dodecahedrons [124]. On the other hand, for open cell structures, equation (2.25) was developed for tetrakaidecahedra [17].

$$
\begin{gathered}
C \xi=\phi\left(1-f_{s}\right) \rho_{r} \\
\rho_{r}=1.06 \frac{\xi^{2}}{\phi^{2}}
\end{gathered}
$$

Figure 2.15 represents lines of constant cell wall thickness in a cell size - relative density map for the two equations. For the closed cell model, a fraction of mass in the struts of 0.2 was assumed, as this is a typical value for low-density cellular materials [17]. As seen in Figure 2.15, the cell wall thickness may impose some geometrical limitations in these structures. For instance, with the theoretical predictions of this figure, a closed-cell material with a cell wall thickness of $40 \mathrm{~nm}$ cannot present a density of 0.2 with a cell size of $100 \mathrm{~nm}$ (Figure 2.15.a). Open cell structures allow obtaining materials with smaller densities at the same cell wall thickness, but the cell wall thickness also imposes some limitations (Figure 2.15.b). These restrictions may be exaggerated since up to date there are no references about the minimum cell wall thickness that could be achieved with a polymer matrix and this is a complicated topic that will need parallel research. However, it provides some understanding of the physical limitations associated with this technology.

a)

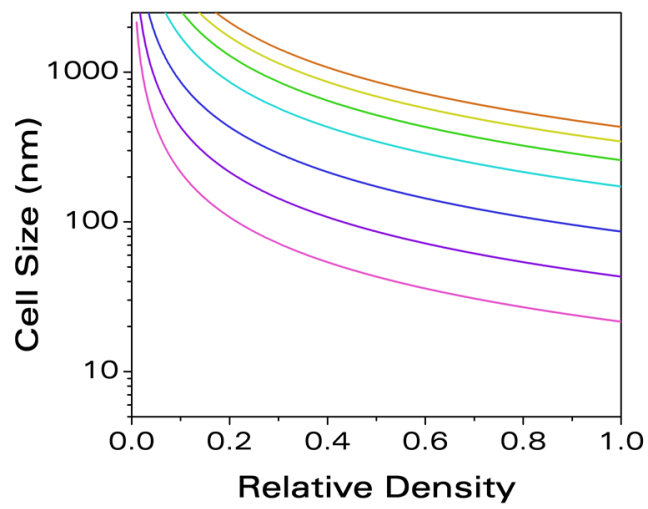

b)

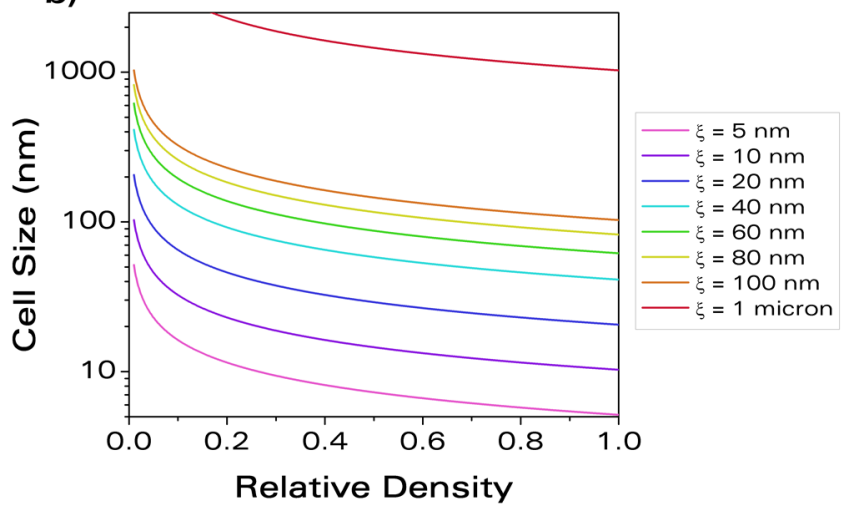

Figure 2.15. Lines of constant cell wall thickness in a cell size - relative density map: a) for closed cell materials, according to the predictions of equation (2.24) for a fraction of mass in the struts of 0.2 and $C=3.46$, and b) for open cell structures according to equation (2.25).

The cell wall thickness limitation leads to another interesting parameter to be discussed, and that is the open cell content. Once a minimum cell wall thickness is reached (that is, the polymer is stretched as much as possible), cell wall rupture might occur. One consequence of the appearance of holes and cracks in the cell walls is that gas might escape through the interconnected structure, preventing further expansion [2]. Also, cracks in the cell walls could also provoke or help in the degeneration of the structure via different mechanisms (coalescence, drainage or coarsening) that will increase the cell size to a significant extent. The presence of nanoparticles o nano-sized polymer domains can cause an enhancement in the degeneration mechanisms, due to the size of the particles and the possibility of having weak interactions in the interface. 
The main conclusion from the previous paragraphs is that the generation of nanocellular structures is a challenging process with enormous complexity. Many factors have a substantial effect on the process, such as the shear and extensional viscosities, the gas uptake and the $T_{g, e f f}$, the gas diffusion, the cell wall thickness or the open cell content. To further complicate the analysis of the effects of the variables, a lot of them are constantly changing throughout the process. Moreover, when a second phase is included in the system, all the factors above can be significantly altered. The geometry of the nucleant, its interaction with the matrix, the nanostructuration of the blend and its rheological behavior, the position of the nucleant in the cellular structure, and other aspects, are new significant parameters to be included in the understanding of the foaming mechanisms. The presence of nucleating species affects every step of the process (as indicated in Figure 2.14), complicating, even more, the analysis of the process.

In summary, there is still room for improvements in the field of fabrication of nanocellular polymers. In particular, understanding some of the critical issues and limitations would be necessary to overcome the current limitations in this area. For instance, with the use of nucleating agents, evaluating the effects of the second phase on the viscosity and rheological properties of the polymer matrix would be key to further develop this strategy, and in particular, it would be very interesting to establish the mechanism that limits the expansion in nanostructured polymer blends with copolymer micelles. Also, understanding the minimum cell wall thickness that different polymeric matrices can achieve would also be very helpful. Furthermore, deepen into the mechanisms of cell growth, degeneration, and stabilization of the cellular structure, would provide new knowledge useful to improve the current production processes and strategies.

As seen in the previous paragraphs, some of the main challenges and limitations in the production of nanocellular polymers are still unclear. Therefore, fundamental research about the production and characterization of these materials is still necessary. This is one of the primary objective of this research: to produce and characterize nanocellular polymers using a heterogeneous nucleation approach to achieve a deep understanding of the physical mechanisms playing a role in the formation of the structure.

\subsection{Properties and applications of nanocellular polymers}

In addition to the interest of the nanocellular structures themselves from a scientific point of view, the reason why nanocellular polymers have aroused so much attention in the field of Materials Science is due to their potential applications. Their unique structure provides them with an outstanding combination of properties that makes them suitable candidates for many advanced applications. In the next paragraphs, some of the most relevant properties of nanocellular polymers would be briefly commented.

\subsubsection{Thermal conductivity: Knudsen effect}

One of the main applications of cellular polymers is thermal insulation, especially in the building sector [125], because of their reduced thermal conductivity. Thermal insulation is a key topic due 
to the current concerns about the efficient use of energy. More than $50 \%$ of the energy used in the building is needed to heat indoor spaces [126], most heat is lost through walls, roofs, windows, and floors. Therefore, better thermal insulators are required, not only to save money, but also to reduce the $\mathrm{CO}_{2}$ emissions associated with energy production.

The thermal conductivity of a cellular polymer $(\lambda)$ is a sum of four contributions:

$$
\lambda_{t}=\lambda_{s}+\lambda_{g}+\lambda_{r}+\lambda_{c}
$$

Where $\lambda_{s}$ is the conduction through the solid phase, $\lambda_{g}$ is the conduction across the gas phase, $\lambda_{r}$ is the thermal radiation term, and $\lambda_{c}$ represents the convection within the cells. Cellular polymers present low thermal conductivity because of the low conductivity by conduction of gasses, for instance in the case of air ( $26 \mathrm{~mW} / \mathrm{mK}$ ), the small amount of solid (therefore, small $\lambda_{s}$ ) due to a low relative density and the suppression of convection within the cells (given they are smaller than 2 $\mathrm{mm}[17,127,128])$. Some of the most common cellular polymers currently used for thermal insulation and having air in the cells, such as expanded polystyrene (EPS) or extruded polystyrene (XPS), present thermal conductivities in the range 30-35 mW/mK [129], and they are already within the limits of their potential.

One way to further reduce the conductivity in cellular polymers is by reducing the conduction through the gas phase. To do so, the air might be replaced by other gases with lower thermal conductivities, but this is not always an environmentally friendly solution [130,131]. Another possibility to reduce this contribution is by reducing the cell size to the nano-scale, that is, producing nanocellular polymers.

When the mean free path of the gas molecules inside the cells is comparable with the cell size, the conduction throughout the gas is significantly reduced, because the collisions among the gas molecules become less probable than the collisions with the cell walls. This effect is well-known as the Knudsen effect [6,132-135]. Thanks to the Knudsen effect, the effective conductivity of the air inside the cell is reduced according to equation $(2.27)[133,136,137]$ :

$$
\lambda_{g}^{\prime}=\frac{\lambda_{g 0}^{\prime}}{1+2 \beta K n}
$$

Where $\lambda_{g 0}^{\prime}$ is the thermal conductivity of the gas that is inside the pores $(26 \mathrm{~mW} / \mathrm{mK}$ in the case of air at normal conditions), $\beta$ is a factor correlating the energy transfer between gas molecules and the structure (varying from 1.5 to 2 for argon and nitrogen [137] and 1.64 being the value for air [133]), and $K n$ is the Knudsen number, defined as:

$$
K n=\frac{l_{g}}{\phi}
$$

Where $l_{g}$ is the mean free path of the gas molecules $\left(l_{g} \approx 70 \mathrm{~nm}\right.$ for air at normal conditions $\left.[6,138]\right)$ and $\phi$ is the average cell size. Theoretically, the Knudsen effect is related to the rarefied gas conduction regime $[133,135]$, which starts to play a role for Knudsen numbers higher than 0.01 , $K n \geq 0.01$ [139]. In other words, this effect starts to become relevant when the cell size is smaller than 100 times the mean free path, $\phi \leq 100 l_{g}$. For a mean free path of $70 \mathrm{~nm}$, this means that the Knudsen effect should be considered when calculating the thermal conductivity of systems with cell 
sizes smaller than 7 microns. This effect has been proved to occur in aerogels [140] and in polymeric nanocellular materials [6].

Figure 2.16 shows the theoretical prediction of the conductivity through the gas phase as a function of the cell size according to equation 2.27. Experimental data points of PMMA-based nanocellular polymers from reference [6] have been included. For cell sizes clearly above the micron, the thermal conductivity is that of air. However, as cell size is reduced, the conduction through the gas phase decreases drastically. For instance, for a cell size of $100 \mathrm{~nm}$ the thermal conductivity of the gas is smaller than $8 \mathrm{~mW} / \mathrm{mK}$, that is, a $70 \%$ reduction compared to the conductivity of air in micrometric cells, and for a cell size of $5 \mathrm{~nm}$ the contribution is smaller than $5 \mathrm{~mW} / \mathrm{mK}$. Therefore, the conduction through the gas phase can be sharply reduced thanks to the Knudsen effect in nanocellular polymers. It has been predicted that reductions in the global thermal conductivity up to 2.5 times with respect to the current insulators used in the market can be achieved with the use of nanocellular polymers with sufficiently low density. As a consequence of this property, nanocellular polymers are promising materials to replace and improve the insulation materials available nowadays.

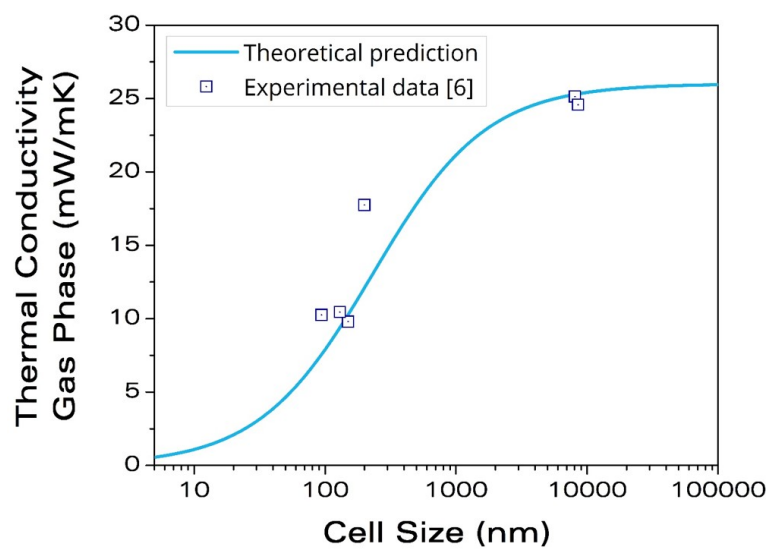

Figure 2.16. Thermal conductivity of the gas phase as a function of the cell size according to equation (2.27) and experimental data points from reference [6].

The literature about the thermal characterization of nanocellular polymers is scarce. Notario and coworkers [6] measured the thermal conductivity of nanocellular PMMA with different cell sizes, proving the Knudsen effect as previously commented. Grassberger et al. [7] demonstrated the same idea in blowing agent free nanocellular PMMA. Sundarram et al. [8] used a model for predicting that films of nanocellular polyetherimide (PEI) with cell sizes of $86 \mathrm{~nm}$ and $80 \%$ porosity could reach a thermal conductivity as low as $15 \mathrm{~mW} / \mathrm{mK}$. In the work of Guo [141], the thermal conductivity of micro and nanocellular PC samples was measured, showing the reduction in the conductivity when the cell size is reduced. Finally, in the work of Wang et al. [121], a nanocellular polymer based on blends of low-density PMMA and TPU was shown to present a thermal conductivity as low as $24.8 \mathrm{~mW} / \mathrm{mK}$.

However, there is still a lack of thermal conductivity data at different densities and cell sizes, and also the contribution of some heat transfer mechanisms (as the radiation contribution) is yet not established. In particular, the contribution of radiation to the total conductivity might not be negligible at low densities, as proposed by the model of Wang et al. [142]. Moreover, the radiation 
mechanism could be more significant in a nanocellular polymer that in conventional or microcellular polymers due to possible modifications in the scattering mechanism. When the cell size is comparable to the wavelength, then the solution of the interaction of the radiation with the cells is the so-called Mie scattering. However, when the cell size is smaller than the wavelength (in particular, 1/10 smaller), Rayleigh scattering takes place. The wavelength of the infrared radiation ranges from $700 \mathrm{~nm}$ to $1 \mathrm{~mm}$, but let us focus on one single wavelength at $10000 \mathrm{~nm}$ (the maximum wavelength emitted by a black body at room temperature). Then, materials with cell sizes smaller than $1000 \mathrm{~nm}$ (that is, nanocellular polymers) would present Rayleigh scattering, that is, the infrared light would be dispersed differently according to their cell size. Also, the amount of infrared radiation dispersed would be reduced for cell sizes under $1000 \mathrm{~nm}$, and the material would become somehow "transparent" to the infrared (in terms of the dispersed radiation, of course, part of the infrared radiation would be still absorbed by the solid polymer matrix). As the infrared region covers a wide range of wavelengths, this effect would depend on the cell size: as the cell size is reduced, more cells would be small enough not to interact with the infrared radiation. This implies that heat transfer via radiation could be enhanced in nanocellular polymers, and there will be probably a compromise between the Knudsen effect and the radiation contribution (i.e. an optimum density and cell size) to achieve the minimum conductivity. But up to date, there is no experimental information about how radiation would interact with a polymer-based nanocellular structure, that is, the extinction coefficient has not yet been measured for nanocellular polymers.

In addition, another possible effect that has not been considered yet is that the contribution of the solid phase might be affected by the confinement of the polymer in the cell walls. In particular, the recent work of $\mathrm{Ma}$ et al. [143] with ultra-thin PS films showed that thermal conductivity reduces as the thickness of the film decreases. However, the paper of Zhang and coworkers [144] showed that the stretching of the polymer chain could increase the thermal conductivity in HDPE. Further, the arrangement of the solid phase in a nanocellular polymer increases the tortuosity with respect to a microcellular polymer (as suggested by electric and thermal conductivity measurements $[4,6]$ ), and this can also have an effect in the conductivity, as the increase in the heat transfer path can reduce the conduction through the solid phase. Thus, there are some evidence that the polymer configuration in the solid phase can affect the thermal conductivity, but these effects are still unexplored.

Another limitation of the current models to predict the thermal conductivity of nanocellular polymers is related to the cell size distribution. Equation (2.27) only considers the average cell size, that is, it assumes that the nanocellular polymer presents a narrow and homogeneous cell size distribution. However, this is not always the case. In particular, bimodal structures, with micro and nanometric cells, cannot be described with the current model, because the average cell size would neglect the contribution of the micrometric pores. Moreover, nanocellular structures with a wide cell size distribution also require a model that takes into account the variation of cell size, because every cell size would present a different contribution to the Knudsen effect. During this research we have developed a model (Chapter 7) to describe the thermal conductivity by conduction of nanocellular polymers presenting heterogeneous structures, such as bimodal structures or wide cell size distributions. 


\subsubsection{Mechanical properties: confinement effect of the solid polymer}

The mechanical properties of cellular materials are related to the propagation of the stress through the cellular structure when a force is applied [17]. A significant change of scale can alter the way the stresses are distributed in the structure, resulting in a modification of the mechanical properties. This was the case in the development of microcellular polymers. The reduction of the cell size to some tens of microns resulted in an essential modification of the topology of the structure that caused an enhancement of the mechanical response of these materials. For instance, impact resistance is improved in microcellular polymers because the small cells no longer behave as stress concentrators [145]. Therefore, it is reasonable to believe that the next change of scale (from micro to nano) would also result in an alteration of the deformation mechanisms and the concentration of the stresses. However, up to date, there is are not enough data or appropriate theoretical models to describe the mechanical behavior of a nanocellular structure.

Another effect of the reduction of the cell size to the nanoscale is that the cell walls thickness is also significantly reduced. The polymer macromolecules in an unperturbed state tend to adopt random shapes (coil conformation) with a certain size, of the order of $100 \mathrm{~nm}$ or more [146]. As a result, in a microcellular structure (cell walls greater than $100 \mathrm{~nm}$ ), the polymer within the cell walls does not suffer significant constraints. However, the cell walls in a nanocellular polymer are smaller than 100 $\mathrm{nm}$ (typical values around 20-60 $\mathrm{nm}[2,3]$ ). To fit into the very thin cell walls, the polymer macromolecules need to change its ground state and adapt to the new configurations. The diameter of polymer macromolecules can be around $10 \mathrm{~nm}$ (for instance, the average diameter of one random PMMA molecule can be about 7-8 nm [4,147]), therefore, to fit into the cell walls, the polymer chains need to be aligned and stretched. This is known as confinement effect and was previously investigated in thin films $[148,149]$. In thin films, it was observed that the glass transition temperature of an amorphous polymer (such as PS) increased as the thickness of the film was reduced [150]. By analogy, the nanometric cell walls in a nanocellular polymer can be considered as self-standing films, and thus this effect in the glass transition temperature also takes place. Figure 2.17 shows a collection of data points from different works in the literature that have measured this increment in the glass transition temperature ( $\Delta T_{g}$ represents the difference between the glass transition of the nanocellular polymer and the solid material). The confinement effect is enhanced as the relative density is reduced, because a greater expansion implies a higher stretching of the solid phase (both the cell walls and the struts) and potentially the presence of thinner cell walls.

The new configuration of the structure in nanometric cells and the confinement effect can significantly modify the mechanical properties of nanocellular polymers. While most of the research about nanocellular polymers is focused on the production, the literature on mechanical characterization is relatively scarce. As a result, the dependency of the mechanical properties with the cell size, cell wall thickness and relative density of nanocellular polymers is not completely established and some data seem to provide contradictory trends. For instance, in the work Notario et al. [3] the mechanical properties of a collection of nanocellular and microcellular PMMA samples were analyzed. Under tensile experiments, the modulus of the nanocellular PMMA was better than that of the microcellular PMMA, once the effect of the density was factored-out. The impact properties were also better in the nanocellular samples. However, the yield strength was reduced. 
Dynamic mechanical analysis (DMA) of nanocellular PMMA also showed enhanced modulus in the work of Reglero et al. [41]. On the contrary, Miller and co-workers [33] found that micro and nanocellular PEI have equal elastic moduli, though the nanocellular PEI systems were found to have better impact properties. In the work of Guo [141], micro and nanocellular polycarbonate (PC) presented equal elastic moduli and impact properties in the range of the investigated relative densities (> 0.6), while the yield strength was also observed to be smaller in the nanocellular materials.

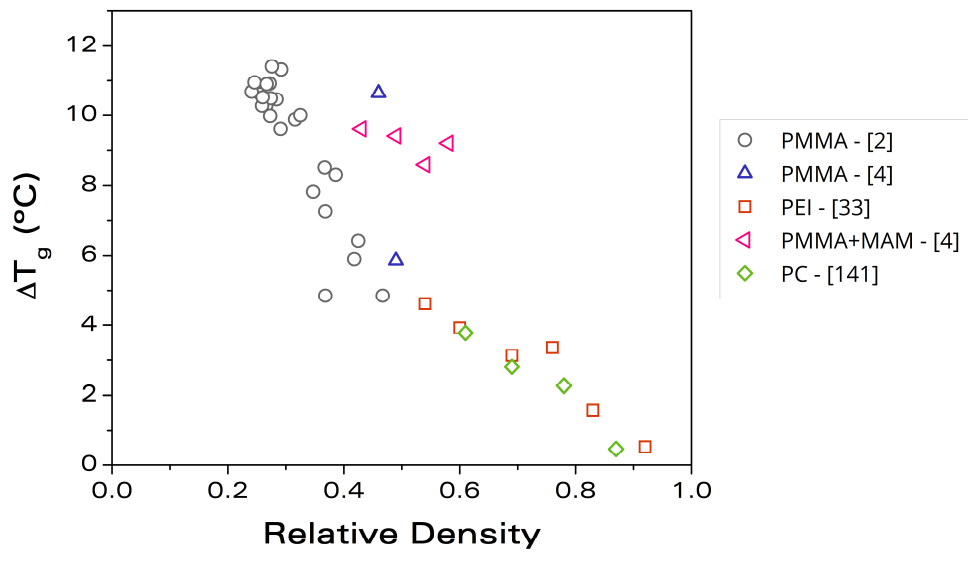

Figure 2.17. Glass transition temperature increment as a function of relative density for different nanocellular systems from references $[2,4,33,141]$.

Establishing general rules for the mechanical behavior of nanocellular polymers with the available data is challenging, since different polymer matrices, cells sizes and cell wall thickness are involved in the works previously reported. More systematic research is necessary to determine the effect of the change of scale in the mechanical properties, but without any doubt, the confinement effect must be a key parameter in the mechanical response of nanocellular polymers.

In particular, the works above were focused on analyzing the properties of nanocellular polymers produced by the homogeneous nucleation strategy. Therefore, there is a lack of knowledge about the effect of nucleating agents on the mechanical properties of nanocellular polymers. This research aims at contributing to this aspect by studying the mechanical properties of nanocellular polymers nucleated by sepiolites.

\subsubsection{Other properties and potential applications: transparency and surface area}

Nanoporous aerogels are fascinating materials due to the combination of their reduced thermal conductivity (a consequence of the Knudsen effect) and their high transparency [151]. The nanometric size of the voids in the aerogel allows this transparent behavior and makes them potential materials for the production of insulating windows.

Taking into account the similarities between inorganic aerogels and nanocellular polymers, it is plausible to assume that transparent nanocellular polymers can also be produced, given the cell size is small enough and the solid polymer matrix was initially transparent [27]. With this idea, Yokoyama et al. [111] measured the refractive index of nanocellular polymer films, showing that optical transparency could indeed be possible. In the work of Perez-Tamarit and coworkers [10], 
the first experimental data on the light transmission of nanocellular polymers based on PMMA were reported. They showed that when the cell size is below the wavelength of the light, the trend in the transmissivity versus cell size curve is opposite to that observed for materials with cells in the microscale or to that predicted by theoretical models, showing that the possibility of producing transparent nanocellular polymers can be a reality. Finally, the recent work of Martin-de Leon [9] reported the production of the first transparent nanocellular polymers. These materials were based on PMMA, and they presented cell sizes from 39 to $14 \mathrm{~nm}$. The same idea was later used in the work of Ye and coworkers [152]. Guo [141] also measured the transmittance of micro and nanocellular PC films, showing that the latter was partially transparent and the former opaque.

In order to obtain transparent nanocellular polymers, extremely low cell sizes (under 50-40 nm) are required, that is, cell sizes much lower than the wavelength of the visible light (that ranges from 400 to $750 \mathrm{~nm}$ ). In particular, when the cell size is smaller than 1/10 of the wavelength, the interaction between the light and the cells is significantly reduced, that is, for the green light (around $500 \mathrm{~nm}$ ) cell sizes as small as $50 \mathrm{~nm}$ are needed to obtain a transparent material. Also, very narrow cell size distributions would be needed to ensure transparency. Moreover, if the cell size is in this range $(<1 / 10$ of the wavelength), the dispersion of the light would follow the Rayleigh scattering equations, that is, the blue light would be more scattered than the red light, providing a blue color to the samples (as seen in aerogels $[153,154]$ ). Note that this behavior is precisely the same followed by the infrared radiation for the thermal conductivity, changing the range of wavelengths and cell size. Up to date, high transparency has only been achieved with very thin samples, since the production of materials with such low cell sizes has not allowed to reduce the density further and obtain thicker transparent materials. The field of transparent nanocellular polymers is promising not only for the production of high insulation windows or layers for these windows, but also for replacing transparent polymer films in many applications.

Another consequence of the reduction of the cell size to the nanoscale is that the surface area increases drastically. This opens the door to new applications in which conventional or microcellular polymers have poorer behavior. Using a very simple model based on perfect spheres, the surface area $S$ exhibited by a collection of spheres of radius $r$ (that is, cells of diameter the cell size) is given by equation (2.29) [155], where $\rho$ is the density.

$$
S=\frac{3}{\rho r}
$$

The predictions of this model are shown in Figure 2.18. It is observed that the surface area increases dramatically when the cell size becomes nanometric, even three orders of magnitude. This equation also predicts that low densities allow maximizing the available surface area. For instance, a material with a relative density of $200 \mathrm{~kg} / \mathrm{m}^{3}$ and a cell size of around $50 \mathrm{~nm}$ would have a surface area of $10^{3} \mathrm{~m}^{2} / \mathrm{g}$. 


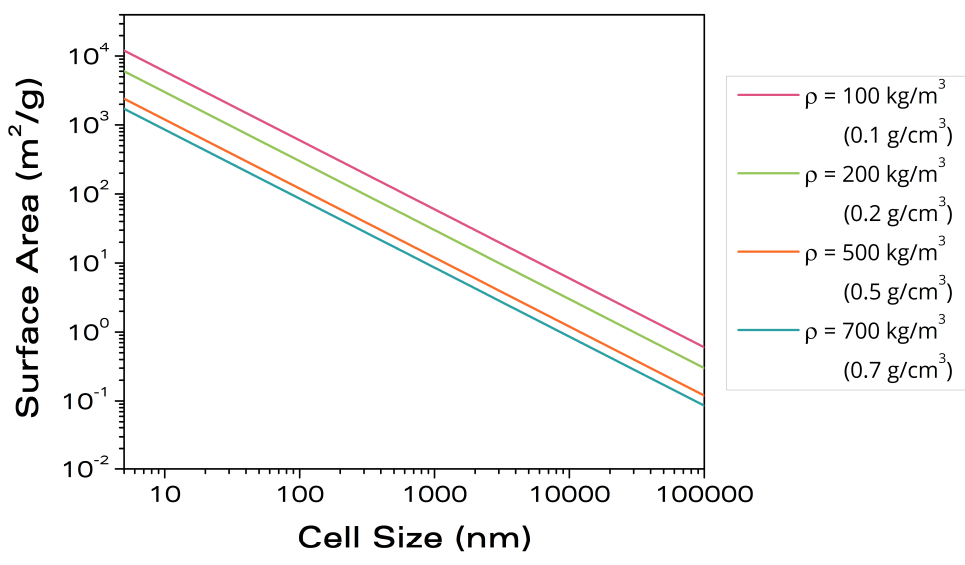

Figure 2.18. Surface area as a function of the cell size according to equation (2.29) for various densities.

The combination of nano-sized cells with an open cell structure allows the use of nanocellular polymers in applications requiring high surface area, such as catalysis, filters, and sensors [12]. However, this field of new applications of nanocellular polymers is still unexploited. One of the reasons for the lack of research in these applications is that it is challenging to produce nanocellular structures with interconnected pores and without a solid skin via the gas dissolution foaming method. More research must be done to develop open cell nanocellular polymers suitable for these new applications.

Finally, the reduction of the cell size in nanocellular polymers can also result in the appearance of new properties that are nowadays not investigated or expected. Some preliminary tests already show different electrical, dielectric, and acoustic properties compared to microcellular polymers $[5,156]$ and for sure future investigations will come up with new applications for these properties. What is clear is that the topic of nanocellular polymers will continue to be under the spotlight, and that future research will undoubtedly bring new and exciting results for the development of this promising field.

\subsection{References}

[1] J. Pinto, M. Dumon, M.A. Rodriguez-Perez, Nanoporous Polymer Foams from Nanostructured Polymer Blends: Preparation, Characterization, and Properties, in: P.. Visakh, G. Markovic, D. Pasquini (Eds.), Recent Dev. Polym. Macro, Micro Nano Blends, Woodhead Publishing in Materials, 2016: pp. 237-288.

[2] J. Martin de-Leon, V. Bernardo, M.A. Rodriguez-Perez, Low Density Nanocellular Polymers Based on PMMA Produced by Gas Dissolution Foaming: Fabrication and Cellular Structure Characterization, Polymers (Basel). 8 (2016) 1-16. doi:10.3390/polym8070265.

[3] B. Notario, J. Pinto, M.A. Rodríguez-Perez, Towards a new generation of polymeric foams: PMMA nanocellular foams with enhanced physical properties, Polymer (Guildf). 63 (2015) 116-126. doi:10.1016/j.polymer.2015.03.003.

[4] J. Pinto, B. Notario, R. Verdejo, M. Dumon, S. Costeux, M.A. Rodriguez-perez, Molecular confinement of solid and gaseous phases of self-standing bulk nanoporous polymers inducing enhanced and unexpected physical properties, Polymer (Guildf). 113 (2017) 27-33. doi:10.1016/j.polymer.2017.02.046.

[5] B. Notario, J. Pinto, R. Verdejo, M.A. Rodríguez-Pérez, Dielectric behavior of porous PMMA: From the micrometer to the nanometer scale, Polymer (Guildf). $107 \quad$ (2016) 302-305. 
doi:10.1016/j.polymer.2016.11.030.

[6] B. Notario, J. Pinto, E. Solorzano, J.A. de Saja, M. Dumon, M.A. Rodriguez-Perez, Experimental validation of the Knudsen effect in nanocellular polymeric foams, Polymer (Guildf). 56 (2015) 57-67. doi:10.1016/j.polymer.2014.10.006.

[7] L. Grassberger, K. Koch, R. Oberhoffer, A. Müller, H.F.M. Klemmer, R. Strey, Blowing agent free generation of nanoporous poly ( methylmethacrylate ) materials, Colloid Polym. Sci. 295 (2017) 379-389. doi:10.1007/s00396-017-4012-1.

[8] S.S. Sundarram, W. Li, On Thermal Conductivity of Micro- and Nanocellular Polymer Foams, Polym. Eng. Sci. 53 (2013). doi:10.1002/pen.

[9] J. Martin-de Leon, V. Bernardo, M.A. Rodriguez-Perez, Key Production Parameters to Obtain Transparent Nanocellular PMMA, Macromol. Mater. Eng. 1700343 (2017) 1-5. doi:10.1002/mame.201700343.

[10] S. Perez-Tamarit, B. Notario, E. Solorzano, M.A. Rodriguez-Perez, Light transmission in nanocellular polymers: are semi-transparent cellular polymers possible?, Mater. Lett. 210 (2017) 39-41. doi:10.1016/j.matlet.2017.08.109.

[11] G.Q. Lu, X.S. Zhao, Nanoporous Materials - An Overview, in: Nanoporous Mater. Sci. Eng., Imperial Collegue Press, London, 2004. doi:10.1142/9781860946561_0001.

[12] J. Pinto, M. Dumon, M.A. Rodriguez-Perez, R. Garcia, C. Dietz, Block Copolymers Self-Assembly Allows Obtaining Tunable Micro or Nanoporous Membranes or Depth Filters Based on PMMA; Fabrication Method and Nanostructures, J. Phys. Chem. C. 118 (2014) 4656-4663. doi:10.1021/jp409803u.

[13] L. Li, L. Schulte, L.D. Clausen, K.M. Hansen, G.E. Jonsson, S. Ndoni, Gyroid nanoporous membranes with tunable permeability, ACS Nano. 5 (2011) 7754-7766. doi:10.1021/nn200610r.

[14] B. Notario, J. Pinto, M.A. Rodriguez-Perez, Nanoporous polymeric materials: A new class of materials with enhanced properties, Prog. Polym. Sci. 78-79 (2016) 93-139. doi:10.1016/j.pmatsci.2016.02.002.

[15] J. Pinto, E. Solórzano, M.A. Rodriguez-Perez, J.A. De Saja, Characterization of the cellular structure based on user-interactive image analysis procedures, J. Cell. Plast. 49 (2013) 555-575. doi:10.1177/0021955X13503847.

[16] V. Kumar, N.P. Suh, A process for making microcellular parts, Polym. Eng. Sci. 30 (1990) 1323-1329. doi:https://doi.org/10.1002/pen.760302010.

[17] L.J. Gibson, M. Ashby, Cellular solids: structure and properties, 2nd Editio, Cambridge University Press, 1997.

[18] D. Eaves, Handbook of Polymer Foams, Rapra Technology, United Kingdom, 2004.

[19] N. Mills, Chapter I: Introduction to polymer foam microstructure, in: Polym. Foam. Handb., ButterworthHeinemann, 2007.

[20] H.P. Hentze, M. Antonietti, Porous polymers and resins for biotechnological and biomedical applications, Rev. Mol. Biotechnol. 90 (2002) 27-53. doi:10.1016/S1389-0352(01)00046-0.

[21] L. Li, X. Shen, S.W. Hong, R.C. Hayward, T.P. Russell, Fabrication of Co-continuous nanostructured and porous polymer membranes: Spinodal decomposition of homopolymer and random copolymer blends, Angew. Chemie - Int. Ed. 51 (2012) 4089-4094. doi:10.1002/anie.201107867.

[22] J.T. Jung, J.F. Kim, H.H. Wang, E. di Nicolo, E. Drioli, Y.M. Lee, Understanding the non-solvent induced phase separation (NIPS) effect during the fabrication of microporous PVDF membranes via thermally induced phase separation (TIPS), J. Memb. Sci. 514 (2016) 250-263. doi:10.1016/j.memsci.2016.04.069.

[23] P. van de Witte, P.J.J. Dijkstra, J.W. a. W. a van den Berg, J. Feijen, Phase separation processes in polymer solutions in relation to membrane formation, J. Memb. Sci. 117 (1996) 1-31. doi:10.1016/0376-7388(96)000889.

[24] M.A. Hillmyer, Nanoporous Materials from Block Copolymer Precursors, Adv. Polym. Sci. 190 (2005) 137-181.

[25] D.A. Olson, L. Chen, M.A. Hillmyer, Templating Nanoporous Polymers with Ordered Block Copolymers, Chem. Mater. 20 (2008) 869-890. doi:10.1021/cm702239k.

[26] C. Forest, P. Chaumont, P. Cassagnau, B. Swoboda, P. Sonntag, CO2 nano-foaming of nanostructured PMMA, Polymer (Guildf). 58 (2015) 76-87. doi:10.1016/j.polymer.2014.12.048.

[27] H. Guo, V. Kumar, Some thermodynamic and kinetic low-temperature properties of the PC-CO2 system and morphological characteristics of solid-state PC nanofoams produced with liquid CO2, Polymer (Guildf). 56 (2015) 46-56. doi:10.1016/j.polymer.2014.09.061.

[28] H. Guo, A. Nicolae, V. Kumar, Solid-state poly(methyl methacrylate) (PMMA) nanofoams. Part II: Low- 
temperature solid-state process space using CO2 and the resulting morphologies, Polymer (Guildf). 70 (2015) 231-241. doi:10.1016/j.polymer.2015.06.031.

[29] S. Costeux, CO2-blown nanocellular foams, J. Appl. Polym. Sci. 131 (2014) 41293(1)-41293(16). doi:10.1002/app.41293.

[30] H. Guo, A. Nicolae, V. Kumar, Fabrication of High Temperature Polyphenylsulfone Nanofoams Using High Pressure Liquid Carbon Dioxide, Cell. Polym. 35 (2015) 2016.

[31] V. Bernardo, J. Martín-de Leon, M.A. Rodriguez-Perez, Production and characterization of nanocellular polyphenylsulfone foams, Mater. Lett. 178 (2016) 155-158. doi:10.1016/j.matlet.2016.05.002.

[32] H. Guo, A. Nicolae, V. Kumar, Solid-State Microcellular and Nanocellular Polysulfone Foams, J. Polym. Sci. Part B Polym. Phys. 53 (2015) 975-985. doi:10.1002/polb.23719.

[33] D. Miller, V. Kumar, Microcellular and nanocellular solid-state polyetherimide (PEI) foams using sub-critical carbon dioxide II. Tensile and impact properties, Polymer (Guildf). 52 (2011) 2910-2919. doi:10.1016/j.polymer.2011.04.049.

[34] S.L. Wells, J. Desimone, $\mathrm{CO}_{2}$ technology platform: An important tool for environmental problem solving, Angew. Chemie - Int. Ed. 40 (2001) 518-527. doi:10.1002/1521-3773(20010202)40:3<518::AIDANIE518>3.0.CO;2-4.

[35] L.J.M. Jacobs, M.F. Kemmere, J.T.F. Keurentjes, Sustainable polymer foaming using high pressure carbon dioxide: A review on fundamentals, processes and applications, Green Chem. 10 (2008) 731-738. doi:10.1039/b801895b.

[36] F.A. Waldman, The processing of microcellular foam, Massachusetts Institute of Technology, 1980.

[37] J.E. Martini-Vvedensky, N.P. Suh, F.A. Waldman, United States Patent - MICROCELLULAR CLOSED CELL FOAMS AND THEIR METHOD OF MANUFACTURE, 4,473,665, 1984

[38] K. Nadella, V. Kumar, W. Li, Constrained solid-state foaming of microcellular panels, Cell. Polym. 24 (2005) $71-$ 90. doi:10.1177/026248930502400202.

[39] V. Kumar, J. Weller, Production of Microcellular Polycarbonate Using Carbon Dioxide for Bubble Nucleation, J. Eng. Ind. 116 (1994) 413-420. doi:10.1115/1.2902122.

[40] Y. Fujimoto, S.S. Ray, M. Okamoto, A. Ogami, K. Yamada, K. Ueda, Well-Controlled Biodegradable Nanocomposite Foams: From Microcellular to Nanocellular, Macromol. Rapid Commun. 24 (2003) 457-461. doi:10.1002/marc.200390068.

[41] J.A. Reglero Ruiz, M. Dumon, J. Pinto, M.A. Rodriguez-Perez, Low-density nanocellular foams produced by high-pressure carbon dioxide, Macromol. Mater. Eng. 296 (2011) 752-759. doi:10.1002/mame.201000346.

[42] F. Rindfleisch, T.P. DiNoia, M. a. McHugh, Solubility of polymers and copolymers in supercritical CO2, J. Phys. Chem. Chem. 100 (1996) 15581-15587. doi:10.1021/jp9615823.

[43] K.F. Webb, A.S. Teja, Solubility and diffusion of carbon dioxide in polymers, Fluid Phase Equilib. 158-160 (1999) 1029-1034. doi:10.1016/S0378-3812(99)00153-3.

[44] M. O'neill, Q. Cao, M. Fang, Solubility of homopolymers and copolymers in carbon dioxide, Ind. Eng. Chem. Res. 5885 (1998) 3067-3079. doi:10.1021/ie980010x.

[45] J. Crank, The mathematics of diffusion, Oxford University Press, 1975. doi:10.1016/0306-4549(77)90072-X.

[46] P.L. Durril, R.G. Griskey, Diffusion and Solution of gases in s Thermally Softened or Molten Polymers: Part I. Development of Technique and Determination of Data, A.I.Ch.E. J. 12 (1966).

[47] W. Wilfried, Model calculation of the temperature dependence of small molecule diffusion in high polymers, J. Phys. Chem. 63 (1968) 1080-1085. doi:10.1021/j150577a012.

[48] J.E. Weller, V. Kumar, Solid State Microcellular PC Foams I, Polym. Eng. Sci. 47 (2007) 21-25. doi:10.1002/pen.

[49] Y.D. Hwang, S.W. Cha, The relationship between gas absorption and the glass transition temperature in a batch microcellular foaming process, Polym. Test. 21 (2002) 269-275. doi:10.1016/S0142-9418(01)00081-2.

[50] P. Alessi, A. Cortesi, I. Kikic, F. Vecchione, Plasticization of Polymers with Supercritical Carbon Dioxide: Experimental Determination of Glass-Transition Temperatures, J. Appl. Polym. Sci. 88 (2003) 2189-2193. doi:10.1002/app.11881.

[51] Z. Zhang, Y.P. Handa, An in situ study of plasticization of polymers by high-pressure gases, J. Polym. Sci. 36 (1998) 977-982. doi:10.1002/(sici)1099-0488(19980430)36:6<977::aid-polb5>3.0.co;2-d. 
[52] V. Kumar, J.E. Weller, A model for the unfoamed skin on microcellular foams, Polym. Eng. Sci. 34 (1994) 169173. doi:10.1002/pen.760340302.

[53] J. Pinto, S. Pardo, E. Solórzano, M.A. Rodríguez-Pérez, M. Dumon, J.A. de Saja, Solid Skin Characterization of PMMA/MAM Foams Fabricated by Gas Dissolution Foaming over a Range of Pressures, Defect Diffus. Forum. 326-328 (2012) 434-439. doi:10.4028/www.scientific.net/DDF.326-328.434.

[54] K. Nadella, H. Guo, J. Weller, V. Kumar, Sorption and Desorption of CO 2 in Polycarbonate (PC) and Acrylonitrile Butadiene Styrene ( ABS ) in the Solid State Microcellular Process, (n.d.).

[55] J. Antonio, R. Ruiz, P. Viot, M. Dumon, Microcellular Foaming of Polymethylmethacrylate in a Batch Supercritical CO 2 Process : Effect of Microstructure on Compression Behavior, J. Appl. Polym. Sci. 118 (2010) 320-331. doi:10.1002/app.

[56] S. Costeux, L. Zhu, Low density thermoplastic nanofoams nucleated by nanoparticles, Polymer (Guildf). 54 (2013) 2785-2795. doi:10.1016/j.polymer.2013.03.052.

[57] C. Forest, P. Chaumont, P. Cassagnau, B. Swoboda, P. Sonntag, Nanofoaming of PMMA using a batch CO2 process: Influence of the PMMA viscoelastic behaviour, Polymer (Guildf). 77 (2015) 1-9. doi:10.1016/j.polymer.2015.09.011.

[58] C. Zeng, N. Hossieny, C. Zhang, B. Wang, Synthesis and processing of PMMA carbon nanotube nanocomposite foams, Polymer (Guildf). 51 (2010) 655-664. doi:10.1016/j.polymer.2009.12.032.

[59] S. Costeux, I. Khan, S.P. Bunker, H.K. Jeon, Experimental study and modeling of nanofoams formation from single phase acrylic copolymers, J. Cell. Plast. 51 (2015) 197-221. doi:10.1177/0021955X14531972.

[60] J.B. Clark, J.W. Hastie, L.H.E. Kihlborg, R. Metselaar, M.M. Thackeray, Definitions of terms relating to phase transitions of the solid state (IUPAC Recomendations 1994), Int. Pure Appl. Chem. 66 (1994) 577-594.

[61] J.H. Aubert, R.L. Clough, Low-density, microcellular polystyrene foams, Polymer (Guildf). 26 (1985) 2047-2054.

[62] V.I. Kalikmanov, Nucleation Theory, Springer, 2013.

[63] M. Mokhtari Motameni Shirvan, M.H.N. Famili, A. Golbang, A Review on the Application of Nucleation Theories in Thermoplastic Foams, Plast. Polym. Technol. 4 (2016) 10-32. doi:10.14355/papt.2016.04.002.

[64] H. Guo, V. Kumar, Solid-state poly(methyl methacrylate) (PMMA) nanofoams. Part I: Low-temperature CO2 sorption, diffusion, and the depression in PMMA glass transition, Polymer (Guildf). 57 (2015) 157-163. doi:10.1016/j.polymer.2014.12.029.

[65] D. Miller, P. Chatchaisucha, V. Kumar, Microcellular and nanocellular solid-state polyetherimide ( PEI ) foams using sub-critical carbon dioxide I . Processing and structure, Polymer (Guildf). 50 (2009) 5576-5584. doi:10.1016/j.polymer.2009.09.020.

[66] S.K. Goel, E.J. Beckman, Generation of Microcellular Polymeric Foams Using Supercritical Carbon Dioxide. I: Effect of Pressure and Temperature on Nucleation, Polym. Eng. Sci. 34 (1994) 1137-1147. doi:10.1002/pen.760341407.

[67] I. Khan, D. Adrian, S. Costeux, A model to predict the cell density and cell size distribution in nano-cellular foams, Chem. Eng. Sci. 138 (2015) 634-645. doi:10.1016/j.ces.2015.08.029.

[68] M. a Shafi, J.G. Lee, R.W. Flumerfelt, Prediction of cellular structure in free expansion polymer foam processing, Polym. Eng. Sci. 36 (1996) 1950-1959. doi:10.1002/pen.10591.

[69] J. Pinto, M. Dumon, M. Pedros, J. Reglero, M.A. Rodriguez-Perez, Nanocellular CO2 foaming of PMMA assisted by block copolymer nanostructuration, Chem. Eng. J. 243 (2014) 428-435. doi:10.1016/j.cej.2014.01.021.

[70] P. Spitael, C.W. Macosko, R.B. Mcclurg, Block Copolymer Micelles for Nucleation of Microcellular Thermoplastic Foams, Macromolecules. 37 (2004) 6874-6882. doi:10.1021/ma049712q.

[71] J.S. Colton, N.P. Suh, Nucleation of Microcellular Foam: Theory and Practice, Polym. Eng. Sci. 27 (1987) 500503.

[72] A.J. Ruiz-Reglero, C. Saiz-arroyo, M. Dumon, M.A. Rodriguez-Perez, L. Gonzalez, Production, cellular structure and thermal conductivity of microcellular (methyl methacrylate)-(butyl acrylate)-(methyl methacrylate) triblock copolymers, Polym. Int. 60 (2011) 146-152. doi:10.1002/pi.2931.

[73] H. Schonhorn, Surface Tension-Viscosity Relationship for liquids, J. Chem. Eng. Data. 12 (1967) 524-525.

[74] S. Yeh, Z. Liao, C. Chu, United States Patent Application - METHOD FOR PRODUCING POLYMER NANOFOAM, US 2017/0130.023 A1, 2017.

[75] Z. Liao, S. Yeh, C. Chu, T. Tseng, Critical Parameters of Generating PMMA Nanocellular Foam, in: SPE ANTEC 
Indianap., 2016: pp. 1773-1778.

[76] C. Zhou, N. Vaccaro, S.S. Sundarram, W. Li, Fabrication and characterization of polyetherimide nanofoams using supercritical CO 2, J. Cell. Plast. 48 (2012) 239-255. doi:10.1177/0021955X12437984.

[77] B. Krause, N.F.A. Van Der Vegt, M. Wessling, Open nanoporous morphologies from polymeric blends by carbon dioxide foaming, Macromolecules. 35 (2002) 1738-1745. doi:10.1021/ma011672s.

[78] J.S. Colton, N.P. Suh, The Nucleation of Microcellular Thermoplastic Foam With Additives: Part I: Theoretical Considerations, Polym. Eng. Sci. 27 (1987) 485-492.

[79] L. Chen, D. Rende, L.S. Schadler, R. Ozisik, Polymer nanocomposite foams, J. Mater. Chem. A. 1 (2013) 38373850. doi:10.1039/c2ta00086e.

[80] N.H. Fletcher, Size effect in heterogeneous nucleation, J. Chem. Phys. 29 (1958) 572-576. doi:10.1063/1.1744540.

[81] W. Zhai, J. Yu, L. Wu, W. Ma, J. He, Heterogeneous nucleation uniformizing cell size distribution in microcellular nanocomposites foams, Polymer (Guildf). 47 (2006) 7580-7589. doi:10.1016/j.polymer.2006.08.034.

[82] V. Mittal, Polymer Nanocomposite Foams, CRC Press, 2014.

[83] J. Fu, H.E. Naguib, Effect of Nanoclay on the Mechanical Properties of PMMA/Clay Nanocomposite Foams, J. Cell. Plast. 42 (2006) 325-342. doi:10.1177/0021955X06063517.

[84] G. Gedler, M. Antunes, T. Borca-Tasciuc, J.I. Velasco, R. Ozisik, Effects of graphene concentration, relative density and cellular morphology on the thermal conductivity of polycarbonate-graphene nanocomposite foams, Eur. Polym. J. 75 (2016) 190-199. doi:10.1016/j.eurpolymj.2015.12.018.

[85] H. Varela-Rizo, M. Weisenberger, D.R. Bortz, I. Martin-Gullon, Fracture toughness and creep performance of PMMA composites containing micro and nanosized carbon filaments, Compos. Sci. Technol. 70 (2010) 11891195. doi:10.1016/j.compscitech.2010.03.005.

[86] Y. Yang, M.C. Gupta, K.L. Dudley, R.W. Lawrence, Conductive carbon nanofiber-polymer foam structures, Adv. Mater. 17 (2005) 1999-2003. doi:10.1002/adma.200500615.

[87] K. Goren, L. Chen, L.S. Schadler, R. Ozisik, Influence of nanoparticle surface chemistry and size on supercritical carbon dioxide processed nanocomposite foam morphology, J. Supercrit. Fluids. 51 (2010) 420-427. doi:10.1016/j.supflu.2009.09.007.

[88] D. Rende, L.S. Schadler, R. Ozisik, Controlling foam morphology of poly(methyl methacrylate) via surface chemistry and concentration of silica nanoparticles and supercritical carbon dioxide process parameters, J. Chem. 2013 (2013). doi:10.1155/2013/864926.

[89] E. Laguna-Gutierrez, C. Saiz-Arroyo, J.I. Velasco, M.A. Rodriguez-Perez, Low density polyethylene/silica nanocomposite foams. Relationship between chemical composition, particle dispersion, cellular structure and physical properties, Eur. Polym. J. 81 (2016) 173-185. doi:10.1016/j.eurpolymj.2016.06.001.

[90] C.M. Chan, J. Wu, J.X. Li, Y.K. Cheung, Polypropylene/calcium carbonate nanocomposites, Polymer (Guildf). 43 (2002) 2981-2992. doi:10.1016/S0032-3861(02)00120-9.

[91] J. Yeh, K. Chang, C. Peng, M. Lai, C. Hung, Effect of dispersion capability of organoclay on cellular structure and physical properties of PMMA / clay nanocomposite foams, Mater. Chem. Phys. 115 (2009) 744-750. doi:10.1016/j.matchemphys.2009.02.017.

[92] H. Janani, M.H.N. Famili, Investigation of a Strategy for Well Controlled Inducement of Microcellular and Nanocellular Morphologies in Polymers, Polym. Eng. Sci. 50 (2010) 1558-1570. doi:10.1002/pen.

[93] S. Siripurapu, J.M. Desimone, S.A. Khan, R.J. Spontak, N. Carolina, N. Carolina, Controlled Foaming of Polymer Films through Restricted Surface Diffusion and the Addition of Nanosilica Particles or CO2-philic Surfactants, Macromolecules. 38 (2005) 2271-2280. doi:10.1021/ma047991b.

[94] J. Santaren, A. Alvarez, A. Esteban-Cubillo, B. Notario, D. Velasco, M.A. Rodriguez-Perez, Improving the Cellular Structure and Thermal Conductivity of PS Foams by Using Sepiolites, in: Foams2012, 2012: pp. 1-5.

[95] Y. Ema, M. Ikeya, M. Okamoto, Foam processing and cellular structure of polylactide-based nanocomposites, Polymer (Guildf). 47 (2006) 5350-5359. doi:10.1016/j.polymer.2006.05.050.

[96] Y.H. Lee, C.B. Park, K.H. Wang, HDPE-Clay Nanocomposite Foams Blown with Supercritical CO2, J. Cell. Plast. 41 (2005) 487-502. doi:10.1177/0021955X05056964.

[97] A. Ameli, M. Nofar, C.B. Park, Polypropylene/carbon nanotube nano/microcellular structures with high dielectric permittivity, low dielectric loss, and low percolation threshold, Carbon N. Y. 71 (2014) 206-207. 
doi:10.1016/j.carbon.2014.01.031.

[98] Y. Ito, M. Yamashita, M. Okamoto, Foam Processing and Cellular Structure of Polycarbonate-Based Nanocomposites, 291 (2006) 773-783. doi:10.1002/mame.200600075.

[99] L. Urbanczyk, C. Calberg, C. Detrembleur, C. Jérôme, M. Alexandre, Batch foaming of SAN/clay nanocomposites with scCO2: A very tunable way of controlling the cellular morphology, Polymer (Guildf). 51 (2010) 3520-3531. doi:10.1016/j.polymer.2010.05.037.

[100] J. Pinto, D. Morselli, V. Bernardo, B. Notario, D. Fragouli, M.A. Rodriguez-Perez, A. Athanassiou, Nanoporous PMMA foams with templated pore size obtained by localized in situ synthesis of nanoparticles and $\mathrm{CO} 2$ foaming, Polymer (Guildf). 124 (2017) 176-185. doi:10.1016/j.polymer.2017.07.067.

[101] S. Liu, B. Zoetebier, L. Hulsman, Y. Zhang, J. Duvigneau, G.J. Vancso, Nanocellular polymer foams nucleated by core-shell nanoparticles, Polymer (Guildf). 104 (2016). doi:10.1016/j.polymer.2016.09.016.

[102] J. Yang, L. Huang, Y. Zhang, F. Chen, P. Fan, M. Zhong, S. Yeh, A new promising nucleating agent for polymer foaming: Applications of ordered mesoporous silica particles in polymethyl methacrylate supercritical carbon dioxide microcellular foaming, Ind. Eng. Chem. Res. 52 (2013) 14169-14178. doi:10.1021/ie4018447.

[103] H. Yu, Y. Lei, X. Yu, X. Wang, T. Liu, S. Luo, Solid-state polyetherimide (PEI) nanofoams: the influence of the compatibility of nucleation agent on the cellular morphology, J. Polym. Res. 23 (2016) 121. doi:10.1007/s10965-016-1009-2.

[104] V. Realinho, M. Antunes, A.B. Martínez, J.I. Velasco, Influence of nanoclay concentration on the CO2 diffusion and physical properties of PMMA montmorillonite microcellular foams, Ind. Eng. Chem. Res. 50 (2011) 1381913824. doi:10.1021/ie201532h.

[105] L. Monnereau, L. Urbanczyk, J.M. Thomassin, M. Alexandre, C. Jérôme, I. Huynen, C. Bailly, C. Detrembleur, Supercritical $\mathrm{CO} 2$ and polycarbonate based nanocomposites: A critical issue for foaming, Polymer (Guildf). 55 (2014) 2422-2431. doi:10.1016/j.polymer.2014.03.035.

[106] M.D. Whitmore, T.W. Smith, Swelling of Copolymer Micelles by Added Homopolymer, Macromolecules. 27 (1994) 4673-4683. doi:10.1021/ma00095a006.

[107] H. Yokoyama, K. Sugiyama, Nanocellular structures in block copolymers with CO2-philic blocks using CO2 as a blowing agent: Crossover from micro- to nanocellular structures with depressurization temperature, Macromolecules. 38 (2005) 10516-10522. doi:10.1021/ma051757j.

[108] J.A. Reglero-Ruiz, E. Cloutet, M. Dumon, Investigation of the Nanocellular Foaming of Polystyrene in Supercritical CO2 by Adding a CO2-Philic Perfluorinated Block Copolymer, J. Appl. Polym. Sci. 121 (2012) 3845. doi:10.1002/app.

[109] R. Dell'Erba, G. Groeninckx, G. Maglio, M. Malinconico, A. Migliozzi, Immiscible polymer blends of semicrystalline biocompatible components: Thermal properties and phase morphology analysis of PLLA/PCL blends, Polymer (Guildf). 42 (2001) 7831-7840. doi:10.1016/S0032-3861(01)00269-5.

[110] S. Wu, Formation of Dispersed Phase in Incompatible Polymer Interfacial and Rheological Effects, Polym. Eng. Sci. 27 (1987) 335-343. doi:10.1002/pen.760270506.

[111] H. Yokoyama, L. Li, T. Nemoto, K. Sugiyama, Tunable nanocellular polymeric monoliths using fluorinated block copolymer templates and supercritical carbon dioxide, Adv. Mater. 16 (2004) 1542-1546. doi:10.1002/adma.200400072.

[112] C. Dutriez, K. Satoh, M. Kamigaito, H. Yokoyama, Nanocellular foaming of fluorine containing block copolymers in carbon dioxide: The role of glass transition in carbon dioxide, RSC Adv. 2 (2012) 2821-2827. doi:10.1039/c2ra01268e.

[113] J. Pinto, J.A. Reglero-Ruiz, M. Dumon, M.A. Rodriguez-Perez, Temperature influence and CO2 transport in foaming processes of poly(methyl methacrylate)-block copolymer nanocellular and microcellular foams, J. Supercrit. Fluids. 94 (2014) 198-205. doi:10.1016/j.supflu.2014.07.021.

[114] A.V. Nawaby, Y.P. Handa, X. Liao, Y. Yoshitaka, M. Tomohiro, Polymer-CO2 systems exhibiting retrograde behavior and formation of nanofoams, Polym. Int. 56 (2007) 67-73. doi:10.1002/pi.2112.

[115] T. Otsuka, K. Taki, M. Ohshima, Nanocellular foams of PS/PMMA polymer blends, Macromol. Mater. Eng. 293 (2008) 78-82. doi:10.1002/mame.200700257.

[116] T. Nemoto, J. Takagi, M. Ohshima, Nanocellular Foams-Cell Structure Difference Between Immiscible and Miscible PEEK/PEI Polymer Blends, Polym. Eng. Sci. 50 (2010) 2408-2416. doi:10.1002/pen.

[117] D. Bao, X. Liao, T. He, Q. Yang, G. Li, Preparation of nanocellular foams from polycarbonate/poly(lactic acid) blend by using supercritical carbon dioxide, J. Polym. Res. 20 (2013). doi:10.1007/s10965-013-0290-6. 
[118] T. Nemoto, J. Takagi, M. Ohshima, Nanoscale cellular foams from a poly(propylene)-rubber blend, Macromol. Mater. Eng. 293 (2008) 991-998. doi:10.1002/mame.200800184.

[119] T. Nemoto, J. Takagi, M. Ohshima, Control of bubble size and location in nano-/microscale cellular poly(propylene)/rubber blend foams, Macromol. Mater. Eng. 293 (2008) 574-580. doi:10.1002/mame.200800015

[120] R.W.B. Sharudin, M. Ohshima, CO2-induced mechanical reinforcement of polyolefin-based nanocellular foams, Macromol. Mater. Eng. 296 (2011) 1046-1054. doi:10.1002/mame.201100085.

[121] G. Wang, J. Zhao, L.H. Mark, G. Wang, K. Yu, C. Wang, C.B. Park, G. Zhao, Ultra-tough and super thermalinsulation nanocellular PMMA/TPU, Chem. Eng. J. 325 (2017) 632-646. doi:10.1016/j.cej.2017.05.116.

[122] Y.P. Handa, Z. Zhang, A New Technique for Measuring Retrograde Vitrification in Polymer-Gas Systems and for Making Ultramicrocellular, J. Polym. Sci. Part B Polym. Phys. 38 (2000) 716-725. doi:10.1002/(SICI)10990488(20000301)38:5<716::AID-POLB9>3.0.CO;2-N.

[123] S. Costeux, S.P. Bunker, Homogeneous nanocellular foams from styrenic-acrylic polymer blends, J. Mater. Res. 17 (2013) 2351. doi:10.1557/jmr.2013.100.

[124] O.A. Almanza, J.A. de Saja, M.A. Rodriguez-Perez, Prediction of the Radiation Term in the Thermal Conductivity of Crosslinked Closed Cell Polyolefin Foams, J. Polym. Sci. Part B Polym. Phys. 38 (2000) 993-1004. doi:10.1002/(SICI)1099-0488(20000401)38:7<993::AID-POLB10>3.0.CO;2-J.

[125] B.P. Jelle, Traditional, state-of-the-art and future thermal building insulation materials and solutions Properties, requirements and possibilities, Energy Build. 43 (2011) 2549-2563. doi:10.1016/j.enbuild.2011.05.015.

[126] International Energy Agency (IEA), Technology Roadmap. Energy efficient building envelopes, (2013). doi:10.1007/SpringerReference_7300.

[127] M. Alvarez-Lainez, M.A. Rodríguez-Pérez, J.A. de Saja, Thermal Conductivity of Open-Cell Polyolefin Foams, J. Polym. Sci. Part B Polym. Phys. 46 (2008) 212-221. doi:10.1002/polb.

[128] N.C. Hilyard, A. Cunningham, Low density cellular plastics--Physical basis of behaviour, Chapman and Hall, London, 1994.

[129] B. Wicklein, A. Kocjan, G. Salazar-Alvarez, F. Carosio, G. Camino, M. Antonietti, L. Bergström, Thermally insulating and fire-retardant lightweight anisotropic foams based on nanocellulose and graphene oxide, Nat. Nanotechnol. 10 (2014) 277-283. doi:10.1038/nnano.2014.248.

[130] C. V. Vo, R.T. Fox, Assessment of hydrofluoropropenes as insulating blowing agents for extruded polystyrene foams, J. Cell. Plast. 49 (2013) 423-438. doi:10.1177/0021955X13488398.

[131] C. V. Vo, F. Bunge, J. Duffy, L. Hood, Advances in thermal insulation of extruded polystyrene foams, Cell. Polym. 30 (2011) 137-156. doi:10.1177/026248931103000303.

[132] M. Knudsen, The Kinetic Theory of Gases, Methuen, London, 1934

[133] S. Song, M.M. Yovanovich, F.O. Goodman, Thermal Gap Conductance of Conforming Surfaces in Contact, J. Heat Transfer. 115 (1993) 533-540. doi:10.1115/1.2910719.

[134] P. Ferkl, R. Pokorný, M. Bobák, J. Kosek, Heat transfer in one-dimensional micro- and nano-cellular foams, Chem. Eng. Sci. 97 (2013) 50-58. doi:10.1016/j.ces.2013.04.018.

[135] N.G. Hadjiconstantinou, The limits of Navier-Stokes theory and kinetic extensions for describing small-scale gaseous hydrodynamics The limits of Navier-Stokes theory and kinetic extensions for describing small-scale gaseous hydrodynamics, Phys. Fluids. 18 (2006) 111301. doi:10.1063/1.2393436.

[136] P.G. Collishaw, J.R.G. Evans, An Assessment of Expressions for the Apparent Thermal Conductivity of Cellular Materials, J. Mater. Sci. 29 (1994) 2261-2273. doi:10.1007/BF00363413.

[137] Z. Li, C. Zhu, X. Zhao, A theoretical and numerical study on the gas-contributed thermal conductivity in aerogel, Int. J. Heat Mass Transf. 108 (2017) 1982-1990. doi:10.1016/j.ijheatmasstransfer.2017.01.051.

[138] C. Forest, P. Chaumont, P. Cassagnau, B. Swoboda, P. Sonntag, Polymer nano-foams for insulating applications prepared from CO 2 foaming, Prog. Polym. Sci. 41 (2015) 122-145. doi:10.1016/j.progpolymsci.2014.07.001.

[139] J. Nassios, Kinetic theory of rarefied gas flows with modern applications, Aust. Math. Soc. Gaz. 40 (2013) 50.

[140] X. Lu, R. Caps, J. Fricke, C.T. Alviso, R.W. Pekala, Correlation between structure and thermal conductivity of organic aerogels, J. Non. Cryst. Solids. 188 (1995) 226-234. doi:10.1016/0022-3093(95)00191-3. 
[141] H. Guo, Solid-state Polymer Nanofoams, University of Washington, 2015.

[142] G. Wang, C. Wang, J. Zhao, G. Wang, C.B. Park, G. Zhao, Modelling of thermal transport through a nanocellular polymer foam: Toward the generation of a new superinsulating material, Nanoscale. 9 (2017) 5996-6009. doi:10.1039/c7nr00327g.

[143] H. Ma, Z. Tian, Effects of polymer chain confinement on thermal conductivity of ultrathin amorphous polystyrene films, Appl. Phys. Lett. 107 (2015). doi:10.1063/1.4929426.

[144] R.-C. Zhang, Z. Huang, D. Sun, D. Ji, M. Zhong, D. Zang, J.-Z. Xu, Y. Wan, A. Lu, New insights into thermal conductivity of uniaxially stretched high density polyethylene films, Polymer (Guildf). 154 (2018) 42-47. doi:10.1016/j.polymer.2018.08.078.

[145] D.I. Collias, D.G. Baird, R.J.M. Borggreve, Impact toughening of polycarbonate by microcellular foaming, Polymer (Guildf). 35 (1994) 3978-3983. doi:10.1016/0032-3861(94)90283-6.

[146] J. Kumaki, Observation of polymer chain structures in two-dimensional films by atomic force microscopy, Polym. J. 48 (2015) 3-14. doi:10.1038/pj.2015.67.

[147] D.Q. Zou, H. Yoshida, Size effect of silica nanoparticles on thermal decomposition of PMMA, J. Ann. Therm. Anal. Calorim. 99 (2010) 21-26. doi:10.1007/s10973-009-0531-4.

[148] S. Kim, M.K. Mundra, C.B. Roth, J.M. Torkelson, Suppression of the $t$ g-nanoconfinement effect in thin poly(vinyl acetate) films by sorbed water, Macromolecules. 43 (2010) 5158-5161. doi:10.1021/ma1005606.

[149] J. Kraus, P. Müller-Buschbaum, T. Kuhlmann, D.W. Schubert, M. Stamm, Confinement effects on the chain conformation in thin polymer films, Europhys. Lett. 49 (2000) 210-216. doi:10.1209/epl/i2000-00135-4.

[150] S. Sills, R.M. Overney, W. Chau, V.Y. Lee, R.D. Miller, J. Frommer, Interfacial glass transition profiles in ultrathin, spin cast polymer films, J. Chem. Phys. 120 (2004) 5334-5338. doi:10.1063/1.1647047.

[151] G.M. Pajonk, Transparent silica aerogels, J. Non. Cryst. Solids. 225 (1998) 307-314. doi:10.1016/S00223093(98)00131-8.

[152] C. Ye, X. Zuo, E. Shevchenko, J. Li, CO2 batch foaming for fabricating semi-transparent PMMA nanofoam films, in: Foams2018, 2018.

[153] A. Soleimani Dorcheh, M.H. Abbasi, Silica aerogel; synthesis, properties and characterization, J. Mater. Process. Technol. 199 (2008) 10-26. doi:10.1016/j.jmatprotec.2007.10.060.

[154] Wanqing Cao, A.J. Hunt, Improving the visible transparency of silica aerogels, J. Non. Cryst. Solids. 176 (1994) 18-25. doi:10.1016/0022-3093(94)90206-2.

[155] S. Lowell, J.E. Shields, M.A. Thomas, M. Thommes, Chapter 1. Introduction, in: J.E. Shields, M.A. Thomas, S. Lowell (Eds.), Charact. Porous Solids Powders Surf. Area, Pore Size Density, Springer, 2004. doi:10.1007/9783-8348-9955-2.

[156] B. Notario, A. Ballesteros, J. Pinto, M.A. Rodriguez-Perez, Nanoporous PMMA: A novel system with different acoustic properties, Mater. Lett. 168 (2016) 76-79. doi:10.1016/j.matlet.2016.01.037.

\section{Abbreviations}

$\begin{array}{cl}\text { HDPE } & \text { High-density polyethylene } \\ \text { MAM } & \text { Poly(methyl methacrylate)-b-poly(buthyl acrylate)-b-poly(methyl methacrylate) } \\ \text { MWCNT } & \text { Multi-walled carbon nanotube } \\ \text { O-FH } & \text { Organo-modified fluorohectorite } \\ \text { O-MMT } & \text { Organo-modified montmorillonite } \\ \text { OMS } & \text { Ordered mesoporous silica particles } \\ \text { PC } & \text { Polycarbonate } \\ \text { PEEK } & \text { Poly(ether ether ketone) } \\ \text { PEI } & \text { Poly(ether imide) } \\ \text { PEMA } & \text { Poly(ethyl methacrylate) } \\ \text { PER } & \text { Propylene-ethylene copolymer }\end{array}$


PLA Poly(lactic acid)

PMMA-PFMA Poly[(methyl methacrylate)-b-(perfluorooctylethyl methacrylate)

POSS Polyhedral oligomeric silsesquioxane

PP Polypropylene

PPSU Polyphenylsulfone

PS-PFDA Poly(styrene)-poly(1,1,2,2-tetrahydroperfluorodecylacrylate)

PS-PFMA Poly(styrene-b-perfluorooctylethyl methacrylate)

PS-PFS Poly[styrene-b-4-(perfluorooctylpropyloxy)styrene]

PSU Polysulfone

RT Room temperature

SAN Styrene-co-acrylonitrile

SEBS Styrene-ethylene-butylene-styrene

$\mathrm{SiO}_{2} \quad$ Nanosilica

TPS Thermoplastic polystyrene elastomer

ZnO Zinc oxide nanoparticles 
Chapter 3.

\section{Materials and Methods}





\section{Chapter 3. Materials and Methods}

\subsection{Materials}

\subsubsection{Poly(methyl methacrylate) (PMMA)}

PMMA has been selected as the polymer matrix to be used in this work. PMMA is an optically transparent thermoplastic amorphous polymer. Its chemical formula is shown in Figure 3.1.

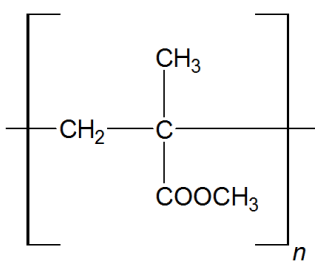

Figure 3.1. Chemical formula of PMMA

One important property of PMMA for this thesis is its high affinity to $\mathrm{CO}_{2}$. Figure 3.2 shows the solubility of PMMA as a function of the saturation temperature (Figure 3.2.a) and pressure (Figure 3.2.b) (data points extracted from references [1-4]). The amount of $\mathrm{CO}_{2}$ uptake increases with increasing pressure and decreasing temperature. Solubility values as high as $48 \mathrm{wt} \%$ have been obtained with this polymer, that is, almost a $50 \%$ increase in weight after the absorption of the gas without significant variation in the volume. Due to this property, PMMA has been extensively used in gas dissolution foaming processes with $\mathrm{CO}_{2}$ as the physical blowing agent [5-9].

a)

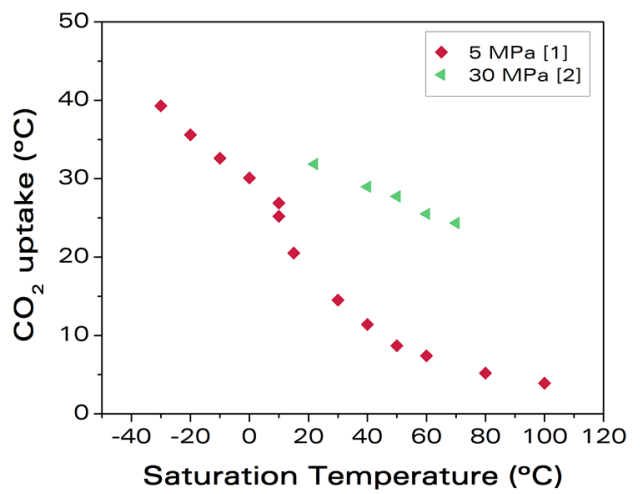

b)

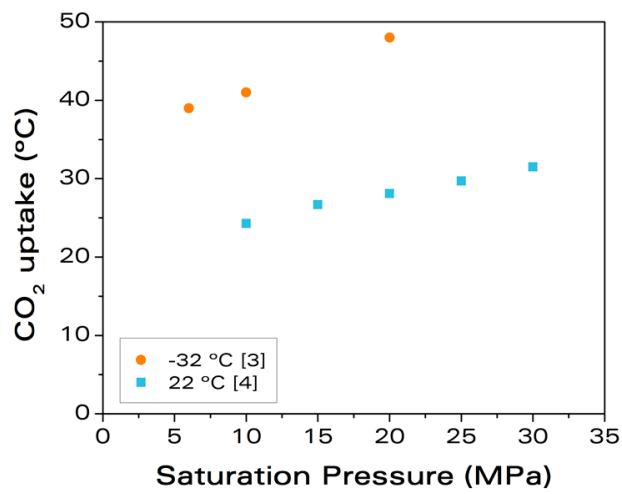

Figure 3.2. $\mathrm{CO}_{2}$ uptake by PMMA at different conditions from various works in the literature [1-4]: a) as a function of the saturation temperature for two different pressures, and b) as a function of the saturation pressure for two different temperatures.

In this thesis, two different commercial PMMA grades supplied by Arkema and Evonik have been used. Their technical specifications are summarized in Table 3.1. The density $(\rho)$ was measured with an air pycnometer, the melt flow index (MFI) was measured at $230^{\circ} \mathrm{C}$ and $2.16 \mathrm{~kg}$, and the glass transition temperature $\left(\mathrm{T}_{\mathrm{g}}\right)$ was determined by differential scanning calorimetry (DSC) in the first heating cycle using a temperature program from 20 to $160^{\circ} \mathrm{C}$ at a rate of $10^{\circ} \mathrm{C} / \mathrm{min}$. Gel permeation chromatography (GPC) was used to determine the molecular weight of the polymers, and in 
particular, the following parameters: the number average molecular weight, $M_{n}$, the weight average molecular weight, $M_{w}$ and the polydispersity index, $I_{p}$ (calculated as $I_{p}=M_{w} / M_{n}$ ).

Table 3.1. Main characteristics of the PMMA polymer matrices.

\begin{tabular}{cccccccc}
\hline Commercial name & Manufacturer & $\begin{array}{c}\rho \\
\left(\mathrm{g} / \mathrm{cm}^{3}\right)\end{array}$ & $\begin{array}{c}\mathrm{MFI} \\
(\mathrm{g} / 10 \mathrm{~min})\end{array}$ & $\mathrm{T}_{\mathrm{g}}\left({ }^{\circ} \mathrm{C}\right)$ & $\begin{array}{c}\mathrm{M}_{\mathrm{n}} \\
(\mathrm{kg} / \mathrm{mol})\end{array}$ & $\begin{array}{c}\mathrm{M}_{\mathrm{w}} \\
(\mathrm{kg} / \mathrm{mol})\end{array}$ & $\mathrm{I}_{\mathrm{p}}$ \\
\hline ALTUGLAS $\otimes$ V 825T & Arkema & 1.186 & 1.8 & 114.5 & 43 & 83 & 1.9 \\
PLEXIGLAS® 7N & Evonik & 1.185 & 3.6 & 109.3 & 45 & 84 & 1.9 \\
\hline
\end{tabular}

Both materials present similar density, but the polymer Plexiglas ${ }^{\circledR} 7 \mathrm{~N}$ presents a higher MFI (almost twice as high) and a smaller glass transition temperature compared to Altuglas $₫$ V 825T. However, both polymers present similar molecular weight and polydispersity index.

\subsubsection{Sepiolites}

Sepiolite is a microcrystalline hydrated magnesium silicate, showing a needle-like morphology [10] with a diameter ranging 20-50 nm and lengths from 1 to 5 microns [11]. Its chemical composition is similar to other clays, but its acicular structure provides a high surface area (around $300 \mathrm{~m}^{2} / \mathrm{g}$ ) [12]. Figure 3.3 shows a transmission electron microscopy (TEM) image of raw sepiolites.

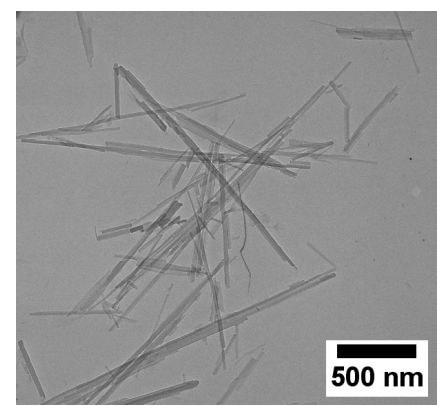

Figure 3.3. Morphology of sepiolites (TEM).

Sepiolites are used in many industrial sectors as a consequence of their optical, absorptive, and rheological properties, such as absorbents, environmental deodorants, catalyst carriers, polyesters, among others [10]. Moreover, they can be used to reinforce the properties of polymers due to their dimensions in the nanoscale [13-15], as well as being employed as a nucleating agent in the production of cellular materials [16].

The sepiolites used in this work were provided by the company Tolsa (Madrid, Spain) (formula $\left.\mathrm{Si}_{12} \mathrm{Mg}_{8} \mathrm{O}_{30}(\mathrm{OH})_{4}\left(\mathrm{OH}_{2}\right)_{4} \cdot 8 \mathrm{H}_{2} \mathrm{O}\right)$. Four different sepiolites with different surface modifications were used (descriptions in Table 3.2) $[16,17]$. The surface modification of sepiolites can enhance the dispersion of the particles in a polymer matrix [18].

The quaternary ammonium salt (QAS) used to chemically modify the surface of the sepiolites SQAS/S-HQAS and S-LQAS was also used as reference material. Sepiolites with two levels of QAS were considered. The amount of salt in each sepiolite (included in Table 3.2) was determined by thermogravimetric analysis (TGA) of the modified sepiolites, the raw salt, and the same sepiolites without surface modification (S-N). 
Table 3.2. Description of the sepiolites nanoparticles.

\begin{tabular}{cc}
\hline Code name & Description \\
\hline S-N & Non-modified sepiolite \\
S-S & Sepiolite modified with a silane \\
S-QAS / S-HQAS & $\begin{array}{c}\text { Sepiolite modified with a higher amount of a quaternary } \\
\text { ammonium salt (QAS) (20.5 wt } \% \text { of salt) }\end{array}$ \\
S-LQAS & $\begin{array}{c}\text { Sepiolite modified with a lower amount of a quaternary } \\
\text { ammonium salt (QAS) (9.5 wt } \% \text { of salt) }\end{array}$ \\
\hline
\end{tabular}

\subsubsection{Tri-block copolymers (MAM)}

MAM is a linear tri-block copolymer with the following chemical composition: poly(methyl methacrylate)-b-poly(butyl acrylate)-b-poly(methyl methacrylate), that is, the outer blocks are PMMA, and the middle block is PBA [19]. A schematic representation of a MAM molecule is plotted in Figure 3.4. The chemical configuration of this copolymer provokes that in the solid state the two phases (PMMA and PBA) appear separated, forming a lamellar structure as long as that the proportions of the two components are not too different [20]. Also, when MAM is dispersed in PMMA, it can self-assembly in nanometric micelles [4]. The PBA block has a higher $\mathrm{CO}_{2}$ philicity than the PMMA block [21,22]. This property, combined with the ability of forming micellar nanostructures, has promoted the use of MAM as a nucleating agent in different foaming processes $[4,23,24]$.

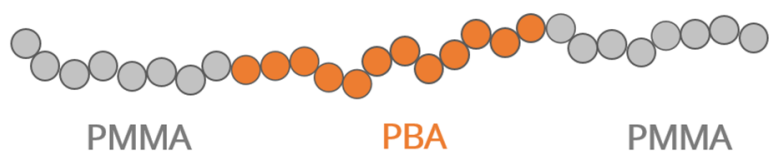

Figure 3.4. Scheme of a MAM copolymer molecule.

In this thesis, three different MAM grades from Arkema have been used. Their technical specifications are summarized in Table 3.3. The density was measured with an air pycnometer, the MFI was measured at $160^{\circ} \mathrm{C}$ and $10 \mathrm{~kg}$, and the glass transition temperature of the PBA block ( $\left.T_{\text {g,PBA }}\right)$ was determined by DSC in the first heating cycle with a temperature program from $-120^{\circ} \mathrm{C}$ to 200 ${ }^{\circ} \mathrm{C}$ at a rate of $20^{\circ} \mathrm{C} / \mathrm{min}$. The molecular weight parameters $\mathrm{M}_{n}, \mathrm{M}_{\mathrm{w}}$, and $\mathrm{I}_{\mathrm{p}}$, were determined by GPC. Nuclear magnetic resonance (NMR) was used to determine the amount of PBA in the copolymer.

Table 3.3. Main characteristics of the MAM block copolymers.

\begin{tabular}{cccccccc}
\hline Commercial name & $\begin{array}{c}\rho \\
\left(\mathrm{g} / \mathrm{cm}^{3}\right)\end{array}$ & $\begin{array}{c}\mathrm{MFI} \\
(\mathrm{g} / 10 \mathrm{~min})\end{array}$ & $\begin{array}{c}\mathrm{T}_{\mathrm{g}, \mathrm{PBA}} \\
\left({ }^{\circ} \mathrm{C}\right)\end{array}$ & $\begin{array}{c}\mathrm{M}_{\mathrm{n}} \\
(\mathrm{kg} / \mathrm{mol})\end{array}$ & $\begin{array}{c}\mathrm{M}_{\mathrm{w}} \\
(\mathrm{kg} / \mathrm{mol})\end{array}$ & $\mathrm{I}_{\mathrm{p}}$ & PBA (wt\%) \\
\hline Nanostrength® M51 & 1.147 & 84 & -26.2 & 25 & 46 & 1.8 & 48 \\
\hline Nanostrength® M52 & 1.150 & 4 & -34.9 & 44 & 75 & 1.7 & 52 \\
\hline Nanostrength® M53 & 1.150 & 0.21 & -39.8 & 82 & 128 & 1.6 & 54 \\
\hline
\end{tabular}

The particular MAM grades summarized in Table 3.3 were selected because they presented similar PBA fractions (ranging from 48 to $54 \mathrm{wt} \%$ ) and, at the same time, very different properties in terms of viscosity and molecular weight. 


\subsubsection{Thermoplastic polyurethane (TPU)}

TPU is a linear thermoplastic elastomer. It is composed of blocks or segments of two different types: soft segments (amorphous structure) and hard segments (semicrystalline structure). The structure of this polymer is schematically represented in Figure 3.5.

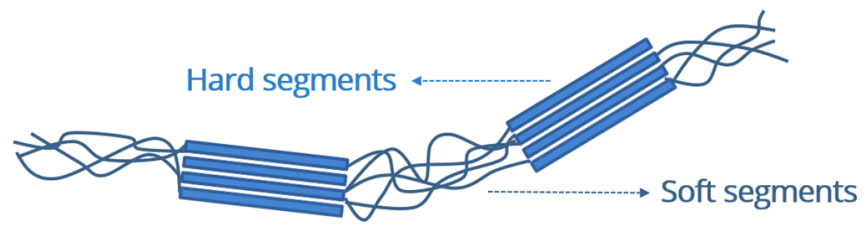

Figure 3.5. Scheme of the structure of TPU.

This polymer was selected as an additive for PMMA because of some promising results regarding its ability to form nanometric domains when blended with PMMA [25] due to the immiscibility of these two polymers.

The TPU used in this thesis was supplied by Lubrizol and presents the characteristics collected in Table 3.4. Density, $\rho$, was measured with an air pycnometer and the MFI was measured at $230^{\circ} \mathrm{C}$ and $2.16 \mathrm{~kg}$. DSC was used to determine the thermal transitions of the TPU, using a temperature program from $-90^{\circ} \mathrm{C}$ to $220^{\circ} \mathrm{C}$ at a rate of $10^{\circ} \mathrm{C} / \mathrm{min}$. In particular, the glass transition temperature of the soft segments $\left(T_{g, s s}\right)$, the melting temperature of the hard segments $\left(T_{m, H S}\right)$ and the enthalpy associated to it $\left(\Delta \mathrm{H}_{\mathrm{m}, \mathrm{HS}}\right)$ were measured (the glass transition temperature of the hard segments was not clearly detected in the DSC). All these characteristics were determined in the first heating cycle during the DSC program.

Table 3.4. Main characteristics of the TPU.

\begin{tabular}{cccccc}
\hline Commercial name & $\begin{array}{c}\rho \\
\left(\mathrm{g} / \mathrm{cm}^{3}\right)\end{array}$ & $\begin{array}{c}\mathrm{MFI} \\
(\mathrm{g} / 10 \mathrm{~min})\end{array}$ & $\mathrm{T}_{\mathrm{g}, \mathrm{SS}}\left({ }^{\circ} \mathrm{C}\right)$ & $\mathrm{T}_{\mathrm{m}, \mathrm{HS}}\left({ }^{\circ} \mathrm{C}\right)$ & $\Delta \mathrm{H}_{\mathrm{m}, \mathrm{Hs}}(\mathrm{g} / \mathrm{g})$ \\
\hline Estane $@$ BCX61 & 1.19 & 27.9 & -44 & 151 & 8.91 \\
\hline
\end{tabular}

\subsubsection{Carbon dioxide $\left(\mathrm{CO}_{2}\right)$}

The blowing agent used in this thesis is $\mathrm{CO}_{2}$. It is a chemical compound formed by two oxygen atoms bonded with a double bond to a central carbon atom. It is gaseous at room temperature. $\mathrm{CO}_{2}$ is considered one environmentally friendly alternative for replacing some of the currently used blowing agents that are pollutant, have global warming potential, or leave chemical compounds that need to be removed [26].

One of the most interesting properties of $\mathrm{CO}_{2}$ to be used as a blowing agent is its excellent diffusion characteristics in the supercritical state, and the relatively mild conditions to reach this state $\left(31^{\circ} \mathrm{C}\right.$ and 7.3 $\mathrm{MPa}$, see phase diagram of $\mathrm{CO}_{2}$ in Figure 3.6). In the supercritical state, $\mathrm{CO}_{2}$ presents a hybrid behavior between a gas and a liquid, allowing to reach high solubilities in polymers and also high diffusivities. As a consequence, much research has been carried out about its use as a physical blowing agent for foaming different polymers [27-29]. 


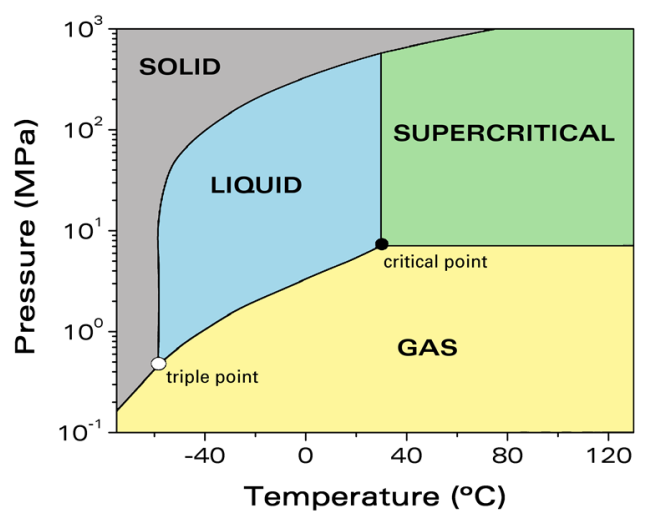

Figure 3.6. Phase diagram of $\mathrm{CO}_{2}$.

\subsection{Production Processes}

The production of the nanocellular materials in this work can be divided into several steps, as schematically shown in Figure 3.7. First, the raw materials were melt blended by extrusion. The pellets resulting from the extrusion were used in a compression molding process to obtain solid sheets for the foaming experiments. In some of the research works carried out, the solid filaments from the extrusion were also used as precursors for foaming. The results with filaments are in Chapter 4 (section 4.3), Chapter 5 (section 5.4), and Chapter 6 (section 6.2). Finally, the nanocellular materials were produced using a gas dissolution foaming process. These steps are explained in the next sections.

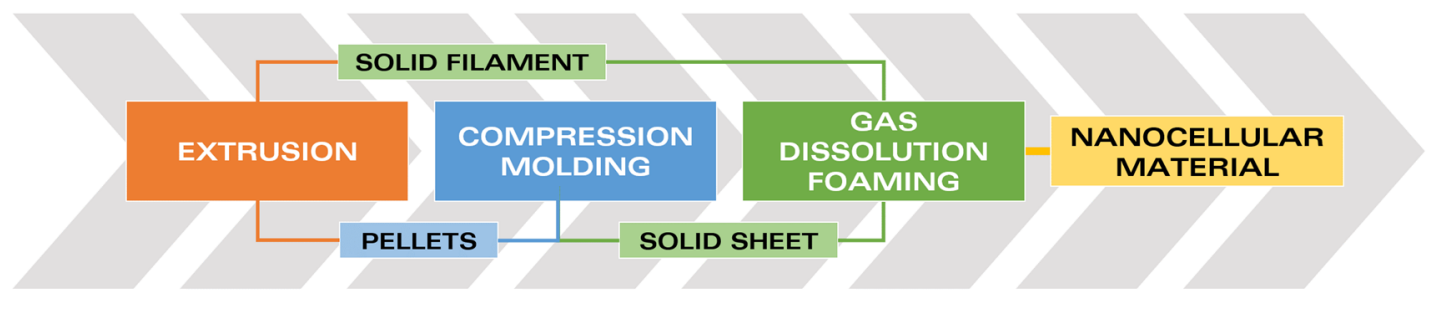

Figure 3.7. Schematic overview of the steps of the production process.

\subsubsection{Production of the solid materials}

All the blends of this thesis were produced by extrusion using a co-rotating twin-screw extruder model COLLIN TEACH-LINE ZK 25T, with L/D equal to 24 and screw diameter equal to $25 \mathrm{~mm}$. Figure 3.8 shows the different sections of the extruder and the stages of the melt-blending process. First, the raw materials were dried before the extrusion to remove the moisture. Typical drying conditions are $50{ }^{\circ} \mathrm{C}$ in a vacuum oven overnight (vacuum pressure: $150 \mathrm{mbar}$ ). Second, the components were manually mixed in the desired proportions. Most of the formulations produced consisted on binary blends (two-component mixture), that is, PMMA with one nucleating agent (sepiolites, MAM or TPU), except in Chapter 6 (section 6.2), in which tri-phasic blends with two additives (sepiolites and MAM) were produced. The resultant mixture was then introduced in the extruder for melt-blending. Some of the nucleating agents were in powder form (sepiolites) or in 
very small spherical pellets (MAM) that can precipitate to the bottom of the hopper, so the feeding was done manually to assure that the material introduced in the extruder barrel was homogeneous. The temperature profile in the extruder was from $160^{\circ} \mathrm{C}$ in the hopper to $200^{\circ} \mathrm{C}$ in the die, increasing in intervals of $10^{\circ} \mathrm{C}$, for the formulations based on the PMMA grade Altuglas $\AA \mathrm{V}$ 825T. A similar temperature profile but reduced $10^{\circ} \mathrm{C}$ was used for the blends with Plexiglas ${ }^{\circledR} 7 \mathrm{~N}$ because this PMMA presents a lower viscosity and glass transition temperature (see Table 3.1). The screw speed was equal to $40 \mathrm{rpm}$ in all the cases. The result from the melt-blending in the barrel left the extruder die in the form of a filament, that was cooled down in water and pelletized. Invariably, all the blends of this thesis were extruded twice with the aim of dispersing the nucleating agents in the PMMA matrix homogeneously. Before the second extrusion cycle (blue line in Figure 3.8), the pellets were dried again to remove the water and moisture. In this step, pellets were dried at $70^{\circ} \mathrm{C}$ during at least two hours. The automatic hopper of the extrusion line (Figure 3.8) was used in the second extrusion, but the rest of the extrusion parameters were the same as those used in the first extrusion cycle. However, the filament of the second cycle was not always pelletized. In some studies, (Chapter 4 (section 4.3), Chapter 5 (section 5.4) and Chapter 6 (section 6.2)), it was directly set aside for the foaming experiments and characterization. In other papers (Chapter 4 (section 4.2), Chapter 5 (section 5.2 and section 5.3), Chapter 6 (section 6.3) and Chapter 7), the filament was pelletized, and an additional processing step (i.e., compression molding) was needed to produce the solid precursors that were later used in the gas dissolution foaming process (and that was also used in characterizing the structure and properties of the solid blend).
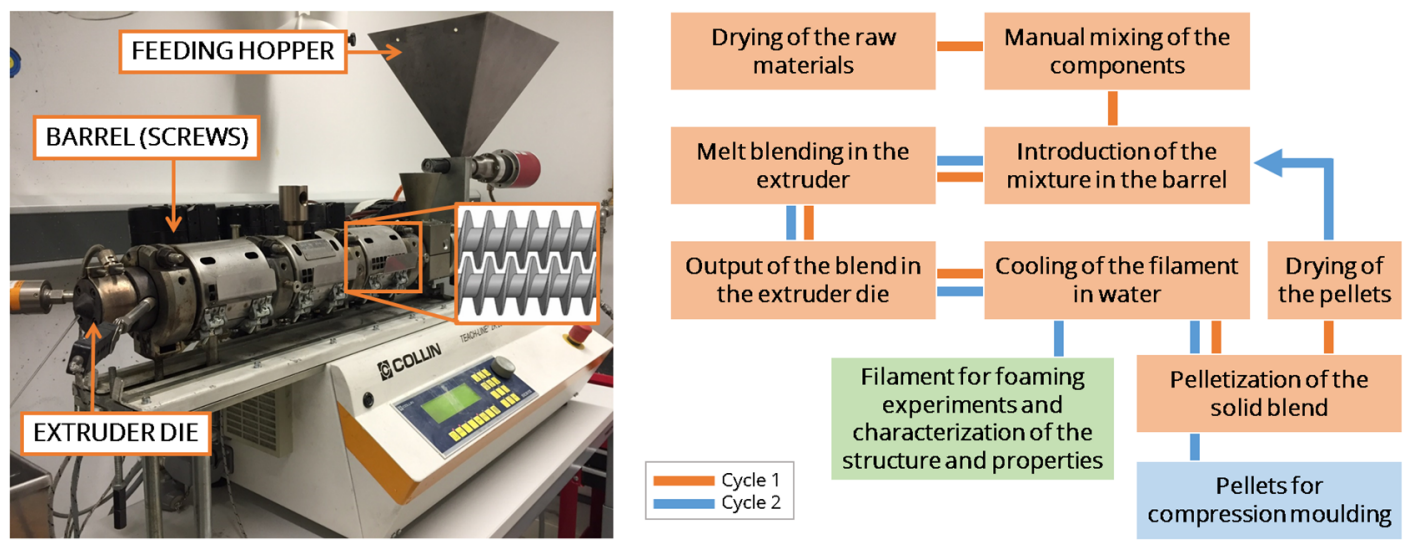

Figure 3.8. Co-rotating twin-screw extruder sections and steps of the blending process.

The solid sheets were prepared by compression molding using a hot plate press provided by Remtex (Barcelona, Spain). Figure 3.9 shows an image of the hot plate press, together with a schematic view of the mold and the different steps of the compression molding process. First, the pellets of the blend were dried under vacuum (150 mbar) at $50{ }^{\circ} \mathrm{C}$ during at least $12 \mathrm{~h}$. Second, the necessary amount of pellets was weighted and placed inside a mold. The mold was introduced in the press, that was pre-heated at a temperature of $250^{\circ} \mathrm{C}$. The materials were first softened without pressure for $8.5 \mathrm{~min}$, and then, they were compacted under constant pressure for another minute. Finally, the samples were cooled down to room temperature under the same pressure.

Different geometries can be produced with this technique. For the foaming experiments, solid prisms of $155 \times 75 \times 4 \mathrm{~mm}^{3}$ were produced, and in this case, the pressure used in the press was equal to $17 \mathrm{MPa}$. From these prisms, samples of different dimensions were cut for the gas dissolution 
foaming experiments. In some studies, solid samples for rheological characterization were also required, and in those situations, additional solid samples with the appropriate geometries were produced by compression molding using a different mold but the same temperature and time parameters.

Note that the pure PMMA grades used to produce the formulations were processed under the same conditions (both by extrusion and compression molding if required) for the sake of comparison. It is necessary to perform this processing of the pure polymer to isolate the effect of the nucleating agent, as the processing might affect the rheological properties and thus the foamability of the polymer [30] and even modify the nucleation process or the cell size distribution [31].
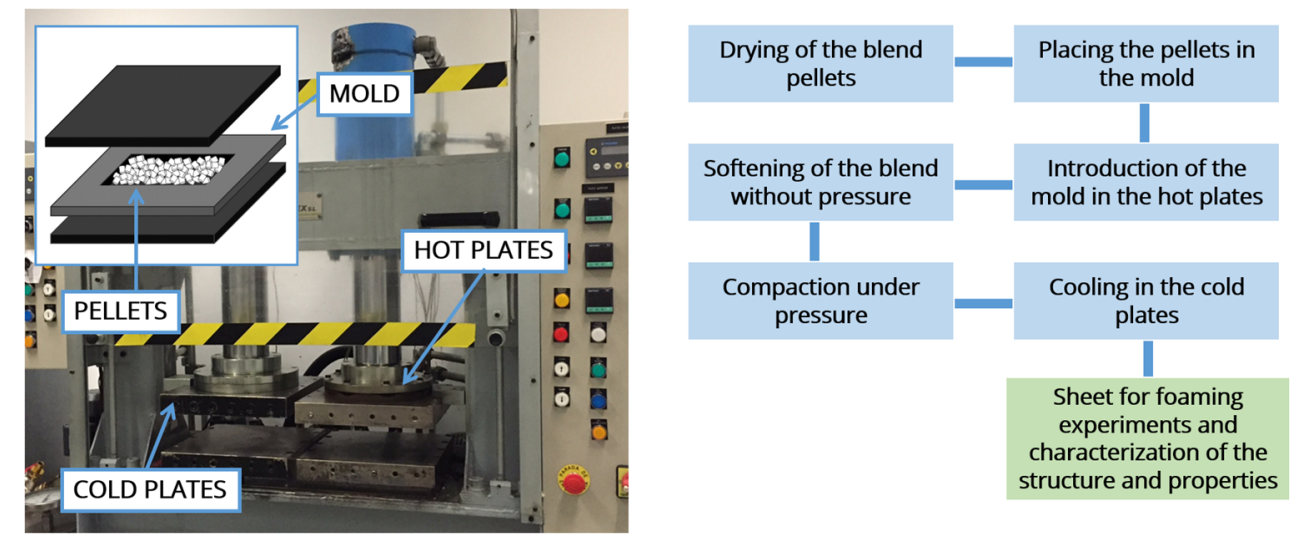

Figure 3.9. Hot and cold plates press and steps of the compression molding process.

\subsubsection{Production of the cellular materials}

The cellular materials were produced using a two-step gas dissolution foaming process using $\mathrm{CO}_{2}$ as the blowing agent [32]. Extensive details about this process and the physical mechanisms involved in it can be found in Chapter 2. The various components of the set-up used for the foaming experiments of this thesis are shown in Figure 3.10. The set-up comprises a high-pressure vessel (model PARR 4681) provided by Parr Instruments Company with a capacity of 1 liter, capable of operating at a maximum temperature of $350{ }^{\circ} \mathrm{C}$ and a maximum pressure of $41 \mathrm{MPa}$. Inside the pressure vessel there is a cylindrical shim of $0.6 \mathrm{~L}$ to reduce the effective volume of the vessel. The pressure is set to the desired value with an accurate pressure pump controller (model SFT-10) provided by Supercritical Fluid Technologies Inc. The temperature is fixed with a clamp heater of 1200 W, controlled via a CAL 3300 temperature controller. Finally, the foaming step was performed in a thermal bath model 600685 provided by J.P. Selecta. The foaming process consists of several steps, as schematically shown in Figure 3.10. Samples were firstly introduced in the pressure vessel under a certain $\mathrm{CO}_{2}$ pressure for the saturation stage. The saturation temperature was equal to 25 ${ }^{\circ} \mathrm{C}$ for all the experiments. The saturation time varied with the pressure used in the experiment and dimensions of the samples, from $20 \mathrm{~h}$ to a maximum of $48 \mathrm{~h}$, long enough to achieve full saturation of $\mathrm{CO}_{2}$ in PMMA at the conditions under study. After saturation, the pressure was abruptly released via an electrovalve. Most of the experiments were conducted using a pressure of $10 \mathrm{MPa}$, and at these conditions, the typical pressure drop rate was $15 \mathrm{MPa} / \mathrm{s}$ in the first seconds of the depressurization (Figure 3.11.a). The pressure drop rate depends on the saturation pressure 
selected (Figure 3.11.b) and can reach values near $100 \mathrm{MPa} / \mathrm{s}$ for pressures of $30 \mathrm{MPa}$. Then, the samples were removed from the vessel and immersed in the thermal bath at the desired temperature during a fixed amount of time for the foaming stage (the specific parameters used can be found in the papers included in the next chapters). The time between the release of pressure and the sample immersion in the thermal baths varied between 2.5 and 3.5 minutes for the different studies, given that all the samples in the same study were subjected to the same desorption time. Finally, after foaming, samples were rapidly removed from the thermal bath and placed inside cool water for quenching the structure.

Different saturation and foaming conditions were used to evaluate their effect of the cellular structure. For instance, the saturation pressures ranged from 6 to $30 \mathrm{MPa}$, whereas foaming temperatures from 60 to $110^{\circ} \mathrm{C}$ and foaming times from 1 to 2 minutes were investigated.
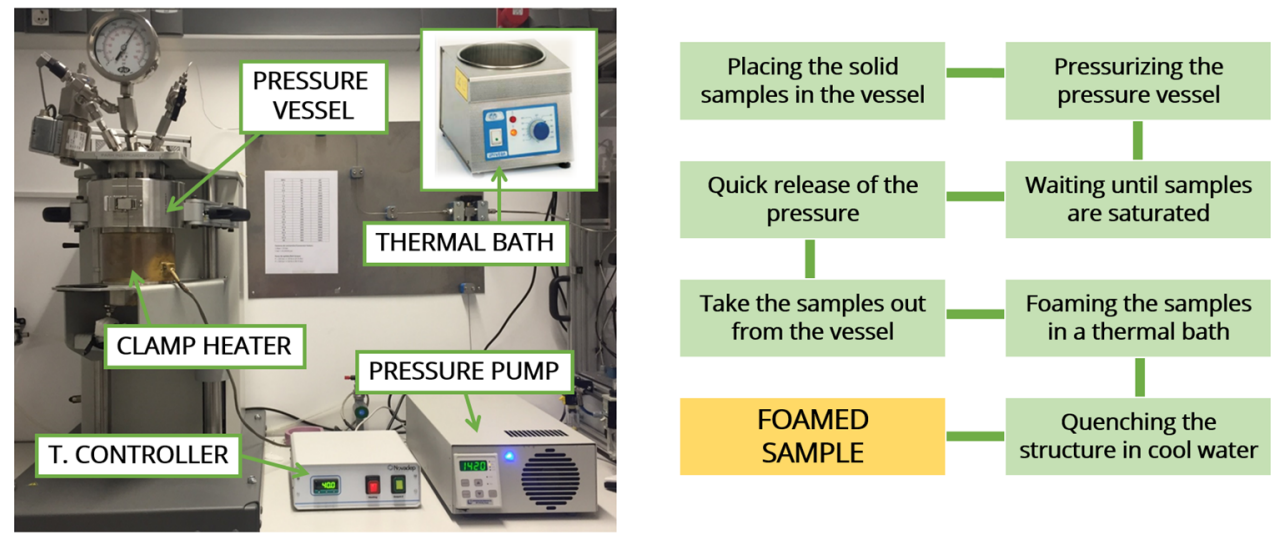

Figure 3.10. Set-up for the foaming experiments and steps of the gas dissolution foaming process.

a)

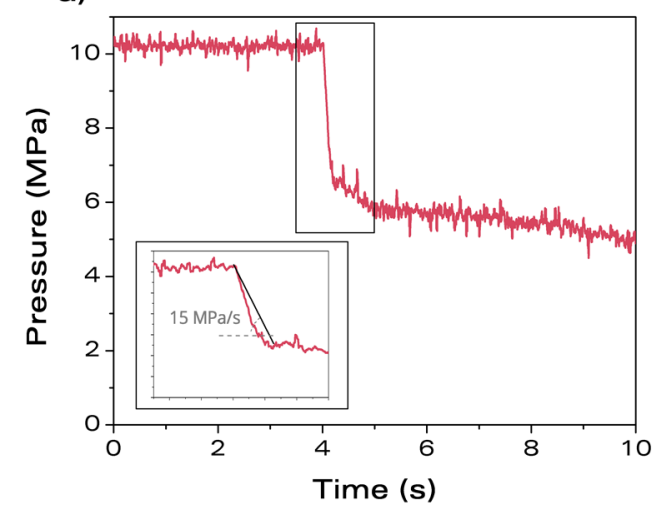

b)

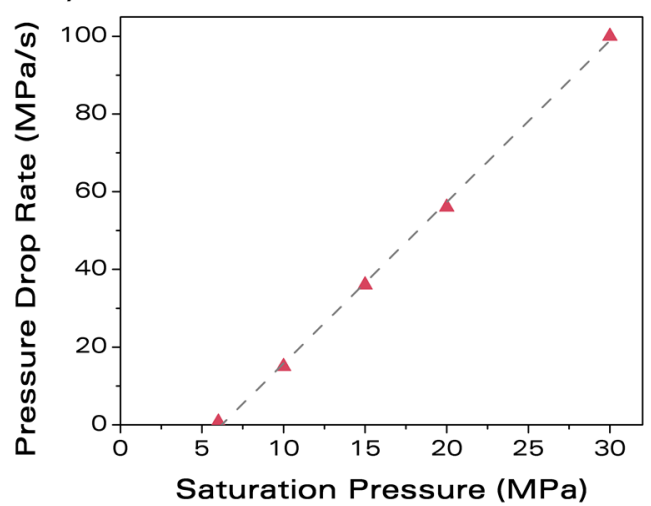

Figure 3.11. a) Pressure drop rate in a typical experiment at $10 \mathrm{MPa}$ and $25^{\circ} \mathrm{C}$ as saturation conditions, and b) pressure drop rates for the different saturation pressures used in this work (saturation temperature: $25^{\circ} \mathrm{C}$ ).

In one of the papers of Chapter 7 (section 7.2), the foaming step was carried out in a hot press instead of a thermal bath $[6,33]$. The objective of that study was to produce flat samples with the appropriate dimensions for mechanical characterization. Details about the foaming process in the press can be found in the corresponding section of the chapter. 


\subsection{Characterization Techniques}

Figure 3.12 shows a schematic overview of the various properties that have been measured to characterize the solids and the cellular materials produced with the processes previously explained. The primary characterization for the solid blends consisted of measuring the density and analyzing their morphology, that is, investigating the state of dispersion of the different nucleating agents in the PMMA matrix. Also, some systems were further characterized by performing rheological measurements and determining the $\mathrm{CO}_{2}$ uptake (that is, the solubility). For the cellular materials, the basic characterization included the determination of the density (and the calculation of the relative density) and an analysis of the cellular structure. In some papers of this thesis, more specific properties were also measured, such as the open cell content, the thermal conductivity, or the mechanical behavior.
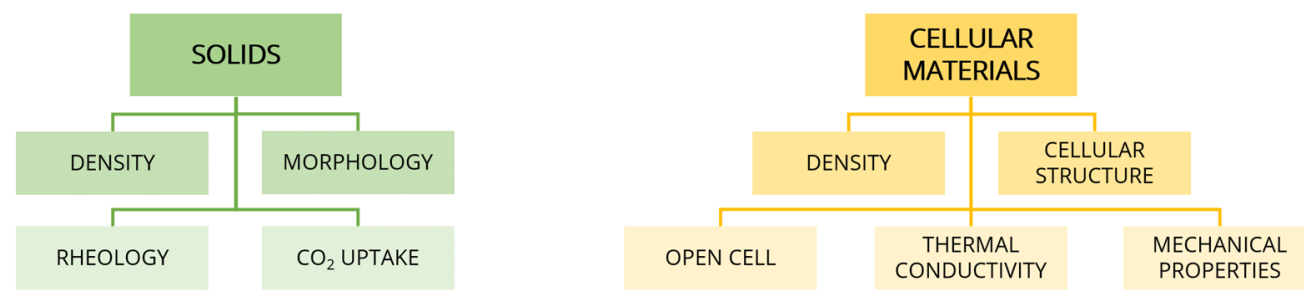

Figure 3.12. Schematic overview of the properties analyzed to characterize the solid and the cellular materials. First row: basic characterization performed for all the materials. Second row: specific characterization only carried out for some studies.

\subsubsection{Solid materials}

\subsubsection{Density}

The density of the solid samples $\left(\rho_{s}\right)$ was measured with a gas pycnometer model AccuPyc II 1340 from Micromeritics. The pycnometer provides the volume of the solid samples with high precision and calculates the density once the mass is given by the user. The density of the solid samples was determined using nitrogen as a gas at a pressure of $19.5 \mathrm{psig}$ (approximately $0.13 \mathrm{MPa}$ ) and performing at least five measurements to obtain an accurate average value of the density.

\subsubsection{Morphology of the solids}

The morphology of the blends was investigated and characterized using different microscopy techniques for the various systems under study. For the PMMA/Sepiolite nanocomposites (Chapter 4), the morphology of the solid samples was analyzed using an ESEM Scanning Electron Microscope (QUANTA $200 \mathrm{FEG}$ ). To prepare the samples for the microscopic visualization, they were cooled down in liquid nitrogen, fractured and coated with gold using a sputter coater (model SCD 005, Balzers Union). For these nanocomposites, the characterization of the morphology was mainly qualitative. Figure 3.13.a shows an example of a SEM image of a solid nanocomposite with sepiolites. 
In the case of the systems with MAM (Chapter 5, sections 5.2 and 5.3), the morphology of the solid PMMA/MAM blends was analyzed using transmission electron microscopy (TEM). TEM images were collected with a Jeol JEM 1011 (Jeol, Japan) electron microscope (Electron Microscopy Facility, Istituto Italiano di Tecnologia, Genova, Italy). The acceleration voltage used was $100 \mathrm{kV}$ and recorded with an $11 \mathrm{Mp}$ fiber optical charge-coupled device (CCD) camera (Gatan Orius SC-1000). To prepare the samples, the solid materials were cut in ultrathin slices (with a thickness of approximately 80-90 $\mathrm{nm}$ ) using a Leica EM UC6 Ultramicrotome. The samples were cut in cryogenic conditions, cooling down the environment and the sample holder at least at $-60^{\circ} \mathrm{C}$, using a specific cryo-system Leica EM FC6 and a specific diamond knife for a low-temperature cut. This step was necessary due to the soft behavior of the polymer. Slices were collected and laid down onto a 200 mesh formvar/carboncoated copper TEM grids. No staining was needed in this analysis. TEM images were used to analyze the nanostructuration found in the solids, resultant from the blending of PMMA and MAM. Volumetric micelle density was calculated by dividing the number of micelles in a TEM image by the volume (area of the image times the thickness of the sample (around $80 \mathrm{~nm}$ )). In some cases, the micelle size was also determined using the software ImageJ/FIJI [34,35]. Also, the intermicelle distance was measured using a Delaunay-Voronoi diagram in ImageJ/FIJl. Figure 3.13.b shows an example of a TEM image showing the nanostructuration of a PMMA/MAM blend.

Finally, in the PMMA/TPU blends (Chapter 5, section 5.4) the morphology of the solids was analyzed using SEM. Images were collected with an SEM microscope FlexSEM 1000 VP-SEM (Hitachi HighTechnologies). To prepare the samples for the visualization, they were fractured after cooling in liquid nitrogen. Then, a chemical etching with tetrahydrofuran (THF) was performed by immersing the fracture surface in THF for 30 minutes. This solvent dissolves quicker the TPU phase, so it selectively removes the TPU domains of the surface, while the PMMA matrix is not affected during this time. After the etching, the surface was coated with gold using a sputter coater (model SCD 005, Balzers Union). SEM images were analyzed using ImageJ/FIII [35]. The density of TPU domains and the size of the domains were analyzed with this tool. Figure 3.13.c shows an example of the nanostructuration found in the PMMA/TPU blends.
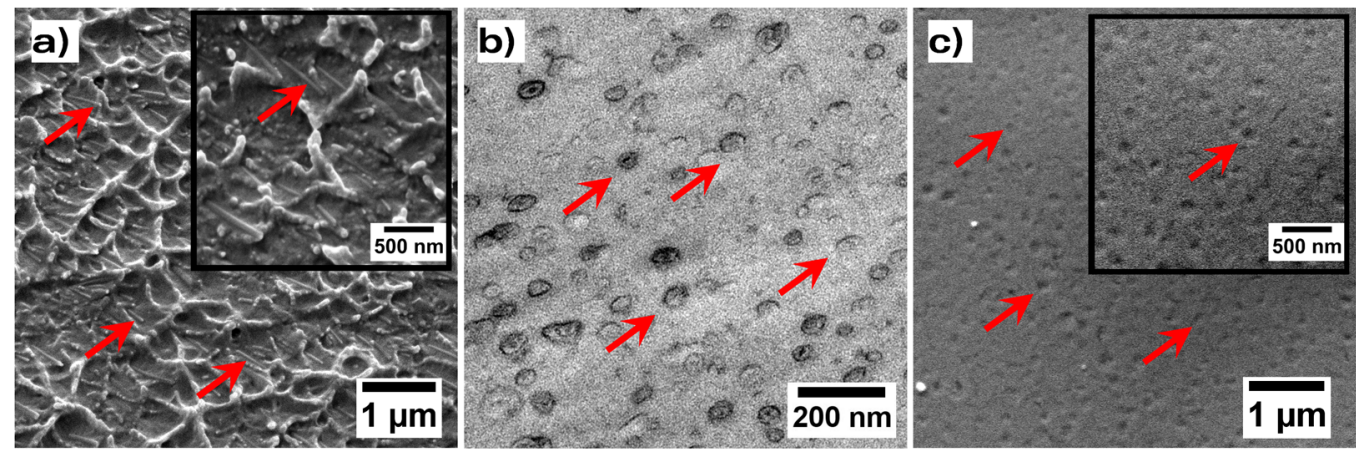

Figure 3.13. Examples of the morphological characterization of the solids: a) PMMA/sepiolites (SEM), b) PMMA/MAM (TEM) and c) PMMA/TPU (SEM). Red arrows indicate the dispersed phase.

\subsubsection{Rheology}

The dynamic shear properties of some PMMA/sepiolite and PMMA/MAM blends were measured using a stress-controlled rheometer, AR 2000 EX from TA Instruments. Measurements were 
performed at a temperature of $230^{\circ} \mathrm{C}$ under a nitrogen atmosphere using a parallel plates geometry of $25 \mathrm{~mm}$ in diameter and a gap of $1 \mathrm{~mm}$. Cylindrical samples with a thickness of $1.5 \mathrm{~mm}$ and a diameter of $25 \mathrm{~mm}$ were used for the experiments (these samples were produced by compression molding using an appropriate mold for producing samples with the required dimensions). In order to define a well-controlled starting point for all the rheological experiments, a time sweep was previously performed at a frequency of $1 \mathrm{rad} / \mathrm{s}$. This time sweep was conducted during $300 \mathrm{~s}$. Then, dynamic-mechanical experiments over an angular frequency range of $0.01<$ $\omega<100 \mathrm{rad} / \mathrm{s}$ were performed. The strain employed was 3\% for the PMMA/Sepiolites nanocomposites and 6\% for the PMMA/MAM blends (within the linear viscoelastic response of the corresponding materials). From these measurements, three magnitudes were analysed: the dynamic shear viscosity $\left(\eta^{*}\right)$, the storage modulus $\left(G^{\prime}\right)$ and the loss modulus $\left(G^{\prime \prime}\right)$.

\subsubsection{4. $\quad \mathrm{CO}_{2}$ uptake}

The amount of gas uptake was calculated as the percentage of weight increment of the sample due to the $\mathrm{CO}_{2}$ sorption. The initial mass was measured before being placed in the pressure vessel, and the final weight was evaluated by weighting the samples immediately after being removed from the pressure vessel. The time between the depressurization and the weight measurement was around 2 minutes. During this time, some gas was lost due to gas diffusion out of the sample. Thus, these measurements are only an estimation of the solubility, and therefore the values obtained were only used for comparison between the different samples. The difference between this estimation method and the proper calculation using the desorption curve (details about this procedure can be found, for instance, in [36]) is around 1-2\%.

\subsubsection{Cellular materials}

\subsubsection{Density}

The density of the cellular materials $\left(\rho_{f}\right)$ was determined with the water-displacement method based on Archimedes' principle. A density determination kit for an AT261 Mettler-Toledo balance was used for this purpose. As explained in Chapter 2, samples produced by gas dissolution foaming present a solid skin and, in some cases, a transition area between the solid skink and the nanocellular core. The solid skin of the foamed samples was removed out with a polisher (model LaboPOI2-LaboForce3, Struers) before measuring their densities. The thickness of the solid skin was measured with SEM images and the samples were sufficiently polished to remove it all. The thickness of the solid skin was measured to be smaller than 100 microns, while typical foamed samples are thicker than $4 \mathrm{~mm}$, so the fraction occupied by the solid skin is small in comparison with the foamed core. In addition, some samples present a transition between the solid skin and the homogeneously foamed core, particularly those based on pure polymers or samples in which heterogeneous nucleation is not predominant. This transition region has a typical thickness of around 200 microns. Finally, the PMMA/TPU samples of this work show a gradient structure, with a significant thickness in comparison with the sample radius (around a $60 \%$ of the radius is occupied by a gradient microcellular structure, see details in Chapter 5 , section 5.4 ). In the samples that 
presented these effects, this transition region was also removed out to determine the density of the core, i.e., the density of the nanocellular region in the material. The relative density, $\rho_{r}$, was determined according to equation (3.1):

$$
\rho_{r}=\frac{\rho_{f}}{\rho_{s}}
$$

\subsubsection{Cellular structure}

The cellular structure of the samples was characterized using SEM image analysis. Two SEM equipments have been used: an ESEM, Environmental Scanning Electron Microscope (Quanta 200 FEG) and an SEM microscope FlexSEM 1000 VP-SEM (Hitachi High-Technologies). To maintain the cellular structure for the microscopic visualization, samples were cooled in liquid nitrogen, fractured and finally coated with gold using a sputter coater (model SCD 005, Balzers Union). A tool based on the software ImageJ/FIII [34,35] was used to quantify the structural parameters using the SEM images. First, a binary mask was manually prepared to have good accuracy when measuring the cell size. Figure 3.14 shows an example of the process to produce a binary image from a regular SEM image. The self-developed software uses the binary image (Figure 3.14.c) to calculate various parameters that describe the cellular structure. Firstly, it measures the dimensions of each cell, and from these measurements, it provides the cell size distribution, the average cell size $(\phi)$ and the standard deviation coefficient of the cell size distribution $(S D)$. Note that the 2D measurements in the SEM image were always corrected to obtain the real 3D values (the 2D value is multiplied by 1.273 to obtain the 3D parameter [35]). The parameter $S D / \phi$ (normalised standard deviation coefficient) was calculated as an indicator of the homogeneity of the cellular structure, useful for comparison among systems with different average cell size.
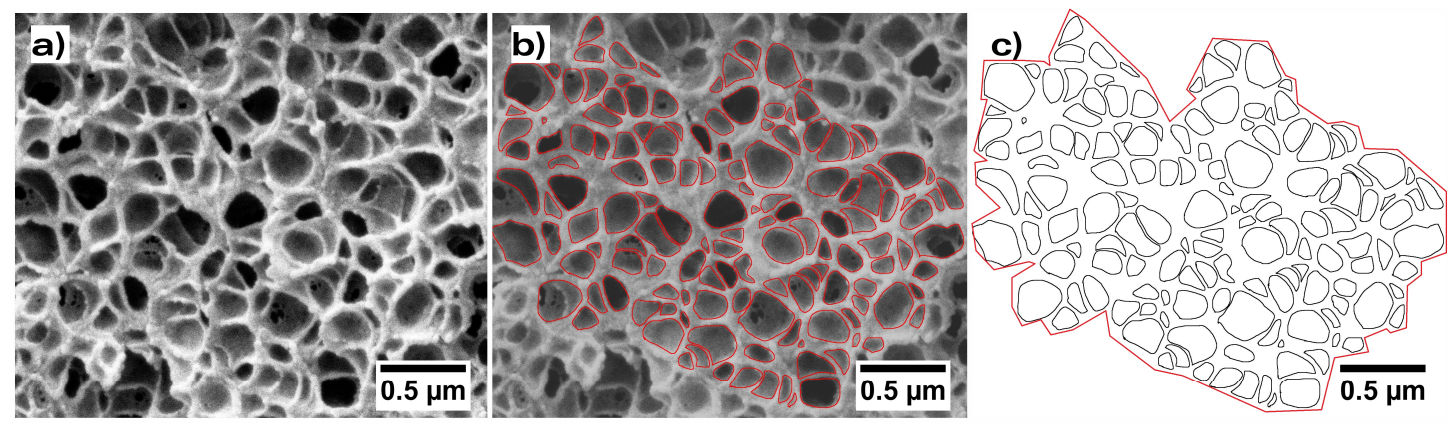

Figure 3.14. Example of image processing: a) original SEM image, b) manual standing out of the cells, and c) binary mask for image analysis.

Cell density $\left(N_{v}\right)$ and cell nucleation density $\left(N_{0}\right)$ were determined using Kumar's theoretical approximation [37] according to equations (3.2) and (3.3), respectively, where $n$ is the number of cells in an area $A$ (for instance, the area surrounded by a red line in Figure 3.14.c). More than 200 cells of different areas of each cellular material were analysed.

$$
\begin{gathered}
N_{v}=\left[\frac{n}{A}\right]^{3 / 2} \\
N_{0}=\frac{N_{v}}{\rho_{r}}
\end{gathered}
$$


In addition, the software provides the anisotropy ratio of each cell, $A R$, defined as the ratio of cell sizes in two perpendicular directions. This parameter was used for characterizing the anisotropic nanocellular polymers obtained in Chapter 4 (section 4.3) and Chapter 6 (section 6.2).

In some papers of this thesis, some advanced cellular structure descriptors were calculated as well. In particular, in Chapter 5 (sections 5.2 and 5.3) the cell wall thickness of the cellular materials was measured directly from the micrographs by measuring at least fifty cell walls. In Chapter 5 (section 5.3) the fraction of mass in the struts was determined using the local thickness analysis of ImageJ/FIII (details can be found elsewhere [38]).

Finally, in systems with a bimodal size distribution (Chapter 4 and Chapter 6 and Chapter 7) the volume fraction occupied by each population of cells was estimated by measuring the area fractions in the SEM images. In addition, in Chapter 4 (section 4.2) the cell size distribution was corrected by multiplying the number of cells times the area of the corresponding cell size with the aim of taking into account the big cells in the cell size distribution. These methods are described in detail in the corresponding papers.

\subsubsection{Open cell content}

The open cell content was measured according to the ASTM D6226-10 standard using a gas pycnometer (Mod. AccuPyc II 1340, Micromeritics). The open cell content ratio OC is defined as:

$$
O C=\frac{V-V_{p}-V_{s}}{V\left(1-\rho_{r}\right)}
$$

where $V$ is the geometric volume of the sample, $V_{p}$ is the volume measured by the pycnometer and $V_{s}$ is a penalty volume to account for the exposed cells at the surface of the sample. The geometric volume was determined from the cellular material density (measured by the water-displacement method as explained in section 3.3.2.1) and its mass $(m)$ (measured with an AT261 Mettler-Toledo balance) as $V=m / \rho . V_{p}$ was determined by performing a pressure scan (from $0.02 \mathrm{MPa}$ to 0.13 $\mathrm{MPa}$ ) in the gas pycnometer and measuring the pycnometric volume for each pressure. It was assumed that no more gas is able to enter the interconnected open cells when the measured volume remains constant for an increase in pressure. $V_{p}$ was calculated as the average of these last measured constant volume values. Note that, as $V_{s}$ is proportional to the cell size, this value becomes negligible for micro and nanocellular materials, so it was neglected in the determination of the open cell content for the samples of this thesis.

\subsubsection{Thermal conductivity}

In Chapter 7 (section 7.3) the thermal conductivity of the cellular materials was determined by the Transient Plane Source (TPS) technique using a thermal conductivimeter TPS $2500 \mathrm{~S}$ (Hotdisk). The TPS is a standard technique (ASTM D 5930-01 [39], ISO 22007-2:2015 [40]) for the thermal properties characterization of different materials, including micro and nanocellular materials [41]. Measurements were carried out with a TPS sensor of radius $3.189 \mathrm{~mm}$. Before measuring, all the samples were dried in vacuum at $50^{\circ} \mathrm{C}$ overnight to remove the moisture. Then, two samples of 
the same material and density were placed in the experimental set-up. The samples and the experimental set-up were allowed to reach equilibrium at room temperature for 30 minutes before the beginning of the measurements. Samples were measured five times with a time span of $20 \mathrm{~min}$ to avoid temperature drift. The measurement time was $40 \mathrm{~s}$ for all samples, whereas the typical power was about 7-9 mW. The conductivity of solid samples with the same chemical composition was also determined for comparison purposes, and in that case, the power used was 19-20 mW, whereas the time was also $40 \mathrm{~s}$.

Before the thermal conductivity measurements, the cellular samples were analyzed using X-ray radiography to ensure their homogeneity and the lack of internal defects [42].

\subsubsection{Mechanical properties}

In Chapter 7 (section 7.2), the mechanical properties of some cellular materials based on PMMA/Sepiolites were determined. First, the mechanical behavior in uniaxial compression was measured using an Instron 5584 electromechanical testing machine (Department of Engineering, University of (ambridge). Specimens were cuboids with in-plane dimensions $10 \times 10 \mathrm{~mm}^{2}$; the thickness varied from $4 \mathrm{~mm}$ to $6 \mathrm{~mm}$ depending on the relative density of the sample. The compression direction was perpendicular to the compression molding direction during the production of the solid sheets. At least three specimens were tested per material system. Tests were carried out at a crosshead velocity equal to $0.5 \mathrm{~mm} / \mathrm{min}$, corresponding to a strain rate equal to $8.3 \cdot 10^{-4} 1 / \mathrm{s}$. The displacement of the Instron plates was measured via a laser extensometer.

Also, single edge notch three-point bending (SENB) tests were performed at room temperature with an Instron 5584 test bench (Department of Engineering, University of Cambridge) at a constant crosshead speed of $10 \mathrm{~mm} / \mathrm{min}$. Specimens were cuboids with in-plane dimensions $55 \times 15 \mathrm{~mm}^{2}$; the thickness varied from $4 \mathrm{~mm}$ to $6 \mathrm{~mm}$ depending on the relative density of the sample. The bending direction was perpendicular to the compression molding direction during the production of the solid sheets. That is, the direction for the fracture toughness tests was the same use in the compression tests. The critical mode I stress intensity factor $K_{I C}$ was calculated as a measure for the fracture toughness in accordance with the standard ASTM D5045-14 [43]. A pre-crack with a sharp tip was made at the end of a sawed notch by tapping with a razor blade. The pre-crack has a length between $45 \%$ and $55 \%$ of the sample width, according to the standard [43].

All samples for the mechanical characterization were firstly analyzed by X-ray radiography [42] and those samples that present defects or inhomogeneities were excluded from the mechanical tests.

\subsection{References}

[1] H. Guo, V. Kumar, Solid-state poly(methyl methacrylate) (PMMA) nanofoams. Part I: Low-temperature CO2 sorption, diffusion, and the depression in PMMA glass transition, Polymer (Guildf). 57 (2015) 157-163. doi:10.1016/j.polymer.2014.12.029.

[2] J. Pinto, J.A. Reglero-Ruiz, M. Dumon, M.A. Rodriguez-Perez, Temperature influence and CO2 transport in foaming processes of poly(methyl methacrylate)-block copolymer nanocellular and microcellular foams, J. Supercrit. Fluids. 94 (2014) 198-205. doi:10.1016/j.supflu.2014.07.021. 
[3] J. Martin-de Leon, V. Bernardo, M.A. Rodriguez-Perez, Key Production Parameters to Obtain Transparent Nanocellular PMMA, Macromol. Mater. Eng. 1700343 (2017) 1-5. doi:10.1002/mame.201700343.

[4] J. Pinto, M. Dumon, M. Pedros, J. Reglero, M.A. Rodriguez-Perez, Nanocellular CO2 foaming of PMMA assisted by block copolymer nanostructuration, Chem. Eng. J. 243 (2014) 428-435. doi:10.1016/j.cej.2014.01.021.

[5] C. Okolieocha, F. Beckert, M. Herling, J. Breu, R. Mülhaupt, V. Altstädt, Preparation of microcellular low-density PMMA nanocomposite foams: Influence of different fillers on the mechanical, rheological and cell morphological properties, Compos. Sci. Technol. 118 (2015) 108-116. doi:10.1016/j.compscitech.2015.08.016.

[6] K. Nadella, V. Kumar, W. Li, Constrained solid-state foaming of microcellular panels, Cell. Polym. 24 (2005) 7190. doi:10.1177/026248930502400202.

[7] S. Siripurapu, J. a. Coughlan, R.J. Spontak, S. a. Khan, Surface-Constrained Foaming of Polymer Thin Films with Supercritical Carbon Dioxide, Macromolecules. 37 (2004) 9872-9879. doi:10.1021/ma0484983.

[8] J. Fu, H.E. Naguib, Effect of Nanoclay on the Mechanical Properties of PMMA/Clay Nanocomposite Foams, J. Cell. Plast. 42 (2006) 325-342. doi:10.1177/0021955X06063517.

[9] F. Zhang, D. Lee, T.J. Pinnavaia, PMMA - mesocellular foam silica nanocomposites prepared through batch emulsion polymerization and compression molding, Polymer (Guildf). 50 (2009) 4768-4774. doi:10.1016/j.polymer.2009.08.007.

[10] A. Alvarez, J. Santaren, A. Esteban-Cubillo, P. Aparicio, Development in Palygorskite-Sepiolite Research, Elsevier, 2011.

[11] D. Garcia-Lopez, J.F. Fernandez, J.C. Merino, J. Santaren, J.M. Pastor, Effect of organic modification of sepiolite for PA 6 polymer/organoclay nanocomposites, Compos. Sci. Technol. 70 (2010) 1429-1436. doi:10.1016/j.compscitech.2010.05.020.

[12] M. Liu, M. Pu, H. Ma, Preparation, structure and thermal properties of polylactide/sepiolite nanocomposites with and without organic modifiers, Compos. Sci. Technol. 72 (2012) 1508-1514. doi:10.1016/j.compscitech.2012.05.017.

[13] J. Ma, J.A. Darr, Preparation of polypropylene/sepiolite nanocomposites using supercritical CO2 assisted mixing, Eur. Polym. J. 43 (2007) 4931-4939. doi:10.1016/j.eurpolymj.2007.09.010.

[14] P. Lu, The Effects of Different Grafted Clays on Thermal Properties of Their PMMA Composites, Polym. Plast. Technol. Eng. 50 (2011) 1541-1545. doi:10.1080/03602559.2011.603780.

[15] Y. Zheng, Y. Zheng, Study on Sepiolite-Reinforced Polymeric Nanocomposites, J. Appl. Polym. Sci. 99 (2006) 2163-2166. doi:10.1002/app.22337.

[16] J. Santaren, A. Alvarez, A. Esteban-Cubillo, B. Notario, D. Velasco, M.A. Rodriguez-Perez, Improving the Cellular Structure and Thermal Conductivity of PS Foams by Using Sepiolites, in: Foams2012, 2012: pp. 1-5.

[17] N. García, J. Guzman, E. Benito, A. Esteban-Cubillo, E. Aguilar, J. Santaren, P. Tiemblo, Surface Modification of Sepiolite in Aqueous Gels by Using Methoxysilanes and Its Impact on the Nanofiber Dispersion Ability, Langmuir. 27 (2011) 3952-3959. doi:10.1021/la104410r.

[18] G. Tartaglione, D. Tabuani, G. Camino, Thermal and morphological characterisation of organically modified sepiolite, Microporous Mesoporous Mater. 107 (2008) 161-168. doi:10.1016/j.micromeso.2007.04.020.

[19] P. Gerard, L. Couvreur, S. Magnet, Controlled Architecture Polymers at Arkema: Synthesis, Morphology and Properties of All- Acrylic Block Copolymers, in: ACS Symp. Ser. 1024, 2009: pp. 361-373.

[20] L. Lalande, C.J.G. Plummer, P. Ge, J.E. Ma, Microdeformation mechanisms in rubber toughened PMMA and PMMA-based copolymers, Eng. Fract. Mech. 73 (2006) 2413-2426. doi:10.1016/j.engfracmech.2006.05.014.

[21] M. Lora, F. Rindfleisch, M.A. McHugh, Influence of the alkyl tail on the solubility of poly(alkyl acrylates) in ethylene and CO2 at high pressures: Experiments and modeling, J. Appl. Polym. Sci. 73 (1999) 1979-1991. doi:10.1002/(SICI)1097-4628(19990906)73:10<1979::AID-APP17>3.0.CO;2-T.

[22] F. Rindfleisch, T.P. DiNoia, M. a. McHugh, Solubility of polymers and copolymers in supercritical CO2, J. Phys. Chem. Chem. 100 (1996) 15581-15587. doi:10.1021/jp9615823.

[23] A.J. Ruiz-Reglero, C. Saiz-arroyo, M. Dumon, M.A. Rodriguez-Perez, L. Gonzalez, Production, cellular structure and thermal conductivity of microcellular (methyl methacrylate)-(butyl acrylate)-(methyl methacrylate) triblock copolymers, Polym. Int. 60 (2011) 146-152. doi:10.1002/pi.2931.

[24] C. Forest, P. Chaumont, P. Cassagnau, B. Swoboda, P. Sonntag, CO2 nano-foaming of nanostructured PMMA, Polymer (Guildf). 58 (2015) 76-87. doi:10.1016/j.polymer.2014.12.048. 
[25] G. Wang, J. Zhao, L.H. Mark, G. Wang, K. Yu, C. Wang, C.B. Park, G. Zhao, Ultra-tough and super thermalinsulation nanocellular PMMA/TPU, Chem. Eng. J. 325 (2017) 632-646. doi:10.1016/j.cej.2017.05.116.

[26] L.J.M. Jacobs, M.F. Kemmere, J.T.F. Keurentjes, Sustainable polymer foaming using high pressure carbon dioxide: A review on fundamentals, processes and applications, Green Chem. 10 (2008) 731-738. doi:10.1039/b801895b.

[27] J.A. Reglero-Ruiz, E. Cloutet, M. Dumon, Investigation of the Nanocellular Foaming of Polystyrene in Supercritical CO2 by Adding a CO2-Philic Perfluorinated Block Copolymer, J. Appl. Polym. Sci. 121 (2012) 3845. doi:10.1002/app.

[28] S.K. Goel, E.J. Beckman, Generation of Microcellular Polymeric Foams Using Supercritical Carbon Dioxide. I: Effect of Pressure and Temperature on Nucleation, Polym. Eng. Sci. 34 (1994) 1137-1147. doi:10.1002/pen.760341407.

[29] Y.H. Lee, C.B. Park, K.H. Wang, HDPE-Clay Nanocomposite Foams Blown with Supercritical CO2, J. Cell. Plast. 41 (2005) 487-502. doi:10.1177/0021955X05056964.

[30] E. Laguna-Gutierrez, A. Lopez-Gil, C. Saiz-Arroyo, R. Van Hooghten, P. Moldenaers, M.A. Rodriguez-Perez, Extensional rheology, cellular structure, mechanical behavior relationships in $\mathrm{HMS} \mathrm{PP/montmorillonite} \mathrm{foams}$ with similar densities, J. Polym. Res. 23 (2016) 251. doi:10.1007/s10965-016-1143-x.

[31] W. Zhai, J. Yu, L. Wu, W. Ma, J. He, Heterogeneous nucleation uniformizing cell size distribution in microcellular nanocomposites foams, Polymer (Guildf). 47 (2006) 7580-7589. doi:10.1016/j.polymer.2006.08.034.

[32] V. Kumar, N.P. Suh, A process for making microcellular parts, Polym. Eng. Sci. 30 (1990) 1323-1329. doi:https://doi.org/10.1002/pen.760302010.

[33] G. Gedler, M. Antunes, J.I. Velasco, Polycarbonate foams with tailor-made cellular structures by controlling the dissolution temperature in a two-step supercritical carbon dioxide foaming process, J. Supercrit. Fluids. 88 (2014) 66-73. doi:10.1016/j.supflu.2014.01.013.

[34] M.D. Abràmoff, P.J. Magalhães, S.J. Ram, Image Processing with ImageJ, Biophotonics Int. 11 (2004) 36.

[35] J. Pinto, E. Solorzano, M.A. Rodriguez-perez, J.A. De Saja, Characterization of the cellular structure based on user-interactive image analysis procedures, J. Cell. Plast. 49 (2013) 555-575. doi:10.1177/0021955X13503847.

[36] M. Tang, T.-B. Du, Y.-P. Chen, Sorption and diffusion of supercritical carbon dioxide in polycarbonate, J. Supercrit. Fluids. 28 (2004) 207-218. doi:10.1016/S0896-8446(03)00045-7.

[37] V. Kumar, Process synthesis for manufacturing microcellular thermoplastic parts, Massachusetts Institute of Technology, 1988.

[38] J. Martin de-Leon, V. Bernardo, M.A. Rodriguez-Perez, Low Density Nanocellular Polymers Based on PMMA Produced by Gas Dissolution Foaming: Fabrication and Cellular Structure Characterization, Polymers (Basel). 8 (2016) 1-16. doi:10.3390/polym8070265.

[39] ASTM International D 5930-01: Standard Test Method for Thermal Conductivity of Plastics by Means of a Transient Line-Source Technique, (n.d.). doi:10.1520/D5930-09.

[40] ISO 22007-2:2015 - Plastics -- Determination of thermal conductivity and thermal diffusivity -- Part 2: Transient plane heat source (hot disc) method, (2005). https://www.iso.org/standard/61190.html.

[41] B. Notario, J. Pinto, E. Solorzano, J.A. de Saja, M. Dumon, M.A. Rodriguez-Perez, Experimental validation of the Knudsen effect in nanocellular polymeric foams, Polymer (Guildf). 56 (2015) 57-67. doi:10.1016/j.polymer.2014.10.006.

[42] J. Escudero, E. Solorzano, M.A. Rodriguez-Perez, F. Garcia-Moreno, J.A. de Saja, Structural Characterization and Mechanical Behaviour of LDPE Structural Foams. A Comparison with Conventional Foams, Cell. Polym. 28 (2009) 289-302. doi:10.1177/026248930902800404.

[43] A. International, D5045 - 14. Standard Test Methods for Plane-Strain Fracture Toughness and Strain Energy Release Rate of Plastic Materials, (n.d.). doi:10.1520/D5045-14.priate. 
Chapter 4.

Fabrication of Nanocellular Polymers based on PMMA filled with Sepiolite Nanoparticles 



\section{Chapter 4. Fabrication of Nanocellular Polymers based on PMMA filled with Sepiolite Nanoparticles}

\subsection{Introduction}

In this chapter, we present the main results related to the fabrication of nanocellular polymers using sepiolites as the nucleating agent. These particles present a needle-like morphology, with diameters in the range from 20 to $50 \mathrm{~nm}$ and variable length of 1 to 5 microns. Sepiolites have been proved to be a suitable additive to produce nanocomposites with reinforced properties, and also to enhance nucleation in conventional and microcellular polymers. This thesis presents the first reports on the use of sepiolites to obtain nanocellular polymers. The sepiolites of our studies were kindly supplied by Tolsa (Spain). Their main characteristics are found in Table 3.2 of Chapter 3.

The PMMA/Sepiolites nanocomposites were melt blended by extrusion, and solid precursors were obtained both directly from the extruded filaments (section 4.3) or by compression molding (section 4.2), as explained in Chapter 3. This fabrication method allows obtaining well-dispersed nanoparticles, but also micron-sized aggregates. As a result of the two levels of dispersion, when the sepiolites act as a nucleating agent, two populations of cells are obtained, that is, the materials obtained with this approach present a bimodal structure. The individual particles produce nanometric cells, whereas microcellular pores are formed in the micrometric aggregates.

This chapter contains two papers dealing with different aspects of the production of PMMA/Sepiolites nanocellular polymers. In section 4.2, the effect of the surface modification of the sepiolites is investigated by using particles with three different surface treatments. Particle contents from $0.5 \mathrm{wt} \%$ to $1.5 \mathrm{wt} \%$ are analyzed. Also, the influence of the saturation and foaming conditions are evaluated. In section 4.3, the effect of the surface modification is further investigated by using two particles treated with the same salt but in different concentrations. Higher particle contents ( 3 $w t \%$ and $10 \mathrm{wt} \%$ ) are used in this section. Finally, the possibility of obtaining anisotropic structures thanks to the alignment of the sepiolites is investigated.

\subsection{PMMA-sepiolite nanocomposites as new promising materials for the production of nanocellular polymers}

This section contains a publication entitled "PMMA-sepiolite nanocomposites as new promising materials for the production of nanocellular polymers", published in European Polymer Journal in 2017 (V. Bernardo, J. Martin-de Leon, E. Laguna-Gutierrez, M.A. Rodriguez-Perez, PMMA-sepiolite nanocomposites as new promising materials for the production of nanocellular polymers, Eur. Polym. J. 96 (2017) 10-26. doi:10.1016/j.eurpolymj.2017.09.002).

Three sepiolite nanoparticles with different surface modifications were used in this study: a nonmodified or natural sepiolite (S-N), a sepiolite modified with a quaternary ammonium salt (S-QAS) and a sepiolite treated with a silane (S-S). Among the three types of particles, only the sepiolite $\mathrm{S}$ - 
QAS can be used as an efficient nucleating agent for the production of nanocellular PMMA. Similar dispersion of the particles is detected by SEM in the solid nanocomposites for the three sepiolites, so we conclude that the effect of the S-QAS is related to its interaction with PMMA and $\mathrm{CO}_{2}$. The addition of this particle produces bimodal cellular structures, with micro and nanometric cells, the nanometric population being predominant (more than $50 \%$ in all the materials).

The influence of the particle content was studied by increasing the sepiolite S-QAS concentration from $0.5 \mathrm{wt} \%$ to $1.5 \mathrm{wt} \%$. We proved that an increase in the content of S-QAS leads to a reduction of the cell size in the nanometric population and an increase of the cell nucleation density. Besides, as particle content increases the fraction of nanometric cells in the bimodal materials increases.

The effect of the saturation pressure was evaluated by using three saturation pressures: 10, 20 and $30 \mathrm{MPa}$. At low pressure (10 and $20 \mathrm{MPa}$ ), where the pure polymer produces a microcellular material, the PMMA/Sepiolites nanocomposites lead to bimodal nanocellular structures. A particle content of $1.5 \mathrm{wt} \%$ increases nucleation in a factor of 160 compared to the pure polymer foamed under the same conditions (10 MPa of saturation pressure, and $80^{\circ} \mathrm{C}$ of foaming temperature), whereas cell size decreases in a factor of 5 . As pressure increases, the nucleation in the pure polymer increases and cell size decreases (homogeneous nucleation). However, in the blends with the sepiolites S-QAS, the nucleation is observed to be almost pressure independent in the range of pressures analyzed, so the heterogeneous nucleation is predominant in these systems.

Finally, the effect of the foaming temperature was investigated by comparing the structures obtained at three different temperatures: $80^{\circ} \mathrm{C}, 100^{\circ} \mathrm{C}$, and $110^{\circ} \mathrm{C}$. Relative density can be reduced by increasing the foaming temperature from $80^{\circ} \mathrm{C}$ to $110^{\circ} \mathrm{C}$, but at the expense of increasing the cell size of the nanocellular population. The cell size increases because of cell coalescence at a high temperature. We hypothesize that the presence of the particles favors cell walls ruptures. In addition, higher particle contents seem to limit the reduction in density.

In conclusion, in this work nanocellular PMMA materials have been produced using for the first time sepiolites as a nucleating agent. The production of these new materials requires not demanding process parameters (medium saturation pressure and room temperature as saturation temperature) and low particle contents. Figure 4.1 shows a graphical abstract of the paper presented and summarized in this section. In the next pages, the full publication is introduced.

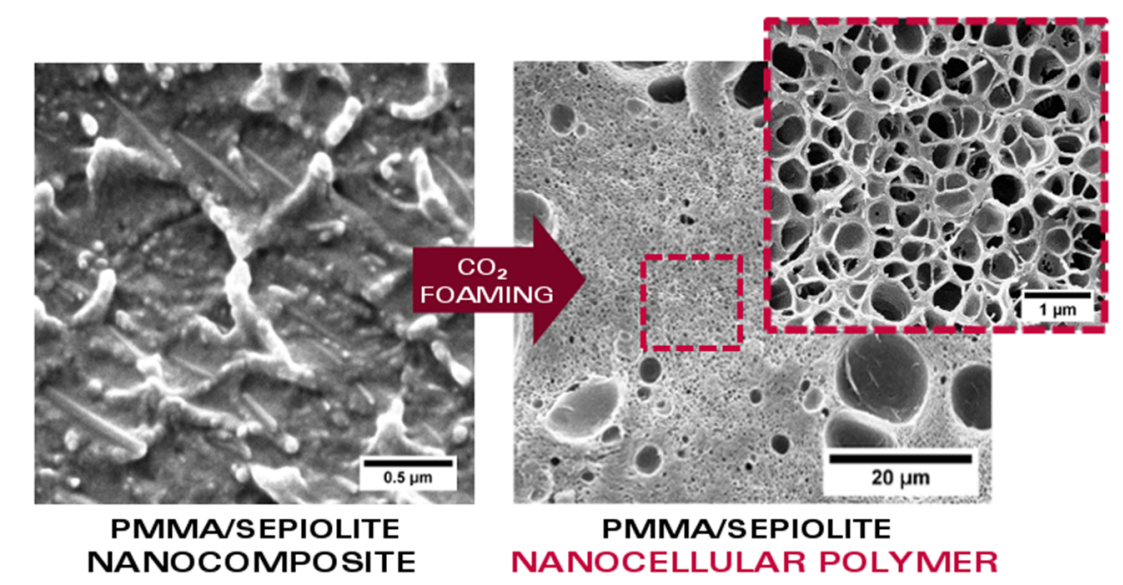

Figure 4.1. Graphical abstract of "PMMA-sepiolite nanocomposites as new promising materials for the production of nanocellular polymers." 


\title{
PMMA-sepiolite nanocomposites as new promising materials for the production of nanocellular polymers
}

Victoria Bernardo, Judith Martín-de León, Ester Laguna-Gutiérrez, Miguel Ángel Rodríguez-Pérez

Cellular Materials Laboratory (CellMat), Condensed Matter Physics Department,

University of Valladolid, Campus Miguel Delibes, Paseo de Belén n7, 47011 Valladolid, Spain

Corresponding author: Victoria Bernardo (vbernardo@fmc.uva.es) +34983184035

\begin{abstract}
In this work, a new system based on poly(methyl methacrylate) (PMMA) sepiolite nanocomposites that allow producing nanocellular polymers by using the gas dissolution foaming technique is described. Nanocomposites with different nanoparticle types and contents have been produced by extrusion. From these blends, cellular materials have been fabricated using the so-called gas dissolution foaming method. An extensive study of the effect of the processing parameters (saturation pressure and foaming temperature) on the cellular materials produced has been performed. Results showed that among the three sepiolites used, only those modified with a quaternary ammonium salt are suitable for being used as nucleating agents in PMMA. With these nanoparticles bimodal cellular polymers, with micro and nanometric cells, have been produced. Cell sizes in the range of $300-500 \mathrm{~nm}$ and cell densities of the order of $10^{13}$. $10^{14}$ nuclei $/ \mathrm{cm}^{3}$ have been obtained in the nanocellular region. A foaming temperature of $80{ }^{\circ} \mathrm{C}$ and a wide range of saturation pressures (between 10 and $30 \mathrm{MPa}$ ) and low particle contents (between 0.5 and $1.5 \mathrm{wt} \%$ ) allow obtaining these materials. Furthermore, it has been found that cell size in the nanometric population can be controlled by means of the particles content; a reduction in the cell size is obtained when the particles content increases. Finally, results indicate that an increase in the foaming temperature leads to cellular nanocomposites with lower relative densities (below 0.21) and larger cell sizes (above $450 \mathrm{~nm}$ ).
\end{abstract}

\section{KEYWORDS}

nanocellular polymer; nanocellular foam; gas dissolution foaming; nanoparticles; sepiolites; PMMA.

\section{INTRODUCTION}

Nanocellular polymers are cellular materials in which the gaseous phase is confined in nanometric pores (cell size smaller than $500 \mathrm{~nm}$ ). It has been recently shown that these materials have better mechanical properties than those of conventional cellular materials or microcellular materials [13]. This fact has been attributed to the confinement of the polymer in very thin cell walls and the large surface area present in these structures [4]. In addition, the nanometric cell size implies a significant reduction of the thermal conductivity due to the decrease of the heat conduction transfer through the gaseous phase (Knudsen effect) [5,6], which results in materials with thermal conductivities lower than that of conventional cellular materials. Moreover, open cell nanocellular 
polymers could be used as membranes for micro and ultrafiltration of particles $[7,8]$ and they can be employed in catalysis and sensors as well [9]. As a consequence of this interesting combination of properties, nanocellular materials have aroused great interest in the scientific community.

Much of the research in this area is focused on the development of new and improved nanocellular polymers with scalable-up production routes. One of the most promising techniques to produce nanocellular polymers is the so-called gas dissolution foaming method, where $\mathrm{CO}_{2}$ is normally used as blowing agent. This technology allows producing large samples using a green solvent $\left(\mathrm{CO}_{2}\right)$ that can be removed without leaving neither residues nor pollutant compounds. However, the production of nanocellular materials using homogeneous systems usually requires extreme saturation conditions so as to obtain the high cell nucleation densities required. For instance, for polycarbonate (PC) [10], polysulfone (PSU) [11] and poly(methyl methacrylate) (PMMA) [12]. Guo and coworkers [12] obtained cell sizes as low as $20 \mathrm{~nm}$ working with extremely low saturation temperatures $\left(-30^{\circ} \mathrm{C}\right)$. Martin-de Leon et al. [13] obtained low density nanocellular PMMA foams with relative densities varying between 0.25 and 0.4 using high saturation pressures (30 MPa). Bernardo et al. [14] showed that high-performance thermoplastic polyphenylsulfone (PPSU) could be used to produce nanocellular polymers at saturation pressures higher than $15 \mathrm{MPa}$. The use of high pressures and low temperatures implies higher energy consumption and higher $\mathrm{CO}_{2}$ spending. Besides, diffusivity extremely decreases for negative temperatures [10,15], and thus under these conditions high saturation times are needed. All these drawbacks limit the of mass production and therefore, finding new production routes using not demanding processing conditions is nowadays a priority in the development of the nanocellular polymers field.

In this respect, an alternative approach consists on favouring nucleation by the addition of appropriate nucleating species that provide heterogeneous surfaces on which the nucleation energy barrier is lowered. With the addition of this second phase heterogeneous nucleation starts to play an important role during the process [16]. Taking advantage of heterogeneous nucleation, nanocellular polymers can be produced by using low saturation pressures and conventional saturation temperatures, as nucleation is mainly controlled by the disperse phase (nanoparticles $[17,18]$ and/or secondary phases in nanostructured polymers [8,19-21]) and not by the amount of gas dissolved into the sample. Besides, the use of a second phase to promote nucleation can help to obtain a more uniform cell size distribution [22].

The addition of nanoparticles to enhance the nucleation density has been investigated in the development of micro and nanocellular materials. A wide variety of polymeric matrices and nanoparticles have been used for this purpose. Spherical nanosilicas [22-24] and layered montmorillonite-type nanoclays $[18,25,26]$ have been proved to be suitable nucleating agents in different polymeric matrices. For instance, in the work of Siripurapu et al. [27] ultraporous PMMA films were produced using silica particles. A $12 \mathrm{wt} \%$ of these particles led to a reduction in the cell size from 10 to almost $1 \mu \mathrm{m}$. Yang and coworkers [24] used spherical ordered mesoporous silica particles to increase the cell density in PMMA. The addition of a $5 \mathrm{wt} \%$ of these particles reduced the pore size from the micro $(1.62 \mu \mathrm{m})$ to the nanometric range $(660 \mathrm{~nm})$. Costeux et al. [17] enhanced the cell nucleation density three orders of magnitude by adding silica nanoparticles to a PMMA matrix. With filler contents below $0.5 \mathrm{wt} \%$ nanocellular materials with cell sizes of $100 \mathrm{~nm}$ and cell densities exceeding $10^{16} \mathrm{cells} / \mathrm{cm}^{3}$ were obtained. Urbanczyk et al. [26] shown the effect of 
montmorillonite-type nanoclays in the production of poly(styrene-co-acrylonitrile) (SAN) micro and nanocellular polymers. In particular, they obtained cell sizes below the micron and relative densities around 0.5 with $3 \mathrm{wt} \%$ of nanoparticles.

Sepiolites have been shown to be appropriate inorganic nanofillers for polymers because of their diameter dimensions at the nanoscale and the high aspect ratio of this fibrous clay. With the appropriate surface treatment these particles can be well dispersed in different types of polymers, including PMMA $[28,29]$. It has been reported that the addition of sepiolites can improve some properties of the polymeric matrix. For instance, they produce a flame retardant effect in polypropylene (PP) [30]. They can also act as a nucleating agents in the crystallization of PP [31]. In epoxy nanocomposites, an improvement in impact and flexural strength is observed when sepiolites are added [32]; whereas in PMMA, sepiolites lead to an improvement in the thermal stability [33]. However, there are few works dealing with the production of cellular materials containing sepiolites. In the patent of Igualada et al. [34] PS/sepiolite cellular materials were fabricated by extrusion foaming using $\mathrm{CO}_{2}$ as physical blowing agent. Results of this patent show that sepiolites produce better nucleation effects than conventional fillers like talc. In the work of Santaren et al. [35] PS/sepiolite microcellular materials were produced using a gas dissolution foaming process. Cell density was increased two orders of magnitude after the addition of a $5 \mathrm{wt} \%$ of sepiolites, whereas cell size decreased from 27 to $4 \mu \mathrm{m}$. Besides, the addition of sepiolites reduced the thermal conductivity and improved the mechanical properties of the cellular materials. Sepiolites have also been used to produce gelatin nanocomposite based cellular materials [36]. A $9 \%$ of sepiolite was found to reduce the cell size from 160 to $100 \mu \mathrm{m}$ and to increase the Young's modulus from 1.5 MPa to $6 \mathrm{MPa}$. In the work of Killen et al. [37] porous poly(vinyl alcohol) was produced using sepiolites. Although the incorporation of sepiolites increased the mean pore size, the tensile strength, modulus and energy at break were improved with the addition of sepiolite contents up to a $6 \mathrm{wt} \%$. In all the previously mentioned works sepiolites were used to produce microcellular polymers.

This work aims to be the first report about the nucleating effect of sepiolites in the production of nanocellular PMMA. Besides, as far as the author knows, there are not works dealing with the production of nanocellular materials using needle-shaped nanoparticles with one dimension in the micrometric range. In particular, solid nanocomposites based on PMMA with different types of sepiolites and with different concentrations have been produced by extrusion. The dispersion of the particles in the blends has been evaluated by image analysis and shear rheology. Then, the foaming behaviour of these systems has been extensively analysed by performing experiments at different saturation and foaming conditions. In the end, one specific grade of the sepiolites analysed have been found to be a very promising nucleating agent for the production of nanocellular PMMA using low saturation pressures and room temperature as saturation conditions. 


\section{EXPERIMENTAL}

\subsection{Materials}

Poly(methyl methacrylate) (PMMA) V 825T was kindly supplied by ALTUGLAS® International in the form of pellets with a density $(\rho)$ of $1.18 \mathrm{~g} / \mathrm{cm}^{3}$ and a glass transition temperature $\left(T_{\mathrm{g}}\right)$ of $114.5{ }^{\circ} \mathrm{C}$ measured by DSC.

Sepiolites were provided by Tolsa S.A (Spain). These clays chemically correspond to hydrated magnesium silicates (formula $\mathrm{Si}_{12} \mathrm{Mg}_{8} \mathrm{O}_{30}(\mathrm{OH})_{4}\left(\mathrm{OH}_{2}\right)_{4} \cdot 8 \mathrm{H}_{2} \mathrm{O}$ ). Sepiolites present a needle-like morphology, with an average particle length ranging between 1 and $2 \mu \mathrm{m}$ and a diameter in the nanometric range (between 20 and $30 \mathrm{~nm}$ ) [38,39]. Three different sepiolites have been employed in this work: non-organically modified sepiolite (labelled from now on as S-N) and two superficially organomodified sepiolites. The first one has been modified with a quaternary ammonium salt (SQAS) and the second one with a silane (S-S). The process to obtain and modify these particles can be found elsewhere $[29,35,40]$.

Finally, medical grade carbon dioxide $\left(\mathrm{CO}_{2}\right)$ (99.9\% purity) was used as blowing agent for the gas dissolution foaming experiments.

\subsection{Solid Blends Production}

Blends of PMMA and sepiolites in the desired proportions (Table 1) were compounded using a twinscrew extruder model COLLIN TEACH-LINE ZK 25T, with L/D of 24 and screw diameter of $25 \mathrm{~mm}$. All materials were dried in a vacuum oven at $50{ }^{\circ} \mathrm{C}$ during 12 hours prior to compounding. The temperature profile set on the extruder was from $160^{\circ} \mathrm{C}$ to $200^{\circ} \mathrm{C}$ (in the die), increasing at intervals of $10^{\circ} \mathrm{C}$, and the screw speed was $40 \mathrm{rpm}$. The produced blends were cooled in a water bath and pelletized. After drying the pellets for 2 hours in a vacuum oven at $50^{\circ} \mathrm{C}$, each material was extruded again with the aim of dispersing homogenously the nanoparticles. The temperature profile and the screw speed remained the same.

In a second step the obtained pellets were compression moulded into solid sheets of $155 \times 75 \times 4$ $\mathrm{mm}^{3}$ using a hot plate press provided by Remtex. The temperature of the press was fixed at 250 ${ }^{\circ} \mathrm{C}$. The materials were first molten without applying any pressure during $8.5 \mathrm{~min}$ and then they were compacted under a constant pressure of $2.2 \mathrm{MPa}$ for another minute. Finally, the sheets were cooled down at room temperature under the same pressure. All materials were first dried in an oven at $80^{\circ} \mathrm{C}$ during $4 \mathrm{~h}$ before processing. Rectangular prims of $20 \times 20 \times 4 \mathrm{~mm}^{3}$ were cut from the sheet for the foaming experiments. In addition, cylindrical samples with a thickness of $1.5 \mathrm{~mm}$ and a diameter of $25 \mathrm{~mm}$ were prepared by compression moulding using the same procedure, and used later for the rheological measurements.

Neat PMMA was processed under the same conditions for the sake of comparison and it will be called from now on as PMMA.

Blends containing $0.5 \mathrm{wt} \%$ of the three types of sepiolites were produced with the aim of analysing the effect of the type of particle. Moreover, two additional blends, with the sepiolite S-QAS, at higher 
particle contents ( 1 and $1.5 \mathrm{wt} \%$ ) were also produced to analyse the influence of the particle content. The formulations used in this work are summarized in Table 1.

Table 1. Formulations used in this work.

\begin{tabular}{ccc}
\hline Material ID & Sepiolite Type & Sepiolite Content $(\mathrm{wt} \%)$ \\
\hline PMMA & - & 0 \\
$0.5 \%$ S-N & S-N & 0.5 \\
$0.5 \%$ S-QAS & S-QAS & 0.5 \\
$0.5 \%$ S-S & S-S & 0.5 \\
$1 \%$ S-QAS & S-QAS & 1 \\
$1.5 \%$ S-QAS & S-QAS & 1.5 \\
\hline
\end{tabular}

\subsection{Gas Dissolution Foaming Experiments}

Foaming experiments were performed using a high pressure vessel (model PARR 4681) provided by Parr Instrument Company with a capacity of 1 litre. The maximum temperature and pressure reached by this device are $350^{\circ} \mathrm{C}$ and $41 \mathrm{MPa}$, respectively. An accurate pressure pump controller (model SFT-10) provided by Supercritical Fluid Technologies Inc. controls automatically the pressure to keep the desired value. The vessel is equipped with a clamp heater of $1200 \mathrm{~W}$, and its temperature is controlled via a CAL 3300 temperature controller. With this set up a set of experiments has been performed using a two-step foaming process [41]. Firstly, samples were introduced in the pressure vessel under certain pressure and temperature conditions for the saturation stage. After saturation, pressure was abruptly released. Then samples were removed from the pressure vessel and immersed in a thermal bath at the desired foaming temperature. The time between the release of pressure and the immersion in the baths was 3.5 minutes.

Saturation temperature has been fixed at $25{ }^{\circ} \mathrm{C}$ and saturation time was $20 \mathrm{~h}$ for all the experiments. Preliminary saturation tests were performed to prove that 20 hours is enough time to achieve full saturation of $\mathrm{CO}_{2}$ in PMMA at all the pressures under study and for the thickness of the samples used. Two sets of experiments have been performed. Firstly the influence of the saturation pressure (and thus the amount of gas absorbed) has been evaluated by choosing three different saturation pressures: 10, 20 and $30 \mathrm{MPa}$. The pressure drop rates in these experiments were $15 \mathrm{MPa} / \mathrm{s}, 56 \mathrm{MPa} / \mathrm{s}$ and $100 \mathrm{MPa} / \mathrm{s}$, respectively. For this study, foaming has been carried out at $80^{\circ} \mathrm{C}$ during 2 minutes. Secondly the effect of the foaming temperature has been analysed by fixing the saturation pressure to $10 \mathrm{MPa}$, varying the foaming temperature from $80^{\circ} \mathrm{C}$ to $110{ }^{\circ} \mathrm{C}$, keeping, once again, 2 minutes as foaming time. It is important to remark that under these conditions ( $25^{\circ} \mathrm{C}$ and $10-30 \mathrm{MPa}$ ) the effective glass transition temperature of PMMA after gas absorption is below room temperature [20], so samples start to expand after being removed from the autoclave as soon as they reach room temperature. Nevertheless, the most of the expansion occurs in the thermal baths. 


\subsection{Characterization}

\subsubsection{Density}

Density of the solid composites was measured with a gas pycnometer (Mod. AccuPyc II 1340, Micromeritics). Density of the corresponding cellular materials was determined with the waterdisplacement method based on Archimedes' principle. A density determination kit for an AT261 Mettler-Toledo balance has been used for this purpose. The solid skin of the samples was removed out with a polisher (model LaboPOI2-LaboForce3, Struers) by removing more than $200 \mu \mathrm{m}$ of each side before measuring their densities. In addition, foamed samples were left to desorb all $\mathrm{CO}_{2}$ before measuring the density. Relative density $\left(\rho_{r}\right)$ has been calculated as the ratio between the cellular material density $\left(\rho_{\mathrm{f}}\right)$ and the density of the solid nanocomposite with the same chemical composition $\left(\rho_{\mathrm{s}}\right)$.

\subsubsection{Solid Nanocomposites Morphology}

The dispersion of the sepiolites in the polymeric matrix was qualitatively analysed using an ESEM Scanning Electron Microscope (QUANTA 200 FEG). Solid nanocomposites were prepared by cooling them in liquid nitrogen, fractured and finally coated with gold using a sputter coater (model SCD 005, Balzers Union).

\subsubsection{Dynamic Shear Properties}

It has been reported that dynamic shear measurements can be employed as a tool to analyse the dispersion of nanoparticles in polymeric matrices $[42,43]$. Besides, rheological properties are important in the analysis of the influence of the polymer viscosity into the nucleation and growing processes $[19,44]$. For these reasons, dynamic shear properties of all the nanocomposites were measured using a stress controlled rheometer, AR 2000 EX from TA Instruments. Measurements were performed at a temperature of $230{ }^{\circ} \mathrm{C}$ under nitrogen atmosphere using a parallel plates geometry of $25 \mathrm{~mm}$ in diameter and a gap of $1 \mathrm{~mm}$. Cylindrical samples with a thickness of $1.5 \mathrm{~mm}$ and a diameter of $25 \mathrm{~mm}$ were used for the experiments (section 2.2).

When the sample is loaded the particles network is partially deformed. The initial state could be recovered again waiting a certain time. In order to define a well-controlled starting point for all the rheological experiments a time sweep was previously performed at a frequency of $1 \mathrm{rad} / \mathrm{s}$. This time sweep was conducted during $300 \mathrm{~s}$. Then, dynamic-mechanical experiments over an angular frequency range of $0.01<\omega<100 \mathrm{rad} / \mathrm{s}$ were performed for all the blends and the pure polymer. The same strain as that employed in the time sweep: $3 \%$ (within the linear viscoelastic response of the materials) was used. From these measurements three magnitudes were analysed: the dynamic shear viscosity $\left(\eta^{*}\right)$, the storage modulus $\left(G^{\prime}\right)$ and the loss modulus $\left(G^{\prime \prime}\right)$.

\subsection{4. $\mathrm{CO}_{2}$ Uptake}

The amount of gas uptake was calculated as the percentage of weight increment of the sample due to the $\mathrm{CO}_{2}$ sorption. The initial mass was measured after drying the samples and the final weight was evaluated by weighting the samples immediately after they were removed from the pressure vessel. The time between the gas depressurization and the weight measurement was around 2 minutes and during this time some gas was lost due to gas diffusion out of the sample. Thus, these 
measurements are only an estimation of the solubility that has been only used for comparison between samples.

\subsubsection{Cellular Structure}

With the aim of maintaining the cellular structure for the microscopic visualization, samples were cooled in liquid nitrogen and fractured. There were also coated with gold using a sputter coater (model SCD 005, Balzers Union). The cellular structure of the samples was analysed using an ESEM Scanning Electron Microscope (QUANTA 200 FEG). Several parameters must be measured in order to obtain a complete analysis of the cellular structure. A specific software based on Image//FIJI [45] has been used for this purpose. Firstly the average cell size $(\phi)$ has been measured and the cell size distribution and the standard deviation of the cell size distribution (SD) have been obtained. The parameter SD/ $\phi$ was calculated as an indicator of the homogeneity of the cellular structure which is useful for comparison between micro and nanocellular materials. Cell nucleation density $\left(\mathrm{N}_{0}\right)$ has been determined using Kumar's theoretical approximation [46] according to equation (1) where $N_{v}$ is the cell density, $n$ is the number of cells in the image and $A$ is the area of the image. More than 200 cells of different areas of each cellular material have been used for this analysis. As the fracture surface may not be perfectly flat, some overestimation of the cell density can result from this analysis. However, fracture is the usual way of preparing samples for analysis of cell structure, so the results of this work will be comparable with those presented in previous literature.

$$
N_{0}=\frac{N_{v}}{\rho_{r}} \quad \text { where } N_{v}=\left[\frac{n}{A}\right]^{3 / 2}
$$

In this work, bimodal cellular structures (with cells in the micro and in the nano scale) have been obtained. This type of cell size populations are characterized by a huge number of nanocells and a small number of microcells that occupy a significant volume of the sample. Due to this, by using a standard cell size distribution in which the number of cells for a given size is represented the contribution of microcells would be negligible. Therefore, it is convenient to introduce a correction to the standard way of presenting cell size distributions accounting for the size of each cell.

The correction we have used consists on multiplying the number of cells of a given diameter $\left(n_{\text {cells }, x}\right.$, where $x$ is the cell diameter) times the surface of the cell (that is, times its radius square). Equation (2) gives the formula to calculate the frequency relative to the surface for each cell size $x$ :

$$
\text { Frequency relative to the surface }(x)=100 \frac{n_{\text {cells }, x} \pi\left(\frac{x}{2}\right)^{2}}{\sum_{x_{i}} n_{\text {cells }, x_{i}} \pi\left(\frac{x_{i}}{2}\right)^{2}}
$$

Figure 1 shows an example of the cell size distribution of a bimodal structure without correction (Figure 1.a) and with the correction (Figure 1.b). In Figure 1.a the microcells play a minor role because it number is negligible. After the correction with the surface of the cell, the bimodal structure is clearly observed (Figure 1.b) and both nano and micro cells are clearly appreciated.

Furthermore, another interesting cellular structure parameter for these bimodal cellular materials is the relative volume occupied by the population of nanometric cells. This parameter has been calculated by measuring the area of these cells in the SEM images $A_{n}$ and the total area of the image, $A_{t}$, according to Equation (3). The surface ratio should be equal to the volume ratio when 
representative surfaces are analysed, according to the Delesse stereology principle [47]. The fraction corresponding to the nanocellular population can be calculated from equation 3 .

$$
\text { Volume fraction nanometric cells }(\%)=100\left(\frac{A_{n}}{A_{t}}\right)
$$
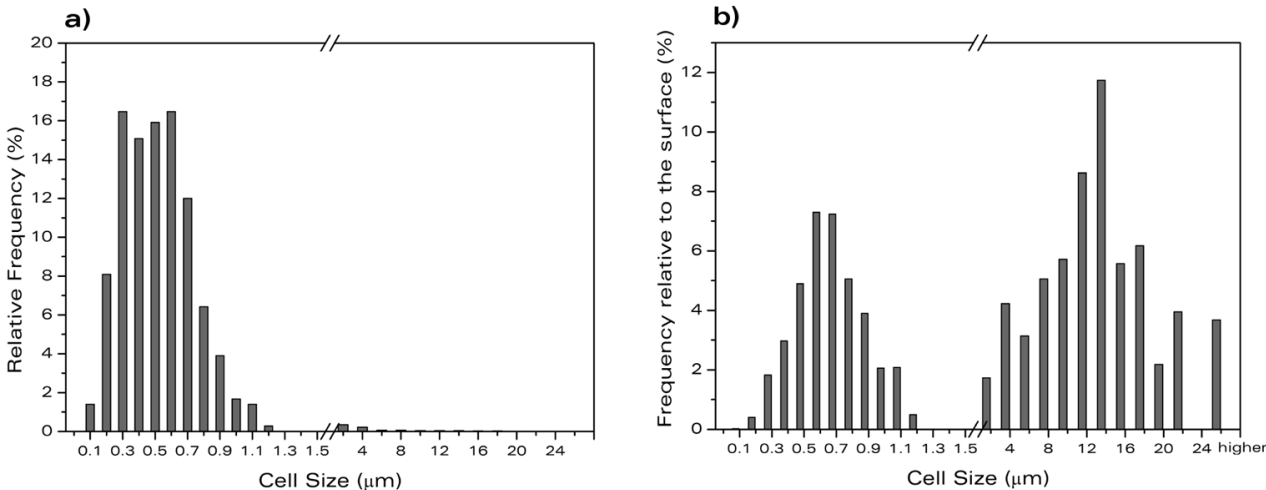

Figure 1. Cell size distribution of a bimodal cellular structure with cells in the micro and in the nano scale a) without the correction that takes into account the size of each cell and b) with the correction that takes into account the size of each cell (equation 2).

\section{RESULTS AND DISCUSSION}

\subsection{Solid Nanocomposites}

\subsubsection{Solid Nanocomposites Morphology}

Figure 2 shows the SEM micrographs of the solid nanocomposites with the different types and contents of sepiolites. These high magnification images show regions in which the sepiolites are well-dispersed: even individual nanoparticles can be appreciated in the images (see red circles in Figure 2). At this magnification, particle aggregates cannot be observed. However, some micrometric particle aggregates appear too (see examples in Figure 3). It is not possible to detect simultaneously (in the same micrograph) both individual particles and aggregates because of their very different size (nanometric vs. micrometric). Bright points in the SEM images displayed in Figure 3 might be attributed to individual sepiolites, but it is necessary to use higher magnifications in order to see the nanoparticles as clear as in Figure 2. Particle aggregates present a wide distribution of sizes, from a few microns to tens of microns. As the particle content increases these aggregates look larger and appear more often in the images; however, this fact cannot be showed in the images since the aggregates are small and not very numerous in any case, so it is not possible to show a collection of them in the same image. This result is expected in nanocomposites: as the particle content increases, so does the probability of interaction between particles and thus the number and size of the aggregates $[17,48]$.

The conclusion is that the extrusion process used to melt compound the nanocomposites was able to disperse up to some extent the particles, but some aggregates were still present after this process. Therefore, the production process was ineffective to fully disperse the fillers in the matrix and this was independent of the surface treatment used in each type of particle. To obtain a better characterization of the dispersion state in each system the rheological behaviour was studied. 

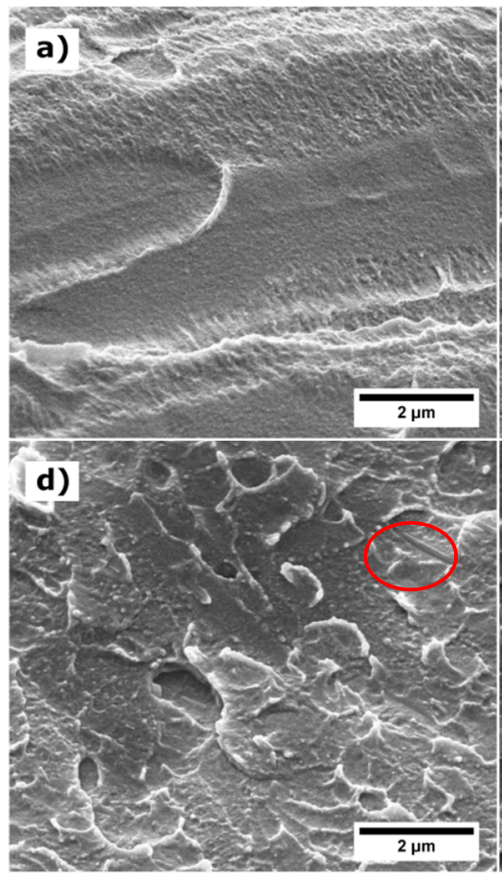

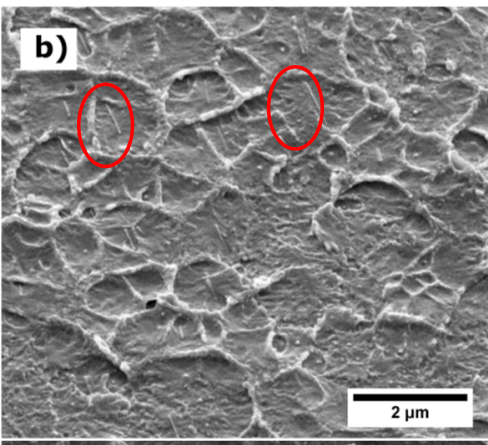

e)

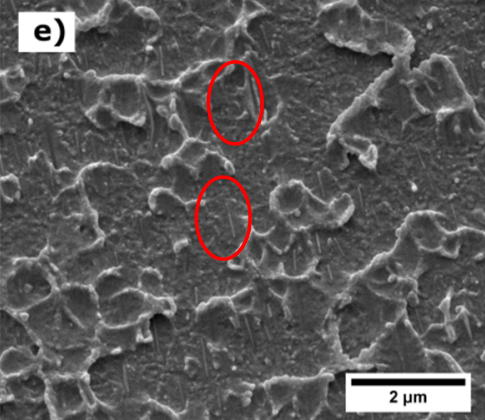

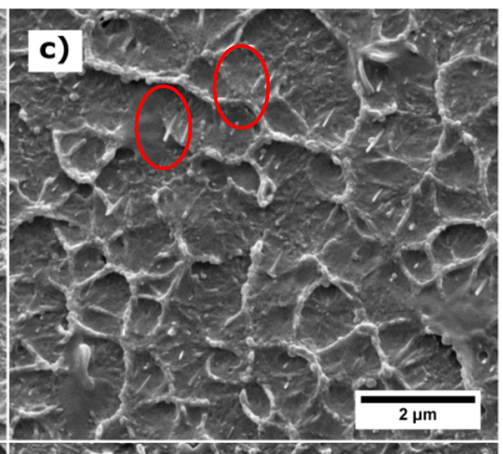

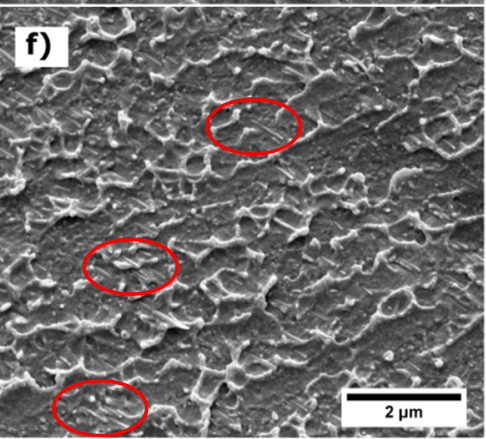

Figure 2. High magnification SEM micrographs of the nanocomposites: a) PMMA, b) 0.5\%_S-N, c) $0.5 \_\% S-Q A S$, d) $0.5 \% S-S$, e) 1_\%S-QAS and f) 1.5_\%S-QAS.
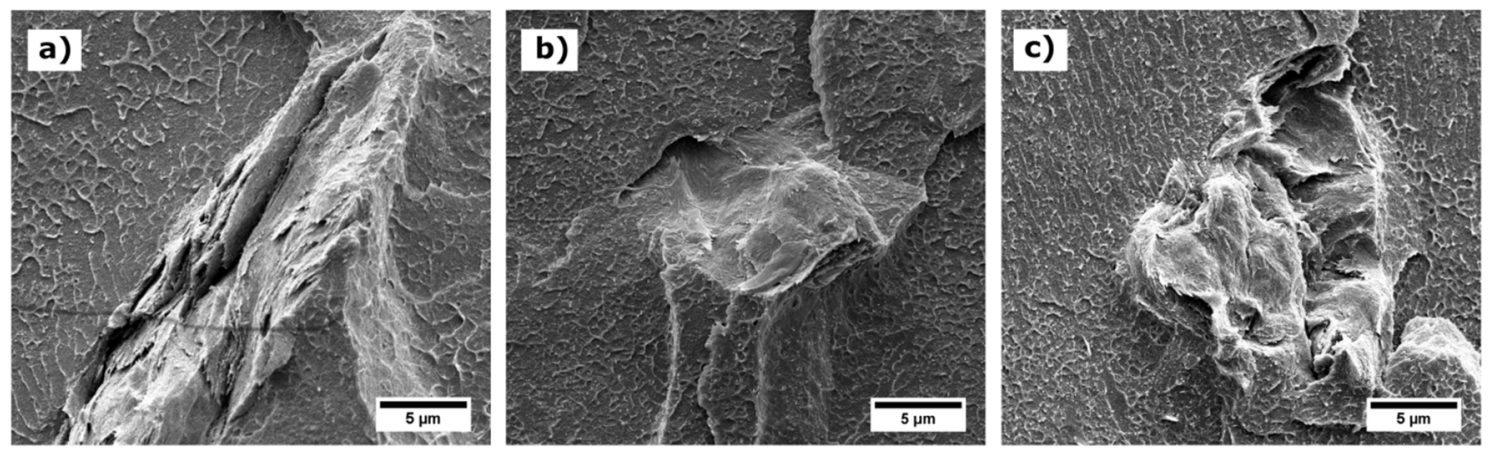

Figure 3. SEM micrographs of the nanocomposites showing some examples of particle aggregates: a) 0.5\%_S-QAS, b) 1\%_S-QAS and c) 1.5\%_S-QAS.

\subsubsection{Rheological behaviour}

Figure 4.a shows the complex viscosity as a function of the angular frequency for the three materials containing a fixed content ( $0.5 \mathrm{wt} \%)$ of sepiolites together with that of the processed PMMA. These results show that the addition of sepiolites induces an increase in the zero-shear viscosity when compared with the reference material without sepiolites (Table 2). The blend with S-N presents the highest complex viscosity. Moreover, the crossover frequency is shifted to slightly higher angular frequencies in the three blends; although, they all present a unique crossover point (Table 2). That means that the dispersion of the particles at this content has not led to a percolation network, regardless of the type of particle employed. Besides, there are no significant variations in the slopes of $G^{\prime}$ and $G^{\prime \prime}$ at low frequencies, in the terminal region (Table 2), since they are proportional to $\omega^{2}$ 
and $\omega$, respectively. This is the typical polymer terminal relaxation behaviour [42]. If a percolation network had been obtained, the slopes would have tended to zero at low frequencies and also $\mathrm{G}^{\prime}$ would have been higher than $\mathrm{G}^{\prime \prime}$ in all the frequency range (characteristic behaviour of solid-like materials). The material with S-QAS shows a slightly smaller $G^{\prime}$ slope when compared with the blends with other sepiolite types. This indicates that a slightly better dispersion has been achieved in this kind of nanocomposite.

a)

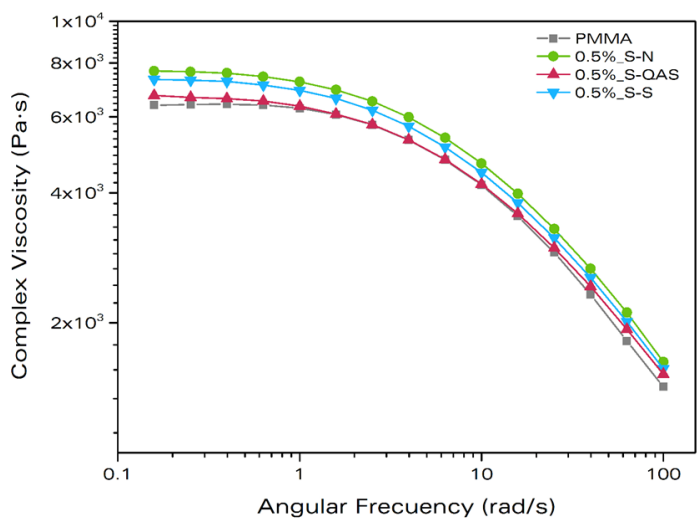

b)

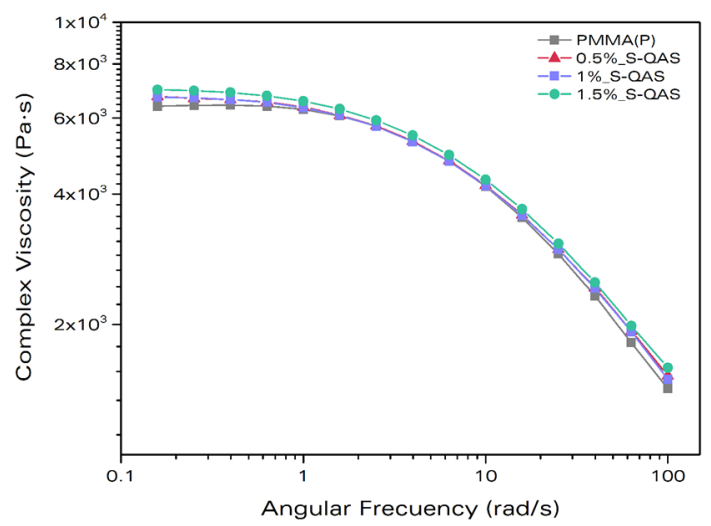

Figure 4. Complex viscosity as a function of the frequency for the materials a) with $0.5 \mathrm{wt} \%$ of sepiolites and b) with different contents of S-QAS.

The complex viscosity of the blends containing S-QAS at different clay contents is plotted in Figure 4.b. There are not significant differences between the blends at low contents ( 0.5 and $1 \mathrm{wt} \%$ ). However, the blend with $1.5 \mathrm{wt} \%$ of sepiolites S-QAS shows a higher viscosity than the others, caused by the higher particle content $[42,43]$. Regarding the crossover frequency, no effect is observed as the particle content increases (Table 2), but there is still only one crossover point. This shows that a percolation network has not been achieved for the particle contents used in this paper. In addition, the slopes of $G^{\prime}$ and $G^{\prime \prime}$ are neither affected by the particle content (Table 2). Therefore, for this type of particles the percolation network should be found by increasing the particle content over $1.5 \mathrm{wt} \%$.

Table 2. Dynamic shear properties of the solid materials.

\begin{tabular}{ccccc}
\hline Material & $\begin{array}{c}\text { Zero shear } \\
\text { viscosity (Pa·s) }\end{array}$ & Slope G' & Slope G" & $\begin{array}{c}\text { Crossover } \\
\text { frequency (rad/s) }\end{array}$ \\
\hline PMMA & $6377 \pm 189$ & $1.78 \pm 0.07$ & $0.99 \pm 0.01$ & $51.34 \pm 1.37$ \\
0.5\%_S-N & $7663 \pm 83$ & $1.88 \pm 0.04$ & $1.00 \pm 0.00$ & $51.86 \pm 0.59$ \\
0.5\%_S-QAS & $6723 \pm 85$ & $1.70 \pm 0.12$ & $0.98 \pm 0.01$ & $57.64 \pm 2.28$ \\
0.5\%_S-S & $7327 \pm 74$ & $1.87 \pm 0.04$ & $0.99 \pm 0.00$ & $52.42 \pm 0.25$ \\
1\%_S-QAS & $6700 \pm 21$ & $1.58 \pm 0.06$ & $0.99 \pm 0.01$ & $56.97 \pm 0.90$ \\
1.5\%_S-QAS & $6970 \pm 1$ & $1.69 \pm 0.06$ & $0.99 \pm 0.01$ & $57.10 \pm 1.05$ \\
\hline
\end{tabular}

The main conclusion of the analysis of the dynamic shear properties is that there are no great differences between the pure PMMA and the blends with sepiolites. Only a slight increase in the complex viscosity has been found as a consequence of the particle addition, but the rheological behaviour of the polymer is not strongly modified by the addition of sepiolites at least for the 
particle contents studied. Besides, it is not possible to achieve a percolated network neither by changing the particle type nor by increasing the particle content up to $1.5 \mathrm{wt} \%$. This fact indicates that some particles could be forming aggregates with a large size (in the micrometric range). These results match with those obtained after the observation of the nanocomposites morphology by SEM. On the one hand some aggregates, with a micrometric size, were detected and on the other hand, SEM micrographs indicate that particles are not forming a random pathway throughout the systems, which once again indicates that a percolated network has not been obtained with this kind of systems. In addition, the difference in dispersion between the three type of particles analysed is small, the particle S-QAS being slightly better dispersed.

\subsection{Cellular Nanocomposites}

\subsubsection{Effect of the Saturation Pressure}

\subsubsection{Effect of the Particle Type}

Table 3 shows the amount of gas absorbed by the blends with $0.5 \mathrm{wt} \%$ of sepiolites at the three different saturation pressures used: 10, 20 and $30 \mathrm{MPa}$. As expected, these data show that the amount of gas uptake increases with pressure, from around $25 \mathrm{wt} \%$ uptake at $10 \mathrm{MPa}$ to more than a $30 \mathrm{wt} \%$ at $30 \mathrm{MPa}$. With these amounts of gas uptake of 25,28 and $30 \mathrm{wt} \%$ and according to reference [15] glass transition temperature of the polymer matrix is depressed up to around $10^{\circ} \mathrm{C}$, $0^{\circ} \mathrm{C}$ and $-5^{\circ} \mathrm{C}$, respectively The nanocomposites containing a $0.5 \mathrm{wt} \%$ of sepiolites present a slightly lower solubility than the pure polymer for the three pressures under study. Assuming that there is no gas sorption in the particles, the solubility values can be corrected to the gas absorbed by the polymer (Table 3, gas uptake corrected $\left(c^{*}\right)$ ). These corrected values recover the solubility of the pure polymer, showing that indeed the reduction in solubility is due to the presence of the particles, which do not promote a higher $\mathrm{CO}_{2}$ uptake under these conditions.

Table 3. Gas uptake, and cellular structure characteristics of the cellular samples produced with the blends containing $0.5 \mathrm{wt} \%$ of sepiolites.

\begin{tabular}{|c|c|c|c|c|c|c|c|c|c|}
\hline Sample & $\begin{array}{c}\text { Saturation } \\
\text { Pressure } \\
\text { (MPa) }\end{array}$ & $\begin{array}{c}\text { Gas } \\
\text { uptake } \\
\text { (wt\%) }\end{array}$ & $\begin{array}{c}\text { Gas } \\
\text { uptake c* } \\
\text { (wt\%) }\end{array}$ & $\begin{array}{l}\text { Relative } \\
\text { Density }\end{array}$ & $\begin{array}{c}\text { Cell Nucleation } \\
\text { Density (nuclei/cm³) }\end{array}$ & $\begin{array}{c}\text { Cell } \\
\text { Size1 } \\
(\mathrm{nm})\end{array}$ & $\begin{array}{c}\mathrm{SD}_{1} / \\
\phi_{1}\end{array}$ & $\begin{array}{c}\text { Cell } \\
\text { Size2 } \\
(\mu \mathrm{m})\end{array}$ & $\begin{array}{c}\mathrm{SD}_{2} / \\
\phi_{2}\end{array}$ \\
\hline PMMA & 10 & 24.6 & - & $0.29 \pm 0.01$ & $(5.8 \pm 0.2) \cdot 10^{11}$ & 1644 & 0.89 & - & - \\
\hline $0.5 \%$ S-N & 10 & 24.3 & 24.4 & $0.29 \pm 0.01$ & $(9.9 \pm 2.3) \cdot 10^{11}$ & 1471 & 0.73 & - & - \\
\hline $0.5 \%$ S-QAS & 10 & 24.4 & 24.5 & $0.27 \pm 0.01$ & $(1.6 \pm 0.2) \cdot 10^{13}$ & 470 & 0.48 & 6.5 & 0.77 \\
\hline $0.5 \%$ S-S & 10 & 24.4 & 24.5 & $0.29 \pm 0.01$ & $(4.8 \pm 0.3) \cdot 10^{11}$ & 1868 & 0.77 & - & - \\
\hline PMMA & 20 & 27.4 & - & $0.26 \pm 0.01$ & $(1.48 \pm 0.02) \cdot 10^{12}$ & 1396 & 0.62 & - & - \\
\hline $0.5 \%$ S-N & 20 & 27.2 & 27.3 & $0.29 \pm 0.01$ & $(1.42 \pm 0.01) \cdot 10^{12}$ & 1454 & 0.50 & - & - \\
\hline $0.5 \%$ S-QAS & 20 & 27.3 & 27.4 & $0.24 \pm 0.01$ & $(1.7 \pm 0.2) \cdot 10^{13}$ & 494 & 0.53 & 6.8 & 0.91 \\
\hline $0.5 \%$ S-S & 20 & 27.3 & 27.4 & $0.24 \pm 0.01$ & $(1.4 \pm 0.4) \cdot 10^{12}$ & 1353 & 0.83 & - & - \\
\hline PMMA & 30 & 30.2 & - & $0.24 \pm 0.01$ & $(1.9 \pm 0.2) \cdot 10^{14}$ & 286 & 0.59 & - & - \\
\hline $0.5 \%$ S-N & 30 & 29.8 & 29.9 & $0.25 \pm 0.01$ & $(1.8 \pm 0.1) \cdot 10^{14}$ & 303 & 0.50 & - & - \\
\hline $0.5 \%$ S-QAS & 30 & 29.9 & 30.1 & $0.23 \pm 0.01$ & $(2.2 \pm 0.7) \cdot 10^{13}$ & 447 & 0.72 & 8.5 & 0.74 \\
\hline $0.5 \%$ S-S & 30 & 29.8 & 29.9 & $0.26 \pm 0.01$ & $(3.5 \pm 0.6) \cdot 10^{14}$ & 230 & 0.57 & - & - \\
\hline
\end{tabular}


The relative density of the cellular samples as a function of the saturation pressure is shown in Figure 5. Relative densities between 0.24 and 0.3 have been obtained for all the materials produced (Table 3). It is observed that an increase in the saturation pressure leads to a small reduction in the relative density. This trend is a consequence of the plasticization effect of the $\mathrm{CO}_{2}$ : when the gas diffuses into a polymer, the glass transition temperature drops [49-52], and the polymer is now characterized by its effective glass transition temperature, $T_{\text {g,eff }}$. The temperature difference between the foaming temperature and the $T_{\text {g,eff }}$ determines the relative density obtained, because once the $T_{\text {g,eff }}$ reaches the temperature of the thermal bath the polymer is no longer in the rubbery state and has no mobility to grow. At a higher pressure, the $T_{\text {g,eff }}$ of the polymer is smaller because of the plasticization effect of a higher amount of $\mathrm{CO}_{2}$. Therefore, after the saturation at three different pressures, three different initial states (characterized by three different $T_{\text {g,eff }}$ ) are obtained. The $T_{g, \text { eff }}$ of the materials saturated at $10 \mathrm{MPa}$ is the highest, whereas the $T_{\mathrm{g} \text {,eff }}$ of the materials saturated at $30 \mathrm{MPa}$ is the lowest. The foaming temperature is the same, so the temperature difference between the foaming temperature and the $T_{\text {g,eff }}$ is higher for the materials saturated at $30 \mathrm{MPa}$; consequently, these materials have more time to grow until they reach the thermal bath temperature. In short, a higher difference between the foaming temperature and the $T_{\text {g,eff }}$ produces a smaller final density (more time to grow). Besides, at higher pressures there is more gas dissolved in the polymer available for growing. These two phenomena explain the reduction in density observed when increasing saturation pressure in these experiments (Figure 5).

On the other hand, there are no significant differences between the relative density of the neat polymer PMMA and that of the materials with sepiolites. The gas uptake was the same, thus at this content sepiolites do not affect the ability to expand of the PMMA, independently of the particle surface modification. These results match with the similar zero-shear viscosities observed.

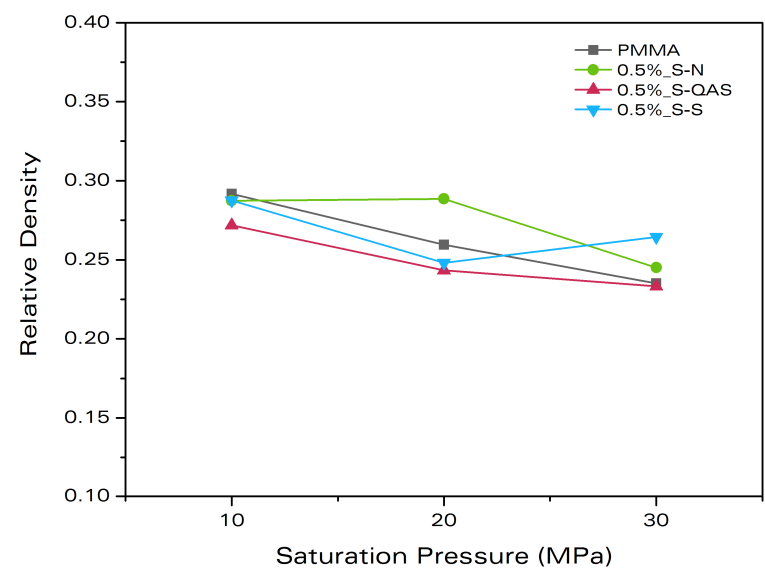

Figure 5. Relative density as a function of the saturation pressure for the blends containing 0.5 $w t \%$ of sepiolites and for the pure PMMA. Foaming conditions were $80^{\circ} \mathrm{C}$ and 2 minutes.

Cellular structure of the samples produced at $10 \mathrm{MPa}$ is shown in Figure 6 as an example. For this saturation pressure, two different structures can be detected. On the one hand, the pure polymer (Figure 6.a) and the blends with S-N (Figure 6.c) and S-S (Figure 6.d) show a microcellular structure, with cell sizes of the order of $1.6 \mu \mathrm{m}$ (Table 3 ). The three systems show a similar cell size distribution (Figure 6 , second column). However, in the blend containing $0.5 \mathrm{wt} \%$ of S-QAS there is a bimodal distribution of the cell size (Figure 6.c). At low magnification, a microcellular population of cells is 
detected, but at high magnification (see zoomed square in Figure 6.c) a nanocellular structure is observed among the microcellular pores. This results in a bimodal distribution of the cell size. The cell size distribution of this system, represented using the same criteria that the others (Figure 6.c, second column), does not show this bimodality due to the very different cell sizes. Thus, the corrected cell size distributions diagrams have been plotted too (squared graphs). Comparing these corrected distributions it is clearly seen that only the material containing S-QAS shows a clear bimodal distribution of the cell size. Notice the break in the cell size axis in this corrected graph after 1.5 micrometres and the change of scale after the break. Due to this difference in size between the largest and the smallest cells, we have separate both contributions in two populations of cells: main (nanocellular) and secondary (microcellular) structures. The cell size corresponding to the nanocellular population has been denoted as $\phi_{1}$ (main structure) and the microcellular cell size has been denoted as $\phi_{2}$ (secondary structure) in Table 3 . The microcellular population is very heterogeneous, with cell sizes ranging from a few microns to tens of microns, the nanocellular population being more homogeneous (check the parameters $\mathrm{SD}_{\mathrm{i}} / \phi_{i}$, with $\mathrm{i}=1$ and 2 , in Table 3). This kind of structure has been found in all the samples containing S-QAS, regardless the saturation pressure used. This bimodal distribution has been previously reported in PS foams with sepiolites [35] and can be caused by particle aggregates. From the shear rheology measurements and the SEM images it was concluded that the dispersion of the particles was not enough to achieve a percolation network and that particles were forming aggregates. This could be the reason of the appearance of the microcellular population. The individual nanometric sepiolites would act as nucleating sites for nanocellular pores and micrometric aggregates could become preferable nucleation places for larger pores. Besides, as observed in the SEM micrographs, there was a wide distribution of the aggregates sizes, which could be leading a wide distribution of the cell sizes in the microcellular population. However, further research is needed to fully understand the origin of these bimodal distributions.

The effect of the saturation pressure in the bimodal cellular structure observed for the material $0.5 \%$ S-QAS is shown in Table 4 and Figure 7. For the three pressures under study, the fraction of nanometric cells is larger than that of micrometric cells (Table 4), justifying the consideration of the nanometric cells as the main population of cells. Besides, volume fractions larger than $50 \%$ of nanometric cells have been obtained regardless the saturation pressure. Similar volume fractions are observed at 10 and $20 \mathrm{MPa}$, whereas at $30 \mathrm{MPa}$ the volume occupied by the nanometric cells is slightly higher (Table 4).

Table 4. Characteristics of the bimodal cellular structure of the cellular materials based of 0.5\%_SQAS for the three saturation pressures used in this work.

\begin{tabular}{ccccccc}
\hline & \multicolumn{3}{c}{ MAIN POPULATION } & \multicolumn{3}{c}{ SECONDARY POPULATION } \\
\hline $\begin{array}{c}\text { Saturation } \\
\begin{array}{c}\text { Pressure } \\
(\mathrm{MPa})\end{array}\end{array}$ & $\begin{array}{c}\text { Volume } \\
\text { fraction }(\%)\end{array}$ & $\begin{array}{c}\text { Cell size } \phi \\
(\mathrm{nm})\end{array}$ & $\begin{array}{c}\text { Standard } \\
\text { deviation } S D \\
(\mathrm{~nm})\end{array}$ & $\begin{array}{c}\text { Volume } \\
\text { fraction }(\%)\end{array}$ & $\begin{array}{c}\text { Cell size } \phi \\
(\mu \mathrm{m})\end{array}$ & $\begin{array}{c}\text { Standard } \\
\text { deviation } S D \\
(\mu \mathrm{m})\end{array}$ \\
\hline 10 & 56.5 & 470 & 227 & 43.5 & 6.5 & 5.0 \\
20 & 56.1 & 494 & 262 & 43.9 & 6.8 & 6.2 \\
30 & 61.5 & 447 & 321 & 38.5 & 8.5 & 6.3 \\
\hline
\end{tabular}



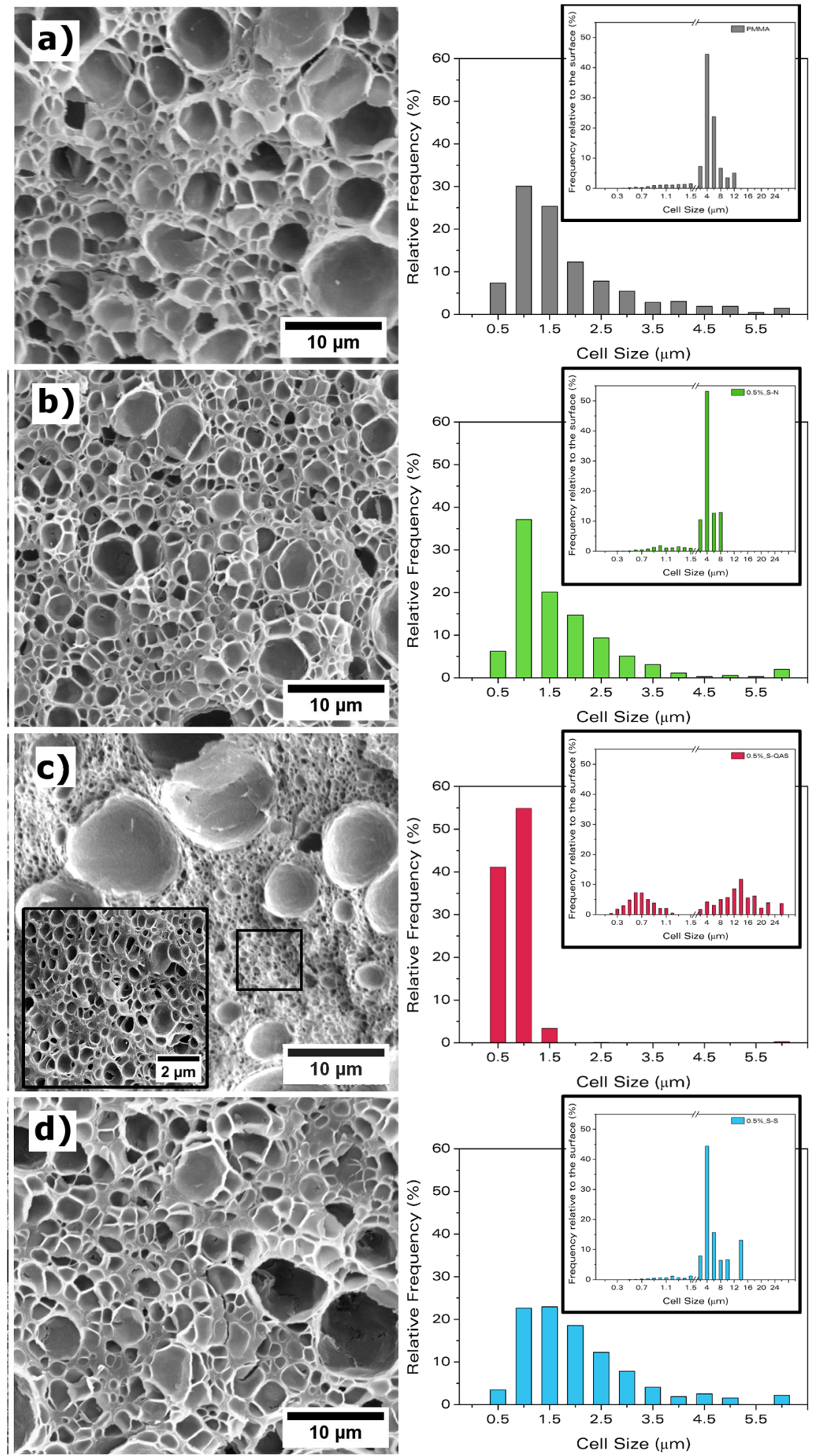

Figure 6. SEM images and cell size distributions of the cellular samples produced at $10 \mathrm{MPa}$ of saturation pressure and $80{ }^{\circ} \mathrm{C}$ of foaming temperature. a) PMMA, b) $0.5 \% \_$S-N, c) $0.5 \%$ S-QAS and

d) $0.5 \%$ S-S. The squared graphs correspond to the cell size distributions calculated using the correction (equation 2). 
Regarding the cell size distributions, it is observed that the two distributions, main and secondary populations of cells, are wider as saturation pressure increases (Figure 7). Meanwhile similar cell sizes are found at 10 and $20 \mathrm{MPa}$, increasing the saturation pressure up to $30 \mathrm{MPa}$ seems to result also in smaller nanometric cells and slightly larger micrometric cells (Table 4).
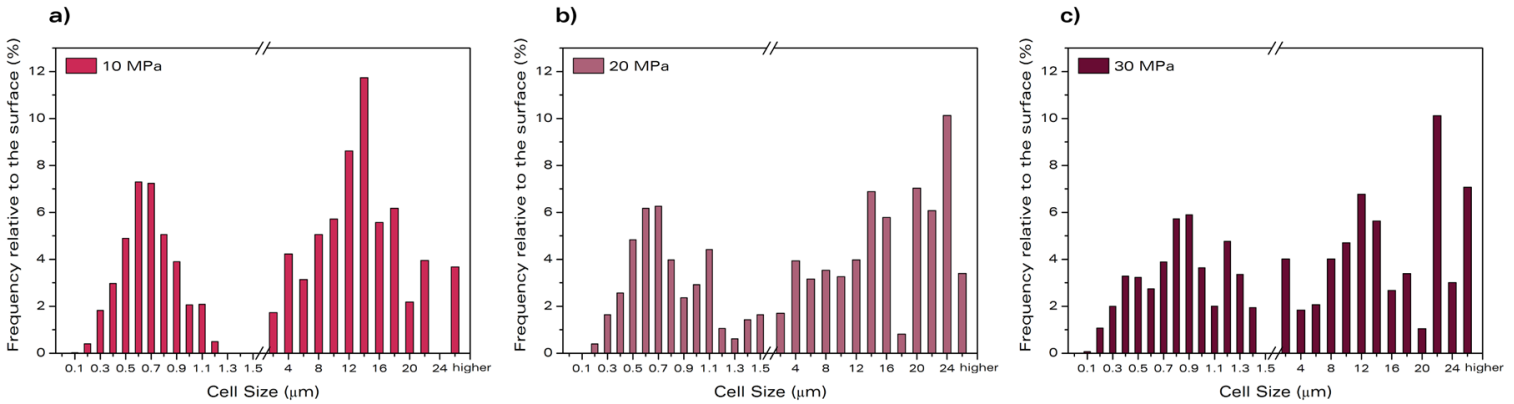

Figure 7. Cell size distributions of the cellular materials based on 0.5\%_S-QAS at different saturation pressures: a) $10 \mathrm{MPa}$, b) $20 \mathrm{MPa}$ and c) $30 \mathrm{MPa}$.

The evolution of the cell nucleation density and the cell size with the saturation pressure for the pure polymer and the nanocomposites with $0.5 \mathrm{wt} \%$ of sepiolites is shown in Figure 8 and Table 3. The cell size represented in Figure $8 . b$ is that of the nanometric pores.

Two different behaviours can be appreciated for the cell nucleation density (Figure 8.a). On the one hand, cell nucleation density of PMMA increases as saturation pressure increases. This is predicted by classical nucleation theory and it is the expected behaviour for pure homopolymers (homogeneous nucleation): higher pressures lead to higher solubilities, which turn into higher nucleation densities and smaller cell sizes [20]. The same trend is observed for 0.5\%_S-N and $0.5 \%$ S-S: nucleation increases with pressure. Besides, the values of cell nucleation densities are similar for these three materials; these values vary between $10^{11}$ nuclei/ $/ \mathrm{cm}^{3}$ at $10 \mathrm{MPa}$ and $10^{14}$ nuclei $/ \mathrm{cm}^{3}$ at $30 \mathrm{MPa}$. Therefore, these two types of particles, S-N and S-S, at a content of $0.5 \mathrm{wt} \%$, do not produce any nucleation effect in PMMA, as the nucleation observed is the same as the one of the pure polymer. On the other hand, the blend produced with the sepiolite modified with a quaternary ammonium salt, $0.5 \%$ S-QAS, shows a completely different behaviour. Cell nucleation density only varies from $1.6 \cdot 10^{13}$ nuclei $/ \mathrm{cm}^{3}$ at $10 \mathrm{MPa}$ to $2.2 \cdot 10^{13}$ nuclei/ $/ \mathrm{cm}^{3}$ at $30 \mathrm{MPa}$, that is, cell nucleation density is almost constant regardless the saturation pressure employed. This is an indicator that nucleation is no longer purely homogeneous when these sepiolites are added. Besides, at $20 \mathrm{MPa}$ nucleation is 11 times higher than that of the neat PMMA, and this factor is increased up to 28 times at $10 \mathrm{MPa}$. Therefore a $0.5 \mathrm{wt} \%$ of S-QAS produces a clear nucleation effect in PMMA, whereas the rest of the particles do not have any affect. From the rheological results it was concluded that a slightly better dispersion was obtained with the sepiolite S-QAS, but the difference between the three types of particles was small and isolated sepiolites were found in the three solid nanocomposites. Therefore, a possible explanation of the nucleating effect of the sepiolite S-QAS should take into account the interaction between the particle, the polymer and the $\mathrm{CO}_{2}$, the surface modification of S-QAS being likely to improve its characteristics to act as a nucleating agent. In fact, some works have reported that nanoparticles with different surface treatments can be just as well dispersed but provide different nucleation efficiencies as a consequence of the interaction of the surface with the $\mathrm{CO}_{2}[53,54]$. These works have shown that 
surface modifications with $\mathrm{CO}_{2}$ philic surfactants reduce the energy barrier for nucleus formation and allow reaching higher nucleation ratios. Thus, we believe that the commercial ammonium salt used in this work contains groups with high $\mathrm{CO}_{2}$ affinity, and then sepiolite S-QAS act as an efficient nucleating agent.

At high pressures homogeneous nucleation in the pure polymer is larger than that caused by heterogeneous nucleation in S-QAS as a consequence of the high amount of gas uptake. This result proves the complexity of producing nanocellular materials using homopolymers pointed out in the introduction: high pressures are needed, whereas the use of particles allows working at not so extreme processing conditions.

a)

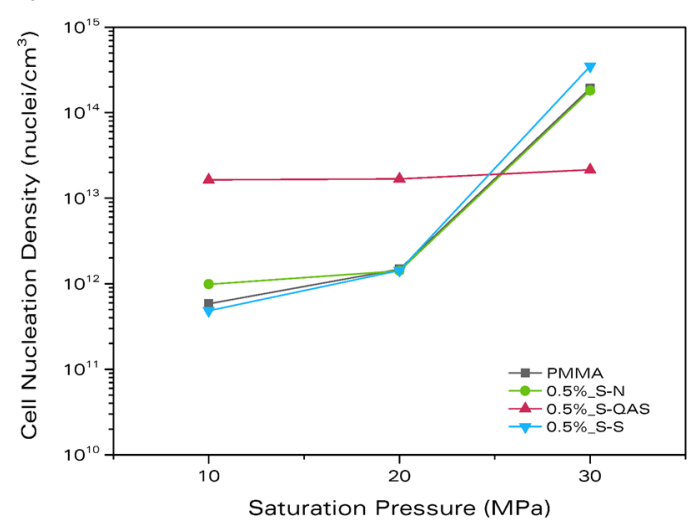

b)

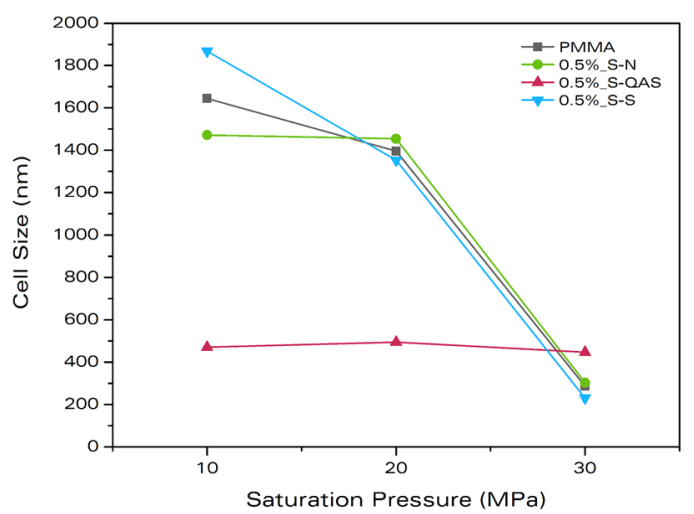

Figure 8. a) Cell nucleation density and b) cell size as a function of the saturation pressure for the blends containing $0.5 \mathrm{wt} \%$ of sepiolites and the pure PMMA.

Regarding cell size, PMMA and the materials with $0.5 \mathrm{wt} \%$ of S-N and S-S present similar behaviours (Figure 8.b). The values obtained change from the microcellular range with pores larger than $1 \mu \mathrm{m}$ at $10 \mathrm{MPa}$ to the nanocellular scale with cell sizes below $300 \mathrm{~nm}$ at $30 \mathrm{MPa}$. However, as with cell density, the material with S-QAS shows a different behaviour, with nanometric pores with almost constant pore sizes along the different saturation pressures. At $10 \mathrm{MPa}$, the addition of only 0.5 wt $\%$ of S-QAS reduces the cell size in a factor of 3.4, from $1.6 \mu \mathrm{m}$ (in the pure PMMA, to $470 \mathrm{~nm}$ (Table 3). With respect to the secondary microcellular population found in the samples with S-QAS, cell size seems to increase with the saturation pressure (Table 3) although this secondary population of micrometric cells is very heterogeneous.

The main conclusion of this section is that among the three types of sepiolites employed in this work, only those modified with a quaternary ammonium salt, S-QAS, have a nucleating effect in PMMA. Using particle contents as low as $0.5 \mathrm{wt} \%$ it is possible to produce materials with a bimodal cellular structure in which there is a large population of cells with sized below $500 \mathrm{~nm}$. To support our claim of nucleation in the well-dispersed sepiolites, Figure 9 shows a high magnification SEM image of one the materials produced with S-QAS. In this image individual sepiolites (red arrows) are observed within the nanometric pores. 


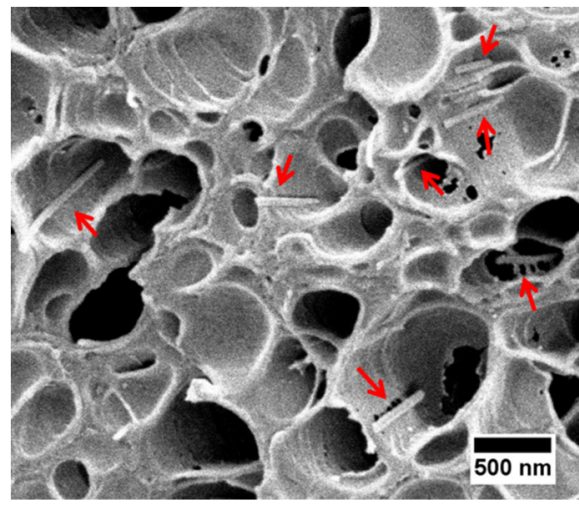

Figure 9. High magnification micrograph showing the individual sepiolites in the surface of the nanometric cells.

\subsubsection{Effect of the Particle Content}

The amount of gas uptake by the blends with a $1 \mathrm{wt} \%$ and a $1.5 \mathrm{wt} \%$ of S-QAS at the different saturation pressures can be found in Table 5. Solubility increases with pressure as found in the previous results. The nanocomposites containing sepiolites present a lower solubility than the pure polymer for the three pressures under study, and lower than that of the blend with $0.5 \mathrm{wt} \%$ of SQAS. As assumed before, if no gas sorption is considered in the particles, the solubility values can be corrected to the gas absorbed by the polymer, and these corrected values recover the solubility of the pure polymer (Table 5). Therefore the assumption was again correct, and the observed reduction in solubility is due to the presence of the particles, which do not absorb $\mathrm{CO}_{2}$ under these conditions.

Table 5. Cellular structure characteristics of the cellular samples produced with the blends containing sepiolite S-QAS at different contents.

\begin{tabular}{|c|c|c|c|c|c|c|c|c|c|}
\hline Sample & $\begin{array}{c}\text { Saturation } \\
\text { Pressure } \\
(\mathrm{MPa}) \\
\end{array}$ & $\begin{array}{c}\text { Gas } \\
\text { uptake } \\
\text { (wt\%) }\end{array}$ & $\begin{array}{c}\text { Gas } \\
\text { uptake c* } \\
\text { (wt\%) }\end{array}$ & $\begin{array}{l}\text { Relative } \\
\text { Density }\end{array}$ & 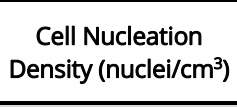 & $\begin{array}{l}\text { Cell } \\
\text { Size1 } \\
(\mathrm{nm}) \\
\end{array}$ & $\begin{array}{c}\mathrm{SD}_{1} / \\
\phi_{1}\end{array}$ & $\begin{array}{c}\text { Cell } \\
\text { Size2 } \\
(\mu \mathrm{m}) \\
\end{array}$ & $\begin{array}{c}\mathrm{SD}_{2} / \\
\phi_{2}\end{array}$ \\
\hline 1\%_S-QAS & 10 & 24.1 & 24.3 & $0.27 \pm 0.01$ & $(3.2 \pm 2.6) \cdot 10^{13}$ & 395 & 0.57 & 4.7 & 0.72 \\
\hline $1.5 \%$ S-QAS & 10 & 24.1 & 24.5 & $0.27 \pm 0.01$ & $(9.3 \pm 0.2) \cdot 10^{13}$ & 314 & 0.55 & 7.8 & 0.95 \\
\hline 1\%_S-QAS & 20 & 27.1 & 27.4 & $0.25 \pm 0.01$ & $(2.8 \pm 0.8) \cdot 10^{13}$ & 441 & 0.62 & 5.2 & 0.66 \\
\hline $1.5 \%$ S-QAS & 20 & 27.0 & 27.4 & $0.24 \pm 0.01$ & $(9.3 \pm 0.8) \cdot 10^{14}$ & 322 & 0.50 & 5.2 & 1.29 \\
\hline 1\%_S-QAS & 30 & 29.8 & 30.1 & $0.25 \pm 0.01$ & $(9.0 \pm 0.4) \cdot 10^{13}$ & 308 & 0.60 & 6.2 & 0.75 \\
\hline $1.5 \%$ S-QAS & 30 & 29.7 & 30.2 & $0.29 \pm 0.01$ & $(9.1 \pm 0.4) \cdot 10^{13}$ & 301 & 0.64 & 6.7 & 1.08 \\
\hline
\end{tabular}

Relative density of the cellular samples as a function of the saturation pressure is shown in Figure 10. An increase in the saturation pressure leads to a small reduction in the relative density (Figure 10) for all the materials except for the one containing $1.5 \mathrm{wt} \%$ of S-QAS, for which relative density seems to increase at $30 \mathrm{MPa}$. Anyway, similar relative densities, between 0.24 and 0.3 , have been obtained for all the materials (Table 5). 


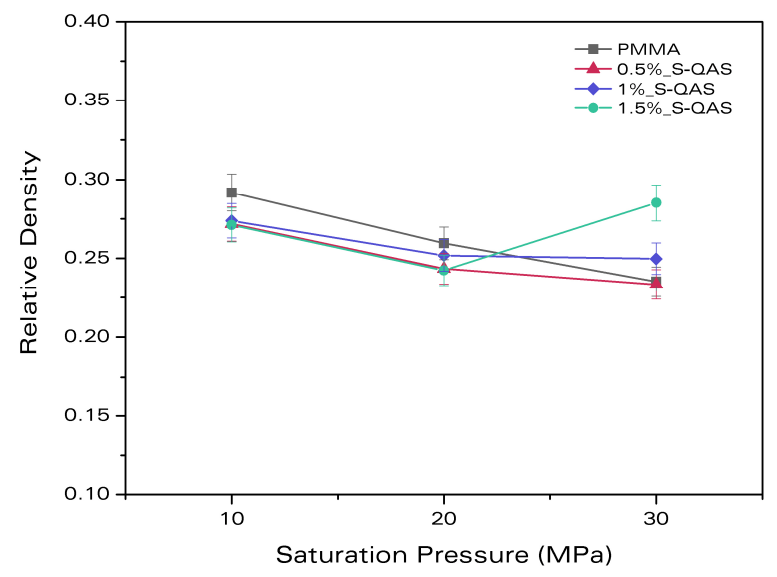

Figure 10. Relative density as a function of the saturation pressure for the blends containing sepiolite S-QAS and the pure PMMA.

As it was previously commented, one interesting feature of the cellular materials produced with SQAS is that they present a bimodal distribution of cell sizes. Figures 11.a, 11.b and 11.c show low magnification micrographs of the three materials with different contents of S-QAS produced at 10 $\mathrm{MPa}$, showing the micro and the nanocellular populations. Figures 11.d, 11.e and 11.f show high magnification micrographs that allow the visualization of the nanocellular structure found among the microcellular pores. This kind of structure has been found in all the bulk cellular materials containing S-QAS regardless the particle content and the saturation and foaming conditions (Table 5).

Figures 11.g, 11.h and 11.i show the cell size distributions of these systems and Table 6 summarizes their main characteristics (volume fractions and average cell sizes). Regarding the nanocellular population, similar distributions are found at for particle contents of $0.5 \mathrm{wt} \%$ and $1 \mathrm{wt} \%$ (Figure 11.g and 11.h), whereas for a content of $1.5 \mathrm{wt} \%$ this distribution moves to smaller cell sizes (Figure 11.i). Moreover, the weight of this distribution is higher (higher frequencies), which matches with the highest volume fraction of nanocellular cells found in this system (Table 6), almost a $80 \%$ of the volume is occupied by nanometric cells. We can then conclude that the addition of sepiolites increases the volume fraction of the main population, whereas it decreases its cell size. On the other hand, the cell size of the secondary population, which is very heterogeneous, is not significantly affected by the sepiolite content.

Table 6. Characteristics of the bimodal cellular structure of the cellular materials produced at 10 $\mathrm{MPa}$ from the three particle contents used in this work.

\begin{tabular}{ccccccc}
\hline & \multicolumn{3}{c}{ MAIN POPULATION } & \multicolumn{3}{c}{ SECONDARY POPULATION } \\
\hline $\begin{array}{c}\text { Particle } \\
\begin{array}{c}\text { Content } \\
(\text { wt\%) }\end{array}\end{array}$ & $\begin{array}{c}\text { Volume } \\
\text { fraction }(\%)\end{array}$ & $\begin{array}{c}\text { Cell size } \phi \\
(\mathrm{nm})\end{array}$ & $\begin{array}{c}\text { Standard } \\
\text { deviation } S D \\
(\mathrm{~nm})\end{array}$ & $\begin{array}{c}\text { Volume } \\
\text { fraction }(\%)\end{array}$ & $\begin{array}{c}\text { Cell size } \phi \\
(\mu \mathrm{m})\end{array}$ & $\begin{array}{c}\text { Standard } \\
\text { deviation } S D \\
(\mu \mathrm{m})\end{array}$ \\
\hline 0.5 & 56.5 & 470 & 227 & 43.5 & 6.5 & 5.0 \\
1 & 62.7 & 395 & 226 & 37.3 & 4.7 & 3.4 \\
1.5 & 77.8 & 314 & 172 & 22.2 & 7.8 & 7.5 \\
\hline
\end{tabular}


$0.5 w t \%$
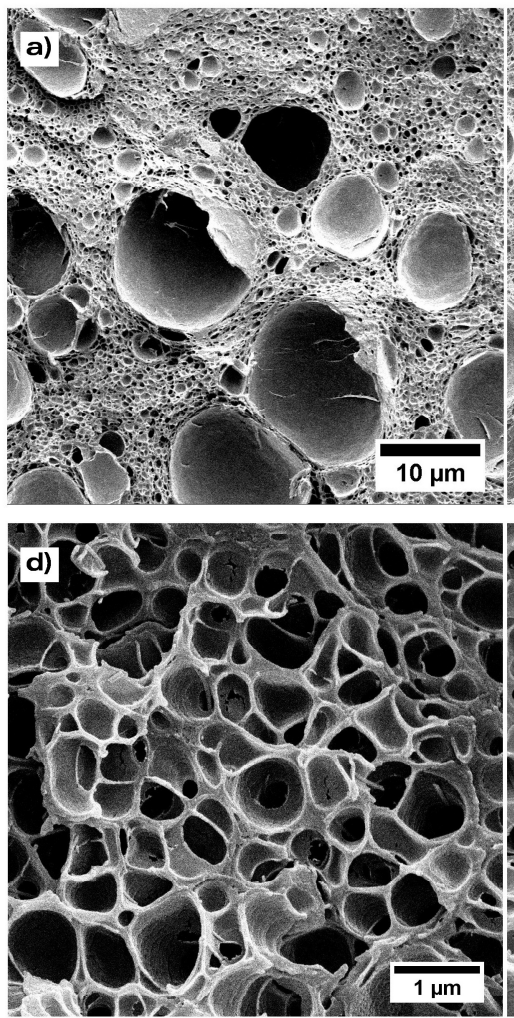

g)

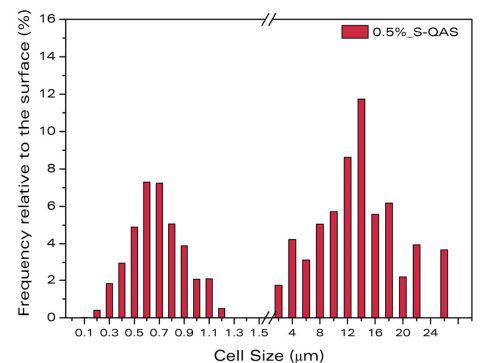

$1 \mathrm{wt} \%$
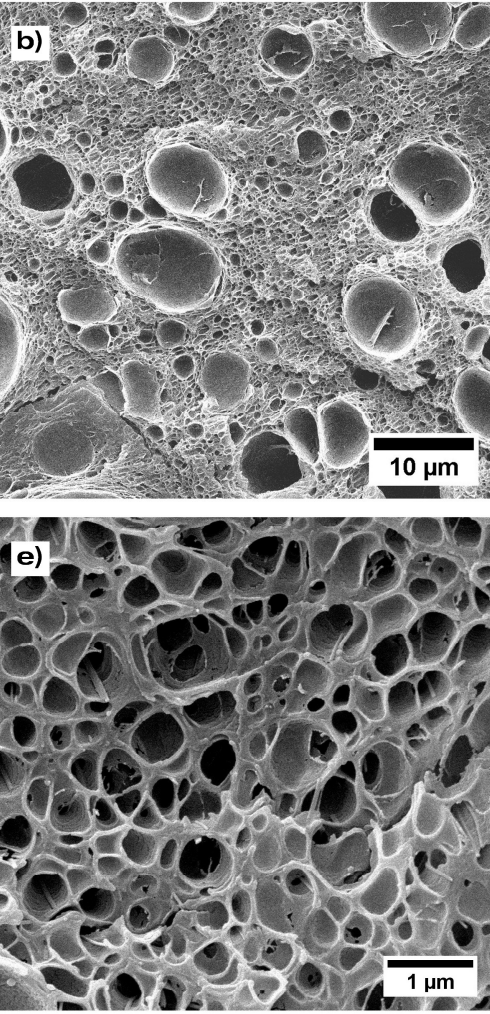

h)

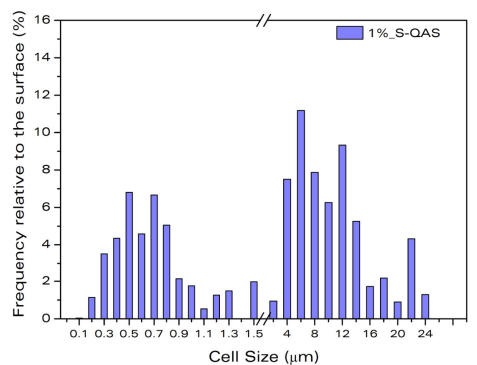

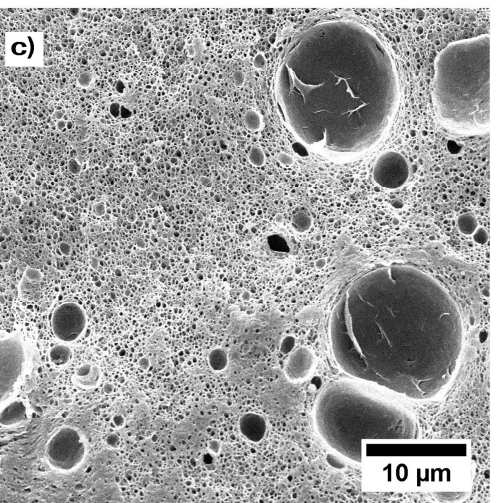

$1.5 \mathrm{wt} \%$

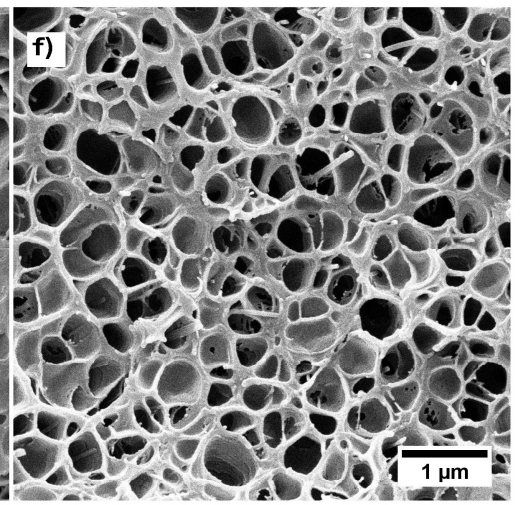

i)

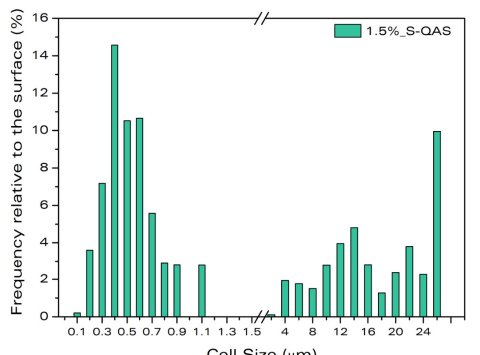

Figure 11. SEM images of the cellular samples produced at $10 \mathrm{MPa}$ of saturation pressure and 80 ${ }^{\circ} \mathrm{C}$ of foaming temperature: a) and d) 0.5_\%S-QAS; b) and e) 1_\%S-QAS; c) and f) 1.5_\%S-QAS. Cell size distributions of these materials: g) 0.5_\%S-QAS, h) 1_\%S-QAS and i) 1.5_\%S-QAS.

Cell nucleation density and the cell size (of the nanometric cells) as a function of the saturation pressure are shown in Figure 12. Two different behaviours can be appreciated for the cell nucleation density (Figure 12.a). On the one hand, cell nucleation density of PMMA increases as saturation pressure increases, as seen in the previous results. On the other hand, all the blends produced with S-QAS present an almost constant cell nucleation density for the three saturation pressures used, which proves that the heterogeneous nucleation mechanism predominates over homogeneous nucleation in these materials. Moreover, cell nucleation density is a function of the particle content: higher particle contents produce higher nucleation densities. For instance, at 10 MPa of saturation pressure, cell nucleation density increases in a factor of 2 when increasing the sepiolite content from $0.5 \mathrm{wt} \%$ to $1 \mathrm{wt} \%$, and in a factor of 6 when the S-QAS content is $1.5 \mathrm{wt} \%$. 
a)

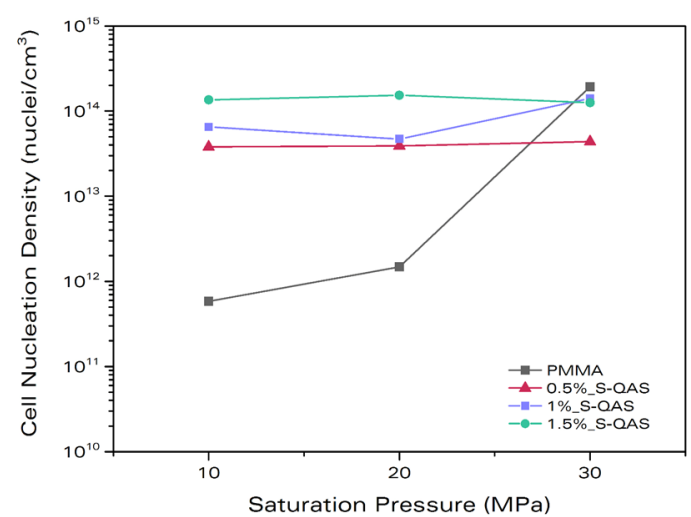

b)

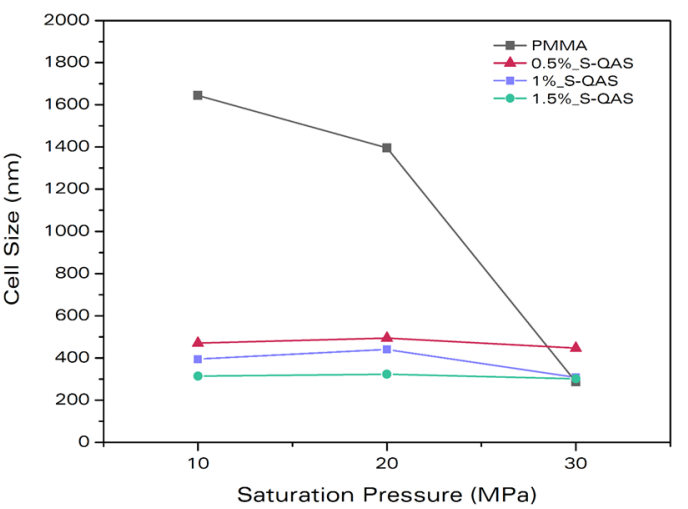

Figure 12. a) Cell nucleation density and b) cell size as a function of the saturation pressure for the blends containing sepiolite S-QAS and the pure PMMA.

Figure 12.b shows that the average cell size of the three materials with S-QAS remains almost constant with pressure, oppositely to the behaviour of the neat PMMA, for which the average cell size decreases with pressure. In fact the three materials present cell sizes below $500 \mathrm{~nm}$. In addition, 1.5\%_S-QAS presents the lowest cell sizes, whereas 0.5_\%S-QAS shows the highest. Thus, there is a reduction of the cell size when the particle content increases (Table 5), which matches with the higher cell densities found for higher particle contents.

The main conclusion of this section is that the amount of sepiolites determines the effective cell nucleation and the final cell size, the cell nucleation density being higher for higher particle contents. This increase of the nucleation density as the particle content increases is a consequence of the heterogeneous nucleation mechanism: larger particle contents imply more nucleation sites where nuclei can appear. Larger cell densities yield to smaller cell sizes. This result is commonly observed in systems filled with nanoparticles [17,22,23,27]. Besides, the volume fraction occupied by the nanometric cell increases as sepiolite content increases. Assuming the well dispersed sepiolites are in the nanocellular volume fraction, this result will imply that higher particle contents lead to better dispersions. In fact, an increase in the particle content in a factor of 3 leads to an increase in the nucleation density of 6 , indicating a slightly better dispersion for a filler loading of $1.5 \mathrm{wt} \%$, in agreement with the largest volume fraction of nanocellular pores.

\subsubsection{Effect of the foaming temperature}

To evaluate the influence of the foaming temperature three different foaming temperatures has been employed, $80^{\circ} \mathrm{C}, 100^{\circ} \mathrm{C}$ and $110^{\circ} \mathrm{C}$. In this case saturation pressure will be kept constant at $10 \mathrm{MPa}$. It has been previously observed that at $80^{\circ} \mathrm{C}$ the blends containing S-QAS produce bimodal cellular structures with relative densities around 0.27 (see Tables 3 and 5). The relative densities obtained at $100{ }^{\circ} \mathrm{C}$ and $110^{\circ} \mathrm{C}$ are displayed in Figure 13. This plot shows that, for a constant saturation pressure, relative density decreases as foaming temperature increases for the three particle contents studied. All the samples had initially the same amount of gas absorbed (same $T_{\text {geff }}$ ) but now the final foaming temperature is different. The higher the foaming temperature, the largest difference between the foaming temperature and the $T_{g, e f f}$, and thus more time to grow, resulting in a lower relative density. 


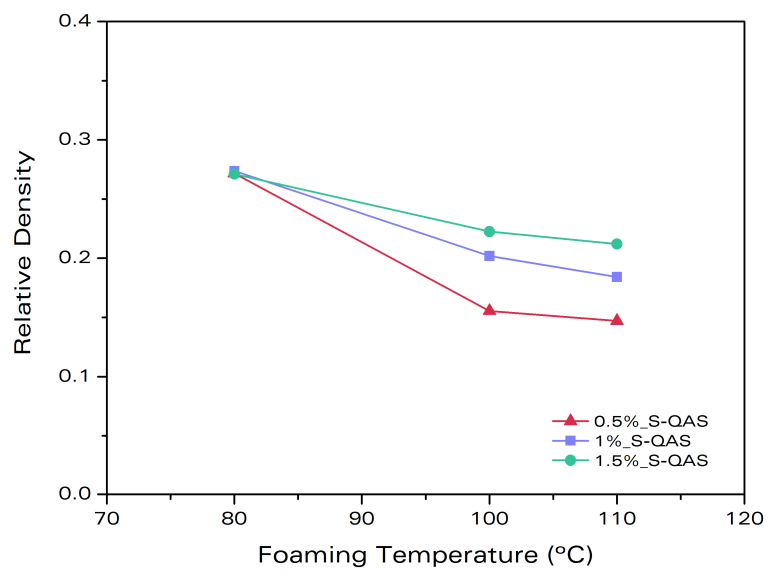

Figure 13. Relative density as a function of the foaming temperature.

However, the reduction in density obtained is different for each material. Whereas the material containing $0.5 \mathrm{wt} \%$ of S-QAS shows a decrease in density in a factor of 1.8 from $80^{\circ} \mathrm{C} 110^{\circ} \mathrm{C}$, in the blend with $1.5 \mathrm{wt} \%$ of sepiolite S-QAS this reduction is only in a factor of 1.3. The conclusion is that the addition of nanoparticles limits the minimum density that can be achieved with this processing route. This can be due to the higher viscosity of the blends with higher particle contents.

SEM micrographs of the samples foamed at higher temperatures are shown in Figure 14. Note that these images correspond to the previously-called nanocellular structure (main population) and not the microcellular population (recall that there was a bimodal cell size distribution in all the materials with S-QAS). Compared to Figure 11, the images in Figure 14, which correspond to cellular materials produced at higher foaming temperatures, show a clear increase of the cell size.

Figure 15 shows the evolution of the cell nucleation density (a) and the cell size (b) of the main population as a function of the foaming temperature. Both cell nucleation density and cell size present important changes when foaming temperature is increased. On the one hand, cell nucleation density decreases as the foaming temperature increases for the three materials under study (Figure 15.a). Thus, there is a reduction in the number of cells in the cellular material, meaning that cell wall rupture phenomena (coalescence events) take place as temperature increases. For instance, for $1.5 \%$ S-QAS, cell nucleation density is reduced from $1.4 \cdot 10^{14}$ nuclei/ $\mathrm{cm}^{3}$ at $80{ }^{\circ} \mathrm{C}$ to $4.3 \cdot 10^{13}$ nuclei/ $\mathrm{cm}^{3}$ at $110{ }^{\circ} \mathrm{C}$, that is, cell nucleation density is halved when the foaming temperature is increased in $30^{\circ} \mathrm{C}$.

As a result of cell coalescence, the average cell size increases as foaming temperature increases (Figure 15.b). The increase in cell size implies that some of the cellular materials produced with these high foaming temperatures cannot be considered nanocellular polymers anymore. Cellular materials produced with a content of $0.5 \mathrm{wt} \%$ of S-QAS present cell sizes of around 670 and $830 \mathrm{~nm}$ at $100{ }^{\circ} \mathrm{C}$ and $110^{\circ} \mathrm{C}$, respectively, above the nanocellular threshold indicated in the introduction of this paper (>500 nm). However, materials with the highest S-QAS content still belong to the nanometric range, with cell sizes of 470 and $480 \mathrm{~nm}$ for foaming temperatures of $100{ }^{\circ} \mathrm{C}$ and 110 ${ }^{\circ} \mathrm{C}$ and they have low relative densities (0.21). 

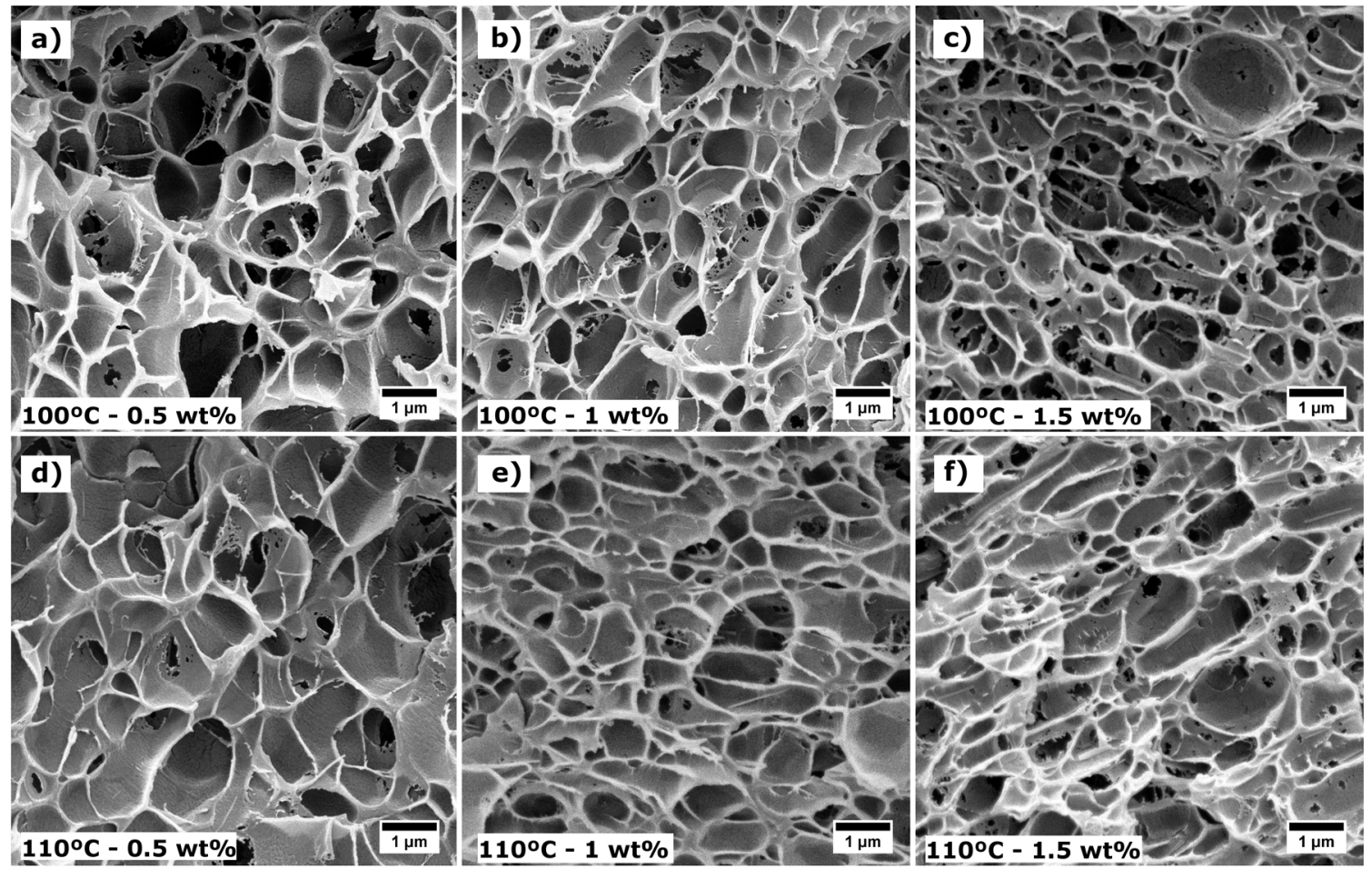

Figure 14. First row: Samples foamed at $100^{\circ} \mathrm{C}$. Second row: Samples foamed at $110^{\circ} \mathrm{C}$. a) and d) $\left.0.5 \_\% S-Q A S ; b\right)$ and e) 1_\%S-QAS; c) and f) 1.5_\%S-QAS.

a)

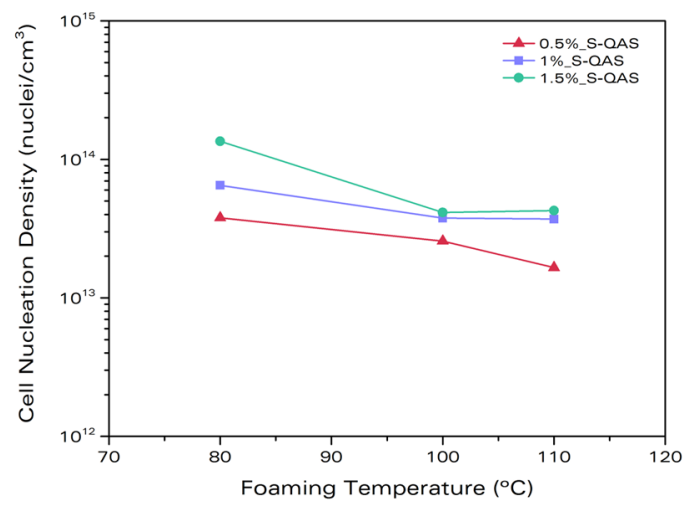

b)

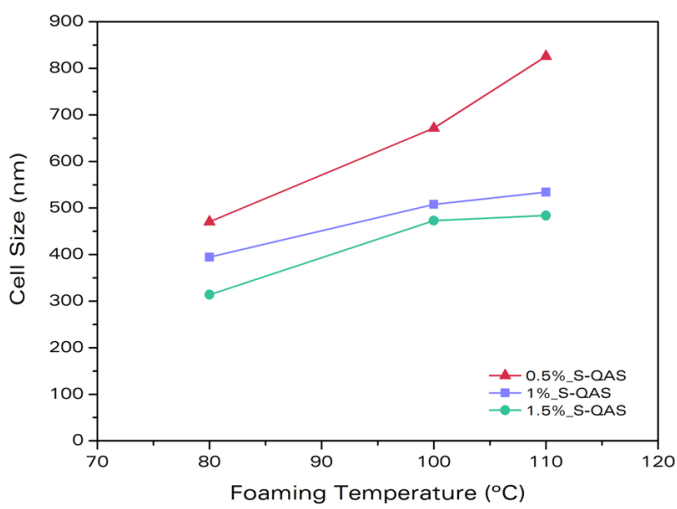

Figure 15. a) Cell nucleation density and b) cell size as a function of the saturation pressure.

The main conclusion of this section is that the relative density can be indeed reduced by increasing the foaming temperature, but in return cell size increases due to cell coalescence. This result is not in agreement with those found in the work of Martin-de Leon et al. [13], which analyses the effect of the foaming temperature in a pure PMMA matrix. They found that cell size remained constant despite the density reduction. Again the role of the sepiolites is crucial to understand the differences between the two systems. In the blends with sepiolites, particle aggregates (and individual particles themselves) are probably larger than cell wall thickness and struts. For this reason, they favour cell coalescence as the cell wall thickness is reduced when the density decreases and due to this these systems are more prone to coalescence than the pure polymer. 


\section{CONCLUSIONS}

Nanocellular polymeric materials based on PMMA and containing nanometric sepiolites have been produced by means of a gas dissolution foaming process. Nanocomposites with different particle types and contents were produced by extrusion and compression moulding. Cell sizes in the range of 300-500 $\mathrm{nm}$ and cell densities of the order of $10^{13}-10^{14}$ nuclei/ $\mathrm{cm}^{3}$ have been obtained. These nanocellular polymers, with relative densities around 0.3 , can be produced in a wide range of saturation pressures (from 10 to $30 \mathrm{MPa}$ ) using low particle contents (between 0.5 and $1.5 \mathrm{wt} \%$ ) and low foaming temperatures $\left(80^{\circ} \mathrm{C}\right)$.

Among the three types of particles employed in this work, it has been identified that only the sepiolite modified with a quaternary ammonium salt (S-QAS) can be used as a nucleating agent for PMMA. The addition of this particle produces bimodal cellular structures, with micro and nanometric cells, the nanometric population being predominant. An increase in the content of sepiolites leads to a reduction of the cell size in the nanometric population, as well as to an increase of the cell nucleation density. Besides, as particle content increases the fraction of nanometric cells increases. At low pressures, where the pure polymer produces microcellular materials, the PMMA/sepiolite blends produce bimodal nanocellular structures. A particle content of $1.5 \mathrm{wt} \%$ increases nucleation in a factor of 160 compared to the pure polymer foamed under the same conditions $\left(10 \mathrm{MPa}, 80^{\circ} \mathrm{C}\right)$, whereas cell size decreases in a factor of 5 . As pressure increases, the nucleation in the pure polymer increases and cell size decreases (homogeneous nucleation). However, this behaviour is not observed in the blends with the sepiolites modified with a quaternary ammonium salt. For these systems the influence of the saturation pressure (and thus of the amount of gas absorbed by the polymer) is not significant, and this is a consequence of a predominant heterogeneous nucleation. Relative density can be reduced by increasing the foaming temperature, but at the expense of increasing the cell size of the nanocellular population. Cell coalescence is significant at a foaming temperature of $100^{\circ} \mathrm{C}$, probably due to the existence of particle aggregates which favour cell wall ruptures.

In conclusion, in this work nanocellular PMMA materials have been produced using for the first time sepiolites as nucleating agent. The production of these new materials requires not demanding process parameters (medium pressure and room temperature) and low particle contents, which make them attractive for mass scale production. Further research will determine the properties, future applications and possibilities of these promising materials.

\section{Acknowledgments:}

Financial support from FPU grant FPU14/02050 (V. Bernardo) from the Spanish Ministry of Education and Junta of Castile and Leon grant Q4718001C (J. Martín-de León) is gratefully acknowledged. Financial assistance from MINECO, FEDER, UE (MAT2015-69234-R) and the Junta de Castile and Leon (VA011U16) are gratefully acknowledged. We would also like to thank the company Tolsa (Madrid, Spain) for supplying the sepiolites of this study. 


\section{REFERENCES}

[1] B. Notario, J. Pinto, M.A. Rodriguez-Perez, Nanoporous polymeric materials: A new class of materials with enhanced properties, Prog. Polym. Sci. 78-79 (2016) 93-139. doi:10.1016/j.pmatsci.2016.02.002.

[2] B. Notario, J. Pinto, M.A. Rodríguez-Perez, Towards a new generation of polymeric foams: PMMA nanocellular foams with enhanced physical properties, Polymer (Guildf). 63 (2015) 116-126. doi:10.1016/j.polymer.2015.03.003.

[3] D. Miller, V. Kumar, Microcellular and nanocellular solid-state polyetherimide (PEI) foams using sub-critical carbon dioxide II . Tensile and impact properties, Polymer (Guildf). 52 (2011) 2910-2919. doi:10.1016/j.polymer.2011.04.049.

[4] S. Costeux, CO2-blown nanocellular foams, J. Appl. Polym. Sci. 131 (2014) 41293(1)-41293(16). doi:10.1002/app.41293.

[5] B. Notario, J. Pinto, E. Solorzano, J.A. de Saja, M. Dumon, M.A. Rodriguez-Perez, Experimental validation of the Knudsen effect in nanocellular polymeric foams, Polymer (Guildf). 56 (2015) 57-67. doi:10.1016/j.polymer.2014.10.006.

[6] M. Knudsen, The Kinetic Theory of Gases, Methuen, London, 1934

[7] L. Li, L. Schulte, L.D. Clausen, K.M. Hansen, G.E. Jonsson, S. Ndoni, Gyroid nanoporous membranes with tunable permeability, ACS Nano. 5 (2011) 7754-7766. doi:10.1021/nn200610r.

[8] J. Pinto, M. Dumon, M.A. Rodriguez-Perez, R. Garcia, C. Dietz, Block Copolymers Self-Assembly Allows Obtaining Tunable Micro or Nanoporous Membranes or Depth Filters Based on PMMA; Fabrication Method and Nanostructures, J. Phys. Chem. C. 118 (2014) 4656-4663. doi:10.1021/jp409803u.

[9] G.Q. Lu, X.S. Zhao, Nanoporous Materials - An Overview, in: Nanoporous Mater. Sci. Eng., Imperial Collegue Press, London, 2004. doi:10.1142/9781860946561_0001.

[10] H. Guo, V. Kumar, Some thermodynamic and kinetic low-temperature properties of the PC-CO2 system and morphological characteristics of solid-state PC nanofoams produced with liquid CO2, Polymer (Guildf). 56 (2015) 46-56. doi:10.1016/j.polymer.2014.09.061.

[11] H. Guo, A. Nicolae, V. Kumar, Solid-State Microcellular and Nanocellular Polysulfone Foams, J. Polym. Sci. Part B Polym. Phys. 53 (2015) 975-985. doi:10.1002/polb.23719.

[12] H. Guo, A. Nicolae, V. Kumar, Solid-state poly(methyl methacrylate) (PMMA) nanofoams. Part II: Lowtemperature solid-state process space using CO2 and the resulting morphologies, Polymer (Guildf). 70 (2015) 231-241. doi:10.1016/j.polymer.2015.06.031.

[13] J. Martin de-Leon, V. Bernardo, M.A. Rodriguez-Perez, Low Density Nanocellular Polymers Based on PMMA Produced by Gas Dissolution Foaming: Fabrication and Cellular Structure Characterization, Polymers (Basel). 8 (2016) 1-16. doi:10.3390/polym8070265.

[14] V. Bernardo, J. Martín-de Leon, M.A. Rodriguez-Perez, Production and characterization of nanocellular polyphenylsulfone foams, Mater. Lett. 178 (2016) 155-158. doi:10.1016/j.matlet.2016.05.002.

[15] H. Guo, V. Kumar, Solid-state poly(methyl methacrylate) (PMMA) nanofoams. Part I: Low-temperature CO2 sorption, diffusion, and the depression in PMMA glass transition, Polymer (Guildf). 57 (2015) 157-163. doi:10.1016/j.polymer.2014.12.029.

[16] V.I. Kalikmanov, Nucleation Theory, Springer, 2013.

[17] S. Costeux, L. Zhu, Low density thermoplastic nanofoams nucleated by nanoparticles, Polymer (Guildf). 54 (2013) 2785-2795. doi:10.1016/j.polymer.2013.03.052.

[18] Y.H. Lee, C.B. Park, K.H. Wang, HDPE-Clay Nanocomposite Foams Blown with Supercritical CO2, J. Cell. Plast. 41 (2005) 487-502. doi:10.1177/0021955X05056964.

[19] C. Forest, P. Chaumont, P. Cassagnau, B. Swoboda, P. Sonntag, CO2 nano-foaming of nanostructured PMMA, Polymer (Guildf). 58 (2015) 76-87. doi:10.1016/j.polymer.2014.12.048.

[20] J. Pinto, M. Dumon, M. Pedros, J. Reglero, M.A. Rodriguez-Perez, Nanocellular CO2 foaming of PMMA assisted by block copolymer nanostructuration, Chem. Eng. J. 243 (2014) 428-435. doi:10.1016/j.cej.2014.01.021.

[21] J. Pinto, J.A. Reglero-ruiz, M. Dumon, M.A. Rodriguez-Perez, Temperature influence and CO2 transport in foaming processes of poly(methyl methacrylate)-block copolymer nanocellular and microcellular foams, J. Supercrit. Fluids. 94 (2014) 198-205. doi:10.1016/j.supflu.2014.07.021. 
nanocomposites foams, Polymer (Guildf). 47 (2006) 7580-7589. doi:10.1016/j.polymer.2006.08.034.

[23] H. Janani, M.H.N. Famili, Investigation of a Strategy for Well Controlled Inducement of Microcellular and Nanocellular Morphologies in Polymers, Polym. Eng. Sci. 50 (2010) 1558-1570. doi:10.1002/pen.

[24] J. Yang, L. Huang, Y. Zhang, F. Chen, P. Fan, M. Zhong, S. Yeh, A new promising nucleating agent for polymer foaming: Applications of ordered mesoporous silica particles in polymethyl methacrylate supercritical carbon dioxide microcellular foaming, Ind. Eng. Chem. Res. 52 (2013) 14169-14178. doi:10.1021/ie4018447.

[25] Y. Fujimoto, S.S. Ray, M. Okamoto, A. Ogami, K. Yamada, K. Ueda, Well-Controlled Biodegradable Nanocomposite Foams : From Microcellular to Nanocellular, Macromol. Rapid Commun. 24 (2003) 457-461.

[26] L. Urbanczyk, C. Calberg, C. Detrembleur, C. Jérôme, M. Alexandre, Batch foaming of SAN / clay nanocomposites with scCO 2 : A very tunable way of controlling the cellular morphology, Polymer (Guildf). 51 (2010) 3520-3531. doi:10.1016/j.polymer.2010.05.037.

[27] S. Siripurapu, J.M. Desimone, S.A. Khan, R.J. Spontak, N. Carolina, N. Carolina, Controlled Foaming of Polymer Films through Restricted Surface Diffusion and the Addition of Nanosilica Particles or CO2-philic Surfactants, Macromolecules. 38 (2005) 2271-2280. doi:10.1021/ma047991b.

[28] M. Liu, M. Pu, H. Ma, Preparation, structure and thermal properties of polylactide / sepiolite nanocomposites with and without organic modifiers, Compos. Sci. Technol. 72 (2012) 1508-1514. doi:10.1016/j.compscitech.2012.05.017.

[29] N. García, J. Guzman, E. Benito, A. Esteban-Cubillo, E. Aguilar, J. Santaren, P. Tiemblo, Surface Modification of Sepiolite in Aqueous Gels by Using Methoxysilanes and Its Impact on the Nanofiber Dispersion Ability, Langmuir. 27 (2011) 3952-3959. doi:10.1021/la104410r.

[30] N.H. Huang, Z.J. Chen, J.Q. Wang, P. Wei, Synergistic effects of sepiolite on intumescent flame retardant polypropylene, Express Polym. Lett. 4 (2010) 743-752. doi:10.3144/expresspolymlett.2010.90.

[31] E. Bilotti, H.R. Fischer, T. Peijs, À. Si, Polymer Nanocomposites Based on Needle-like Sepiolite Clays : Effect of Functionalized Polymers on the Dispersion of Nanofiller, Crystallinity, and Mechanical Properties, J. Appl. Polym. Sci. 107 (2008) 1116-1123. doi:10.1002/app.

[32] Y. Zheng, Y. Zheng, Study on Sepiolite-Reinforced Polymeric Nanocomposites, J. Appl. Polym. Sci. 99 (2006) 2163-2166. doi:10.1002/app.22337.

[33] P. Lu, The Effects of Different Grafted Clays on Thermal Properties of Their PMMA Composites, Polym. Plast. Technol. Eng. 50 (2011) 1541-1545. doi:10.1080/03602559.2011.603780.

[34] J.A. Igualada, J.L. Feijoo, POLYMER FOAMS - United States Patent Application, US 2015/0337103, 2015.

[35] J. Santaren, A. Alvarez, A. Esteban-Cubillo, B. Notario, D. Velasco, M.A. Rodriguez-Perez, Improving the Cellular Structure and Thermal Conductivity of PS Foams by Using Sepiolites, in: Foams2012, 2012: pp. 1-5.

[36] M. Frydrych, C. Wan, R. Stengler, U.O. Kelly, B. Chen, Structure and mechanical properties of gelatin/sepiolite nanocomposite foams, J. Mater. Chem. 30 (2011) 9103-9111. doi:10.1039/c1jm10788g.

[37] D. Killeen, M. Frydrych, B. Chen, Porous poly (vinyl alcohol)/ sepiolite bone scaffolds: Preparation, structure and mechanical properties, Mater. Sci. Eng. C. 32 (2012) 749-757. doi:10.1016/j.msec.2012.01.019.

[38] A. Alvarez, J. Santaren, A. Esteban-Cubillo, P. Aparicio, Development in Palygorskite-Sepiolite Research, Elsevier, 2011.

[39] E. Ruiz-Hitzky, Molecular access to intracrystalline tunnels of sepiolite, J. Mater. Chem. 11 (2001) 86-91. doi:10.1039/b003197f.

[40] D. Garcia-Lopez, J.F. Fernandez, J.C. Merino, J. Santaren, J.M. Pastor, Effect of organic modification of sepiolite for PA 6 polymer/organoclay nanocomposites, Compos. Sci. Technol. 70 (2010) 1429-1436. doi:10.1016/j.compscitech.2010.05.020.

[41] V. Kumar, N.P. Suh, A process for making microcellular parts, Polym. Eng. Sci. 30 (1990) 1323-1329. doi:https://doi.org/10.1002/pen.760302010.

[42] J. Zhao, A.B. Morgan, J.D. Harris, Rheological characterization of polystyrene-clay nanocomposites to compare the degree of exfoliation and dispersion, Polymer (Guildf). 46 (2005) 8641-8660. doi:10.1016/j.polymer.2005.04.038.

[43] E. Laguna-Gutierrez, R. Van Hooghten, P. Moldenaers, M.A. Rodriguez-Perez, Effects of extrusion process, type and content of clays, and foaming process on the clay exfoliation in HMS PP composites, J. Appl. Polym. Sci. 132 (2015) 42430(1)-42430(14). doi:10.1002/app.42828. 
[44] C. Forest, P. Chaumont, P. Cassagnau, B. Swoboda, P. Sonntag, Nanofoaming of PMMA using a batch CO2 process: Influence of the PMMA viscoelastic behaviour, Polymer (Guildf). 77 (2015) 1-9. doi:10.1016/j.polymer.2015.09.011.

[45] J. Pinto, E. Solorzano, M.A. Rodriguez-perez, J.A. De Saja, Characterization of the cellular structure based on user-interactive image analysis procedures, J. Cell. Plast. 49 (2013) 555-575. doi:10.1177/0021955X13503847.

[46] V. Kumar, Process synthesis for manufacturing microcellular thermoplastic parts, Massachusetts Institute of Technology, 1988.

[47] C.A. Mandarim-de-Lacerda, Stereological tools in biomedical research, Ann. Brazilian Acad. Sci. 75 (2003) 469486.

[48] C. Saiz-Arroyo, M.A. Rodriguez-Perez, J.I. Velasco, J.A. de Saja, Influence of foaming process on the structure properties relationship of foamed LDPE / silica nanocomposites, Compos. Part B. 48 (2013) 40-50. doi:10.1016/j.compositesb.2012.10.045.

[49] J.E. Weller, V. Kumar, Solid State Microcellular PC Foams I, Polym. Eng. Sci. 47 (2007) 21-25. doi:10.1002/pen.

[50] Y.D. Hwang, S.W. Cha, The relationship between gas absorption and the glass transition temperature in a batch microcellular foaming process, Polym. Test. 21 (2002) 269-275. doi:10.1016/S0142-9418(01)00081-2.

[51] P. Alessi, A. Cortesi, I. Kikic, F. Vecchione, Plasticization of Polymers with Supercritical Carbon Dioxide: Experimental Determination of Glass-Transition Temperatures, J. Appl. Polym. Sci. 88 (2003) 2189-2193. doi:10.1002/app.11881.

[52] Z. Zhang, Y.P. Handa, An in situ study of plasticization of polymers by high-pressure gases, J. Polym. Sci. 36 (1998) 977-982. doi:10.1002/(sici)1099-0488(19980430)36:6<977::aid-polb5>3.0.co;2-d.

[53] D. Rende, L.S. Schadler, R. Ozisik, Controlling foam morphology of poly(methyl methacrylate) via surface chemistry and concentration of silica nanoparticles and supercritical carbon dioxide process parameters, J. Chem. 2013 (2013). doi:10.1155/2013/864926.

[54] K. Goren, L. Chen, L.S. Schadler, R. Ozisik, Influence of nanoparticle surface chemistry and size on supercritical carbon dioxide processed nanocomposite foam morphology, J. Supercrit. Fluids. 51 (2010) 420-427. doi:10.1016/j.supflu.2009.09.007. 


\subsection{Anisotropy in nanocellular polymers promoted by the addition of needle-like sepiolites}

This section contains a publication entitled "Anisotropy in nanocellular polymers promoted by the addition of needle-like sepiolites". This paper published in Polymer International in 2019 (V. Bernardo, J. Martin-de Leon, M.A. Rodriguez-Perez, Anisotropy in nanocellular polymers promoted by the addition of needle-like sepiolites, Polym. Int. 68 (2019) 1204-1214. doi:10.1002/pi.5813). This paper is the natural continuation of the work presented in the previous section. Also, it shows new results about the production of anisotropic nanocellular materials using sepiolites to promote the formation of the anisotropy.

To begin with, in the first paper (section 4.2) we proved that only the sepiolite modified with a quaternary ammonium salt produces a nucleating effect in PMMA. To further investigate this, in this section a sepiolite with a smaller amount of the salt was used, and also the raw salt QAS was used as a nucleating agent to evaluate its influence. The addition of a $1.5 \mathrm{wt} \%$ of the salt has an effect of the cellular structure of microcellular PMMA, leading to an increase of the nucleation density and a slight reduction of the cell size. However, it does not produce nanocellular structures as the sepiolites modified with this salt do. Then, we conclude the salt itself is not responsible for all the nucleation process that induces the formation of nanometric cells.

The sepiolite with the highest amount of salt (S-HQAS) has the strongest nucleating effect compared to the sepiolite modified with less amount of salt (S-LQAS) and the raw QAS (see the amount of salt of each particle in Table 3.2 in Chapter 3). This effect is due to a better dispersion of the particles in the solid material with the highest amount of salt (a smaller fraction of microcellular pores is observed).

In the previous section, particle contents up to $1.5 \mathrm{wt} \%$ were investigated, so in this paper higher sepiolite contents are evaluated. An increase in the sepiolite content from $1.5 \mathrm{wt} \%$ to $3 \mathrm{wt} \%$ and 10 wt $\%$ increases the nucleation density, while the cell size decreases.

Some novel and original results were found in this research. Materials with highly anisotropic nanometric cells have been produced for the first time. In this paper, the solid precursors were filaments produced by extrusion (as explained in Chapter 3), to reinforce the anisotropic effect of the needle-like particles. The sepiolites align during the extrusion process, and as a result of this alignment, the nanocellular materials with sepiolites have anisotropic cells in the extrusion direction (and isotropic structures in the traverse plane). Anisotropy ratios from 1.38 to 2.15 are obtained with the different sepiolites and concentration of particles used in this work. In particular, it is observed that the higher the number of sepiolites, the higher the anisotropy ratio, so the highest anisotropy ratio is found in the nanocomposite with $10 \mathrm{wt} \%$ of particles.

The anisotropy found in these systems is not because of a preferable expansion during cell growth, because most of the expansion takes place in the traverse plane. Therefore, we propose that cell coalescence is responsible for the formation of anisotropic cells, because the sepiolites are weak points for cell wall rupture (as discussed in the previous section), and as they are aligned, cells coalesce in that direction, causing an overall anisotropic structure. The graphical abstract of this paper (see Figure 4.2) schematizes this mechanism. Besides, open cell measurements support this 
conclusion. The different anisotropy ratios found in the various nanocomposites can be correlated with the density of well-dispersed sepiolites. The possibility of creating highly anisotropic structures with this system gives the opportunity of producing materials with optimized properties in one specific direction.

In the following pages, the publication summarized in this section is included.

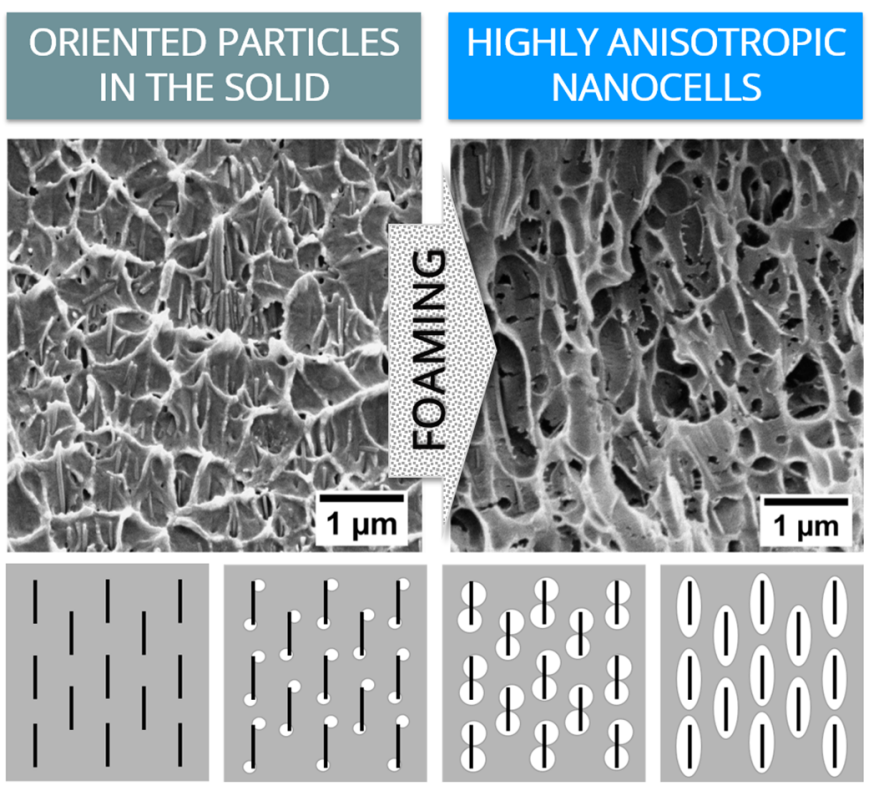

Figure 4.2. Graphical abstract of "Anisotropy in nanocellular polymers promoted by the addition of needle-like sepiolites". 


\title{
Anisotropy in nanocellular polymers promoted by the addition of needle-like sepiolites
}

\author{
Victoria Bernardo, Judith Martín-de León, Miguel Ángel Rodríguez-Pérez \\ Cellular Materials Laboratory (CellMat), Condensed Matter Physics Department, \\ University of Valladolid, Campus Miguel Delibes, Paseo de Belén n'7, 47011 Valladolid, Spain \\ Corresponding author: Victoria Bernardo (vbernardo@fmc.uva.es)+34983184035
}

\begin{abstract}
This work presents a new strategy to obtain nanocellular materials with high anisotropy ratios by means of the addition of needle-like nanoparticles. Nanocellular polymers are of great interest due to their outstanding properties, whereas anisotropic structures allow obtaining improved thermal and mechanical properties in certain directions. Nanocomposites based on poly (methyl methacrylate) (PMMA) with nanometric sepiolites are generated by extrusion. From the extruded filaments, cellular materials are produced using a two-step gas dissolution foaming method. The effect of adding various types and contents of sepiolites is investigated. As a result of the extrusion process, the needle-like sepiolites are aligned in the machine direction in the solid nanocomposites. Regarding the cellular materials, the addition of sepiolites allows obtaining anisotropic nanocellular polymers with cell sizes in the range from 150 to $420 \mathrm{~nm}$ and cell nucleation densities of $10^{13}-10^{14}$ nuclei $/ \mathrm{cm}^{3}$ and presenting anisotropy ratios ranging from 1.38 to 2.15 , the extrusion direction being the direction of the anisotropy. To explain the appearance of anisotropy, a mechanism based on cell coalescence is proposed and discussed. In addition, it is shown that it is possible to control the anisotropy ratio of the PMMA/sepiolite nanocellular polymers by changing the amount of well-dispersed sepiolites in the solid nanocomposites.
\end{abstract}

\section{KEYWORDS}

nanocellular polymer; PMMA; gas dissolution foaming; nanoparticles; anisotropy.

\section{INTRODUCTION}

Cellular polymers present a very interesting combination of properties that have promoted their widespread use in almost every industrial sector, such as the automotive and aeronautical industries, renewable energies, construction, biotechnology, cushioning and packaging [1]. The cellular polymer market is, therefore, a relevant economic sector, and it is estimated to reach $\$ 126.08$ billion by 2022 , at an annual growth rate of $5.86 \%$ [2]. Due to the importance of cellular polymers, there is much research focusing on producing these materials with enhanced and new properties. In particular, one of the most promising research areas in this field is the study of nanocellular polymers, that is, cellular polymers with cell sizes in the range of tens to hundreds of nanometers [3-5]. 
The reduction of the cell size to the nanometric range is known to have an important effect on the performance of cellular materials $[6,7]$. For instance, it has been proved that nanocellular polymers exhibit the so-called Knudsen effect, which results in a drastic decrease in the conductivity of the gas phase in these materials [8-12]. Also, it has been recently shown that nanocellular materials can be semi-transparent [13,14], among other effects [6,15-18]. Some of the most interesting properties of these materials, such as the very low thermal conductivity or the transparent behavior, depend strongly on the density of the cellular material and require low-density materials to reach their maximum potential. However, it is well-established that the reduction of the density in cellular polymers implies a significant reduction of the mechanical response, with normally a square dependency with density [19]. One strategy to avoid this loss of properties is the production of anisotropic cellular materials with improved mechanical performance in the direction in which cells are oriented. In addition to this, anisotropy can also be used to modify the thermal conductivity because both conduction through the solid phase and radiation strongly depend on anisotropy.

Anisotropic cellular structures are characterized by cells elongated in one direction. The cell anisotropy can be quantified through the anisotropy ratio, which is defined as the ratio between the maximum and the minimum length of the cell [20]. It has been extensively proved that the anisotropy of the cellular structure has significant effects on the mechanical properties of cellular polymers. Huber and Gibson [20] proposed a theoretical model to predict the increase in properties such as the Young's modulus, the plastic collapse or the fracture toughness, this model being validated using polyurethane (PU) cellular materials. Moreover, for example, Andersons et al. [21] showed that the stiffness of low-density closed-cell cellular polyisocyanurate (PIR) increased by a factor of 3 in the anisotropy direction for anisotropy ratios around 1.5. The thermal conductivity of cellular polymers is also a function of cells anisotropy; thermal conductivity is reduced when the cells are elongated in a perpendicular direction to that of the heat flow [22-24]. One the one hand, the conductivity due to the solid phase is reduced due to the higher solid phase tortuosity of the cellular structure in the heat flow direction (when cells are elongated in the perpendicular direction to that of the heat flow). In addition, the number of cell walls to scatter radiation is also increased in the heat flow direction increasing the extinction coefficient and reducing the thermal conductivity.

Cellular polymers usually present anisotropy ratios around 1.3 or smaller [20], so specific production routes must be designed to obtain materials with higher anisotropy ratios. Most of the strategies used up to date to produce anisotropic cellular structures rely on the selective growth of the cells in one direction. For instance, the freeze-casting technique, which is well-known to be useful to produce anisotropic porous structures [25], was used successfully to produce porous poly(vinyl alcohol)/sepiolite nanocomposites with anisotropy ratios of 1.34 by Killeen and coworkers [26]. The anisotropy observed was due to the growth of the ice crystal in a mold and increased by the addition of fibrous sepiolites. In the work of Laguna-Gutierrez et al. [27] cellular polypropylene (PP) with anisotropy ratios around 3 was obtained via the improve compression molding (ICM) technique, that forces cell growth in one direction. Mold shape was used by Arora and coworkers [28] to obtain polystyrene (PS) based anisotropic cellular materials. Oliveira-Salmazo et al. [29] used a different approach to control the anisotropy ratio (from 0.9 to 2.48) in natural rubber cellular samples by means of varying the dimensions of the solid precursors. In the work of 
Bernardo et al. [30], cell anisotropy was also promoted by the mold shape, but controlled by the process parameters. This process allowed obtaining cellular high-density polyethylene (HDPE) with very high anisotropy ratios, ranging from 2.95 to 3.75 .

In this work, a new strategy has been developed to obtain anisotropic structures in nanocellular materials. Instead of inducing the anisotropy via cellular growth, in this paper the anisotropy was obtained solely because of the addition of needle-like particles with a strong orientation in the solid material. Poly(methyl methacrylate) (PMMA) with nanometric sepiolites nanocomposites have been produced by extrusion and foamed using the gas dissolution foaming method. As a result of the alignment of the particles during the extrusion, the cells are elongated in the extrusion direction. The strategy used to achieve highly anisotropic cells is new, and also, as far as the authors know, this is the first time that anisotropic nanocellular polymers are produced. These materials would have the potential to be very efficient thermal insulators in the direction perpendicular to that of the orientation of the cell and present significantly better mechanical performance in the anisotropy direction.

\section{EXPERIMENTAL}

\subsection{Materials}

Poly(methyl methacrylate) (PMMA) V $825 \mathrm{~T}\left(\mathrm{M}_{\mathrm{n}}=43 \mathrm{~kg} / \mathrm{mol}, \mathrm{M}_{\mathrm{w}}=83 \mathrm{~kg} / \mathrm{mol}\right)$ was kindly supplied by ALTUGLAS $®$ International in the form of pellets with a density $(\rho)$ of $1.18 \mathrm{~g} / \mathrm{cm}^{3}$ and a glass transition temperature $\left(T_{g}\right)$ of $114.5^{\circ} \mathrm{C}$ as measured by DSC.

Sepiolites were kindly provided by Tolsa S.A (Spain). The chemical formulation of these particles corresponds to hydrated magnesium silicates (formula $\mathrm{Si}_{12} \mathrm{Mg}_{8} \mathrm{O}_{30}(\mathrm{OH})_{4}\left(\mathrm{OH}_{2}\right)_{4} \cdot 8 \mathrm{H}_{2} \mathrm{O}$ ). They present a needle-like morphology, with an average particle length ranging from $1 \mu \mathrm{m}$ to $2 \mu \mathrm{m}$ and a diameter between $20 \mathrm{~nm}$ and $30 \mathrm{~nm}$ [31,32]. The sepiolites used in this work have been modified with a quaternary ammonium salt (QAS). Two types of sepiolites with different grade of modification were used: S-LQAS, sepiolite modified with a low amount of quaternary ammonium salt (9.5 wt\% of QAS), and S-HQAS, sepiolite modified with a higher amount of the same salt (20.5 wt\%, more than twice the other sepiolite). The amount of QAS in each sepiolite was determined by performing thermogravimetric analysis (TGA) of the modified sepiolites, the raw salt and the same sepiolites without surface modification. The process to obtain and modify these particles is detailed elsewhere [33,34]. The raw quaternary ammonium salt used for the modification, QAS, was also used in this work as a filler to evaluate its effect on the cellular materials.

Medical grade carbon dioxide $\left(\mathrm{CO}_{2}\right)(99.9 \%$ purity) was used as the blowing agent for the gas dissolution foaming experiments.

\subsection{Solid blends production}

A twin-screw extruder model COLLIN TEACH-LINE ZK 25T, with L/D equal to 24 and screw diameter equal to $25 \mathrm{~mm}$ was used to produce the PMMA/sepiolite nanocomposites. The materials produced in this work are summarized in Table 1. PMMA was dried in a vacuum oven at $50{ }^{\circ} \mathrm{C}$ for at least 12 
hours before blending, whereas sepiolites were dried at higher temperature $\left(80^{\circ} \mathrm{C}\right)$ also under vacuum. The temperature profile set on the extruder was from $160^{\circ} \mathrm{C}$ to $200{ }^{\circ} \mathrm{C}$ in the die, increasing at intervals equal to $10^{\circ} \mathrm{C}$. The screw speed was equal to $40 \mathrm{rpm}$. The produced blends were cooled in a water bath and pelletized. After drying the pellets, each blend was extruded again using the same processing conditions to have a homogeneous dispersion of the particles. During the second extrusion, the extruded filament (with a thickness of around 3-4 $\mathrm{mm}$ ) was not pelletized but set aside for the foaming experiments. Cylindrical samples of $30 \mathrm{~mm}$ in length and 3-4 $\mathrm{mm}$ in diameter were cut from the extruded filaments for the foaming experiments.

Note that the pure PMMA was processed under the same conditions for comparison purposes. Also, a material with the quaternary ammonium salt (but without sepiolites) was produced to analyze its effect on the foaming behavior. Rheology measurements, MFI and DSC were used to validate that the extrusion process did not affect significantly the morphology and properties of PMMA [35-37] (see Supplementary Information for these results).

Table 1. The formulations used in this work.

\begin{tabular}{ccc}
\hline Material ID & Filler type & $\begin{array}{c}\text { Filler content } \\
(\text { wt } \%)\end{array}$ \\
\hline PMMA & None & 0 \\
1.5\%-QAS & Quaternary ammonium salt (QAS) & 1.5 \\
$1.5 \%-$ S-LQAS & Sepiolite modified with a low amount of QAS (S-LQAS) & 1.5 \\
1.5\%-S-HQAS & Sepiolite modified with a high amount of QAS (S-HQAS) & 1.5 \\
3\%-S-HQAS & Sepiolite modified with a high amount of QAS (S-HQAS) & 3 \\
10\%-S-HQAS & Sepiolite modified with a high amount of QAS (S-HQAS) & 10 \\
\hline
\end{tabular}

\subsection{Gas Dissolution Foaming Experiments}

Foaming experiments were performed using a high-pressure vessel (model PARR 4681) provided by Parr Instrument Company with a capacity of 1 liter, able to operate at maximum temperature and pressure of $350{ }^{\circ} \mathrm{C}$ and $41 \mathrm{MPa}$, respectively. Pressure is controlled with a pressure pump controller (model SFT-10) provided by Supercritical Fluid Technologies Inc. A clamp heater of 1200 W and a CAL 3300 temperature controller allow the control of the temperature of the vessel. Foaming experiments were conducted by a two-step foaming process [38]. First, samples were put into the pressure vessel at a constant $\mathrm{CO}_{2}$ pressure of $10 \mathrm{MPa}$ and at a temperature of $25^{\circ} \mathrm{C}$ for the saturation stage during $20 \mathrm{~h}$, enough to achieve saturation of $\mathrm{CO}_{2}$ in the PMMA samples [39]. Then, the pressure was abruptly released at a pressure drop rate of $15 \mathrm{MPa} / \mathrm{s}$ at the first moments of the pressure drop. Finally, the samples were removed from the pressure vessel and immediately after (around 2.5 minutes) introduced into a thermal bath with water at $80{ }^{\circ} \mathrm{C}$ for 1 minute for the foaming step. 


\subsection{Characterization}

\subsubsection{Density}

The density of the solid materials was measured with a gas pycnometer (Mod. AccuPyc II 1340, Micromeritics). The density of the cellular materials was determined with the water-displacement method based on the Archimedes' principle using a density determination kit for an AT261 MettlerToledo balance. The solid skin of the cylindrical foamed samples was removed with a polisher (model LaboPOI2-LaboForce3, Struers) by polishing off more than $500 \mu \mathrm{m}$ of the surface before measuring their densities. Relative density $\left(\rho_{r}\right)$ is defined as the ratio between the cellular material density $(\rho)$ and the density of the solid materials with the same composition $\left(\rho_{s}\right)$.

\subsubsection{Morphology of the solids and cellular structure}

Samples were cooled down in liquid nitrogen and then fractured for microscopic visualization and coated with gold using a sputter coater (model SCD 005, Balzers Union). The morphology of the samples was analyzed using an ESEM Scanning Electron Microscope (QUANTA 200 FEG). Both solid and cellular materials were fractured in two perpendicular directions to visualize two planes: the plane parallel to the extrusion direction (MD, machine direction) and the plane perpendicular to the extrusion line (TD, traverse direction) (Figure 1).

a)

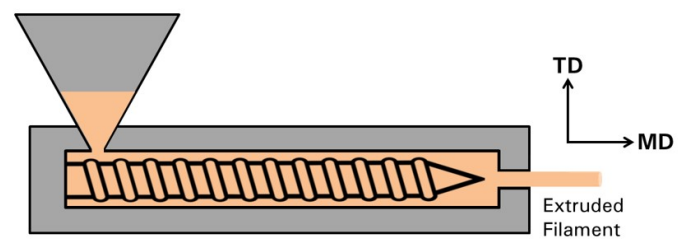

b)

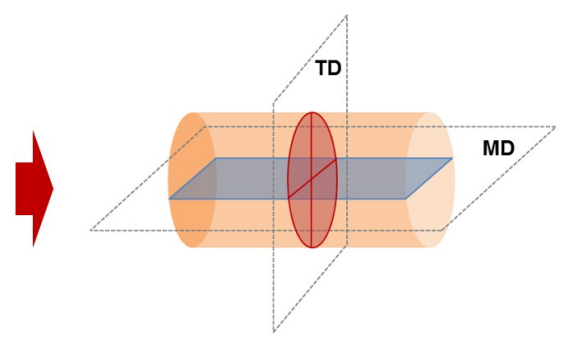

Figure 1. a) Scheme of the extrusion process and b) planes analyzed to characterize the solid materials and the foamed samples.

For the solid nanocomposites, the density of nanoparticles was determined by counting the number of particles $\left(n_{p}\right)$ in a given area $\left(A_{p}\right)$. Taking into account that the surfaces analysed come from a fracture, we assume that we are only observing half of the particles that were in this area $A_{p}$ (the other half would be in the other fracture surface). Then, the density of nanoparticles $\left(N_{p}\right)$ is calculated according to equation (1), where the 2 -factor counts for the miscount of particles in the analysis:

$$
N_{p}=\left[\frac{2 n_{p}}{A_{p}}\right]^{3 / 2}
$$

The cellular materials of this work with sepiolites present a bimodal structure with micrometric and nanometric cells. In a bimodal cellular structure, the micrometric cells, though smaller in number, typically occupy a significant volume of the sample. Then, to quantify the observed bimodality, the relative volume occupied by the population of nanometric cells, $V_{\text {nano, }}$, is measured [39]: 


$$
V_{\text {nano }}=100 \frac{A_{t}-A_{m}}{A_{t}}
$$

where $A_{m}$ is the observed area occupied by the micrometric cells (cell sizes higher than 1 micron) in the SEM images, and $A_{t}$ the total area of the image. The resulting two-dimensional area ratio is equivalent to the three-dimensional volume ratio given that the surfaces analysed were uniform and random, according to Delesse principle in stereology $[40,41]$. In the microcellular materials without a nanocellular structure (that is, those without sepiolites), this parameter was not calculated and considered as zero.

A software based on ImageJ/FIJI was used to characterize the cellular structure of the foamed samples [42]. Cell density $\left(N_{v}\right)$ and cell nucleation density $\left(N_{0}\right)$ were determined from the SEM images using Kumar's theoretical approximation [43] according to Equations (3) and (4), where $n$ is the number of cells in the image and $A$ is the area of the image. For the determination of these parameters all the cells in a given area were taken into consideration, both micro and nanocellular, so the cell density was measured in the same way for the systems with and without sepiolites.

$$
\begin{gathered}
N_{v}=\left[\frac{n}{A}\right]^{3 / 2} \\
N_{0}=\frac{N_{v}}{\rho_{r}}
\end{gathered}
$$

The software measures the dimensions of each cell in four directions and then it calculates the cell size of each cell by averaing the values obtained in the four directions. Once all the cells are measured, the software provides the distribution of the cell size, from which the average cell size $(\phi)$ of the sample and the standard deviation of the cell size distribution, $S D$ are calculated. Note that the 2D cell size values were always corrected to obtain the correct 3D value by multiplying by 1.273 [42]. For the microcellular materials (without sepiolites), all the cells were considered to calculate the average cell size $\phi$ and the $S D$. For the materials with sepiolites, in which there is a bimodal structure, only the nanometric cells were count for determining these parameters $(\phi, S D$ and $S D / \phi$ ). The motivation underlying this analysis is that the majority of cells are nanometric and the fraction occupied by the micrometric cells is usually small (a 10\% in volume for some materials). In addition, this work is focused on characterazing the nanocellular structure. In a previous work [39] we already characterized in detail the two populations of cells in PMMA/sepiolite systems. The cell sizes of all the materials were determined in both the MD and TD planes.

In addition, anisotropic nanocellular structures were observed. To quantify the orientation of the cells, the anisotropy ratio was measured. Once again, for the microcellular materials, all the cells were considered in the analysis, whereas for the bimodal systems with micro and nanometric cells only the second ones were taken into account. The anisotropy ratio was determined in the two planes explained in Figure 1.b: in the MD plane, $A R_{M D}$ was measured as the ratio between the cell size observed in the extrusion direction to the average cell size measured a direction perpendicular to the extrusion direction (Equation (5)), whereas in the TD plane, $A R_{T D}$ was calculated as the ratio between two perpendicular cell sizes (Equation (6)) (note that because of the symmetry of the cylindrical filaments, there are not well-defined directions in the TD plane). The software provides the distribution of anisotropy ratios, from which the average anisotropy ratios and the standard deviation of the distribution can be calculated. 


$$
\begin{aligned}
& A R_{M D}=\frac{\phi_{M D}}{\phi_{T D}} \\
& A R_{T D}=\frac{\phi_{T D_{1}}}{\phi_{T D_{2}}}
\end{aligned}
$$

\subsubsection{Open Cell content}

Open cell content (OC) of the cellular materials was measured according to the ASTM D6226-10 standard using a gas pycnometer (Mod. AccuPyc II 1340, Micromeritics). The equation to calculate the open cell content is:

$$
\text { OC }(\%)=100 \frac{V-V_{p}-V_{s}}{V\left(1-\rho_{r}\right)}
$$

where $V$ is the geometric volume of the sample, $V_{p}$ is the volume measured by the pycnometer and $V_{s}$ is a penalty volume to account for the exposed cells at the surface of the sample. The geometric volume was determined from the cellular material density (measured by the water-displacement method) and its mass (measured with an AT261 Mettler-Toledo balance). $V_{p}$ was determined by performing a pressure scan (from $0.02 \mathrm{MPa}$ to $0.13 \mathrm{MPa}$ ) in the gas pycnometer and measuring the pycnometric volume for each pressure. It was assumed that no more gas is able to enter the interconnected open cells when the measured volume remains constant for an increase in pressure. $V_{p}$ was calculated as the average of these last measured constant volume values. Note that, as $V_{s}$ is proportional to the cell size, this value becomes negligible for micro and nanocellular materials.

\section{RESULTS AND DISCUSSION}

\subsection{Orientation of the sepiolites in the extruded filaments}

In a previous work [39] we proved that the addition of sepiolites to a PMMA matrix lead to both micron-sized aggregates and well-dispersed individual sepiolites. In the present work, micrometric aggregates were also detected in the solids containing sepiolites, but it is not possible to detect in the same micrograph both individual particles and aggregates because of their very different scale (nanometric vs. micrometric). For the purposes of this work, we will focus our attention on the welldispersed sepiolites that are, as it will be explained later, the final reason for having an anisotropic cellular structure. General SEM images of the nanocomposites and particle aggregates can be found in the Supplementary Information.

Figure 2 shows high magnification images of the morphology of the solid materials produced in this work in which the individual sepiolites can be detected. The images in the first row correspond to the surface perpendicular to the extrusion direction (TD plane), whereas the second row presents the SEM micrographs taken in the extrusion plane (MD). The well-dispersed individual particles can be observed in the SEM micrographs, and moreover, significant differences are found between the two planes analyzed. In the TD plane (Figure 2.a to 2.d), only the upper extreme of the particles can be seen in the images. In contrast, in the MD plane (Figure 2.e to 2.h) the complete needle-like sepiolites are observed, showing that the particles are aligned in the extrusion direction. Then, from 
the SEM qualitative analysis we conclude that as a result of the extrusion process, the sepiolites are mainly placed along the machine direction.

Table 2 collects the quantitative analysis of the density of sepiolites in the two planes considered. Note that the particle density is smaller in the MD plane due to the needle-like shape of the sepiolites. Particle densities exceeding $10^{13}$ particle $/ \mathrm{cm}^{3}$ are measured. Regarding the effect of the different types of particles, we observe that the material 1.5\%-S-LQAS shows a smaller particle density that $1.5 \%-\mathrm{S}-\mathrm{HQAS}$, that is, a higher amount of quaternary ammonium salt improves the dispersion of the particles. For the systems with higher contents of the sepiolite S-HQAS, a greater number of particles is observed when the content increases. In particular, when the content is as high as $10 \mathrm{wt} \%$ (Figure 2.h) a high density of particles is detected (see Supplementary Information for more images of this nanocomposite).

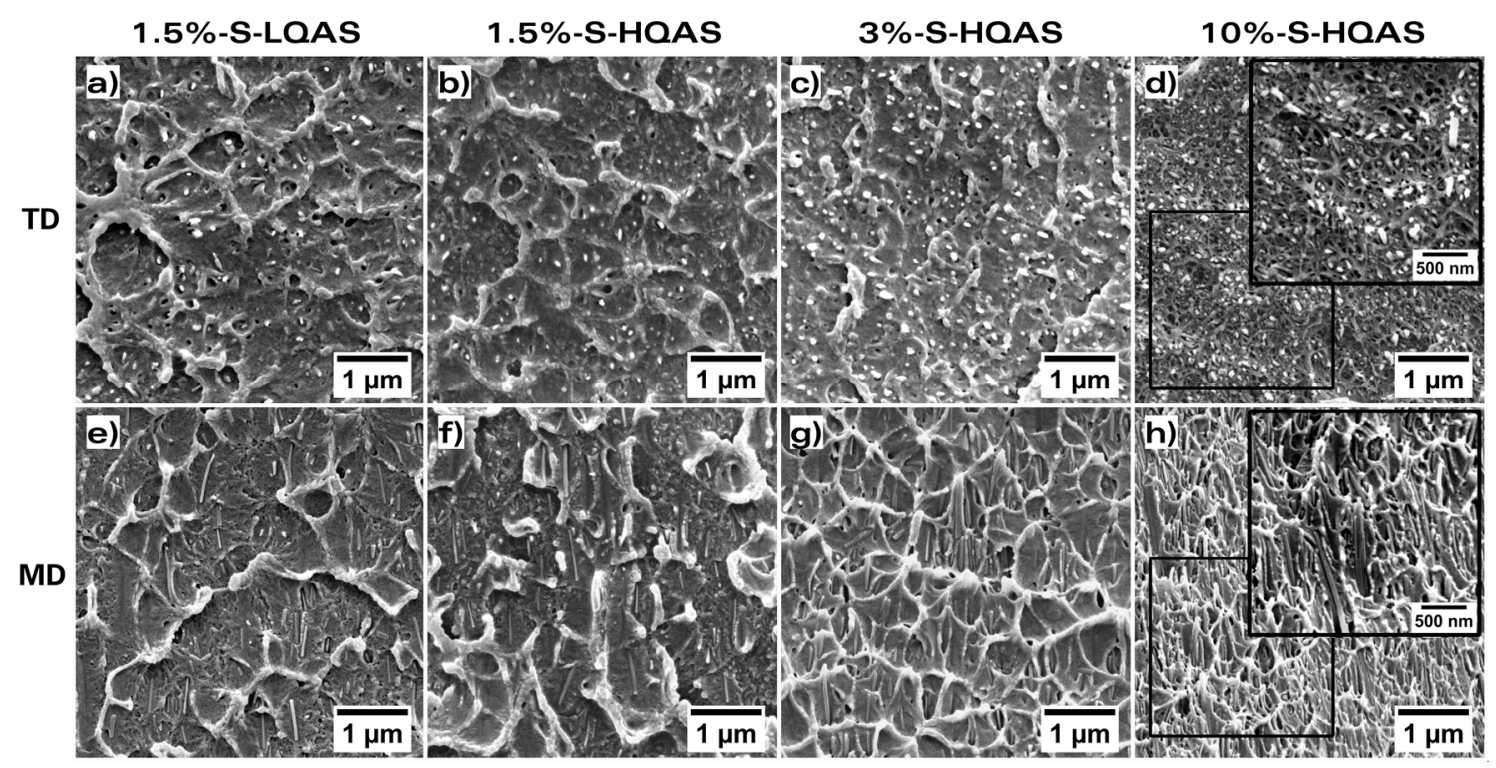

Figure 2. SEM micrographs of the solid PMMA/sepiolite nanocomposites: a-e) 1.5\%-S-LQAS, b-f) $1.5 \%-S-H Q A S, c-g) 3 \%-S-H Q A S$ and d-h) 10\%-S-HQAS. The images in the first row show the TD plane and those of the second row, the MD plane.

Table 2. Density of sepiolites in the solid PMMA/sepiolite nanocomposites.

\begin{tabular}{ccc}
\hline Material & $\begin{array}{c}\text { Particle Density TD } \\
(\text { particle/cm })\end{array}$ & $\begin{array}{c}\text { Particle Density MD } \\
(\text { particle/cm }\end{array}$ \\
\hline $1.5 \%$-S-LQAS & $(1.9 \pm 0.5) \cdot 10^{13}$ & $(1.1 \pm 0.1) \cdot 10^{13}$ \\
1.5\%-S-HQAS & $(2.4 \pm 0.3) \cdot 10^{13}$ & $(1.3 \pm 0.1) \cdot 10^{13}$ \\
3\%-S-HQAS & $(1.0 \pm 0.2) \cdot 10^{14}$ & $(1.8 \pm 0.3) \cdot 10^{13}$ \\
10\%-S-HQAS & $(5.0 \pm 2.0) \cdot 10^{14}$ & $(9.7 \pm 0.9) \cdot 10^{13}$ \\
\hline
\end{tabular}

\subsection{Effect of the modification of the sepiolites}

Table 3 summarizes the relative density of the cellular materials produced with the pure PMMA and the composites with $1.5 \mathrm{wt} \%$ of different filler types. It is observed that, with the foaming conditions used in this work, the four materials present very similar densities. Then, the addition of a $1.5 \mathrm{wt} \%$ of the QAS or the sepiolites S-LQAS and S-HQAS does not affect the ability to expand of the PMMA. 
Table 3. Relative density, volume fraction of nanometric cells and cell nucleation density of the cellular materials produced with a $1.5 \mathrm{wt} \%$ of different filler types.

\begin{tabular}{ccccc}
\hline Material & $\begin{array}{c}\text { Relative } \\
\text { Density }\end{array}$ & $\boldsymbol{V}_{\text {nano }}(\%)$ & $\begin{array}{c}\text { Cell Nucleation Density TD } \\
(\text { nuclei/cm })^{3}\end{array}$ & $\begin{array}{c}\text { Cell Nucleation Density } \\
\text { MD (nuclei/cm }\end{array}$ \\
\hline PMMA & $0.30 \pm 0.02$ & 0 & $(4.6 \pm 0.5) \cdot 10^{11}$ & $(5.5 \pm 0.5) \cdot 10^{11}$ \\
$1.5 \%-Q A S$ & $0.28 \pm 0.01$ & 0 & $(4.2 \pm 0.4) \cdot 10^{12}$ & $(4.8 \pm 0.5) \cdot 10^{12}$ \\
$1.5 \%$-S-LQAS & $0.28 \pm 0.01$ & 79 & $(4.7 \pm 0.9) \cdot 10^{13}$ & $(2.9 \pm 0.3) \cdot 10^{13}$ \\
$1.5 \%$-S-HQAS & $0.27 \pm 0.01$ & 88 & $(9.3 \pm 0.1) \cdot 10^{13}$ & $(4.5 \pm 0.1) \cdot 10^{13}$ \\
\hline
\end{tabular}

On the other hand, significant variations in the cellular structures are detected in the SEM micrographs (Figure 3). The pure polymer shows a microcellular structure with cell sizes of few microns. Although the cell size distribution is heterogeneous, similar structures are found in both the TD plane (Figure 3.a) and the MD plane (Figure 3.e). After the addition of the quaternary ammonium salt, the cellular structure varies appreciably (Figure 3.b and Figure 3.f). A bimodal structure appears, with the main population of micrometric cells (cells around 3 microns) and submicrometric cells (slightly smaller than 1 micron) among them. Then, the addition of the QAS has a strong effect on the cellular structure of PMMA.

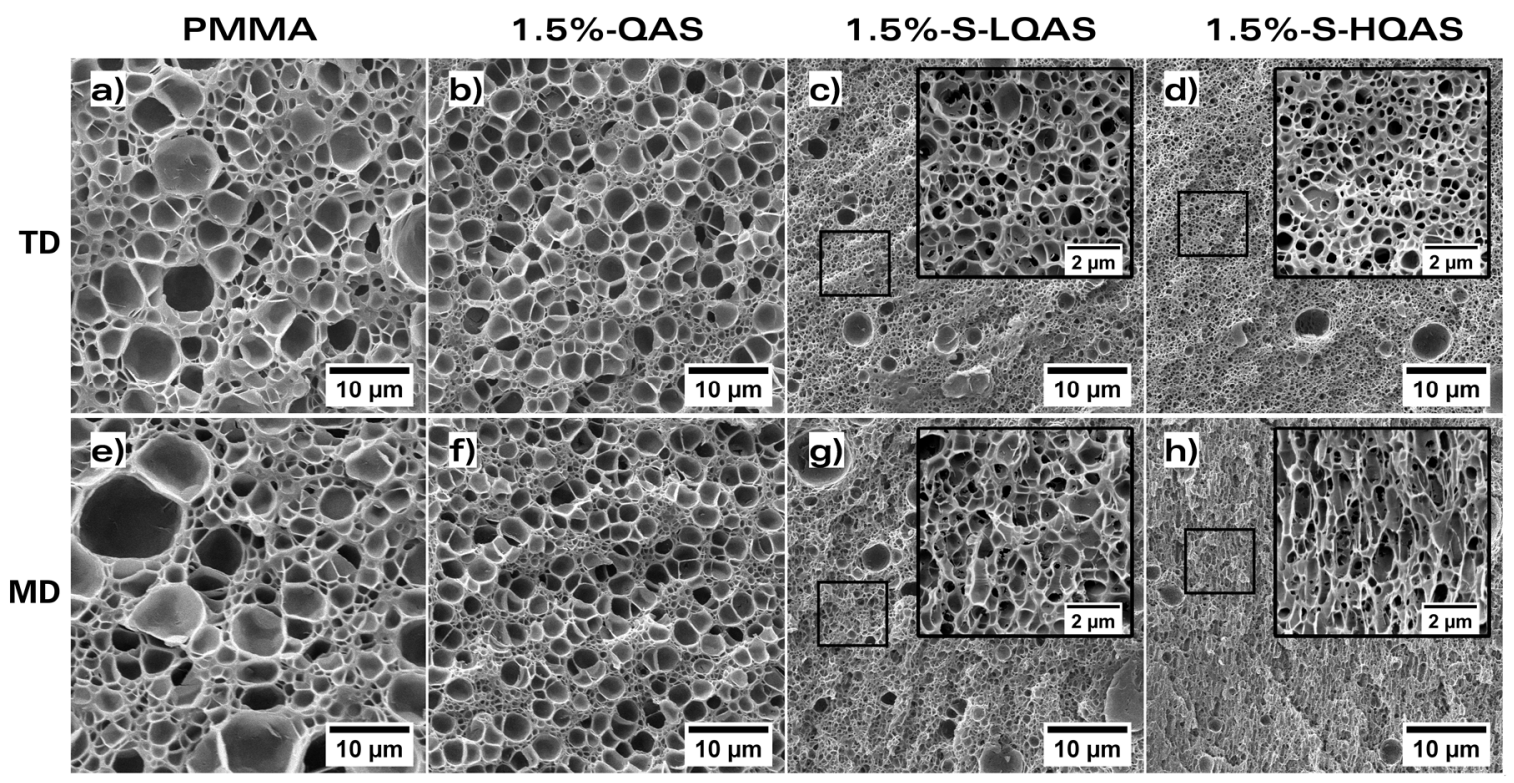

Figure 3. SEM micrographs of the cellular materials produced with a $1.5 \mathrm{wt} \%$ of different filler types: a-e) PMMA, b-f) 1.5\%-QAS, c-g) 1.5\%-S-LQAS, and d-h) 1.5\%-S-HQAS. The images in the first row show the TD plane and those of the second row, the MD plane.

To analyze this effect in detail, the cell size distributions of the PMMA and the material 1.5\%-QAS are displayed in Figure 4. Figure 4.a shows that the pure polymer presents a wide but monomodal distribution of the cell size, with an average cell size of around 1.8 microns both in the TD and the MD plane. On the other hand, in Figure 4.b the bimodal structure seen in the SEM images can be appreciated, with a sharp peak around 0.5-1 microns and wide peak around 3 microns. As a consequence of the higher number of small cells, the average cell size is below the micron. Once again, the TD and MD planes show very similar distributions. Therefore, it can be concluded that 
the addition of a quaternary ammonium salt induces the appearance of sub-micrometric cells in the PMMA.

a)

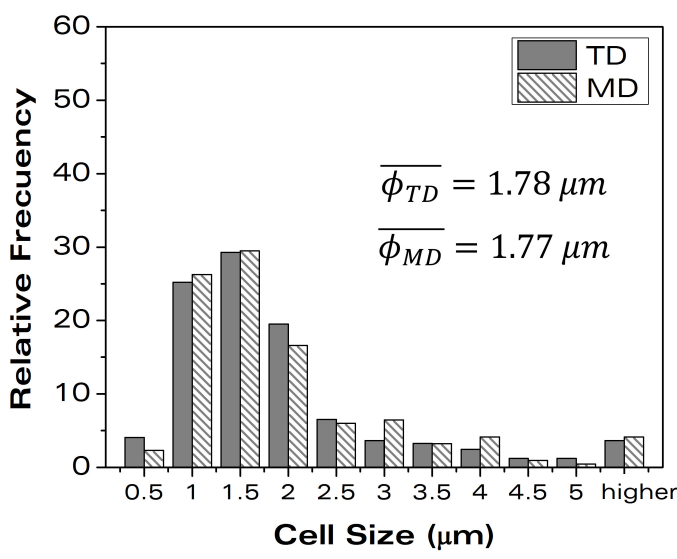

b)

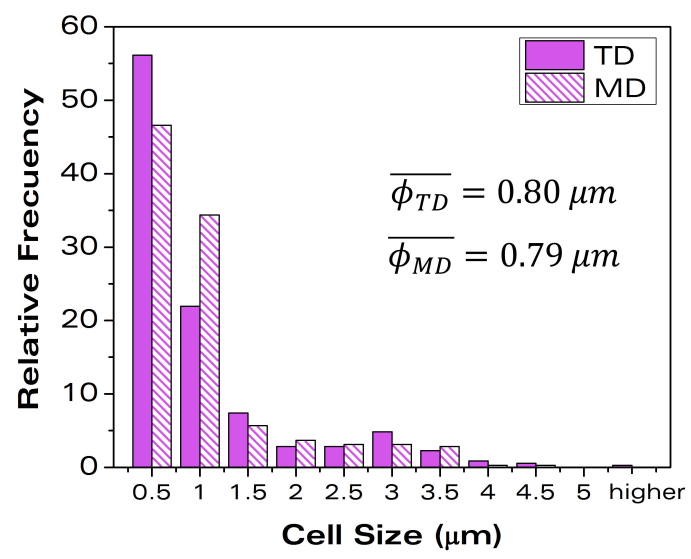

Figure 4. Cell size distributions and average cell sizes measured in the planes TD and MD of a) PMMA and b) $1.5 \%$-QAS.

On the other hand, the addition of sepiolites modified with this salt causes a completely different structure. Figure 3.c-g and Figure 3.d-h show the micrographs of the materials produced with SLQAS and S-HQAS, respectively. In this case, a bimodal structure is also observed, but with a small fraction of micrometric cells and a predominant population of nanometric cells, as seen in the zoomed images of Figure 3.c-g and Figure 3.d-h. We already reported [39] that the addition of sepiolites modified with a quaternary ammonium salt act as a nucleating agent in the gas dissolution foaming of PMMA. It was suggested that the microcellular pores appear due to micronsized sepiolite aggregates, whereas the well-dispersed sepiolites (as shown in Figure 2) account for the presence of nanocellular pores. For these materials, the volume fraction occupied by the nanometric cells is high: around $80 \%$ for $1.5 \%$-S-LQAS and almost $90 \%$ for $1.5 \%$-S-HQAS (Table 3). If we assume the micrometric pores are due to particle aggregates, we can conclude that the sepiolite S-LQAS was poorer dispersed than the sepiolite S-HQAS. This is agreement with the analysis of the solid nanocomposites (Table 2). Then, it is plausible to believe that a higher content of the salt (a 20.5 wt\% in S-HQAS versus a 9.5 wt\% in S-LQAS) enhances the dispersion of the sepiolites.

The cell nucleation density of the four materials of this section is included in Table 3, both in the TD and the MD planes. The addition of QAS increases the cell nucleation density from $5 \cdot 10^{11}$ nuclei $/ \mathrm{cm}^{3}$ to $4 \cdot 10^{12}$ nuclei/ $\mathrm{cm}^{3}$, that is, almost one order of magnitude. Regarding the effect of the sepiolites, they increase the nucleation even more, up to $4.7 \cdot 10^{13}$ nuclei/cm ${ }^{3}$ for $1.5 \%$-S-LQAS and almost to $10^{14}$ nuclei/cm ${ }^{3}$ for $1.5 \%$-S-HQAS in the TD plane. The sepiolite with the highest amount of QAS has the strongest nucleating effect according to the results of Table 3, also in agreement with the observation of Figure 3. This result can also be attributed to a worse dispersion of the sepiolites in the nanocomposite 1.5\%-S-LQAS. For the same total amount of particles, more particles are aggregated in the material with the sepiolite S-LQAS, resulting in less well-dispersed sepiolites and thus a lower nucleating effect. The cell nucleation densities reported in Table 3 are of the same order of magnitude of the particle densities estimated in Table 2, supporting that the well dispersed particles are acting as nucleating sites. Regarding the differences between the two planes, it is observed that for the blends 1.5\%-S-LQAS and 1.5\%-S-HQAS, the nucleation in the TD 
plane is higher than that of the MD plane. This is because of the different particle densities in both planes due to the needle-like shape of the sepiolites.

Regarding the effect of the surface modification of the sepiolites in the cell size, Figure 5 shows the cell size distribution in the nanocellular region for the materials with a $1.5 \mathrm{wt} \%$ of S-LQAS and SHQAS. It is observed that as a consequence of the higher cell nucleation density previously reported, 1.5\%-S-HQAS presents smaller cell sizes than 1.5\%-S-LQAS in the TD plane, 320 versus $390 \mathrm{~nm}$. Moreover, the cell sizes in the MD plane are higher than in the TD plane, especially for the system with S-HQAS. This result implies some anisotropy in the structure that was not detected in the materials without sepiolites.

a)

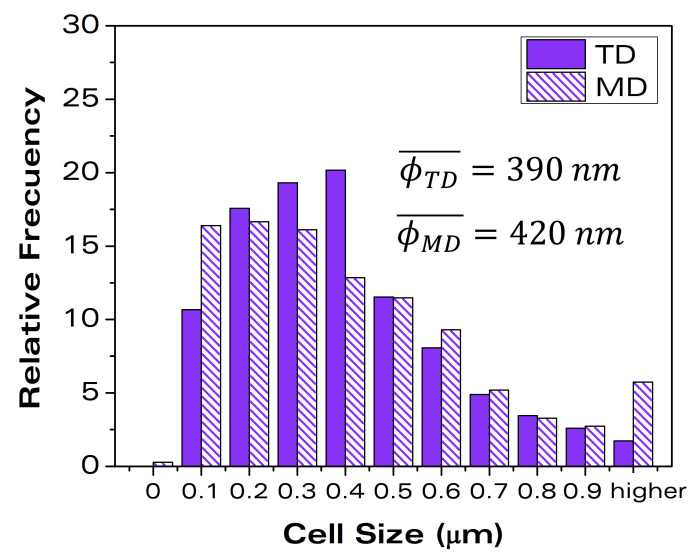

b)

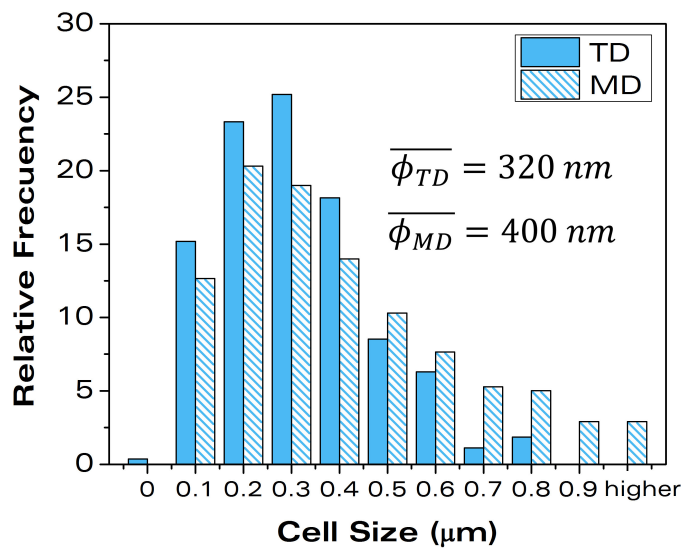

Figure 5. Cell size distributions and average cell sizes measured in the nanocellular region of the planes TD and MD of a) 1.5\%-S-LQAS and b) 1.5\%-S-HQAS.

In fact, the newest and most interesting finding of this work is detected when the structures in the TD plane are compared with those of the MD plane in the materials with sepiolites. In the plane perpendicular to the extrusion direction, spherically shaped cells are detected. Meanwhile, in the MD plane, in which the sepiolites were aligned in the extrusion direction in the solids (second row of Figure 2), cells are elongated along the same direction (second row of Figure 3). As a result, anisotropic nanocellular materials are obtained. In contrast, the micrometric cells in these bimodal materials (low magnification images in Figure 3) are isotropic. Then, the anisotropy is related to the presence of the well-dispersed sepiolites. Figure 6 shows the anisotropy ratio of the materials analyzed in this section. While the pure PMMA and the material with QAS show anisotropy ratios close to one in both planes, nanocomposites with sepiolites present anisotropy ratios greater than one in the MD direction. In particular, the material 1.5\%-S-HQAS presents an average anisotropy ratio as high as 1.88. The mechanisms underlying this anisotropy will be discussed in section 3.4. 


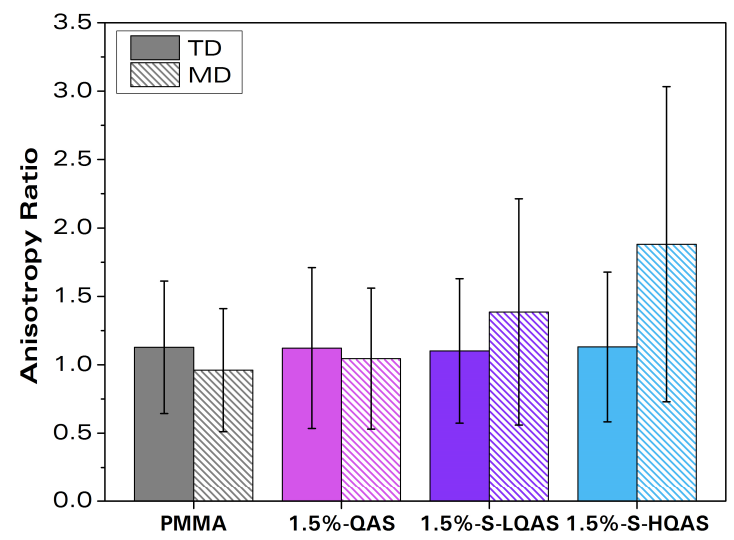

Figure 6. Anisotropy ratio of the cellular materials produced with a $1.5 \mathrm{wt} \%$ of different filler types measured in the planes TD and MD.

\subsection{Effect of the content of sepiolites}

Table 4 summarizes the relative density of the materials produced with higher contents of the sepiolite S-HQAS. It is observed than when the content is as high as $10 \mathrm{wt} \%$, the expansion capability of the PMMA is reduced and the density of the cellular material is increased. The higher densities measured for the material 10\%-S-HQAS could be due to the higher viscosity of the polymer at high particle loads, and also to a decrease of the amount of gas uptake (it was already proven than sepiolites did not absorb $\mathrm{CO}_{2}$ during the gas dissolution foaming process [39]).

Table 4. Relative density, volume fraction of nanometric cells and cell nucleation density of the cellular materials produced with different contents of S-HQAS.

\begin{tabular}{|c|c|c|c|c|}
\hline Material & $\begin{array}{l}\text { Relative } \\
\text { Density }\end{array}$ & $V_{\text {nano }}(\%)$ & $\begin{array}{c}\text { Cell Nucleation Density TD } \\
\left(\text { nuclei } / \mathrm{cm}^{3}\right)\end{array}$ & $\begin{array}{c}\text { Cell Nucleation Density } \\
\text { MD (nuclei/cm }{ }^{3} \text { ) }\end{array}$ \\
\hline $3 \%-S-H Q A S$ & $0.29 \pm 0.01$ & 87 & $(1.1 \pm 0.5) \cdot 10^{14}$ & $(4.5 \pm 0.1) \cdot 10^{13}$ \\
\hline $10 \%-S-H Q A S$ & $0.40 \pm 0.02$ & 66 & $(1.4 \pm 0.8) \cdot 10^{14}$ & $(4.6 \pm 0.2) \cdot 10^{13}$ \\
\hline
\end{tabular}

Figure 7 shows the cellular structure of the materials 3\%-S-HQAS and 10\%-S-HQAS in TD plane (first row) and the MD plane (second row). The sample with $1.5 \mathrm{wt} \%$ of S-HQAS has also been included in Figure 7 for the sake of comparison. Once again, these materials with sepiolites show a bimodal structure due to the sepiolite aggregates. Table 4 shows that whereas the nanocellular volume fraction in the material with $3 \mathrm{wt} \%$ of S-HQAS is similar to that obtained for a $1.5 \mathrm{wt} \%$ of S-HQAS (Table 3), the material with a $10 \mathrm{wt} \%$ of particles presents a smaller fraction of nanometric cells. In addition, micrometric cells are higher in this system. We conclude that the addition of a $10 \mathrm{wt} \%$ of sepiolites leads to a greater aggregation of the particles, so there are more and bigger aggregates, causing more and bigger micrometric cells (see SEM images of the nanocomposites in the Supplementary Information). The micrometric cells are isotropic in both planes (Figure 7). Regarding the nanocellular structure, it is observed that an increase in the sepiolite content leads to a higher cell nucleation density in both planes, the nucleation density being higher in the TD plane (Table 4). This is because there are more well-dispersed nanoparticles as sepiolite content increases (see Table 2). As a consequence of the higher nucleation density, the cell size in the nanocellular region 
decreases as particle content increases (Figure 8.a). Cell sizes as low as $150 \mathrm{~nm}$ are obtained in the TD plane for the material with a $10 \mathrm{wt} \%$ of particles.

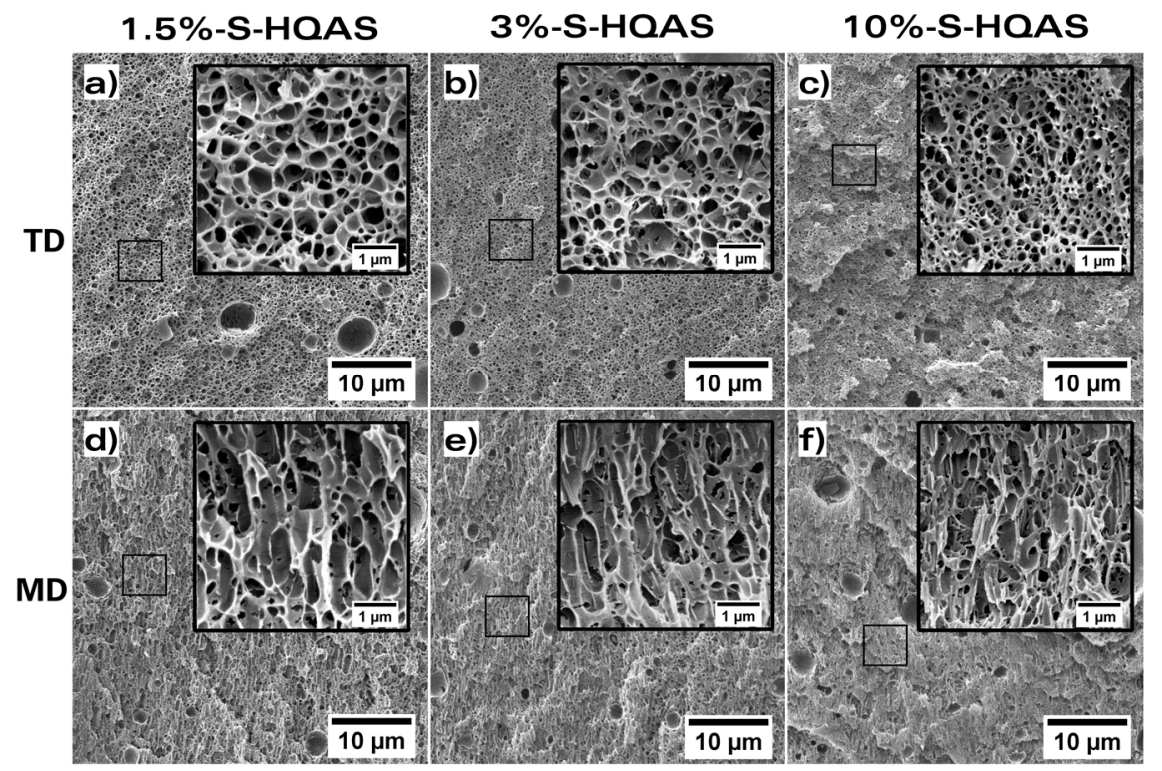

Figure 7. SEM micrographs of the cellular materials produced with various contents of S-HQAS: ad) 1.5\%-S-HQAS, b-e) 3\%-S-HQAS, c-f) 10\%-S-HQAS. The images in the first row show the TD plane and those of the second row, the MD plane.

a)

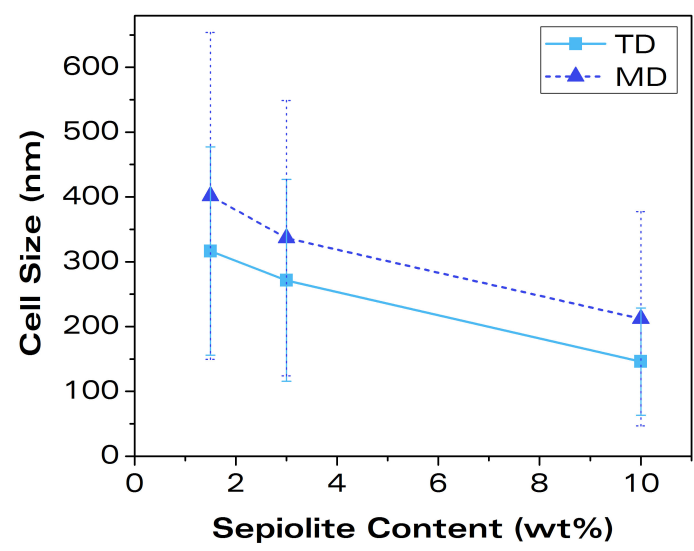

b)

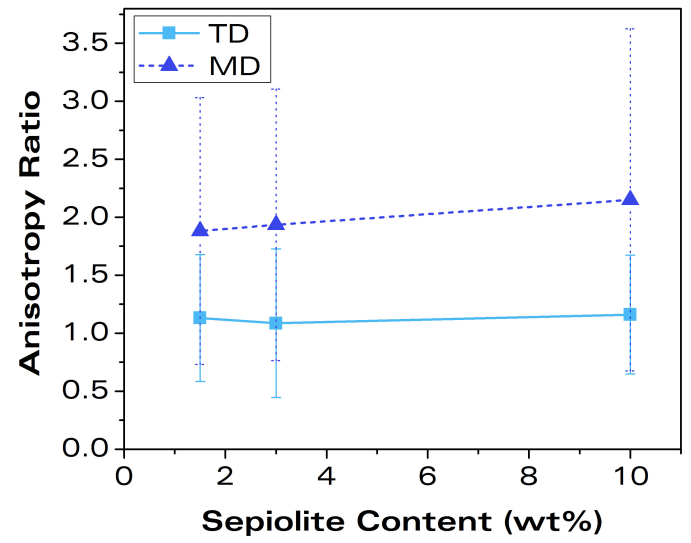

Figure 8. a) Average cell size and b) anisotropy ratio measured in the nanocellular region of the planes TD and MD of the cellular materials produced with various contents of S-HQAS.

As already seen in the materials with sepiolites of the previous section, the nanocellular structure is isotropic in the TD plane and anisotropic in the MD direction (Figure 7 and Figure 8). This leads to higher average cell size in the MD plane compared to that measured in the TD plane (Figure 8.a). It is observed that as particle content increases, the anisotropy ratio slightly increases, from 1.88 at a particle content of $1.5 \mathrm{wt} \%$ to 2.15 when the sepiolite content is $10 \mathrm{wt} \%$. In addition, the width of the distribution of the anisotropy of the cells (given by the error bar in Figure 8.b) also increases as particle content does, meaning that more cells are anisotropic for higher particle contents. The anisotropy ratio distributions of these three materials are shown in Figure 9, supporting these results. As particle content increases, the distribution of anisotropy of the cells becomes wider. The 
mechanisms underlying the anisotropy appearance and its dependence on the type of sepiolite and its content will be discussed in the next section.

a)

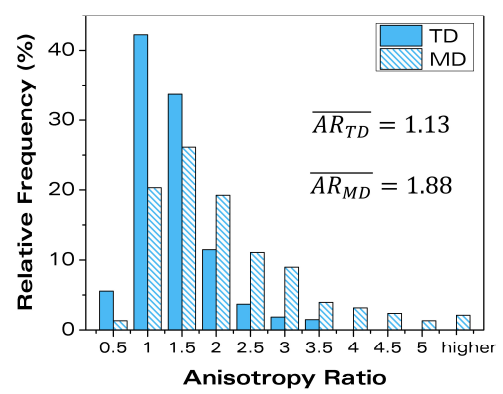

b)

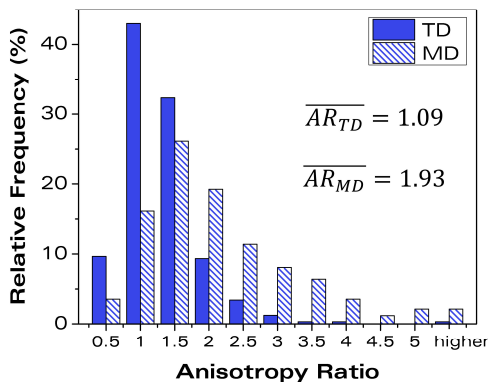

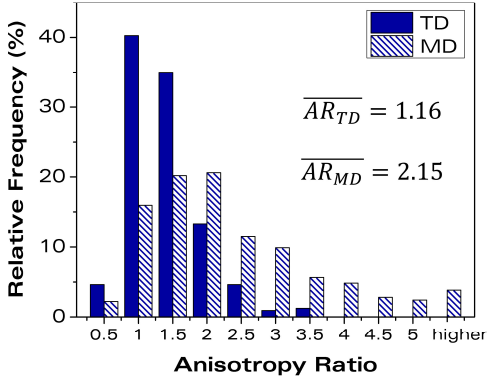

Figure 9. Anisotropy ratio distributions and average anisotropy measured in the nanocellular region of the planes TD and MD of the cellular materials produced with various contents of SHQAS: a) 1.5\%-S-HQAS, b) 3\%-S-HQAS and c) 10\%-S-HQAS.

\subsection{Discussion: mechanisms of anisotropy formation}

Several works [27-30,44] claim that anisotropic cellular structures can be a result of a preferable growth of the cells in a certain direction. To evaluate if this was the reason underneath the anisotropy observed in the materials of this work, the expansion ratio in different directions of the cellular materials were measured. The expansion ratio in the TD direction, $E R_{T D}$, was calculated as the ratio between the final diameter of the cellular material and the initial diameter of the solid precursor, whereas the expansion ratio in the MD plane, $E R_{M D}$, was determined as the ratio between the final and the initial lengths. Table 5 summarizes the expansion ratios of all the materials produced in this work in both directions. For all the materials, most of the expansion occurs in the TD plane, that is, in the direction perpendicular to the extrusion direction and opposite to the anisotropy observed. This effect occurs for all materials regardless of the filler type and content, so it is an effect related to the morphology of the polymer matrix. During the extrusion process the polymer is stretched in the extrusion direction, and thus internal tensions (molecular orientation in the extrusion direction) must remain within the solid samples. Then, when the polymer has enough mobility during the foaming process, the tendency is to relax those tensions by growing in the radial direction. The results of Table 5 indicate that the growth direction is not the mechanism of anisotropy formation. In fact, the samples without sepiolites (PMMA and 1.5\%-QAS) presented an anisotropy ratio slightly smaller than 1 in the MD direction (Figure 6), supporting that the cell growth takes place mostly in the TD direction.

The mechanism we propose to explain the anisotropy is related to a particular effect of the presence of the sepiolites during the growth of the cells. We have observed that the individual sepiolites are in the middle of the cells, both particle and cell elongated in the same direction (Figure 10). So one possible rationale to explain the anisotropy might be that the cells grow around the sepiolite, which has an elongated shape, and thus the cells are anisotropic. On the other hand, it is also observed that some sepiolites appear between two cells that have been joined to one (red arrows in Figure 10). Then, sepiolites could be acting as weak points for cell wall rupture, causing 
coalescence in the direction of the sepiolite, and then provoking than the resultant cell is anisotropic. This mechanism is schematically explained in Figure 11.

Table 5. Expansion ratio in the TD and the MD directions for the all the cellular materials produced in this work.

\begin{tabular}{ccc}
\hline Material ID & $\boldsymbol{E R}_{\boldsymbol{T D}}$ & $\boldsymbol{E R}_{\boldsymbol{M D}}$ \\
\hline PMMA & 1.58 & 1.43 \\
1.5\%-QAS & 1.64 & 1.44 \\
1.5\%-S-LQAS & 1.66 & 1.44 \\
1.5\%-S-HQAS & 1.65 & 1.46 \\
3\%-S-HQAS & 1.64 & 1.37 \\
\hline 10\%-S-HQAS & 1.53 & 1.11 \\
\hline
\end{tabular}

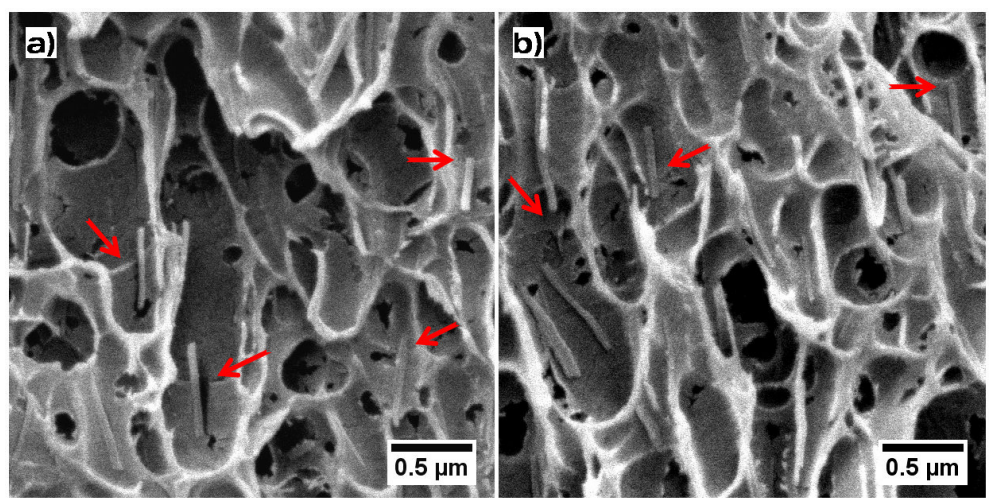

Figure 10. Examples of SEM micrographs of the MD plane of the sample 3\%-S-HQAS, showing in detail the sepiolites in the cells.

To check this hypothesis, the open cell content was measured and plotted against the anisotropy ratio (Figure 12.a). It is observed that a higher open cell content is measured in the samples with SHQAS, those that presented higher anisotropy ratios. In fact, the materials with more particles, 3 wt $\%$ and $10 \mathrm{wt} \%$, show open cell contents of $100 \%$, that is, a completely open structure. These results support the idea that some cell wall rupture is taking place in these systems.

a)

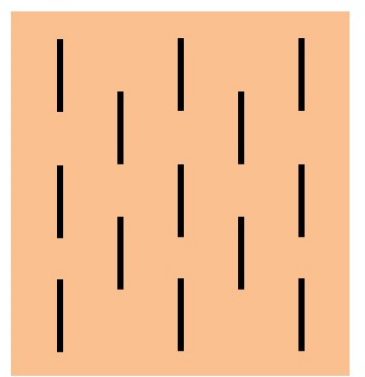

b)

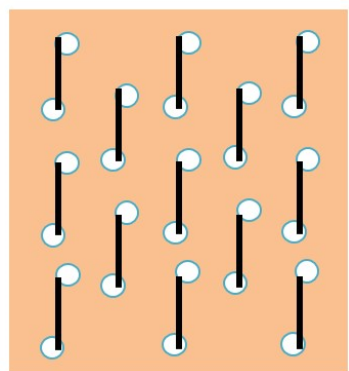

c)

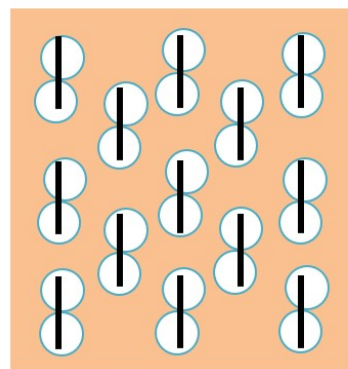

d)

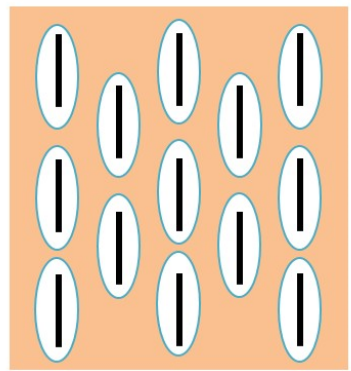

Figure 11. Scheme of the mechanism of anisotropy formation during the foaming process: a) solid material with sepiolites, b) nucleation on the edges of the sepiolites, c) growth of the cells and d) coalescence in the sepiolites and appearance of the anisotropy. 
The different anisotropy ratios found in the materials of this work can be then correlated with the number of well-dispersed sepiolites in each material. As the number of sepiolites increases, the distance between particles decreases, and then it is more likely that two or more sepiolites are aligned and a very anisotropic cell is formed around them. The number of sepiolites is somehow related to the cell nucleation density (assuming one particle produces one cell). Then, the cell nucleation density has been plotted as a function of the anisotropy ratio (Figure 12.b), showing this idea that a higher number of particles (higher nucleation densities) yields to a greater anisotropy ratio. Therefore, controlling the number and dispersion of sepiolites is a tool to control the anisotropy ratio in these systems.

a)

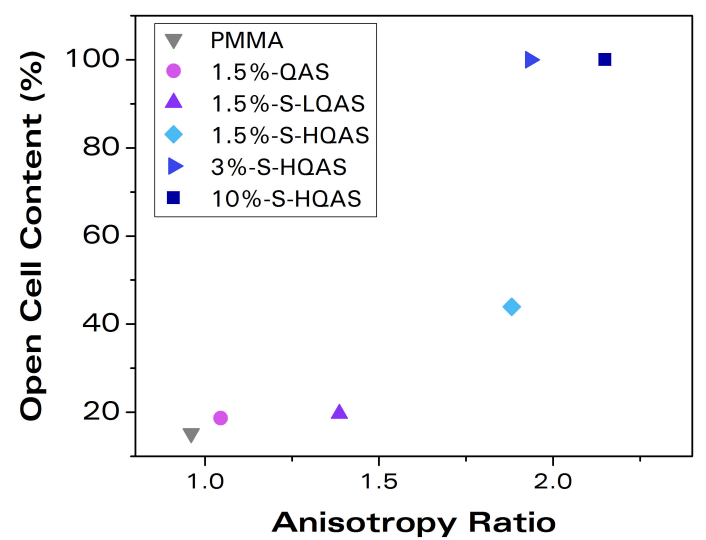

b)

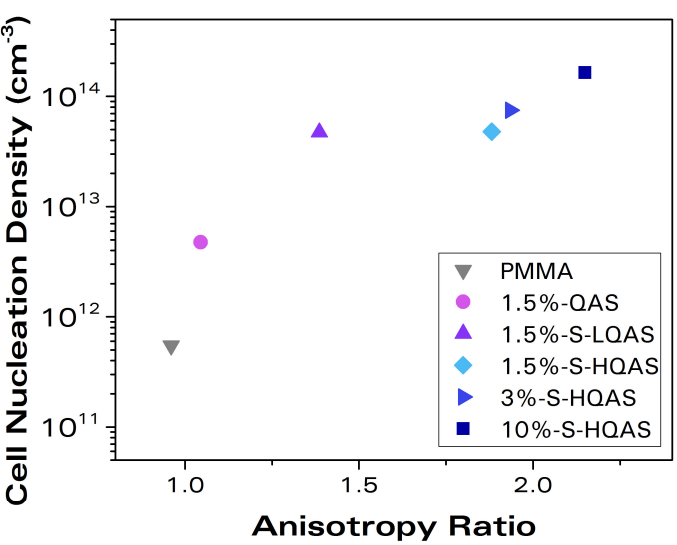

Figure 12. a) Open cell content and b) cell nucleation density in the MD plane as a function of the anisotropy ratio in the MD plane for all the materials produced in this work.

\section{CONCLUSIONS}

Anisotropic nanocellular polymers based on PMMA with needle-like sepiolites have been produced using a two-step gas dissolution foaming method. Anisotropy ratios from 1.38 and as high as 2.15 are obtained thanks to the addition of the nanoparticles.

Solid materials were produced using a twin-screw extruder, and the filaments from the extrusion were used as precursors for the solid-state foaming process. The morphology of the solid samples reveals that the extrusion process aligns the sepiolites in the extrusion direction.

Results show that the addition of a $1.5 \mathrm{wt} \%$ of a quaternary ammonium salt (QAS) has an effect of the cellular structure of microcellular PMMA, leading to an increase of the nucleation density of one order of magnitude and a slight reduction of the average cell size. On the other hand, the addition of the same content of sepiolites modified with this salt is even more significant, increasing the nucleation density above the $10^{13}$ nuclei/ $/ \mathrm{cm}^{3}$ and leading to the appearance of a bimodal structure with a predominance of nanometric pores. In particular, between the two sepiolites used in this work, that with the highest amount of QAS has the strongest nucleating effect, due to a better dispersion of the particles in the solid material. In addition, it is observed that whereas the pure PMMA and the blend with QAS are isotropic, the cellular nanocomposites with sepiolites are highly anisotropic in the plane parallel to the extrusion direction (and isotropic in the traverse plane). Moreover, increasing the sepiolite content from $1.5 \mathrm{wt} \%$ to $3 \mathrm{wt} \%$ and $10 \mathrm{wt} \%$ increases even more 
the anisotropy observed in these materials, at the same time as the nucleation density increases and the cell size decreases.

After analyzing the expansion ratio of the materials, it is concluded that the anisotropy is not a consequence of a preferable expansion during the growth of the cells. Instead, a mechanism based on cell coalescence is proposed as responsible for the formation of anisotropic cells. The needlelike particles act as most likely spots for cell wall rupture, and as they are aligned in the machine direction, cells break and join in that direction, causing an overall anisotropic structure. This hypothesis is supported by open cell measurements. Also, the different anisotropy ratios found in the various nanocomposites can be correlated with the density of well-dispersed sepiolites.

\section{Acknowledgments:}

Financial support from the FPU grant FPU14/02050 (V. Bernardo) from the Spanish Ministry of Education and the Junta of Castile and Leon grant (J. Martín-de León) are gratefully acknowledged. Financial assistance from MINECO, FEDER, UE (MAT2015-69234-R) and the Junta de Castile and Leon (VA275P18) are gratefully acknowledged. We would also like to thank Tolsa (Madrid, Spain) for supplying the sepiolites of this study.

\section{REFERENCES}

[1] D. Eaves, Handbook of Polymer Foams, Rapra Technology, United Kingdom, 2004.

[2] Marketsandmarkets.com, http://www.marketsandmarkets.com/Market-Reports/foams-market-1011.html, (n.d.).

[3] S. Costeux, CO2-blown nanocellular foams, J. Appl. Polym. Sci. 131 (2014) 41293(1)-41293(16). doi:10.1002/app.41293.

[4] H. Yokoyama, L. Li, T. Nemoto, K. Sugiyama, Tunable nanocellular polymeric monoliths using fluorinated block copolymer templates and supercritical carbon dioxide, Adv. Mater. 16 (2004) 1542-1546. doi:10.1002/adma.200400072.

[5] H. Guo, A. Nicolae, V. Kumar, Solid-state poly(methyl methacrylate) (PMMA) nanofoams. Part II: Lowtemperature solid-state process space using $\mathrm{CO} 2$ and the resulting morphologies, Polymer (Guildf). 70 (2015) 231-241. doi:10.1016/j.polymer.2015.06.031.

[6] B. Notario, J. Pinto, M.A. Rodriguez-Perez, Nanoporous polymeric materials: A new class of materials with enhanced properties, Prog. Polym. Sci. 78-79 (2016) 93-139. doi:10.1016/j.pmatsci.2016.02.002.

[7] D. Miller, V. Kumar, Microcellular and nanocellular solid-state polyetherimide (PEI) foams using sub-critical carbon dioxide II. Tensile and impact properties, Polymer (Guildf). 52 (2011) 2910-2919. doi:10.1016/j.polymer.2011.04.049.

[8] B. Notario, J. Pinto, E. Solorzano, J.A. de Saja, M. Dumon, M.A. Rodriguez-Perez, Experimental validation of the Knudsen effect in nanocellular polymeric foams, Polymer (Guildf). 56 (2015) 57-67. doi:10.1016/j.polymer.2014.10.006.

[9] G. Wang, C. Wang, J. Zhao, G. Wang, C.B. Park, G. Zhao, Modelling of thermal transport through a nanocellular polymer foam: Toward the generation of a new superinsulating material, Nanoscale. 9 (2017) 5996-6009. doi:10.1039/c7nr00327g.

[10] S. Liu, J. Duvigneau, G.J. Vancso, Nanocellular polymer foams as promising high performance thermal insulation materials, Eur. Polym. J. 65 (2015) 33-45. doi:10.1016/j.eurpolymj.2015.01.039.

[11] C. Forest, P. Chaumont, P. Cassagnau, B. Swoboda, P. Sonntag, Polymer nano-foams for insulating applications prepared from CO 2 foaming, Prog. Polym. Sci. 41 (2015) 122-145. doi:10.1016/j.progpolymsci.2014.07.001. 
[12] G. Wang, J. Zhao, L.H. Mark, G. Wang, K. Yu, C. Wang, C.B. Park, G. Zhao, Ultra-tough and super thermalinsulation nanocellular PMMA/TPU, Chem. Eng. J. 325 (2017) 632-646. doi:10.1016/j.cej.2017.05.116.

[13] S. Perez-Tamarit, B. Notario, E. Solorzano, M.A. Rodriguez-Perez, Light transmission in nanocellular polymers: are semi-transparent cellular polymers possible?, Mater. Lett. $210 \quad$ (2017) 39-41. doi:10.1016/j.matlet.2017.08.109.

[14] J. Martin-de Leon, V. Bernardo, M.A. Rodriguez-Perez, Key Production Parameters to Obtain Transparent Nanocellular PMMA, Macromol. Mater. Eng. 1700343 (2017) 1-5. doi:10.1002/mame.201700343.

[15] B. Notario, J. Pinto, R. Verdejo, M.A. Rodríguez-Pérez, Dielectric behavior of porous PMMA: From the micrometer to the nanometer scale, Polymer (Guildf). $107 \quad$ (2016) 302-305. doi:10.1016/j.polymer.2016.11.030.

[16] J. Pinto, B. Notario, R. Verdejo, M. Dumon, S. Costeux, M.A. Rodriguez-perez, Molecular confinement of solid and gaseous phases of self-standing bulk nanoporous polymers inducing enhanced and unexpected physical properties, Polymer (Guildf). 113 (2017) 27-33. doi:10.1016/j.polymer.2017.02.046.

[17] B. Notario, J. Pinto, M.A. Rodríguez-Perez, Towards a new generation of polymeric foams: PMMA nanocellular foams with enhanced physical properties, Polymer (Guildf). 63 (2015) 116-126. doi:10.1016/j.polymer.2015.03.003.

[18] B. Notario, A. Ballesteros, J. Pinto, M.A. Rodriguez-Perez, Nanoporous PMMA: A novel system with different acoustic properties, Mater. Lett. 168 (2016) 76-79. doi:10.1016/j.matlet.2016.01.037.

[19] L.J. Gibson, M. Ashby, Cellular solids: structure and properties, 2nd Editio, Cambridge University Press, 1997.

[20] A.T. Huber, L.J. Gibson, Anisotropy of foams, J. Mater. Sci. 23 (1988) 3031-3040. doi:10.1007/BF00547486.

[21] J. Andersons, M. Kirpluks, L. Stiebra, U. Cabulis, Anisotropy of the stiffness and strength of rigid low-density closed-cell polyisocyanurate foams, Mater. Des. 92 (2016) 836-845. doi:10.1016/j.matdes.2015.12.122.

[22] J.A. Martinez-Diez, M.A. Rodriguez-Perez, J.A. de Saja, L.O. Arcos y Rabago, O.A. Almanza, The Thermal Conductivity of a Polyethylene Foam Block Produced by a Compression Molding Process, J. Cell. Plast. 37 (2001) 21-42. doi:10.1106/D0MJ-HJH8-5YDQ-H5VB.

[23] M.A. Rodríguez-Pérez, O. Alonso, J. Souto, J.A. de Saja, Thermal conductivity of physically crosslinked closed cell polyolefin foams, Polym. Test. 16 (1997) 287-298. doi:10.1016/S0142-9418(96)00050-5.

[24] M. Antunes, V. Realinho, J.I. Velasco, E. Solórzano, M.Á. Rodríguez-Pérez, J.A. De Saja, Thermal conductivity anisotropy in polypropylene foams prepared by supercritical CO 2 dissolution, Mater. Chem. Phys. 136 (2012) 268-276. doi:10.1016/j.matchemphys.2012.07.001.

[25] B. Wicklein, A. Kocjan, G. Salazar-Alvarez, F. Carosio, G. Camino, M. Antonietti, L. Bergström, Thermally insulating and fire-retardant lightweight anisotropic foams based on nanocellulose and graphene oxide, Nat. Nanotechnol. 10 (2014) 277-283. doi:10.1038/nnano.2014.248.

[26] D. Killeen, M. Frydrych, B. Chen, Porous poly (vinyl alcohol)/ sepiolite bone scaffolds: Preparation, structure and mechanical properties, Mater. Sci. Eng. C. 32 (2012) 749-757. doi:10.1016/j.msec.2012.01.019.

[27] E. Laguna-Gutierrez, R. Van Hooghten, P. Moldenaers, M.A. Rodriguez-Perez, Understanding the foamability and mechanical properties of foamed polypropylene blends by using extensional rheology, J. Appl. Polym. Sci. 132 (2015) 42430(1)-42430(14). doi:10.1002/app.42430.

[28] K.A. Arora, A.J. Lesser, T.J. McCarthy, Preparation and characterization of microcellular polystyrene foams processed in supercritical CO2, Macromolecules. 38 (1997) 446-447. doi:10.1021/ma971811z.

[29] L. Oliveira-Salmazo, A. Lopez-Gil, F. Silva-Bellucci, A.E. Job, M.A. Rodriguez-Perez, Natural rubber foams with anisotropic cellular structures: Mechanical properties and modeling, Ind. Crops Prod. 80 (2016) 26-35. doi:10.1016/j.indcrop.2015.10.050.

[30] V. Bernardo, E. Laguna-Gutierrez, A. Lopez-Gil, M.A. Rodriguez-Perez, Highly anisotropic crosslinked HDPE foams with a controlled anisotropy ratio: Production and characterization of the cellular structure and mechanical properties, Mater. Des. 114 (2016) 83-91. doi:10.1016/j.matdes.2016.10.051.

[31] A. Alvarez, J. Santaren, A. Esteban-Cubillo, P. Aparicio, Development in Palygorskite-Sepiolite Research, Elsevier, 2011.

[32] E. Ruiz-Hitzky, Molecular access to intracrystalline tunnels of sepiolite, J. Mater. Chem. 11 (2001) 86-91. doi:10.1039/b003197f.

[33] J. Santaren, A. Alvarez, A. Esteban-Cubillo, B. Notario, D. Velasco, M.A. Rodriguez-Perez, Improving the Cellular Structure and Thermal Conductivity of PS Foams by Using Sepiolites, in: Foams2012, 2012: pp. 1-5. 
[34] N. García, J. Guzman, E. Benito, A. Esteban-Cubillo, E. Aguilar, J. Santaren, P. Tiemblo, Surface Modification of Sepiolite in Aqueous Gels by Using Methoxysilanes and Its Impact on the Nanofiber Dispersion Ability, Langmuir. 27 (2011) 3952-3959. doi:10.1021/la104410r.

[35] P. Shahi, A.H. Behravesh, S. Rasel, G. Rizvi, R. Pop-lliev, Morphological analysis of foamed hdpe/lldpe blends by x-ray micro-tomography: Effect of blending, mixing intensity and foaming temperature, Cell. Polym. 36 (2017) 221-250. doi:10.1177/026248931703600501.

[36] J. Ludwiczak, S. Frackowiak, R. Łuzny, Effect of recycling on the cellular structure of polylactide in a batch process, Cell. Polym. 37 (2018) 69-79. doi:10.1177/026248931803700202.

[37] E. Laguna-Gutierrez, R. Van Hooghten, P. Moldenaers, M.A. Rodriguez-Perez, Effects of extrusion process, type and content of clays, and foaming process on the clay exfoliation in HMS PP composites, J. Appl. Polym. Sci. 132 (2015) 42430(1)-42430(14). doi:10.1002/app.42828.

[38] V. Kumar, N.P. Suh, A process for making microcellular parts, Polym. Eng. Sci. 30 (1990) 1323-1329. doi:https://doi.org/10.1002/pen.760302010.

[39] V. Bernardo, J. Martin-de León, E. Laguna-Gutiérrez, M.Á. Rodríguez-Pérez, PMMA-sepiolite nanocomposites as new promising materials for the production of nanocellular polymers, Eur. Polym. J. 96 (2017) 10-26. doi:10.1016/j.eurpolymj.2017.09.002.

[40] C.A. Mandarim-de-Lacerda, Stereological tools in biomedical research, Ann. Brazilian Acad. Sci. 75 (2003) 469486.

[41] N.C. Hilyard, A. Cunningham, Low density cellular plastics--Physical basis of behaviour, Chapman and Hall, London, 1994.

[42] J. Pinto, E. Solorzano, M.A. Rodriguez-perez, J.A. De Saja, Characterization of the cellular structure based on user-interactive image analysis procedures, J. Cell. Plast. 49 (2013) 555-575. doi:10.1177/0021955X13503847.

[43] V. Kumar, Process synthesis for manufacturing microcellular thermoplastic parts, Massachusetts Institute of Technology, 1988.

[44] I. Singh, A. Gandhi, M. Biswal, S. Mohanty, S.K. Nayak, Multi-Stage recycling induced morphological transformations in solid-State microcellular foaming of polystyrene, Cell. Polym. 37 (2018) 121-149. doi:10.1177/026248931803700302. 


\section{Supplementary Information:}

\section{Anisotropy in nanocellular polymers promoted by the addition of needle-like sepiolites}

Victoria Bernardo, Judith Martín-de León, Miguel Ángel Rodríguez-Pérez

Cellular Materials Laboratory (CellMat), Condensed Matter Physics Department,

University of Valladolid, Campus Miguel Delibes, Paseo de Belén n7, 47011 Valladolid, Spain

Corresponding author: Victoria Bernardo (vbernardo@fmc.uva.es) +34983184035

\section{EVALUATION OF THE EFFECT OF THE PROCESSING IN THE PMMA MATRIX}

Table S1 collects the melt flow index (MFI) and the glass transition temperature $\left(\mathrm{T}_{\mathrm{g}}\right)$ of the unprocessed PMMA and the PMMA after two extrusion cycles. MFI was measured at $230^{\circ} \mathrm{C}$ and $2.16 \mathrm{~kg}$, and the glass transition temperature was determined by differential scanning calorimetry (DSC) using a temperature program from 20 to $160^{\circ} \mathrm{C}$ at a rate of $10^{\circ} \mathrm{C} / \mathrm{min}$. In addition, dynamic shear properties were measured using a stress controlled rheometer, AR 2000 EX from TA Instruments. Measurements were performed at a temperature of $230{ }^{\circ} \mathrm{C}$ under nitrogen atmosphere using a parallel plates geometry over an angular frequency range of $0.01<\omega<100$ $\mathrm{rad} / \mathrm{s}$. Solid cylindrical samples were prepared by compression moulding for the tests. From the dynamic shear viscosity measurements (Figure S1), the zero shear viscosity $\left(\eta_{0}\right)$ is calculated (Table S1). Using the zero shear viscosity, it is possible to estimate the molecular weight of the polymer [1].

Table S1. MFI, $\mathrm{T}_{\mathrm{g}}$ and rheological properties of the PMMA unprocessed and the PMMA after two extrusion cycles.

\begin{tabular}{ccccc}
\hline Material ID & MFI (g/10 min) & $\mathrm{T}_{\mathrm{g}}\left({ }^{\circ} \mathrm{C}\right)$ & $\begin{array}{c}\text { Zero shear } \\
\text { viscosity (Pa.s) }\end{array}$ & $\begin{array}{c}\text { Estimated molecular } \\
\text { weight (kg/mol) }\end{array}$ \\
\hline Unprocessed PMMA & $1.79 \pm 0.01$ & 114.5 & $7095 \pm 5$ & $130 \pm 40$ \\
PMMA (2 extrusion) & $1.76 \pm 0.01$ & 114.7 & $6761 \pm 26$ & $129 \pm 40$ \\
\hline
\end{tabular}

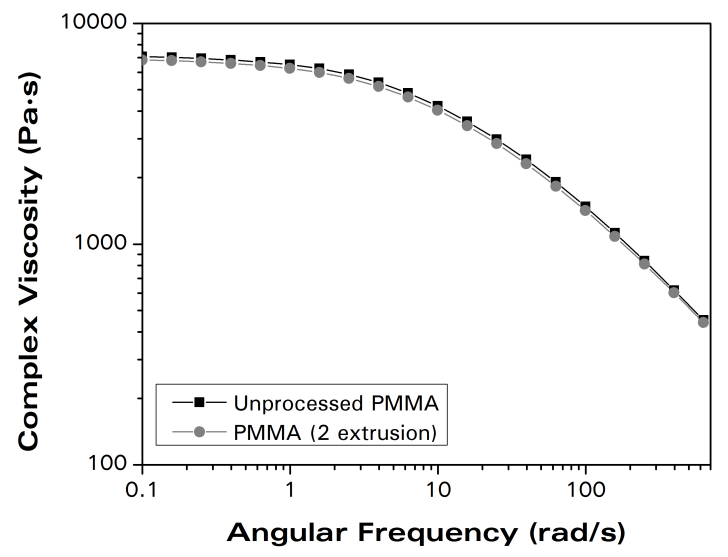

Figure S1. Complex viscosity as a function of the frequency of the PMMA unprocessed and the PMMA after two extrusion cycles. 
The results of Table S1 confirm that the extrusion process used in this study is not affecting substantially to the PMMA polymer matrix, since similar MFI, glass transition temperature and rheological properties are observed before and after the compounding. and rheological properties are observed before and after the compounding.

\section{SEM CHARACTERIZATION OF THE SOLID NANOCOMPOSITES}

Figure S2 and Figure S3 show general SEM images of the solid nanocomposites produced in this work, in the TD and the MD planes, respectively. In these images, the micrometric particle aggregates can be appreciated (indicated with red arrows). We observe that the size of the aggregates is very variable, from less than a micron (see for instance Figure S2.e) to several microns (like Figure S3.e). In general, the composite 10\%-S-HQAS shows bigger aggregates.
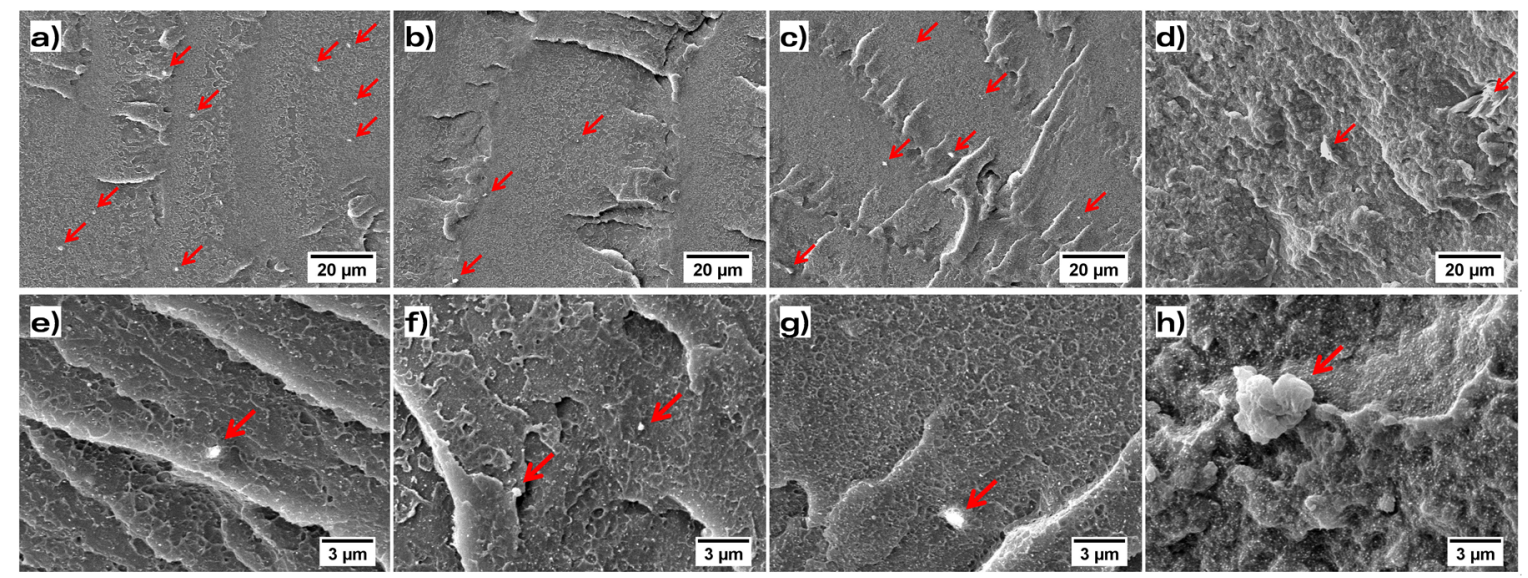

Figure S2. SEM micrographs of the solid PMMA/sepiolite nanocomposites in the TD plane: a-e) 1.5\%-S-LQAS, b-f) 1.5\%-S-HQAS, c-g) 3\%-S-HQAS and d-h) 10\%-S-HQAS. The images of the second row correspond to zoomed images of the first row.
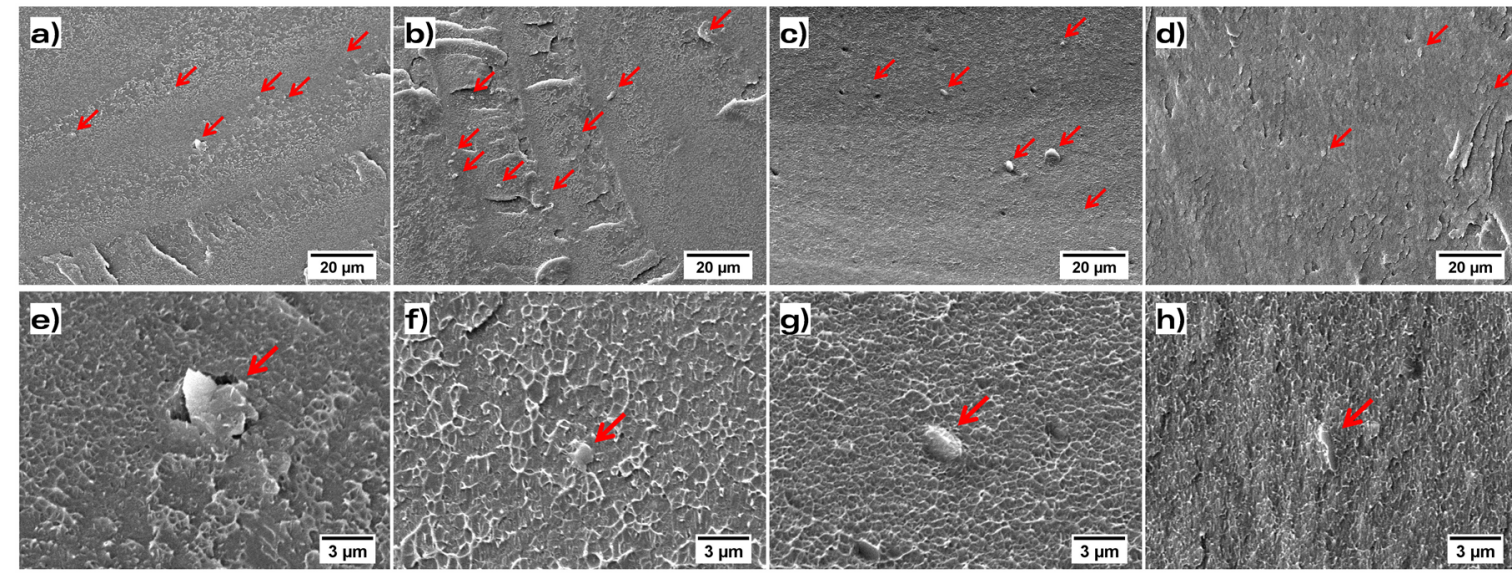

Figure S3. SEM micrographs of the solid PMMA/sepiolite nanocomposites in the MD plane: a-e) 1.5\%-S-LQAS, b-f) 1.5\%-S-HQAS, c-g) 3\%-S-HQAS and d-h) 10\%-S-HQAS. The images of the second row correspond to zoomed images of the first row.

Figure S4 shows examples of details of big particle aggregates (several microns) for different nanocomposites, Finally, Figure S5 presents images of the nanocomposite 10\%-S-HQAS in the MD 
plane, showing the high density of particles present in this system. Red arrows indicate regions in which sepiolites are agglomerated due to the high amount of particles in this nanocomposite.
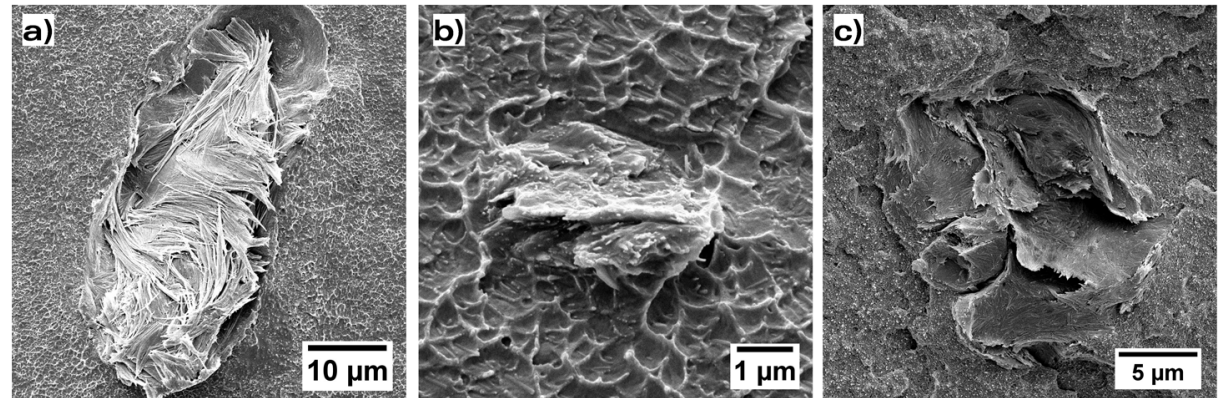

Figure S5. Examples of detailed images of the particle aggregates found in the solid nanocomposites.

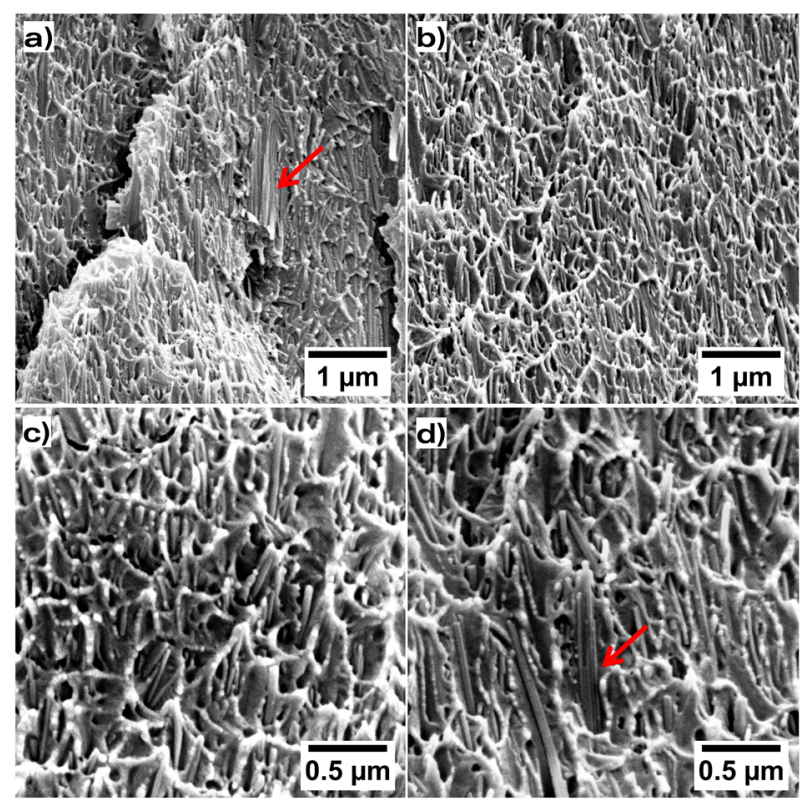

Figure S5. SEM images of the nanocomposite 10\%-S in the MD plane. Red arrows indicate regions were sepiolites appear to be in touch with one another.

\section{REFERENCES}

[1] J.M. Dealy, J. Wang, Melt Rheology and its Applications in the Plastics Industry, Springer, 2013. doi:10.1007/978-94-007-6395-1. 
Chapter 5.

Fabrication of Nanocellular Polymers based on PMMA Nanostructured Polymer Blends 



\section{Chapter 5. Fabrication of Nanocellular Polymers based on Nanostructured PMMA Blends}

\subsection{Introduction}

This chapter contains the results obtained in the studies related to the production of nanocellular polymers using nanostructured PMMA-based polymer blends. Two different systems are investigated in this chapter: PMMA/MAM and PMMA/TPU.

In the first two sections, we present the main results obtained with the PMMA/MAM systems. MAM is a tri-block copolymer able to form nanometric structures when blended with PMMA and has a high affinity to $\mathrm{CO}_{2}$, so it is suitable to be used as a nucleating agent. Three grades of MAM with different molecular weights and similar PBA fractions are used (kindly supplied by Arkema). The main characteristics of these polymers are included in Table 3.3 of Chapter 3. In section 5.2, the influence of the molecular weight of the MAM phase is evaluated by producing samples with a fixed concentration of MAM (10 wt\%). The mechanisms involved in the formation of the micellar structure in the solids and the later nanocellular structure are investigated. Section 5.3 contains a paper that is the continuation of the first one. In this study, the effect of reducing the amount of MAM is analyzed, both in the solids and in the nanocellular materials. The influence of the foaming temperature is also studied. Once again, the foaming mechanisms are explained and discussed.

Section 5.4 of this chapter contains a paper about the use of PMMA/TPU blends. This is a new system barely investigated so far, but it is a promising material for the production of nanocellular polymers. Our paper investigates the effect of the addition of TPU and the influence of the saturation pressure and the foaming conditions (temperature and time), with the aim of gaining knowledge about this new blend.

\subsection{Understanding the role of MAM molecular weight on the production of PMMAVMAM nanocellular polymers}

This section contains a publication entitled "Understanding the role of MAM molecular weight on the production of PMMAMAM nanocellular polymers", published in Polymer in 2018 (V. Bernardo, J. Martin-de Leon, E. Laguna-Gutierrez, T. Catelani, J. Pinto, A. Athanassiou, M.A. Rodriguez-Perez, Understanding the role of MAM molecular weight on the production of PMMA/MAM nanocellular polymers, Polymer (Guildf). 153 (2018) 262-270. doi:10.1016/j.polymer.2018.08.022).

The main goal of this research was to evaluate the effect of the molecular weight of the block copolymer on the cellular structure of the nanocellular polymers. To do so, three PMMA/MAM blends with a $10 \mathrm{wt} \%$ of MAM and different MAM grades were produced and foamed using the same conditions. The three MAM grades have similar PBA fractions (around 50\%, see Table 3.3 in Chapter 3), so we can neglect the influence of this parameter in the results and focus on the molecular weight. 
Regarding the nanostructuration of the solid blends (studied by TEM as commented in Chapter 3), significant differences are detected among the three MAM grades. The micelle density was found to increase as MAM molecular weight increases. To explain this, we claim that the nanostructuration is a consequence of two phenomena: first, the dispersion of the MAM during the extrusion process, and second, the self-assembly of the MAM molecules. A MAM with a higher viscosity (that is, a higher molecular weight) is dispersed in smaller domains during the extrusion. In these MAM-rich domains, self-assembly occurs. As the size of the domains decreases for higher molecular weight and the three samples have the same fraction of MAM, higher molecular weights lead to higher micelle densities. Therefore, the extrusion process could be tuned to control the nanostructuration of the blends.

In the cellular materials, higher MAM molecular weights produce nanocellular materials with higher cell nucleation densities, because micelle density controls the nucleation process (nucleation happens within the micelle). As a consequence, cell size decreases as MAM molecular weight increases. This is a result of the distance between the micelles: the higher the micelle density, the smaller the intermicelle distance, so the micelles have less space to grow. The homogeneity of the cellular structure is directly related to the homogeneity of the intermicelle distance. The relative density increases as MAM molecular weight increases. We propose a mechanism to explain this: cells can grow until a minimum cell wall thickness is reached, so the higher the MAM molecular weight, the smaller the intermicelle distance and the higher the density. Finally, we propose a mechanism to explain the limited density that can be achieved with these PMMA/MAM systems. We hypothesize that micelles can only grow spherically because of the molecular organization of the micelle, so once the maximum expansion in the radial direction is achieved, the expansion stops.

The general conclusion of this first paper is that MAM molecular weight can be used as a tool to control the nanostructuration in the PMMA/MAM samples, and thus to modify the nanocellular structure in the resultant foamed samples. Figure 5.1 shows the graphical abstract of this publication, which is attached in the next pages.

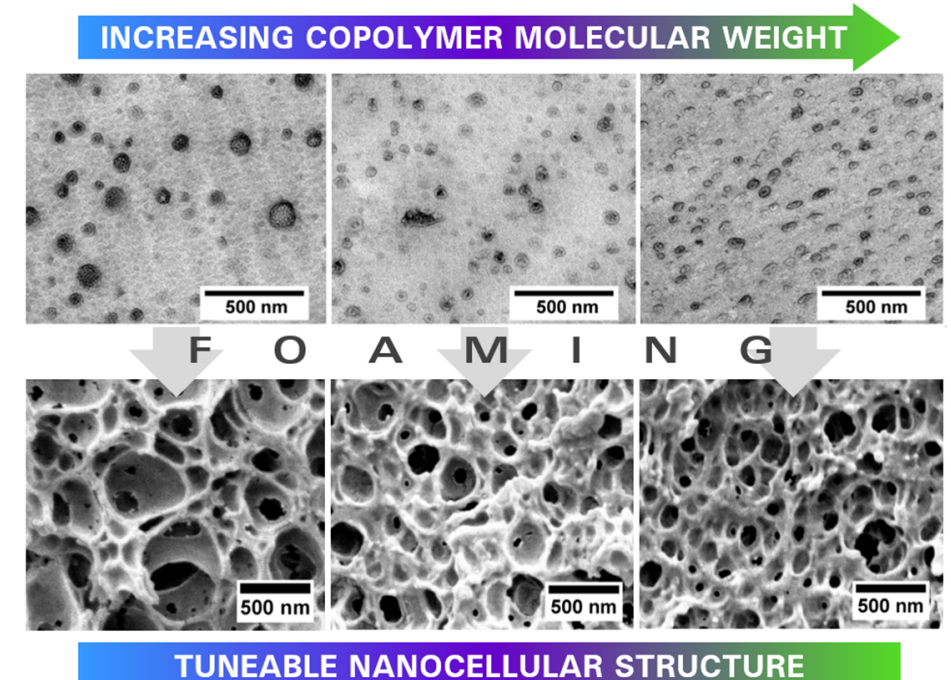

Figure 5.1. Graphical abstract of "Understanding the role of MAM molecular weight on the production of PMMAVMAM nanocellular polymers." 


\title{
Understanding the role of MAM molecular weight on the production of PMMA/MAM nanocellular polymers
}

Victoria Bernardo ${ }^{*}$, Judith Martín-de León ${ }^{1}$, Ester Laguna-Gutiérrez¹, Tiziano Catelani², Javier Pinto $^{2}$, Athanassia Athanassiou², Miguel Ángel Rodríguez-Pérez ${ }^{1}$

1. Cellular Materials Laboratory (CellMat), Condensed Matter Physics Department, University of Valladolid, Campus Miguel Delibes, Paseo de Belén n7, 47011 Valladolid, Spain

2. Nanophysics, Istituto Italiano di Tecnologia (IIT), Genova, Italy *Corresponding author: Victoria Bernardo (vbernardo@fmc.uva.es)+34983184035

\begin{abstract}
Nanostructured polymer blends with $\mathrm{CO}_{2}$-philic domains can be used to produce nanocellular materials with controlled nucleation. It is well known that this nanostructuration can be induced by the addition of a block copolymer poly(methyl methacrylate)-poly(butyl acrylate)-poly(methyl methacrylate) (MAM) to a poly(methyl methacrylate) (PMMA) matrix. However, the effect of the block copolymer molecular weight on the production of nanocellular materials is still unknown. In this work, this effect is analysed by using three types of MAM triblock copolymers with different molecular weights, and a fixed blend ratio of 90 wt $\%$ PMMA and 10 wt $\%$ of MAM. Blends were produced by extrusion. As a result of the extrusion process, a non-equilibrium nanostructuration takes place in the blends, and the micelle density increases as MAM molecular weight increases. Micelle formation is proposed to occur as result of two mechanisms: dispersion, controlled by the extrusion parameters and the relative viscosities of the polymers, and self-assembly of MAM molecules in the dispersed domains. On the other hand, in the nanocellular materials produced with these blends, cell size decreases from 200 to $120 \mathrm{~nm}$ as MAM molecular weight increases. Cell growth is suggested to be controlled by the intermicelle distance and limited by the cell wall thickness. Furthermore, a theoretical explanation of the mechanisms underlying the limited expansion of PMMA/MAM systems is proposed and discussed.
\end{abstract}

\section{KEYWORDS}

nanocellular polymer; gas dissolution foaming; nanostructuration.

\section{INTRODUCTION}

The study of nanocellular polymers is an interesting topic in the frontier of cellular materials science. These materials are characterised by cell sizes in the range of tens to hundreds of nanometres. They have been recently proved to present a unique combination of properties, such as very low thermal conductivities together with improved mechanical properties, compared to conventional cellular polymers [1-6]. The criteria to determine the maximum cell size of such materials should be related to the effects associated with the change of scale to the nanometric range, so it may vary among properties. For instance, thermal conductivity starts to decrease 
significantly thanks to the Knudsen effect from cell sizes of $500 \mathrm{~nm}[1,2]$, whereas for obtaining semi-transparent nanocellular polymers cell sizes as low as $50 \mathrm{~nm}$ are needed $[7,8]$. Therefore, nanocellular polymers with cell sizes below $500 \mathrm{~nm}$ could be used as highly efficient thermal insulator materials, whereas those with cell sizes of $50 \mathrm{~nm}$ could be employed in the production of semi-transparent and super insulator windows. In addition to these applications, and due to their nanometric cell size, nanocellular polymers can also be employed in some specific applications in which other cellular materials cannot be used; for instance, in membranes for micro and ultrafiltration applications or in catalysis and sensors [9-11].

However, the production of these materials is still a challenging task. The fabrication of nanocellular polymers requires specific production routes able to produce and stabilise cells in the nanoscale. Among the diverse techniques employed for this purpose [1,12,13], foaming methods allow producing large samples without the use of organic solvents. In particular, $\mathrm{CO}_{2}$ gas dissolution foaming has been proved to be suitable for the production of bulk nanocellular polymers using different matrices, such as poly(methyl methacrylate) (PMMA) [7,14-16], polycarbonate (PC) [17], polysulfone (PSU) [18], polyphenylsulfone [19,20], or polyetherimide [21-23].

In particular, to produce nanocellular materials based on PMMA using the gas dissolution foaming method, two approaches have been followed based on homogeneous or heterogeneous nucleation. According to the nucleation theories for homogeneous nucleation [24], nucleation ratio in a pure polymer can be increased by maximising $\mathrm{CO}_{2}$ solubility using extreme processing conditions, a strategy followed in all the previously mentioned examples [7,14-16]. Otherwise, the nucleation can be enhanced by taking advantage of the heterogeneous nucleation mechanism. When adding an appropriate second phase to a pure polymer, the interfaces between the matrix and the second phase act as preferable nucleation sites, that is, the Gibbs energy barrier, which should be overcome to form a nucleus, is lower when this second phase is added [24]. To produce nanocellular polymers with this approach, nanoparticles [25-27] or block copolymer micelles [10,28-30] can be used as the second phase. In particular, block copolymer spherical micelles with $\mathrm{CO}_{2}$-philic domains gather all the qualities required to act as ideal nucleants: the nucleation is favourable in the micelles, they present uniform size and surface properties, they are easily dispersible, and the number of micelles formed is usually large [31].

The first successful attempts to produce nanocellular polymers using this approach were those of Yokoyama and coworkers [32,33] with solvent-cast films. Bulk nanocellular PMMA using a tri-block copolymer poly(methyl methacrylate)-poly(butyl acrylate)-poly(methyl methacrylate) (MAM) was produced for the first time by Reglero et al. [34]. They used a MAM with a 30\% of the poly(butyl acrylate) (PBA) phase, with a molecular weight of $70 \mathrm{~kg} / \mathrm{mol}$ in that block and $90 \mathrm{~kg} / \mathrm{mol}$ in the PMMA blocks. Working with a MAM content of $10 \mathrm{wt} \%$ they were able to obtain cell sizes around $200 \mathrm{~nm}$ and relative densities of 0.4 . Pinto et al. $[10,29,30]$ worked with blends of PMMA and MAM with different MAM contents and under several processing conditions. In their work, the MAM block copolymer used presented at $36 \mathrm{wt} \%$ of PBA and an average molecular weight of $180 \mathrm{~kg} / \mathrm{mol}$. They showed that nucleation actually took place in the micelles [29] and that the cellular structure was controlled by the nanostructuration. Cell sizes in the range $150-200 \mathrm{~nm}$ and relative densities of 0.4-0.6 were obtained in these works. Forest and coworkers [28] analysed the effect of changing the copolymer content in the structure of PMMA/MAM-based nanocellular polymers, founding that 
higher copolymer contents (up to $20 \mathrm{wt} \%$ ) led to larger cell nucleation densities. They also analysed the effect of the PMMA viscoelastic behaviour in PMMA/MAM blends, by using two PMMA with different molecular weights [35]. They found that the viscoelastic behaviour of the PMMA matrix conditioned the cell growth mechanisms and thus, the density of the final material. In the works of Forest et al. [28,35], MAM with a 55\% of PBA block was used. The glass transition of the PBA phase was found at $-46^{\circ} \mathrm{C}$ and the molecular weight of the copolymer was not specified.

In the aforementioned literature, the effect of the copolymer content on the morphology of the blends and thus, on the cellular structure of these materials, has been widely analysed. The effect of the MAM chemistry on the nanostructuration under equilibrium conditions and the mechanical performance of solid PMMA/MAM blends has also been studied [36-39]. However, there is a lack of knowledge about the influence of the molecular weight of the copolymer on the nanostructuration when the blends are produced by extrusion, and also on the resultant nanocellular structure. Therefore, this work aims to identify the role of the block copolymer molecular weight in the production of nanocellular polymers. For this purpose, three grades of MAM tri-block copolymers will be used. In particular, it is the first time that the particular MAM grades of this work, with PBA ratios of $48-54 \%$ and glass transition temperatures of the PBA phase ranging -40 to $-20^{\circ} \mathrm{C}$, are used for producing nanocellular polymers. First, the influence of the MAM molecular weight on the nanostructuration of solid blends obtained by extrusion containing $90 \mathrm{wt} \%$ PMMA and 10 wt $\%$ of each MAM will be studied. Then, these solid blends will be employed as precursors to be foamed using a two-step gas dissolution foaming method with the goal of analysing the influence of the block copolymer molecular weight on the resultant cellular structure. The results show that the MAM molecular weight has a significant influence on the nanostructuration of the solid blends. In addition, it was proved that the nanostructuration controls the cell growth and stabilisation. Therefore, MAM molecular weight was demonstrated to be a critical processing parameter in the production of PMMA/MAM nanocellular materials.

\section{EXPERIMENTAL}

\subsection{Materials}

PMMA V 825T was kindly supplied by ALTUGLAS ${ }^{8}$ International in the form of pellets. PMMA $\left(M_{n}=\right.$ $43 \mathrm{~kg} / \mathrm{mol}, \mathrm{M}_{\mathrm{w}}=83 \mathrm{~kg} / \mathrm{mol}$ ) with a melt flow index (MFI) of $1.8 \mathrm{~g} / 10$ min (measured at $230^{\circ} \mathrm{C}$ and $2.16 \mathrm{~kg})$, a density $(\rho)$ of $1.19 \mathrm{~g} / \mathrm{cm}^{3}$ and a glass transition temperature $\left(\mathrm{T}_{\mathrm{g}}\right)$ of $114.5^{\circ} \mathrm{C}$, measured by DSC.

MAM block copolymers were kindly supplied by Arkema Company (France). Three MAM copolymers with different molecular weights were used in this study. The three MAM present roughly a 48-54 wt\% of the soft block, poly(butyl acrylate) (PBA), according to the data provided by Arkema and confirmed with NMR (Table 1, see Supplementary information for more details about the NMR). Commercial names of these copolymers are Nanostrength M51 (low molecular weight), M52 (medium molecular weight) and M53 (high molecular weight). Table 1 summarises the main characteristics of these copolymers. MFI was measured at $160^{\circ} \mathrm{C}$ and $10 \mathrm{~kg}$ and molecular weight was determined using GPC measurements. PBA fraction was determined from NMR measurements. $T_{g}$ of the PBA phase was determined by DSC. 
Table 1. Characteristics of the MAM block copolymers used in this work.

\begin{tabular}{ccccccc}
\hline ID & Description & $\mathrm{M}_{\mathrm{n}}(\mathrm{kg} / \mathrm{mol})$ & $\mathrm{M}_{\mathrm{w}}(\mathrm{kg} / \mathrm{mol})$ & $\mathrm{MFI}(\mathrm{g} / 10 \mathrm{~min})$ & $\mathrm{T}_{\mathrm{g}, \mathrm{PBA}}\left({ }^{\circ} \mathrm{C}\right)$ & $\mathrm{PBA}(\mathrm{wt} \%)$ \\
\hline $\mathrm{L}$ & Low molecular weight & 25 & 46 & $84 \pm 9$ & -26.2 & 48 \\
$\mathrm{M}$ & Medium molecular weight & 44 & 75 & $4 \pm 1$ & -34.9 & 52 \\
$\mathrm{H}$ & High molecular weight & 82 & 128 & $0.208 \pm 0.003$ & -39.8 & 54 \\
\hline
\end{tabular}

Further characterization of the block copolymers (molecular weight distributions and NMR measurements) can be found in the Supplementary Information.

Finally, medical grade carbon dioxide $\left(\mathrm{CO}_{2}\right)$ (99.9\% purity) was used as blowing agent for the gas dissolution foaming experiments.

\subsection{Solid Blends Production}

PMMA/MAM blends with a 10 wt\% of MAM were compounded using a twin-screw extruder model COLLIN TEACH-LINE ZK 25T, with L/D of 24 and screw diameter of $25 \mathrm{~mm}$. All materials were dried under vacuum at $50^{\circ} \mathrm{C}$ during 12 hours prior to compounding. The temperature profile set on the extruder varied from $160^{\circ} \mathrm{C}$ to $200^{\circ} \mathrm{C}$ (in the die), increasing in intervals of $10^{\circ} \mathrm{C}$. The screw speed was equal to $40 \mathrm{rpm}$. The produced blends were cooled in a water bath and pelletized. After a drying of 2 hours in a vacuum oven at $50^{\circ} \mathrm{C}$, the material was extruded again under the same conditions, with the aim of homogeneously mixing the two components. After this process, homogeneous and transparent blends were obtained. Blends will be called from now on as 90/10_L, 90/10_M and 90/10_H (that is, 90 wt\% of PMMA and 10 wt\% of MAM with low (L), medium (M) or high $(\mathrm{H})$ molecular weight).

Solid precursors of the blends with different geometries were prepared by compression moulding using a hot plate press provided by Remtex. All materials were dried under vacuum at $50{ }^{\circ} \mathrm{C}$ during 12 hours before processing. The temperature of the press was fixed at $250^{\circ} \mathrm{C}$. The materials were first softened without pressure for 8.5 minutes, and then, they were compacted under a constant pressure of $1.7 \mathrm{MPa}$ for another minute. Finally, the samples were cooled down to room temperature under the same pressure. Solid prisms of $155 \times 75 \times 4 \mathrm{~mm}^{3}$ were produced and samples of $20 \times 10 \times 4 \mathrm{~mm}^{3}$ were cut from the solid prisms and used in the foaming experiments. In addition, cylindrical samples for the shear rheological measurements with a thickness of $2 \mathrm{~mm}$ and a diameter of $25 \mathrm{~mm}$ were prepared using the same press and the same conditions.

Neat PMMA was processed under the same conditions (both by extrusion and compression moulding) for the sake of comparison.

\subsection{Gas Dissolution Foaming Experiments}

Foaming experiments were performed in a high-pressure vessel (model PARR 4681) provided by Parr Instruments Company with a capacity of 1 litre, capable of operating at a maximum temperature of $350^{\circ} \mathrm{C}$ and a maximum pressure of $41 \mathrm{MPa}$. An accurate pressure pump controller (model SFT-10) provided by Supercritical Fluid Technologies Inc. controls automatically the pressure 
to keep the desired value. The vessel is equipped with a clamp heater of $1200 \mathrm{~W}$, and its temperature is controlled via a CAL 3300 temperature controller. With this set up foaming experiments were performed using a two-step foaming process [40]. Samples were firstly introduced in the pressure vessel under a particular pressure for the saturation stage. After saturation, the pressure was abruptly released at a pressure drop rate of $15 \mathrm{MPa} / \mathrm{s}$. Then samples were removed from the pressure vessel and immersed in a thermal bath at the desired foaming temperature. The time between the release of pressure and the immersion of samples in the baths was 3.5 minutes.

The saturation temperature was fixed at $25^{\circ} \mathrm{C}$, the saturation pressure was equal to $10 \mathrm{MPa}$, and the saturation time was $20 \mathrm{~h}$, as this time is enough to ensure that the PMMA samples will be saturated at these conditions [29]. Foaming was carried out in a water bath at $80{ }^{\circ} \mathrm{C}$ during 1.5 minutes. It is important to remark that under these saturation conditions $\left(25^{\circ} \mathrm{C}\right.$ and $10 \mathrm{MPa}$ ) the effective glass transition temperature of PMMA after the gas absorption is below room temperature [29], so samples start to expand immediately after the release of pressure. Nevertheless, this expansion is clearly smaller than that taking place when the samples are introduced in the thermal bath.

\subsection{Characterization}

\subsubsection{Nanostructuration of the Blends}

Nanostructuration of the solid PMMA/MAM precursors was analysed using transmission electron microscopy (TEM). For this purpose, each sample was cut in ultrathin slices (with a thickness of approximately 80 - $90 \mathrm{~nm}$ ) using a Leica EM UC6 Ultramicrotome. Because of the soft behaviour of the polymer, it was necessary to trim and cut all the samples in cryogenic conditions, cooling down the environment and the sample holder at least at $-60^{\circ} \mathrm{C}$, using a specific cryo-system Leica EM FC6 and a specific diamond knife for low-temperature cuts. Slices were collected and laid down onto a 200 mesh formvar/carbon-coated copper TEM grids.

Transmission electron microscopy (TEM) images were collected with a Jeol JEM 1011 (Jeol, Japan) electron microscope (Electron Microscopy Lab. - Nanochemistry Dept., Istituto Italiano di Tecnologia), operating at an acceleration voltage of $100 \mathrm{kV}$, and recorded with a $11 \mathrm{Mp}$ fiber optical charge-coupled device (CCD) camera (Gatan Orius SC-1000).

TEM images were used to quantify the nanostructuration found in the solid blends. Micelle size $\left(\phi_{m}\right)$ was measured using the software ImageJ/FIJI [41,42]. More than 100 micelles of different areas were considered for the analysis. The standard deviation (SD) of the micelle size distribution and the normalized parameter $\mathrm{SD} / \phi_{m}$ were calculated as an indicator of the homogeneity of the micelle size distribution. The volumetric micelle density $\left(n_{\text {mic }}\right)$ was calculated by dividing the number of micelles in a TEM image by the volume (area of the image times the thickness of the sample (around $80 \mathrm{~nm})$ ). In addition, the intermicelle distance was measured using a Delaunay-Voronoi diagram in Image J/FIJI [42].

From the micelle density $\left(n_{\text {mic }}\right.$ ), the aggregation number $N_{c}$ (number of copolymer molecules per micelle) was estimated theoretically using equation (1) [31], where $w$ is the amount of copolymer, 
$N_{a v}$ is the Avogadro's number, $\rho$ is the density of the blend, and $M_{n}$ is the molecular weight of the copolymer.

$$
N_{c}=\frac{w N_{a v} \rho}{M_{n} n_{m i c}}
$$

\subsubsection{Rheological Behaviour}

Rheological behaviour of the pure PMMA and the PMMA/MAM blends was investigated using a stress-controlled rheometer, AR 2000 EX from TA Instruments. Shear rheology measurements were performed at a temperature equal to $230^{\circ} \mathrm{C}$ under a nitrogen atmosphere using a parallel plates geometry of $25 \mathrm{~mm}$ in diameter and a fixed gap of $1 \mathrm{~mm}$. Dynamic-mechanical experiments over an angular frequency range of $0.01<\omega<100 \mathrm{rad} / \mathrm{s}$ were performed for all the blends and the pure polymer. A strain of $4 \%$ for the pure PMMA and $6 \%$ for the PMMA/MAM blends, both within the linear viscoelastic response of the different materials, was used. From these measurements three magnitudes were analysed: the dynamic shear viscosity $\left(\eta^{*}\right)$, the storage modulus $\left(G^{\prime}\right)$ and the loss modulus $\left(G^{\prime \prime}\right)$.

\subsubsection{Density}

The density of the solid samples was measured with a gas pycnometer (model AccuPyc II 1340, Micromeritics). The density of the corresponding cellular materials was determined with the waterdisplacement method based on Archimedes' principle. A density determination kit for an AT261 Mettler-Toledo balance has been used for this purpose. The solid skin of the foamed samples was removed out with a polisher (model LaboPOl2-LaboForce3, Struers) before measuring their densities. Relative density $\left(\rho_{\mathrm{r}}\right)$ was calculated as the ratio between the cellular material density $\left(\rho_{\mathrm{f}}\right)$ and the density of the solid polymer blend $\left(\rho_{\mathrm{s}}\right)$.

\subsection{4. $\mathrm{CO}_{2}$ Uptake}

The amount of gas uptake was calculated as the percentage of weight increment of the sample due to the $\mathrm{CO}_{2}$ sorption. The initial mass was measured after drying the samples and before being placed in the pressure vessel and the final weight was evaluated by weighting the samples immediately after being removed from the pressure vessel. The time between the depressurisation and the weight measurement was around 2 minutes. During this time some gas was lost due to gas diffusion out of the sample. Thus, these measurements are only an estimation of the solubility, and therefore the values obtained were only used for comparison between the different samples.

\subsubsection{Cellular Structure}

The cellular structure of the samples was analysed using an ESEM, Environmental Scanning Electron Microscope (Quanta $200 \mathrm{FEG}$ ). With the aim of maintaining the cellular structure for the microscopic visualisation, samples were cooled in liquid nitrogen, fractured and finally coated with gold using a sputter coater (model SCD 005, Balzers Union). Various parameters were measured in order to obtain a complete analysis of the cellular structure. A tool based on the software ImageJ/FIJI [41,42] was used to quantify the structural parameters. Firstly, the average cell size $(\phi)$, the cell size distribution and the standard deviation coefficient of the cell size distribution (SD) were obtained. The parameter SD $/ \phi$ (normalised standard deviation coefficient) was calculated as an indicator of the homogeneity of the cellular structure. This parameter is used for comparison between 
materials with a different cell size. Cell density $\left(N_{v}\right)$ and cell nucleation density $\left(N_{0}\right)$ were determined using Kumar's theoretical approximation [43] according to equations (2) and (3), respectively, where $n$ is the number of cells in the image and $A$ is the area of the image. More than 200 cells of different areas of each cellular material were analysed.

$$
\begin{gathered}
N_{v}=\left[\frac{n}{A}\right]^{3 / 2} \\
N_{0}=\frac{N_{v}}{\rho_{r}}
\end{gathered}
$$

Cell wall thickness of the cellular materials was measured directly from the micrographs. More than fifty cell walls were measured per material.

\section{RESULTS AND DISCUSSION}

\subsection{Nanostructuration of the Blends}

Figure 1 shows the TEM images of the solid PMMA/MAM blends. The TEM micrographs reveal the existence of a nanostructuration in these materials. As seen in the images, block copolymer selfassemble forming nanometric spherical micelles. Note that these nanostructures are a consequence of an extrusion process, and thus they can be considered as non-equilibrium structures.

The influence of MAM copolymer molecular weight on the nanostructuration can be appreciated in Figure 1; the higher the molecular weight, the greater the number of micelles, for the same area. This first impression was later on confirmed by the analysis of the micelle density (Table 2 ). It is important to remark that this analysis is based on the interfaces between the micelle and the matrix detected by TEM, and no staining was used to reveal the block copolymer. An increase in the micelle density is detected when the MAM molecular weight increases. In fact, the blend containing the copolymer with the lowest molecular weight, 90/10_L, shows a micelle density almost four times smaller than that of the blend 90/10_H. This is an important result which could induce significant differences in the cellular structure when these materials are used for foaming applications.

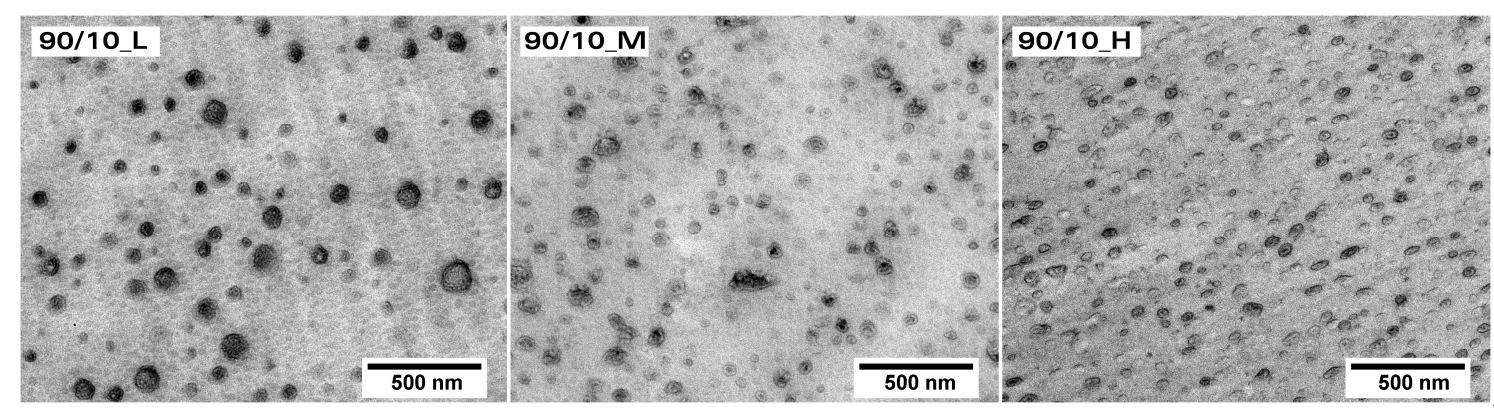

Figure 1. TEM micrographs showing the nanostructuration of the PMMA/MAM blends with the different block copolymers. Left: 90/10_L, Middle: 90/10_M. Right: 90/10_H.

Moreover, the micelle size looks smaller for higher MAM molecular weights (Figure 1). The average apparent size of the micelles varies from $40 \mathrm{~nm}$ for 90/10_H to $70 \mathrm{~nm}$ for 90/10_L (Table 2). This is in agreement with the micelle density trends, as the three blends have a constant content of MAM. 
In conclusion, increasing MAM molecular weight leads to smaller micelles and higher micelle densities. On the other hand, micelle size distributions in the three blends are homogeneous and present similar homogeneities, as they show a similar value of the parameter SD $/ \phi_{m}$ (Table 2).

Table 2. Nanostructure characteristic of PMMA/MAM 90/10 solid blends precursors.

\begin{tabular}{ccccc}
\hline Sample ID & $\begin{array}{c}\text { Micelle density } \\
(\text { micelles/cm }\end{array}$ & $\begin{array}{c}\text { Micelle size } \\
(\mathrm{nm})\end{array}$ & $\mathbf{S D} / \boldsymbol{\phi}_{\boldsymbol{m}}$ & $\begin{array}{c}\text { Aggregation } \\
\text { number }\end{array}$ \\
\hline 90/10_L & $(2.1 \pm 0.0) \cdot 10^{14}$ & 68 & 0.37 & 13400 \\
90/10_M & $(7.3 \pm 0.4) \cdot 10^{14}$ & 60 & 0.37 & 2200 \\
90/10_H & $(7.7 \pm 0.9) \cdot 10^{14}$ & 40 & 0.35 & 1100 \\
\hline
\end{tabular}

The differences among the three copolymers are too high to be related with the small differences found in the PBA content (Table 1). In addition, previous works show that micelle densities as high as $4 \cdot 10^{14}$ nuclei/ $\mathrm{cm}^{3}$ could be achieved in 90/10 PMMA/MAM blends with only a $36 \mathrm{wt} \%$ of PBA in the MAM phase [29], higher than that obtained with the blend 90/10_L that has a higher PBA content. Then, the variations found in the blends of this work should be related with the different molecular weights of the copolymers.

In order to understand the origin of the nanostructuration of the blends, we propose that it might be a consequence of two processes: the dispersion of the MAM in the PMMA during the extrusion process and the self-assembly of the MAM molecules to form the micelles. The first process is controlled by the relative viscosities of the PMMA and the MAM at the extrusion conditions. According to the model proposed by Wu [44], when a polymer of viscosity $\eta_{d}$ is dispersed in a matrix of viscosity $\eta_{m}$ (with $\eta_{m}>\eta_{d}$, according to the MFI data reported in section 2.1), the dispersed phase will form aggregates of size :

$$
d=\frac{\sigma \cdot 4}{\eta_{m}^{0.16} \dot{\gamma} \eta_{d}^{0.84}}
$$

Where $\sigma$ is the interphase surface tension and $\dot{\gamma}$ is the shear velocity of the extruder screws. According to this equation, for a fixed matrix, the size of the aggregates will decrease with increasing viscosity of the dispersed polymer. Since higher molecular weights are associated with higher viscosities (see Table 1), then the higher the MAM molecular weight, the smaller the aggregates or MAM-rich regions.

On the other hand, in the MAM-rich regions, molecules should self-assembly to create the micelles. For an equilibrium process, the maximum number of micelles $\left(n_{\max }\right)$ can be estimated theoretically [31] according to equation (4). Assuming constant aggregation number and copolymer content, this equation would predict that the number of micelles will depend inversely on the molecular weight. But during the extrusion process (non-equilibrium), the MAM is dispersed in regions which are smaller for higher molecular weights. Then, it is plausible to assume that the number of molecules in each region will decrease with the increase of the molecular weight, as not only the regions are smaller but also the molecules occupy a higher volume. If the molecules in each MAM-rich region self-assembly in a micelle, then the number of molecules in a micelle (that is, the aggregation number) will be smaller for larger MAM molecular weights. This hypothesis is in agreement with equation (4) and the results of Table 2, in which the aggregation numbers were estimated. 
Aggregation numbers ranging 1100-13000 were calculated for these systems. These results are in agreement with the typical aggregation numbers found in the literature, which vary from 1000 10000 [45] to 40-400 [46].

Hence, the dispersion of the copolymer during the extrusion process is the key process controlling the nanostructuration of the blends. Therefore, by adjusting the extrusion parameters, the size of the MAM-rich dispersed regions could be reduced, and thus the aggregation number decreased, yielding to higher micelle densities for the same amount of MAM. It is interesting to calculate the maximum micelle density achievable with these PMMA/MAM systems assuming a smaller aggregation number. For instance, for an aggregation number of 400 , micelle densities as high as $5 \cdot 10^{15}$ micelles $/ \mathrm{cm}^{3}$ could be achieved. Therefore, there could be room for a further improvement of the nanostructure by adjusting the extrusion parameters. If the optimization of the extrusion process allows the dispersion of the MAM on small regions of about 400 molecules, it would be possible to increase the nucleation density in one order of magnitude.

\subsection{Rheological Behaviour}

Figure 2 shows the complex viscosity (a), the storage modulus (b) and the loss modulus (c) as a function of angular frequency for the pure PMMA and the for the blends containing $10 \%$ of the high, medium and low molecular weight MAMs. Figure 2.a indicates that there is a relationship between the complex viscosity (obtained at low frequencies) and the copolymer molecular weight. The lower the MAM molecular weight, the lower the complex viscosity of the blend.

Moreover, these measurements also indicate that at low frequencies, in the terminal region, the shape of the complex viscosity and storage modulus curves depends on the polymer matrix. The pure PMMA follows the typical behaviour of a thermoplastic polymer. The storage modulus is proportional to the square of the frequency, $G^{\prime} \propto \omega^{2}$ and the loss modulus is proportional to the frequency, $G^{\prime \prime} \propto \omega$. Guided lines of these slopes have been added to Figures 2.b and 2.c as reference. On the other hand, the complex viscosity reaches a Newtonian plateau. However, the PMMA/MAM blends do not follow this trend. Figure 2 indicates that as the MAM molecular weight increases the Newtonian plateau is progressively replaced by a non-Newtonian power law (Figure 2.a) and the slope of the storage modulus is approaching zero (Figure 2.b). In particular, for the blend 90/10_H, the slope is as low as 0.4. This behavior could be ascribed to a percolation phenomenon produced by the fact of having an incompatible polymer blend, which was previously observed through TEM characterization (Figure 1) [47,48]. An increase in the MAM molecular weight led to an increase of the micelle density (see Table 2) and hence, to a stronger interaction between the micelles, as they are closer. It has been reported for different polymer blends with rubber particles that the drastic increase of the complex viscosity in the terminal region and the appearance of a secondary plateau in the storage modulus curve, at low frequencies, is attributed to a network-type structure formed by the soft nodules $[28,47,48]$. 


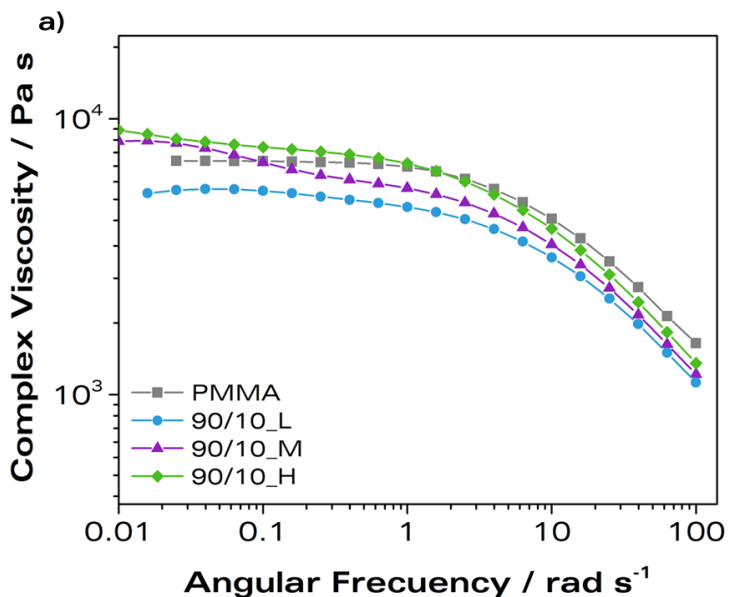

b)

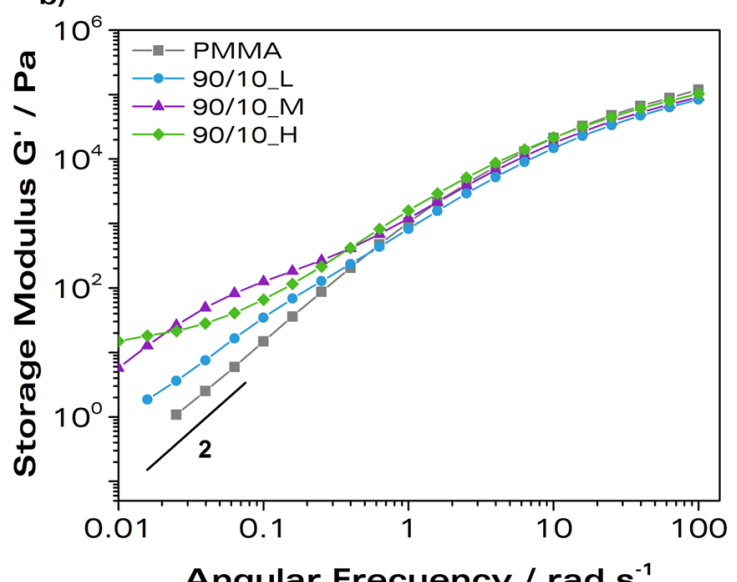

c)

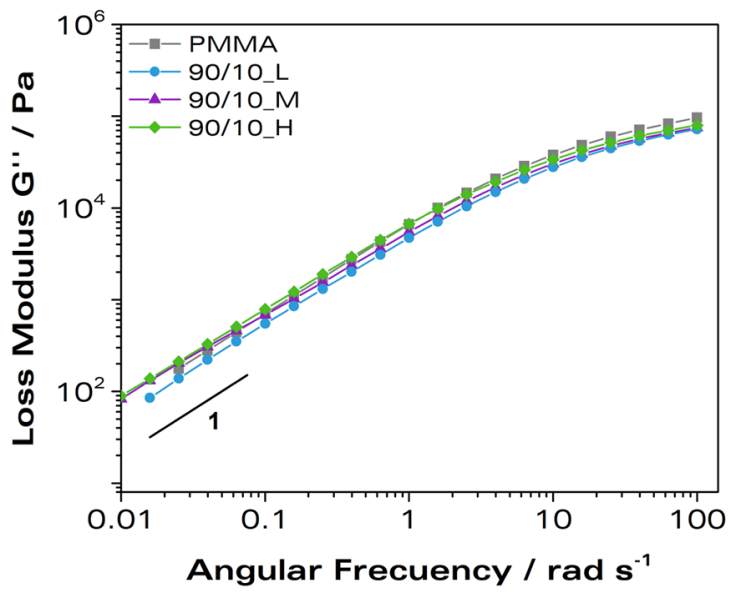

Figure 2. a) Complex viscosity, b) storage modulus ( $\left.G^{\prime}\right)$ and c) loss modulus (G") of PMMA and PMMA/MAM blends as a function of the angular frequency at $230{ }^{\circ} \mathrm{C}$. The slope of the typical behaviour of a typical thermoplastic polymer of both the storage modulus and the loss modulus in the terminal region is also shown in this figure.

\subsection{Cellular Structure}

Cellular materials were obtained from the solid PMMA and PMMA/MAM blends at constant saturation (10 MPa and $25^{\circ} \mathrm{C}$ ) and foaming ( $80^{\circ} \mathrm{C}$ and $1.5 \mathrm{~min}$ ) conditions. The cellular structure of 
these materials was characterised to analyse the effect of the MAM copolymer molecular weight on the foaming process. Table 3 summarises the structural parameters of these materials.

Table 3. Cellular structure characteristics of the samples produced at $10 \mathrm{MPa}$ of saturation pressure and $80^{\circ} \mathrm{C}$ of foaming temperature.

\begin{tabular}{ccccccc}
\hline Sample & $\begin{array}{c}\text { Gas Uptake } \\
(\text { wt\% })\end{array}$ & $\begin{array}{c}\text { Relative } \\
\text { Density }\end{array}$ & $\begin{array}{c}\text { Cell Nucleation } \\
\text { Density }\left(\text { nuclei/cm }{ }^{3}\right)\end{array}$ & $\begin{array}{c}\text { Cell Size } \\
(\mathrm{nm})\end{array}$ & SD / $\boldsymbol{C}$ & $\begin{array}{c}\text { Cell Wall } \\
\text { Thickness }(\mathrm{nm})\end{array}$ \\
\hline PMMA & 24.1 & 0.30 & $(5.60 \pm 0.50) \cdot 10^{11}$ & 1701 & 0.82 & $160 \pm 50$ \\
90/10_L & 25.5 & 0.37 & $(2.51 \pm 0.70) \cdot 10^{14}$ & 202 & 0.80 & $28 \pm 6$ \\
90/10_M & 25.4 & 0.49 & $(4.48 \pm 0.00) \cdot 10^{14}$ & 156 & 0.64 & $24 \pm 6$ \\
90/10_H & 25.6 & 0.57 & $(8.74 \pm 0.30) \cdot 10^{14}$ & 119 & 0.43 & $25 \pm 6$ \\
\hline
\end{tabular}

Under these conditions, pure PMMA absorbs a $24.1 \mathrm{wt} \%$ of $\mathrm{CO}_{2}$ (Table 3). Solubility measurements in the PMMA/MAM blends show that $\mathrm{CO}_{2}$ absorption increases with respect to the pure polymer up to a $25.5 \mathrm{wt} \%$, approximately. Literature data show that PBA homopolymer has a higher $\mathrm{CO}_{2}$ solubility than PMMA [49]; as a result, higher $\mathrm{CO}_{2}$ concentrations are measured in the blends containing MAM. Similar results were also found by Pinto and coworkers $[10,29,30]$. Moreover, these results also indicate that the MAM molecular weight is not affecting the blend solubility as no trend is observed by modifying this parameter.

Figure 3 shows the cellular structure of the pure polymer and the different blends. Clear differences are found among these materials. Whereas the pure polymer presents a microcellular structure (Figure 3.a), the blends with MAM show a nanocellular structure (Figure 3.b, 4.c and 3.d). This different behaviour can be explained taking into account that the saturation pressure used (10 MPa) is not high enough to achieve a nanocellular structure in the pure PMMA. However, the nanostructure found in the PMMA/MAM blends supports their excellent performance as systems to produce nanocellular materials, without the need of using extremely high saturation pressures.

At these conditions, the pure polymer shows a cell nucleation density of $5.6 \cdot 10^{11}$ nuclei/ $\mathrm{cm}^{3}$ (Table 3), while the PMMA/MAM blends have cell nucleation densities higher than $10^{14}$ nuclei/ $/ \mathrm{cm}^{3}$ (Table 3). In order to analyse the effect of the MAM molecular weight on nucleation, cell nucleation density was plotted as a function of the molecular weight and compared with the micelle density (Figure 4). Both the cell nucleation density and the micelle density increase with block copolymer molecular weight. In addition, these nucleation densities are similar to the micelle densities found in the solid precursors (Figure 4). These results support the already proved fact that the nanostructuration in the PMMA/MAM blends is controlling the cell nucleation density in the cellular material [29], that is, one micelle in the solid precursor contributes to the creation of one single cell in the cellular material. This result implies that no coalescence is taking place in these materials. Therefore, the molecular weight of the MAM can be used as a tool to control firstly the micelles nanostructuration and then, the cell nucleation density. With the block copolymers used in this work, cell nucleation density can be varied in a factor of 4 (from $2 \cdot 10^{14}$ to $8 \cdot 10^{14}$ nuclei/ $/ \mathrm{cm}^{3}$ ) just by tuning the molecular weight of the block copolymer. 


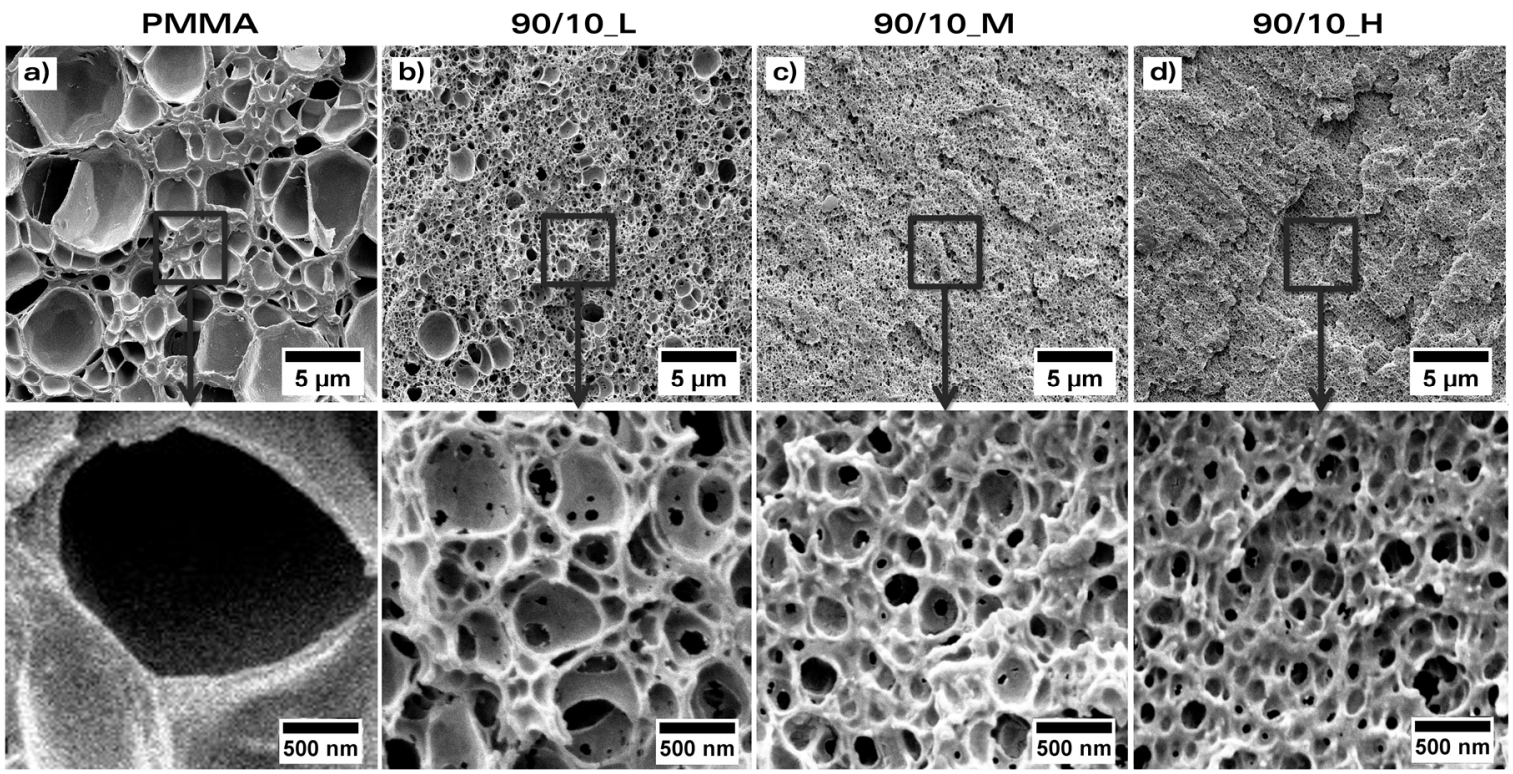

Figure 3. SEM images of the samples produced at $10 \mathrm{MPa}$ of saturation pressure and $80{ }^{\circ} \mathrm{C}$ of foaming temperature, a) PMMA, b) 90/10_L, c) 90/10_M and d) 90/10_H. The second row corresponds to high-magnification images.

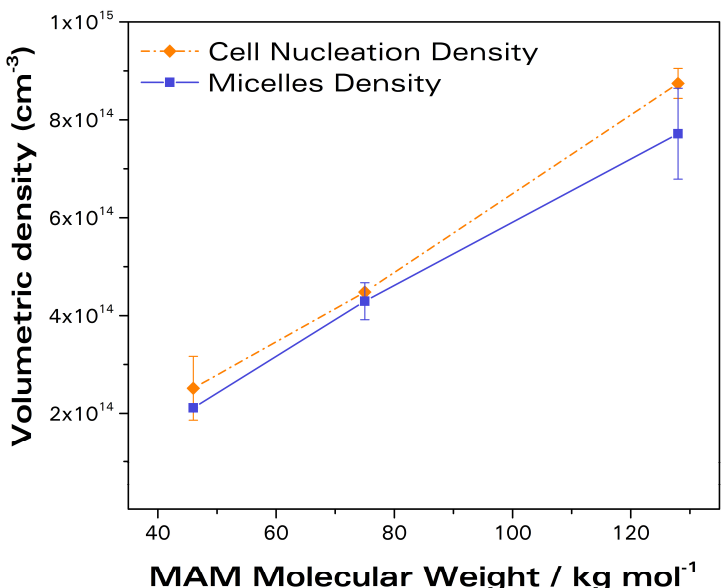

Figure 4. Micelle density and cell nucleation density (at $80^{\circ} \mathrm{C}$ ) as a function of the MAM molecular weight.

Regarding the cell size of the materials, it is observed that it decreases as MAM molecular weight increases (Table 3). In particular, a cell size of $200 \mathrm{~nm}$ is observed for 90/10_L, while 90/10_H presents a cell size of $120 \mathrm{~nm}$. This result can be explained taking into account that the higher the nucleation density, the more limited is the growing of the cells, yielding to smaller cell sizes. This can be precisely understood by observing the Voronoi diagrams of the micelle nanostructations on the solids (Figure 5): the higher the number of micelles, the smaller the area of the tessellation polygons and the distance between the micelles (intermicelle distance), so the smaller the space available for growing. In fact, the intermicelle distances in the solid blends show a similar trend with the MAM molecular weight than the cell size of the cellular materials (see Table 3), supporting this idea. 
90/10 L

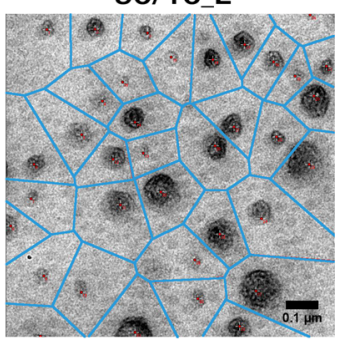

90/10 M

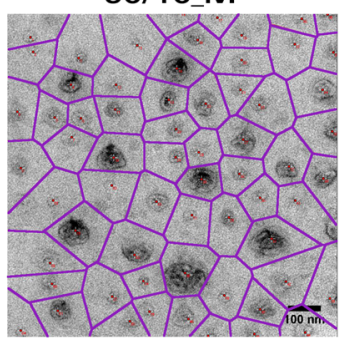

$90 / 10 \mathrm{H}$

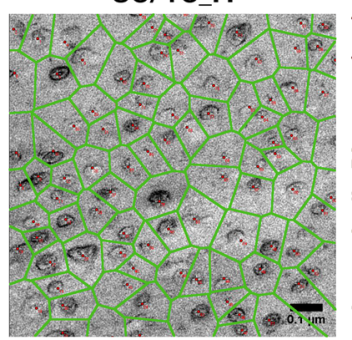

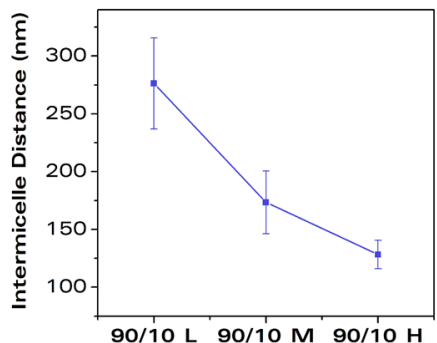

Figure 5. Voronoi diagrams and results: average intermicelle distance and standard deviation.

In addition to the differences found in the cell size, it was detected that the homogeneity of the cellular structure (measured by the parameter $S D / \phi$ ) is also influenced by the MAM molecular weight. Table 3 shows that the pure polymer and the blend 90/10_L show a very heterogeneous cell size distribution ( $S D / \phi$ higher than 0.8), while the other two blends, 90/10_M and 90/10_H, present a better homogeneity (lower values of $S D / \phi$.) In Figure 3.b, which showed the cellular structure of the blend 90/10_L, the very heterogeneous cell size distribution of this material can be appreciated. This result can be related with the heterogeneous distribution of the distance between the micelles, shown in Figure 6 (notice the standard deviation of the intermicelle distance is much higher in the blend 90/10_L). This heterogeneous dispersion of the micelles may cause that each micelle has a different space for growing, leading to a heterogeneous cellular structure.

Regarding the effect of the molecular weight on the relative density, an increase of this parameter is observed when the MAM molecular weight increases (Table 3). Besides, the relative density reached with the PMMA/MAM blends is higher than that of the pure polymer despite the largest $\mathrm{CO}_{2}$ uptake in the blends. This is a known limitation of the strategy of using block copolymers to produce nanocellular polymers. It is believed that nucleation takes place within the micelles [29] and hence, the nanodomains cannot grow enough to achieve large expansion ratios [5]. In this work, we proposed a theoretical explanation of this phenomenon by taking into account the cell wall thickness measured in these materials. It is observed that this parameter is constant (around $25 \mathrm{~nm}$ ) for the three cellular materials, independently of the MAM molecular weight (Table 3). So we hypothesised that the micelles grow until the polymer between them reaches a minimum limit of thickness. After this limit is achieved, no further expansion occurs. This is schematized in the first column of Figure 6 . The physical mechanism underlying this limitation may be related to the stretching of the polymer molecular chains in very thin cell walls. Once all the molecules are aligned no further stretching is allowed and confinement effect appears [6]. On the other hand, there may be a geometric limitation due to the size of the polymeric chains in the nanometric range [50,51]. Furthermore, once a very thin cell wall is reached, walls may fail, causing ruptures in the walls. Then, cellular structure becomes open cell and gas pressure is lost through the holes, preventing further expansion [7].

Our argument agrees with relevant literature results; for instance, in PMMA nanocellular polymers a cell wall thickness of around $25 \mathrm{~nm}$ was measured [7] and in PMMA/MAM system this value was around $30 \mathrm{~nm}$ [6]. Moreover, cell wall thickness in other works with PMMA and PMMA copolymers $[25,29,35]$ also varies in the range $25-30 \mathrm{~nm}$. Thus, it looks like cell wall thickness limitation is indeed a mechanism that should be taken into consideration to understand the formation of nanocellular polymers. Assuming that this is the mechanism that limits the expansion, we can explain the 
differences in relative density found for the different MAM molecular weights. We observed that the higher the MAM molecular weight, the higher the relative density of the cellular material. Higher MAM molecular weights imply larger number of micelles and therefore smaller distances among them. Thus more micelles have less space to grow before reaching this minimum cell wall thickness. As a result, higher micelle densities in the solid (higher MAM molecular weights) produce higher densities in the cellular material.

In an own previous work [7] we detected a cell wall thickness of around $25 \mathrm{~nm}$ for nanocellular polymers based on pure PMMA. However, in that work we proved that density could be further reduced by reducing the fraction of mass in the struts, obtaining relative densities as low as 0.24 . However, this is not observed in the PMMA/MAM-based materials. The explanation is schematized in Figure 6. In a pure PMMA, the nuclei can grow into cells until they reach a minimum cell wall thickness. After that, the cells can further grow by reducing the struts thickness, becoming polygons. In a PMMA/MAM-based system, the growing mechanism is entirely different. Nucleation takes places within the micelle, and the micelle itself grows to form the cells. The existence of the micelles implies the presence of certain order between the MAM and PMMA molecules of the micelles and around them. Once the nucleation takes place and the cells start to grow, this molecular order plays a role on the expansion of the cells, promoting the preservation of the spherical shape (i.e., the change from spheres to polygons requires not only the stretching of the molecules, but also a disruption of this molecular order; whereas on an homogeneous PMMA matrix the molecules present a higher freedom allowing the adoption of polygon shapes). This theoretical explanation matches with the literature view of the limited cell packing of templated systems [5].

PMMA/MAM

a)

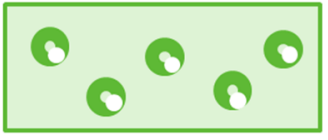

b)

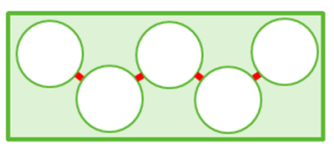

c)

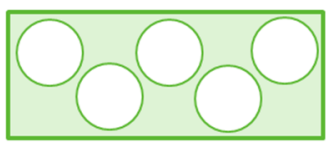

d)

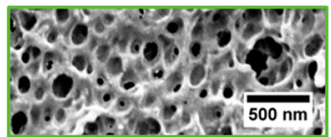

PMMA
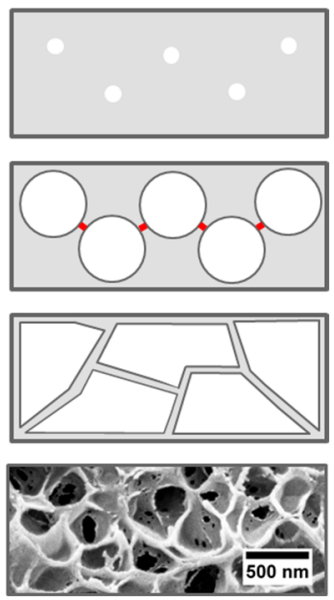

Figure 6. Growing mechanisms in a PMMA/MAM blend and a pure PMMA: a) Nucleation in the micelles or the PMMA, b) growing until a minimum cell wall thickness is reached, c) stabilization of the spherical cells in the PMMA/MAM system and further growth in the PMMA system by reducing the struts thickness and d) SEM images showing spherical cells in PMMA/MAM and polygonal cells in PMMA. 


\section{CONCLUSIONS}

Nanocellular polymeric materials based on PMMA/MAM blends have been produced by means of a two-step gas dissolution foaming process. Three MAM copolymers were used with the aim of analysing the effect of the molecular weight of the block copolymer. Throughout the paper, it was shown that MAM molecular weight could be used as a tool to control the nanostructuration in PMMA/MAM blends, which in turn controls the cellular structure.

In particular, nanostructuration of the blends was studied by TEM image analysis. It was detected that after the extrusion process a nanostructuration appears in the PMMA/MAM solid blends. Note that these structures should be considered as non-equilibrium structures. The micelle density was found to increase as MAM molecular weight increases. To explain this result, two phenomena must be taken into consideration: the dispersion of the MAM during the extrusion process and the selfassembly of the MAM molecules. During the extrusion process, a MAM with higher viscosity (i.e., higher molecular weight) is dispersed in smaller domains. In these MAM-rich domains, selfassembly takes place, in such a way that the aggregation number is lower for higher molecular weights, leading to higher micelle densities. Therefore, extrusion process could be tuned to control or modify the nanostructuration of the blends.

Regarding the cellular materials, higher MAM molecular weights produce nanocellular materials with higher cell nucleation densities. In fact, micelle density and cell nucleation density are practically the same, so it was confirmed that nucleation happens within the micelles and each micelle produces a cell. Cell size decreases as MAM molecular weight increases. This is a result of the distance between the micelles. The intermicelle distance decreases as micelle density increases, so the micelles have less space to grow. The homogeneity of the cellular structure was proved to be directly related to the homogeneity of the intermicelle distance. In addition, it was detected that the relative density increases as MAM molecular weight increases. Once again, this result can be related to the growing of the cells. We proposed that cells can grow until a minimum cell wall thickness (of around $25 \mathrm{~nm}$ ) is reached. As this minimum thickness is reached sooner for higher MAM molecular weights (smaller intermicelle distance), higher densities are obtained. In addition, the mechanisms of growing in PMMA/MAM systems were discussed. We hypothesise that micelles could only grow spherically, this being the reason underneath the limited expansion that can be achieved with these systems.

\section{Acknowledgements:}

Financial assistance from MINECO, FEDER, UE (MAT2015-69234-R) and the Junta de Castile and Leon (VA011U16) are gratefully acknowledged. Financial support from Junta of Castile and Leon grant (J. Martín-de León) and FPU grant FPU14/02050 (V. Bernardo) from the Spanish Ministry of Education is gratefully acknowledged. We also want to thank Arkema for supplying the copolymers used in this research.

\section{REFERENCES}

[1] B. Notario, J. Pinto, M.A. Rodriguez-Perez, Nanoporous polymeric materials: A new class of materials with 
enhanced properties, Prog. Polym. Sci. 78-79 (2016) 93-139. doi:10.1016/j.pmatsci.2016.02.002.

[2] B. Notario, J. Pinto, E. Solorzano, J.A. de Saja, M. Dumon, M.A. Rodriguez-Perez, Experimental validation of the Knudsen effect in nanocellular polymeric foams, Polymer (Guildf). 56 (2015) 57-67. doi:10.1016/j.polymer.2014.10.006.

[3] B. Notario, J. Pinto, M.A. Rodríguez-Perez, Towards a new generation of polymeric foams: PMMA nanocellular foams with enhanced physical properties, Polymer (Guildf). $63 \quad$ (2015) 116-126. doi:10.1016/j.polymer.2015.03.003.

[4] B. Notario, A. Ballesteros, J. Pinto, M.A. Rodriguez-Perez, Nanoporous PMMA: A novel system with different acoustic properties, Mater. Lett. 168 (2016) 76-79. doi:10.1016/j.matlet.2016.01.037.

[5] S. Costeux, CO2-blown nanocellular foams, J. Appl. Polym. Sci. 131 (2014) 41293(1)-41293(16). doi:10.1002/app.41293.

[6] J. Pinto, B. Notario, R. Verdejo, M. Dumon, S. Costeux, M.A. Rodriguez-perez, Molecular confinement of solid and gaseous phases of self-standing bulk nanoporous polymers inducing enhanced and unexpected physical properties, Polymer (Guildf). 113 (2017) 27-33. doi:10.1016/j.polymer.2017.02.046.

[7] J. Martin de-Leon, V. Bernardo, M.A. Rodriguez-Perez, Low Density Nanocellular Polymers Based on PMMA Produced by Gas Dissolution Foaming: Fabrication and Cellular Structure Characterization, Polymers (Basel). 8 (2016) 1-16. doi:10.3390/polym8070265.

[8] S. Perez-Tamarit, B. Notario, E. Solorzano, M.A. Rodriguez-Perez, Light transmission in nanocellular polymers: are semi-transparent cellular polymers possible?, Mater. Lett. 210 (2017) 39-41. doi:10.1016/j.matlet.2017.08.109.

[9] L. Li, L. Schulte, L.D. Clausen, K.M. Hansen, G.E. Jonsson, S. Ndoni, Gyroid nanoporous membranes with tunable permeability, ACS Nano. 5 (2011) 7754-7766. doi:10.1021/nn200610r.

[10] J. Pinto, M. Dumon, M.A. Rodriguez-Perez, R. Garcia, C. Dietz, Block Copolymers Self-Assembly Allows Obtaining Tunable Micro or Nanoporous Membranes or Depth Filters Based on PMMA; Fabrication Method and Nanostructures, J. Phys. Chem. C. 118 (2014) 4656-4663. doi:10.1021/jp409803u.

[11] G.Q. Lu, X.S. Zhao, Nanoporous Materials - An Overview, in: Nanoporous Mater. Sci. Eng., Imperial Collegue Press, London, 2004. doi:10.1142/9781860946561_0001.

[12] H.P. Hentze, M. Antonietti, Porous polymers and resins for biotechnological and biomedical applications, Rev. Mol. Biotechnol. 90 (2002) 27-53. doi:10.1016/S1389-0352(01)00046-0.

[13] D.A. Bernards, T.A. Desai, Nanoscale porosity in polymer films: fabrication and therapeutic applications., Soft Matter. 6 (2010) 1621-1631. doi:10.1039/B922303G.

[14] J. Martin-de Leon, V. Bernardo, M.A. Rodriguez-Perez, Key Production Parameters to Obtain Transparent Nanocellular PMMA, Macromol. Mater. Eng. 1700343 (2017) 1-5. doi:10.1002/mame.201700343.

[15] H. Guo, A. Nicolae, V. Kumar, Solid-state poly(methyl methacrylate) (PMMA) nanofoams. Part II: Lowtemperature solid-state process space using CO2 and the resulting morphologies, Polymer (Guildf). 70 (2015) 231-241. doi:10.1016/j.polymer.2015.06.031.

[16] H. Guo, V. Kumar, Solid-state poly(methyl methacrylate) (PMMA) nanofoams. Part I: Low-temperature CO2 sorption, diffusion, and the depression in PMMA glass transition, Polymer (Guildf). 57 (2015) 157-163. doi:10.1016/j.polymer.2014.12.029.

[17] H. Guo, V. Kumar, Some thermodynamic and kinetic low-temperature properties of the PC-CO2 system and morphological characteristics of solid-state PC nanofoams produced with liquid CO2, Polymer (Guildf). 56 (2015) 46-56. doi:10.1016/j.polymer.2014.09.061.

[18] H. Guo, A. Nicolae, V. Kumar, Solid-State Microcellular and Nanocellular Polysulfone Foams, J. Polym. Sci. Part B Polym. Phys. 53 (2015) 975-985. doi:10.1002/polb.23719.

[19] V. Bernardo, J. Martín-de Leon, M.A. Rodriguez-Perez, Production and characterization of nanocellular polyphenylsulfone foams, Mater. Lett. 178 (2016) 155-158. doi:10.1016/j.matlet.2016.05.002.

[20] H. Guo, A. Nicolae, V. Kumar, Fabrication of High Temperature Polyphenylsulfone Nanofoams Using High Pressure Liquid Carbon Dioxide, Cell. Polym. 35 (2015) 2016.

[21] D. Miller, P. Chatchaisucha, V. Kumar, Microcellular and nanocellular solid-state polyetherimide ( PEI ) foams using sub-critical carbon dioxide I. Processing and structure, Polymer (Guildf). 50 (2009) 5576-5584. doi:10.1016/j.polymer.2009.09.020.

D. Miller, V. Kumar, Microcellular and nanocellular solid-state polyetherimide (PEI) foams using sub-critical 
carbon dioxide II . Tensile and impact properties, Polymer (Guildf). 52 (2011) 2910-2919. doi:10.1016/j.polymer.2011.04.049.

[23] C. Zhou, N. Vaccaro, S.S. Sundarram, W. Li, Fabrication and characterization of polyetherimide nanofoams using supercritical CO 2, J. Cell. Plast. 48 (2012) 239-255. doi:10.1177/0021955X12437984.

[24] V.I. Kalikmanov, Nucleation Theory, Springer, 2013.

[25] S. Costeux, L. Zhu, Low density thermoplastic nanofoams nucleated by nanoparticles, Polymer (Guildf). 54 (2013) 2785-2795. doi:10.1016/j.polymer.2013.03.052.

[26] V. Bernardo, J. Martin-de León, E. Laguna-Gutiérrez, M.Á. Rodríguez-Pérez, PMMA-sepiolite nanocomposites as new promising materials for the production of nanocellular polymers, Eur. Polym. J. 96 (2017) 10-26. doi:10.1016/j.eurpolymj.2017.09.002.

[27] J. Pinto, D. Morselli, V. Bernardo, B. Notario, D. Fragouli, M.A. Rodriguez-Perez, A. Athanassiou, Nanoporous PMMA foams with templated pore size obtained by localized in situ synthesis of nanoparticles and $\mathrm{CO} 2$ foaming, Polymer (Guildf). 124 (2017) 176-185. doi:10.1016/j.polymer.2017.07.067.

[28] C. Forest, P. Chaumont, P. Cassagnau, B. Swoboda, P. Sonntag, CO2 nano-foaming of nanostructured PMMA, Polymer (Guildf). 58 (2015) 76-87. doi:10.1016/j.polymer.2014.12.048.

[29] J. Pinto, M. Dumon, M. Pedros, J. Reglero, M.A. Rodriguez-Perez, Nanocellular CO2 foaming of PMMA assisted by block copolymer nanostructuration, Chem. Eng. J. 243 (2014) 428-435. doi:10.1016/j.cej.2014.01.021.

[30] J. Pinto, J.A. Reglero-ruiz, M. Dumon, M.A. Rodriguez-Perez, Temperature influence and CO2 transport in foaming processes of poly(methyl methacrylate)-block copolymer nanocellular and microcellular foams, J. Supercrit. Fluids. 94 (2014) 198-205. doi:10.1016/j.supflu.2014.07.021.

[31] P. Spitael, C.W. Macosko, R.B. Mcclurg, Block Copolymer Micelles for Nucleation of Microcellular Thermoplastic Foams, Macromolecules. 37 (2004) 6874-6882. doi:10.1021/ma049712q.

[32] H. Yokoyama, K. Sugiyama, Nanocellular structures in block copolymers with CO2-philic blocks using CO2 as a blowing agent: Crossover from micro- to nanocellular structures with depressurization temperature, Macromolecules. 38 (2005) 10516-10522. doi:10.1021/ma051757j.

[33] H. Yokoyama, L. Li, C. Dutriez, Y. Iwakura, K. Sugiyama, H. Masunaga, S. Sasaki, H. Okuda, Horizontally and Vertically Aligned Polymeric Nanosheets: CO2-Induced Morphological Changes of Block Copolymer Thin Films, Macromolecules. 41 (2008) 8626-8631. doi:10.1021/ma801487a.

[34] J.A. Reglero Ruiz, M. Dumon, J. Pinto, M.A. Rodriguez-Perez, Low-density nanocellular foams produced by high-pressure carbon dioxide, Macromol. Mater. Eng. 296 (2011) 752-759. doi:10.1002/mame.201000346.

[35] C. Forest, P. Chaumont, P. Cassagnau, B. Swoboda, P. Sonntag, Nanofoaming of PMMA using a batch CO2 process: Influence of the PMMA viscoelastic behaviour, Polymer (Guildf). 77 (2015) 1-9. doi:10.1016/j.polymer.2015.09.011.

[36] P. Gerard, L. Couvreur, S. Magnet, Controlled Architecture Polymers at Arkema : Synthesis, Morphology and Properties of All- Acrylic Block Copolymers, in: ACS Symp. Ser. 1024, 2009: pp. 361-373.

[37] L. Lalande, Structure et mécanismes de microdéformation de polyméthylméthacrylates renforcés au choc, École Polytechnique Fédérale De Lausanne, 2007.

[38] L. Lalande, C.J.G. Plummer, J.E. Manson, P. Gerard, The influence of matrix modification on fracture mechanisms in rubber toughened polymethylmethacrylate, Polymer (Guildf). 47 (2006) 2389-2401. doi:10.1016/j.polymer.2006.02.016.

[39] L. Lalande, C.J.G. Plummer, P. Ge, J.E. Ma, Microdeformation mechanisms in rubber toughened PMMA and PMMA-based copolymers, Eng. Fract. Mech. 73 (2006) 2413-2426. doi:10.1016/j.engfracmech.2006.05.014.

[40] V. Kumar, N.P. Suh, A process for making microcellular parts, Polym. Eng. Sci. 30 (1990) 1323-1329. doi:https://doi.org/10.1002/pen.760302010.

[41] M.D. Abràmoff, P.J. Magalhães, S.J. Ram, Image Processing with ImageJ, Biophotonics Int. 11 (2004) 36.

[42] J. Pinto, E. Solorzano, M.A. Rodriguez-perez, J.A. De Saja, Characterization of the cellular structure based on user-interactive image analysis procedures, J. Cell. Plast. 49 (2013) 555-575. doi:10.1177/0021955X13503847.

[43] V. Kumar, Process synthesis for manufacturing microcellular thermoplastic parts, Massachusetts Institute of Technology, 1988.

[44] S. Wu, Formation of Dispersed Phase in Incompatible Polymer Interfacial and Rheological Effects, Polym. Eng. Sci. 27 (1987) 335-343. doi:10.1002/pen.760270506. 
[45] M.D. Whitmore, T.W. Smith, Swelling of Copolymer Micelles by Added Homopolymer, Macromolecules. 27 (1994) 4673-4683. doi:10.1021/ma00095a006.

[46] T. Imae, H. Tabuchi, K. Funayama, A. Sato, Self-assemblies of block copolymer of 2-perfluorooctylethyl methacrylate and methyl methacrylate, Colloids Surfaces A. 167 (2000) 73-81. doi:10.1016/S09277757(99)00484-7.

[47] N.A. Memon, Rheological properties and the interface in polycarbonate/impact modifier blends: Effect of modifier shell molecular weight, J. Polym. Sci. Part B-Polymer Phys. 36 (1998) 1095-1105. doi:10.1002/(sici)1099-0488(199805)36:7<1095::aid-polb1>3.3.co;2-n.

[48] P. Bardollet, M. Bousmina, R. Muller, Relationship between structure and rheological properties in the melt of polymers containing spherical inclusions, Polym. Adv. Technol. 6 (1995) 301-308. doi:10.1002/pat.1995.220060508.

[49] F. Rindfleisch, T.P. DiNoia, M. a. McHugh, Solubility of polymers and copolymers in supercritical CO2, J. Phys. Chem. Chem. 100 (1996) 15581-15587. doi:10.1021/jp9615823.

[50] J. Kumaki, Observation of polymer chain structures in two-dimensional fi Ims by atomic force microscopy, Polym. J. 48 (2015) 3-14. doi:10.1038/pj.2015.67.

[51] D.Q. Zou, H. Yoshida, Size effect of silica nanoparticles on thermal decomposition of PMMA, J. Ann. Therm. Anal. Calorim. 99 (2010) 21-26. doi:10.1007/s10973-009-0531-4. 


\section{Supplementary Information:}

\section{Understanding the role of MAM molecular weight on the production of PMMA/MAM nanocellular polymers}

Victoria Bernardo1*, Judith Martín-de León1, Ester Laguna-Gutiérrez¹, Tiziano Catelani², Javier Pinto $^{2}$, Athanassia Athanassiou², Miguel Ángel Rodríguez-Pérez ${ }^{1}$

1. Cellular Materials Laboratory (CellMat), Condensed Matter Physics Department, University of Valladolid, Campus Miguel Delibes, Paseo de Belén n7, 47011 Valladolid, Spain

2. Nanophysics, Istituto Italiano di Tecnologia (IIT), Genova, Italy

*Corresponding author: Victoria Bernardo (vbernardo@fmc.uva.es)+34983184035

\section{CHARACTERIZATION OF THE BLOCK COPOLYMERS}

\subsection{Molecular weight distribution (GPC)}

Molecular weight distributions of the polymers were determined by gel permeation chromatography (GPC). GPC analyses were carried out with Styragel Water columns (HR0.5, HR1, HR4; 300*7.8 mm, 5 microns nominal particle size). THF was used as a solvent. Measurements were performed al $35^{\circ} \mathrm{C}$ at a flow rate of $1 \mathrm{~mL} / \mathrm{min}$ using a RI detector (Waters, model 410 ) at a concentration of $4 \mathrm{mg} / \mathrm{mL}$. Molecular weights of polymers were referenced to polystyrene standards. Table S1 summarizes the main characteristics measured by GPC: the number average molecular weight, $M_{n}$, weight average molecular weight, $M_{w}$, and the dispersity index, $I_{p}$ (calculated as $\left.I_{p}=M_{w} / M_{n}\right)$.

Table S1. Characteristics measured by GPC of the MAM block copolymers and PMMA used in this work.

\begin{tabular}{ccccc}
\hline Material & Description & $\mathrm{M}_{\mathrm{n}}(\mathrm{kg} / \mathrm{mol})$ & $\mathrm{M}_{\mathrm{w}}(\mathrm{kg} / \mathrm{mol})$ & $\mathrm{I}_{\mathrm{p}}$ \\
\hline PMMA & - & 43 & 83 & 1.9 \\
$\mathrm{~L}$ & Low molecular weight copolymer & 25 & 46 & 1.8 \\
$\mathrm{M}$ & Medium molecular weight copolymer & 44 & 75 & 1.7 \\
$\mathrm{H}$ & High molecular weight copolymer & 82 & 128 & 1.6 \\
\hline
\end{tabular}

Figure $\mathrm{S} 1$ shows the molecular weight distributions of the PMMA and the MAM block copolymers used in this work. It is observed that the distribution moves to higher molecular weights as the average molecular weight of the copolymer increases. It is also noticed that the molecular weight distribution of the $\mathrm{H}$ copolymer shows a narrower peak, which results in a lower dispersity index than the other materials. In addition, the PMMA and the copolymer M present the most similar molecular weight distributions and average molecular weights, the $\mathrm{M}$ copolymer being less disperse. 


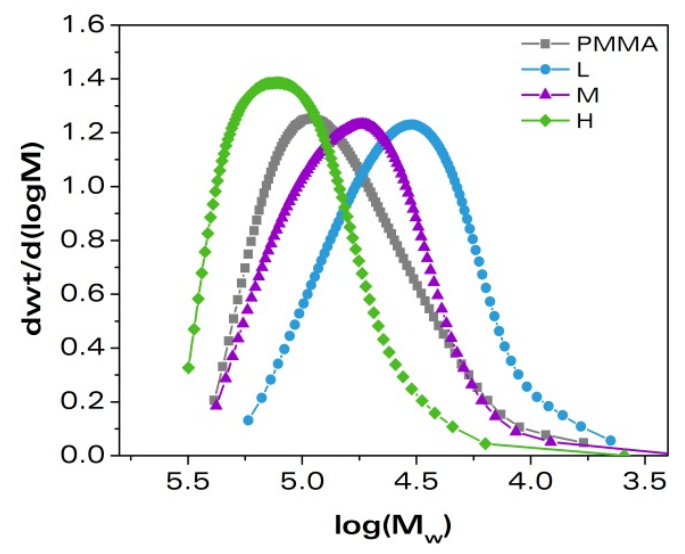

Figure S1. Molecular weight distributions of the PMMA and the MAM block copolymers used in this work.

\subsection{Amount of block copolymer (NMR)}

NMR spectra were recorded on Agilent DD2 500 instruments. ${ }^{1} \mathrm{H}$ and ${ }^{13} \mathrm{C}$ NMR chemical shifts ( $\delta$ ) are reported in parts per million (ppm) and are referenced to TMS, using solvents as an internal reference. Standard abbreviations used to indicate multiplicity: $\mathrm{s}=$ singlet, $\mathrm{d}=$ doublet, $\mathrm{t}=$ triplet, $\mathrm{m}=$ multiplet, $\mathrm{br}=$ broad. ${ }^{1} \mathrm{H}$ and ${ }^{13} \mathrm{C}$ assignments were performed by utilizing $2 \mathrm{D}$ NMR methods (COSY, HSQC and HMBC). The chemical shifts are listed below:

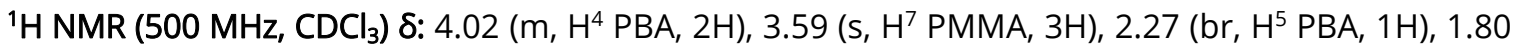
(br, $\mathrm{H}^{9}$ PMMA, 2H), 1.59 (m, $\mathrm{H}^{6}$ PBA, 2H), 1.58 ( $\mathrm{m}, \mathrm{H}^{3}$ PBA, 2H), $1.36\left(\mathrm{~m}, \mathrm{H}^{2}\right.$ PBA, 2H), $0.92\left(\mathrm{t}, \mathrm{H}^{1}\right.$ PBA, $3 \mathrm{H}), 0.83\left(\mathrm{~s}, \mathrm{H}^{8} \mathrm{PMMA}, 3 \mathrm{H}\right)$.

${ }^{13} \mathrm{C}$ NMR (101 MHz, CDCl $)_{3}$ ) 8: 177.75 (COO PMMA), 174.41 (COO PBA), 64.37 (C PBA), 54.39 ( $\mathrm{C}^{9}$ PMMA), 51.76 ( $C^{7}$ PMMA), 44.49 (C ${ }^{10}$ PMMA), 41.36 ( $C^{5}$ PBA), 35.40 ( $C^{6}$ PBA), 30.57 ( $\left.C^{3} P B A\right), 19.04\left(C^{2}\right.$ PBA, 16.39 (C ${ }^{8}$ PMMA), 13.67 (C' PBA).

The quantification of the NMR spectra were used to determine the relative fraction of PMMA versus PBA, divding the integral of a sign corresponding to the PMMA by one of the PBA. Table S2 summarizes the ratios PMMA/MAM of the different copolymers and the corresponding fractions of each block. From the molar fractions determined by NMR, the weight fractions were calculated using the molar masses of a BA unit $(128 \mathrm{~g} / \mathrm{mol})$ and a MMA monomer $(100 \mathrm{~g} / \mathrm{mol})$. It is observed that the three block copolymers show similar fractions of the PBA phase, ranging 48 to $50 \%$. Taking into account the chemical structure of the MAM block copolymer (PMMA-PBA-PMMA), the molecular mass of the PMMA and the PBA blocks was also estimated.

Table S2. Characteristics measured by NMR of the MAM block copolymers used in this work.

\begin{tabular}{cccccccccc}
\hline Copolymer & $\begin{array}{c}\text { Ratio } \\
\text { PMMA/PBA }\end{array}$ & $\begin{array}{c}\text { Molar } \\
\text { fraction } \\
\text { PMMA }\end{array}$ & $\begin{array}{c}\text { Molar } \\
\text { fraction } \\
\text { PBA }\end{array}$ & $\begin{array}{c}\text { PMMA } \\
(w t \%)\end{array}$ & $\begin{array}{c}\text { PBA } \\
(w+\%)\end{array}$ & $\begin{array}{c}M_{n} \\
\text { PMMA } \\
(\mathrm{kg} / \mathrm{mol})\end{array}$ & $\begin{array}{c}\mathrm{M}_{\mathrm{w}} \\
\text { PMMA } \\
(\mathrm{kg} / \mathrm{mol})\end{array}$ & $\begin{array}{c}\mathrm{M}_{\mathrm{n}} \text { PBA } \\
(\mathrm{kg} / \mathrm{mol})\end{array}$ & $\begin{array}{c}\mathrm{M}_{\mathrm{w}} \text { PBA } \\
(\mathrm{kg} / \mathrm{mol})\end{array}$ \\
\hline $\mathrm{L}$ & 1.36 & 0.58 & 0.42 & 52 & 48 & 6.4 & 11.8 & 12.1 & 22.3 \\
$\mathrm{M}$ & 1.16 & 0.54 & 0.46 & 48 & 52 & 10.5 & 17.8 & 23.1 & 39.3 \\
$\mathrm{H}$ & 1.09 & 0.52 & 0.48 & 46 & 54 & 18.9 & 29.4 & 44.3 & 69.1 \\
\hline
\end{tabular}


From the three copolymers, is the $\mathrm{H}$ copolymer that has a PMMA phase with the highest molecular weight and also more similar to the PMMA used as matrix (see Table S1). This could result in a higher affinity between these two polymers (PMMA and $\mathrm{H}$ copolymer).

\section{EFFECT OF THE BLOCK COPOLYMER ON THE GLASS TRANSITION OF THE BLENDS (DSC)}

The glass transition temperature $\left(T_{g}\right)$ of the PMMA/MAM solid blends has been measured using a Mettler DSC822e differential-scanning calorimeter previously calibrated with indium. The $T_{g}$ was taken as the mid-point of the drop in the DSC thermogram that characterizes this transition. The weights of the samples were approximately $5 \mathrm{mg}$. The temperature program used for these PMMA based materials consists of four steps. First, a first heating step performed between $20^{\circ} \mathrm{C}$ and $160^{\circ} \mathrm{C}$ at $10^{\circ} \mathrm{C} / \mathrm{min}$. Then, the samples were maintained at $160^{\circ} \mathrm{C}$ for 3 minutes to erase, and then they were cooled from $160^{\circ} \mathrm{C}$ to $20^{\circ}$ at $-10^{\circ} \mathrm{C} / \mathrm{min}$. Finally, the initial cycle of heating from $20^{\circ} \mathrm{C}$ to $160^{\circ} \mathrm{C}$ at $10^{\circ} \mathrm{C} / \mathrm{min}$ was performed again to determine the glass transition temperature of all samples with the same thermal history.

Table S2 shows the glass transition measured on the second heating step. It is observed that the glass transition is not significantly affected by the fact of adding the block copolymers. The DSC curves of the three blends and the reference PMMA are plotted in Figure S2, showing that the four materials behave similarly. Then, we can conclude that the addition of the MAM at a content of a $10 \mathrm{wt} \%$ does not affect the thermal transitions of the PMMA matrix.

Table S2. Glass transition temperature (measured by DSC) of the PMMA and the PMMA/MAM blends produced in this work.

\begin{tabular}{cc}
\hline Material & $\mathrm{T}_{\mathrm{g}}\left({ }^{\circ} \mathrm{C}\right)$ \\
\hline PMMA & 114.5 \\
90/10_L & 114.5 \\
90/10_M & 114.7 \\
90/10_H & 115.0 \\
\hline
\end{tabular}

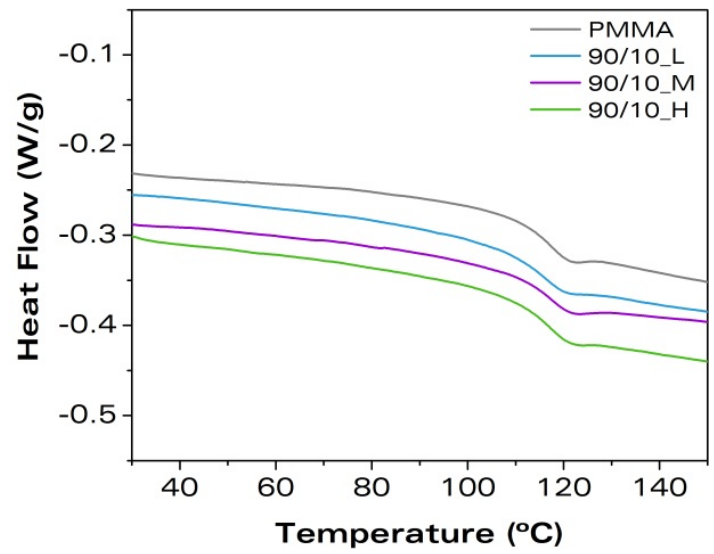

Figure S2. DSC curves of the second heating step of the PMMA and the PMMA/MAM blends used in this work. 



\subsection{Low-density PMMAMAM nanocellular polymers using low MAM contents: production and characterization}

This section contains a publication entitled "Low-density PMMAMMAM nanocellular polymers using Iow MAM contents: production and characterization", published in Polymer in 2019 (V. Bernardo, J. Martin-de Leon, J. Pinto, T. Catelani, A. Athanassiou, M.A. Rodriguez-Perez, Low-density PMMA/MAM nanocellular polymers using low MAM contents: Production and characterization, Polymer (Guildf). 163 (2019) 115-124. doi:10.1016/j.polymer.2018.12.057). This paper is the next step in the study of the different copolymers investigated in the previous section.

From experience gained in the first paper (section 5.2), it was evident that the presence of the micelles was a limiting factor in reducing the density in the PMMA/MAM blends. Then, in this paper, we aim at overcoming this limitation by reducing the amount of block copolymer, from $10 \mathrm{wt} \%$ to $0.1 \mathrm{wt} \%$. Results show that reducing the amount of MAM causes a decrease in the micelle density. Even at very low MAM contents ( $0.1 \mathrm{wt} \%)$ some micelles are detected, but as the number of micelles observed do not account for all the copolymer in the blend, we conclude that some MAM molecules are dispersed in the PMMA matrix in small aggrupations or MAM-rich domains, but without forming a micelle.

The three MAM grades with different molecular weights (see Table 3.3, Chapter 3) that were evaluated in section 5.2 were also used in this study. All of them presented the same trend in the micelle density with the amount of MAM explained in the previous paragraph.

As a consequence of this different nanostructuration, in the nanocellular materials, a reduction of the cell nucleation density is observed when MAM concentration is reduced. In the systems with low MAM content, the nucleation density is higher than the micelle density, so some nucleation takes place in the MAM-rich domains. The materials produced with low MAM contents present higher cell sizes and smaller relative densities.

Finally, the influence of the foaming temperature is investigated. Blends with high MAM contents are not able to expand when the foaming temperature increases, because growth may be limited by the micelles and stops once a minimum cell wall thickness is reached (this effect was explained in section 5.2). As a counterpart, low MAM contents show smaller densities for higher foaming temperatures. As nucleation in these systems takes place partially in MAM-rich regions instead of in micelles, those cells can grow in any shape, because they are not limited by the spherical shape imposed by the copolymer molecules. Thus, in these blends with low MAM contents, it is possible to reduce the density by decreasing the fraction of mass in the struts. Once again, the three copolymers with variable molecular weights presented the same behavior.

The main conclusion of this section is that reducing the amount of MAM and inducing nucleation in MAM-rich domains instead of micelles are essential factors that allow obtaining PMMA/MAM nanocellular polymers with reduced density. Figure 5.2 shows the graphical abstract of this paper that schematizes this primary conclusion. The full paper is included in the following pages. 


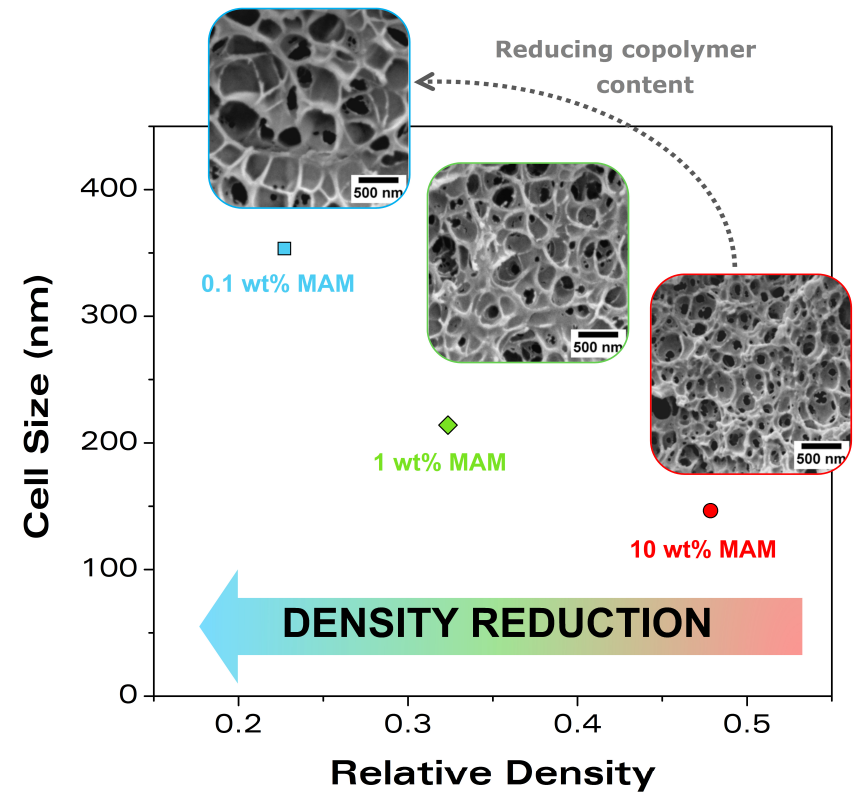

Figure 5.2. Graphical abstract of "Low-density PMMAMAM nanocellular polymers using low MAM contents: production and characterization." 


\title{
Low-density PMMA/MAM nanocellular polymers using low MAM contents: production and characterization
}

\author{
Victoria Bernardo1*, Judith Martín-de León1 , Javier Pinto², Tiziano Catelani³ ${ }^{3}$ Athanassia \\ Athanassiou², Miguel Ángel Rodríguez-Pérez ${ }^{1}$ \\ 1. Cellular Materials Laboratory (CellMat), Condensed Matter Physics Department, \\ University of Valladolid, Campus Miguel Delibes, Paseo de Belén n7, 47011 Valladolid, Spain \\ 2. Smart Materials, Istituto Italiano di Tecnologia, Via Morego 30, 16163 Genova, Italy \\ 3. Electron Microscopy Facility, Istituto Italiano di Tecnologia, Via Morego 30, 16163 Genova, Italy \\ *Corresponding author: Victoria Bernardo (vbernardo@fmc.uva.es) +34983184035
}

\begin{abstract}
Low-density nanocellular polymers are required to take advantage of the full potential of these materials as high efficient thermal insulators. However, their production is still a challenging task. One promising approach is the use of nanostructured polymer blends of poly(methyl methacrylate) (PMMA) and a block copolymer poly(methyl methacrylate)-poly(butyl acrylate)poly(methyl methacrylate) (MAM), which are useful for promoting nucleation but seem to present a severe drawback, as apparently avoid low relative densities. In this work, new strategies to overcome this limitation and produce low-density nanocellular materials based on these blends are investigated. First, the effect of very low amounts of the MAM copolymer is analysed. It is detected that nanostructuration can be prevented using low copolymer contents, but nucleation is still enhanced as a result of the copolymer molecules with high $\mathrm{CO}_{2}$ affinity dispersed in the matrix, so nanocellular polymers are obtained using very low percentages of the copolymer. Second, the influence of the foaming temperature is studied. Results show that for systems in which there is not a clear nanostructuration, cells can grow more freely and smaller relative densities can be achieved.

For these studies, blends of PMMA with MAM with copolymer contents from 10 wt $\%$ and as low as $0.1 \mathrm{wt} \%$ are used. For the first time, the production strategies proposed in this work have allowed obtaining low density (relative density 0.23 ) nanocellular polymers based on PMMA/MAM blends.
\end{abstract}

\section{KEYWORDS}

nanocellular polymer; nanocellular foam; gas dissolution foaming; block copolymer; nanostructuration; PMMA; MAM.

\section{INTRODUCTION}

Efficient energy use is one of the main concerns of nowadays society. All sectors are in need of efficient management of the energy use, but the major challenge from the next decades lies in buildings, according to the European Commission [1]. More than one-third of global energy 
consumption is used in buildings, and from this energy, more than $50 \%$ is needed to heat indoor spaces [2]. Most heat is lost through walls, roofs, and floors. Therefore, proper insulation is required to reduce the losses and therefore the energy consumptions. With improved thermal insulators not only would money be saved, but also $\mathrm{CO}_{2}$ emissions associated with energy production would be significantly reduced.

Therefore, finding new and better materials with enhanced insulation properties becomes a mandatory task. Current trends to reduce the thermal conductivity of insulating materials are to replace the air inside them with vacuum [3] or to reduce the pore size below the mean free path of air molecules [4,5], that is, producing nanocellular materials.

Nanocellular materials, characterized by cell sizes in the range of tens to hundreds of nanometers, present a unique combination of properties [5-10], and in particular a reduced thermal conductivity thanks to the Knudsen effect $[5,11,12]$. To fully take advantage of this effect, low-density nanocellular materials are required [13]. Nevertheless, the production of such low-density materials is still not well established.

Several attempts to produce low-density nanocellular polymers have been carried out using the socalled gas dissolution foaming technique [14-17]. Up to date, the most promising results have been obtained using poly(methyl methacrylate), PMMA, as the polymer matrix. Guo et al. [18] used a low temperature set up $\left(-20^{\circ} \mathrm{C}\right)$ to produce nanocellular PMMA with cell sizes of $235 \mathrm{~nm}$ and relative densities of 0.14 . In the work of Martin-de Leon [19], high saturation pressure (31 MPa) was needed to obtain a cellular PMMA with a relative density of 0.24 , keeping the cell size in the nanoscale (216 $\mathrm{nm})$. They also established a procedure to tune the relative density by changing the foaming temperature. In the work of Costeux et al. [20], the effect of the molecular structure of some PMMA copolymers was investigated, achieving relative densities around 0.2 and cell sizes below $400 \mathrm{~nm}$. A high saturation pressure (30 MPa) was also required in their work. As a rule, the production of nanocellular polymers using pure polymers demands extreme processing conditions, such as high pressures or low temperatures (under $0^{\circ} \mathrm{C}$ ) $[14,15,17,21]$. Both approaches are difficult to scale-up to the industrial production, due to the technical requirements and costs associated to work at these conditions. For this reason, the use of nucleating species has become a common strategy to reach high nucleation densities at mild processing conditions that could be easier and cost-effective to use in the industrial scale.

The first approach is the use of nanoparticles as nucleating agents to favor nucleation [22,23]. Costeux et al. [24] take advantage of heterogeneous nucleation for the production of low relative density (0.15) nanocellular PMMA (cell size of $100 \mathrm{~nm}$ ). They used silica nanoparticles contents below $0.5 \mathrm{wt} \%$ to achieve this result, but the saturation pressure required was still high (30 MPa). Bernardo et al. [25] used needle-like sepiolites to obtain bimodal structures, with both micro and nanocells, in PMMA. The relative densities were between 0.21 and 0.28 and the cell size between 300 and $500 \mathrm{~nm}$ for sepiolite contents in the range from 0.5 to $1.5 \mathrm{wt} \%$. They showed that it was possible to produce these materials using not demanding processing conditions (soaking at $10 \mathrm{MPa}$ and room temperature).

On the other hand, nanostructured polymer blends with $\mathrm{CO}_{2}$-philic domains can be used as nucleating species $[26,27]$. Nevertheless, reducing the relative density under 0.3 using this 
approach is still a challenge not overcome. Pinto et al. [28-30] worked with blends of PMMA and poly(methyl methacrylate)-poly(butyl acrylate)-poly(methyl methacrylate) (MAM) with contents of MAM of $5 \mathrm{wt} \%, 10 \mathrm{wt} \%, 20 \mathrm{wt} \%$ and higher. They obtained cell sizes below $200 \mathrm{~nm}$ at $10 \mathrm{MPa}$ of saturation pressure with a $10 \mathrm{wt} \%$ of MAM, but with relative densities above 0.4. Bernardo et al. [31] investigated the influence of the MAM molecular weight in the production of PMMA/MAM nanocellular polymers. They showed that reducing the MAM molecular weight allows decreasing the relative density up to 0.37 , the cell size being around $200 \mathrm{~nm}$. Forest and coworkers [32] analyzed the effect of changing the copolymer content in the structure of PMMA/MAM-based nanocellular polymers. They found that higher copolymer contents (up to $20 \mathrm{wt} \%$ ) led to larger cell nucleation densities, but also higher relative densities. In that work, MAM contents up to a $1 \mathrm{wt} \%$ were used, and nanocellular polymers of around $150 \mathrm{~nm}$ were obtained using a $1 \mathrm{wt} \%$ of MAM, but with a relative density of 0.42 . Low saturation pressure $(3.2 \mathrm{MPa})$ and low saturation temperature $\left(0^{\circ} \mathrm{C}\right)$, were required to obtain those materials.

In all the previously mentioned works, copolymer contents of at least $1 \mathrm{wt} \%$ were necessary to achieve a nanocellular structure, whereas the densities obtained were far away from the results obtained using pure polymers or nanoparticles as a nucleating agent. In an own previous work [31] we proposed that the presence of the micelles is a limiting parameter in the production of low density nanocellular materials based on PMMA/MAM blends. Besides, these copolymers are usually expensive and not easily available, and due to this, the high contents needed complicate its use as possible nucleating agents on the industrial production of nanocellular polymers.

In this work, the effect of the copolymer content in the production of PMMA/MAM nanocellular polymers has been explored as a strategy to reduce the relative density of such materials. Contents below $10 \mathrm{wt} \%$ were analyzed. In particular, very low MAM contents ( $0.1 \mathrm{wt} \%$ and $0.5 \mathrm{wt} \%$ ) have been used, allowing to obtain nanocellular materials based on PMMA-MAM with relative densities below 0.3 for the first time.

\section{EXPERIMENTAL}

\subsection{Materials}

PMMA V 825T was kindly supplied by ALTUGLAS $®$ International in the form of pellets. This PMMA presents a melt flow index (MFI) of $1.8 \mathrm{~g} / 10 \mathrm{~min}$ (measured at $230^{\circ} \mathrm{C}$ and $2.16 \mathrm{~kg}$ ), a density $(\rho)$ of $1.19 \mathrm{~g} / \mathrm{cm}^{3}$ and a glass transition temperature $\left(\mathrm{T}_{\mathrm{g}}\right)$ of $114.5^{\circ} \mathrm{C}$, measured by DSC. The molecular weight of this PMMA is $M_{n}=43 \mathrm{~kg} / \mathrm{mol}$ and $M_{w}=83 \mathrm{~kg} / \mathrm{mol}$ as determined by GPC.

MAM block copolymers were kindly supplied by Arkema Company (France). Three MAM copolymers with different molecular weights were used in this study. The three copolymers have roughly a 50 wt\% of the soft block, poly(butyl acrylate) (PBA). Commercial names of these copolymers are Nanostrength M51 (low molecular weight), M52 (medium molecular weight) and M53 (high molecular weight). Table 1 summarizes the main characteristics of these copolymers. MFI was measured at $160{ }^{\circ} \mathrm{C}$ and $10 \mathrm{~kg}$, and molecular weight was determined using GPC measurements. PBA fraction was determined from NMR measurements. $T_{g}$ of the PBA phase was determined by DSC. More details about the characterization of the copolymers can be found elsewhere [31]. 
Table 1. Characteristics of the MAM block copolymers used in this work.

\begin{tabular}{ccccccc}
\hline ID & Description & $\mathrm{M}_{\mathrm{n}}(\mathrm{kg} / \mathrm{mol})$ & $\mathrm{M}_{\mathrm{w}}(\mathrm{kg} / \mathrm{mol})$ & $\begin{array}{c}\mathrm{MFI} \\
(\mathrm{g} / 10 \mathrm{~min})\end{array}$ & $\mathrm{T}_{\mathrm{g}, \mathrm{PBA}}\left({ }^{\circ} \mathrm{C}\right)$ & $\mathrm{PBA}(\mathrm{wt} \%)$ \\
\hline $\mathrm{L}$ & Low molecular weight & 25 & 46 & $84 \pm 9$ & -26.2 & 48 \\
$\mathrm{M}$ & Medium molecular weight & 44 & 75 & $4 \pm 1$ & -34.9 & 52 \\
$\mathrm{H}$ & High molecular weight & 82 & 128 & $0.208 \pm 0.003$ & -39.8 & 54 \\
\hline
\end{tabular}

Finally, medical grade carbon dioxide $\left(\mathrm{CO}_{2}\right)$ (99.9\% purity) was used as the blowing agent for the gas dissolution foaming experiments.

\subsection{Solid Blends Production}

PMMA/MAM blends with different MAM contents were compounded using a twin-screw extruder model COLLIN TEACH-LINE ZK 25T, with L/D of 24 and screw diameter of $25 \mathrm{~mm}$. Before compounding, PMMA and MAM were dried in vacuum at $50^{\circ} \mathrm{C}$ for 12 hours. Then, the blends with the appropriate proportions were extruded with a temperature profile from $160^{\circ} \mathrm{C}$ to $200^{\circ} \mathrm{C}$ (in the die), increasing in intervals of $10^{\circ} \mathrm{C}$, and at a screw speed of $40 \mathrm{rpm}$. The produced blends were cooled in a water bath and pelletized. After drying for 2 hours in a vacuum oven at $50{ }^{\circ} \mathrm{C}$, the materials were extruded again under the same conditions. Homogeneous and transparent blends were obtained after this process. Blends with five different MAM contents, from $0.1 \mathrm{wt} \%$ to $10 \mathrm{wt} \%$, were produced. Table 2 summarizes the materials produced in this work.

Table 2. Formulations used in this work.

\begin{tabular}{|c|c|c|c|c|c|c|}
\hline & & \multicolumn{5}{|c|}{ MAM content } \\
\hline & & $0.1 \mathrm{wt} \%$ & 0.5 wt $\%$ & $1 \mathrm{wt} \%$ & $5 \mathrm{wt} \%$ & $10 \%$ \\
\hline \multirow{3}{*}{$\begin{array}{l}\text { Type of } \\
\text { MAM }\end{array}$} & $\mathrm{L}$ & $0.1 \%-\mathrm{L}$ & $0.5 \%-\mathrm{L}$ & $1 \%-\mathrm{L}$ & $5 \%-\mathrm{L}$ & $10 \%-\mathrm{L}$ \\
\hline & M & $0.1 \%-\mathrm{M}$ & $0.5 \%-\mathrm{M}$ & $1 \%-\mathrm{M}$ & $5 \%-M$ & $10 \%-M$ \\
\hline & $\mathrm{H}$ & $0.1 \%-\mathrm{H}$ & $0.5 \%-\mathrm{H}$ & $1 \%-\mathrm{H}$ & $5 \%-\mathrm{H}$ & $10 \%-\mathrm{H}$ \\
\hline
\end{tabular}

Solid precursors of these blends were prepared by compression molding using a hot plate press provided by Remtex. Solid prisms of $155 \times 75 \times 4 \mathrm{~mm}^{3}$ were produced. First, all materials were dried in a vacuum oven at $50^{\circ} \mathrm{C}$ overnight. Then, the material was first softened at $250^{\circ} \mathrm{C}$ without applying pressure for 8.5 minutes and then compacted under constant pressure of $1.7 \mathrm{MPa}$ for another minute. Finally, the samples were cooled down at room temperature on the cold plates under the same pressure. Samples of $20 \times 10 \times 4 \mathrm{~mm}^{3}$ were cut from the solid prisms for the foaming experiments. Neat PMMA was processed under the same conditions (both by extrusion and compression molding) for comparison.

\subsection{Gas Dissolution Foaming Experiments}

Foaming experiments were performed in a high-pressure vessel (model PARR 4681) provided by Parr Instruments Company with a capacity of 1 liter, capable of operating at a maximum temperature of $350^{\circ} \mathrm{C}$ and a maximum pressure of $41 \mathrm{MPa}$. Pressure is set to the desired value 
with an accurate pressure pump controller (model SFT-10) provided by Supercritical Fluid Technologies Inc. The temperature is fixed with a clamp heater of $1200 \mathrm{~W}$, controlled via a CAL 3300 temperature controller. Foaming experiments were performed using a two-step foaming process [33]. Samples were firstly introduced in the pressure vessel under $10 \mathrm{MPa}$ of $\mathrm{CO}_{2}$ pressure for the saturation stage. Saturation temperature was equal to $25^{\circ} \mathrm{C}$ and saturation time was $20 \mathrm{~h}$, as this time was proved to be enough to achieve full saturation of $\mathrm{CO}_{2}$ in PMMA at the conditions under study. After saturation, the pressure was abruptly released (pressure drop rate: $15 \mathrm{MPa} / \mathrm{s}$ ), and the samples were immersed in a thermal bath at the desired temperature for the foaming stage. The time between the release of pressure and the sample immersion in the thermal baths was 3.5 minutes. The sorption process depends on pressure and temperature. At the conditions used in this work $\left(10 \mathrm{MPa}\right.$ and $25^{\circ} \mathrm{C}$ ) solubility of $\mathrm{CO}_{2}$ in PMMA is around $24 \mathrm{wt} \%$. This value was calculated by weighting the sample before and immediately after the saturation process. For the MAM copolymers, the solubility was estimated by weighting samples with $10 \mathrm{wt} \%$ of MAM and calculating the amount absorbed by the copolymer in the blend. It is observed than MAM presents a higher $\mathrm{CO}_{2}$ affinity that PMMA and can absorb approximately $38 \mathrm{wt} \%$ at $10 \mathrm{MPa}$ and $25^{\circ} \mathrm{C}$. See Supplementary Information for details about the procedure to measure the solubility.

The influence of the amount of block copolymer was evaluated by fixing the foaming temperature at $80^{\circ} \mathrm{C}$. Then, the effect of the foaming temperature was analyzed by using two additional foaming temperatures: 60 and $100^{\circ} \mathrm{C}$. Foaming time was 1.5 minutes for all the experiments. Under these saturation conditions $\left(25^{\circ} \mathrm{C}\right.$ and $10 \mathrm{MPa}$ ) the effective glass transition temperature of PMMA after gas absorption is below room temperature [29], and thus samples start to expand immediately after the depressurization. However, the largest expansion occurs in the thermal baths.

\subsection{Characterization}

\subsubsection{Nanostructuration of the Blends}

Morphology of the solid PMMA/MAM blends was analyzed using transmission electron microscopy (TEM). Each material was cut in ultrathin slices (with a thickness of approximately 80 - $90 \mathrm{~nm}$ ) using a Leica EM UC6 Ultramicrotome. The samples were cut in cryogenic conditions, cooling down the environment and the sample holder at least at $-60^{\circ} \mathrm{C}$, using a specific cryo-system Leica EM FC6 and a specific diamond knife for a low-temperature cut. This step was necessary due to the soft behavior of the polymer. Slices were collected and laid down onto a 200 mesh formvar/carboncoated copper TEM grids.

Transmission electron microscopy (TEM) images were collected with a Jeol JEM 1011 (Jeol, Japan) electron microscope (Electron Microscopy Facility, Istituto Italiano di Tecnologia, Genova, Italy). The acceleration voltage used was $100 \mathrm{kV}$ and recorded with an $11 \mathrm{Mp}$ fiber optical charge-coupled device (CCD) camera (Gatan Orius SC-1000).

TEM images were used to analyze the nanostructuration found in the solid blends. Volumetric micelle density was calculated by dividing the number of micelles in a TEM image by the volume (area of the image times the thickness of the sample (around $80 \mathrm{~nm}$ )). 
From the micelle density $\left(n_{\text {mic }}\right.$ ), the aggregation number $N_{c}$ (number of copolymer molecules per micelle) was estimated theoretically using equation (1) [34], where $w$ is the amount of copolymer in weight percent, $N_{a v}$ is the Avogadro's number, $\rho$ is the density of the blend and $M_{n}$ is the molecular weight of the copolymer.

$$
n_{m i c}=\frac{w N_{a v} \rho}{M_{n} N_{c}}
$$

\subsubsection{Density}

The density of the solid samples was measured with a gas pycnometer (model AccuPyc II 1340, Micromeritics) and the density of the cellular materials was determined with the waterdisplacement method based on Archimedes' principle. For this purpose, a density determination kit for an AT261 Mettler-Toledo balance was used. Before measuring the density, the solid skin of these foamed samples was removed out with a polisher (model LaboPOI2-LaboForce3, Struers) by removing at least $200 \mu \mathrm{m}$ of each side. Relative density $\left(\rho_{r}\right)$ has been calculated as the ratio between the cellular material density $\left(\rho_{f}\right)$ and the density of the solid polymer blend $\left(\rho_{s}\right)$.

\subsubsection{Cellular Structure}

The cellular structure of the samples was analyzed using an ESEM, Environmental Scanning Electron Microscope (Quanta $200 \mathrm{FEG}$ ). For the visualization, samples were fractured after cooling in liquid nitrogen. Also, they were coated with gold using a sputter coater (model SCD 005, Balzers Union). A tool based on the software ImageJ/FII [35] has been used to quantify the structural parameters that characterize the cellular structure. First, the average cell size $(\phi)$ has been measured, and the standard deviation coefficient of the cell size distribution $(S D)$ has been obtained. Cell density $\left(N_{v}\right)$ and cell nucleation density $\left(N_{0}\right)$ were determined using Kumar's theoretical approximation [36] according to equation (2) and (3), respectively, where $n$ is the number of cells in the image and $A$ is the area of the image. More than 200 cells of different areas of each cellular material were analysed.

$$
\begin{gathered}
N_{v}=\left[\frac{n}{A}\right]^{3 / 2} \\
N_{0}=\frac{N_{v}}{\rho_{r}}
\end{gathered}
$$

Cell wall thickness of the cellular materials was measured directly from the micrographs. More than fifty cell walls were measured per material system. Finally, the fraction of mass in the struts was determined using the local thickness analysis of Image J/FIII (details can be found elsewhere [19]).

\section{RESULTS}

\subsection{Nanostructuration of the Blends}

Figure 1 shows the TEM images of the solid blends for all the contents of MAM and the three grades of MAM. It should be noted that the nanostructuration observed on these samples is obtained from a non-equilibrium process as the extrusion is [31]. The micelle nanostructuration is detected at contents from $10 \mathrm{wt} \%$ down to $0.5 \mathrm{wt} \%$. It is observed that micelle density decreases in one order of magnitude (from $10^{14}$ nuclei/ $\mathrm{cm}^{3}$ to $10^{13}$ nuclei/ $/ \mathrm{cm}^{3}$ ) when MAM content is reduced from 10 to $0.5 \mathrm{wt} \%$ (Table 2). This effect is observed for the three different copolymers. However, at a content 
of $0.1 \mathrm{wt} \%$, there is not an evident nanostructuration. For the blends $0.1 \%-\mathrm{M}$ and $0.1 \%-\mathrm{H}$ some dispersed micelles were detected and quantified for the analysis of the micelle density (Table 2), whereas for the blend $0.1 \%-\mathrm{L}$ it was not possible to perform such an analysis because micelles were not detected. It is also observed that higher MAM molecular weights lead to higher micelle densities, as it was already reported and explained in own previous work [31].

$0.1 w t \%$

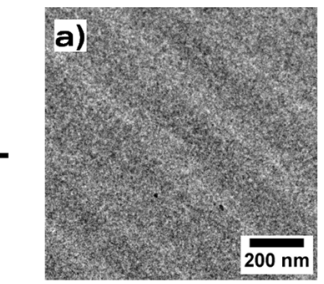

\section{$\mathbf{L}$}
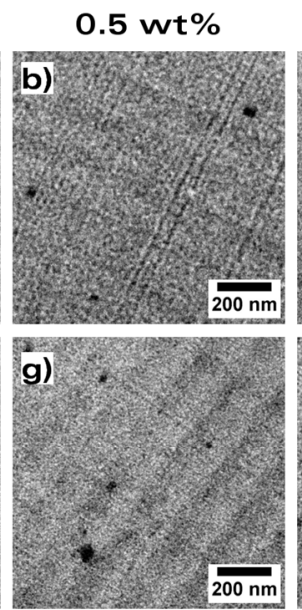

M
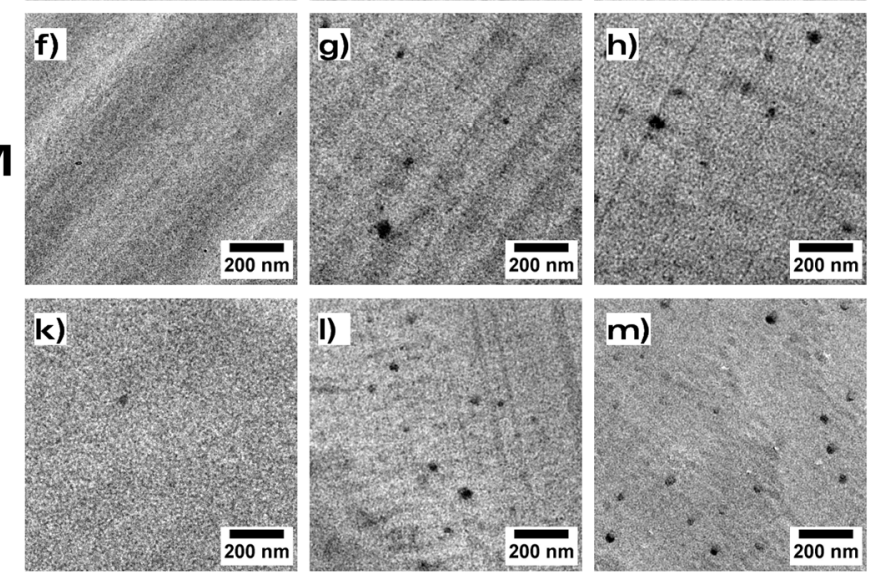

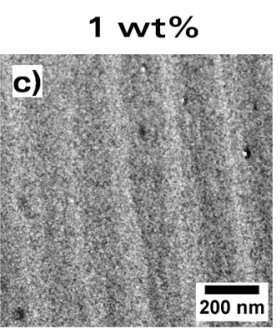

$5 \mathrm{wt} \%$
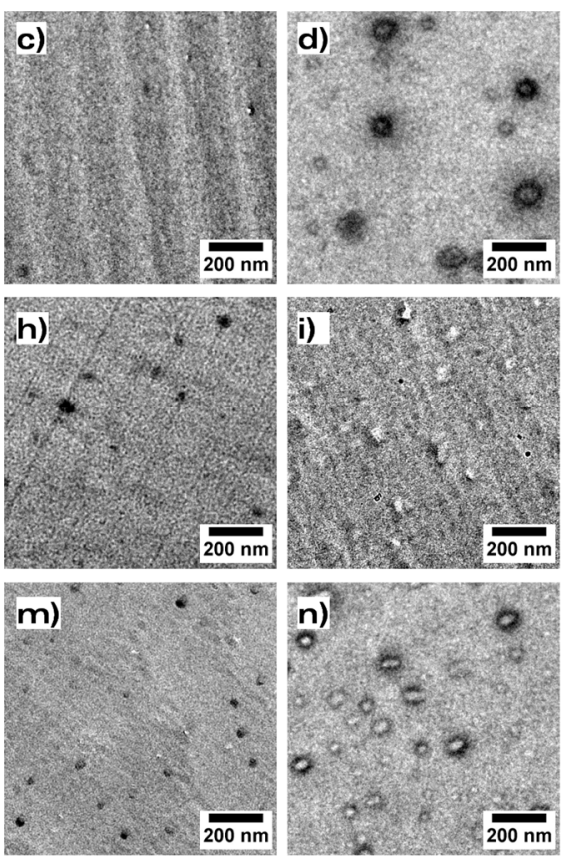

$10 w t \%$
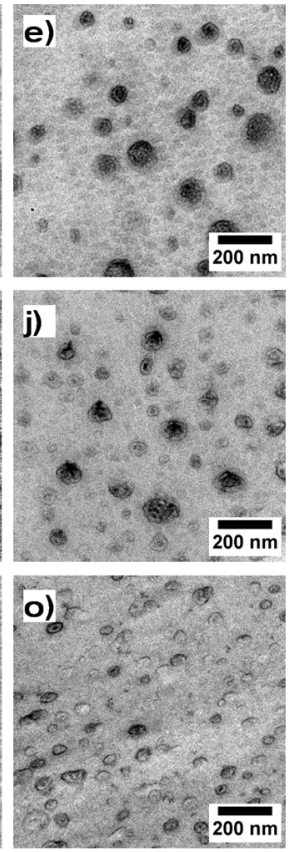

Figure 1. TEM images showing the nanostructuration (black spots) of the PMMA/MAM blends: a) $0.1 \%-L$, b) $0.5 \%-L$, c) $1 \%-L$, d) $5 \%-L$, e) $10 \%-L$, f) $0.1 \%-M$, g) $0.5 \%-M$, h) $1 \%-M$, i) $5 \%-M$, j) $10 \%-M, k$ ) $0.1 \%-\mathrm{H}, \mathrm{I}) 0.5 \%-\mathrm{H}, \mathrm{m}) 1 \%-\mathrm{H}, \mathrm{n}) \mathrm{5} \%-\mathrm{H}$ and o) $10 \%-\mathrm{M}$.

We hypothesized that formation of the micelles is a consequence of two processes [31]: dispersion during the extrusion and self-assembly of the MAM molecules in the domains formed by the extrusion. That is, during the extrusion process, MAM will be dispersed forming MAM-rich regions. This dispersion is mainly controlled by the relative viscosities of the matrix and the copolymer, so the different trends found for the three copolymers are related to their different viscosities [31]. In the domains formed during the extrusion, if the number of copolymer molecules is high enough, self-assembly takes place, resulting in micelles. In order to evaluate the number of copolymer molecules involved in the formation of the micelles, it is possible to estimate theoretically the aggregation numbers using equation (1) and the experimental number of micelles (Table 2). This number is calculated by assuming all the copolymer lies inside the micelles. If this estimation is in agreement with the TEM observation, which shows the number and sizes of the micelles, we can assume the hypothesis is correct. If not, then it is plausible to assume that some of the copolymer is dispersed in the matrix without forming a micelle. From the correlation between the predicted aggregation number and the TEM observations, we can distinguish three levels of distribution of MAM in the PMMA matrix: mainly forming micelles, dispersed and foaming micelles, and mainly dispersed (Table 2). 
When MAM content is reduced from $10 \mathrm{wt} \%$ to $5 \mathrm{wt} \%$, a decrease in the micelle density is observed (Table 2), but also micelles look larger (Figure 1). As micelles are larger at $5 \mathrm{wt} \%$, this means the number of molecules per micelle (i.e., aggregation number) should be higher at $5 \mathrm{wt} \%$ than at 10 wt\% (in agreement with Table 2). Then, MAM is dispersed in bigger regions for $5 \mathrm{wt} \%$ compared to $10 \mathrm{wt} \%$. However, these two contents are of the same order of magnitude, and we can consider both micelle density and aggregation numbers comparable. Pinto and coworkers [29] already showed comparable nanostructures at 5 and $10 \mathrm{wt} \%$ of MAM. For these two contents, the MAM is distributed forming micelles (Table 2).

However, when content is reduced from $5 \mathrm{wt} \%$ to $1 \mathrm{wt} \%$, micelles are smaller, so MAM-rich regions should be smaller. Accordingly, the estimated aggregation number decreases (Table 2). So in the blends with $1 \mathrm{wt} \%$ of MAM the copolymer is also distributed forming micelles.

Table 2. Nanostructure characteristics of PMMA/MAM solid precursors.

\begin{tabular}{cccc}
\hline Sample ID & $\begin{array}{c}\text { Micelle density } \\
(\text { micelles/cm }\end{array}$ & $\begin{array}{c}\text { Predicted } \\
\text { aggregation number }\end{array}$ & MAM distribution on the PMMA matrix \\
\hline $0.1 \%-\mathrm{L}$ & - & - & Mainly dispersed \\
\hline $0.5 \%-\mathrm{L}$ & $(2.4 \pm 0.2) \cdot 10^{13}$ & 5800 & Dispersed and forming micelles \\
\hline $1 \%-\mathrm{L}$ & $(9.0 \pm 3.0) \cdot 10^{13}$ & 3000 & Mainly forming micelles \\
\hline $5 \%-\mathrm{L}$ & $(8.4 \pm 0.1) \cdot 10^{13}$ & 16800 & Mainly forming micelles \\
\hline $10 \%-\mathrm{L}$ & $(2.1 \pm 0.0) \cdot 10^{14}$ & 13400 & Mainly forming micelles \\
\hline $0.1 \%-\mathrm{M}$ & $(1.6 \pm 0.7) \cdot 10^{13}$ & 1000 & Dispersed and forming micelles \\
\hline $0.5 \%-\mathrm{M}$ & $(6.6 \pm 0.1) \cdot 10^{13}$ & 1200 & Dispersed and forming micelles \\
\hline $1 \%-\mathrm{M}$ & $(1.4 \pm 0.5) \cdot 10^{14}$ & 1100 & Mainly forming micelles \\
\hline $5 \%-\mathrm{M}$ & $(1.3 \pm 0.3) \cdot 10^{14}$ & 6000 & Mainly forming micelles \\
\hline $10 \%-\mathrm{M}$ & $(7.3 \pm 0.4) \cdot 10^{14}$ & 2200 & Mainly forming micelles \\
\hline $0.1 \%-\mathrm{H}$ & $(4.0 \pm 2.0) \cdot 10^{12}$ & 2300 & Dispersed and forming micelles \\
\hline $0.5 \%-\mathrm{H}$ & $(8.0 \pm 3.0) \cdot 10^{13}$ & 500 & Dispersed and forming micelles \\
\hline $1 \%-\mathrm{H}$ & $(2.0 \pm 1.0) \cdot 10^{14}$ & 400 & Mainly forming micelles \\
\hline $5 \%-\mathrm{H}$ & $(2.0 \pm 0.2) \cdot 10^{14}$ & 2200 & Mainly forming micelles \\
\hline $10 \%-\mathrm{H}$ & $(7.7 \pm 0.9) \cdot 10^{14}$ & 1100 & Mainly forming micelles \\
\hline
\end{tabular}

For lower contents ( $0.5 \mathrm{wt} \%$ and $0.1 \mathrm{wt} \%)$, equation (1) predicts very high aggregation numbers, even higher than those obtained at $1 \mathrm{wt} \%$ (for instance, for $0.1 \%-\mathrm{H}$ an aggregation number as high as 2300 is predicted). In those cases, this prediction is contradictory with the TEM observation, in which fewer and smaller micelles are detected (Figure 1). Therefore, the hypothesis that all of the molecules are forming micelles is not true at these low contents. According to literature, there exists a critical micelle concentration ( $\mathrm{cmc}$ ), that is, a minimum amount of MAM needed to create a micelle [37-39]. Then, it is plausible to assume that at these very low contents ( $0.5 \mathrm{wt} \%$ and $0.1 \mathrm{wt} \%$ ) some MAM molecules might be dispersed without forming micelles, because the amount of MAM may be below the cmc. This is for sure the case of $0.1 \%-\mathrm{L}$, in which micelles were not detected (and therefore, no aggregation number was estimated). Thus, we conclude that in the blends $0.5 \%-\mathrm{L}$, 
$0.5 \%-\mathrm{M}, 0.5 \%-\mathrm{H}, 0.1 \%-\mathrm{M}$ and $0.1 \%-\mathrm{H}$, the MAM is forming micelles (observed in TEM), but also partially dispersed in the matrix. Finally, in the blend $0.1 \%$-L the MAM is mainly dispersed.

\subsection{Effect of the copolymer content on the cellular structure}

Cellular materials were obtained from the solid PMMA and the PMMA/MAM blends at constant saturation $\left(10 \mathrm{MPa}\right.$ and $\left.25^{\circ} \mathrm{C}\right)$ and foaming $\left(80^{\circ} \mathrm{C}\right.$ and $\left.1.5 \mathrm{~min}\right)$ conditions. Figure 2 shows the cellular structure of the different samples. Under these conditions, the pure PMMA shows a microcellular structure [31] (see Supplementary Information for details about the structure of the microcellular PMMA). Three main conclusions can be extracted from the SEM micrographs of Figure 2. First, most of the PMMA/MAM blends produce nanocellular structures. Only the material $0.1 \%-\mathrm{L}$ shows cells larger than $500 \mathrm{~nm}$. Second, reducing the amount of MAM increases the cell size. Third and last, the molecular weight of the MAM also plays an important role, the cell sizes of the materials based on the copolymer $\mathrm{L}$ being sharply larger than the rest, as already proved for the materials with a content of $10 \mathrm{wt} \%$ [31].

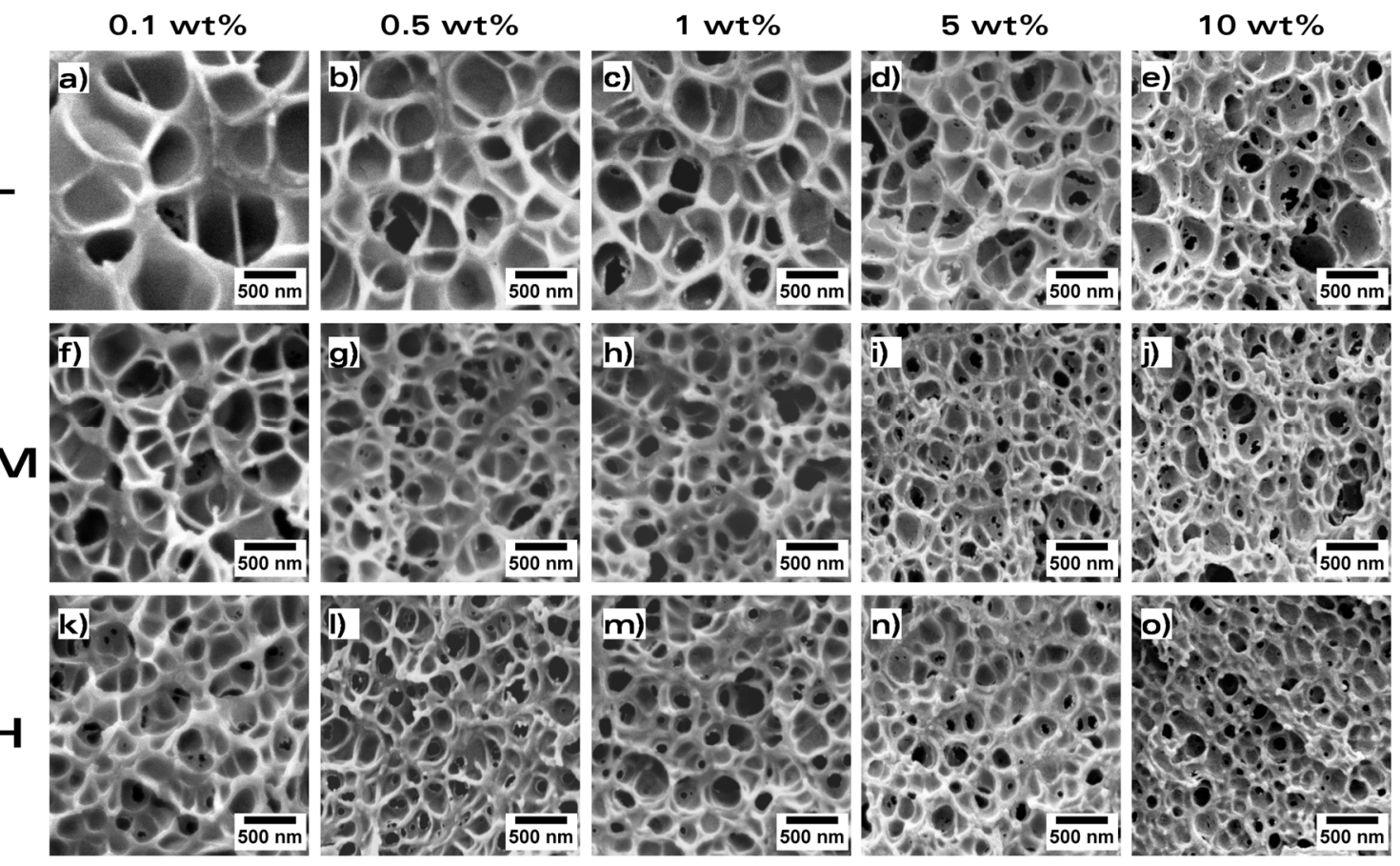

Figure 2. SEM images showing the cellular structure of the materials produced at $80^{\circ} \mathrm{C}$ of foaming temperature: a) $0.1 \%-L$, b) $0.5 \%-L$, c) $1 \%-L$, d) $5 \%-L$, e) $10 \%-L$, f) $0.1 \%-M$, g) $0.5 \%-M$, h) $1 \%-M$, i) $5 \%$ $M$, j) $10 \%-M$, k) $0.1 \%-H$, I) $0.5 \%-H, m$ ) $1 \%-H$, n) $5 \%-H$ and o) $10 \%-H$.

The analysis in deep detail of the cellular structure of these cellular materials is shown in Figure 3. On the one hand, Figure 3.a shows the cell nucleation density as a function of the MAM content. It decreases as MAM content decreases. From the micelle density analysis, this result was expected, as micelle density controls nucleation in nanostructured polymer blends $[26,27,29]$ and it was found to follow the same trend (Table 2). There is a reasonable correlation between the micelle density and the cell nucleation density, except for the very low MAM contents $(0.5 \mathrm{wt} \%$ and 0.1 $w t \%)$. For these systems, the nucleation density is much higher than the micelle density, and also 
greater than that of the pure PMMA (see Table S2 and Figure S3 in the Supplementary information). Therefore, the nucleation cannot be merely explained as a consequence of nucleation in the micelles, as in the systems with high MAM contents. As previously mentioned, it is possible that at these low copolymer contents a part of MAM might be dispersed in the PMMA without forming a micelle. As the PBA is $\mathrm{CO}_{2}$-philic, the Gibbs energy of nucleus formation is reduced in these molecules compared to the pure PMMA. Also, the surface tension in the PBA phase is smaller than that of the PMMA [29]. Therefore, nucleation can take place in the small MAM-rich regions. Colton et al. reported a similar idea for a zinc stearate-polystyrene system, in which nucleation below the solubility limit was even higher than after the formation of the zinc stearate particles [40]. We propose that nucleation in these PMMA/MAM systems with low MAM contents is a consequence of two processes: nucleation in the micelles and in the MAM-rich regions, which are too small to form a micelle. We have analyzed in more detail this nucleation effect by studying the effect of the saturation pressure in the Supplementary Information.

On the other hand, cell size presents the opposite behavior (Figure 3.b): lower MAM contents lead to higher cell sizes. All the blends show cell sizes in the range 340-120 nm, except for the blend $0.1 \%-\mathrm{L}$, which shows a sub-micrometric cellular structure. As far as the authors know, this is the first time PMMA/MAM nanocellular polymers have been produced using such low copolymer contents. In particular, a cell size of $260 \mathrm{~nm}$ combined with a relative density of 0.29 has been obtained for the material $0.1 \%-\mathrm{H}$. The cell size is a consequence of the micelle density: the smaller the number of micelles, the greater the distance among them and therefore more space for the micelles to grow (higher cell size) [31]. The cell size distribution of these samples can be found in the Supplementary Information (Figure S6).
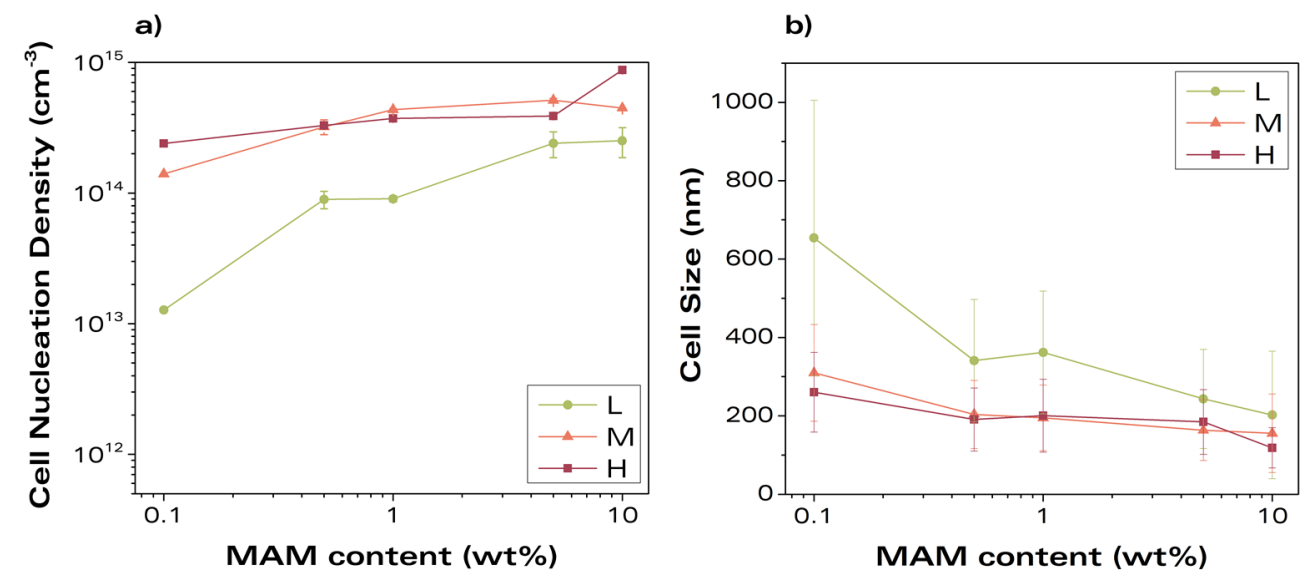

Figure 3. a) Cell nucleation density and b) cell size of the cellular materials produced at $80^{\circ} \mathrm{C}$ of foaming temperature as a function of the MAM content for the three grades of MAM.

The relative density of these cellular materials is shown in Figure 4. Relative densities between 0.57 and 0.29 were obtained. A reduction in the MAM copolymer content causes a reduction of the relative density. This reduction is more relevant for the copolymers $\mathrm{M}$ and $\mathrm{H}$. For instance, for the copolymer $\mathrm{H}$, a reduction in the MAM content from $10 \mathrm{wt} \%$ to $0.1 \mathrm{wt} \%$ (100 times reduction) yields to a decrease in density of a $49 \%$ (from 0.57 to 0.29 ). The pure PMMA processed under the same conditions gives a microcellular material with a relative density of 0.3 [31] (dashed line in Figure 4), so when the copolymer content is reduced the density approaches that obtained with the pure 
polymer. This decreasing trend of the relative density can be related to the cell size: the lower the MAM content, the greater the cell size and thus the smaller the density. A small change in the cell size can become a great difference in density due to the high density of cells in these materials. For instance, a change from 120 to $180 \mathrm{~nm}$ leads to a reduction of the density from 0.57 to 0.40 when the MAM type $\mathrm{H}$ is reduced from $10 \mathrm{wt} \%$ to $5 \mathrm{wt} \%$.

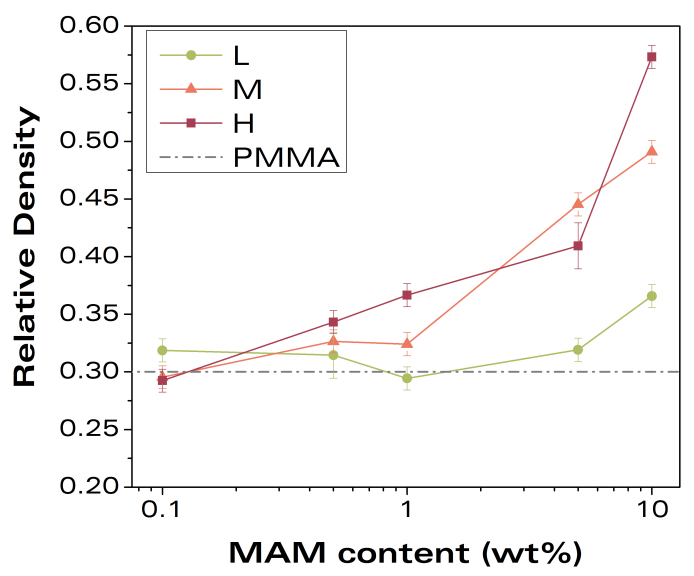

Figure 4. Relative density of the cellular materials produced at $80^{\circ} \mathrm{C}$ of foaming temperature as a function of the MAM content for the three grades of MAM. Pure PMMA (continuous dashed line) was added as a reference.

\subsection{Effect of the foaming temperature on the cellular structure}

To further reduce the relative densities obtained so far, two additional foaming temperatures were tested, 60 and $100{ }^{\circ} \mathrm{C}$, whereas the rest of the processing parameters remained the same. Only those blends based on the copolymer with medium molecular weight, $\mathrm{M}$, were used in this section to make the study clearer. Nonetheless, similar results and trends were observed for the other materials.

SEM micrographs of some of these materials are shown in Figure 5. The blend $10 \%-\mathrm{M}$ present a very similar cellular structure at 60 and $100{ }^{\circ} \mathrm{C}$, but an increase in the cell size is observed when foaming temperature increases for $0.1 \%-\mathrm{M}$ and $1 \%-\mathrm{M}$.

Cell nucleation density is not affected by the foaming temperature regardless of the MAM content (Figure 6.a). In Figure 6.b and in the cell size distributions (Figure S7, see Supplementary Information) it is observed that the blends with high MAM content (5\%-M and $10 \%-\mathrm{M})$ show constant cell size and narrow cell size distribution for the different temperatures. The blends with medium content (say $0.5 \%-\mathrm{M}$ and $1 \%-\mathrm{M}$ ) also show constant average cell size with temperature, but the cell size distribution becomes wider (also observed in Figure 5.e). Finally, the blend 0.1\%-M presents an increase in the cell size for higher foaming temperatures. We can conclude that in the systems presenting only micelles in a high density the increase of foaming temperature does not allow further cell growth, because the cell growth is limited by the distance between the micelles [31]. However, in systems with fewer micelles (separated greater distances) such as $0.5 \%-\mathrm{M}$ and $1 \%-\mathrm{M}$, cells can grow slightly more, causing a wider cell size distribution when temperature increases. In addition, as there might be some nucleation in dispersed MAM groups of molecules, those nuclei 
have not any restriction to grow. Accordingly, in the system without micelles $(0.1 \%-\mathrm{M})$ there is no restriction at all, and foaming temperature enhances cell growth.

All the cell sizes reported in Figure $6 . \mathrm{b}$ are smaller than $360 \mathrm{~nm}$, that is, for contents from $0.1 \mathrm{wt} \%$ to $10 \mathrm{wt} \%$ of MAM, and for foaming temperatures varying between 60 and $100{ }^{\circ} \mathrm{C}$, nanocellular polymers can be produced.

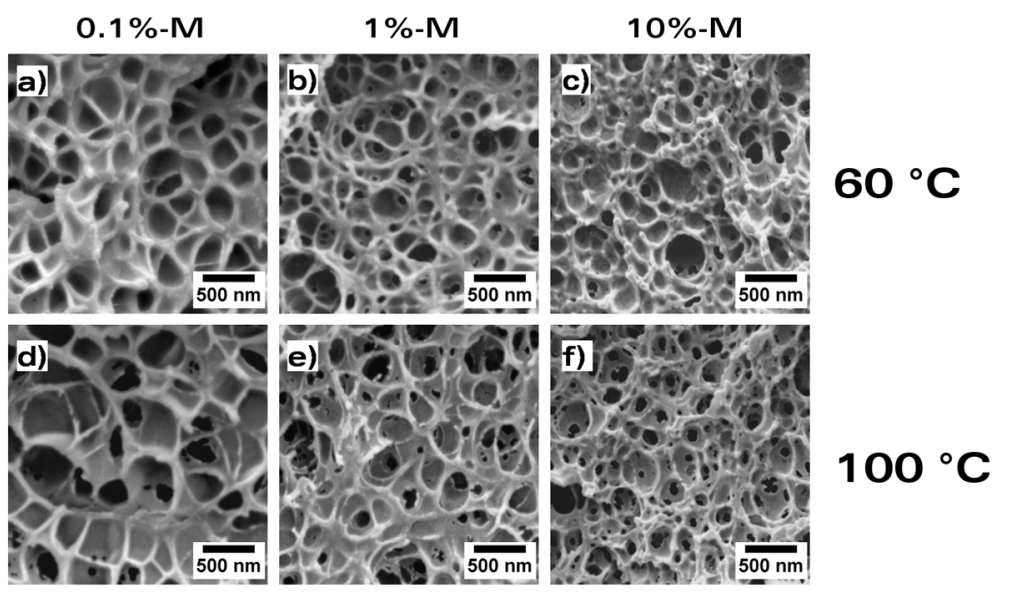

Figure 5. SEM images, showing the cellular structure of representative materials, $0.1 \%-\mathrm{M}, 1 \%-\mathrm{M}$ and $10 \% \mathrm{M}$, produced at $60^{\circ} \mathrm{C}(\mathrm{a}-\mathrm{c})$ and $100^{\circ} \mathrm{C}$ (d-f) of foaming temperature.
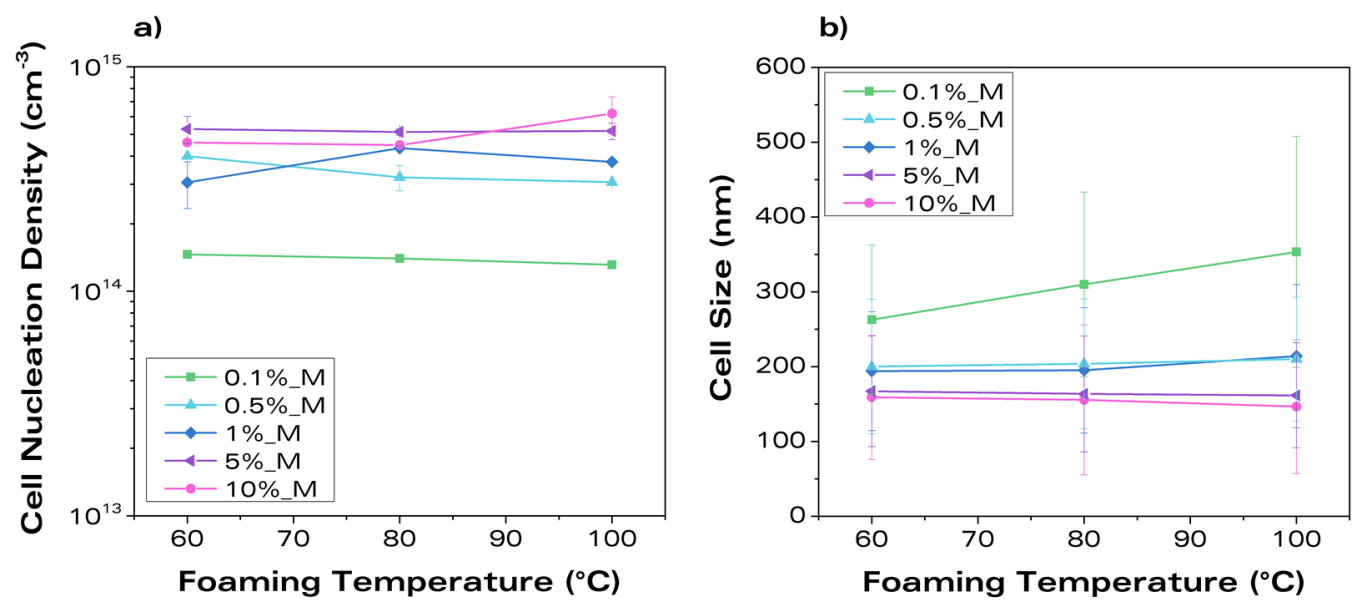

Figure 6. a) Cell nucleation density and b) cell size as a function of the foaming temperature for the blends based on the copolymer M with different MAM contents.

Figure 7 shows the evolution of the relative density as a function of the foaming temperature for the blends with different contents of MAM (type M). The relative density of the pure polymer produced under the same conditions was also included as reference. High and low copolymer contents behave differently. For high MAM contents ( $5 \mathrm{wt} \%$ and $10 \mathrm{wt} \%$ ) foaming temperature does not produce a significant effect on the density. However, for copolymer contents of $1 \mathrm{wt} \%$ or less, an increase in the foaming temperature leads to a reduction in the relative density. The lowest MAM content provides the lowest relative density: at $100^{\circ} \mathrm{C}$ the blend $0.1 \%-\mathrm{M}$ presents a relative density of 0.23 . 


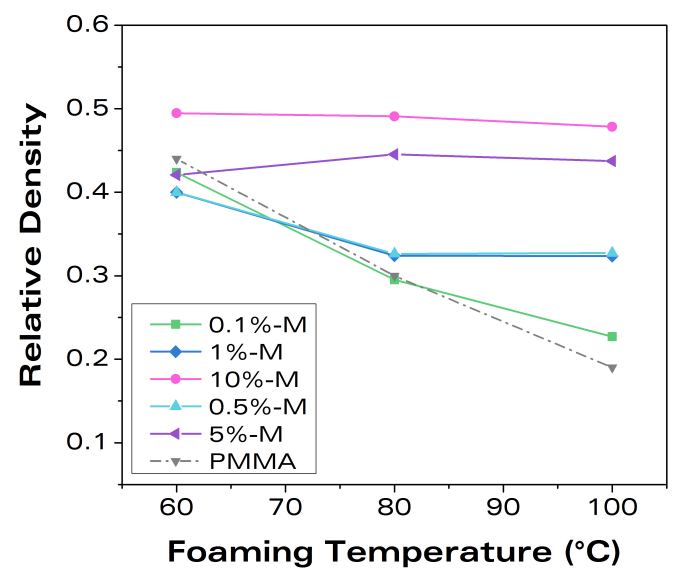

Figure 7. Relative density as a function of the foaming temperature for the blends based on the copolymer M with different MAM contents.

As the cell nucleation density was observed to be independent on the foaming temperature, the growth of the cells must be taken into account to explain the trends observed for the relative density. At high MAM contents (5 wt\% and $10 \mathrm{wt} \%$ ), it seems that micelles are limiting the growth because of the organization of the copolymer molecules around the micelle. This limitation is geometric, as the spherical organization in the micelle induces cell growth with the same geometry. According to previous results, we hypothesized that in these systems cells grow until a certain cell wall thickness is reached (around $25 \mathrm{~nm}$ ) [31]. Once this thickness is reached the cells cannot grow any further, so foaming temperature does not induce any change in relative density (Table 3 and Figure 7). For $1 \mathrm{wt} \%$ and $0.5 \mathrm{wt} \%$, the behavior is different. An increase of the foaming temperature from 60 to $100^{\circ} \mathrm{C}$ induces a reduction of the density. However, cell nucleation density is constant, and cell sizes vary only slightly (from 194 to $210 \mathrm{~nm}$ for $0.5 \%-\mathrm{M}$ ) (Figure 6). Cell wall thickness is also constant, around $30 \mathrm{~nm}$ (Table 3). The reduction of the relative density must be understood by taking into account the reduction of the fraction of mass in the struts (Table 3). This result is even more evident for the blend $0.1 \%$-M: relative density decreases as a consequence of a reduction of the mass in the struts, as already seen for nanocellular PMMA [19]. Figure 8 shows local thickness analysis of the materials based on $0.1 \%-\mathrm{M}$ foamed at different temperatures, showing the reduction of mass in the struts. In Figure 9, the fraction of mass in the struts is represented as a function of the relative density. It is observed that lower relative densities imply smaller fractions of mass in the struts.

The difference between high and low MAM contents is based on the different nucleation. At high contents, nucleation takes place in the spherical micelles, which limit the growing process [31]. On the other hand, at low contents nucleation also takes place in the MAM-rich regions that are not a micelle. In that case, there is not a limitation of spherical growth due to the organization of the copolymer molecules. Therefore, cells can grow in any shape and adopt polygonal geometries to fill the space. As a consequence, relative density can be reduced by this mechanism of decreasing the polymer mass in the struts. 
Table 3. Relative density, cell wall thickness and fraction of mass in the struts for the blends $0.1 \%$ $\mathrm{M}, 1 \%-\mathrm{M}$ and 10\%-M foamed at different temperatures.

\begin{tabular}{ccccc}
\hline Sample ID & $\begin{array}{c}\text { Foaming } \\
\text { Temperature }\left({ }^{\circ} \mathrm{C}\right)\end{array}$ & $\begin{array}{c}\text { Relative } \\
\text { Density }\end{array}$ & $\begin{array}{c}\text { Cell Wall Thickness } \\
(\mathrm{nm})\end{array}$ & $\begin{array}{c}\text { Fraction of mass in } \\
\text { the struts }\end{array}$ \\
\hline $0.1 \%-\mathrm{M}$ & 60 & 0.42 & $38 \pm 11$ & $0.70 \pm 0.04$ \\
\hline $0.1 \%-\mathrm{M}$ & 80 & 0.30 & $37 \pm 9$ & $0.52 \pm 0.02$ \\
\hline $0.1 \%-\mathrm{M}$ & 100 & 0.23 & $34 \pm 11$ & $0.42 \pm 0.00$ \\
\hline $1 \%-\mathrm{M}$ & 60 & 0.40 & $32 \pm 9$ & $0.72 \pm 0.04$ \\
$1 \%-\mathrm{M}$ & 80 & 0.32 & $29 \pm 8$ & $0.64 \pm 0.01$ \\
$1 \%-\mathrm{M}$ & 100 & 0.32 & $27 \pm 9$ & $0.61 \pm 0.02$ \\
$10 \%-\mathrm{M}$ & 60 & 0.49 & $24 \pm 6$ & $0.71 \pm 0.04$ \\
$10 \%-\mathrm{M}$ & 80 & 0.49 & $25 \pm 6$ & $0.72 \pm 0.04$ \\
$10 \%-\mathrm{M}$ & 100 & 0.48 & $26 \pm 7$ & $0.68 \pm 0.03$ \\
\hline
\end{tabular}
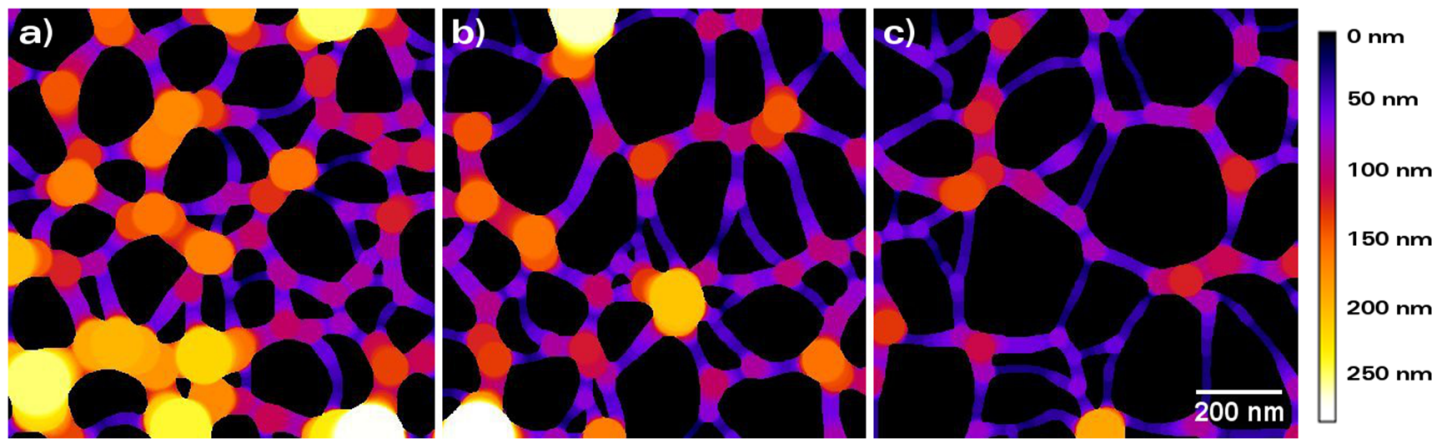

Figure 8. Local thickness analysis of the materials based on $0.1 \%-\mathrm{M}$ foamed at different temperatures: a) $60^{\circ} \mathrm{C}$, b) $80^{\circ} \mathrm{C}$ and c) $100^{\circ} \mathrm{C}$.

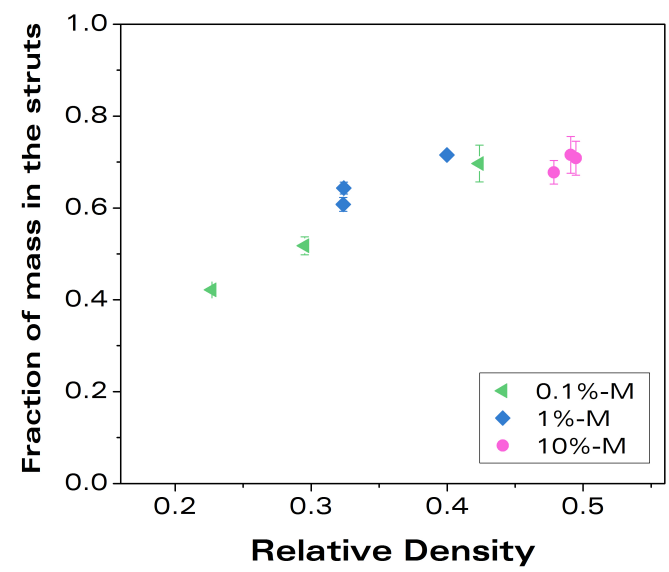

Figure 9. Fraction of mass in the struts as a function of the relative density for the blends $0.1 \%-\mathrm{M}$, $1 \%-\mathrm{M}$ and $10 \%-\mathrm{M}$ foamed at different temperatures.

Therefore, a new strategy to reduce the relative density in PMMA/MAM systems has been identified. By reducing the amount of block copolymer to contents below the critical micelle concentration, the formation of micelles is avoided, but block copolymer is still present in the blend. As a result, nucleation is enhanced, but the growing of the cells is not limited by the spherical organization 
induced by the micelles, allowing obtaining reduced relative densities for these very low MAM contents.

Thanks to this strategy, materials with a wide range of relative densities and cell sizes have been produced. All the materials produced in this work are shown in the cell size - relative density map of Figure 10, including materials produced with the copolymers $L$ and $H$ at different foaming temperatures (not discussed in section 2.3). Some materials from the literature are also included as a reference. Lines of constant cell nucleation density, calculated using equation (4) [33], are also included. In addition, a boundary line representing a constant cell wall thickness was plotted. According to equation (5) [41], the cell wall thickness $(\xi)$ is related to the cell size, the relative density, the fraction of mass in the struts $\left(f_{s}\right)$ and $C$ is a constant that depends on the cell shape. This equation is valid for closed cell cellular materials. For the line in Figure 10, a fraction of mass in the struts of 0.2 was considered, as this is a typical value for low density cellular materials [41]. For the cell wall thickness, a value of $5 \mathrm{~nm}$ was assumed, a reasonable minimum value for a cell wall formed by aligned polymer chains with a certain width (for instance, the radius of gyration of PMMA was estimated around $4 \mathrm{~nm}$ [42]). Regarding the constant $C$, it takes a value of 3.46 for pentagonal dodecahedrons [43].

$$
\begin{gathered}
1-\rho_{r}=\frac{\pi \phi^{3}}{6} N_{v} \\
C \xi=\phi\left(1-f_{s}\right) \rho_{r}
\end{gathered}
$$

As displayed in Figure 10, the materials produced in this work cover a wide range of relative densities (ranging from $0.17-0.58$ ) and cell sizes $(770$ to $120 \mathrm{~nm}$ ). Also, all the cellular materials plotted in this map, both from this work and from literature, lie above or near the theoretical line of constant cell wall thickness, supporting our hypothesis of the limitation imposed by the minimum cell wall thickness.

According to this idea, the region under the theoretical line of constant cell wall thickness, it is a forbidden region, because materials in that part of the graph will require cell wall thicknesses smaller than $5 \mathrm{~nm}$, so there are some combinations of relative density and cell size that might be impossible. For instance, according to this model and for a PMMA matrix with a minimum cell wall of $5 \mathrm{~nm}$, a closed cell cellular material with a relative density of 0.1 and a cell size of $50 \mathrm{~nm}$ would be unachievable due to geometric limitations.

This is, of course, a very strong hypothesis because up to know there is no definitive evidence of what is the minimum cell wall thickness that could be achieved in these nanocellular polymers. However, it seems reasonable to assume the existence of a limit value of the cell wall thickness, which would depend on the size of the molecules and would be in the range of some nanometers. In the case of open cell cellular materials, it is expectable that the window of achievable materials would be wider. 


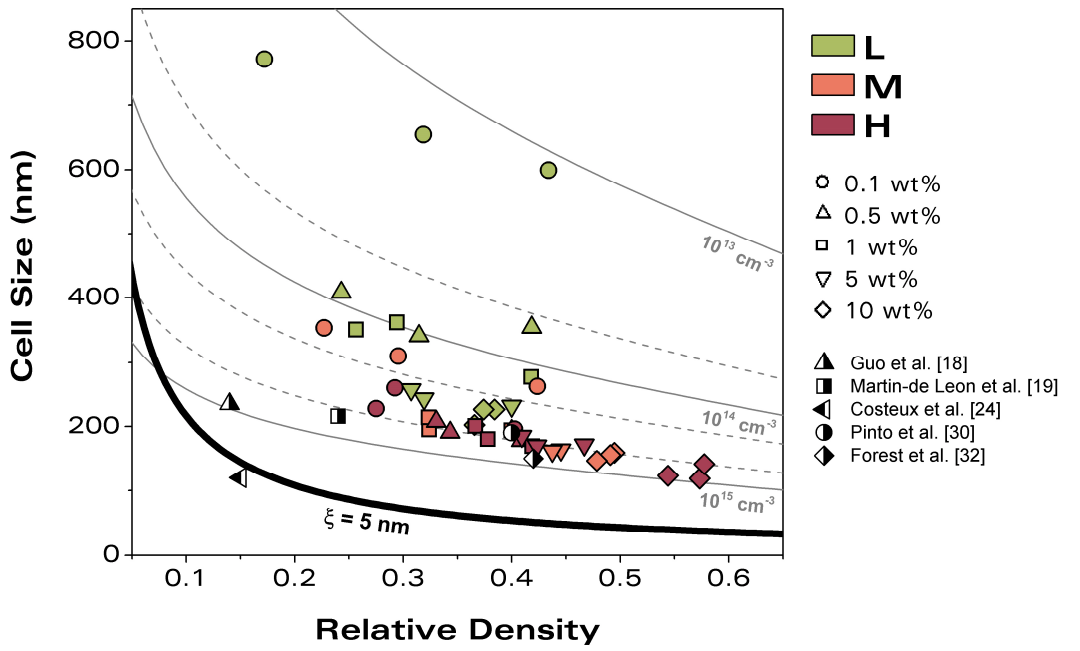

Figure 10. Cell size - relative density map of all the materials produced in this work and some literature materials. Circles: $0.1 \mathrm{wt} \%$, up triangles: $0.5 \mathrm{wt} \%$, squares: $1 \mathrm{wt} \%$, down triangles: $5 \mathrm{wt} \%$, diamond: 10 wt\%. Green: copolymer L, orange: copolymer M, red: copolymer H. Grey curves indicate regions of constant cell nucleation density according to equation (4). The constant thick black line indicates the curve of constant cell wall thickness according to equation (5).

\section{CONCLUSIONS}

In this work, new strategies to obtain low-density nanocellular materials based on PMMA/MAM blends have been explored. First, the influence of the amount of block copolymer was tested by producing blends at five MAM contents (from $0.1 \mathrm{wt} \%$ to $10 \mathrm{wt} \%$ ). Second, the effect of the foaming temperature as a way to reduce the density was investigated. Results show that both strategies, reducing the amount of MAM and increasing the foaming temperature, promote a reduction of the density in these systems.

The non-equilibrium nanostructuration achieved after the extrusion was dependent on the MAM content. Results show that the lower the MAM content, the smaller the micelle density. This result is understood by taking into consideration two phenomena: the dispersion of the MAM during the extrusion process and the self-assembly of the MAM molecules. During the extrusion process, lower MAM contents are dispersed in smaller domains, leading to lower micelle densities. For very low MAM contents, the micelles were hardly detected, so it was assumed that some MAM should be dispersed in the matrix forming MAM-rich regions, but without forming a micelle.

In the analysis of the effect of the MAM content on the cellular materials, a reduction of the relative density was detected when the amount of block copolymer decreases, but also an increase of the cell size. Despite the higher cell sizes obtained at low contents, nanocellular materials (cell size 260 $\mathrm{nm}$ ) with low relative density (0.3) were obtained. At low contents, cell nucleation density was larger than micelle density, so we hypothesized that nucleation could also occur in small MAM-rich regions even though there is no micelle.

On the other hand, the effect of the foaming temperature on the density was analyzed. High and low MAM contents behave very differently. Blends with high MAM contents were not able to expand more when the foaming temperature was increased. As growth may be limited by the organization 
of the molecules in the micelles, growth would stop once a minimum cell wall thickness is reached. On the other hand, low MAM contents show smaller densities for higher foaming temperatures. As nucleation in these systems takes place partially in MAM-rich regions, those cells can grow in any shape, reducing the density. This idea was supported by measuring the fraction of mass in the struts, which is indeed constant for high MAM contents and it reduces with density for low MAM contents. Finally, by applying the strategies identified in this work, a material with a minimum density of 0.23 and $350 \mathrm{~nm}$ of cell size was obtained.

\section{Acknowledgements:}

Financial assistance from MINECO, FEDER, UE (MAT2015-69234-R) and the Junta de Castile and Leon (VA011U16) are gratefully acknowledged. Financial support from FPU grant FPU14/02050 (V. Bernardo) from the Spanish Ministry of Education, Juan de la Cierva-Incorporación grant IJCI-201629992 (J. Pinto) from Spanish MINECO, and Junta of Castile and Leon grant of J. Martín-de León are gratefully acknowledged. We also want to thank Arkema for supplying the copolymers used in this research.

\section{REFERENCES}

[1] European Commission, Horizon 2020 Work Programme 2018 - 2020: 10. Secure, Clean and Efficient Energy, 2017. https://ec.europa.eu/programmes/horizon2020/en/h2020-section/secure-clean-and-efficient-energy.

[2] International Energy Agency (IEA), Technology Roadmap. Energy efficient building envelopes, (2013). doi:10.1007/SpringerReference_7300.

[3] M. Alam, H. Singh, M.C. Limbachiya, Vacuum insulation panels (VIPS) for building construction industry - a review of the contemporary developments and future directions, Appl. Energy. 88 (2011) 3592-3602. doi:10.1016/j.apenergy.2011.04.040.

[4] B.P. Jelle, Traditional, state-of-the-art and future thermal building insulation materials and solutions Properties, requirements and possibilities, Energy Build. 43 (2011) 2549-2563. doi:10.1016/j.enbuild.2011.05.015.

[5] B. Notario, J. Pinto, E. Solorzano, J.A. de Saja, M. Dumon, M.A. Rodriguez-Perez, Experimental validation of the Knudsen effect in nanocellular polymeric foams, Polymer (Guildf). 56 (2015) 57-67. doi:10.1016/j.polymer.2014.10.006.

[6] B. Notario, J. Pinto, M.A. Rodríguez-Perez, Towards a new generation of polymeric foams: PMMA nanocellular foams with enhanced physical properties, Polymer (Guildf). $63 \quad$ (2015) 116-126. doi:10.1016/j.polymer.2015.03.003.

[7] B. Notario, J. Pinto, M.A. Rodriguez-Perez, Nanoporous polymeric materials: A new class of materials with enhanced properties, Prog. Polym. Sci. 78-79 (2016) 93-139. doi:10.1016/j.pmatsci.2016.02.002.

[8] J. Pinto, B. Notario, R. Verdejo, M. Dumon, S. Costeux, M.A. Rodriguez-perez, Molecular confinement of solid and gaseous phases of self-standing bulk nanoporous polymers inducing enhanced and unexpected physical properties, Polymer (Guildf). 113 (2017) 27-33. doi:10.1016/j.polymer.2017.02.046.

[9] B. Notario, A. Ballesteros, J. Pinto, M.A. Rodriguez-Perez, Nanoporous PMMA: A novel system with different acoustic properties, Mater. Lett. 168 (2016) 76-79. doi:10.1016/j.matlet.2016.01.037.

[10] S. Perez-Tamarit, B. Notario, E. Solorzano, M.A. Rodriguez-Perez, Light transmission in nanocellular polymers: are semi-transparent cellular polymers possible?, Mater. Lett. $210 \quad$ (2017) 39-41. doi:10.1016/j.matlet.2017.08.109.

[11] G. Wang, J. Zhao, L.H. Mark, G. Wang, K. Yu, C. Wang, C.B. Park, G. Zhao, Ultra-tough and super thermalinsulation nanocellular PMMA/TPU, Chem. Eng. J. 325 (2017) 632-646. doi:10.1016/j.cej.2017.05.116.

[12] C. Forest, P. Chaumont, P. Cassagnau, B. Swoboda, P. Sonntag, Polymer nano-foams for insulating 
applications prepared from CO 2 foaming, Prog. Polym. Sci. 41 (2015) 122-145. doi:10.1016/j.progpolymsci.2014.07.001.

[13] Z. Li, C. Zhu, X. Zhao, A theoretical and numerical study on the gas-contributed thermal conductivity in aerogel, Int. J. Heat Mass Transf. 108 (2017) 1982-1990. doi:10.1016/j.ijheatmasstransfer.2017.01.051.

[14] V. Bernardo, J. Martín-de Leon, M.A. Rodriguez-Perez, Production and characterization of nanocellular polyphenylsulfone foams, Mater. Lett. 178 (2016) 155-158. doi:10.1016/j.matlet.2016.05.002.

[15] H. Guo, V. Kumar, Some thermodynamic and kinetic low-temperature properties of the PC-CO2 system and morphological characteristics of solid-state PC nanofoams produced with liquid CO2, Polymer (Guildf). 56 (2015) 46-56. doi:10.1016/j.polymer.2014.09.061.

[16] D. Miller, P. Chatchaisucha, V. Kumar, Microcellular and nanocellular solid-state polyetherimide ( PEI ) foams using sub-critical carbon dioxide I. Processing and structure, Polymer (Guildf). 50 (2009) 5576-5584. doi:10.1016/j.polymer.2009.09.020.

[17] H. Guo, A. Nicolae, V. Kumar, Solid-State Microcellular and Nanocellular Polysulfone Foams, J. Polym. Sci. Part B Polym. Phys. 53 (2015) 975-985. doi:10.1002/polb.23719.

[18] H. Guo, A. Nicolae, V. Kumar, Solid-state poly(methyl methacrylate) (PMMA) nanofoams. Part II: Lowtemperature solid-state process space using $\mathrm{CO} 2$ and the resulting morphologies, Polymer (Guildf). 70 (2015) 231-241. doi:10.1016/j.polymer.2015.06.031.

[19] J. Martin de-Leon, V. Bernardo, M.A. Rodriguez-Perez, Low Density Nanocellular Polymers Based on PMMA Produced by Gas Dissolution Foaming: Fabrication and Cellular Structure Characterization, Polymers (Basel). 8 (2016) 1-16. doi:10.3390/polym8070265.

[20] S. Costeux, I. Khan, S.P. Bunker, H.K. Jeon, Experimental study and modeling of nanofoams formation from single phase acrylic copolymers, J. Cell. Plast. 51 (2015) 197-221. doi:10.1177/0021955X14531972.

[21] H. Guo, A. Nicolae, V. Kumar, Fabrication of High Temperature Polyphenylsulfone Nanofoams Using High Pressure Liquid Carbon Dioxide, Cell. Polym. 35 (2015) 2016.

[22] J. Pinto, D. Morselli, V. Bernardo, B. Notario, D. Fragouli, M.A. Rodriguez-Perez, A. Athanassiou, Nanoporous PMMA foams with templated pore size obtained by localized in situ synthesis of nanoparticles and $\mathrm{CO} 2$ foaming, Polymer (Guildf). 124 (2017) 176-185. doi:10.1016/j.polymer.2017.07.067.

[23] L. Urbanczyk, C. Calberg, C. Detrembleur, C. Jérôme, M. Alexandre, Batch foaming of SAN / clay nanocomposites with scCO 2 : A very tunable way of controlling the cellular morphology, Polymer (Guildf). 51 (2010) 3520-3531. doi:10.1016/j.polymer.2010.05.037.

[24] S. Costeux, L. Zhu, Low density thermoplastic nanofoams nucleated by nanoparticles, Polymer (Guildf). 54 (2013) 2785-2795. doi:10.1016/j.polymer.2013.03.052.

[25] V. Bernardo, J. Martin-de León, E. Laguna-Gutiérrez, M.Á. Rodríguez-Pérez, PMMA-sepiolite nanocomposites as new promising materials for the production of nanocellular polymers, Eur. Polym. J. 96 (2017) 10-26. doi:10.1016/j.eurpolymj.2017.09.002.

[26] J. Pinto, M. Dumon, M.A. Rodriguez-Perez, Nanoporous Polymer Foams from Nanostructured Polymer Blends: Preparation, Characterization, and Properties, in: P.. Visakh, G. Markovic, D. Pasquini (Eds.), Recent Dev. Polym. Macro, Micro Nano Blends, Woodhead Publishing in Materials, 2016: pp. 237-288.

[27] S. Costeux, CO2-blown nanocellular foams, J. Appl. Polym. Sci. 131 (2014) 41293(1)-41293(16). doi:10.1002/app.41293.

[28] J. Pinto, M. Dumon, M.A. Rodriguez-Perez, R. Garcia, C. Dietz, Block Copolymers Self-Assembly Allows Obtaining Tunable Micro or Nanoporous Membranes or Depth Filters Based on PMMA; Fabrication Method and Nanostructures, J. Phys. Chem. C. 118 (2014) 4656-4663. doi:10.1021/jp409803u.

[29] J. Pinto, M. Dumon, M. Pedros, J. Reglero, M.A. Rodriguez-Perez, Nanocellular CO2 foaming of PMMA assisted by block copolymer nanostructuration, Chem. Eng. J. 243 (2014) 428-435. doi:10.1016/j.cej.2014.01.021.

[30] J. Pinto, J.A. Reglero-ruiz, M. Dumon, M.A. Rodriguez-Perez, Temperature influence and CO2 transport in foaming processes of poly(methyl methacrylate)-block copolymer nanocellular and microcellular foams, J. Supercrit. Fluids. 94 (2014) 198-205. doi:10.1016/j.supflu.2014.07.021.

[31] V. Bernardo, J. Martin-de Leon, E. Laguna-Gutierrez, T. Catelani, J. Pinto, A. Athanassiou, M.A. Rodriguez-Perez, Understanding the role of MAM molecular weight on the production of PMMA/MAM nanocellular polymers, Polymer (Guildf). 153 (2018) 262-270. doi:10.1016/j.polymer.2018.08.022.

[32] C. Forest, P. Chaumont, P. Cassagnau, B. Swoboda, P. Sonntag, CO2 nano-foaming of nanostructured PMMA Polymer (Guildf). 58 (2015) 76-87. doi:10.1016/j.polymer.2014.12.048. 
[33] V. Kumar, N.P. Suh, A process for making microcellular parts, Polym. Eng. Sci. 30 (1990) 1323-1329. doi:https://doi.org/10.1002/pen.760302010.

[34] P. Spitael, C.W. Macosko, R.B. Mcclurg, Block Copolymer Micelles for Nucleation of Microcellular Thermoplastic Foams, Macromolecules. 37 (2004) 6874-6882. doi:10.1021/ma049712q.

[35] J. Pinto, E. Solorzano, M.A. Rodriguez-perez, J.A. De Saja, Characterization of the cellular structure based on user-interactive image analysis procedures, J. Cell. Plast. 49 (2013) 555-575. doi:10.1177/0021955X13503847.

[36] V. Kumar, Process synthesis for manufacturing microcellular thermoplastic parts, Massachusetts Institute of Technology, 1988.

[37] R.G. Alargova, I.I. Kochijashky, M.L. Sierra, R. Zana, Micelle Aggregation Numbers of Surfactants in Aqueous Solutions: A Comparison between the Results from Steady-State and Time-Resolved Fluorescence Quenching, Langmuir. 7463 (1998) 5412-5418. doi:10.1021/la980565x.

[38] S. Siripurapu, J.M. Desimone, S.A. Khan, R.J. Spontak, N. Carolina, N. Carolina, Controlled Foaming of Polymer Films through Restricted Surface Diffusion and the Addition of Nanosilica Particles or CO2-philic Surfactants, Macromolecules. 38 (2005) 2271-2280. doi:10.1021/ma047991b.

[39] M.D. Whitmore, T.W. Smith, Swelling of Copolymer Micelles by Added Homopolymer, Macromolecules. 27 (1994) 4673-4683. doi:10.1021/ma00095a006.

[40] J.S. Colton, N.P. Suh, The Nucleation of Microcellular Thermoplastic Foam With Additives: Part I: Theoretical Considerations, Polym. Eng. Sci. 27 (1987) 485-492.

[41] L.J. Gibson, M. Ashby, Cellular solids: structure and properties, 2nd Editio, Cambridge University Press, 1997.

[42] D.Q. Zou, H. Yoshida, Size effect of silica nanoparticles on thermal decomposition of PMMA, J. Ann. Therm. Anal. Calorim. 99 (2010) 21-26. doi:10.1007/s10973-009-0531-4.

[43] O.A. Almanza, J.A. de Saja, M.A. Rodriguez-Perez, Prediction of the Radiation Term in the Thermal Conductivity of Crosslinked Closed Cell Polyolefin Foams, J. Polym. Sci. Part B Polym. Phys. 38 (2000) 993-1004. doi:10.1002/(SICI)1099-0488(20000401)38:7<993::AID-POLB10>3.0.CO;2-J. 


\section{Supplementary Information:}

\section{Low-density PMMA/MAM nanocellular polymers using low MAM contents: production and characterization}

Victoria Bernardo ${ }^{1 *}$, Judith Martin-de Leon ${ }^{1}$, Javier Pinto ${ }^{2}$, Tiziano Catelani ${ }^{3}$, Athanassia Athanassiou ${ }^{2}$, Miguel Angel Rodriguez-Perez ${ }^{1}$

1. Cellular Materials Laboratory (CellMat), Condensed Matter Physics Department, University of Valladolid, Campus Miguel Delibes, Paseo de Belén n7, 47011 Valladolid, Spain

2. Smart Materials, Istituto Italiano di Tecnologia, Via Morego 30, 16163 Genova, Italy 3. Electron Microscopy Facility, Istituto Italiano di Tecnologia, Via Morego 30, 16163 Genova, Italy

*Corresponding author: Victoria Bernardo (vbernardo@fmc.uva.es) +34983184035

\section{ESTIMATION OF THE SOLUBILITY OF MAM}

The solubility of PMMA and blends with $10 \mathrm{wt} \%$ of MAM was measured experimentally elsewhere [1] using the following procedure. The amount of gas uptake was calculated as the percentage of weight increment of the sample due to the $\mathrm{CO}_{2}$ sorption. The initial mass was measured after drying the samples and before being placed in the pressure vessel and the final weight was evaluated by weighting the samples immediately after being removed from the pressure vessel. The time between the depressurisation and the weight measurement was around 2 minutes. During this time some gas was lost due to gas diffusion out of the sample. Thus, these measurements are only an estimation of the solubility, and therefore the values obtained were only used for comparison between the different samples. Note that the accurate way to calculate the solubility consist on measuring the mass lost during desorption and extrapolating the mass to zero desorption time to have the real mass after saturation [2]. However, the difference between the values calculated here and those that would be obtained by extrapolation are smaller than $1 \%$, so this way of estimating the solubility gives the correct order of magnitude.

The results are summarized in Table S1. From these values, the solubility in the MAM phase can be estimated. We conclude that under these conditions $\left(10 \mathrm{MPa}\right.$ and $25^{\circ} \mathrm{C}$ ) the MAM copolymer can absorb as much as $38 \mathrm{wt} \%$ of gas, and that no significant differences among the three copolymers are detected.

Table S1. Solubility of PMMA and PMMA/MAM blends with $10 \mathrm{wt} \%$ of MAM and estimation of the MAM solubility (10 MPa of saturation pressure and $25^{\circ} \mathrm{C}$ of saturation temperature).

\begin{tabular}{cccc}
\hline Sample & $\begin{array}{c}\text { Total Gas } \\
\text { Uptake (wt\%) }\end{array}$ & $\begin{array}{c}\text { Fraction of } \\
\text { MAM }\end{array}$ & $\begin{array}{c}\text { Gas Uptake in the } \\
\text { MAM phase (wt\%) }\end{array}$ \\
\hline PMMA & 24.1 & 0 & - \\
10\%-L & 25.5 & 0.1 & 38.1 \\
$10 \%-\mathrm{M}$ & 25.4 & 0.1 & 37.1 \\
$10 \%-\mathrm{H}$ & 25.6 & 0.1 & 39.1 \\
\hline
\end{tabular}




\section{CELLULAR STRUCTURE OF MICROCELLULAR PMMA}

The characteristics of the cellular structure of pure PMMA cellular material produced at the same conditions (saturation at $10 \mathrm{MPa}$ and $25{ }^{\circ} \mathrm{C}$ and foaming at $80{ }^{\circ} \mathrm{C}$ during 1.5 minutes) are summarized in Table S2 [1]. Under these conditions, the pure polymer shows a microcellular structure with a cell size of almost 2 microns, the cell size distribution being wide and heterogeneous, as seen in the high value of the parameter $S D / \phi$ and Figure S1.a, respectively. Figure S1.b shows a zoom of the low cell size region (cell sizes up to a micron). Although some cells are detected with cell sizes smaller than the micron, the major part of the cells (more than $60 \%$ according to Figure S1.b) are much larger than 1 micron. This plot of Figure S1.b was included also as a reference to be compared with the cell size distributions of the blends with MAM (see next section, Figure S4). The cellular structure of this microcellular PMMA sample can be observed in Figure S2.a. As a reference to see the change of scale, the nanocellular structure of the sample 10\%$M$ was also included in this figure (Figure S2.b).

Table S2. Gas uptake, relative density, and cellular structure characteristics of the PMMA foam produced at $10 \mathrm{MPa}$ of saturation pressure and $80^{\circ} \mathrm{C}$ of foaming temperature.

\begin{tabular}{ccccccc}
\hline Sample & $\begin{array}{c}\text { Gas Uptake } \\
(\mathrm{wt} \%)\end{array}$ & $\begin{array}{c}\text { Relative } \\
\text { Density }\end{array}$ & $\begin{array}{c}\text { Cell Nucleation } \\
\text { Density }\left(\text { nuclei/cm }{ }^{3}\right)\end{array}$ & $\begin{array}{c}\text { Cell Size } \\
(\mathrm{nm})\end{array}$ & SD / $\phi$ & $\begin{array}{c}\text { Cell Wall } \\
\text { Thickness }(\mathrm{nm})\end{array}$ \\
\hline PMMA & 24.1 & 0.30 & $(5.60 \pm 0.50) \cdot 10^{11}$ & 1701 & 0.82 & $160 \pm 50$ \\
\hline
\end{tabular}

a)

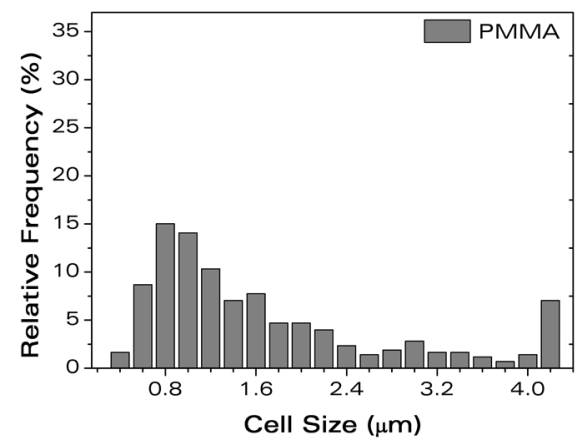

b)

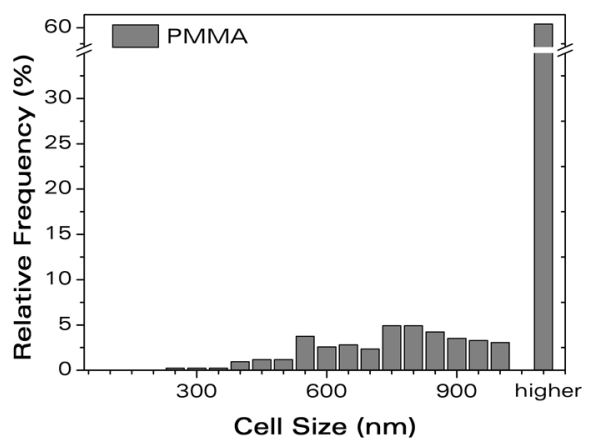

Figure S1. Cell size distribution of the PMMA sample produced at $10 \mathrm{MPa}$ of saturation pressure and $80^{\circ} \mathrm{C}$ of foaming temperature: a) Micrometric range and b) nanometric range.
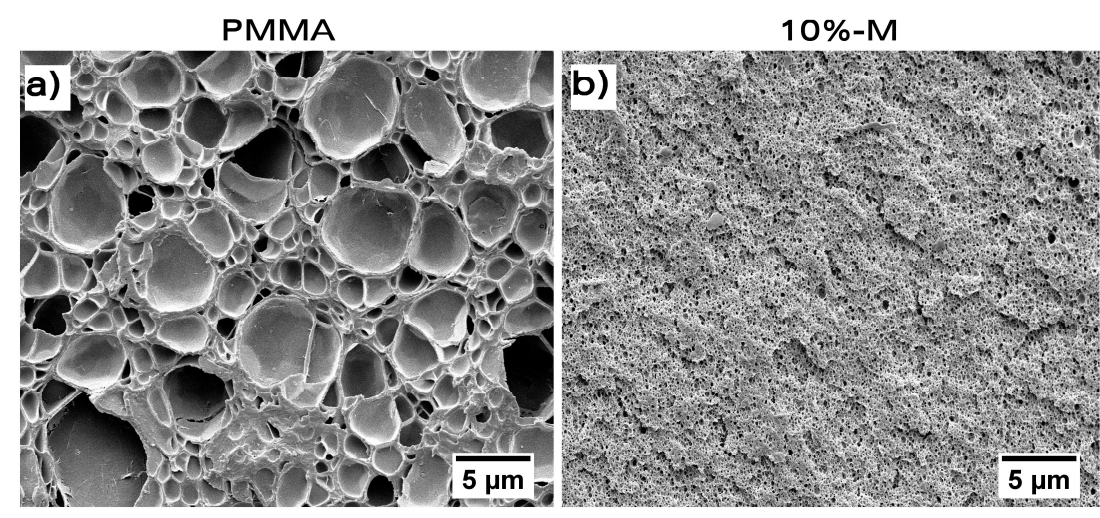

Figure S2. SEM micrographs of two samples produced at $10 \mathrm{MPa}$ of saturation pressure and $80^{\circ} \mathrm{C}$ of foaming temperature: a) PMMA and b) 10\%-M. 


\section{COMPARISON BETWEEN PMMA AND BLENDS WITH 0.1 wt\% OF MAM}

One of the main findings of this work is that the use of very low MAM contents in a PMMA matrix allows to obtain low-density samples (with densities close to those of the pure PMMA) while keeping the cell size in the nanoscale. Figure S3 shows a comparison among the cellular structure of the pure PMMA and those of the blends with the lowest MAM content used in this work (0.1 wt\%). Note that whereas PMMA shows a microcellular structure with very thick cell walls, the blend $0.1 \%-\mathrm{L}$ presents a sub-microcellular structure (cell size around $700 \mathrm{~nm}$ ) and the blends $0.1 \%-\mathrm{M}$ and $0.1 \%$ $\mathrm{H}$ are clearly nanocellular. Therefore, the presence of MAM is key to induce the formation of a nanocellular structure with a relative density close to that of the pure polymer.

PMMA

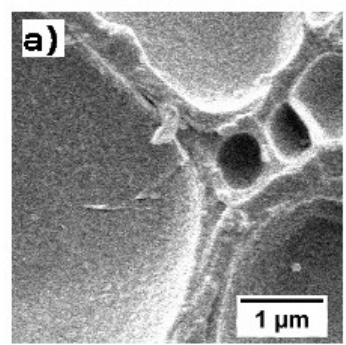

$0.1 \%-L$

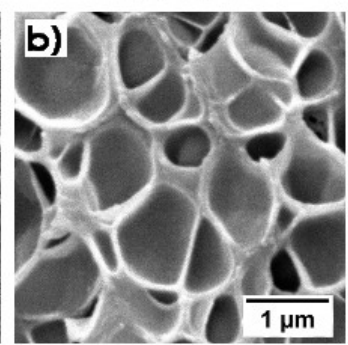

$0.1 \%-M$

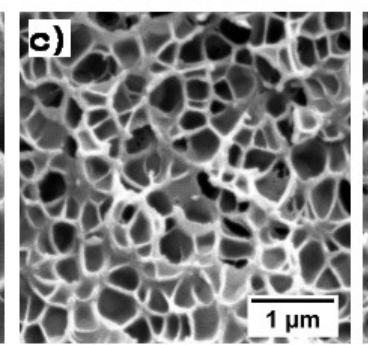

$0.1 \%-\mathrm{H}$

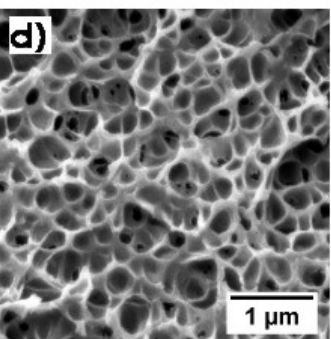

Figure S3. SEM micrographs of samples produced at $10 \mathrm{MPa}$ of saturation pressure and $80^{\circ} \mathrm{C}$ of foaming temperature: a) PMMA, b) 0.1\%-L, c) 0.1\%-M and d) $0.1 \%-H$.

\section{NUCLEATION MECHANISMS IN BLENDS WITH LOW MAM CONTENT}

It is well-established that in systems where nucleation is purely homogeneous there exists a huge influence of the amount of gas absorbed in the cellular structure, whereas in systems with heterogeneous nucleation this effect is reduced or neglected. One parameter that affects strongly to the $\mathrm{CO}_{2}$ absorbed by the sample is the saturation pressure. In order to study the nucleation mechanisms taking place in the PMMA/MAM blends with low MAM contents, foaming experiments at different saturation pressures were performed. Saturation pressures used were 5, 10, 20 and 30 $\mathrm{MPa}$, while saturation temperature was kept constant at $25^{\circ} \mathrm{C}$. After saturation at those conditions, all materials were foamed in a boiling water bath at $100{ }^{\circ} \mathrm{C}$ for 1 minute. In this study, only the blends with the lowest MAM content, $0.1 \mathrm{wt} \%$ of MAM, were analyzed.

Figure S4 shows the cellular structure of the materials obtained, together with the TEM image of the nanostructuration. The effect of the saturation pressure in the cellular structure is evident in the blend $0.1 \%-\mathrm{L}$, but not so evident in the other materials. Cell nucleation density was measured to quantify this effect and compare with that of pure PMMA produced under the same conditions (Figure S5). In the pure PMMA, an increase of the saturation pressure leads to an important change in the cell nucleation density, from $10^{11}$ to $10^{14}$ nuclei/ $\mathrm{cm}^{3}$. This is the expected behavior of a system that presents solely homogeneous nucleation: higher pressures lead to higher solubilities, which turn into higher nucleation densities. However, in the blends $0.1 \%-\mathrm{M}$ and $0.1 \%-\mathrm{H}$, nucleation is almost constant with pressure, indicating a heterogeneous nucleation in these systems. The independence of nucleation with the saturation pressure is a common behavior in different systems presenting heterogeneous nucleation, such as blends with nanoparticles [2] and also 
other PMMA/MAM systems [3]. Finally, the blend $0.1 \%-\mathrm{L}$ presents an intermediate nucleation behavior. Nucleation is not constant with pressure, but it varies only one order of magnitude, from $10^{13}$ to $10^{14}$ nuclei $/ \mathrm{cm}^{3}$. These results suggest that nucleation in $0.1 \%-\mathrm{L}$ is not homogeneous as in the pure PMMA, otherwise pressure should have a more significant effect on the nucleation. Therefore, heterogeneous nucleation is also playing a role in this system. As there were no micelles, the nucleation should take place in the small MAM-rich domains. However, the dependence of nucleation with pressure suggests that the nucleation in these MAM-rich regions is not predominant at any conditions at the conditions tested.

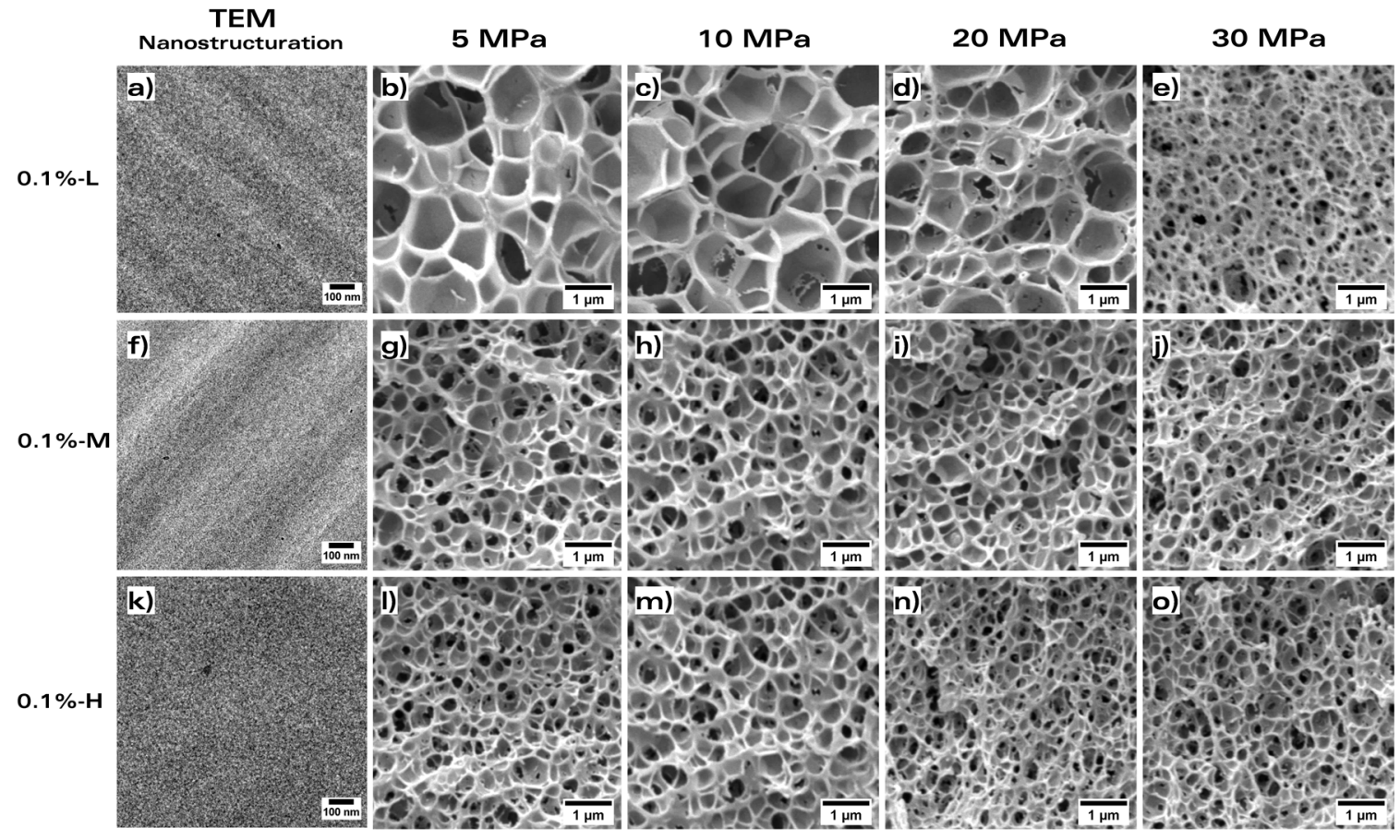

Figure S4. TEM nanostructuration of the solids and SEM micrographs of the materials saturated at different foaming temperatures.

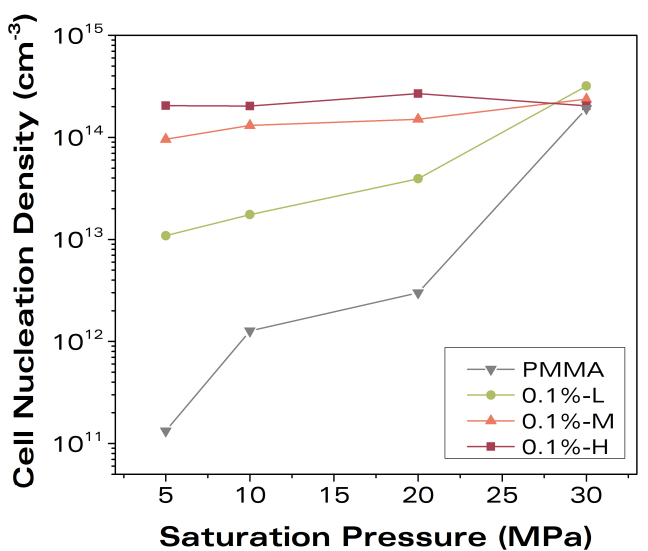

Figure 55. Cell nucleation density as a function of the saturation pressure for the blends with 0.1 $w t \%$ of MAM and the pure PMMA.

To explain this effect of the pressure, the critical radius $r_{c}$ must be taken into consideration. In can be calculated from the pressure gradient $\Delta p$ and the surface tension according to equation (S1) [4- 
6]. Any cluster of gas molecules smaller than the critical radius will not be stable, whereas nuclei with a size larger than the critical radius will survive and grow. The critical radius has been estimated several times $[3,7,8]$ and it takes values between 0.2 and $8 \mathrm{~nm}$.

$$
r_{c}=\frac{2 \gamma}{\Delta p}
$$

As no clear micelle nanostructuration is observed in the system 0.1\%-L (Figure S4.a), we propose that nucleation takes place in small MAM-rich domains. However, these small MAM-rich domains have a certain size, and to act as effective nucleating agents, this size should be larger than the critical radius. The critical radius decreases with the pressure gradient. Therefore, we hypothesize that for low pressures, only some aggrupation of molecules could have a size big enough to act as a nucleation point. As pressure increases, the critical radius decreases, and thus more molecules can behave as nucleating agents. This hypothesis also explains why this effect is not observed for the other blends $0.1 \%-\mathrm{M}$ and $0.1 \%-\mathrm{H}$ : as the MAM molecular weight is higher in these blends, the radius of the molecules is also higher, and they are more suitable to act as nucleating agents. Besides, in those blends, some micelles with sufficient radius were detected, which also contribute to the nucleation.

\section{CELL SIZE DISTRIBUTION OF THE PMMA/MAM BLENDS FOAMED AT $80^{\circ} \mathrm{C}$}

Figure $\mathrm{S} 6$ shows the cell size distribution of the materials produced at $10 \mathrm{MPa}$ of saturation pressure and foamed at $80^{\circ} \mathrm{C}$ during 1.5 minutes (see last page of this file for high resolution image). This information completes the data of Figure 3.b (in the main text) and supports the discussion about the effect of the MAM content in the cell size.
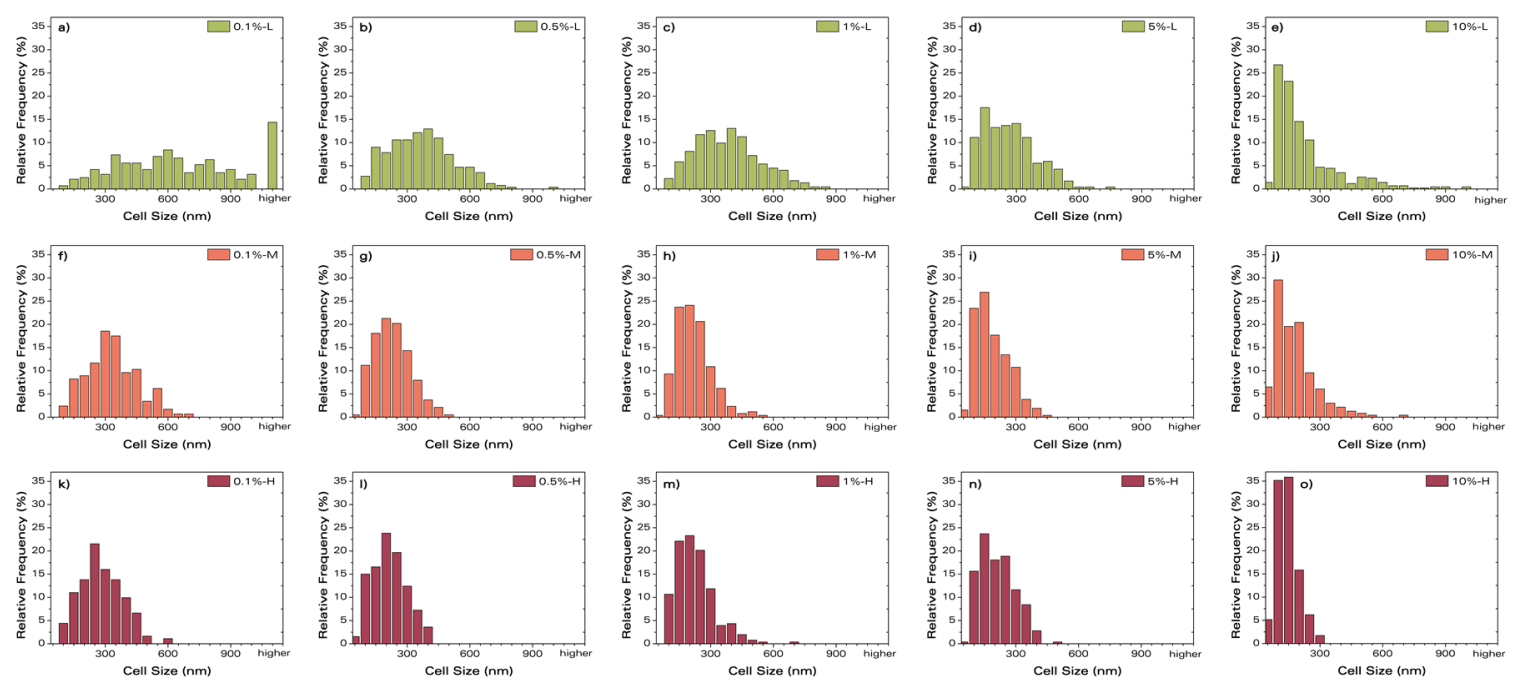

Figure S6. Cell size distribution of the materials produced at $80^{\circ} \mathrm{C}$ of foaming temperature: a) $0.1 \%-L$, b) $0.5 \%-L$, c) $1 \%-L$, d) $5 \%-L$, e) $10 \%-L$, f) $0.1 \%-M$, g) $0.5 \%-M$, h) $1 \%-M$, i) $5 \%-M$, j) $10 \%-M$, k) $0.1 \%-\mathrm{H}, \mathrm{I}) 0.5 \%-\mathrm{H}, \mathrm{m}) 1 \%-\mathrm{H}, \mathrm{n}) 5 \%-\mathrm{H}$ and o) $10 \%-\mathrm{H}$. 


\section{Cell size distribution of the PMMA/MAM blends foamed at various temperatures}

Figure 57 shows the cell size distribution of the most representative materials produced at $10 \mathrm{MPa}$ of saturation pressure and foamed at $60^{\circ} \mathrm{C}$ and $100^{\circ} \mathrm{C}$. This information completes the data of Figure 6.b (in the main text) and supports the discussion about the temperature effect in the cell size.
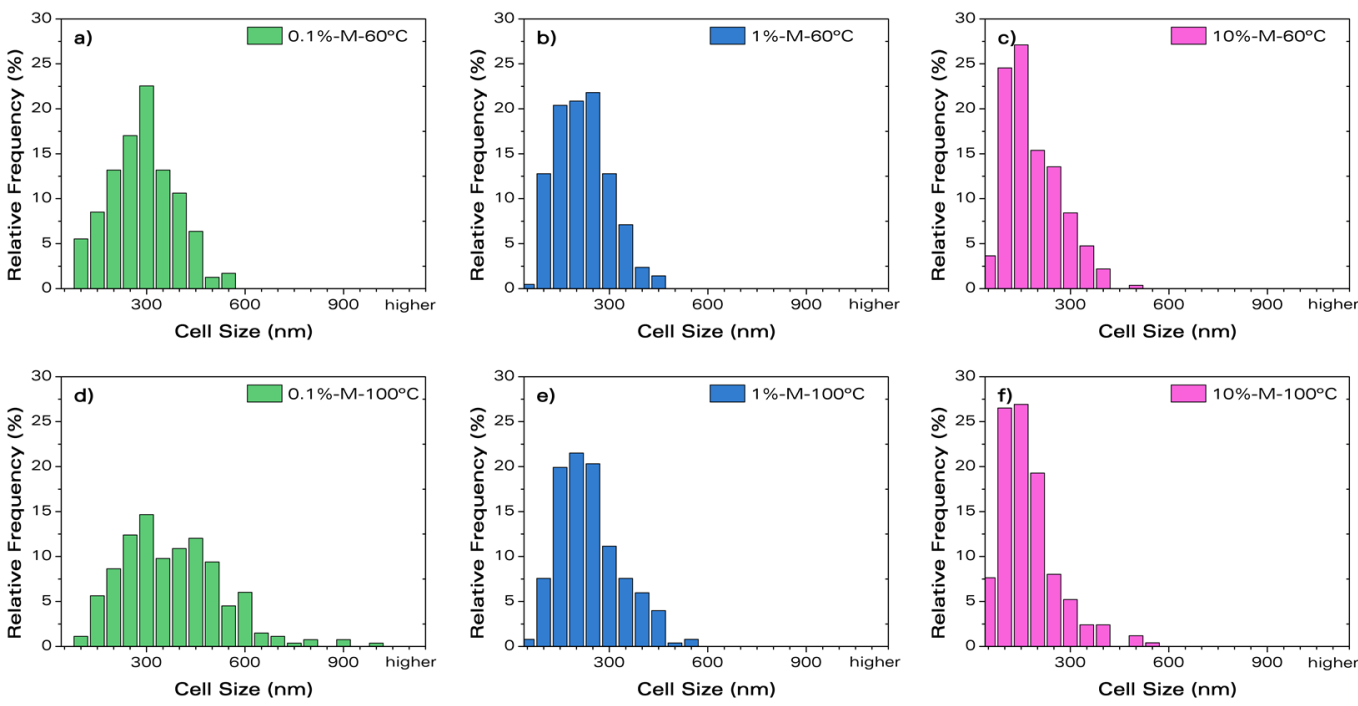

Figure S7. Cell size distribution of representative materials, $0.1 \%-\mathrm{M}, 1 \%-\mathrm{M}$ and $10 \% \mathrm{M}$, produced at $60{ }^{\circ} \mathrm{C}(\mathrm{a}-\mathrm{c})$ and $100^{\circ} \mathrm{C}(\mathrm{d}-\mathrm{f})$ of foaming temperature.

\section{REFERENCES}

[1] V. Bernardo, J. Martin-de Leon, E. Laguna-Gutierrez, T. Catelani, J. Pinto, A. Athanassiou, M.A. Rodriguez-Perez, Understanding the role of MAM molecular weight on the production of PMMA/MAM nanocellular polymers, Polymer (Guildf). 153 (2018) 262-270. doi:10.1016/j.polymer.2018.08.022.

[2] V. Bernardo, J. Martin-de León, E. Laguna-Gutiérrez, M.Á. Rodríguez-Pérez, PMMA-sepiolite nanocomposites as new promising materials for the production of nanocellular polymers, Eur. Polym. J. 96 (2017) 10-26. doi:10.1016/j.eurpolymj.2017.09.002.

[3] J. Pinto, M. Dumon, M. Pedros, J. Reglero, M.A. Rodriguez-Perez, Nanocellular CO2 foaming of PMMA assisted by block copolymer nanostructuration, Chem. Eng. J. 243 (2014) 428-435. doi:10.1016/j.cej.2014.01.021.

[4] S.K. Goel, E.J. Beckman, Generation of Microcellular Polymeric Foams Using Supercritical Carbon Dioxide. I: Effect of Pressure and Temperature on Nucleation, Polym. Eng. Sci. 34 (1994) 1137-1147.

[5] I. Khan, D. Adrian, S. Costeux, A model to predict the cell density and cell size distribution in nano-cellular foams, Chem. Eng. Sci. 138 (2015) 634-645. doi:10.1016/j.ces.2015.08.029.

[6] M. a Shafi, J.G. Lee, R.W. Flumerfelt, Prediction of cellular structure in free expansion polymer foam processing, Polym. Eng. Sci. 36 (1996) 1950-1959. doi:10.1002/pen.10591.

[7] S. Costeux, L. Zhu, Low density thermoplastic nanofoams nucleated by nanoparticles, Polymer (Guildf). 54 (2013) 2785-2795. doi:10.1016/j.polymer.2013.03.052.

[8] P. Spitael, C.W. Macosko, R.B. Mcclurg, Block Copolymer Micelles for Nucleation of Microcellular Thermoplastic Foams, Macromolecules. 37 (2004) 6874-6882. 


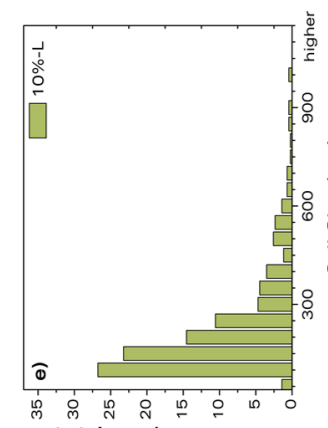

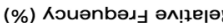

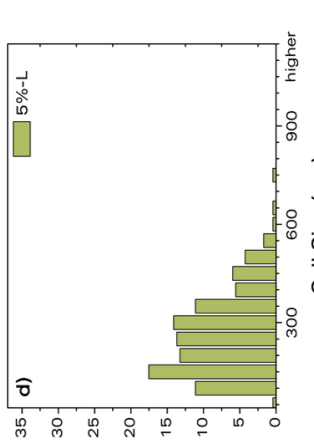

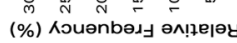
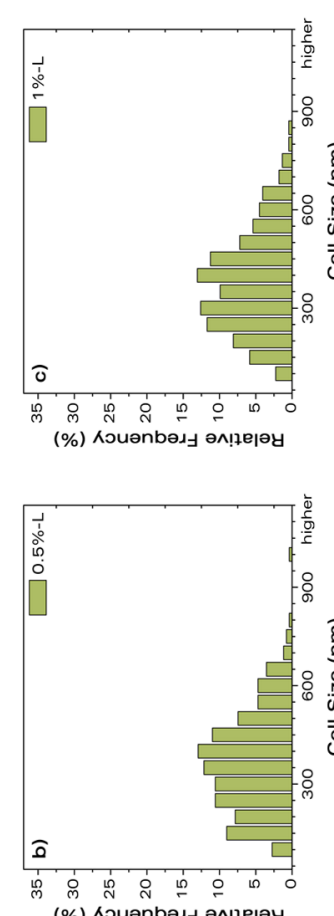

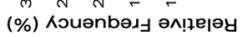
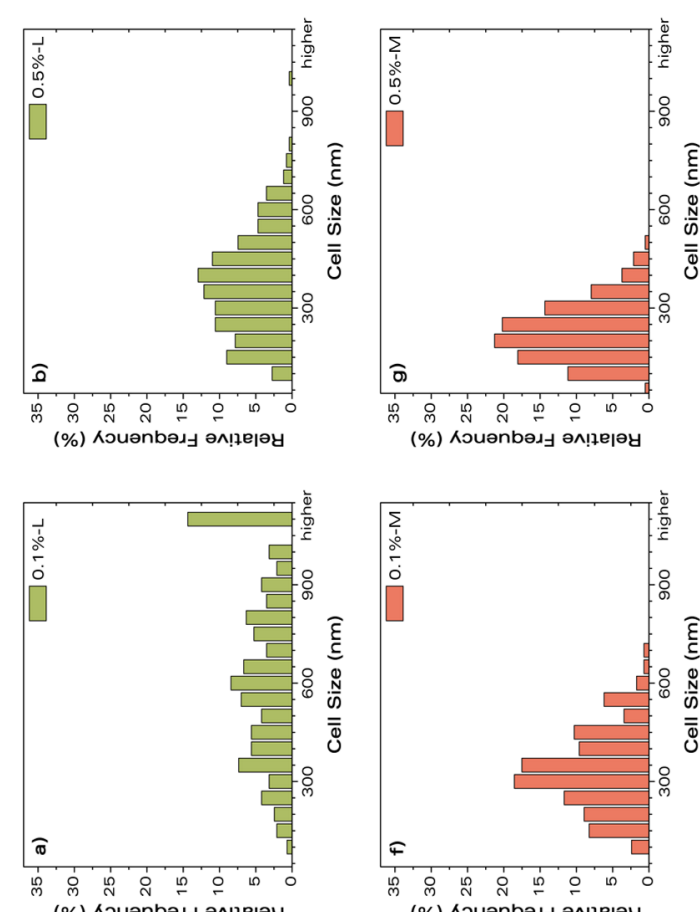

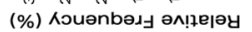
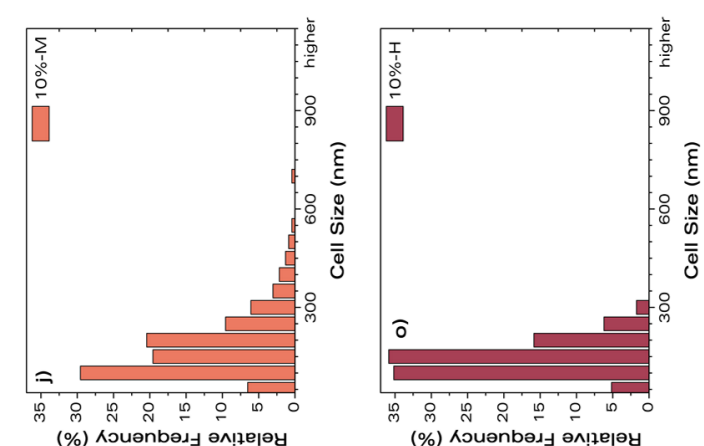
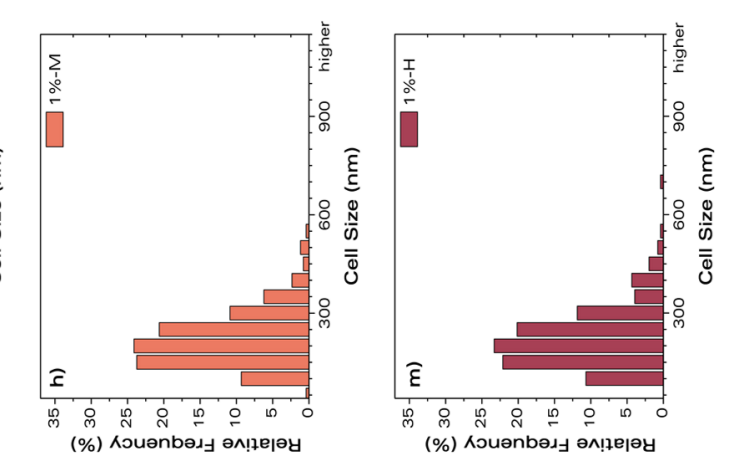

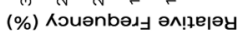

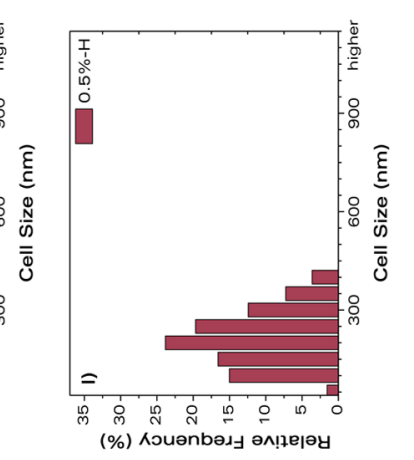

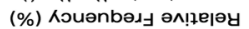

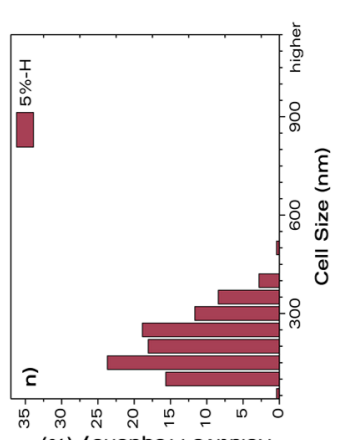

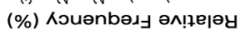

(\%) ᄉวuənbəגy әм!ฺе|әу
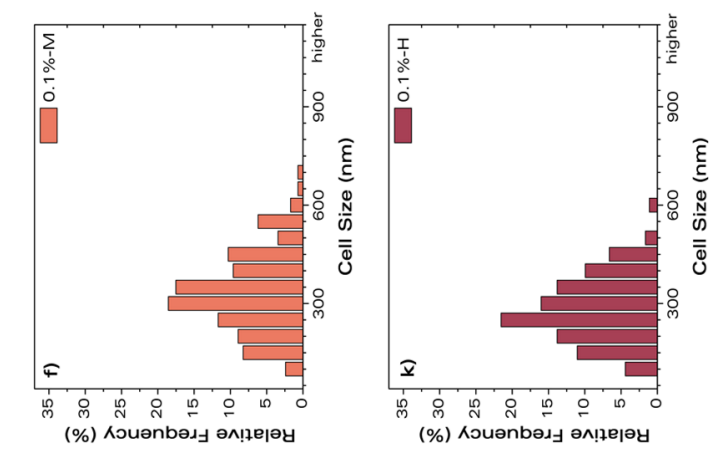

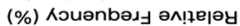

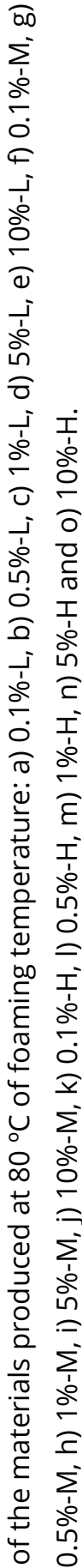

这

ธ

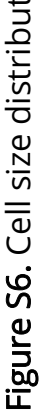




\subsection{Nanocellular polymers based on PMMAVTPU blends by gas dissolution foaming}

This section contains a publication entitled "Nanocellular polymers with a gradient cellular structure based on PMMAVTPU blends by gas dissolution foaming", submitted and pending of acceptance. This paper is the first approach in CellMat Laboratory to the research in the promising use of TPU as a nucleating agent for PMMA. Several crucial aspects are investigated to open this field for future studies.

PMMA/TPU blends are produced by extrusion, and the solid filament was used as a precursor for the foaming experiments, as explained in Chapter 3. The first goal of this study is to understand the effect of the addition of TPU in a PMMA matrix. These two polymers are immiscible, and our results show that a blend with a $2 \mathrm{wt} \%$ of TPU results in a nanostructuration formed by nanometric TPU domains in a density higher than $10^{13}$ domains $/ \mathrm{cm}^{3}$. As a consequence of the nanostructuration, TPU seems to be a suitable candidate to generate nanocellular structures.

In the foamed samples produced at $15 \mathrm{MPa}$ of saturation pressure, the addition of TPU has several effects. First, we observe that both pure PMMA and PMMA/TPU blends show a graded structure, but in the case of PMMA the effect is smooth, whereas in the PMMA/TPU sample a sharp cell size gradient is found. Second, the PMMA sample is microcellular, whereas the PMMA/TPU sample shows a homogeneous nanocellular core and a transition region towards micrometric cell sizes. Various conclusions are extracted from this analysis. First, that the addition of TPU induces an increase of the cell nucleation density of 3 orders of magnitude and a significant reduction of the cell size compared to PMMA, but only in the center of the cylindrical filaments. The nucleation density obtained in the core of the PMMA/TPU sample is similar to the TPU domain density measured in the solids, so we conclude that nucleation is taking place in the dispersed TPU domains or in the interface of the PMMA/TPU. However, this heterogeneous nucleation mechanism is not strong enough to produce a homogeneous nanocellular sample over all the sample thickness.

To understand the appearance of the graded structure in the PMMA/TPU system, the effect of the saturation pressure is investigated by changing the pressure from 6 to $20 \mathrm{MPa}$. At every pressure, a graded structure as that obtained at $15 \mathrm{MPa}$ is observed. The increase in pressure causes a rise in the cell density in the PMMA/TPU system. At $6 \mathrm{MPa}$ the nucleation density is smaller than the domain density (thus microcellular structures are obtained), but higher than the nucleation density in the pure PMMA. Therefore, there is a nucleating effect, but smaller than that found at higher pressures (10-20 MPa). These results indicate that the heterogeneous nucleation in the TPU is not predominant at all pressures. With this result, we explain the gradient of cell sizes found in these systems. Between the pressure release and the foaming, there is a time span of 2 minutes, and during this time some gas is diffusing out quickly through the cylinder surface. Therefore, there is a pressure gradient in the sample when the foaming step starts. As a consequence of this pressure (or gas concentration) gradient, gradient nucleation takes place in the PMMA/TPU samples, because nucleation depends on pressure. As a result, graded structures with a nanocellular core are obtained. This mechanism is schematically explained in the graphical abstract of this paper (Figure 5.3). 
Finally, an analysis of the foaming conditions was carried out by changing both the foaming temperature and foaming time. Results show that an excessive foaming time can lead to the appearance of degeneration mechanisms in the PMMA/TPU nanocellular polymers, such as coalescence and collapse, causing an increase in cell size.

In conclusion, TPU is a new promising nucleating agent for the production of low-density nanocellular polymers. In our work, nanocellular polymers with relative densities from 0.16 to 0.30 and cell sizes from 310 to $480 \mathrm{~nm}$ (in the nanocellular core) have been produced, showing that this approach combined with a low viscosity PMMA is an interesting way towards low-density nanocellular materials. In addition, we produced graded nanocellular structures, and cellular polymers with a gradient morphology present improved properties for some applications. This paper is included in the following pages.
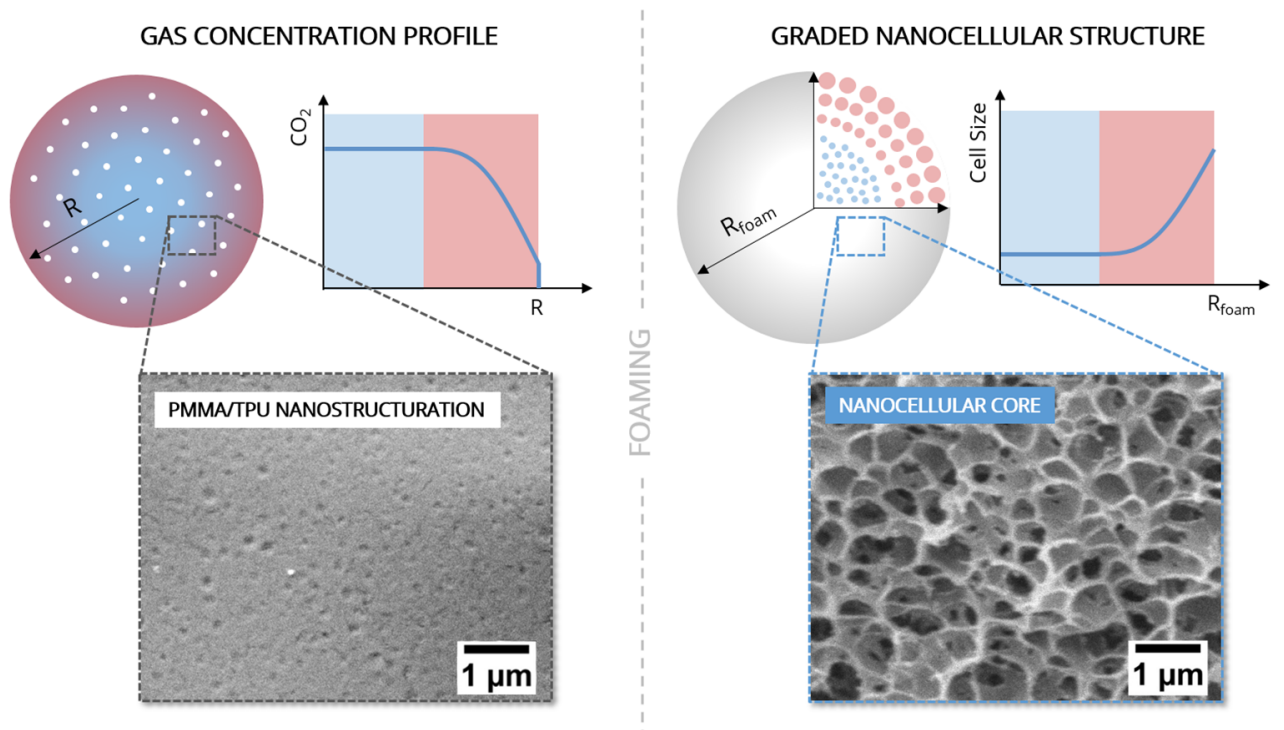

Figure 5.3. Graphical abstract of "Nanocellular polymers with a gradient cellular structure based on PMMATTU blends by gas dissolution foaming." 


\title{
Nanocellular polymers with a gradient cellular structure based on PMMA/TPU blends produced by gas dissolution foaming
}

Victoria Bernardo*, Judith Martín-de León1', Ismael Sánchez-Calderón', Ester Laguna-Gutiérrez², Miguel Ángel Rodríguez-Pérez ${ }^{1}$

1. Cellular Materials Laboratory (CellMat), Condensed Matter Physics Department, University of Valladolid, Campus Miguel Delibes, Paseo de Belén n7, 47011 Valladolid, Spain

2. CellMat Technologies S.L. Paseo de Belén n'9A, 47011 Valladolid, Spain *Corresponding author: Victoria Bernardo (vbernardo@fmc.uva.es) +34983184035

\begin{abstract}
Graded structures and nanocellular polymers are two examples of advanced cellular morphologies. In this work, we report a methodology to obtain low-density graded nanocellular polymers based on PMMA/TPU blends produced by gas dissolution foaming. A systematic study of the effect of the processing conditions, such as the saturation pressure and the foaming parameters, is presented. Results show that the melt-blending of PMMA with TPU results in a nanostructured material formed by nanometric TPU domains with a volumetric density higher than $10^{13}$ domains $/ \mathrm{cm}^{3}$. The PMMA/TPU foamed samples produced from this precursor show a gradient cellular structure, with a homogeneous nanocellular core. In the core, the TPU domains act as nucleating sites, enhancing nucleation in 3 orders of magnitude compared to pure PMMA and allowing the change from a microcellular to a nanocellular structure in the center of the resultant cellular material. Nonetheless, the outer region shows a gradient of cell sizes from nano- to micron-sized cells. We attribute this gradient structure to a non-constant pressure profile in the samples due to gas desorption before foaming. This hypothesis is validated by observing that indeed the nucleation in the PMMA/TPU system depends on pressure, because an increase of the saturation pressure from 6 to $20 \mathrm{MPa}$ causes an increase in the cell density. Regarding the effect of the foaming conditions, it is proved that it is necessary a fine control to obtain the desired structures and avoid degeneration of the cellular materials. Graded nanocellular polymers with relative densities from 0.16 to 0.30 and cell sizes in 3D from 310 to $480 \mathrm{~nm}$ (in the nanocellular core) have been produced in this work.
\end{abstract}

\section{KEYWORDS}

nanocellular polymer; nanostructuration; graded foam; gas dissolution foaming.

\section{INTRODUCTION}

The current demands for cost reductions have sharply increased the use of light-weight materials in many industrial sectors. In particular, the use of polymer foams or cellular polymers is extremely widespread. Cellular polymers combine the properties of polymers with cost and weight reductions, meeting the requirements for a wide variety of applications. The key parameters 
determining the properties of cellular polymers are the density and cellular morphology [1]. Thus, the research in cellular polymers is constantly evolving towards new and advanced structures that allow reaching enhanced performance [2].

Graded cellular polymers, that is, materials with a gradient in their cellular structure and/or density, are one example of advanced structures. Some of the porous structures found in nature, such as wood or bones, present complex structures that conferred them the properties required for their biological purpose [3]. In the case of manufactured cellular polymers, it has been proved that a non-homogeneous structure can lead to better behavior for some specific applications, such as high energy absorption [4,5], acoustic absorption [6] or electromagnetic interference shielding [7]. There are several strategies to produce cellular polymers with graded morphologies. One approach is the use of nucleating agents gradually distributed, such as in the work of Pinto et al. [8]. With a localized synthesis of the nanoparticles in the solid material, they reached a templated porous structure after foaming. In the work of $\mathrm{Yu}$ and coworkers [9], polymers were foamed in a nanoporous substrate, that enhanced nucleation near the substrate, reaching a graded cellular structure. A gradient in the foaming parameters might also induce the formation of a nonhomogeneous structure. For instance, Ngo et al. [10] designed an experimental set-up to generate non-constant temperature profiles to induce the formation of graded structures. Another approach is related to the use of non-constant distributions of the blowing agent. Zhou and coworkers [11] proposed the use of non-equilibrium concentration profiles in the gas dissolution foaming method. With this idea, Trofa et al. [12] generate multi-graded cellular polymers by applying advanced timevariable gas concentration profiles.

In the way towards advanced structures, another promising research line is the reduction of the cell size, that is, the production of microcellular and nanocellular polymers. Particularly, nanocellular polymers have aroused great attention recently due to their new properties. It has been proved that the thermal conductivity through the gas phase can be reduced when the cell size moves to the nanoscale [13-16]. Enhanced mechanical performance was also demonstrated in some nanocellular polymers [17,18]. Further, it is possible to produce semi-transparent nanocellular polymers [19,20], among other interesting properties and applications [21-23]. The challenge in the production of these systems is currently in the reduction of the density while keeping the cell size in the nanometric range.

Currently, the most interesting results to produce low-density nanocellular polymers have been achieved using poly(methyl methacrylate) (PMMA) foamed via a gas dissolution method [24-28]. Among the different strategies, the use of nanostructured polymer blends allows producing lowdensity nanocellular materials at mild processing conditions. The blend of poly(methyl methacrylate)-poly(butyl acrylate)-poly(methyl methacrylate) (MAM) copolymer with PMMA [29-32] was proved recently to allow reaching relative densities of 0.23 and cell sizes of $350 \mathrm{~nm}$. Another promising system is the immiscible blend of PMMA with thermoplastic polyurethane (TPU) that results in a nanostructuration of the TPU phase, as shown by Wang and coworkers [15]. Using a two-step gas dissolution foaming method with an extra cooling step, they obtained a very lowdensity nanocellular polymer with a relative density as low as 0.125 , while the cell size was only 205 $\mathrm{nm}$. 
In this paper, we produce cellular polymers based on PMMA/TPU blends that combine the two advanced structures previously mentioned. On the one hand, the samples produced in this work present a graded cellular structure thanks to the joint action of a non-equilibrium concentration profile and the addition of the TPU phase. On the other hand, the cell size moves from the micro to the nanoscale. In addition, the materials present low relative densities. The effects of the saturation pressure and foaming conditions have been evaluated to gain knowledge about the foaming mechanisms taking place in these systems.

\section{EXPERIMENTAL}

\subsection{Materials}

PMMA PLEXIGLAS $® 7 N$, in the form of pellets, was provided by Evonik. This PMMA grade is characterized by a melt flow index (MFI) of $3.6 \mathrm{~g} / 10$ min (obtained at $230{ }^{\circ} \mathrm{C}$ and $2.16 \mathrm{~kg}$ ) and a density of $1.19 \mathrm{~g} / \mathrm{cm}^{3}$. The glass transition temperature, measured by DSC, is $109^{\circ} \mathrm{C}$. The molecular weight of the polymer (measured by GPC) is $M_{n}=45 \mathrm{~kg} / \mathrm{mol}$ and $M_{w}=84 \mathrm{~kg} / \mathrm{mol}$.

TPU Estane ${ }^{\circledR}$ BCX61 was kindly supplied by Lubrizol. The MFI of this TPU is $27.9 \mathrm{~g} / 10 \mathrm{~min}$ (determined at $230{ }^{\circ} \mathrm{C}$ and $2.16 \mathrm{~kg}$ ), and the density is $1.19 \mathrm{~g} / \mathrm{cm}^{3}$. This TPU is a semicrystalline polymer formed by hard (semicrystalline) and soft (amorphous) segments. The hard segments are characterized by a melting temperature at $151{ }^{\circ} \mathrm{C}$, while the glass transition of the soft segments is around $-44^{\circ} \mathrm{C}$ (determined by DSC). The glass transition of the hard segments was not detected in the DSC experiment.

The blowing agent used was medical grade carbon dioxide $\left(\mathrm{CO}_{2}\right)$ of $99.9 \%$ purity.

\subsection{Solid Blends Production}

A PMMA/TPU blend with a 2 wt\% of TPU was melt blending by extrusion. The equipment used was a twin-screw extruder with a ratio L/D equal to 24 and screw diameter equal to $25 \mathrm{~mm}$ (model COLLIN TEACH-LINE ZK 25T). PMMA and TPU were dried in a vacuum oven at $50^{\circ} \mathrm{C}$ during at least 12 hours before the extrusion. The blend was extruded with a temperature range from $150{ }^{\circ} \mathrm{C}$ in the hopper to $190^{\circ} \mathrm{C}$ in the die, while the screw speed was equal to $40 \mathrm{rpm}$. The blend obtained from the first extrusion cycle was cooled in a water bath and afterward pelletized. The pellets were dried, and then the material was extruded again under the same processing parameters to assure homogeneity. In the second extrusion cycle, the extruded filament was set aside a let cool at room temperature. The cylindrical filament (that presents an average diameter of 3-4 $\mathrm{mm}$ ) was cut in samples of $30 \mathrm{~mm}$ in length for the foaming experiments. As-received PMMA was processed using the same extrusion conditions to obtain samples for the foaming experiments.

\subsection{Gas Dissolution Foaming Experiments}

Foaming experiments were conducted in a high-pressure vessel, model PARR 4681 (Parr Instrument Company). The pressure was controlled with an accurate pressure pump model SFT-10 
(Supercritical Fluid Technologies Inc.). A clamp heater of $1200 \mathrm{~W}$, regulated via a CAL 3300 temperature controller, adjusts the temperature of the vessel. The procedure used for all the experiments was the so-called two-step foaming process [33]. First, samples were put into the pressure vessel at a constant $\mathrm{CO}_{2}$ pressure (ranging from 6 to $20 \mathrm{MPa}$ in this work) at a constant temperature $\left(25^{\circ} \mathrm{C}\right)$ for the saturation stage. Saturation time was $24 \mathrm{~h}$ in all the experiments except in the case of $6 \mathrm{MPa}$, in which saturation time was $48 \mathrm{~h}$. The selected times were overestimated from data available at these pressures for sheets $[31,34]$ to ensure full saturation in the cylindrical samples. After saturation, the pressure was quickly released using an electrovalve. The pressure drop rate during the first pressure drop increases with saturation pressure: $0.7 \mathrm{MPa} / \mathrm{s}, 15 \mathrm{MPa} / \mathrm{s}$, $36 \mathrm{MPa} / \mathrm{s}$ and $56 \mathrm{MPa} / \mathrm{s}$ for the pressures of 6, 10,15 and $20 \mathrm{MPa}$, respectively. Then, the samples were removed from the vessel and immersed in a thermal bath at the desired temperature $\left(90^{\circ} \mathrm{C}\right.$ or $100{ }^{\circ} \mathrm{C}$ ) for the foaming stage. Foaming time was $0.5,1$ or 2 minutes. Between the release of pressure and the immersion of the samples in the thermal bath, there was a time gap of 2.5 minutes.

\subsection{Characterization}

\subsubsection{Nanostructuration of the PMMAVTPU blend}

The morphology of the solid PMMA/TPU blends was investigated using scanning electron microscopy (SEM). Images were collected with a SEM microscope FlexSEM 1000 VP-SEM (Hitachi High-Technologies). To prepare the solid materials for this analysis, they were cooled in liquid nitrogen and fractured. Then, a chemical etching with tetrahydrofuran (THF) was performed by immersing the fractured surface in THF for 30 minutes. This solvent dissolves quicker the TPU phase, so it selectively removes the TPU domains of the surface, while the PMMA matrix is not affected during this time. After the etching, the surface was coated with gold using a sputter coater model SCD 005 (Balzers Union). SEM images were analyzed with the software ImageJ/FIJI. The density of TPU domains $\left(N_{d}\right)$ was determined according to equation (1), where $n_{d}$ is the number of TPU domains in a region of area $A_{d}$. The domain size $\left(\phi_{d}\right)$ was calculated by averaging the size measurements of a satisfactory number of domains.

$$
N_{d}=\left(\frac{n_{d}}{A_{d}}\right)^{3 / 2}
$$

\subsubsection{Density}

A gas pycnometer model AccuPyc II 1340 (Micromeritics) was used to measure the density of the solid materials. On the other hand, the water-displacement method based on Archimedes' principle was used to measure the density of the foamed samples using a density determination kit for an AT261 Mettler-Toledo balance. The samples of this work present a gradient structure, as shown schematically in Figure 1. Then, the density of the foamed samples was determined twice. First, the density of the complete foamed sample was measured and the relative density of the global sample $\left(\rho_{r, g}\right)$ was determined. Then, the density of the homogeneous core (blue region in Figure 1) was determined by removing the transition region with a polisher model LaboPOI2-LaboForce3 
(Struers) and measuring the density in the resultant sample. The thickness of the transition region to be removed was determined with SEM image analysis.

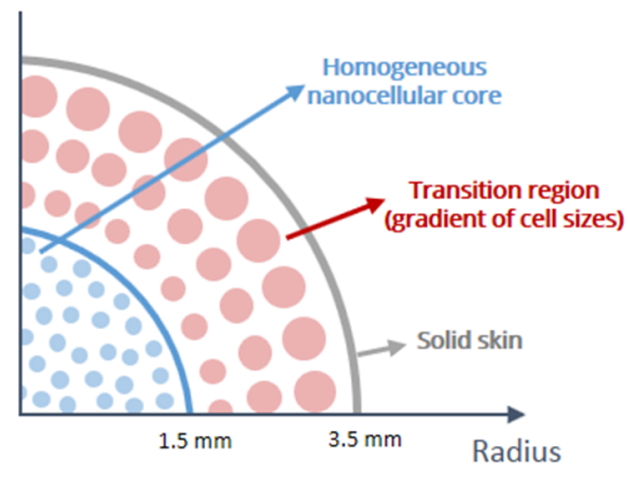

Figure 1. Schematic structure of the cylindrical samples obtained in this work.

\subsubsection{Cellular Structure}

The cellular structure was investigated using a scanning electron microscope FlexSEM 1000 VP-SEM (Hitachi High-Technologies). Previously, the foamed samples were cooled in liquid nitrogen and fractured, and then coated with gold using a sputter coater model SCD 005 (Balzers Union). To fully characterize the gradient structure of the samples (as that of the scheme of Figure 1), SEM images were taken at different distances along the sample radius. To analyze the images and quantify the structural parameters that characterize the cellular structure at every point, a tool based on the software ImageJ/FII [35] was used. First, the cell size distribution was measured, from which the average cell size in 3D $(\phi)$ and the standard deviation coefficient of the cell size distribution $(S D)$ were obtained (3D values were obtained by multiplying the $2 \mathrm{D}$ values by the correction factor 1.273 [35]). Cell density $\left(N_{v}\right)$ was determined using Kumar's method [36] according to equation (2), where $A$ is the area analyzed and $n$ is the number of cells in that area. In every region, more than 200 cells were analyzed.

$$
N_{v}=\left(\frac{n}{A}\right)^{3 / 2}
$$

In the core of the sample, that presents homogeneous cells, the cell nucleation density $\left(N_{0}\right)$ was determined using equation (3) using the relative density of the core $\rho_{r, c}$.

$$
N_{0}=\frac{N_{v}}{\rho_{r, c}}
$$

\section{RESULTS AND DISCUSSION}

\subsection{Nanostructuration of the PMMATTPU blend}

Figure 2.a shows the SEM image corresponding to the fracture surface of the solid PMMA/TPU blend after the etching process with THF. Nanometric holes are observed all along the sample, indicating the former presence of spherical TPU domains that are dissolved during the etching. Therefore, the immiscible blend of PMMA and TPU results in the formation of a nanostructure in which the TPU is 
dispersed forming nanometric domains. The number of the holes per unit of volume that is, the TPU domains density, was determined to be $3.3 \cdot 10^{13}$ domains $/ \mathrm{cm}^{3}$. This volumetric density is high enough to promote the formation of sub-micron and nanocellular structures. The average size of the domains is $89 \mathrm{~nm}$, and the domain size distribution is represented in Figure 2.b. Note that the real size of the domains is not measured, but assumed to be equal to the size of the hole remaining after the dissolution of the TPU phase. Then, it is plausible to claim that the TPU domain sizes provided in Figure 2.b are an upper limit of the real TPU domain sizes, that should be smaller than $89 \mathrm{~nm}$ on average. Up to the precision of our measurements, there are no significant differences in the nanostructuration observed through the sample thickness.
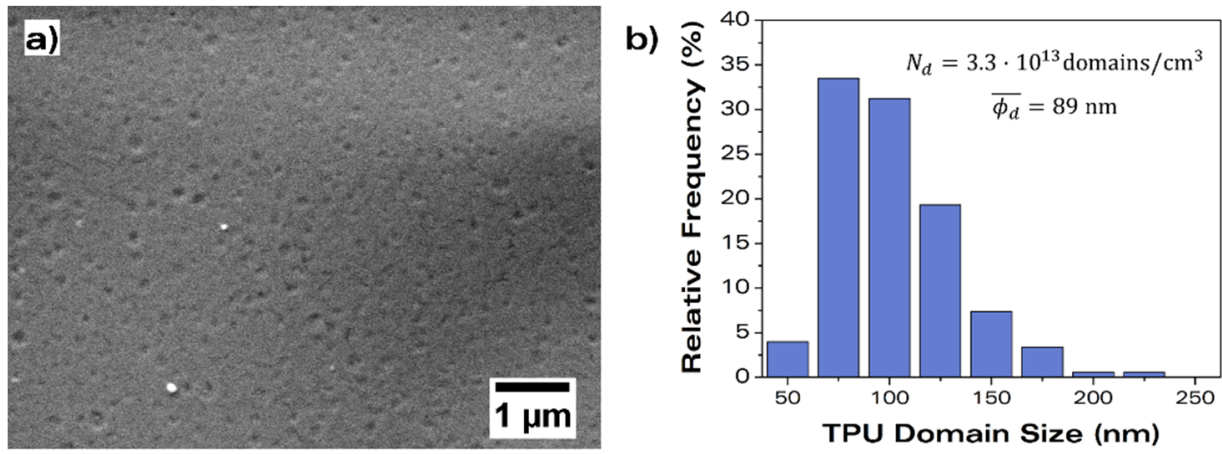

Figure 2. a) SEM image of the etched fracture of the solid PMMA/TPU blend, showing the nanostructuration, and b) domain size distribution, domain density, and average domain size.

\subsection{Effect of the addition of TPU}

To evaluate the effect of the addition of TPU, a single foaming experiment was performed. Saturation pressure was fixed at $15 \mathrm{MPa}$, while foaming was carried out at a temperature equal to $100{ }^{\circ} \mathrm{C}$ during 1 minute. The pressure was selected to be low enough to prevent excessive homogeneous nucleation in the PMMA matrix that could hide the effect of the TPU.

Table 1 collects the amount of gas uptake by the PMMA and the PMMA/TPU blend at $15 \mathrm{MPa}$ of saturation pressure. The pure polymer absorbs as much as $28 \mathrm{wt} \%$ of $\mathrm{CO}_{2}$, whereas the PMMA/TPU blend absorbs a smaller amount of gas because at these conditions TPU absorbs around $18 \mathrm{wt} \%$ of $\mathrm{CO}_{2}$ (measured in a pure TPU sample), less than PMMA. Then, the changes detected under the addition of TPU would not be due to an increase in the $\mathrm{CO}_{2}$ solubility.

Table 1. Amount of gas uptake, relative density, and cell nucleation densities in the core of the PMMA and the PMMA/TPU cellular samples produced at $15 \mathrm{MPa}$ of saturation pressure and foaming at $100^{\circ} \mathrm{C}$ during 1 minute.

\begin{tabular}{ccccc}
\hline Sample & $\begin{array}{c}\text { Gas uptake } \\
\text { (wt\%) }\end{array}$ & $\begin{array}{c}\text { Relative Density } \\
\text { (Global) }\end{array}$ & Relative Density (Core) & $\begin{array}{c}\boldsymbol{N}_{\mathbf{0}, \text { core }} \\
(\text { nuclei/cm }\end{array}$ \\
\hline PMMA & 28.0 & $0.12 \pm 0.01$ & $0.15 \pm 0.01$ & $4.7 \cdot 10^{11}$ \\
PMMATPU & 27.2 & $0.17 \pm 0.02$ & $0.18 \pm 0.01$ & $9.3 \cdot 10^{13}$ \\
\hline
\end{tabular}

Figure 3 shows representative SEM images taken at increasing distances from the center of the sample of the PMMA and the PMMA/TPU samples. The quantitative analysis of the cellular structure 
(cell size and cell density) throughout the sample radius is plotted in Figure 4. As commented in Figure 1, the samples present a gradient structure (Figure 3): the cell nucleation density decreases (Figure 3.a) and the cell size increases (Figure 3.b) towards the border of the sample. The effect is more noticeable in the PMMA/TPU blend. The relative densities (global and core) of the two foamed samples are included in Table 1. It is observed that PMMA presents a lower density than the PMMA/TPU blend, and that the global density is smaller than the core density, the differences around $10-20 \%$. Then, there exists also a gradient in the density along the sample radius.

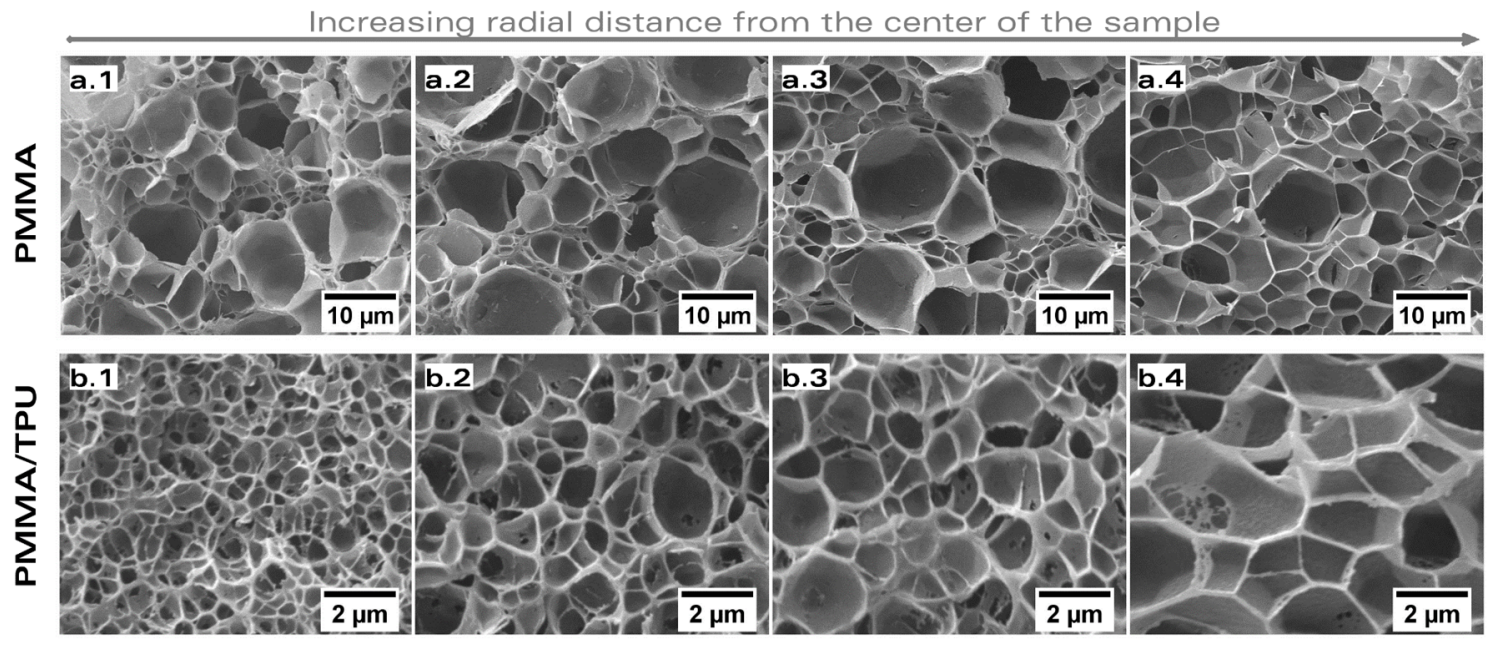

Figure 3. Representative SEM images of the cellular samples produced at $15 \mathrm{MPa}$ of saturation pressure and foamed at $100^{\circ} \mathrm{C}$ during 1 minute: a) PMMA and b) PMMA/TPU. Each image is taken at increasing distance from the center of the sample (d) (a.1 and b.1: $d<40 \%$ (CORE); a.2 and b.2: $d \sim 50 \%$; a.3 and b.3: $d \sim 70 \%$; a.4 and b.4: $d>90 \%)$.

a)

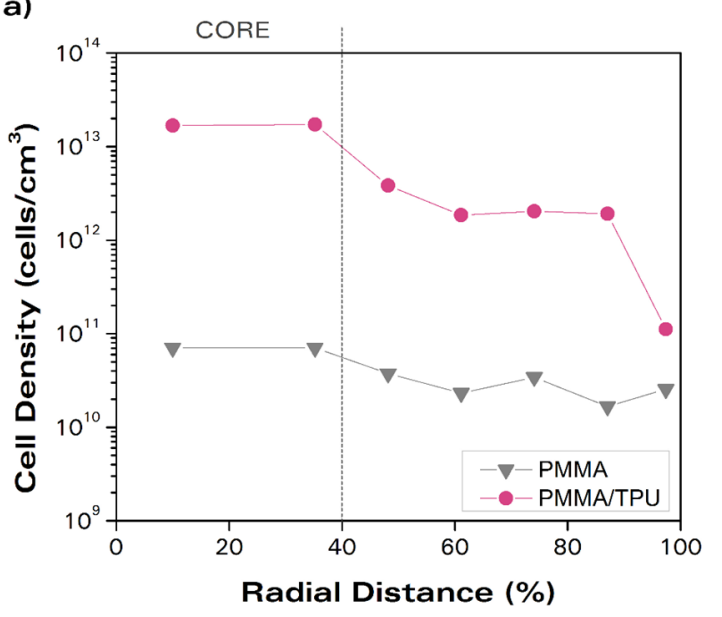

b)

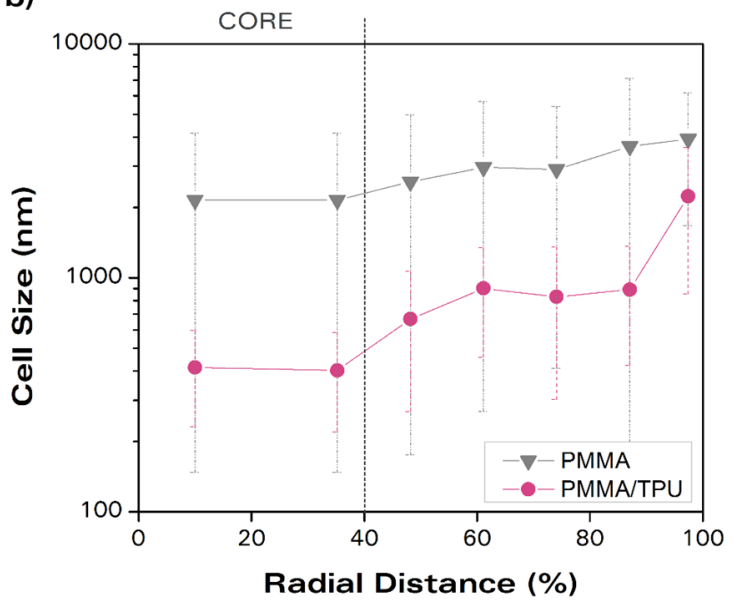

Figure 4. a) Cell density and b) cell size of the PMMA and the PMMA/TPU cellular samples produced at $15 \mathrm{MPa}$ of saturation pressure and foamed at $100^{\circ} \mathrm{C}$ during 1 minute, as a function of the radial distance from the center of the sample $(0 \%$ is the center of the sample and $100 \%$ is the border). Error bars in b) indicate $S D$ of the cell size distribution.

The PMMA sample presents a microcellular structure, with pores of some microns (around 2-4 $\mu \mathrm{m}$ ), while the PMMA/TPU system shows a nanocellular structure in the core (cell size of $400 \mathrm{~nm}$ ), that gradually becomes microcellular towards the border. The so-called core region covers around $40 \%$ 
of the sample radius (Figure 4), or in other words, roughly $16 \%$ of the volume of the sample. In this core region, the PMMA/TPU sample is characterized by cell sizes around $400 \mathrm{~nm}$, a relative density of 0.18 and a cell nucleation density exceeding $7 \cdot 10^{13}$ nuclei/ $\mathrm{cm}^{3}$ (Table 1 ). The nucleation density is of the same order of magnitude as the volumetric density of TPU domains in the solid (Figure 2). Then, we conclude that the addition of TPU produces a clear nucleation effect in PMMA by enhancing the nucleation and reducing the cell size.

Concerning the gradient structure, it is observed that in the PMMA/TPU material the cell density increases in two orders of magnitude from the border to the core of the sample (Figure 4.a). The possible mechanisms under the appearance of this gradient of cell sizes will be discussed in the next section.

\subsection{Effect of the saturation pressure}

The effect of the saturation pressure in the PMMA/TPU blend was evaluated by performing four saturation experiments at different pressures: 6, 10, 15 and $20 \mathrm{MPa}$, while keeping the foaming conditions constant $\left(100^{\circ} \mathrm{C}\right.$ and 1 minute). Figure 5 shows the SEM images of the samples produced for this study. Only the core regions are shown for the sake of comparison, but all the samples present a gradient cellular structure from the core to the border as already observed in Figure 2 . Table 2 summarizes the densities of these materials (both the core and the global density) and the cell nucleation densities calculated in the core region, whereas Figure 6 shows the cell size (Figure 6.a) and the cell density (Figure 6.b) for the different pressures as a function of the distance from the center of the sample.
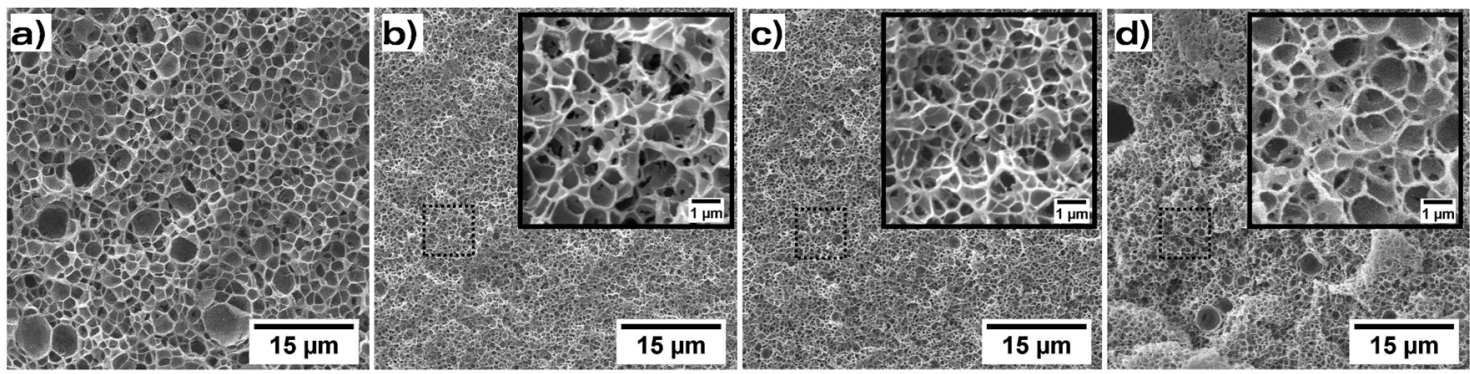

Figure 5. SEM images of the core of the PMMA/TPU samples produced at different saturation pressures: a) $6 \mathrm{MPa}$, b) $10 \mathrm{MPa}$, c) $15 \mathrm{MPa}$ and d) $20 \mathrm{MPa}$. (Foaming was carried out at $100^{\circ} \mathrm{C}$ during 1 minute).

Table 2. Relative densities and cell nucleation densities in the core of the PMMA/TPU cellular samples produced at various saturation pressures and foaming at $100^{\circ} \mathrm{C}$ during 1 minute.

\begin{tabular}{ccccc}
\hline Sample & $\begin{array}{c}\text { Saturation } \\
\text { Pressure }\end{array}$ & $\begin{array}{c}\text { Relative Density } \\
\text { (Global) }\end{array}$ & Relative Density (Core) & $\begin{array}{c}\boldsymbol{N}_{\mathbf{0}, \text { core }} \\
\text { (nuclei/cm }\end{array}$ \\
\hline PMMA/TPU & 6 & $0.16 \pm 0.01$ & $0.19 \pm 0.01$ & $2.3 \cdot 10^{12}$ \\
PMMA/TPU & 10 & $0.16 \pm 0.01$ & $0.18 \pm 0.01$ & $7.1 \cdot 10^{13}$ \\
PMMATTPU & 15 & $0.17 \pm 0.01$ & $0.18 \pm 0.01$ & $9.3 \cdot 10^{13}$ \\
PMMATTPU & 20 & $0.18 \pm 0.01$ & $0.20 \pm 0.01$ & $9.5 \cdot 10^{13}$ \\
\hline
\end{tabular}


a)

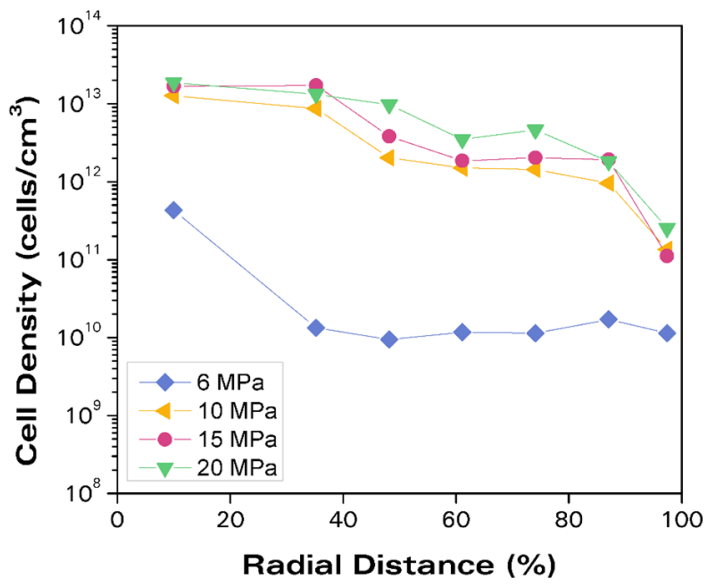

b)

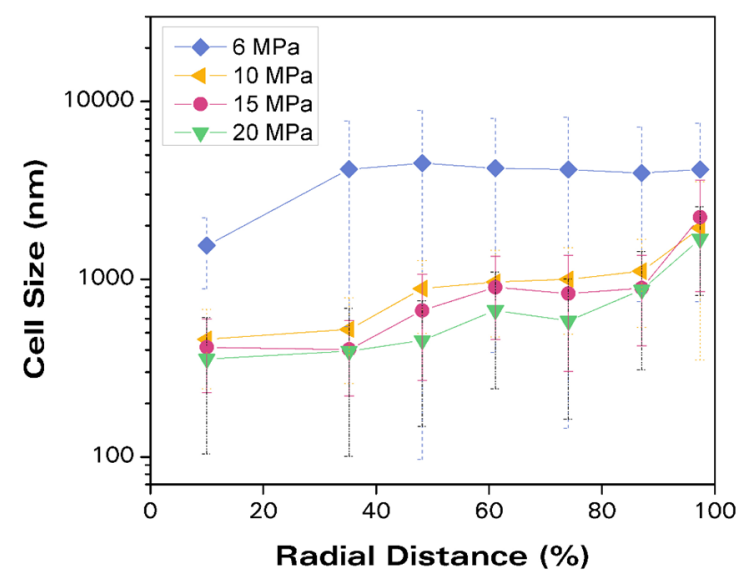

Figure 6. a) Relative density and b) cell nucleation density (left axis) and cell size (right axis) as a function of the saturation pressure for the PMMA/TPU samples. Error bars in b) indicate $S D$ of the cell size distribution.

Focusing on the core region of the samples, at $6 \mathrm{MPa}$ we observe a microcellular structure. When pressure increases from $6 \mathrm{MPa}$ to $10 \mathrm{MPa}$, nucleation density changes from $2 \cdot 10^{12} \mathrm{nuclei} / \mathrm{cm}^{3}$ to 7 - $10^{13}$ nuclei/ $\mathrm{cm}^{3}$ (Table 2), and as a consequence, cell size moves from the micro to the nanoscale $(460 \mathrm{~nm})$. For a saturation pressure of $15 \mathrm{MPa}$, nucleation is slightly higher than at $10 \mathrm{MPa}$, resulting in similar cell size (400 nm) (Figure 6.b). At $20 \mathrm{MPa}$, there is not a significant change in nucleation (Table 2), but the structure becomes less homogeneous. At low magnification, some large pores are detected in Figure 5.d, and at high magnification (inset of Figure 5.d) a very heterogeneous structure is found, with tiny pores and other pores near the micron, which in average result in a cell size around $360 \mathrm{~nm}$. The relative densities of these samples are summarized in Table 2. It can be said that the values are almost constant with the saturation pressure, ranging from 0.18 to 0.20 in the core region.

The conclusion from the analysis of the core region is that the heterogeneous nucleation effect due to the addition of TPU is pressure-dependent. This is a surprising result, since in other heterogeneous systems such as in blends with nanoparticles [37] or with nanometric micelles [31] the heterogeneous nucleation was proved to be predominant over a wide range of pressures. However, this is not the case for the PMMA/TPU system. The nucleation observed at $6 \mathrm{MPa}$ is smaller than the TPU domain density (Figure 2) by one order of magnitude. Therefore, at this low pressure, we cannot claim that heterogeneous nucleation is taking place in all the TPU domains. However, the presence of the TPU nano-domains does enhance nucleation at $6 \mathrm{MPa}$, because the nucleation in the PMMA/TPU system is higher than in the pure PMMA (at 15 MPa the nucleation in PMMA was $10^{11}$ nuclei/cm ${ }^{3}$, (Table 1) while in the PMMA/TPU blend at $6 \mathrm{MPa}$ is $10^{12} \mathrm{nuclei} / \mathrm{cm}^{3}$ ). Then, we conclude that the TPU domains are partially acting as nucleating sites, but the efficiency of the nucleation depends on the saturation pressure.

To explain the dependence of nucleation with the pressure, we can consider two ideas. First, the nucleation in the PMMA/TPU system could be not purely heterogeneous, but a mixture of homogeneous nucleation in the PMMA phase and heterogeneous nucleation in the TPU. As nucleation does depend on the pressure in the pure PMMA, this combined effect would explain the 
dependency observed in the PMMA/TPU sample. Also, it is possible to explain results taking into account the critical radius, $r_{c}$, [38-40], defined according to equation (4), where $\gamma$ is the surface tension of the system and $\Delta p$ is the pressure gradient. It is known that the ratio between the radius of the nucleating species, $R$, and the critical radius plays a key role in the reduction of the energy barrier in a heterogeneous nucleation process [41]. As the critical radius varies with pressure (equation (4)), it is understandable that the efficiency of the nucleation could also depends on pressure. For a low pressure, $r_{c}$ might be too high compared to the size of the TPU domains, and then the efficiency of the nucleation is poor. As pressure increases, $r_{c}$ decreases, so the two radii get closer and the efficiency of the nucleation increases.

$$
r_{c}=\frac{2 \gamma}{\Delta p}
$$

With these results, we can aim at explaining the gradient cellular structures observed in these samples. As the analysis of the solids showed that the dispersion of the TPU phase was homogeneous throughout the sample thickness, it is unlikely that the gradient structure is due to a heterogeneous distribution of the TPU phase in the solid. Then, and based on the results observed at different pressures, we suggest that this phenomenon is a consequence of the fast diffusion of the gas out of the cylindrical samples. Once the pressure is released, the gas is leaving the samples quickly, and there is a gradient of pressure inside the sample when foaming starts. That is, there exist a non-equilibrium concentration profile from the center towards the border of the sample, that could lead to graded structures [11,12], and in fact, in the pure PMMA a slight gradient is also observed (Figure 3 and Figure 4). Because nucleation depends on pressure in the PMMA/TPU systems, gradient nucleation takes place in the PMMA/TPU sample, causing a sharp gradient in cell sizes. Figure 7 schematically shows the mechanisms involved in the formation of the nanocellular graded structure.

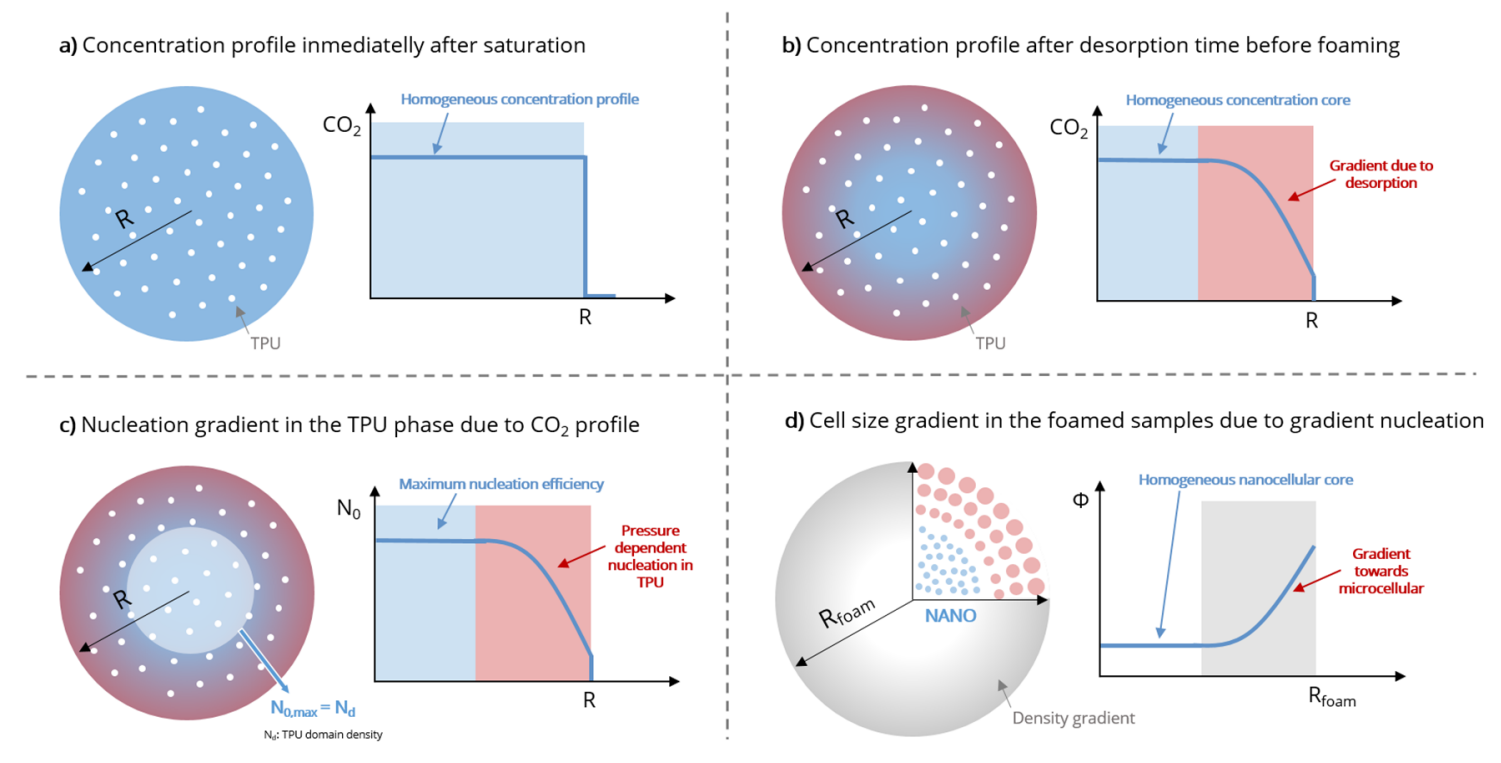

Figure 7. Schematic representation of our hypothesis of the formation of the graded cellular structure with a nanocellular core region in the PMMA/TPU systems. 
Regarding the effect of pressure on the gradient structure, it is observed that the homogeneous core is smaller at $6 \mathrm{MPa}$ (Figure 6), supporting the previous discussion about the effect of the pressure. Among the three other pressures, the cell sizes and cell densities follow the same trends that in the core, that is, cell size decreases with saturation pressure along all the sample radius (Figure 6).

\subsection{Effect of the foaming conditions}

To further investigate the foaming behavior of the PMMA/TPU system, additional foaming experiments were performed. In this case, the saturation pressure was fixed at $15 \mathrm{MPa}$, as at this pressure the best results were found in the previous section. Meanwhile, the foaming parameters were varied. Five sets of foaming conditions (temperature / time) were used and compared with the results of the previous section $\left(100^{\circ} \mathrm{C} / 1 \mathrm{~min}\right): 90^{\circ} \mathrm{C} / 0.5 \mathrm{~min}, 90^{\circ} \mathrm{C} / 1 \mathrm{~min}, 90^{\circ} \mathrm{C} / 2 \mathrm{~min}, 100$ ${ }^{\circ} \mathrm{C} / 0.5 \mathrm{~min}$ and $100^{\circ} \mathrm{C} / 2 \mathrm{~min}$. The cellular structure in the core of the materials produced is shown in Figure 8. All the samples presented a gradient structure as in previous studies. Figure 9 shows the cell density and the cell size as a function of the radial distance for the different samples produced, at $90^{\circ} \mathrm{C}$ (Figure 9.a and Figure 9.b) and $100^{\circ} \mathrm{C}$ (Figure 9.c and Figure 9.d). Table 3 collects the density of these samples and the cell nucleation density calculated in the core.

Regarding the effect of the foaming temperature, the most significant difference is found in the effect of the radial distance (Figure 9). Whereas at $100{ }^{\circ} \mathrm{C}$ the core region appears determined in the region of radial distances smaller than a $40 \%$ of the total radius (Figure $9 . c$ and Figure 9.d), at 90 ${ }^{\circ} \mathrm{C}$ the transition is less pronounced, especially at 2 minutes (Figure 9.a and Figure 9.b).

The effect of the foaming time is investigated by comparing the structures in the core. At $90^{\circ} \mathrm{C}$, an increase in the foaming time from $0.5 \mathrm{~min}$ to 2 min causes a significant reduction of the relative density (from 0.30 to 0.16 in the core, Table 3), but at the same time the cell size increases from 350 to $480 \mathrm{~nm}$ (Figure 9.b). The maximum nucleation is observed at 1 minute, and at 2 minutes the nucleation is reduced (Table 3). From these observations, we conclude that increasing foaming time at $90{ }^{\circ} \mathrm{C}$ up to 2 minutes causes cell coalescence, the cell nucleation density measured is smaller and the cell sizes are higher (Figure 9.b and Figure 9.b). This effect allows a reduction of the density, but at the expenses of increasing the cell size. At $100^{\circ} \mathrm{C}$, the cell nucleation density is observed to be maximum between $0.5 \mathrm{~min}$ and $1 \mathrm{~min}$, whereas at $2 \mathrm{~min}$ it is reduced (Table 3). The cell size increases as foaming time does, from 310 to $440 \mathrm{~nm}$ (Figure 9.b). Relative density reduces from 0.5 min to $1 \mathrm{~min}$, but increasing time to 2 minutes does not reduce the density further even though the cell size increases. Then, at $100{ }^{\circ} \mathrm{C}$ a foaming time of 2 minutes also degenerates the cellular structure (higher cell size and smaller cell nucleation density).

In general, similar cell sizes and nucleation densities are detected at $90^{\circ} \mathrm{C}$ and $100{ }^{\circ} \mathrm{C}$, but we observe that at $100{ }^{\circ} \mathrm{C}$ expansion occurs faster, that is, at 0.5 minutes the density is smaller and also the cell nucleation density is already the maximum possible. The slower expansion occurring at $90^{\circ} \mathrm{C}$ can explain the smaller homogeneous core region found at this temperature. 

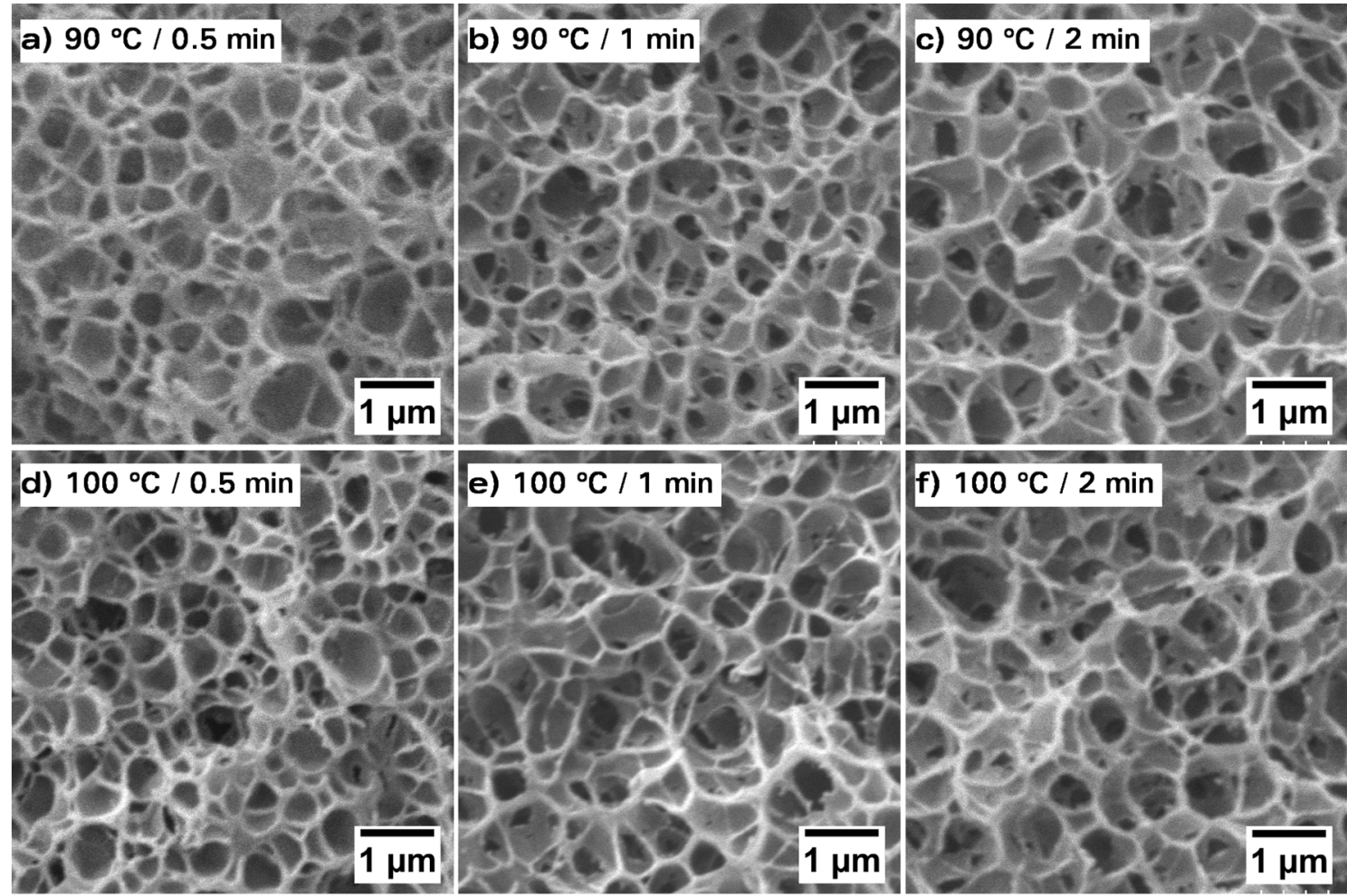

Figure 8. SEM images taken in the center of the PMMA/TPU samples produced at various foaming conditions: a) $90^{\circ} \mathrm{C} \mathrm{/} 0.5 \mathrm{~min}$, b) $\left.\left.\left.90^{\circ} \mathrm{C} / 1 \mathrm{~min}, \mathrm{c}\right) 90^{\circ} \mathrm{C} / 2 \mathrm{~min}, \mathrm{~d}\right) 100^{\circ} \mathrm{C} / 0.5 \mathrm{~min}, \mathrm{e}\right) 100{ }^{\circ} \mathrm{C} / 1$ min, and f) $100{ }^{\circ} \mathrm{C} / 2 \mathrm{~min}$. (Saturation pressure was equal to $15 \mathrm{MPa}$ ).

Table 3. Relative densities and cell nucleation densities in the core of the PMMA/TPU cellular samples produced at several foaming conditions after saturation and $15 \mathrm{MPa}$.

\begin{tabular}{ccccc}
\hline $\begin{array}{c}\text { Foaming } \\
\text { Temperature }\left({ }^{\circ} \mathrm{C}\right)\end{array}$ & $\begin{array}{c}\text { Foaming } \\
\text { time }(\mathrm{min})\end{array}$ & $\begin{array}{c}\text { Relative Density } \\
\text { (Global) }\end{array}$ & $\begin{array}{c}\text { Relative Density } \\
\text { (Core) }\end{array}$ & $\begin{array}{c}\boldsymbol{N}_{\mathbf{0}, \text { core }} \\
(\text { nuclei//cm }\end{array}$ \\
\hline 90 & 0.5 & $0.24 \pm 0.00$ & $0.30 \pm 0.00$ & $6.1 \cdot 10^{13}$ \\
90 & 1 & $0.17 \pm 0.01$ & $0.20 \pm 0.01$ & $9.2 \cdot 10^{12}$ \\
90 & 2 & $0.14 \pm 0.01$ & $0.16 \pm 0.01$ & $6.6 \cdot 10^{13}$ \\
100 & 0.5 & $0.20 \pm 0.00$ & $0.30 \pm 0.00$ & $9.6 \cdot 10^{13}$ \\
100 & 1 & $0.17 \pm 0.01$ & $0.18 \pm 0.01$ & $9.3 \cdot 10^{13}$ \\
100 & 2 & $0.19 \pm 0.01$ & $0.18 \pm 0.01$ & $6.4 \cdot 10^{13}$ \\
\hline
\end{tabular}

We can conclude that the foaming parameters are essential to obtain the desired structures in the PMMA/TPU blends. In particular, foaming time is crucial, since a slight increase can induce coalescence of the cellular structure. In other PMMA-based nanocellular polymers, the effect of foaming time (even 5 minutes) was not so significant [24]. One possible rationale to explain the narrow processing window in the production of nanocellular polymers with the PMMA/TPU blend is the low viscosity of the PMMA matrix used in this research. Another reason might be related to the presence of the TPU domains, that are around $90 \mathrm{~nm}$ in size. They should be placed in the cell walls, and they could be weak points for cell wall rupture when the polymer is stretched to the low densities achieved in this paper. 
a)

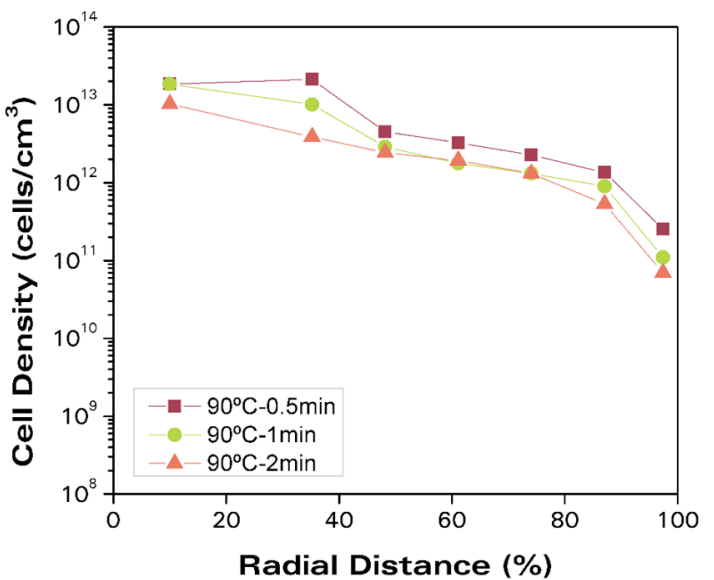

c)

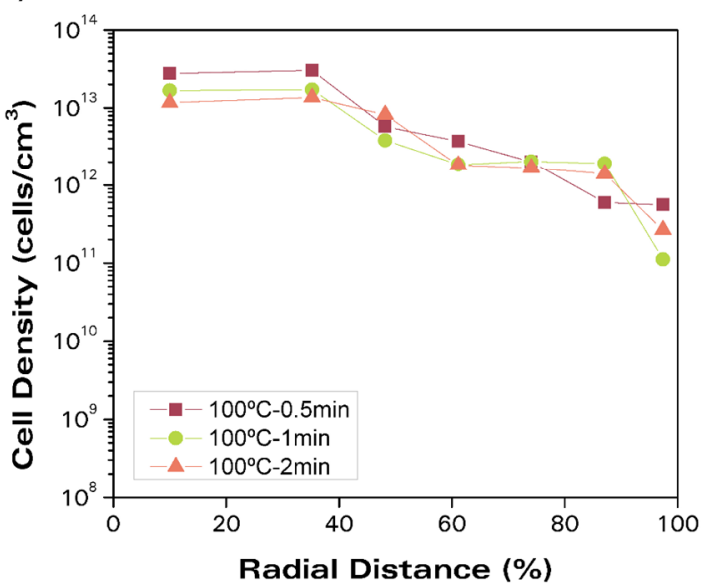

b)

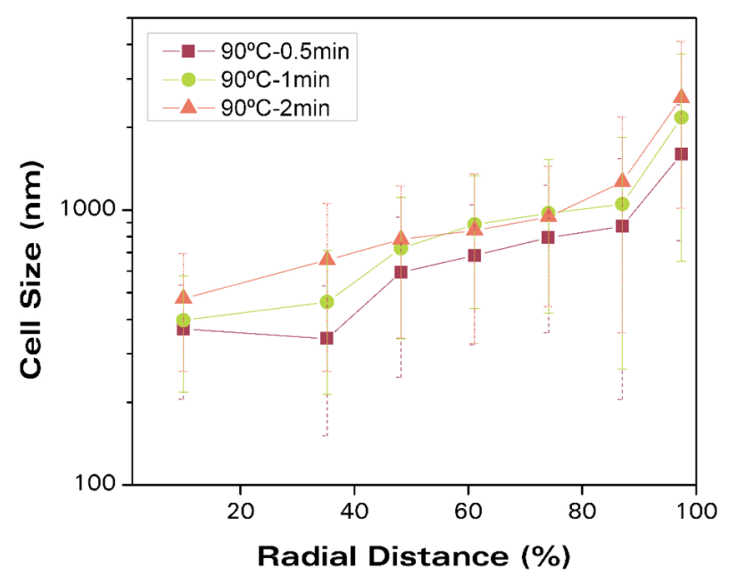

d)

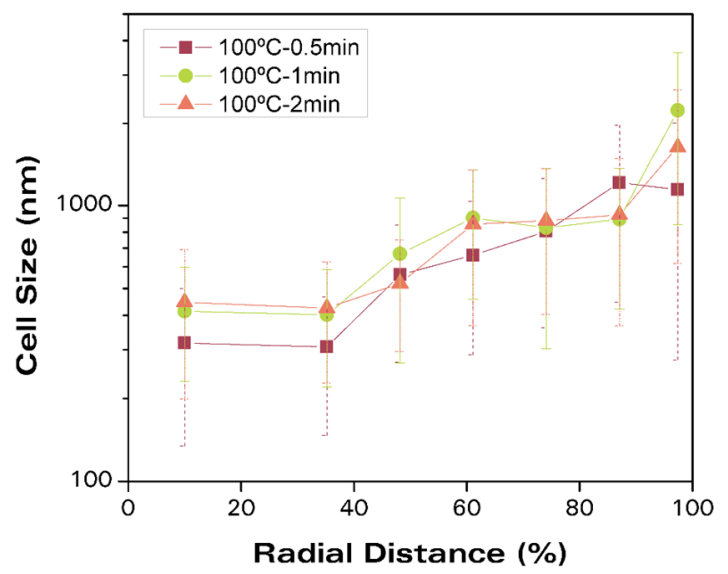

Figure 9. a) Cell nucleation density and b) cell size of the PMMA/TPU samples produced at $90{ }^{\circ} \mathrm{C}$, and a) cell nucleation density and b) cell size of the PMMA/TPU samples produced at $100^{\circ} \mathrm{C}$, for various foaming times. Error bars in b) and d) indicate $S D$ of the cell size distribution.

\section{CONCLUSIONS}

Low-density nanocellular polymers with a gradient cellular structure based on PMMA/TPU blends have been produced via a gas dissolution foaming process. PMMA was melt blended with a 2 wt\% of TPU by extrusion. As a result of the dispersion of the TPU during the extrusion on the immiscible blend, the solid material presents a nanostructuration formed by nanometric TPU domains in a density higher than $10^{13}$ domains $/ \mathrm{cm}^{3}$.

Results show that the PMMA/TPU samples present a gradient cell size from the core to the border, from a homogeneous nanocellular core to a microcellular transition region. In the nanocellular core of the samples, the addition of TPU induces an increase of the cell nucleation density of 3 orders of magnitude and a reduction of the cell size, going from a microcellular structure in the pure PMMA to nanocellular material in the PMMA/TPU at $15 \mathrm{MPa}$ of saturation pressure. The nucleation density obtained in the PMMA/TPU sample is similar to the TPU domain density measured in the solids, showing that the dispersed TPU domains in the PMMA matrix are acting as nucleating agents. 
An increase of the saturation pressure from 6 to $20 \mathrm{MPa}$ causes an increase in the cell nucleation density in the PMMA/TPU system. This result indicates that the heterogeneous nucleation in the TPU domains is not predominant at all pressures. Then, we hypothesize that the formation of the gradient of cell sizes is due to gradient nucleation in the PMMA/TPU samples, caused by a nonconstant gas concentration profile in the samples due to the desorption of gas before the foaming step.

Finally, the analysis of the foaming conditions shows that an excessive foaming time can lead to the appearance of degeneration mechanisms in the PMMA/TPU nanocellular polymers, such as coalescence, causing an increase of the cell size.

\section{Acknowledgments:}

Financial assistance from MINECO, FEDER, UE (MAT2015-69234-R), the Junta de Castile and Leon (VA275P18) and Spanish Ministry of Science, Innovation and Universities (RTI2018-098749-B-I00) are gratefully acknowledged. Financial support from FPU grant FPU14/02050 (V. Bernardo) from the Spanish Ministry of Education and Junta of Castile and Leon grant (J. Martín-de León) are gratefully acknowledged.

\section{REFERENCES}

[1] L.J. Gibson, M. Ashby, Cellular solids: structure and properties, 2nd Editio, Cambridge University Press, 1997.

[2] D. Eaves, Handbook of Polymer Foams, Rapra Technology, United Kingdom, 2004.

[3] M.A. Meyers, J. McKittrick, P.-Y. Chen, Structural Biological Materials: Critical Mechanics-Materials Connections, Sience. 339 (2013) 773-780.

[4] N. Gupta, A functionally graded syntactic foam material for high energy absorption under compression, Mater. Lett. 61 (2007) 979-982. doi:10.1016/j.matlet.2006.06.033.

[5] L. Cui, S. Kiernan, M.D. Gilchrist, Designing the energy absorption capacity of functionally graded foam materials, Mater. Sci. Eng. A. 507 (2009) 215-225. doi:10.1016/j.msea.2008.12.011.

[6] C. V. Vo, F. Bunge, J. Duffy, L. Hood, Advances in thermal insulation of extruded polystyrene foams, Cell. Polym. 30 (2011) 137-156. doi:10.1177/026248931103000303.

[7] L. Monnereau, L. Urbanczyk, J.M. Thomassin, T. Pardoen, C. Bailly, I. Huynen, C. Jérôme, C. Detrembleur Gradient foaming of polycarbonate/carbon nanotube based nanocomposites with supercritical carbon dioxide and their EMI shielding performances, Polymer (Guildf). 59 (2015) 117-123. doi:10.1016/j.polymer.2014.11.063.

[8] J. Pinto, D. Morselli, V. Bernardo, B. Notario, D. Fragouli, M.A. Rodriguez-Perez, A. Athanassiou, Nanoporous PMMA foams with templated pore size obtained by localized in situ synthesis of nanoparticles and $\mathrm{CO} 2$ foaming, Polymer (Guildf). 124 (2017) 176-185. doi:10.1016/j.polymer.2017.07.067.

[9] J. Yu, L. Song, F. Chen, P. Fan, L. Sun, M. Zhong, J. Yang, Preparation of polymer foams with a gradient of cell size: Further exploring the nucleation effect of porous inorganic materials in polymer foaming, Mater. Today Commun. 9 (2016) 1-6. doi:10.1016/j.mtcomm.2016.08.006.

[10] M.T. Ngo, J.S. Dickmann, J.C. Hassler, E. Kiran, A new experimental system for combinatorial exploration of foaming of polymers in carbon dioxide: The gradient foaming of PMMA, J. Supercrit. Fluids. 109 (2016) 1-19. doi:10.1016/j.supflu.2015.09.030.

[11] C. Zhou, P. Wang, W. Li, Fabrication of functionally graded porous polymer via supercritical CO2foaming, Compos. Part B Eng. 42 (2011) 318-325. doi:10.1016/j.compositesb.2010.11.001.

[12] M. Trofa, E. Di Maio, P.L. Maffettone, Multi-graded foams upon time-dependent exposition to blowing agent, Chem. Eng. J. 362 (2019) 812-817. doi:10.1016/j.cej.2019.01.077. 
[13] B. Notario, J. Pinto, E. Solorzano, J.A. de Saja, M. Dumon, M.A. Rodriguez-Perez, Experimental validation of the Knudsen effect in nanocellular polymeric foams, Polymer (Guildf). 56 (2015) 57-67. doi:10.1016/j.polymer.2014.10.006.

[14] L. Grassberger, K. Koch, R. Oberhoffer, A. Müller, H.F.M. Klemmer, R. Strey, Blowing agent free generation of nanoporous poly ( methylmethacrylate ) materials, Colloid Polym. Sci. 295 (2017) 379-389. doi:10.1007/s00396-017-4012-1.

[15] G. Wang, J. Zhao, L.H. Mark, G. Wang, K. Yu, C. Wang, C.B. Park, G. Zhao, Ultra-tough and super thermalinsulation nanocellular PMMA/TPU, Chem. Eng. J. 325 (2017) 632-646. doi:10.1016/j.cej.2017.05.116.

[16] Z. Li, C. Zhu, X. Zhao, A theoretical and numerical study on the gas-contributed thermal conductivity in aerogel, Int. J. Heat Mass Transf. 108 (2017) 1982-1990. doi:10.1016/j.ijheatmasstransfer.2017.01.051.

[17] D. Miller, V. Kumar, Microcellular and nanocellular solid-state polyetherimide (PEI) foams using sub-critical carbon dioxide II . Tensile and impact properties, Polymer (Guildf). 52 (2011) 2910-2919. doi:10.1016/j.polymer.2011.04.049.

[18] B. Notario, J. Pinto, M.A. Rodríguez-Perez, Towards a new generation of polymeric foams: PMMA nanocellular foams with enhanced physical properties, Polymer (Guildf). $63 \quad$ (2015) 116-126. doi:10.1016/j.polymer.2015.03.003.

[19] J. Martín-de León, J.L. Pura, V. Bernardo, M.Á. Rodríguez-Pérez, Transparent nanocellular PMMA: Characterization and modeling of the optical properties, Polymer (Guildf). 170 (2019) 16-23. doi:10.1016/j.polymer.2019.03.010.

[20] S. Perez-Tamarit, B. Notario, E. Solorzano, M.A. Rodriguez-Perez, Light transmission in nanocellular polymers: are semi-transparent cellular polymers possible?, Mater. Lett. $210 \quad$ (2017) 39-41. doi:10.1016/j.matlet.2017.08.109.

[21] J. Pinto, B. Notario, R. Verdejo, M. Dumon, S. Costeux, M.A. Rodriguez-perez, Molecular confinement of solid and gaseous phases of self-standing bulk nanoporous polymers inducing enhanced and unexpected physical properties, Polymer (Guildf). 113 (2017) 27-33. doi:10.1016/j.polymer.2017.02.046.

[22] B. Notario, J. Pinto, R. Verdejo, M.A. Rodŕiguez-Pérez, Dielectric behavior of porous PMMA: From the micrometer to the nanometer scale, Polymer (Guildf). $107 \quad$ (2016) 302-305. doi:10.1016/j.polymer.2016.11.030.

[23] B. Notario, A. Ballesteros, J. Pinto, M.A. Rodriguez-Perez, Nanoporous PMMA: A novel system with different acoustic properties, Mater. Lett. 168 (2016) 76-79. doi:10.1016/j.matlet.2016.01.037.

[24] J. Martin de-Leon, V. Bernardo, M.A. Rodriguez-Perez, Low Density Nanocellular Polymers Based on PMMA Produced by Gas Dissolution Foaming: Fabrication and Cellular Structure Characterization, Polymers (Basel). 8 (2016) 1-16. doi:10.3390/polym8070265.

[25] S. Costeux, I. Khan, S.P. Bunker, H.K. Jeon, Experimental study and modeling of nanofoams formation from single phase acrylic copolymers, J. Cell. Plast. 51 (2015) 197-221. doi:10.1177/0021955X14531972.

[26] H. Guo, A. Nicolae, V. Kumar, Solid-state poly(methyl methacrylate) (PMMA) nanofoams. Part II: Lowtemperature solid-state process space using CO2 and the resulting morphologies, Polymer (Guildf). 70 (2015) 231-241. doi:10.1016/j.polymer.2015.06.031.

[27] S. Liu, B. Zoetebier, L. Hulsman, Y. Zhang, J. Duvigneau, G.J. Vancso, Nanocellular polymer foams nucleated by core-shell nanoparticles, Polymer (Guildf). 104 (2016). doi:10.1016/j.polymer.2016.09.016.

[28] S. Costeux, L. Zhu, Low density thermoplastic nanofoams nucleated by nanoparticles, Polymer (Guildf). 54 (2013) 2785-2795. doi:10.1016/j.polymer.2013.03.052.

[29] J. Pinto, M. Dumon, M.A. Rodriguez-Perez, R. Garcia, C. Dietz, Block Copolymers Self-Assembly Allows Obtaining Tunable Micro or Nanoporous Membranes or Depth Filters Based on PMMA; Fabrication Method and Nanostructures, J. Phys. Chem. C. 118 (2014) 4656-4663. doi:10.1021/jp409803u.

[30] J. Pinto, J.A. Reglero-Ruiz, M. Dumon, M.A. Rodriguez-Perez, Temperature influence and CO2 transport in foaming processes of poly(methyl methacrylate)-block copolymer nanocellular and microcellular foams, J. Supercrit. Fluids. 94 (2014) 198-205. doi:10.1016/j.supflu.2014.07.021.

[31] J. Pinto, M. Dumon, M. Pedros, J. Reglero, M.A. Rodriguez-Perez, Nanocellular CO2 foaming of PMMA assisted by block copolymer nanostructuration, Chem. Eng. J. 243 (2014) 428-435. doi:10.1016/j.cej.2014.01.021.

[32] C. Forest, P. Chaumont, P. Cassagnau, B. Swoboda, P. Sonntag, CO2 nano-foaming of nanostructured PMMA, Polymer (Guildf). 58 (2015) 76-87. doi:10.1016/j.polymer.2014.12.048.

[33] V. Kumar, N.P. Suh, A process for making microcellular parts, Polym. Eng. Sci. 30 (1990) 1323-1329. 
doi:https://doi.org/10.1002/pen.760302010.

[34] H. Guo, V. Kumar, Solid-state poly(methyl methacrylate) (PMMA) nanofoams. Part I: Low-temperature CO2 sorption, diffusion, and the depression in PMMA glass transition, Polymer (Guildf). 57 (2015) 157-163. doi:10.1016/j.polymer.2014.12.029.

[35] J. Pinto, E. Solorzano, M. a. Rodriguez-Perez, J. a. de Saja, Characterization of the cellular structure based on user-interactive image analysis procedures, J. Cell. Plast. 49 (2013) 555-575. doi:10.1177/0021955X13503847.

[36] V. Kumar, Process synthesis for manufacturing microcellular thermoplastic parts, Massachusetts Institute of Technology, 1988.

[37] V. Bernardo, J. Martin-de León, E. Laguna-Gutiérrez, M.Á. Rodríguez-Pérez, PMMA-sepiolite nanocomposites as new promising materials for the production of nanocellular polymers, Eur. Polym. J. 96 (2017) 10-26. doi:10.1016/j.eurpolymj.2017.09.002.

[38] S.K. Goel, E.J. Beckman, Generation of Microcellular Polymeric Foams Using Supercritical Carbon Dioxide. I: Effect of Pressure and Temperature on Nucleation, Polym. Eng. Sci. 34 (1994) 1137-1147. doi:10.1002/pen.760341407.

[39] I. Khan, D. Adrian, S. Costeux, A model to predict the cell density and cell size distribution in nano-cellular foams, Chem. Eng. Sci. 138 (2015) 634-645. doi:10.1016/j.ces.2015.08.029.

[40] M. a Shafi, J.G. Lee, R.W. Flumerfelt, Prediction of cellular structure in free expansion polymer foam processing, Polym. Eng. Sci. 36 (1996) 1950-1959. doi:10.1002/pen.10591.

[41] N.H. Fletcher, Size effect in heterogeneous nucleation, J. Chem. Phys. 29 (1958) 572-576. doi:10.1063/1.1744540. 
Chapter 6.

\section{Other Fabrication Strategies} Based on Heterogeneous

Nucleation 



\section{Chapter 6. Other Fabrication Strategies Based on Heterogeneous Nucleation}

\subsection{Introduction}

This chapter contains two additional scientific publications related to the fabrication of nanocellular polymers via the heterogeneous approach. These works are short communications reporting some new results but based on concepts already discussed in the previous chapters.

The first paper deals with the production of nanocellular polymers using two nucleating agents: MAM and sepiolites. The main goal of this research is to evaluate the combined nucleating effect of the two additives. Also, due to the interesting anisotropic structures found in sepiolites when extruded filaments are used (Chapter 4, section 4.3), the tri-phasic PMMA/MAM/Sepiolites blends were produced solely by extrusion to investigate the anisotropy of the structure.

The second paper is an extension of the works reported in Chapter 4 and Chapter 5 about the production of PMMA/Sepiolites and PMMA/MAM nanocellular polymers. The novelty of this work is the use of very low pressures to produce nanocellular polymers. The results obtained at low pressure for the two systems are presented together and compared with those reported in the literature.

\subsection{Highly anisotropic nanocellular polymers based on tri-phasic blends of PMMA with two nucleating agents}

This section contains a short scientific publication entitled "Highly anisotropic nanocellular polymers based on tri-phasic blends of PMMA with two nucleating agents", submitted and pending of acceptance.

To analyze the effect of the addition of sepiolites to a PMMA/MAM matrix, two series of materials are prepared. First, a PMMA/MAM series with two concentrations of MAM: $0.1 \mathrm{wt} \%$ and $10 \mathrm{wt} \%$, to investigate the influence of the MAM concentration. Second, a PMMA/MAM+1.5\%Sepiolites, with the same PMMA/MAM ratios but including a $1.5 \mathrm{wt} \%$ of sepiolites. Pure PMMA and PMMA with 1.5 $w t \%$ of sepiolites are also produced as reference materials of the two series.

The results in the PMMA/MAM blends are similar to those obtained in Chapter 5 (section 5.3) regarding the effect of the amount of MAM in the cellular structure. However, as the solid precursors were produced only by extrusion (instead of extrusion and compression molding as in the previous chapter), there is an alignment of the micelles in the extrusion direction. As a consequence, in the material with $10 \mathrm{wt} \%$ of MAM, the cells appear aligned in the plane parallel to the extrusion. There is some cell coalescence in that direction because the micelles are very close to each other, and as a result, some anisotropy is detected in the extrusion direction. 
The effect of adding sepiolites to the PMMA/MAM precursors is different for low and high MAM concentrations. For low MAM contents $(0.1 \mathrm{wt} \%)$, the cell nucleation density observed when sepiolites are included in the formulation is an intermediate value between the nucleation densities observed in the binary blends with only one additive. That is, at low concentrations of MAM, none of the nucleants has a predominant effect, and as a result, the nucleation is in between the values obtained with only one nucleant, sepiolites or MAM. Cell size in the tri-phasic blend is also intermediate. However, the addition of sepiolites has one interesting effect. While the PMMA/MAM samples with $0.1 \mathrm{wt} \%$ of MAM are isotropic, the tri-phasic materials with the same PMMA/MAM ratio but with $1.5 \mathrm{wt} \%$ of sepiolites present anisotropic cells in the extrusion direction (same mechanisms explained in section 4.3 in Chapter 4).

In the material with high MAM content (10 wt\%), the nucleation is mainly dominated by the MAM micelles, so the cell nucleation density and the cell size are not affected by the presence of the sepiolites. Nevertheless, the anisotropy found in the extrusion direction is enhanced when sepiolites are included because the coalescence among micelles is promoted with the addition of needle-like particles that are aligned in the same direction. With the combined action of both additives, anisotropy ratios as high as 2.77 are obtained in the tri-phasic blends with $10 \mathrm{wt} \%$ of MAM and $1.5 \mathrm{wt} \%$ of sepiolites. In fact, the structure in these samples present highly elongated cells and even channels throughout the sample length, but the average anisotropy ratio is reduced because of the presence of very small pores among the channels.

Figure 6.1 shows the graphical abstract of this publication, schematizing this idea and the different mechanisms taking place in the binary PMMA/MAM system with $10 \mathrm{wt} \%$ of MAM and in the triphasic blend that includes $1.5 \mathrm{wt} \%$ of sepiolites. This short paper is introduced in the next pages of this chapter.

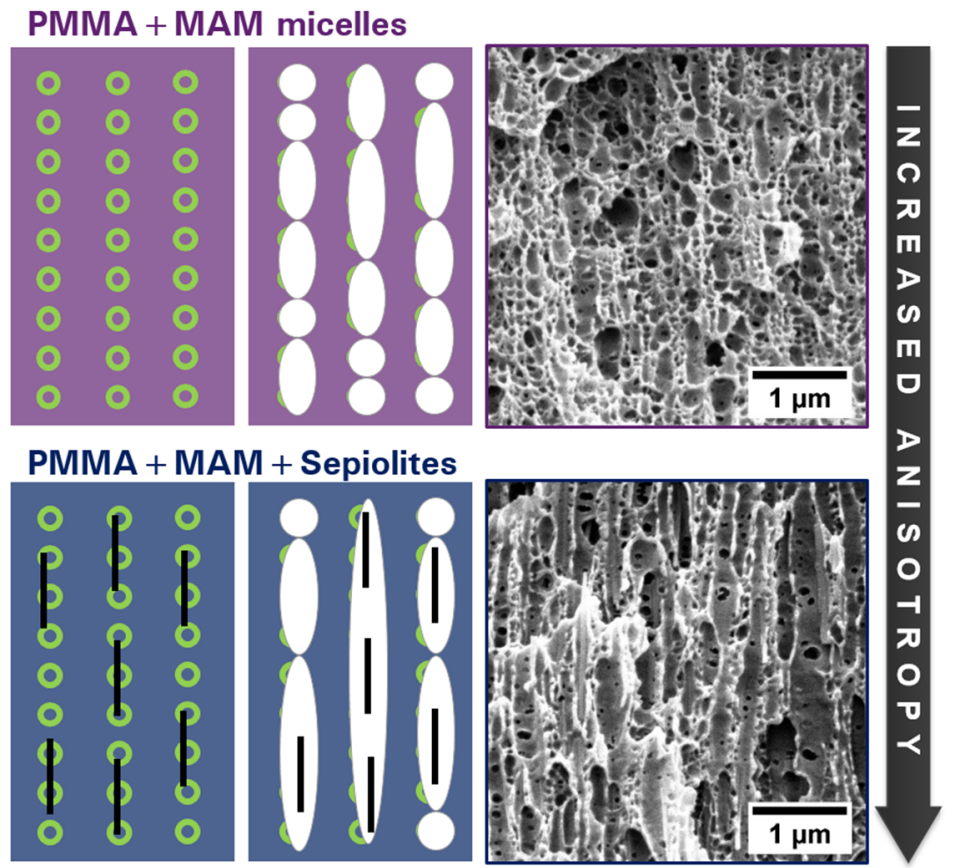

Figure 6.1. Graphical abstract of "Highly anisotropic nanocellular polymers based on tri-phasic blends of PMMA with two nucleating agents." 


\title{
Highly anisotropic nanocellular polymers based on tri-phasic blends of PMMA with two nucleating agents
}

\author{
Victoria Bernardo ${ }^{1 *}$, Judith Martín-de León ${ }^{1}$, Miguel Ángel Rodríguez-Pérez ${ }^{1,2}$ \\ 1. Cellular Materials Laboratory (Cel/Mat), Condensed Matter Physics Department, \\ University of Valladolid, Campus Miguel Delibes, Paseo de Belén n7, 47011 Valladolid, Spain \\ 2. Instituto BIOECOUVA, Universidad de Valladolid, Valladolid, Spain \\ *Corresponding author: Victoria Bernardo (vbernardo@fmc.uva.es) +34983184035
}

\begin{abstract}
One strategy to produce nanocellular polymers is the use of nucleating species to promote nucleation. Whereas two-phase systems are widely studied, tri-phasic blends with two nucleating agents are uncommonly investigated. In this work, nanocellular polymers are obtained using triphasic blends of polymethylmethacrylate (PMMA) with two nucleating agents: needle-like sepiolites and a polymethylmethacrylate-polybutylacrylate-polymethylmethacrylate (MAM) block copolymer. Blends of PMMA with different concentrations of MAM and a fixed amount of sepiolites are produced by extrusion. Results show that at low MAM contents (1 wt\%), the nucleation is a combination of the action of the two additives, but the addition of sepiolites induces the appearance of anisotropic structures. Meanwhile, at high MAM concentrations (10 $w t \%)$, MAM nanostructuration controls the nucleation and sepiolites increase the anisotropy. The alignment of the MAM micelles and the sepiolites in the extrusion direction promotes coalescence in this direction, leading to highly anisotropic nanocellular structures. Mean cell sizes of 100-300 nm and an average anisotropy ratio of 2.77 are obtained thanks to the combined effect of MAM and sepiolites.
\end{abstract}

\section{KEYWORDS}

nanocellular polymer; gas dissolution foaming; nanoparticles; nanostructuration; PMMA; anisotropy.

\section{INTRODUCTION}

Nanocellular polymers are characterized by cell sizes from tens to hundreds of nanometers [1]. They have aroused great attention due to the potential applications of a polymer with nanometric cells [2-4]. Nowadays, much research in this area is focused on finding new systems allowing the production of nanocellular polymers with tunable structures.

One production strategy is the use of nucleating species, such as nanoparticles [5-8] or nanostructured polymer blends [9-12], to increase the nucleation and reduce the cell size. For instance, in the work of Costeux et al. [13] the cell nucleation density of polymethylmethacrylate (PMMA) was enhanced three orders of magnitude using silica nanoparticles, obtaining nanocellular materials with cell sizes of $100 \mathrm{~nm}$ and cell densities exceeding $10^{16} \mathrm{cells} / \mathrm{cm}^{3}$. Regarding the 
approach of nanostructured polymer blends, the addition of polymethylmethacrylatepolybutylacrylate-polymethylmethacrylate (MAM) block copolymer in a PMMA matrix results in nanometric micelles that act as efficient nucleating agents, as Reglero and coworkers [14] and later Pinto et al. [15] demonstrated. Nucleation densities of $10^{14}$ nuclei $/ \mathrm{cm}^{3}$ combined with cell sizes of 150-200 nm were obtained with this approach. Although the literature about the effect of one nucleating agent is relatively vast, as far as the authors know, there are still no previous reports on the combined action of more than one nucleating agent.

In this work, we investigate the combined effect of two nucleating agents for the production of nanocellular PMMA. MAM and nanometric sepiolites were used as nucleating species. As aforementioned, MAM is well-known for being a good nucleating agent in the production of nanocellular polymers [16]. Meanwhile, sepiolites have been used successfully for producing nanocellular PMMA [17], and also to induce the formation of anisotropic nanocellular structures [18], which are of great interest due to the enhancement of mechanical properties in the anisotropy direction.

This paper aims at analyzing the resultant cellular structures when the two nucleating agents are combined. Also, highly anisotropic cellular structures are obtained as a result of the two additives. The mechanisms of anisotropy formation are also discussed.

\section{EXPERIMENTAL}

\subsection{Materials}

PMMA V825T ( $\left.\mathrm{M}_{\mathrm{n}}=43 \mathrm{~kg} / \mathrm{mol}, \mathrm{M}_{\mathrm{w}}=83 \mathrm{~kg} / \mathrm{mol}\right)$ was kindly supplied by ALTUGLAS $\AA$ International. Sepiolites (needle-like magnesium silicate nanoparticles) modified with a quaternary ammonium salt [19] were kindly provided by Tolsa S.A (Spain). MAM block copolymer Nanostrength M52 ( $M_{n}=$ $44 \mathrm{~kg} / \mathrm{mol}, \mathrm{M}_{\mathrm{w}}=75 \mathrm{~kg} / \mathrm{mol}, 52 \mathrm{wt} \%$ of PBA [16]) was kindly supplied by Arkema. Medical grade carbon dioxide $\left(\mathrm{CO}_{2}\right)(99.9 \%$ purity) was used as the blowing agent.

\subsection{Solid blends production}

Two series of blends were produced: binary PMMA/MAM blends with two ratios of MAM ( 1 and 10 wt\%) and tri-phasic blends of PMMA/MAM+1.5\%SP, keeping the ratios of PMMA/MAM of the binary blends and adding a $1.5 \mathrm{wt} \%$ of sepiolites. In addition, a pure PMMA and a binary blend with sepiolites but without MAM were also produced for comparison.

The blends were produced with a twin-screw extruder COLLIN TEACH-LINE ZK 25T (L/D = 24, screw diameter $=25 \mathrm{~mm}$ ). The materials were first dried in vacuum at $50^{\circ} \mathrm{C}$. The temperature profile in the extruder varied from $160^{\circ} \mathrm{C}$ to $200^{\circ} \mathrm{C}$, and the screw speed was $40 \mathrm{rpm}$. The extruded material was cooled down in a water bath and pelletized. After drying, each formulation was extruded again to assure homogeneity. The filament from the second extrusion (thickness of 3-4 mm) was set aside and cut in cylindrical samples of $30 \mathrm{~mm}$ in length for the foaming experiments. MD direction in the filaments corresponds to the extrusion direction and TD direction is any direction perpendicular to it. 


\subsection{Gas Dissolution Foaming Experiments}

The foaming experiments were performed using a high-pressure vessel (PARR 4681, Parr Instrument Company). Pressure is controlled with a pressure pump controller (SFT-10, Supercritical Fluid Technologies Inc). A clamp heater of $1200 \mathrm{~W}$ and a CAL 3300 temperature controller allow the control of the temperature. A two-step foaming process was used [20]. The samples were put into the pressure vessel at a $\mathrm{CO}_{2}$ pressure of $10 \mathrm{MPa}$ and a temperature of $25^{\circ} \mathrm{C}$ for the saturation stage during $20 \mathrm{~h}$. Then, the pressure was abruptly released (pressure drop rate: $15 \mathrm{MPa} / \mathrm{s}$ ). Finally, the samples were removed from the vessel and introduced into a thermal bath at $80{ }^{\circ} \mathrm{C}$ for 1 minute for foaming. The time between the release of the pressure and the immersion of the samples in the bath was 2.5 minutes.

\subsection{Characterization}

The density of the solids $\left(\rho_{s}\right)$ was measured with a gas pycnometer (AccuPyc II 1340, Micromeritics). The density of the cellular materials $(\rho)$ was determined with the water-displacement method using a density determination kit for an AT261 Mettler-Toledo balance. More than $500 \mathrm{~m}$ of the surface of cellular samples were removed with a polisher (LaboPOI2-LaboForce3, Struers) before measuring the densities. Relative density is defined as $\rho_{r}=\rho / \rho_{s}$.

The samples were fractured by cooling in liquid nitrogen for visualization and coated with gold using a sputter coater (SCD 005, Balzers Union). The surface morphology was analyzed using an ESEM Scanning Electron Microscope (QUANTA 200 FEG). The planes parallel (MD) and perpendicular (TD) to the extrusion direction were analyzed. The materials with sepiolites present a bimodal cellular structure with micro and nanometric cells, and the relative volume occupied by the population of nanometric cells, $V_{\text {nano }}$, was measured. The nanometric cells were fully characterized. The cell nucleation density (calculated using Kumar's approach [20]) was measured in the two planes $\left(N_{0, M D}\right.$ and $\left.N_{0, T D}\right)$. The cell sizes were measured in two directions, calculating an average 3D cell size in the MD direction $\left(\phi_{M D}\right)$ and in the TD direction $\left(\phi_{T D}\right)$ with their corresponding standard deviations $(S D)$ associated to the cell size distributions. For every single cell, the average anisotropy ratio in the MD direction was calculated as the ratio $\phi_{M D} / \phi_{T D}[21,22]$, leading to an average anisotropy ratio value $A R_{M D}$ and a standard deviation of the anisotropy ratio distribution (SD).

\section{RESULTS AND DISCUSSION}

\subsection{Relative density}

The relative density of the PMMA matrix in the foaming conditions used was 0.29 (Table 1), similar to that obtained when sepiolites are introduced in the system (0.26). The addition of MAM increases the relative density to values of 0.45 for $1 \%$ MAM content and to 0.56 for $10 \mathrm{wt} \%$ MAM. This is due to the limited expansion when nanostructured materials with a high micelle density are used $[16,23]$. The combination of MAM with sepiolites reduces the relative density for a MAM content of $1 \%$ (from 0.45 to 0.37 ) and maintains the relative density for the system containing a $10 \%$ of MAM. 
Table 1. Characteristics of the materials produced in this work (*amount of MAM in the PMMA/MAM matrix). Cell sizes $\phi_{T D}, \phi_{M D}$ and $A R_{M D}$ show the averages, while values in brackets represent the $S D$ of the cell size /anisotropy ratio distributions.

\begin{tabular}{|c|c|c|c|c|c|c|c|c|c|}
\hline Series & $\begin{array}{c}\text { MAM } \\
\text { content* } \\
\text { (wt } \%)\end{array}$ & $\begin{array}{c}\text { Sepiolite } \\
\text { content } \\
\text { (wt\%) }\end{array}$ & $\rho_{r}$ & $\begin{array}{c}V_{\text {nano }} \\
(\%)\end{array}$ & $\begin{array}{c}N_{0, T D} \\
\text { (nuclei/cm })\end{array}$ & $\begin{array}{c}N_{0, M D} \\
\text { (nuclei/cm } / \mathrm{cm}^{3} \text { ) }\end{array}$ & $\begin{array}{c}\phi_{T D} \\
(\mathrm{~nm})\end{array}$ & $\begin{array}{l}\phi_{M D} \\
(\mathrm{~nm})\end{array}$ & $A R_{M D}$ \\
\hline PMMA/MAM & 0 & 0 & 0.29 & 100 & $4.6 \cdot 10^{11}$ & $5.6 \cdot 10^{11}$ & $\begin{array}{c}1900 \\
( \pm 1500)\end{array}$ & $\begin{array}{c}1700 \\
( \pm 1300)\end{array}$ & $\begin{array}{c}0.96 \\
( \pm 0.45)\end{array}$ \\
\hline PMMA/MAM & 1 & 0 & 0.45 & 100 & $5.2 \cdot 10^{14}$ & $9.1 \cdot 10^{14}$ & $\begin{array}{c}125 \\
( \pm 67)\end{array}$ & $\begin{array}{c}128 \\
( \pm 72)\end{array}$ & $\begin{array}{c}1.12 \\
( \pm 0.57)\end{array}$ \\
\hline PMMA/MAM & 10 & 0 & 0.56 & 100 & $9.7 \cdot 10^{14}$ & $6.3 \cdot 10^{14}$ & $\begin{array}{c}96 \\
( \pm 59)\end{array}$ & $\begin{array}{c}158 \\
( \pm 167)\end{array}$ & $\begin{array}{c}1.71 \\
( \pm 1.25)\end{array}$ \\
\hline PMMA/MAM+1.5\%SP & 0 & 1.5 & 0.26 & 88 & $1.4 \cdot 10^{14}$ & $5.1 \cdot 10^{13}$ & $\begin{array}{c}294 \\
( \pm 172)\end{array}$ & $\begin{array}{c}509 \\
( \pm 379)\end{array}$ & $\begin{array}{c}1.88 \\
( \pm 1.15)\end{array}$ \\
\hline PMMA/MAM+1.5\%SP & 1 & 1.5 & 0.37 & 96 & $3.0 \cdot 10^{14}$ & $1.6 \cdot 10^{14}$ & $\begin{array}{c}189 \\
( \pm 127)\end{array}$ & $\begin{array}{c}273 \\
( \pm 268)\end{array}$ & $\begin{array}{c}1.48 \\
( \pm 0.86)\end{array}$ \\
\hline PMMA/MAM+1.5\%SP & 10 & 1.5 & 0.57 & 99 & $1.2 \cdot 10^{15}$ & $1.1 \cdot 10^{14}$ & $\begin{array}{c}106 \\
( \pm 76)\end{array}$ & $\begin{array}{c}288 \\
( \pm 365)\end{array}$ & $\begin{array}{c}2.77 \\
( \pm 2.68)\end{array}$ \\
\hline
\end{tabular}

\subsection{Cellular structure}

\subsubsection{Binary blends: PMMAMAM and PMMAVSepiolites}

This section focusses on the behaviour of the binary blends. The addition of MAM to the PMMA matrix leads to a reduction of the cell size to the nanometric scale (Figure 1.a-f and Table 1), and the higher the amount of MAM, the smaller the cell size [23]. Isotropic cellular structures in TD and MD planes are found for $1 \mathrm{wt} \%$ of MAM. However, the sample with $10 \mathrm{wt} \%$ of MAM shows an orientation of the cells in the extrusion direction, causing an anisotropic structure (Figure 1.f), whereas the TD surface is isotropic (Figure 1.c). This effect was previously observed in PMMA/MAM by Pinto and coworkers [15], and it is a consequence of the alignment of the micelles due to the extrusion process. Nemoto et al. [24] also detected that aligned nanometric nucleants in the extruded solid resulted in aligned pores in the nanocellular material.

Regarding the materials with sepiolites, the addition of $1.5 \mathrm{wt} \%$ of particles (without MAM) produces a bimodal structure, due to the presence micron-sized aggregates and well-dispersed sepiolites, the structure being anisotropic in the MD plane (Figure 1.g and Figure 1.j). In this case, the anisotropy is believed to be controlled by coalescence phenomena taking place along the sepiolites, which are aligned in the extrusion direction [18].

\subsubsection{Tri-phasic blends with low content of MAM (1 wt\%)}

When the two nucleating agents are combined, intermediate effects are observed. For the system with $1 \mathrm{wt} \%$ of MAM, the addition of sepiolites implies a slight increase of the cell size, from around $130 \mathrm{~nm}$ to $190-270 \mathrm{~nm}$ and a reduction of the nucleation from 5 to $3 \cdot 10^{14}$ nuclei/ $/ \mathrm{cm}^{3}$ (in the TD plane) (Table 1). From the other perspective, the addition of $1 \mathrm{wt} \%$ of MAM to the sample with sepiolites increases the nucleation and reduces the cell size (from 290-510 to 190-270 nm) (Table 1). We conclude that with low contents of both nucleating agents there is a competition between the two, resulting in an intermediate nucleation density and cell size. However, the addition of sepiolites implies that anisotropic cells appear in the extrusion direction. The anisotropy ratio in the system with MAM and sepiolites is smaller than that in the system without MAM (1.48 versus 
1.88) due to the presence of very small pores in the sample with MAM. In addition, the fraction of nanometric cells is slightly reduced by adding MAM (Table 1 ).
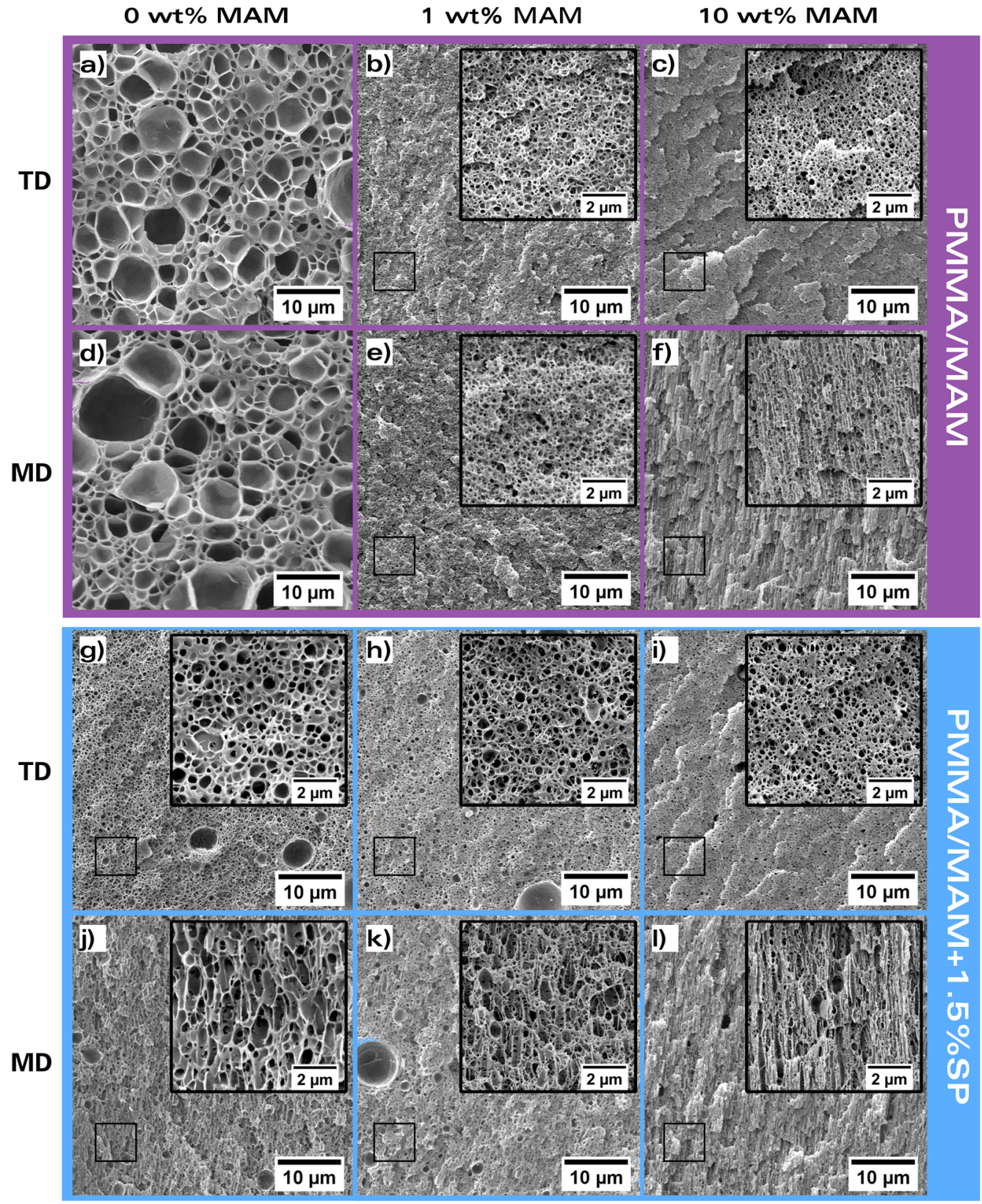

Figure 1. SEM micrographs of: pure PMMA ( $a$ and d), PMAM/MAM blends (b, $c$, e and $f$ ), PMMA+1.5\%SP ( $g$ and $j$ ) and PMMA/MAM+1.5\%SP ternary blends $(h, i, k$ and $l)$. First and third rows: TD plane. Second and forth rows: MD plane.

\subsubsection{Tri-phasic blends with high content of MAM (10 wt\%)}

For $10 \mathrm{wt} \%$ of MAM, similar structures with and without sepiolites are observed in the TD plane (Figure 1.c and Figure 1.i), with cell sizes around $100 \mathrm{~nm}$ and cell nucleation densities close to $10^{15}$ nuclei $/ \mathrm{cm}^{3}$ (Table 1). Then, when the fraction of MAM is $10 \mathrm{wt} \%$, the effect of the sepiolites in the nucleation is no longer visible, and the micelle nanostructuration controls the nucleation. Regarding the presence of micrometric cells, the addition of a $10 \mathrm{wt} \%$ of MAM strongly avoids the formation 
of a bimodal structure (the fraction of nanometric cells increases, Table 1). However, sepiolites have an effect, and it is the increase in the anisotropy ratio in the MD direction (Figure 1.l). As a consequence of the presence of the sepiolites, larger cells aligned in the extrusion direction appear, and anisotropy ratio increases from 1.7 to more than 2.7 when sepiolites are added (Table 1). In fact, not only the average anisotropy ratio is increased, but also the distribution of anisotropy ratios is wider, as seen in Figure 2, meaning that in the system with MAM and sepiolites there are more cells with higher anisotropy ratios.

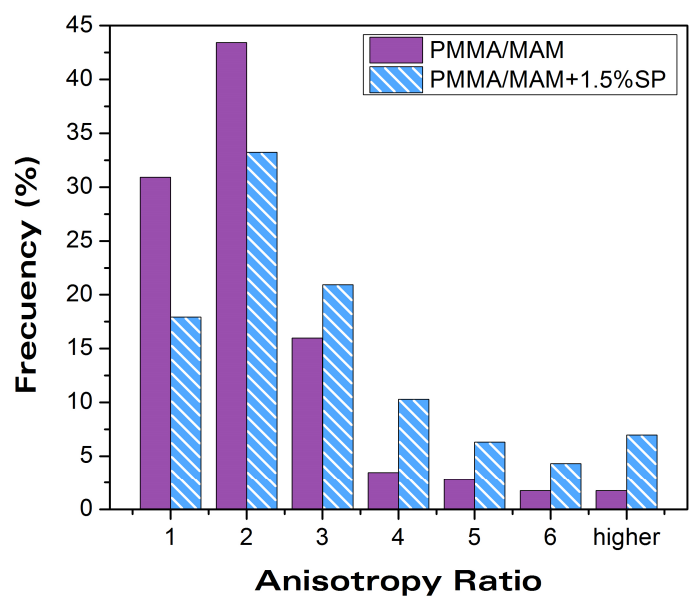

Figure 2. Anisotropy ratio distribution in the MD direction for the materials with $10 \mathrm{wt} \%$ of MAM with and without sepiolites.

Figure 3.a and Figure 3.b show schemes of the mechanisms of anisotropy formation in these systems. Without sepiolites (Figure 3.a), anisotropy appears as a result of the alignment of the nanometric MAM micelles in the extrusion direction, inducing oriented coalescence. In the system with particles (Figure 3.b) the the presence of the needle-like sepiolites, which are long in comparison with the cell size, enhances the coalescence, leading to higher anisotropy ratios.

a)

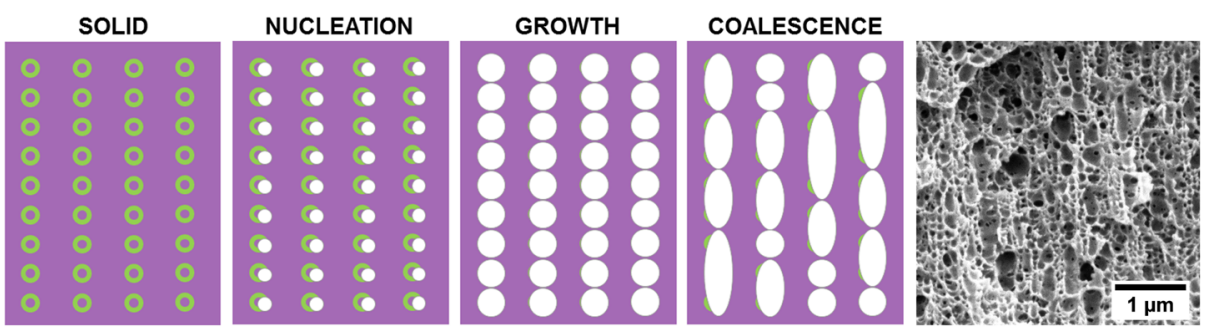

b)
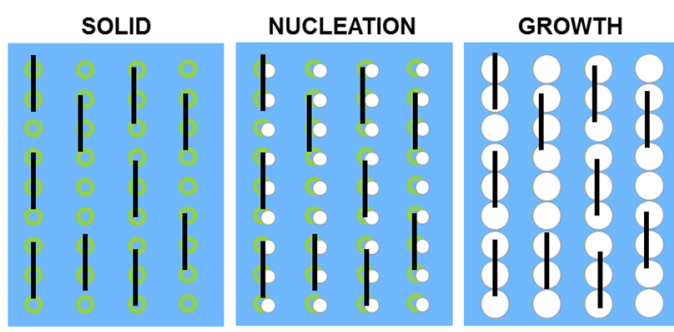
COALESCENCE

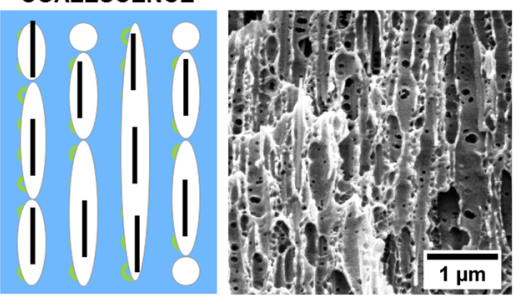

Figure 3. a) Schematic representation of the formation of anisotropy in PMMA/MAM and b) PMMA/MAM+1.5\%SP. (Green circles: MAM micelles, black lines: sepiolites). 
In a previous work, we proved that the addition of $10 \mathrm{wt} \%$ of sepiolites could induce the appearance of anisotropic cells with an average anisotropy ratio as high as 2.15 [18]. In this work, combining the action of aligned nanometric micelles in a PMMA/MAM matrix and oriented sepiolites particles it has been possible to reach anisotropy ratios as high as 2.77 only using $1.5 \mathrm{wt} \%$ of sepiolites.

\section{CONCLUSIONS}

Highly anisotropic nanocellular materials based on PMMA/MAM with sepiolites have been produced by gas dissolution foaming. The nucleation mechanisms resulting from the addition of two different nucleating species have been also analyzed.

Results show that for low MAM contents (1 wt\%), the nucleation in the PMMA/MAM+1.5\%SP system is in between those obtained in the samples with only one nucleating agent, meaning that none of the nucleants dominates, but he addition of sepiolites leads to the appearance of anisotropy in the MD direction (anisotropy ratio around 1.5). Regarding the system with high MAM content (10 wt\%), nucleation is proved to be controlled by the MAM phase and not the sepiolites. The system without sepiolites presented already an anisotropic structure as a consequence of the aligned MAM micelles in the extrusion direction. However, the addition of sepiolites oriented in the same direction enhanced the anisotropy, leading to highly anisotropic structures with anisotropy ratios as high as 2.77 .

\section{Acknowledgments:}

Financial support from the FPU grant FPU14/02050 (V. Bernardo) from the Spanish Ministry of Education and the Junta of Castile and Leon grant (J. Martín-de León) are gratefully acknowledged. Financial assistance from MINECO, FEDER, UE (MAT2015-69234-R), the Junta de Castile and Leon (VA275P18) and Spanish Ministry of Science, Innovation and Universities (RTI2018-098749-B-I00) are gratefully acknowledged. We would also like to thank Tolsa (Madrid, Spain) for supplying the sepiolites and Arkema for supplying the copolymers used in this research.

\section{REFERENCES}

[1] S. Costeux, CO2-blown nanocellular foams, J. Appl. Polym. Sci. 131 (2014) 41293(1)-41293(16). doi:10.1002/app.41293.

[2] S. Liu, J. Duvigneau, G.J. Vancso, Nanocellular polymer foams as promising high performance thermal insulation materials, Eur. Polym. J. 65 (2015) 33-45. doi:10.1016/j.eurpolymj.2015.01.039.

[3] B. Notario, J. Pinto, M.A. Rodriguez-Perez, Nanoporous polymeric materials: A new class of materials with enhanced properties, Prog. Polym. Sci. 78-79 (2016) 93-139. doi:10.1016/j.pmatsci.2016.02.002.

[4] G. Wang, C. Wang, J. Zhao, G. Wang, C.B. Park, G. Zhao, Modelling of thermal transport through a nanocellular polymer foam: Toward the generation of a new superinsulating material, Nanoscale. 9 (2017) 5996-6009. doi:10.1039/c7nr00327g.

[5] Y. Fujimoto, S.S. Ray, M. Okamoto, A. Ogami, K. Yamada, K. Ueda, Well-Controlled Biodegradable Nanocomposite Foams: From Microcellular to Nanocellular, Macromol. Rapid Commun. 24 (2003) 457-461. doi:10.1002/marc.200390068.

[6] S. Liu, B. Zoetebier, L. Hulsman, Y. Zhang, J. Duvigneau, G.J. Vancso, Nanocellular polymer foams nucleated by core-shell nanoparticles, Polymer (Guildf). 104 (2016). doi:10.1016/j.polymer.2016.09.016. 
H. Yu, Y. Lei, X. Yu, X. Wang, T. Liu, S. Luo, Solid-state polyetherimide (PEI) nanofoams: the influence of the compatibility of nucleation agent on the cellular morphology, J. Polym. Res. 23 (2016) 121. doi:10.1007/s10965-016-1009-2.

[8] L. Urbanczyk, C. Calberg, C. Detrembleur, C. Jérôme, M. Alexandre, Batch foaming of SAN/clay nanocomposites with scCO2 : A very tunable way of controlling the cellular morphology, Polymer (Guildf). 51 (2010) 3520-3531. doi:10.1016/j.polymer.2010.05.037.

[9] T. Nemoto, J. Takagi, M. Ohshima, Nanoscale cellular foams from a poly(propylene)-rubber blend, Macromol. Mater. Eng. 293 (2008) 991-998. doi:10.1002/mame.200800184.

[10] C. Forest, P. Chaumont, P. Cassagnau, B. Swoboda, P. Sonntag, CO2 nano-foaming of nanostructured PMMA, Polymer (Guildf). 58 (2015) 76-87. doi:10.1016/j.polymer.2014.12.048.

[11] G. Wang, J. Zhao, L.H. Mark, G. Wang, K. Yu, C. Wang, C.B. Park, G. Zhao, Ultra-tough and super thermalinsulation nanocellular PMMA/TPU, Chem. Eng. J. 325 (2017) 632-646. doi:10.1016/j.cej.2017.05.116.

[12] R.W.B. Sharudin, M. Ohshima, CO2-induced mechanical reinforcement of polyolefin-based nanocellular foams, Macromol. Mater. Eng. 296 (2011) 1046-1054. doi:10.1002/mame.201100085.

[13] S. Costeux, L. Zhu, Low density thermoplastic nanofoams nucleated by nanoparticles, Polymer (Guildf). 54 (2013) 2785-2795. doi:10.1016/j.polymer.2013.03.052.

[14] J.A. Reglero Ruiz, M. Dumon, J. Pinto, M.A. Rodriguez-Perez, Low-density nanocellular foams produced by high-pressure carbon dioxide, Macromol. Mater. Eng. 296 (2011) 752-759. doi:10.1002/mame.201000346.

[15] J. Pinto, M. Dumon, M. Pedros, J. Reglero, M.A. Rodriguez-Perez, Nanocellular CO2 foaming of PMMA assisted by block copolymer nanostructuration, Chem. Eng. J. 243 (2014) 428-435. doi:10.1016/j.cej.2014.01.021.

[16] V. Bernardo, J. Martin-de Leon, E. Laguna-Gutierrez, T. Catelani, J. Pinto, A. Athanassiou, M.A. Rodriguez-Perez, Understanding the role of MAM molecular weight on the production of PMMA/MAM nanocellular polymers, Polymer (Guildf). 153 (2018) 262-270. doi:10.1016/j.polymer.2018.08.022.

[17] V. Bernardo, J. Martin-de León, E. Laguna-Gutiérrez, M.Á. Rodríguez-Pérez, PMMA-sepiolite nanocomposites as new promising materials for the production of nanocellular polymers, Eur. Polym. J. 96 (2017) 10-26. doi:10.1016/j.eurpolymj.2017.09.002.

[18] V. Bernardo, J. Martin-de Leon, M.A. Rodriguez-Perez, Anisotropy in nanocellular polymers promoted by the addition of needle-like sepiolites, Polym. Int. 68 (2019) 1204-1214. doi:10.1002/pi.5813.

[19] J. Santaren, A. Alvarez, A. Esteban-Cubillo, B. Notario, D. Velasco, M.A. Rodriguez-Perez, Improving the Cellular Structure and Thermal Conductivity of PS Foams by Using Sepiolites, in: Foams2012, 2012: pp. 1-5.

[20] V. Kumar, N.P. Suh, A process for making microcellular parts, Polym. Eng. Sci. 30 (1990) 1323-1329. doi:https://doi.org/10.1002/pen.760302010.

[21] A.T. Huber, L.J. Gibson, Anisotropy of foams, J. Mater. Sci. 23 (1988) 3031-3040. doi:10.1007/BF00547486.

[22] J. Xu, T. Wu, J. Zhang, H. Chen, W. Sun, C. Peng, Microstructure measurement and microgeometric packing characterization of rigid polyurethane foam defects, Cell. Polym. 36 (2017) 183-204. doi:10.1177/026248931703600402.

[23] V. Bernardo, J. Martin-de Leon, J. Pinto, T. Catelani, A. Athanassiou, M.A. Rodriguez-Perez, Low-density PMMA/MAM nanocellular polymers using low MAM contents: Production and characterization, Polymer (Guildf). 163 (2019) 115-124. doi:10.1016/j.polymer.2018.12.057.

[24] T. Nemoto, J. Takagi, M. Ohshima, Nanocellular Foams-Cell Structure Difference Between Immiscible and Miscible PEEK/PEI Polymer Blends, Polym. Eng. Sci. 50 (2010) 2408-2416. doi:10.1002/pen. 


\subsection{Production of PMMA-based nanocellular polymers using low demanding saturation conditions}

This section contains a letter entitled "Production of PMMA-based nanocellular polymers using low demanding saturation conditions", submitted and pending of acceptance.

This letter presents results of two systems already discussed in the previous chapters: PMMA/Sepiolites (Chapter 4, section 4.2) and PMMA/MAM (Chapter 5, section 5.2 and 5.3). The same formulations produced for those chapters (fabricated by extrusion and compression molding) are foamed at a lower pressure (6 $\mathrm{MPa}$ ) and room temperature in this section.

The aim of this study is to test two features. First, from a scientific point of view, it is interesting to see if the heterogeneous nucleation mechanism with these fillers is still predominant when the pressure is reduced. Second, from a practical perspective, the possibility of producing nanocellular polymers using low pressure (without needing a pressure pump) can be helpful in the future implementation of the gas dissolution foaming process at the industrial scale to produce nanocellular samples.

Regarding the PMMA/Sepiolites systems, the results of this section prove that the heterogeneous nucleation in the nanometric particles is still predominant at low-pressure. Particle contents from 0.5 to $10 \mathrm{wt} \%$ are evaluated, and very similar nucleation densities are obtained at $6 \mathrm{MPa}$ compared to $10 \mathrm{MPa}$ or higher pressures (see section 4.2 in Chapter 4). As in the previous studies, bimodal cellular structures with a high fraction (higher than $>50 \%$ in volume) of nanometric pores are obtained, and the increase of the sepiolite concentration increases the nucleation and reduces the cell size.

In the PMMA/MAM systems, three MAM grades and two MAM concentrations (10 wt $\%$ and $0.1 \mathrm{wt} \%$ ) are used. At $10 \mathrm{wt} \%$ of MAM, the structures and nucleation densities at $6 \mathrm{MPa}$ are the same as those measured at $10 \mathrm{MPa}$ (see section 5.2 in Chapter 5). At low MAM content, a slight decrease in the nucleation is observed compared to the results at $10 \mathrm{MPa}$ (see section 5.3 in Chapter 5), especially for the MAM grade with the lowest molecular weight, but still, nanocellular structures appear. Thus, the nucleation in the MAM micelles is predominant at any pressure from $6 \mathrm{MPa}$, but the nucleation in the MAM-rich domains (occurring for low MAM concentrations for low MAM molecular weights) has some pressure dependency.

Cell sizes in the range from 120 to $900 \mathrm{~nm}$ with relative densities of 0.16-0.58 are obtained in this work without the need for a pressure pump or a cooling/heating system during the saturation stage.

Figure 6.2 shows the graphical abstract of this letter, that compares the saturation conditions used in this work with other works in the literature that are produced at more demanding processing conditions. This letter is attached in the following pages. 

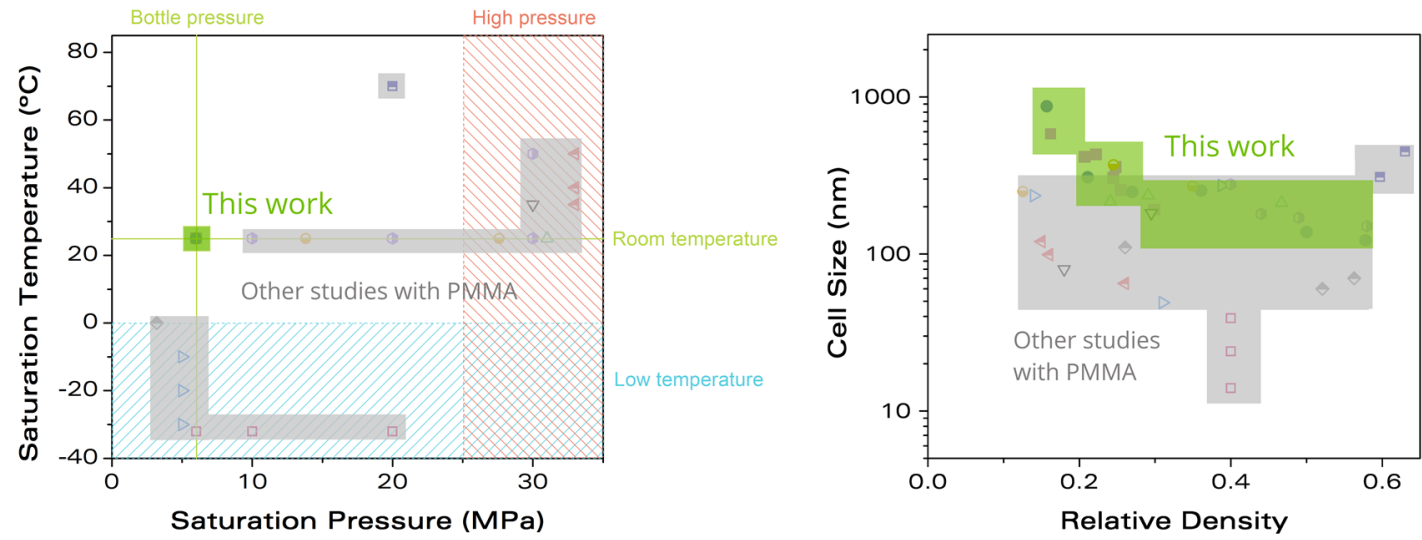

Figure 6.2. Graphical abstract of "Production of PMMA-based nanocellular polymers using low demanding saturation conditions." 


\title{
Production of PMMA-based nanocellular polymers using low demanding saturation conditions
}

\author{
Victoria Bernardo*, Judith Martín-de León, Miguel Ángel Rodríguez-Pérez \\ Cellular Materials Laboratory (CellMat), Condensed Matter Physics Department, \\ University of Valladolid, Campus Miguel Delibes, Paseo de Belén n7, 47011 Valladolid, Spain \\ *Corresponding author: Victoria Bernardo (vbernardo@fmc.uva.es)+34983184035
}

\begin{abstract}
Nanocellular polymers are novel materials characterized by nanometric cell sizes with huge potential in many industrial applications. However, their production is challenging and usually requires demanding processing conditions that make difficult the production at industrial scale. In this work, we prove that nanocellular polymers based on PMMA can be obtained, thanks to the addition of nucleating species, using low saturation pressure (6 $\mathrm{MPa})$ and room saturation temperature in a gas dissolution foaming process. Nanoparticles and block copolymers at different concentrations are used to obtain a collection of nanocellular polymers with densities ranging 0.16-0.58 and cell sizes from 120 to $900 \mathrm{~nm}$. Comparison with the literature results shows that the processing parameters used in this work are the less demanding ever used for producing nanocellular PMMA.
\end{abstract}

\section{KEYWORDS}

nanocellular polymer; nanocellular foam; gas dissolution foaming; nanoparticles; sepiolites; MAM; nanostructuration; PMMA;

\section{INTRODUCTION}

Nowadays, the use of cellular polymers is extremely widespread in almost every sector, such as automotive, leisure or packaging, among others [1,2]. Due to their technological relevance in many applications, the development of new and advanced cellular polymers is always a priority field of research in this area. The next generation of cellular polymers are the so-called nanocellular polymers, characterized by cell sizes from tens to hundreds of nanometers. The relevance of these materials lies in their interesting properties [3], such as reduced their thermal conductivity [4-6], improved mechanical properties [7,8],the possibility of producing transparent nanocellular polymers $[9,10]$, their interesting dielectric and acoustic properties $[11,12]$ and their high surface area [13].

One of the key challenges in the field of nanocellular polymers is the production of these materials using facile and scalable-up production routes. The most extended fabrication process for nanocellular polymers is the so-called gas dissolution foaming [14], developed in the 1980s with the invention of microcellular polymers [15]. However, the evolution from microcellular polymers to nanocellular materials implies a significant increase in the nucleation density, from $10^{9}$ to $10^{13}$ 
nuclei/ $\mathrm{cm}^{3}$, so the complexity of the process increases accordingly. Currently, there are two main approaches to produce nanocellular polymers. The first one is the use of processing conditions that maximize the amount of gas absorbed in the sample, and thus the nucleation. High saturation pressures $[16,17]$ or low saturation temperatures $[18,19]$ allow reaching the high solubilities needed to produce nanocellular polymers. However, these conditions complicate the possible industrial production. Another possibility is the use of nucleating species to promote nucleation $[20,21]$, and in this case, mild processing conditions can be used.

In this work, we have produced nanocellular poly(methyl methacrylate) (PMMA) using low pressure (6 $\mathrm{MPa}$ ) and room temperature as saturation conditions, using two different nucleating agents: sepiolite nanoparticles and MAM (poly(methyl methacrylate)-poly(butyl acrylate)-poly(methyl methacrylate)) block copolymer. Nanometric cell sizes from 120 to $900 \mathrm{~nm}$ are obtained. To our knowledge, only in the work of Liu and coworkers [22] there are some previous studies with similar conditions. Working at 5.5 MPa and room temperature, they obtained foamed films of PMMA with $400 \mathrm{~nm}$ of cell size and relative density 0.32 by adding nanosilica particles with a poly(dimethylsiloxane) (PDMS) shell. Apart from that paper, all the PMMA-based nanocellular materials reported in the literature are produced at higher pressures and/or lower temperature [23]. Then, this is the first time that bulk nanocellular polymers (i.e., samples of several millimeters thick) based on PMMA are produced using such a low pressure (6 MPa) with saturation at room temperature. Our work aims at paving the way for future studies in the implementation of the gas dissolution foaming process at industrial scale to produce nanocellular parts to be used in real applications.

\section{EXPERIMENTAL}

\subsection{Materials}

PMMA V825T $\left(M_{n}=43 \mathrm{~kg} / \mathrm{mol}, M_{w}=83 \mathrm{~kg} / \mathrm{mol}\right)$ was kindly supplied by ALTUGLAS $\AA$ International. Sepiolites (needle-like magnesium silicate nanoparticles [24]) modified with a quaternary ammonium salt (SQAS) [25] were kindly provided by Tolsa S.A (Spain). Several MAM block copolymers: Nanostrength M51 ( $\mathrm{M}_{\mathrm{n}}=25 \mathrm{~kg} / \mathrm{mol}, \mathrm{M}_{\mathrm{w}}=46 \mathrm{~kg} / \mathrm{mol}, 48 \mathrm{wt} \%$ of PBA), Nanostrength M52 $\left(M_{n}=44 \mathrm{~kg} / \mathrm{mol}, M_{w}=75 \mathrm{~kg} / \mathrm{mol}, 52 \mathrm{wt} \%\right.$ of PBA $)$ and Nanostrength $M 53\left(M_{n}=82 \mathrm{~kg} / \mathrm{mol}, M_{w}\right.$ $=128 \mathrm{~kg} / \mathrm{mol}, 54 \mathrm{wt} \%$ of PBA) [26] were kindly supplied by Arkema. These MAM grades would be referred from now on as $\mathrm{L}, \mathrm{M}$ and $\mathrm{H}$, respectively (low, medium and high molecular weight). Medical grade $\mathrm{CO}_{2}$ (99.9\% purity) was used as the blowing agent.

\subsection{Solid blends production}

Various nanocomposites of PMMA/Sepiolites and PMMA/MAM binary blends were produced (see the different samples fabricated in Table 1). The raw PMMA and the selected filler (sepiolites or MAM) in the desired proportions were melt-blended with a twin-screw extruder COLLIN TEACHLINE ZK $25 \mathrm{~T}(\mathrm{~L} / \mathrm{D}=24$, screw diameter $=25 \mathrm{~mm})$. The materials were first dried in vacuum at $50^{\circ} \mathrm{C}$ overnight. The temperature profile varied from $160^{\circ} \mathrm{C}$ to $200^{\circ} \mathrm{C}$, and the screw speed was $40 \mathrm{rpm}$. The extruded material was cooled in a water bath and pelletized. After drying, each formulation 
was extruded again under the same conditions. Then, the pelletized formulations were compressed molded into $4 \mathrm{~mm}$ thick solid sheets using a hot press (Talleres Remtex, Barcelona). The temperature in the press was $250{ }^{\circ} \mathrm{C}$. During 8.5 minutes, the pellets were heated, and then a constant pressure of $17 \mathrm{MPa}$ was applied during one minute at the same temperature. Then the samples were cooled down using the same pressure. From the solid sheets, samples of $20 \times 10 \times 4$ $\mathrm{mm}^{3}$ were cut for the foaming experiments. Note that pure PMMA was processed with the same conditions to be used as reference material.

\subsection{Gas Dissolution Foaming Experiments}

The foaming experiments were performed using a high-pressure vessel (PARR 4681, Parr Instrument Company). Pressure can be controlled with a pressure pump controller (SFT-10, Supercritical Fluid Technologies Inc). A clamp heater of $1200 \mathrm{~W}$ and a CAL 3300 temperature controller allow the control of the temperature. A two-step foaming process was used [14]. The samples were put into the pressure vessel at a $\mathrm{CO}_{2}$ pressure of $6 \mathrm{MPa}$ and a temperature of $25^{\circ} \mathrm{C}$ for the saturation stage during $72 \mathrm{~h}$ to assure saturation [27]. At these conditions, pure PMMA absorbs around $22 \mathrm{wt} \%$ of $\mathrm{CO}_{2}$. Then, the pressure was abruptly released (pressure drop rate: 0.7 $\mathrm{MPa} / \mathrm{s})$. Finally, the samples were removed from the vessel and introduced into a thermal bath for 2 minutes for foaming. The foaming temperature, $T_{\text {foam }}$, was optimized for every system to achieve the maximum expansion (Table 1). The time between the release of the pressure and the immersion of the samples in the bath was 3.5 minutes.

\subsection{Characterization}

The density of the solids $\left(\rho_{s}\right)$ was measured with a gas pycnometer (AccuPyc II 1340, Micromeritics). The density of the cellular materials $(\rho$ ) was determined with the water-displacement method based on the Archimedes' principle using a density determination kit for an AT261 Mettler-Toledo balance. More than $200 \mu \mathrm{m}$ of the surface of cellular samples were removed with a polisher (LaboPOI2LaboForce3, Struers) before measuring the densities. Relative density is defined as $\rho_{r}=\rho / \rho_{s}$.

The samples were fractured by cooling them in liquid nitrogen for visualization and coated with gold using a sputter coater (SCD 005, Balzers Union). The surface morphology was analyzed using an ESEM Scanning Electron Microscope (QUANTA 200 FEG). The materials with sepiolites present a bimodal structure with micro and nanometric cells, and the relative volume occupied by the population of nanometric cells, $V_{\text {nano }}$, was measured to quantify the bimodality. The PMMA/MAM samples and the nanometric population in the PMMA/Sepiolite samples was characterized using a self-developed tool in ImageJ/FII [28]. The average cell size, $\phi$, and the standard deviation of the cell size distribution, $S D$, were determined. The parameter $S D / \phi$ was calculated as an indicator of the homogeneity of the structure. The cell nucleation density $N_{0}$ was measured using Kumar's approach [14]. 


\section{RESULTS}

Table 1 collects the main characteristics of the materials produced in this work. Note that at these conditions the reference PMMA (samples 1-3, Table 1) are microcellular. Figure 1 shows the cellular structure of the samples based on PMMA/MAM (samples 4-9). Nanocellular samples with cell sizes from 250 to $120 \mathrm{~nm}$ are obtained with $10 \mathrm{wt} \%$ of MAM, whereas $0.1 \mathrm{wt} \%$ of MAM produces higher cell sizes but with lower densities. Figure 2 shows the micrographs of some of the samples of PMMA/Sepiolites. The addition of sepiolites causes a bimodal cellular structure with micrometric pores due to the particle aggregates [29] (first row of Figure 2), while the well-dispersed sepiolites produce nanocellular pores (second row of Figure 2). The parameters $N_{0}$ and $\phi$ in Table 1 correspond to the analysis of the nanocellular region. The fraction occupied by the nanometric pores is higher than $70 \%$ for all the materials except for the 10\%-SQAS (sample 16) that this value is only $52 \%$ because of the big particle aggregates in this system.

Table 1. Characteristics of the materials produced in this work at $6 \mathrm{MPa}$ and $25^{\circ} \mathrm{C}$ (foaming time equal to 2 minutes for all the samples). Samples 1-3: Reference PMMA; Samples 4-9: PMMA/MAM;

Samples 10-16: PMMA/Sepiolites.

\begin{tabular}{|c|c|c|c|c|c|c|c|c|c|}
\hline$\#$ & Sample & $\begin{array}{l}\text { Filler } \\
\text { type }\end{array}$ & $\begin{array}{c}\text { Filler content } \\
(w t \%)\end{array}$ & $\begin{array}{l}T_{\text {foam }} \\
\left({ }^{\circ} \mathrm{C}\right)\end{array}$ & $\rho_{r}$ & $V_{\text {nano }}(\%)$ & $\begin{array}{c}N_{0} \\
\text { (nuclei } / \mathrm{cm}^{3} \text { ) }\end{array}$ & $\begin{array}{c}\phi \phi \\
(\mathrm{nm})\end{array}$ & $\frac{S D}{\phi}$ \\
\hline 1 & PMMA_80C & - & 0 & 80 & 0.277 & 0 & $9.0 \cdot 10^{10}$ & 3360 & 0.79 \\
\hline 2 & PMMA_90C & - & 0 & 90 & 0.197 & 0 & $1.4 \cdot 10^{11}$ & 3490 & 0.68 \\
\hline 3 & PMMA_100C & - & 0 & 100 & 0.152 & 0 & $1.4 \cdot 10^{11}$ & 3610 & 0.81 \\
\hline 4 & $0.1 \%-\mathrm{L}$ & MAM L & 0.1 & 100 & 0.157 & 100 & $1.3 \cdot 10^{13}$ & 872 & 0.45 \\
\hline 5 & $0.1 \%-\mathrm{M}$ & MAM M & 0.1 & 100 & 0.211 & 100 & $9.9 \cdot 10^{13}$ & 308 & 0.43 \\
\hline 6 & $0.1 \%-\mathrm{H}$ & MAM H & 0.1 & 100 & 0.270 & 100 & $2.6 \cdot 10^{14}$ & 248 & 0.41 \\
\hline 7 & $10 \%-L$ & MAM L & 10 & 80 & 0.361 & 100 & $1.4 \cdot 10^{14}$ & 253 & 0.74 \\
\hline 8 & $10 \%-M$ & MAM M & 10 & 80 & 0.500 & 100 & $6.9 \cdot 10^{14}$ & 138 & 0.48 \\
\hline 9 & $10 \%-\mathrm{H}$ & MAM H & 10 & 80 & 0.578 & 100 & $8.2 \cdot 10^{14}$ & 122 & 0.45 \\
\hline 10 & $0.5 \%$-SQAS & SQAS & 0.5 & 100 & 0.162 & 70 & $3.7 \cdot 10^{13}$ & 582 & 0.52 \\
\hline 11 & $1 \%$-SQAS & SQAS & 1 & 100 & 0.207 & 84 & $7.6 \cdot 10^{13}$ & 415 & 0.51 \\
\hline 12 & $1.5 \%$-SQAS & SQAS & 1.5 & 90 & 0.222 & 78 & $5.6 \cdot 10^{13}$ & 430 & 0.56 \\
\hline 13 & $2 \%-S Q A S$ & SQAS & 2 & 90 & 0.248 & 84 & $8.3 \cdot 10^{13}$ & 357 & 0.55 \\
\hline 14 & $3 \%-S Q A S$ & SQAS & 3 & 90 & 0.245 & 90 & $1.3 \cdot 10^{14}$ & 305 & 0.68 \\
\hline 15 & $5 \%$-SQAS & SQAS & 5 & 90 & 0.255 & 77 & $2.1 \cdot 10^{14}$ & 255 & 0.71 \\
\hline 16 & $10 \%-S Q A S$ & SQAS & 10 & 90 & 0.299 & 52 & $3.9 \cdot 10^{14}$ & 191 & 0.63 \\
\hline
\end{tabular}

So far, the structures presented are not so different of other results with these very same systems [26,29-31]. Reducing the amount of MAM reduces density but increases the cell size [30], whereas a higher MAM molecular weight also causes smaller cells and higher nucleation densities [26]. Regarding the sepiolites, the use of higher particle contents reduces the cell size in the nanocellular region because there are more well-dispersed particles [29], but the fraction of nanometric pores is reduced because there are also more micron-sized aggregates [31]. 

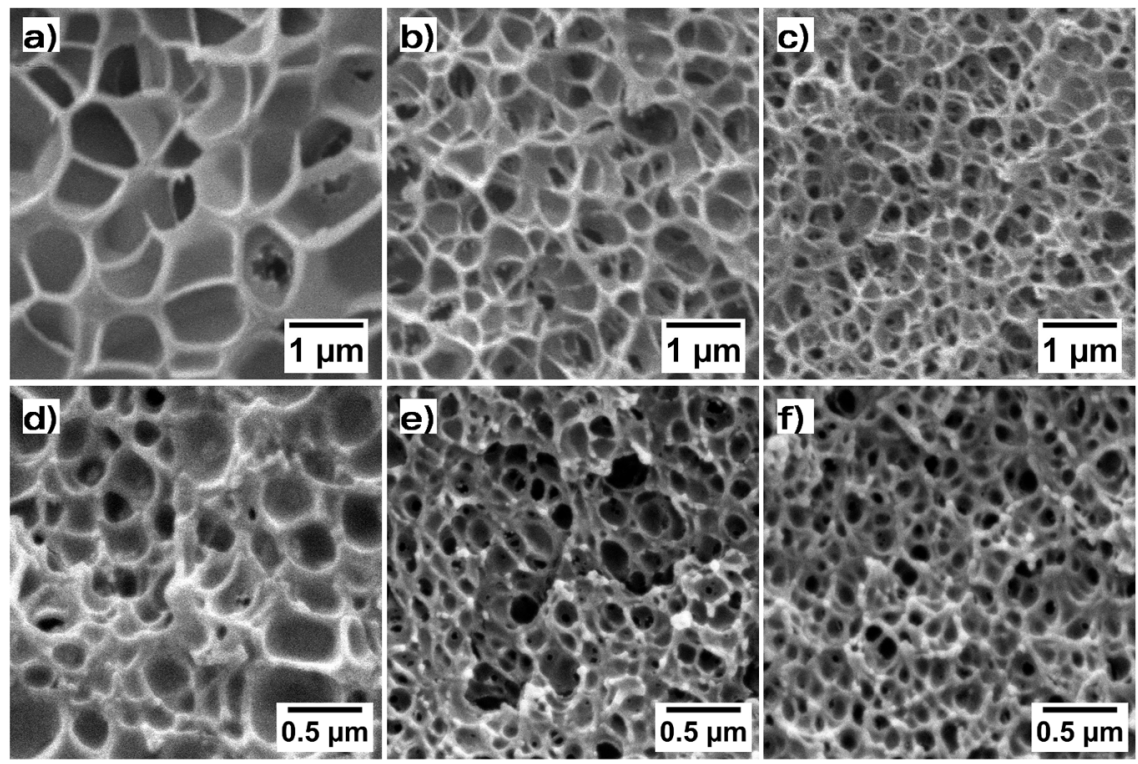

Figure 2. SEM micrographs of the PMMA/MAM nanocellular samples: a) Sample 4 (0.1\%-L), b) Sample $5(0.1 \%-M)$, c) Sample $6(0.1 \%-H)$, d) Sample $7(10 \%-L)$, e) Sample $8(10 \%-M)$ and f) Sample $9(10 \%-H)$.

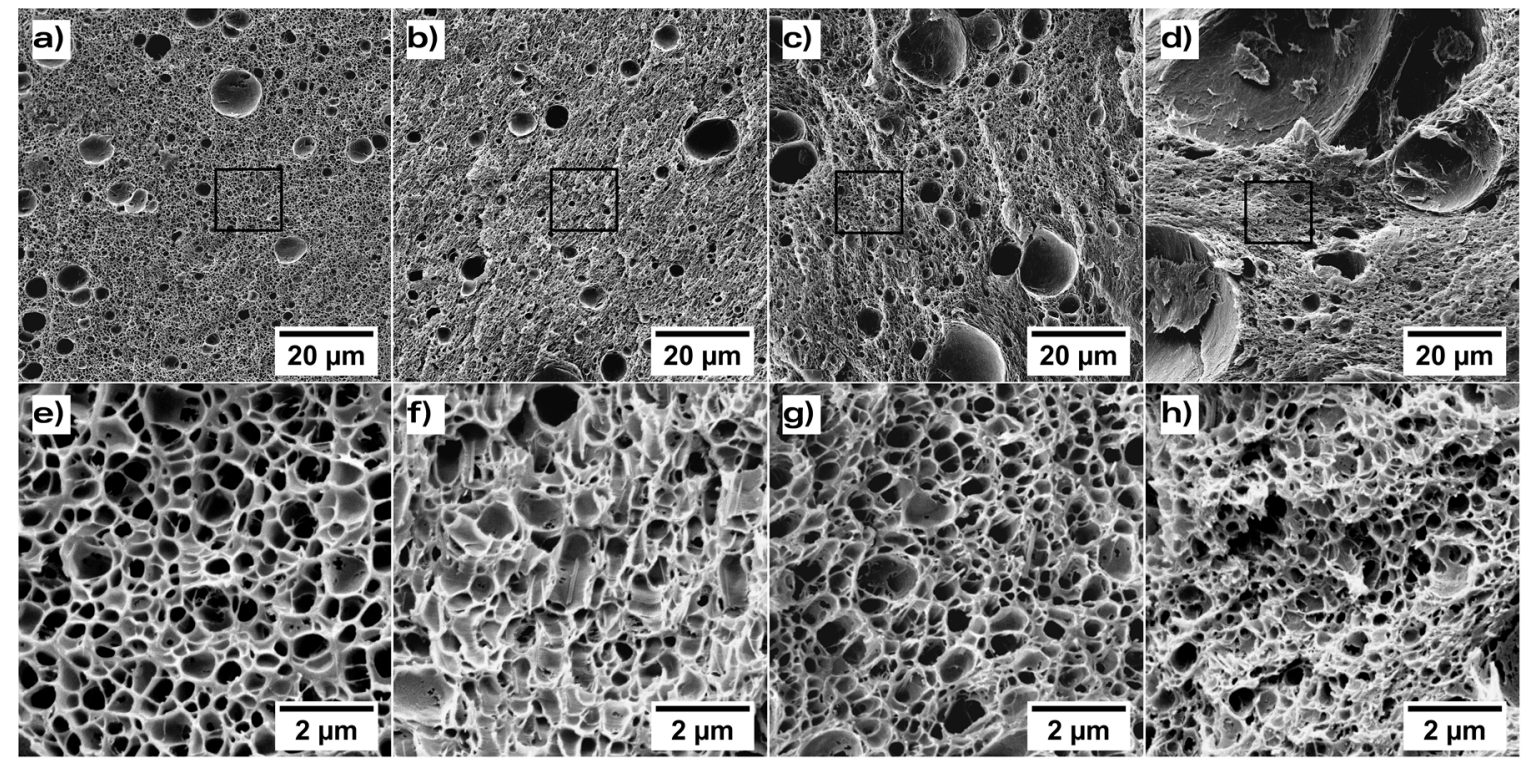

Figure 2. SEM micrographs of some of the PMMA/Sepiolites bimodal nanocellular samples: a-e) Sample 11 (1\%-SQAS), b-f) Sample 14 (3\%-SQAS), c-g) Sample 15 (5\%-SQAS), d-h) Sample 16 (10\%SQAS). Second row corresponds to zoomed images of the first row.

The main novelty of this work lies in the processing conditions used to produce these materials. Figure 3.a shows a map the processing conditions (saturation pressure and temperature) used in various works from the literature (references $[9,16,18,21,32-37]$ ) compared to the parameters used in this paper. All the systems selected for this comparison are based on PMMA as the polymer matrix. Figure 3.b presents the cell size and relative densities of the samples of this work and those extracted from the bibliography. Those samples with small cell sizes $(<100 \mathrm{~nm}$, Figure 3.b) are produced using either high saturation pressure or extremely low saturation temperatures (Figure 3.a). Meanwhile, the materials of this work are obtained at room temperature and using a very low 
pressure of $6 \mathrm{MPa}$, that is, the pressure of the bottle of gas. Therefore, it is not necessary to use a pressure pump or a heating system during the saturation stage to obtain these materials.

a)

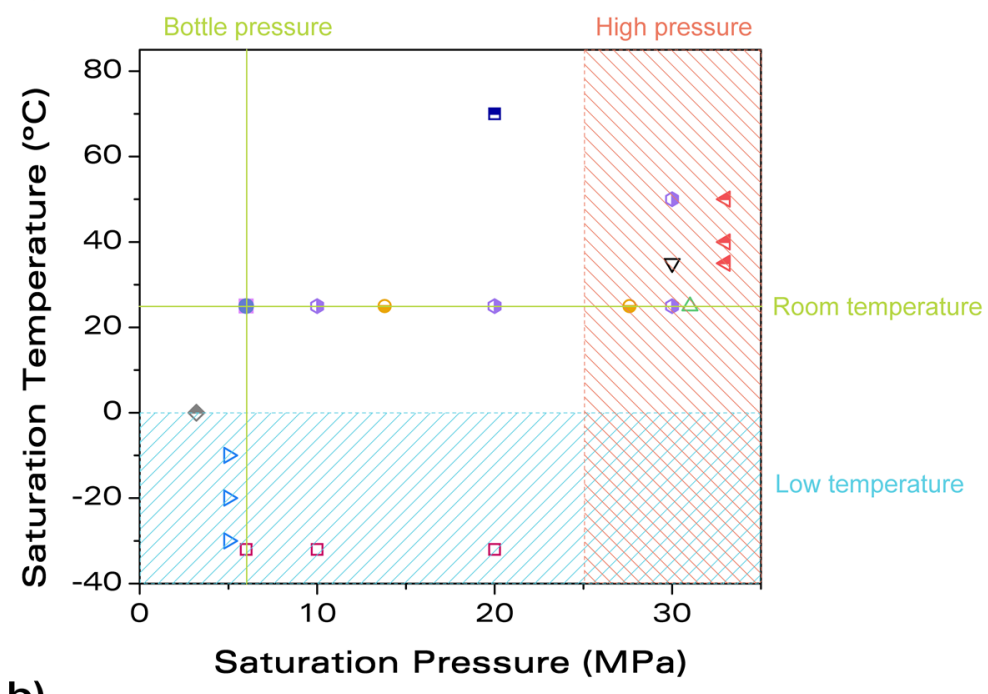

- PMMA/Sepiolites (this work)

- PMMA/MAM (this work)

․ Martin-de Leon, PMMA - [9]

$\triangle$ Martin-de Leon, PMMA - [16]

$\nabla$ Costeux, PMMA - [32]

$\triangle$ Guo, PMMA - [18]

- Pinto, PMMA/MAM - [33,34]

$\Leftrightarrow \quad$ Forest, PMMA/MAM - [35]

$\triangleleft$ Costeux, PMMA/POSS- [21]

- Realinho, PMMA/O-MMT [36]

- Wang, PMMA/TPU - [37]

b)

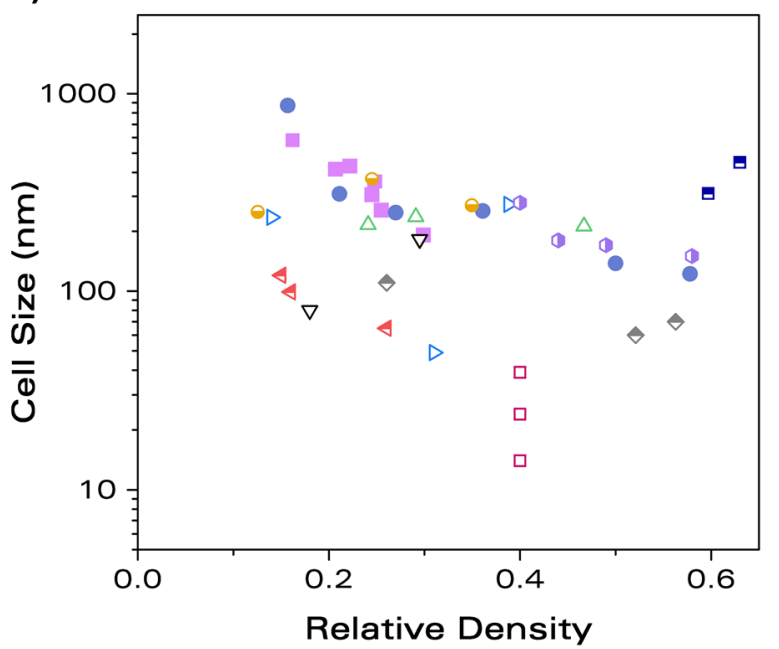

PMMA/Sepiolites (this work)

- PMMA/MAM (this work)

- Martin-de leon, PMMA - [9]

$\triangle \quad$ Martin-de Leon, PMMA - [16]

$\nabla$ Costeux, PMMA - [32]

$\triangleright$ Guo, PMMA - [18]

- Pinto, PMMA/MAM - $[33,34]$

$\diamond \quad$ Forest, PMMA/MAM - [35]

$\triangleleft$ Costeux, PMMA/POSS- [21]

- Realinho, PMMA/O-MMT [36]

- Wang, PMMA/TPU - [37]

Figure 3. a) Saturation temperature - saturation pressure, and b) cell size - relative density maps comparing some of the most interesting results from the literature with the materials produced in this work.

\section{CONCLUSIONS}

Nanocellular polymers based on PMMA filled with different additives were produced using low pressure and room temperature as saturation conditions. Cell sizes in the range from 120 to 900 $\mathrm{nm}$ with relative densities of $0.16-0.58$ were obtained with this approach.

Two systems able to produce nanocellular polymers based on heterogeneous nucleation were used. First, PMMA nanocomposites with nanometric sepiolites, that allowed producing bimodal cellular structures with a high fraction (> 50\%) of nanometric pores. The increase of the sepiolite concentration increases the nucleation and reduces the cell size. Second, PMMA/MAM blends, with 
three MAM grades and at two MAM concentrations. Increasing the MAM molecular weight and the MAM content enhances nucleation and results in smaller cell sizes.

The results of this work prove that it is possible to produce nanocellular polymers based on PMMA without the need of a pressure pump or a heating system during the saturation stage, which is interesting for the possible production at industrial scale.

\section{Acknowledgments:}

Financial support from the FPU grant FPU14/02050 (V. Bernardo) from the Spanish Ministry of Education and the Junta of Castile and Leon grant (J. Martín-de León) are gratefully acknowledged. Financial assistance from MINECO, FEDER, UE (MAT2015-69234-R), the Junta de Castile and Leon (VA275P18) and Spanish Ministry of Science, Innovation and Universities (RTI2018-098749-B-100) are gratefully acknowledged. We would also like to thank Tolsa (Madrid, Spain) for supplying the sepiolites and Arkema for supplying the copolymers used in this research.

\section{REFERENCES}

[1] L.J. Gibson, M. Ashby, Cellular solids: structure and properties, 2nd Editio, Cambridge University Press, 1997.

[2] D. Eaves, Handbook of Polymer Foams, Rapra Technology, United Kingdom, 2004.

[3] B. Notario, J. Pinto, M.A. Rodriguez-Perez, Nanoporous polymeric materials: A new class of materials with enhanced properties, Prog. Polym. Sci. 78-79 (2016) 93-139. doi:10.1016/j.pmatsci.2016.02.002.

[4] B. Notario, J. Pinto, E. Solorzano, J.A. de Saja, M. Dumon, M.A. Rodriguez-Perez, Experimental validation of the Knudsen effect in nanocellular polymeric foams, Polymer (Guildf). 56 (2015) 57-67. doi:10.1016/j.polymer.2014.10.006.

[5] C. Forest, P. Chaumont, P. Cassagnau, B. Swoboda, P. Sonntag, Polymer nano-foams for insulating applications prepared from CO 2 foaming, Prog. Polym. Sci. 41 (2015) 122-145. doi:10.1016/j.progpolymsci.2014.07.001.

[6] S. Liu, J. Duvigneau, G.J. Vancso, Nanocellular polymer foams as promising high performance thermal insulation materials, Eur. Polym. J. 65 (2015) 33-45. doi:10.1016/j.eurpolymj.2015.01.039.

[7] B. Notario, J. Pinto, M.A. Rodríguez-Perez, Towards a new generation of polymeric foams: PMMA nanocellular foams with enhanced physical properties, Polymer (Guildf). $63 \quad$ (2015) 116-126. doi:10.1016/j.polymer.2015.03.003.

[8] D. Miller, V. Kumar, Microcellular and nanocellular solid-state polyetherimide (PEI) foams using sub-critical carbon dioxide II. Tensile and impact properties, Polymer (Guildf). 52 (2011) 2910-2919. doi:10.1016/j.polymer.2011.04.049.

[9] J. Martin-de Leon, V. Bernardo, M.A. Rodriguez-Perez, Key Production Parameters to Obtain Transparent Nanocellular PMMA, Macromol. Mater. Eng. 1700343 (2017) 1-5. doi:10.1002/mame.201700343.

[10] S. Perez-Tamarit, B. Notario, E. Solorzano, M.A. Rodriguez-Perez, Light transmission in nanocellular polymers: are semi-transparent cellular polymers possible?, Mater. Lett. $210 \quad$ (2017) 39-41. doi:10.1016/j.matlet.2017.08.109.

[11] B. Notario, J. Pinto, R. Verdejo, M.A. Rodŕiguez-Pérez, Dielectric behavior of porous PMMA: From the micrometer to the nanometer scale, Polymer (Guildf). 107 (2016) 302-305. doi:10.1016/j.polymer.2016.11.030.

[12] B. Notario, A. Ballesteros, J. Pinto, M.A. Rodriguez-Perez, Nanoporous PMMA: A novel system with different acoustic properties, Mater. Lett. 168 (2016) 76-79. doi:10.1016/j.matlet.2016.01.037.

[13] H. Yokoyama, K. Sugiyama, Nanocellular structures in block copolymers with CO2-philic blocks using CO2 as a blowing agent: Crossover from micro- to nanocellular structures with depressurization temperature, Macromolecules. 38 (2005) 10516-10522. doi:10.1021/ma051757j. 
[14] V. Kumar, N.P. Suh, A process for making microcellular parts, Polym. Eng. Sci. 30 (1990) 1323-1329. doi:https://doi.org/10.1002/pen.760302010.

[15] J.E. Martini-Vvedensky, N.P. Suh, F.A. Waldman, United States Patent - MICROCELLULAR CLOSED CELL FOAMS AND THEIR METHOD OF MANUFACTURE, 4,473,665, 1984.

[16] J. Martin de-Leon, V. Bernardo, M.A. Rodriguez-Perez, Low Density Nanocellular Polymers Based on PMMA Produced by Gas Dissolution Foaming: Fabrication and Cellular Structure Characterization, Polymers (Basel). 8 (2016) 1-16. doi:10.3390/polym8070265.

[17] S. Costeux, S.P. Bunker, Homogeneous nanocellular foams from styrenic-acrylic polymer blends, J. Mater. Res. 17 (2013) 2351. doi:10.1557/jmr.2013.100.

[18] H. Guo, A. Nicolae, V. Kumar, Solid-state poly(methyl methacrylate) (PMMA) nanofoams. Part II: Lowtemperature solid-state process space using CO2 and the resulting morphologies, Polymer (Guildf). 70 (2015) 231-241. doi:10.1016/j.polymer.2015.06.031.

[19] K. Nadella, H. Guo, J. Weller, V. Kumar, Sorption and Desorption of CO 2 in Polycarbonate (PC) and Acrylonitrile Butadiene Styrene ( ABS ) in the Solid State Microcellular Process, (n.d.).

[20] C. Forest, P. Chaumont, P. Cassagnau, B. Swoboda, P. Sonntag, CO2 nano-foaming of nanostructured PMMA, Polymer (Guildf). 58 (2015) 76-87. doi:10.1016/j.polymer.2014.12.048.

[21] S. Costeux, L. Zhu, Low density thermoplastic nanofoams nucleated by nanoparticles, Polymer (Guildf). 54 (2013) 2785-2795. doi:10.1016/j.polymer.2013.03.052.

[22] S. Liu, B. Zoetebier, L. Hulsman, Y. Zhang, J. Duvigneau, G.J. Vancso, Nanocellular polymer foams nucleated by core-shell nanoparticles, Polymer (Guildf). 104 (2016). doi:10.1016/j.polymer.2016.09.016.

[23] S. Costeux, CO2-blown nanocellular foams, J. Appl. Polym. Sci. 131 (2014) 41293(1)-41293(16). doi:10.1002/app.41293.

[24] A. Alvarez, J. Santaren, A. Esteban-Cubillo, P. Aparicio, Development in Palygorskite-Sepiolite Research, Elsevier, 2011.

[25] J. Santaren, A. Alvarez, A. Esteban-Cubillo, B. Notario, D. Velasco, M.A. Rodriguez-Perez, Improving the Cellular Structure and Thermal Conductivity of PS Foams by Using Sepiolites, in: Foams2012, 2012: pp. 1-5.

[26] V. Bernardo, J. Martin-de Leon, E. Laguna-Gutierrez, T. Catelani, J. Pinto, A. Athanassiou, M.A. Rodriguez-Perez, Understanding the role of MAM molecular weight on the production of PMMA/MAM nanocellular polymers, Polymer (Guildf). 153 (2018) 262-270. doi:10.1016/j.polymer.2018.08.022.

[27] H. Guo, V. Kumar, Solid-state poly(methyl methacrylate) (PMMA) nanofoams. Part I: Low-temperature CO2 sorption, diffusion, and the depression in PMMA glass transition, Polymer (Guildf). 57 (2015) 157-163. doi:10.1016/j.polymer.2014.12.029.

[28] J. Pinto, E. Solórzano, M.A. Rodriguez-Perez, J.A. De Saja, Characterization of the cellular structure based on user-interactive image analysis procedures, J. Cell. Plast. 49 (2013) 555-575. doi:10.1177/0021955X13503847.

[29] V. Bernardo, J. Martin-de León, E. Laguna-Gutiérrez, M.Á. Rodríguez-Pérez, PMMA-sepiolite nanocomposites as new promising materials for the production of nanocellular polymers, Eur. Polym. J. 96 (2017) 10-26. doi:10.1016/j.eurpolymj.2017.09.002.

[30] V. Bernardo, J. Martin-de Leon, J. Pinto, T. Catelani, A. Athanassiou, M.A. Rodriguez-Perez, Low-density PMMA/MAM nanocellular polymers using low MAM contents: Production and characterization, Polymer (Guildf). 163 (2019) 115-124. doi:10.1016/j.polymer.2018.12.057.

[31] V. Bernardo, J. Martin-de Leon, M.A. Rodriguez-Perez, Anisotropy in nanocellular polymers promoted by the addition of needle-like sepiolites, Polym. Int. 68 (2019) 1204-1214. doi:10.1002/pi.5813.

[32] S. Costeux, I. Khan, S.P. Bunker, H.K. Jeon, Experimental study and modeling of nanofoams formation from single phase acrylic copolymers, J. Cell. Plast. 51 (2015) 197-221. doi:10.1177/0021955X14531972.

[33] J. Pinto, M. Dumon, M. Pedros, J. Reglero, M.A. Rodriguez-Perez, Nanocellular CO2 foaming of PMMA assisted by block copolymer nanostructuration, Chem. Eng. J. 243 (2014) 428-435. doi:10.1016/j.cej.2014.01.021.

[34] J. Pinto, J.A. Reglero-Ruiz, M. Dumon, M.A. Rodriguez-Perez, Temperature influence and CO2 transport in foaming processes of poly(methyl methacrylate)-block copolymer nanocellular and microcellular foams, J. Supercrit. Fluids. 94 (2014) 198-205. doi:10.1016/j.supflu.2014.07.021.

[35] C. Forest, P. Chaumont, P. Cassagnau, B. Swoboda, P. Sonntag, Nanofoaming of PMMA using a batch CO2 process: Influence of the PMMA viscoelastic behaviour, Polymer (Guildf). 77 (2015) 1-9. doi:10.1016/j.polymer.2015.09.011. 
[36] V. Realinho, M. Antunes, A.B. Martínez, J.I. Velasco, Influence of nanoclay concentration on the CO2 diffusion and physical properties of PMMA montmorillonite microcellular foams, Ind. Eng. Chem. Res. 50 (2011) 1381913824. doi:10.1021/ie201532h.

[37] G. Wang, J. Zhao, L.H. Mark, G. Wang, K. Yu, C. Wang, C.B. Park, G. Zhao, Ultra-tough and super thermalinsulation nanocellular PMMA/TPU, Chem. Eng. J. 325 (2017) 632-646. doi:10.1016/j.cej.2017.05.116. 

Chapter 7.

Properties of Nanocellular Polymers Produced by Heterogeneous Nucleation 



\section{Chapter 7. Properties of Nanocellular Polymers Produced by Heterogeneous Nucleation}

\subsection{Introduction}

This chapter includes two papers dealing with the physical properties of some of the nanocellular polymers produced in the previous chapters. The first paper is related to the mechanical characterization of bimodal nanocellular polymers based on PMMA/Sepiolites nanocomposites as those produced in Chapter 4. In this work, the mechanical properties in compression and the fracture toughness are measured for a selection of materials with several sepiolite concentrations and densities to understand the effect of the bimodal cellular structure and the presence of the particles in the mechanical performance.

The second paper is about the thermal conductivity of bimodal nanocellular polymers. In this thesis, various bimodal structures with nanometric pores have been obtained. However, there were not suitable models to predict the thermal conductivity of such systems. Thus, this work is focused on the development of a model to predict the thermal conductivity by conduction of nanocellular polymers with a bimodal cellular structure. The results of the model are validated by measuring the conductivity of real bimodal systems based on PMMA/Sepiolites and PMMA/MAM.

\subsection{Mechanical properties of PMMA-sepiolite nanocellular materials with a bimodal cellular structure}

This section contains a publication entitled "Mechanical properties of PMMA-sepiolite nanocellular materials with a bimodal cellular structure", published in Macromolecular Materials and Engineering in 2019 (V. Bernardo, F. Van Loock, J. Martin-de Leon, N.A. Fleck, M.A. Rodriguez-Perez, Mechanical Properties of PMMA-Sepiolite Nanocellular Materials with a Bimodal Cellular Structure, Macromol. Mater. Eng. 1900041 (2019) 1-12. doi:10.1002/mame.201900041). The mechanical tests were carried out at the University of Cambridge under the supervision of Prof. Norman A. Fleck.

PMMA/Sepiolites nanocomposites with various particle contents (from 1 wt $\%$ to 5 wt\%) were produced via extrusion and compression molding. From the solids precursors, cellular materials with different densities (from 0.5 to 0.25 ) were produced. In this work, the foaming step was carried out in a hot press to assure that the samples were flat enough for the mechanical characterization. With the materials produced, two different properties are tested: mechanical properties in compression and fracture toughness behavior. The solid nanocomposites and a purely microcellular PMMA are also tested as reference materials.

Regarding the tests in compression, results show that the addition of sepiolites increases the elastic modulus and the compressive strength in the solid nanocomposites compared to PMMA. This was the expected behavior since the incorporation of nanometric particles is a general strategy to improve the mechanical properties of solid polymers. To factor-out this effect when analyzing the 
cellular materials, the relative properties (modulus and strength) were calculated and compared between the microcellular PMMA and the bimodal nanocomposites. Then, to have an average behavior over all the density range, an analysis was done (see details in the paper manuscript attached in the next pages). Our results show that over all the density range, the relative elastic modulus of the foams is not affected by the sepiolite concentration, whereas the compressive strength seems to decrease slightly when particle content increases. However, in the relative modulus - relative density plot, we observe that at a high relative density (0.5) the nanocomposites have a higher relative modulus that the PMMA (this effect is not observed in the analysis over all the density range because it is averaged with the other densities). We conclude that there is a reinforcement in the relative modulus at high relative density. As the reinforcement in the solid is eliminated by calculating the relative property, the enhancement should be a consequence of the cellular structure. To check if the nanocellular pores or the bimodal structure are having an effect, samples with sepiolites but with a $100 \%$ microcellular structure were produced. We observe that bimodal and microcellular materials have the same properties. Then, the improvements are associated with other effects. In particular, we observed that the amount of particle aggregates is reduced after the foaming process, and also, the aggregates are placed inside the microcellular pores. Then, the negative effect of the aggregates on the properties is reduced in the cellular composites, and we hypothesize this is the reason underneath the enhancement of the modulus at high relative density.

The fracture toughness of the solids decreases as particle content increases. This might be related to the presence of particle aggregates, that act as weak points for fracture propagation. For the cellular materials, the same analysis done for the compression properties is carried out to factor out the properties of the solids and the density. In this case, the relative fracture toughness of the cellular nanocomposites is enhanced compared to the microcellular PMMA. Again, this is not related to the bimodal structure, but it is due to the dispersion and the position of the particle aggregates in the cellular nanocomposites: the bad influence they had in the solids is reduced due to an improved dispersion and its position inside the microcellular pores. In short, we concluded that the combination of the nanoparticles and the foaming process created a synergetic effect improving the mechanical properties, and more specifically improving the fracture toughness of the nanocellular nanocomposites. Figure 7.1 shows the graphical abstract of this publication.

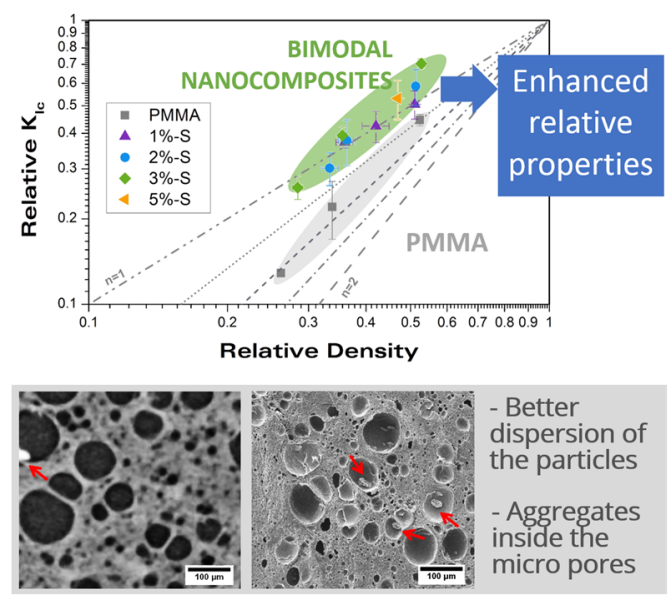

Figure 7.1. Graphical abstract of "Mechanical properties of PMMA-sepiolite nanocellular materials with a bimodal cellular structure." 


\title{
Mechanical properties of PMMA-sepiolite nanocellular materials with a bimodal cellular structure
}

\author{
Victoria Bernardo ${ }^{1 *}$, Frederik Van Loock² Judith Martín-de León' ${ }^{1}$, Norman A. Fleck², Miguel Ángel \\ Rodríguez-Pérez ${ }^{1}$ \\ 1. Cellular Materials Laboratory (Cel/Mat), Condensed Matter Physics Department, \\ University of Valladolid, Campus Miguel Delibes, Paseo de Belén n7, 47011 Valladolid, Spain \\ 2. Engineering Department, University of Cambridge, Trumpington Street, CB2 1PZ Cambridge, \\ United Kingdom \\ *Corresponding author: Victoria Bernardo (vbernardo@fmc.uva.es) +34983184035
}

\begin{abstract}
Bimodal cellular PMMA with micro- and nano-sized $(300-500 \mathrm{~nm})$ cells with up to $5 \mathrm{wt} \%$ of nanosized sepiolites are produced by solid-state foaming. The porosity of $50 \%$ to $75 \%$ exists in a bimodal cell size distribution with micro- and nano-sized cells. Uniaxial compression tests are performed to measure the effect of sepiolite concentration on the elastic modulus and the yield strength of the solid and cellular nanocomposites. Single edge notch bend tests are conducted to relate the fracture toughness of the solid and cellular nanocomposites to sepiolite concentration. The relative modulus is independent of sepiolite content to within material scatter when considering the complete porosity range. In contrast, a mild enhancement of the relative modulus is observed by the addition of sepiolite particles for the foamed nanocomposites with a porosity close to $50 \%$. The relative compressive strength of the cellular nanocomposites mildly decreases as a function of sepiolite concentration. A strong enhancement of the relative fracture toughness by the addition of sepiolites is observed. The enhancement of the relative fracture toughness and the relative modulus (at $50 \%$ porosity) can be attributed to an improved dispersion of the particles due to foaming and the migration of micro-sized aggregates from the solid phase to the microcellular pores during foaming.
\end{abstract}

\section{KEYWORDS}

nanocellular polymer; nanocellular foam; nanocomposites; mechanical properties; PMMA.

\section{INTRODUCTION}

Nanocellular polymers are polymer foams characterised by cell sizes in the range of tens to hundreds of nanometres [1]. An attractive property of these nanocellular polymers is their low thermal conductivity due to the Knudsen effect [2,3]: theoretically, the reductions in the thermal conduction of the gas phase start to be significant in comparison with microcellular polymers for cell sizes under $500 \mathrm{~nm}$. Moreover, recently, semi-transparent nanocellular foams have been reported $[4,5]$ and, due to their nano-sized cell size, these materials have the potential to be used in membranes for ultrafiltration or in catalysis and sensors [6-8]. Most research on nanocellular 
polymers is focused on their production, whereas the literature on the mechanical characterisation is relatively scarce. Notario et al. [9] found that the material performance index for a light, stiff beam in bending $E^{1 / 2} / \rho$ (where $E$ is the Young's modulus and $\rho$ is the density) for a nanocellular foam exceeded that for a microcellular foam [10]. They attributed this stiffening to the fact that the size of the cell walls of the nanocellular material is in the order of the radius of gyration of a PMMA molecule [9]. Miller and co-workers [11] found that micro- and nanocellular polyetherimide (PEI) have similar values for $E$ whereas the nanocellular PEI materials had a greater impact resistance. Guo [12] observed that micro- and nanocellular polycarbonate (PC) have similar values of $E / \rho$ and similar impact resistance properties for cellular materials with relative densities higher than 0.6. In the case of polymer blends, Wang and coworkers [13] reported the nanocellular polymers produced with PMMA blended with thermoplastic polyurethane (TPU) showed higher tensile toughness and impact toughness compared to microcellular PMMA. For polypropylene (PP) blended with polytetrafluoroethylene (PTFE), Wang et al. [14] showed that a nanocellular sample based on PP/PTFE has a higher impact strength than conventional PP cellular material. Reglero-Ruiz et al. [15] measured $E$ for nanocellular samples based on nanostructured PMMA/MAM (poly(methyl methacrylate)-poly(butyl acrylate)-poly(methyl methacrylate)).

The addition of inorganic nanoparticles to a polymer matrix is a common strategy to improve the mechanical properties of a polymer [16-20]. When these nanocomposites are foamed, the resulting cellular nanocomposites inherit this reinforcement and this strategy could be used to further enhance the mechanical properties of nanocellular foams [21,22]. In addition, nano-sized particles have successfully been used as heterogeneous nucleation agents for the production of micro- [2326] and nanocellular [27-31] polymers. The addition of nanoparticles is therefore a promising method to enhance the mechanical performance of nanocellular polymers. In the recent work of Yeh et al. [32], the addition of nanoclays was proved to enhance the modulus and yield strength of nanocellular TPU. However, the authors have been unable to locate any more studies that investigate the effect of nanoparticles on the mechanical properties of nanocellular polymers.

In the present study, PMMA is reinforced with nano-sized needle-like sepiolites, and cellular materials are produced by gas dissolution foaming. The effect of the sepiolite concentration on the mechanical properties (such as the compressive yield strength, the compressive elastic modulus, and the fracture toughness) of the solid and cellular nanocomposites is measured. In an earlier work [31] we showed that the addition of sepiolites, modified with a quaternary ammonium salt, in a PMMA matrix resulted in bimodal cellular structures comprizing micro- and nano-sized (300-500 $\mathrm{nm}$ ) cells. In this paper, our goal is to analyse the mechanical behaviour of bimodal nanocellular polymers based PMMA/sepiolite nanocomposites with various particle concentrations and densities, and to determine the effect of the addition of sepiolites particles on their mechanical properties.

\section{EXPERIMENTAL}

\subsection{Materials}

Polymethylmethacrylate (PMMA) V 825T $\left(M_{n}=43 \mathrm{~kg} / \mathrm{mol}, \mathrm{M}_{\mathrm{w}}=83 \mathrm{~kg} / \mathrm{mol}\right)$ was supplied by ALTUGLAS $®$ International in the form of pellets with a density $(\rho)$ of $1.18 \mathrm{~g} / \mathrm{cm}^{3}$ and a glass transition 
temperature $\left(T_{g}\right)$ close to $114.5{ }^{\circ} \mathrm{C}$ as measured by DSC. Sepiolites were provided by Tolsa S.A (Spain). These particles are hydrated magnesium silicates. Sepiolites present a needle-like morphology, with an average particle length ranging from $1 \mu \mathrm{m}$ to $2 \mu \mathrm{m}$ and a diameter in the nanometre range (between $20 \mathrm{~nm}$ and $30 \mathrm{~nm}$ ) [33,34]. The sepiolites used in this work have been modified with a quaternary ammonium salt. The process to obtain and modify these particles is detailed elsewhere $[35,36]$. Medical grade carbon dioxide $\left(\mathrm{CO}_{2}\right)(99.9 \%$ purity) was used as the blowing agent for the gas dissolution foaming experiments.

\subsection{Solid Blends Production}

Blends of PMMA with varying sepiolite contents were compounded using a twin-screw extruder model COLLIN TEACH-LINE ZK 25T, with L/D equal to 24 and screw diameter equal to $25 \mathrm{~mm}$ (Table 1). PMMA and sepiolites were dried in a vacuum oven at $50{ }^{\circ} \mathrm{C}$ for 12 hours before blending. The temperature profile set on the extruder was from $160^{\circ} \mathrm{C}$ at the hopper to $200{ }^{\circ} \mathrm{C}$ in the die. The screw speed was equal to $40 \mathrm{rpm}$. The produced blends were cooled in a water bath and pelletized. After drying the pellets for 2 hours in a vacuum oven at a temperature equal to $50{ }^{\circ} \mathrm{C}$, each blend was extruded again using the same processing conditions to have a homogeneous dispersion of the particles.

Next, the obtained pellets were compression moulded into solid sheets of $155 \times 75 \times 4 \mathrm{~mm}^{3}$ using a hot plate press provided by Remtex. The pellets were first dried in a vacuum oven at $50^{\circ} \mathrm{C}$ overnight before processing. Subsequently, they were made molten by holding them at $250^{\circ} \mathrm{C}$ for $500 \mathrm{~s}$ and then compacted at $250^{\circ} \mathrm{C}$ with a constant pressure of $17 \mathrm{MPa}$ for $60 \mathrm{~s}$. Finally, the sheets were cooled down to room temperature with the pressure of $17 \mathrm{MPa}$ maintained. Rectangular specimens with dimensions corresponding to $50 \times 15 \times 4 \mathrm{~mm}^{3}$ were machined from the sheet for the foaming experiments. Note that PMMA absent the sepiolite was processed under the same conditions for comparison purposes.

Table 1. The PMMA-sepiolite blend formulations.

\begin{tabular}{cc}
\hline Material ID & Sepiolite concentration (wt\%) \\
\hline PMMA & 0 \\
$1 \%-S$ & 1 \\
$2 \%-S$ & 2 \\
$3 \%-S$ & 3 \\
$5 \%-S$ & 5 \\
\hline
\end{tabular}

\subsection{Gas Dissolution Foaming Experiments}

Foaming experiments were performed using a pressure vessel (model PARR 4681) provided by Parr Instrument Company with a capacity of 1 litre. The maximum temperature and pressure reached by the pressure vessels correspond to $350{ }^{\circ} \mathrm{C}$ and $41 \mathrm{MPa}$, respectively. The pressure is automatically controlled by a pressure pump controller (model SFT-10) provided by Supercritical Fluid Technologies Inc. The vessel is equipped with a clamp heater of $1200 \mathrm{~W}$, and its temperature is regulated via a CAL 3300 temperature controller. Foaming experiments were conducted by a two- 
step foaming process [37]. First, samples were put into the pressure vessel at a constant $\mathrm{CO}_{2}$ pressure $\left(p_{\text {sat }}=10 \mathrm{MPa}\right)$ and temperature $\left(T_{\text {sat }}=25^{\circ} \mathrm{C}\right)$ for the saturation stage. At these conditions, full saturation of $\mathrm{CO}_{2}$ in PMMA is achieved within 20 hours [31]. The pressure was progressively released to ambient pressure with an instantaneous pressure drop rate of $15 \mathrm{MPa} / \mathrm{s}$ at the first pressure drop.

The foaming step was carried out in a hot and cold plates press from Remtex [38]. Details about this foaming process can be found in the Supplementary Information. To obtain materials with different densities, the temperature of the press and the foaming time were varied (see Table 2). After the foaming step in the hot and cold plates press, flat samples, suitable for mechanical characterization, were obtained. From these pieces, samples with adequate dimensions for the different mechanical tests (see section 2.4.5) were machined using a band sawing machine. For the blend with the highest particle content (5\%-S), it was only possible to produce the materials with high relative densities, as the presence of too many aggregates of the sepiolites particles led to cracking of the samples at the highest foaming temperatures used to produce the low and medium relative density cellular nanocomposites.

Table 2. Foaming parameters in the press.

\begin{tabular}{ccc}
\hline Target relative density & Temperature $\left({ }^{\circ} \mathrm{C}\right)$ & Time $(\mathrm{s})$ \\
\hline High $(\sim 0.5)$ & 40 & 300 \\
Medium $(\sim 0.35)$ & 60 & 300 \\
Low $(\sim 0.3)$ & 100 & 60 \\
\hline
\end{tabular}

\subsection{Characterization}

\subsubsection{Density}

The density of the solid nanocomposites was measured with a gas pycnometer (Mod. AccuPyc II 1340, Micromeritics). The density of the cellular materials was determined with the waterdisplacement method based on the Archimedes' principle using a density determination kit for an AT261 Mettler-Toledo balance. The solid skin of the samples was removed with a polisher (model LaboPOl2-LaboForce3, Struers) by polishing off $200 \mu \mathrm{m}$ from the top and bottom faces of the sample before measuring their densities. The relative density $\left(\rho_{r}\right)$ is defined as the ratio of the cellular material density $(\rho)$ to the density of the solid nanocomposite with the same composition $\left(\rho_{s}\right)$.

\subsubsection{Cellular Structure}

Samples were immersed in liquid nitrogen and then fractured for microscopic visualization and coated with gold using a sputter coater (model SCD 005, Balzers Union). The cellular structure of the samples was analysed using an ESEM Scanning Electron Microscope (QUANTA 200 FEG). Dedicated in-house software based on Image]/FIJI was used for this purpose [39]. Firstly the average cell size $(\phi)$ was measured and the standard deviation of the cell size distribution (SD) was obtained. The parameter $S D / \phi$ was calculated as an indicator of the homogeneity of the cellular structure. The nanocomposite cellular materials of this work possess a bimodal cellular structure with microsized cells (above $1 \mu \mathrm{m}$ ) and nano-sized cells (below $1 \mu \mathrm{m}$ ), and values for the average cell size $\phi$ 
and standard deviation $S D$ were measured for both distributions. We write the average cell size as $\phi_{1}$ for the nano-sized cells and as $\phi_{2}$ for the micro-sized cells. Similarly, $S D_{1}$ refers to the standard deviation of the cell size distribution of the nano-sized cells and $S D_{2}$ denotes the standard deviation of the cell size distribution of the micro-sized cells. The anisotropy ratio $A R$ was measured as the ratio between the average cell size of the whole population of cells observed in the plane aligned with the compression moulding direction to the average cell size of the whole population of cells measured in the plane perpendicular to the compression moulding direction. Cell density $\left(N_{v}\right)$ and cell nucleation density $\left(N_{0}\right)$ were determined from the SEM images using Kumar's theoretical approximation [40] according to:

$$
\begin{gathered}
N_{v}=\left[\frac{n}{A}\right]^{3 / 2} \\
N_{0}=\frac{N_{v}}{\rho_{r}}
\end{gathered}
$$

where $n$ is the number of cells in the SEM image and $A$ is the area of the image. Note that more than 200 cells from various regions of each cellular material were analysed.

In this work, bimodal cellular structures (with cell sizes in the micro and the nano scale) are obtained. The observed cellular structures were found to have a much larger proportion of nanosized cells than micro-sized cells. The micro-sized cells, however, typically occupied a significant volume of the sample, in the range from $20 \%$ to $40 \%$. To quantify the observed bimodality, the relative volume occupied by the population of nano-sized cells, $V_{\text {nano }}$, is measured [31]:

$$
V_{\text {nano }}=\frac{A_{t}-A_{m}}{A_{t}}
$$

where $A_{m}$ is the observed area occupied by the micro-sized cells (cell size above $1 \mu \mathrm{m}$ ) in the SEM images, and $A_{t}$ the total area of the image. The resulting two-dimensional area ratio should be equivalent to the three-dimensional volume ratio when an adequate amount of surfaces are analysed, according to Delesse principle in stereology [41,42].

\subsubsection{Open Cell Content}

The open cell content of the cellular materials was measured according to the ASTM D6226-10 standard using a gas pycnometer (Mod. AccuPyc II 1340, Micromeritics). The open cell content ratio $O C$ is defined as:

$$
\mathrm{OC}=\frac{V-V_{p}-V_{s}}{V\left(1-\rho_{r}\right)}
$$

where $V$ is the geometric volume of the sample, $V_{p}$ is the volume measured by the pycnometer and $V_{s}$ is a penalty volume to account for the exposed cells at the surface of the sample. The geometric volume was determined from the cellular material density (measured by the water-displacement method) and its mass $(m)$ (measured with an AT261 Mettler-Toledo balance) as $V=m / \rho . V_{p}$ was determined by performing a pressure scan (from $0.02 \mathrm{MPa}$ to $0.13 \mathrm{MPa}$ ) in the gas pycnometer and measuring the pycnometric volume for each pressure. It was assumed that no more gas is able to enter the interconnected open cells when the measured volume remains constant for an increase in pressure. $V_{p}$ was calculated as the average of these last measured constant volume values. Note 
that, as $V_{s}$ is proportional to the cell size, this value becomes negligible for micro and nanocellular materials.

\subsubsection{X-Ray Analysis}

X-ray imaging is employed to determine the number of particle aggregates in the nanocomposite material. For this purpose, $\mathrm{X}$-ray tomography images of both solid and cellular materials were taken with a spatial resolution of $2.5 \mu \mathrm{m}$ (i.e. aggregates with dimensions larger than $2.5 \mu \mathrm{m}$ can be detected) [43]. The mass of the aggregates is calculated by measuring the volume occupied by the aggregates and taking into account the real volume fraction of particles in the sample.

In addition, all samples were analysed by X-ray radiography [44] and those samples presenting defects or inhomogeneities were excluded from the mechanical tests.

\subsubsection{Mechanical Tests}

Mechanical properties in uniaxial compression were measured using an Instron 5584 electromechanical testing machine. Specimens were cuboids with in-plane dimensions $10 \times 10 \mathrm{~mm}^{2}$; the thickness varied from $4 \mathrm{~mm}$ to $6 \mathrm{~mm}$ depending on the relative density of the sample. The compression direction was perpendicular to the compression moulding direction. At least three specimens were tested per material system. Tests were carried out at a crosshead velocity equal to $0.5 \mathrm{~mm} \mathrm{~min}^{-1}$, corresponding to a strain rate equal to $8.3 \times 10^{-4} \mathrm{~s}^{-1}$. Displacement of the platens was measured via a laser extensometer. All tests were conducted at room temperature.

Single edge notch three point bending (SENB) tests were performed at room temperature with an Instron 5584 test bench at a constant crosshead speed of $10 \mathrm{~mm} / \mathrm{min}$. Specimens were cuboids with in-plane dimensions $55 \times 15 \mathrm{~mm}^{2}$; the thickness varied from $4 \mathrm{~mm}$ to $6 \mathrm{~mm}$ depending on the relative density of the sample. The critical mode I stress intensity factor $K_{I C}$ was calculated as a measure for the fracture toughness in accordance with the ASTM D5045-14 [45]. A pre-crack with a sharp tip was made at the end of a sawed notch by tapping with a razor blade.

\section{RESULTS AND DISCUSSION}

\subsection{Cellular Structure}

Representative cellular structures of the cellular materials with a relative density close to 0.5 are shown in Figure 1 (SEM images from the plane parallel to the compression moulding direction). At very low magnification (first row of Figure 1), a homogeneous structure is observed for PMMA, whereas the blends with sepiolites have a heterogeneous structure with pore sizes exceeding 100 $\mu \mathrm{m}$. Using a higher magnification, one can observe the microcellular structure of the pure PMMA and the blends with sepiolites (see second row of Figure 1). The cell size distribution of the pure PMMA is unimodal; there are no nano-sized pores present (see third row of Figure 1 where an even higher magnification is used). In contrast, the PMMA/sepiolite blends have a bimodal cell size distribution, the dominant population of cells is nanocellular (ranging from 300 to $500 \mathrm{~nm}$ ) as detailed below (see the third row in Figure 1). Earlier work demonstrated that sepiolites modified with a quaternary ammonium salt act as a nucleating agent during gas dissolution foaming of PMMA [31]. It was suggested that the microcellular pores appear due to micro-sized sepiolite 
aggregates. The well-dispersed sepiolites account for the presence of nanocellular pores. The second and third rows show images of the same materials at increased magnification.

The main parameters characterizing the cellular structure of all the material systems produced in this study are summarized in Table 3. Due to the difference in size between the largest and the smallest cells in the materials with bimodal cell size distribution, we identify two sets of cells: the main (nanocellular, from 300 to $500 \mathrm{~nm}$ ) and the secondary (microcellular) structures. The microcellular pores were measured using SEM micrographs with the magnification of the images shown in the second row of Figure 1 (cell size around 1-10 $\mu \mathrm{m}$ ). The volumetric fraction of nanosized cells ( $V_{\text {nano }}$ in Table 3 ) is greater than $50 \%$ for all the materials and, for this reason, the nanocellular population is considered to be the dominant one.

PMMA
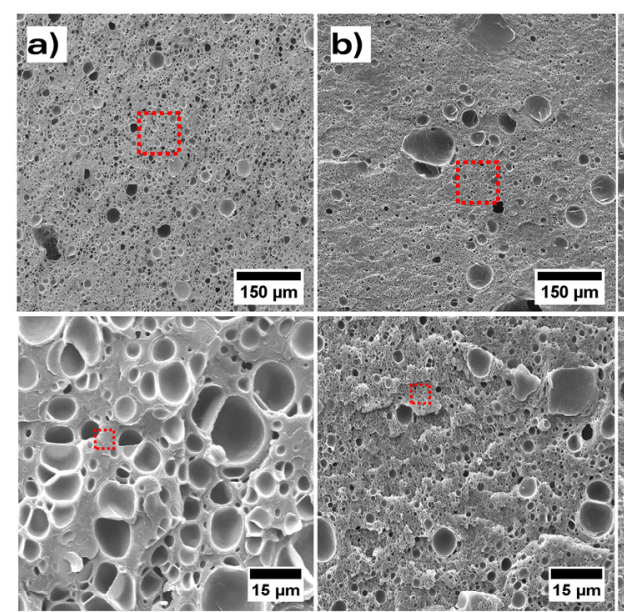

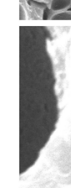
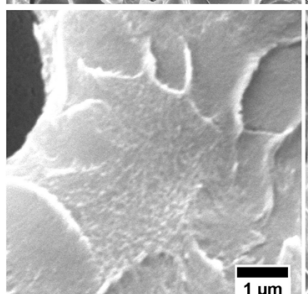

$2 \%-S$

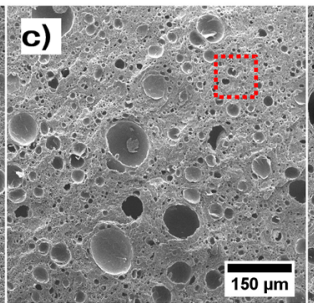

3\%-S

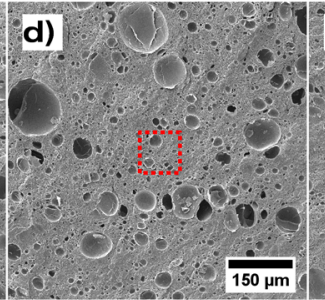

$5 \%-S$

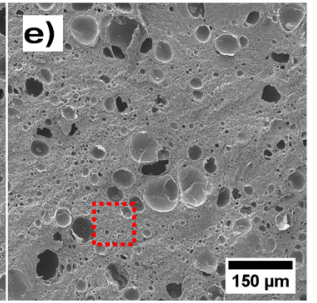

Figure 1. SEM images of the samples produced at a foaming temperature equal to $40^{\circ} \mathrm{C}$ and foaming time equal to 5 minutes: a) PMMA, b) 1\%-S, c) 2\%-S, d) 3\%-S and e) 5\%-S. Second row shows zoomed images of the size of the red square in the first row, third row shows zoomed images of the size of the red square in the second row.

Bimodal micro- and nanocellular materials with average cell sizes ranging from $330 \mathrm{~nm}$ to $500 \mathrm{~nm}$ in the nano-sized cell population are obtained, whereas for the micro-sized cell population the cell size ranges from $3 \mu \mathrm{m}$ to $7 \mu \mathrm{m}$. The nanocellular cell populations are more homogeneous, with $S D_{1} / \phi_{1}$ values around $0.5-0.7$, while the microcellular population is strongly heterogeneous with values for $S D_{2} / \phi_{2}$ higher than 1. It is observed that, for the high-density materials (samples 1 to 5 ), an increased sepiolite content leads to a mild reduction of the average cell size. For the lower density materials, this effect is less obvious. For a given sepiolite concentration, the cell size tends to increase when density is reduced. Regarding the cell nucleation density, an increase of the nucleation in three orders of magnitude with respect to the pure PMMA is detected when sepiolites are added. The cellular materials were found to be closed-celled as the measured open cell 
contents were lower than $10 \%$ for all the material systems. In addition, the materials can be considered as isotropic because the anisotropy ratio is close to 1 for all the systems under study.

Regarding the homogeneity of the samples, it was found that all the samples showed a uniform cellular structure along the thickness, once the solid skin was removed (see Figure S3 in Supplementary Information).

Table 3. Measured cellular structure parameters and open cell content of the cellular samples produced in this work.

\begin{tabular}{ccccccccccc}
\hline$\#$ & Material & $\begin{array}{c}\text { Relative } \\
\text { Density }\end{array}$ & $\begin{array}{c}\text { Cell Nucleation } \\
\text { Density } \\
(\text { nuclei/cm })\end{array}$ & $\boldsymbol{V}_{\text {nano }}$ & $\begin{array}{c}\boldsymbol{\phi}_{1} \\
(\mathrm{~nm})\end{array}$ & $\begin{array}{c}\mathrm{SD}_{1} / \\
\boldsymbol{\phi}_{1}\end{array}$ & $\begin{array}{c}\boldsymbol{\phi}_{2} \\
(\mu \mathrm{m})\end{array}$ & $\begin{array}{c}\mathrm{SD}_{2} / \\
\boldsymbol{\phi}_{2}\end{array}$ & $\boldsymbol{A R}$ & $\boldsymbol{O C}$ \\
\hline 1 & PMMA & $0.52 \pm 0.04$ & $2.1 \cdot 10^{10}$ & 0.00 & 4300 & 0.77 & - & - & $1.1 \pm 0.4$ & 0.077 \\
\hline 2 & $1 \%-\mathrm{S}$ & $0.50 \pm 0.02$ & $1.2 \cdot 10^{13}$ & 0.75 & 460 & 0.51 & 3.4 & 0.92 & $1.3 \pm 0.5$ & 0.097 \\
\hline 3 & $2 \%-\mathrm{S}$ & $0.51 \pm 0.02$ & $2.9 \cdot 10^{13}$ & 0.79 & 350 & 0.52 & 3.7 & 1.08 & $1.0 \pm 0.5$ & 0.057 \\
\hline 4 & $3 \%-\mathrm{S}$ & $0.53 \pm 0.01$ & $2.0 \cdot 10^{13}$ & 0.61 & 330 & 0.72 & 3.1 & 1.07 & $1.1 \pm 0.5$ & 0.086 \\
\hline 5 & $5 \%-\mathrm{S}$ & $0.47 \pm 0.02$ & $3.1 \cdot 10^{13}$ & 0.66 & 310 & 0.66 & 3.6 & 1.02 & $1.1 \pm 0.4$ & 0.059 \\
\hline 6 & PMMA & $0.35 \pm 0.01$ & $7.0 \cdot 10^{10}$ & 0.0 & 3200 & 0.92 & - & - & $1.2 \pm 0.5$ & 0.065 \\
\hline 7 & $1 \%-\mathrm{S}$ & $0.38 \pm 0.04$ & $1.6 \cdot 10^{13}$ & 0.71 & 440 & 0.56 & 4.0 & 0.74 & $1.1 \pm 0.4$ & 0.041 \\
\hline 8 & $2 \%-\mathrm{S}$ & $0.35 \pm 0.01$ & $1.2 \cdot 10^{13}$ & 0.55 & 420 & 0.69 & 5.0 & 1.00 & $1.2 \pm 0.5$ & 0.049 \\
\hline 9 & $3 \%-\mathrm{S}$ & $0.35 \pm 0.01$ & $1.3 \cdot 10^{13}$ & 0.61 & 420 & 0.72 & 7.2 & 0.80 & $1.4 \pm 0.7$ & 0.070 \\
\hline 10 & PMMA & $0.29 \pm 0.04$ & $4.5 \cdot 10^{10}$ & 0.00 & 3900 & 0.92 & - & - & $1.1 \pm 0.5$ & 0.020 \\
\hline 11 & $1 \%-S$ & $0.33 \pm 0.03$ & $1.0 \cdot 10^{13}$ & 0.60 & 500 & 0.66 & 4.9 & 0.65 & $1.1 \pm 0.5$ & 0.029 \\
\hline 12 & $2 \%-S$ & $0.32 \pm 0.03$ & $4.4 \cdot 10^{13}$ & 0.82 & 390 & 0.51 & 5.7 & 1.06 & $1.2 \pm 0.4$ & 0.049 \\
\hline 13 & $3 \%-S$ & $0.27 \pm 0.02$ & $1.7 \cdot 10^{13}$ & 0.66 & 480 & 0.60 & 4.7 & 0.76 & $1.2 \pm 0.4$ & 0.079 \\
\hline
\end{tabular}

\subsection{Uniaxial Compression Tests}

\subsubsection{Effect of Relative Density}

Figure 2 shows an example of the nominal stress versus nominal strain curves obtained for the uniaxial compression tests of the solid and cellular nanocomposites. The solid PMMA is compared with the nanocomposite $2 \%$-S, together with their corresponding cellular materials at high relative density (close to 0.5 ). The solid and cellular materials initially deform in a linear, elastic manner up until the yield point after which softening and subsequent hardening is observed [46]. The elastic (secant) modulus $E$ is measured from the slope of the initial linear region. The compressive yield strength $\sigma_{y}$ corresponds to the peak load before softening.

Figure 3 shows the elastic modulus and the compressive yield strength of the solid nanocomposites as a function of sepiolite content. It is observed that both properties increase as the sepiolite content increases up to a content in the range of $2 \mathrm{wt} \%$ to $3 \mathrm{wt} \%$. Increasing the sepiolite content to $5 \mathrm{wt} \%$ does not result in a further increase of the modulus and strength. These trends represent the typical behaviour of polymer nanocomposites: the mechanical properties are enhanced when the filler concentration increases, but there is a critical filler concentration at which there is no further enhancement of the mechanical properties [47]. We observe that the addition of sepiolites induces enhancement of the mechanical properties of the PMMA in uniaxial compression. In 
particular, for the composite $2 \%-\mathrm{S}$, an increase of $15 \%$ in the elastic modulus and a $5 \%$ in the compressive strength are observed compared to the PMMA without sepiolites. These observations are in agreement with previous reports of an increased strength and modulus when sepiolite particles are added to a polymer matrix [48-50]. In the Supplementary Information, several analytical models are used to capture the measured elastic modulus versus relative density trends.

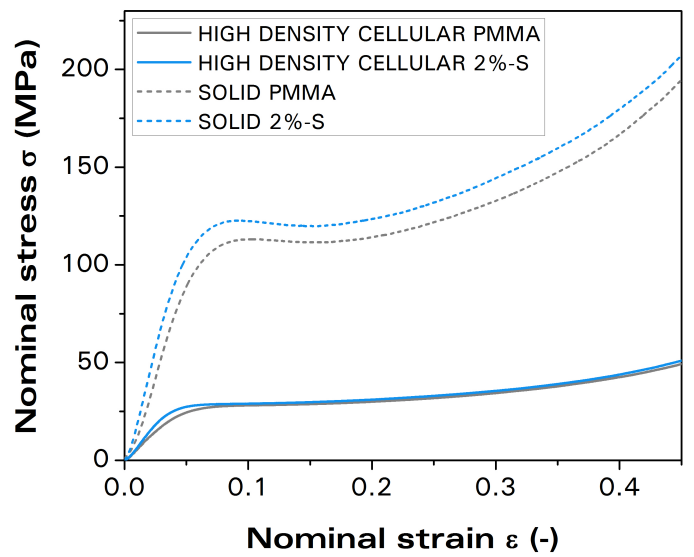

Figure 2. Example of stress-strain curves obtained during uniaxial compression of the solid materials and cellular samples with high relative density (around 0.5) based on the PMMA and 2\%-S material systems.
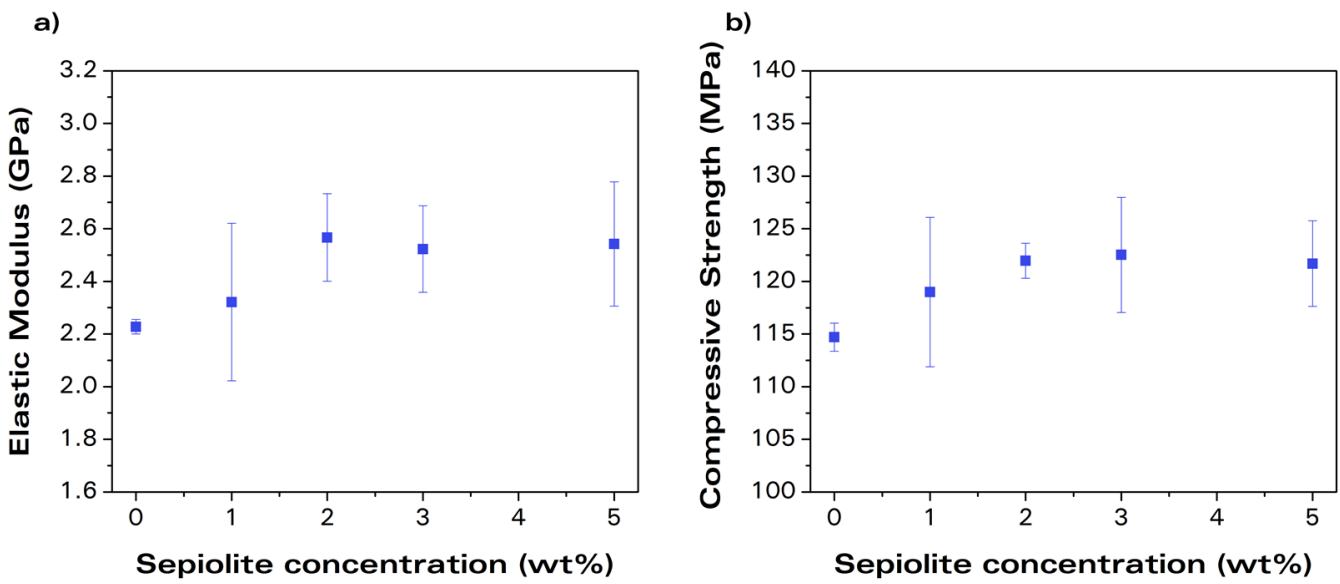

Figure 3. a) Elastic modulus and b) compressive yield strength of the solid nanocomposites as a function of sepiolite concentration.

To evaluate the mechanical properties of the cellular materials, the relative elastic modulus $\left(E_{r}\right)$ and compressive strength $\left(\sigma_{y, r}\right)$ are calculated according to equations (5) and (6), respectively, where $E$ and $\sigma_{y}$ are the properties of the cellular materials and $E_{s}$ and $\sigma_{y, s}$ are the properties of the solid material with the same sepiolite concentration.

$$
\begin{gathered}
E_{r}=\frac{E}{E_{s}} \\
\sigma_{y, r}=\frac{\sigma_{y}}{\sigma_{y, s}}
\end{gathered}
$$


The measured trends for the relative modulus versus relative density and the compressive strength versus relative density for the cellular nanocomposites and the cellular PMMA are plotted in Figure 4.a and Figure 4.c, respectively. Slightly higher values of the relative modulus for the $1 \%-\mathrm{S}, 2 \%-\mathrm{S}$, and 3\%-S composites at a relative density close to 0.5 are observed. In particular, the relative modulus for the composites $1 \%-\mathrm{S}, 2 \%-\mathrm{S}$ and $3 \%-\mathrm{S}$ are $11 \%, 23 \%$ and $20 \%$ higher than that of the pure PMMA at the same density, respectively. However, the relative modulus at lower densities is observed to be independent of sepiolite concentration. It was found that the relative yield strength mildly decreases as a function of sepiolite concentration for all investigated relative densities.

It has been reported by several authors [51-54] that a given material property of a cellular polymer $\left(P_{c}\right)$ is related to the material property of the solid polymer $\left(P_{s}\right)$ by:

$$
\frac{P_{c}}{P_{s}}=K \rho_{r}^{n}
$$

Where $K$ and $n$ are constants to be experimentally determined. For most cellular polymers $K$ is close to 1 , while $n$ is related to the cellular morphology of the cellular material, being close to 1 for closed cell structures and in the range of 1.5 to 2 for open cell and high density materials [51]. The trends predicted by equation (7) for $K=1$ are shown in Figure 4.a (relative modulus) and in Figure 4.c (relative strength) for different values of $n$. One can observe that the relative modulus versus relative density trend of the cellular materials with a high density is captured by equation (7) for $n$ close to 2 . In contrast, for the cellular materials with lower relative densities, a $n$ value of 1.5 gives a more accurate fit. The relative compressive strength versus relative density trends (see Figure 4.c) are captured by $n$ between 1.5 and 2 for all material systems.

The effect of the relative density is evaluated by fitting equation (7) to the measured relative modulus and relative strength data, giving a fitted $n$ value for each material system with a given sepiolite content (see Figure 4.b and Figure 4.d). Note that, for this analysis, the system 5\%-S was excluded as there were no data points at low densities.

An average $n$ value is calculated from the fitted $n$ values for each material system: $n=1.42$ for the modulus and $n=1.61$ for the strength. Equation (7) is then fitted to the measured relative modulus of each material system and the measured relative strength of each material system with the average $n$ by varying $K$. We will use $A$ to denote the $K$ constant for the modulus and $B$ for the $K$ constant for the compressive strength. The obtained values for $A$ and $B$ for each sepiolite concentration are divided by $A_{0}$ and $B_{0}$, the value of $A$ and $B$ for the cellular PMMA without sepiolite particles, respectively, as shown in Figure 5a (modulus) and Figure 5b (strength). The measured modulus of the solid nanocomposite divided by the modulus of the solid PMMA is plotted as a function of the sepiolite concentration in Figure $5 \mathrm{a}$. The strength of the solid nanocomposite divided by the strength of the solid PMMA is plotted as a function of the sepiolite concentration in Figure 5.b. From Figure 5.a and Figure 5.b we conclude that, although there is an enhancement of the relative modulus and the relative strength for the solids due to the addition of the sepiolite particles, there is no reinforcement found for the cellular nanocomposites. The trends shown in Figure 5.a and Figure 5.b are replotted with error bars in the Supplementary Information. 
a)

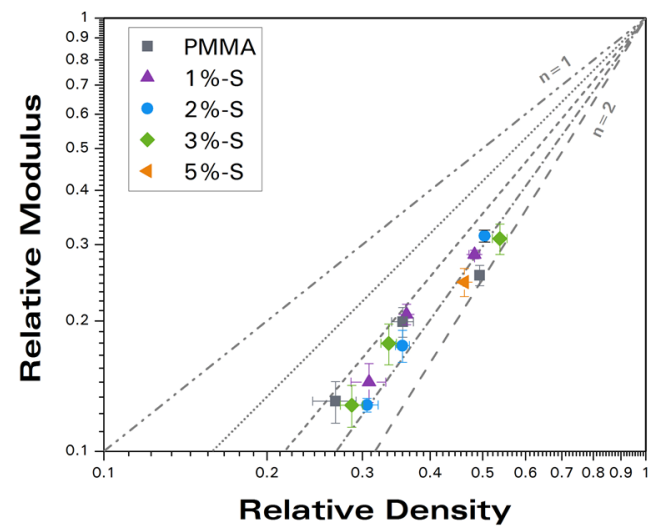

c)

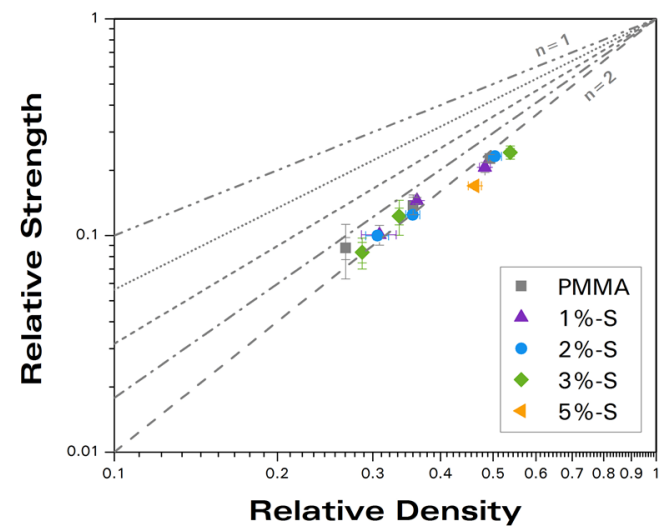

b)

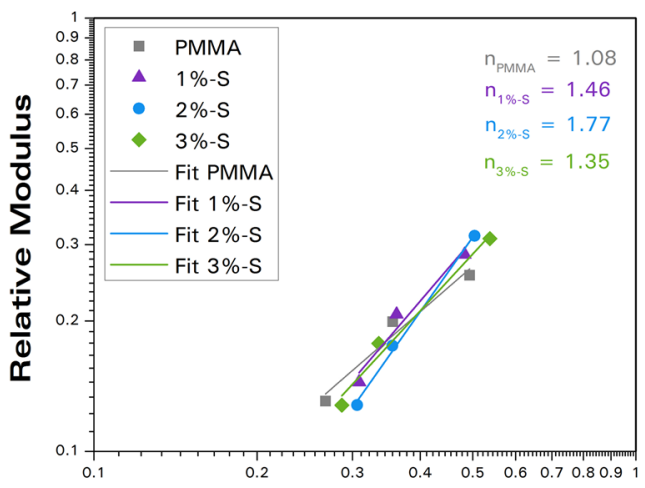

Relative Density

d)

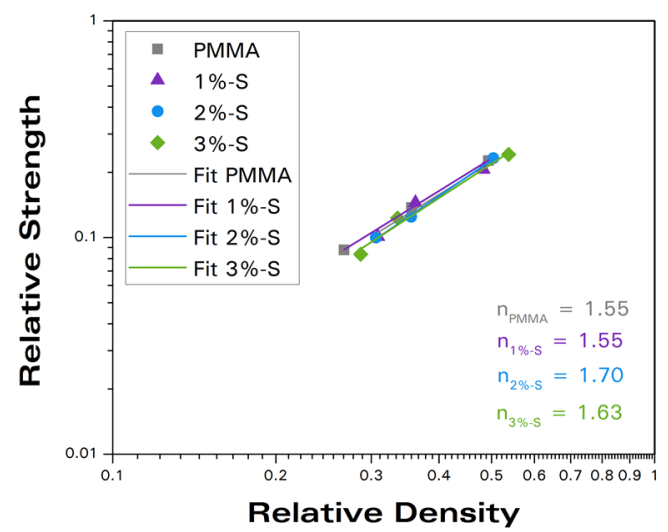

Figure 4. a) Relative modulus of the cellular PMMA and the nanocomposites as a function of the relative density with contours predicted by equation (7) for $K=1$ and $n$ values ranging from 1 to 2 ; b) Predicted trends by fitting equation (7) to the relative modulus data with corresponding $n$ values; c) Relative compressive strength of the cellular PMMA and the nanocomposites as a function of the relative density with contours predicted by equation (7) for $K=1$ and $n$ values ranging from 1 to 2 ; b) Predicted trends by fitting equation (7) to the relative strength data with resulting fitted $n$ values.

a)

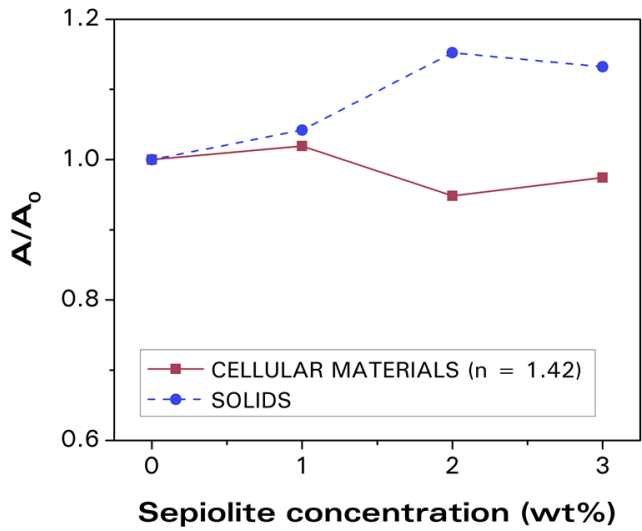

b)

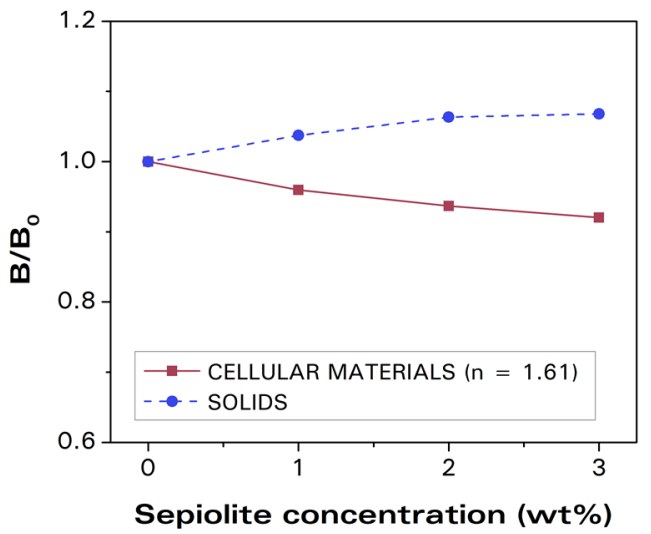

Figure 5. a) $A / A_{0}$ (elastic modulus) and b) $B / B_{0}$ (compressive strength) as a function of the sepiolite concentration for the cellular materials and the solids. 


\subsubsection{Reinforcement at High Relative Density}

In Figure 4.a one can observe that, at high relative densities, the modulus values of the nanocomposites are higher than those of the cellular PMMA. We now perform the same analysis as in Section 3.2.1, but assume $n=2$. The $n=2$ assumption for high relative densities ( $>0.5$ ) is in agreement with several previous works [53,55-57]. For this analysis, as only the high density materials are considered, the samples with 5\%-S are also included. Figure 6 shows the results of this analysis for the high density materials. One can observe that $A / A_{0}$ for the cellular nanocomposites with a high density is above unity for all sepiolite concentrations. A clear reinforcement effect is observed for the elastic modulus for the nanocomposites $1 \%-\mathrm{S}$ and $2 \%-\mathrm{S}$, for which the parameter $A / A_{0}$ takes values as high as 1.18 , that is, an $18 \%$ enhancement of the modulus by the addition of $2 \mathrm{wt} \%$ sepiolites. No reinforcement is detected for the compressive strength by assuming $n=2$ for the high density materials.

a)

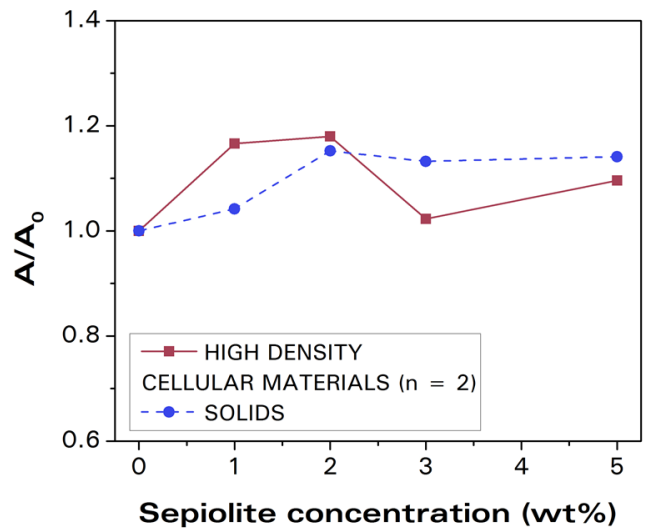

b)

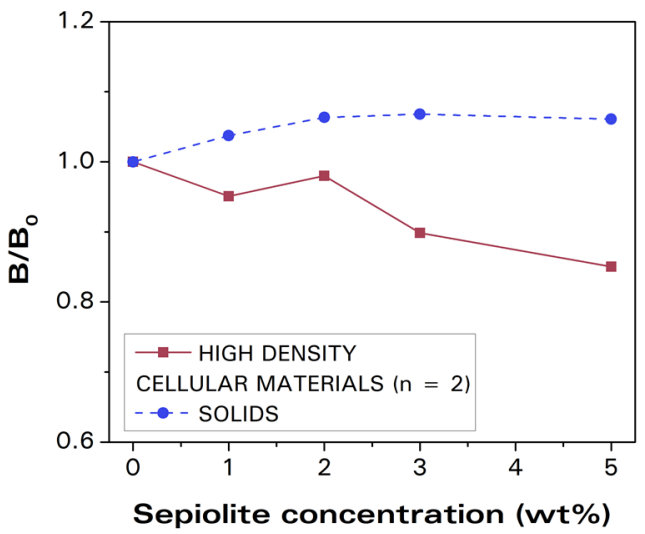

Figure 6. a) $A / A_{0}$ (elastic modulus) and b) $B / B_{0}$ (compressive strength) as a function of the sepiolite concentration for the cellular materials with high relative density and the solids.

The observed enhancement of the elastic modulus values of the high density materials can be attributed to the presence of the sepiolite particles. Yet, the bimodal cell size distribution and the nano-sized cells could also lead to a potential enhancement of the mechanical properties, see for instance, Notario and colleagues [9] and Miller and coworkers [11]. To verify whether cell size and cell size distribution play a role, additional microcellular materials with $3 w t \%$ of sepiolites were produced and tested in uniaxial compression (see Supplementary Information). It was observed that the measured values for the elastic modulus of the bimodal and the microcellular samples were close to each other. These outcomes suggest that the observed enhancement is not caused by the nano-sized cell size and/or the bimodal cell size distribution. Instead, we concluded that the observed reinforcement is due to the addition of sepiolite particles in presence of a cellular structure. This effect was also observed by Laguna-Gutierrez and co-workers who measured the elastic modulus of low density foamed polyethylene reinforced with silica nanoparticles [58].

Another possible rationale behind the reinforcement detected in the cellular nanocomposites compared to the solid nanocomposites with the same sepiolite content is the improved dispersion of the particles in the cellular materials due to the foaming process. Multiple studies have demonstrated that foaming can lead to better dispersion of particles [59-62]. To validate this 
hypothesis, the number of particle aggregates was determined before and after the foaming process for the material with $2 \mathrm{wt} \%$ of sepiolites (for which the highest enhancement of the modulus was observed at a relative density close to 0.5 ) using tomography and image analysis. Figure 7 shows an example of the reconstructed images for the solid and a cellular material with a relative density close to 0.5 . The bright dots represent areas of higher density (note that the pores, filled with air, are black). So the bright dots are the sepiolites aggregates, with dimensions larger than $2.5 \mu \mathrm{m}$ (corresponding to the spatial resolution of the computed tomography instrument). These aggregates represent $0.57 \mathrm{wt} \%$ in the solid material, whereas they only account for $0.15 \mathrm{wt} \%$ in the cellular material. Moreover, the number of large aggregates decreases by foaming. These outcomes indicate that the particles are less aggregated in the cellular samples than in the solids. This effect is related to the stretching suffered by the polymer chains during the cell growth [6164]. The enhanced dispersion is expected to enhance the mechanical properties of the solid phase. As a result, the reinforcement found for the modulus of the cellular nanocomposites is stronger than in the solid nanocomposites, especially for the systems with $1 \mathrm{wt} \%$ and $2 \mathrm{wt} \%$ of sepiolites.
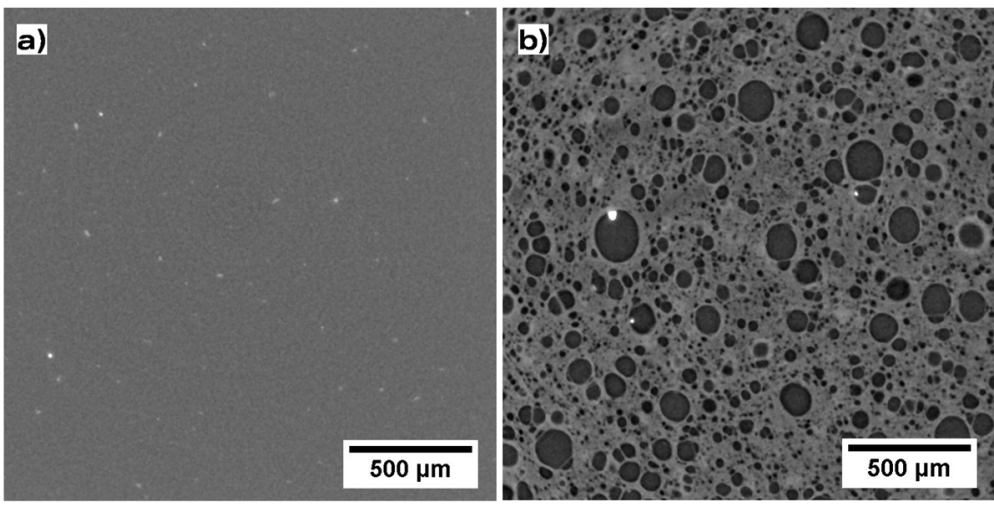

Figure 7. Reconstructed tomography images of 2\%-S: a) solid nanocomposite and b) cellular nanocomposite with a relative density close to 0.5 .
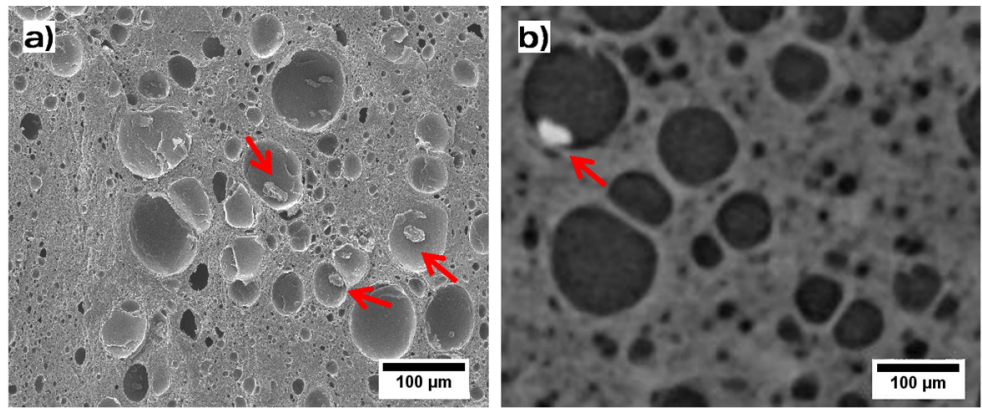

Figure 8. Example of aggregates inside the microcellular pores (red arrows): a) SEM micrograph of the cellular material 5\%-S with relative density close to 0.5 and b) reconstructed tomography of the cellular material 2\%-S with relative density around 0.5 .

Another potential rationale behind the observed enhancement of the elastic modulus values of the high density materials is related to the position of the aggregates in the cellular materials. Based on SEM micrographs and tomography images, we observe that most of the micro-sized aggregates are isolated from the the solid phase and located within the microcellular pores as a result of the foaming process (see Figure 8). The solid phase in the cellular material is therefore reinforced by the small well-dispersed sepiolites, whereas the big aggregates (potentially reducing the 
mechanical properties of the solid) are not affecting the mechanical performance, as they are located in the microcellular pores. This observation suggests that the presence of a cellular structure in a nanocomposite can balance out, up to some extent, the negative influence of the particle aggregates on the mechanical properties.

\subsection{Fracture Toughness}

\subsection{Effect of Relative Density}

Figure 9 shows the measured ${ }^{1} K_{I C}$ of the solid nanocomposites and the pure PMMA as a function of sepiolite concentration. The measured fracture toughness of the unfilled PMMA is close to 1.7 MPa $\mathrm{m}^{1 / 2}$, in agreement with reported values for $K_{I C}$ of PMMA in the literature [65]. It is observed that the fracture toughness decreases as the sepiolite content increases. This result is in agreement with earlier works reporting that high aspect ratio fillers such as sepiolites cause embrittlement of the nanocomposite $[65,66]$.

The fracture toughness of the cellular materials is evaluated by calculating the relative fracture toughness $\left(K_{I C, r}\right)$ according to equation (8), where $K_{I C}$ is the toughness of the cellular materials and $K_{I C, S}$ is the property of the solid material with the same sepiolite concentration.

$$
K_{I C, r}=\frac{K_{I C}}{K_{I C, S}}
$$

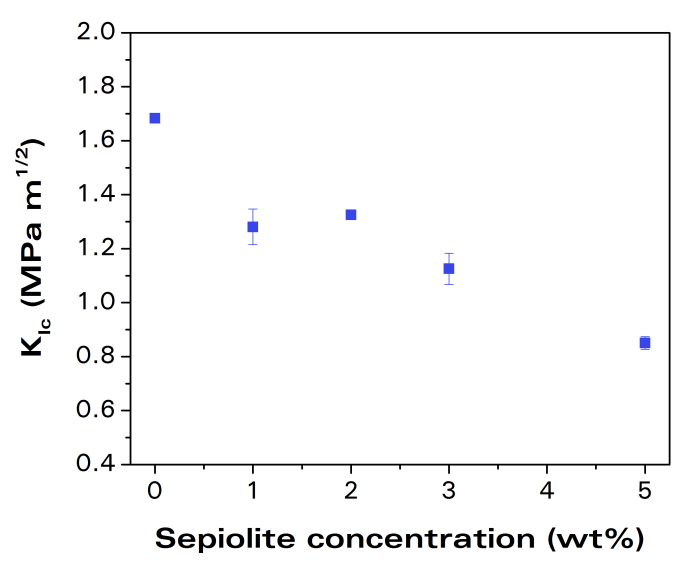

Figure 9. Fracture toughness $\left(K_{I C}\right)$ of the unfilled PMMA and of the solid nanocomposites as a function of sepiolite content.

The trends for the relative fracture toughness versus relative density of the cellular nanocomposites and the cellular PMMA are plotted in Figure 10.a. All the samples present a brittle fracture behaviour (see Supplementary Information for SEM images of the fracture surface). Over the complete density range, the measured relative toughness of the cellular materials with sepiolite particles is higher than the measured relative fracture toughness of the cellular materials without sepiolites. At high relative density, the relative fracture toughness of the composites $1 \%-\mathrm{S}, 2 \%-\mathrm{S}$, $3 \%-\mathrm{S}$ and $5 \%-\mathrm{S}$ are higher than that of the PMMA in $14 \%, 31 \%, 58 \%$ and $19 \%$, respectively. At lower

\footnotetext{
${ }^{1}$ The load versus indenter displacement trend for all $K_{I C}$ measurements of the solid and cellular material systems was linear up until fracture of the SENB specimens.
} 
density (0.34), the differences can be as high as $79 \%$ for the sample 3\%-S. The trends predicted by equation (7) for $K=1$ are also shown in Figure 10.a for different $n$ values.

Equation (7) is fitted to every material system, see Figure 10.b. An average $n$ value is calculated from the fitted $n$ values: $n=1.43$. Equation (8) is subsequently fitted to the measured fracture toughness values for each material system for $n=1.43$ by varying $K$. We will use $C$ to denote the $K$ constant for the fracture toughness. The obtained $C$ values for each sepiolite concentration are divided by $C_{0}$, the value for $C$ for the cellular PMMA without sepiolite particles, as shown in Figure 11. The fracture toughness of the solid nanocomposites divided by the fracture toughness of the solid PMMA as a function of the sepiolite content is shown in Figure 11 too. From Figure 11 we conclude that, although there is a significant decrease of the fracture toughness of the solids as the sepiolite concentration increases, addition of sepiolite particles to the cellular materials leads to an enhanced fracture toughness. This enhancement found in the cellular materials could be a consequence of the presence of a bimodal cell size distribution in combination with nano-sized cell sizes. To evaluate this effect, the fracture toughness of an additional set of microcellular materials with a $3 \mathrm{wt} \%$ sepiolite concentration was measured (Supplementary Information). It was found that the cell size distribution had no effect on the toughness of the samples. These outcomes therefore suggest that a better dispersion of the sepiolites in the cellular nanocomposites and the presence of the aggregates inside the microcellular pores lead to an improved relative fracture toughness, or in other words, the negative effects of the particle aggregates in the fracture toughness of the solids are hidden in the cellular materials.

a)

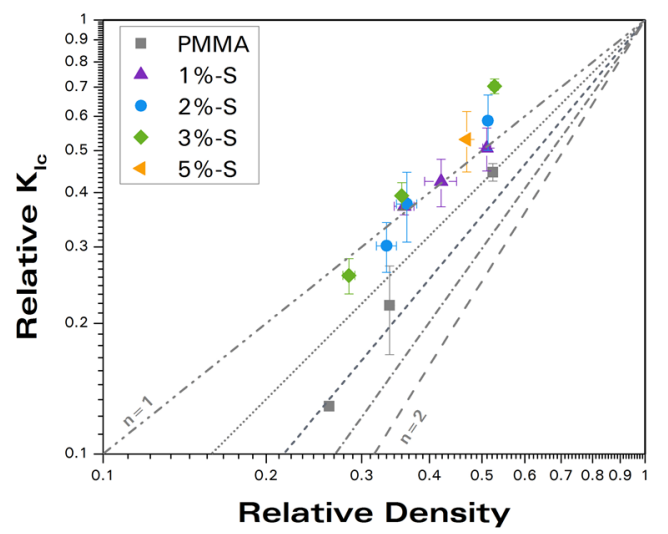

b)

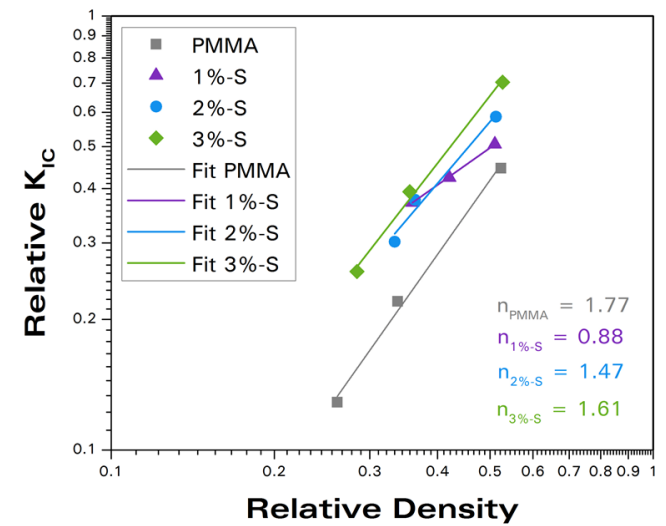

Figure 10. a) Relative fracture toughness $\left(K_{I C}\right)$ of the cellular PMMA and the nanocomposites as a function of the relative density with contours predicted by equation (7) for $K=1$ and varying $n$ values ranging from 1 to 2 ; b) Fits of the relative modulus according to equation (7) and resulting fitted $n$ values. 


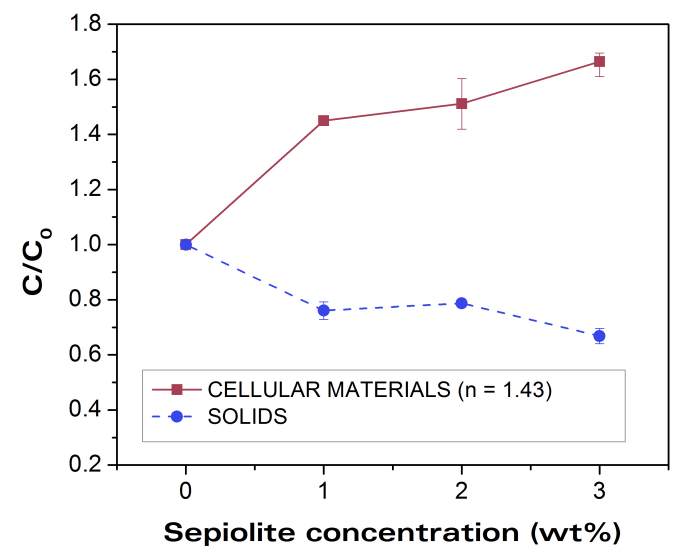

Figure 11. $C / C_{0}$ (fracture toughness constants) as a function of the sepiolite concentration for the cellular materials and the solids.

\section{CONCLUSIONS}

The present study reveals that the addition of up to $3 \mathrm{wt} \%$ of nanoparticles made from hydrated magnesium silicates (so-called sepiolites) to solid PMMA leads to a mild increase in modulus (by $15 \%$ ) and in yield strength (by 5\%) but to a decrease in bulk fracture toughness (by $40 \%$ ). The effect of sepiolite content upon the mechanical properties of PMMA cellular materials with a bimodal cellular structure with nanometric cells ( 300 to $500 \mathrm{~nm}$ ) is more complex. First, the porosity of $50 \%$ to $75 \%$ exists in a bimodal cell size distribution with one population of cells on the nanoscale (cell sizes below $500 \mathrm{~nm}$ ) and the other on the microscale. The presence of porosity degrades the modulus, strength and toughness for both pure PMMA and for the PMMA-sepiolite composites. In order to isolate the effect of sepiolite content on the relative properties of the foamed PMMA, it is necessary to factor-out the effect of porosity. When this is done, it was found that the relative modulus is independent of sepiolite concentration, whereas the addition of sepiolites results in a mild decrease in relative strength. The relative fracture toughness strongly increases as a function of sepiolite content. Moreover, for the cellular nanocomposites with a relatively low porosity (close to $50 \%$ ), the addition of sepiolite particles leads to an increase in the relative modulus. Our observations suggest that the enhancement of the relative fracture toughness and the relative modulus (for the porosity of 50\%) of the nanocellular PMMA by the addition of sepiolites is caused by the improved dispersion of the sepiolites due to the foaming process and by the migration of the micro-sized sepiolite aggregates to the micro-sized pores during foaming.

\section{Acknowledgements:}

Financial support from the FPU grant FPU14/02050 (V. Bernardo) from the Spanish Ministry of Education, the Junta of Castile and Leon grant (J. Martín-de León) and the Engineering and Physical Sciences Research Council (UK) award 1611305 (F. Van Loock) is gratefully acknowledged. Financial assistance from MINECO, FEDER, UE (MAT2015-69234-R), the Junta de Castile and Leon (VA275P18), the ERC MULTILAT grant 669764 and SABIC are gratefully acknowledged too. We would also like to 
thank Dr. Martin van Es from SABIC for the technical assistance and fruitful discussions and Tolsa (Madrid, Spain) for supplying the sepiolites for this study.

\section{REFERENCES}

[1] B. Notario, J. Pinto, M.A. Rodriguez-Perez, Nanoporous polymeric materials: A new class of materials with enhanced properties, Prog. Polym. Sci. 78-79 (2016) 93-139. doi:10.1016/j.pmatsci.2016.02.002.

[2] B. Notario, J. Pinto, E. Solorzano, J.A. de Saja, M. Dumon, M.A. Rodriguez-Perez, Experimental validation of the Knudsen effect in nanocellular polymeric foams, Polymer (Guildf). 56 (2015) 57-67. doi:10.1016/j.polymer.2014.10.006.

[3] G. Wang, C. Wang, J. Zhao, G. Wang, C.B. Park, G. Zhao, Modelling of thermal transport through a nanocellular polymer foam: Toward the generation of a new superinsulating material, Nanoscale. 9 (2017) 5996-6009. doi:10.1039/c7nr00327g.

[4] J. Martin de-Leon, V. Bernardo, M.A. Rodriguez-Perez, Low Density Nanocellular Polymers Based on PMMA Produced by Gas Dissolution Foaming: Fabrication and Cellular Structure Characterization, Polymers (Basel). 8 (2016) 1-16. doi:10.3390/polym8070265.

[5] S. Perez-Tamarit, B. Notario, E. Solorzano, M.A. Rodriguez-Perez, Light transmission in nanocellular polymers: are semi-transparent cellular polymers possible?, Mater. Lett. 210 (2017) 39-41. doi:10.1016/j.matlet.2017.08.109.

[6] L. Li, L. Schulte, L.D. Clausen, K.M. Hansen, G.E. Jonsson, S. Ndoni, Gyroid nanoporous membranes with tunable permeability, ACS Nano. 5 (2011) 7754-7766. doi:10.1021/nn200610r.

[7] J. Pinto, M. Dumon, M.A. Rodriguez-Perez, R. Garcia, C. Dietz, Block Copolymers Self-Assembly Allows Obtaining Tunable Micro or Nanoporous Membranes or Depth Filters Based on PMMA; Fabrication Method and Nanostructures, J. Phys. Chem. C. 118 (2014) 4656-4663. doi:10.1021/jp409803u.

[8] G.Q. Lu, X.S. Zhao, Nanoporous Materials - An Overview, in: Nanoporous Mater. Sci. Eng., Imperial Collegue Press, London, 2004. doi:10.1142/9781860946561_0001.

[9] B. Notario, J. Pinto, M.A. Rodríguez-Perez, Towards a new generation of polymeric foams: PMMA nanocellular foams with enhanced physical properties, Polymer (Guildf). 63 (2015) 116-126. doi:10.1016/j.polymer.2015.03.003.

[10] M.F. Ashby, Materials Selection in Mechanical Design, Third edit, Elsevier, 1992. doi:10.1016/B978-1-85617663-7.00011-4.

[11] D. Miller, V. Kumar, Microcellular and nanocellular solid-state polyetherimide (PEI) foams using sub-critical carbon dioxide II. Tensile and impact properties, Polymer (Guildf). 52 (2011) 2910-2919. doi:10.1016/j.polymer.2011.04.049.

[12] H. Guo, Solid-state Polymer Nanofoams, University of Washington, 2015.

[13] G. Wang, J. Zhao, L.H. Mark, G. Wang, K. Yu, C. Wang, C.B. Park, G. Zhao, Ultra-tough and super thermalinsulation nanocellular PMMA/TPU, Chem. Eng. J. 325 (2017) 632-646. doi:10.1016/j.cej.2017.05.116.

[14] G. Wang, G. Zhao, L. Zhang, Y. Mu, C.B. Park, Lightweight and tough nanocellular PP/PTFE nanocomposite foams with defect-free surfaces obtained using in situ nanofibrillation and nanocellular injection molding, Chem. Eng. J. 350 (2018) 1-11. doi:10.1016/j.cej.2018.05.161.

[15] J.A. Reglero Ruiz, M. Dumon, J. Pinto, M.A. Rodriguez-Perez, Low-density nanocellular foams produced by high-pressure carbon dioxide, Macromol. Mater. Eng. 296 (2011) 752-759. doi:10.1002/mame.201000346.

[16] H. Fischer, Polymer nanocomposites : from fundamental research to specific applications, Mater. Sci. Eng. 23 (2003) 763-772. doi:10.1016/j.msec.2003.09.148.

[17] F. Yang, G.L. Nelson, PMMA / Silica Nanocomposite Studies : Synthesis and Properties, J. Appl. Polym. Sci. 91 (2004) 844-3850.

[18] A.S. Blivi, F. Benhui, J. Bai, D. Kondo, Experimental evidence of size effect in nano-reinforced polymers : Case of silica reinforced PMMA, Polym. Test. 56 (2016) 337-343. doi:10.1016/j.polymertesting.2016.10.025.

[19] S. Pavlidou, C.D. Papaspyrides, A review on polymer - layered silicate nanocomposites, Prog. Polym. Sci. 33 (2008) 1119-1198. doi:10.1016/j.progpolymsci.2008.07.008.

[20] M. Vahidi, H. Azizi, Preparation and properties of styrene butadiene styrene/nano calcium carbonate 
thermoplastics elastomer composite foams: Morphology and mechanical properties, Cell. Polym. 36 (2017) 251-268. doi:10.1177/026248931703600502.

[21] V. Mittal, Polymer Nanocomposite Foams, CRC Press, 2014.

[22] C.C. Ibeh, M. Bubacz, Current Trends in Nanocomposite Foams, J. Cell. Plast. 44 (2008) 493-515. doi:10.1177/0021955X08097707.

[23] H. Janani, M.H.N. Famili, Investigation of a Strategy for Well Controlled Inducement of Microcellular and Nanocellular Morphologies in Polymers, Polym. Eng. Sci. 50 (2010) 1558-1570. doi:10.1002/pen.

[24] W. Zhai, J. Yu, L. Wu, W. Ma, J. He, Heterogeneous nucleation uniformizing cell size distribution in microcellular nanocomposites foams, Polymer (Guildf). 47 (2006) 7580-7589. doi:10.1016/j.polymer.2006.08.034.

[25] J. Yang, L. Huang, Y. Zhang, F. Chen, P. Fan, M. Zhong, S. Yeh, A new promising nucleating agent for polymer foaming: Applications of ordered mesoporous silica particles in polymethyl methacrylate supercritical carbon dioxide microcellular foaming, Ind. Eng. Chem. Res. 52 (2013) 14169-14178. doi:10.1021/ie4018447.

[26] S. Siripurapu, J.M. Desimone, S.A. Khan, R.J. Spontak, N. Carolina, N. Carolina, Controlled Foaming of Polymer Films through Restricted Surface Diffusion and the Addition of Nanosilica Particles or CO2-philic Surfactants, Macromolecules. 38 (2005) 2271-2280. doi:10.1021/ma047991b.

[27] Y. Fujimoto, S.S. Ray, M. Okamoto, A. Ogami, K. Yamada, K. Ueda, Well-Controlled Biodegradable Nanocomposite Foams : From Microcellular to Nanocellular, Macromol. Rapid Commun. 24 (2003) 457-461.

[28] Y.H. Lee, C.B. Park, K.H. Wang, HDPE-Clay Nanocomposite Foams Blown with Supercritical CO2, J. Cell. Plast. 41 (2005) 487-502. doi:10.1177/0021955X05056964.

[29] L. Urbanczyk, C. Calberg, C. Detrembleur, C. Jérôme, M. Alexandre, Batch foaming of SAN / clay nanocomposites with scCO 2 : A very tunable way of controlling the cellular morphology, Polymer (Guildf). 51 (2010) 3520-3531. doi:10.1016/j.polymer.2010.05.037.

[30] S. Costeux, L. Zhu, Low density thermoplastic nanofoams nucleated by nanoparticles, Polymer (Guildf). 54 (2013) 2785-2795. doi:10.1016/j.polymer.2013.03.052.

[31] V. Bernardo, J. Martin-de León, E. Laguna-Gutiérrez, M.Á. Rodríguez-Pérez, PMMA-sepiolite nanocomposites as new promising materials for the production of nanocellular polymers, Eur. Polym. J. 96 (2017) 10-26. doi:10.1016/j.eurpolymj.2017.09.002.

[32] S.K. Yeh, Y.C. Liu, C.C. Chu, K.C. Chang, S.F. Wang, Mechanical Properties of Microcellular and Nanocellular Thermoplastic Polyurethane Nanocomposite Foams Created Using Supercritical Carbon Dioxide, Ind. Eng. Chem. Res. 56 (2017) 8499-8507. doi:10.1021/acs.iecr.7b00942.

[33] A. Alvarez, J. Santaren, A. Esteban-Cubillo, P. Aparicio, Development in Palygorskite-Sepiolite Research, Elsevier, 2011.

[34] E. Ruiz-Hitzky, Molecular access to intracrystalline tunnels of sepiolite, J. Mater. Chem. 11 (2001) 86-91. doi:10.1039/b003197f.

[35] J. Santaren, A. Alvarez, A. Esteban-Cubillo, B. Notario, D. Velasco, M.A. Rodriguez-Perez, Improving the Cellular Structure and Thermal Conductivity of PS Foams by Using Sepiolites, in: Foams2012, 2012: pp. 1-5.

[36] N. García, J. Guzman, E. Benito, A. Esteban-Cubillo, E. Aguilar, J. Santaren, P. Tiemblo, Surface Modification of Sepiolite in Aqueous Gels by Using Methoxysilanes and Its Impact on the Nanofiber Dispersion Ability, Langmuir. 27 (2011) 3952-3959. doi:10.1021/la104410r.

[37] V. Kumar, N.P. Suh, A process for making microcellular parts, Polym. Eng. Sci. 30 (1990) 1323-1329. doi:https://doi.org/10.1002/pen.760302010.

[38] K. Nadella, V. Kumar, W. Li, Constrained solid-state foaming of microcellular panels, Cell. Polym. 24 (2005) 7190.

[39] J. Pinto, E. Solorzano, M.A. Rodriguez-perez, J.A. De Saja, Characterization of the cellular structure based on user-interactive image analysis procedures, J. Cell. Plast. 49 (2013) 555-575. doi:10.1177/0021955X13503847.

[40] V. Kumar, Process synthesis for manufacturing microcellular thermoplastic parts, Massachusetts Institute of Technology, 1988.

[41] C.A. Mandarim-de-Lacerda, Stereological tools in biomedical research, Ann. Brazilian Acad. Sci. 75 (2003) 469486.

[42] N.C. Hilyard, A. Cunningham, Low density cellular plastics--Physical basis of behaviour, Chapman and Hall, London, 1994. 
[43] E. Solórzano, J. Pinto, S. Pardo, F. Garcia-Moreno, M.A. Rodriguez-Perez, Application of a microfocus X-ray imaging apparatus to the study of cellular polymers, Polym. Test. 32 (2013) 321-329. doi:10.1016/j.polymertesting.2012.11.016.

[44] J. Escudero, E. Solorzano, M.A. Rodriguez-Perez, F. Garcia-Moreno, J.A. de Saja, Structural Characterization and Mechanical Behaviour of LDPE Structural Foams. A Comparison with Conventional Foams, Cell. Polym. 28 (2009) 289-302. doi:10.1177/026248930902800404.

[45] A. International, D5045 - 14. Standard Test Methods for Plane-Strain Fracture Toughness and Strain Energy Release Rate of Plastic Materials, (n.d.). doi:10.1520/D5045-14.priate.

[46] F. Van Loock, N.A. Fleck, Deformation and failure maps for PMMA in uniaxial tension, Polym. (United Kingdom). 148 (2018) 259-268. doi:10.1016/j.polymer.2018.06.027.

[47] L. Chen, D. Rende, L.S. Schadler, R. Ozisik, Polymer nanocomposite foams, J. Mater. Chem. A. 1 (2013) 38373850. doi:10.1039/c2ta00086e.

[48] X. Li, Q. Wang, H. Li, H. Ji, X. Sun, J. He, Effect of sepiolite fiber on the structure and properties of the sepiolite/silica aerogel composite, J. Sol-Gel Sci. Technol. 67 (2013) 646-653. doi:10.1007/s10971-013-3124-4.

[49] D. Garcia-Lopez, J.F. Fernandez, J.C. Merino, J. Santaren, J.M. Pastor, Effect of organic modification of sepiolite for PA 6 polymer/organoclay nanocomposites, Compos. Sci. Technol. 70 (2010) 1429-1436. doi:10.1016/j.compscitech.2010.05.020.

[50] J. Ma, J.A. Darr, Preparation of polypropylene/sepiolite nanocomposites using supercritical CO2 assisted mixing, Eur. Polym. J. 43 (2007) 4931-4939. doi:10.1016/j.eurpolymj.2007.09.010.

[51] L.J. Gibson, M. Ashby, Cellular solids: structure and properties, 2nd Editio, Cambridge University Press, 1997.

[52] N.J. Mills, H.X. Zhu, The high strain compression of closed cell polymer foams, J. Mech. Phys. Solids. 47 (1999) 669-695.

[53] A. Lopez-Gil, C. Saiz-Arroyo, J. Tirado, M.A. Rodriguez-Perez, Production of non-crosslinked thermoplastic foams with a controlled density and a wide range of cellular structures, J. Appl. Polym. Sci. 132 (2015) 1-10. doi:10.1002/app.42324.

[54] M. Frydrych, C. Wan, R. Stengler, U.O. Kelly, B. Chen, Structure and mechanical properties of gelatin/sepiolite nanocomposite foams, J. Mater. Chem. 30 (2011) 9103-9111. doi:10.1039/c1jm10788g.

[55] V. Kumar, M. Vanderwel, J. Weller, K.A. Seeler, Experimental Characterization of the Tensile Behavior of Microcellular Polycarbonate Foams, J. Eng. Mater. Technol. 116 (1994) 439-445.

[56] J. Fu, C. Jo, H.E. Naguib, Effect of Processing Parameters on Cellular Structures and Mechanical Properties of PMMA Microcellular Foams, Cell. Polym. 24 (2005) 177-195.

[57] C. Saiz-Arroyo, M.A. Rodriguez-Perez, J. Tirado, A. López-Gil, J.A. de Saja, Structure-property relationships of medium-density polypropylene foams, Polym. Int. 62 (2013) 1324-1333. doi:10.1002/pi.4424.

[58] E. Laguna-Gutierrez, C. Saiz-Arroyo, J.I. Velasco, M.A. Rodriguez-Perez, Low density polyethylene/silica nanocomposite foams. Relationship between chemical composition, particle dispersion, cellular structure and physical properties, Eur. Polym. J. 81 (2016) 173-185. doi:10.1016/j.eurpolymj.2016.06.001.

[59] J.I. Velasco, M. Antunes, O. Ayyad, C. Saiz-Arroyo, M.A. Rodrıguez-Perez, F. Hidalgo, J.A. de Saja, Foams Based on Low Density Polyethylene / Hectorite Nanocomposites: Thermal Stability and Thermomechanical Properties, J. Appl. Polym. Sci. 105 (2007) 1658-1667. doi:10.1002/app.

[60] J.I. Velasco, M. Antunes, O. Ayyad, J.M. Lopez-Cuesta, P. Gaudon, C. Saiz-Arroyo, M.A. Rodriguez-Perez, J.A. de Saja, Foaming behaviour and cellular structure of LDPE / hectorite nanocomposites, Polymer (Guildf). 48 (2007) 2098-2108. doi:10.1016/j.polymer.2007.02.008.

[61] E. Laguna-Gutierrez, R. Van Hooghten, P. Moldenaers, M.A. Rodriguez-Perez, Effects of extrusion process, type and content of clays, and foaming process on the clay exfoliation in HMS PP composites, J. Appl. Polym. Sci. 132 (2015) 42430(1)-42430(14). doi:10.1002/app.42828.

[62] J. Escudero, B. Notario, C. Jimenez, M.A. Rodriguez-Perez, Characterization of nanoclay intercalation during foaming with in situ energy-dispersive X-ray diffraction, J. Appl. Polym. Sci. (2016) 43432(1)-43432(9). doi:10.1002/app.43432.

[63] W. Zhai, C.B. Park, M. Kontopoulou, Nanosilica addition dramatically improves the cell morphology and expansion ratio of polypropylene heterophasic copolymer foams blown in continuous extrusion, Ind. Eng. Chem. Res. 50 (2011) 7282-7289. doi:10.1021/ie102438p.

[64] A. Ameli, M. Nofar, C.B. Park, Polypropylene / carbon nanotube nano / microcellular structures with high 
dielectric permittivity , low dielectric loss, and low percolation threshold, Carbon N. Y. 71 (2014) 206-207. doi:10.1016/j.carbon.2014.01.031.

[65] H. Varela-Rizo, M. Weisenberger, D.R. Bortz, I. Martin-Gullon, Fracture toughness and creep performance of PMMA composites containing micro and nanosized carbon filaments, Compos. Sci. Technol. 70 (2010) 11891195. doi:10.1016/j.compscitech.2010.03.005.

[66] B. Cotterell, J.Y.H. Chia, K. Hbaieb, Fracture mechanisms and fracture toughness in semicrystalline polymer nanocomposites, Eng. Fract. Mech. 74 (2007) 1054-1078. doi:10.1016/j.engfracmech.2006.12.023. 


\section{Supplementary Information:}

\section{Mechanical properties of PMMA-sepiolite nanocellular materials with a bimodal cellular structure}

Victoria Bernardo1*, Frederik Van Loock², Judith Martín-de León' ${ }^{1}$ Norman A. Fleck², Miguel Ángel Rodríguez-Pérez ${ }^{1}$

1. Cellular Materials Laboratory (CellMat), Condensed Matter Physics Department, University of Valladolid, Campus Miguel Delibes, Paseo de Belén n7, 47011 Valladolid, Spain 2. Engineering Department, University of Cambridge, Trumpington Street, CB2 1PZ Cambridge, United Kingdom

*Corresponding author: Victoria Bernardo (vbernardo@fmc.uva.es) +34983184035

\section{FOAMING IN PRESS: EXPERIMENTAL PROCEDURE.}

The cellular materials of this work were produced via a two-step gas dissolution foaming process using a press for the foaming step [1]. During the saturation step at $10 \mathrm{MPa}$ and $25^{\circ} \mathrm{C}$, the $\mathrm{PMMA} /$ sepiolite samples absorb roughly $24-25 \mathrm{wt} \%$ of $\mathrm{CO}_{2}$ [2]. With this gas concentration, the effective glass transition of PMMA is reduced up to approximately $10{ }^{\circ} \mathrm{C}$ [3]. Then, to prevent foaming during the transfer of the samples to the press, the samples were kept in an insulator container with ice once they were removed from the pressure vessel. The time between the release of the pressure and the beginning of the foaming process was approximately 3.5 minutes.

The set up used for foaming in the hot and cold press is illustrated in Figure S1. The samples were placed between two aluminum foils (at room temperature) and two steel plates, pre-heated at the desired foaming temperature. In addition, a steel frame with a thickness equal to $4 \mathrm{~mm}$ (approximately equal to the sample thickness) was placed around the sample to act as a shim and control the gap between the press plates (Figure S1.a). The configuration of Figure S1.a was placed between the press plates (also pre-heated at the foaming temperature), and the upper plate was lowered until the steel plates and the frame were in contact (Figure S1.b). No pressure was exerted in the samples during the foaming process.

a)

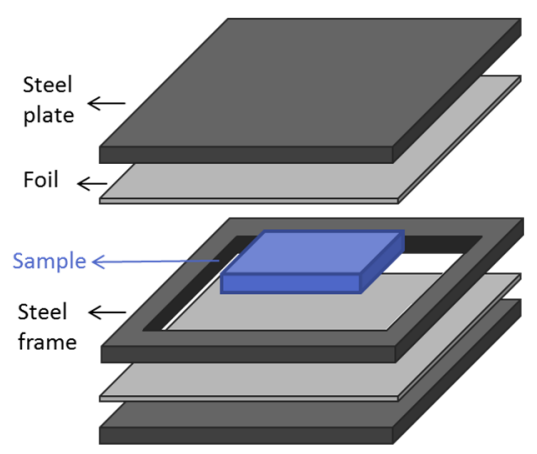

b)

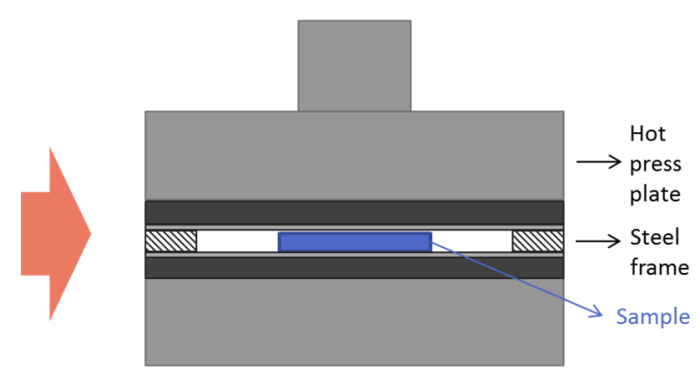

Figure S1. Illustration of a) the configuration of the sample and b) position of the sample in the hot press plates. 
After the desired foaming time, the upper plate was lifted up. The foaming occurs both during the time the plate is down and also when it is released (Figure S2.a). Then, the set plates-frame-sample was moved to the cold plates of the press. The upper cold plate position was fixed to be in touch with the steel plate but without exerting any pressure (Figure S2.b). This step was performed to slowly cool down the samples (and to prevent the growth of any defects during the gas desorption).

a)

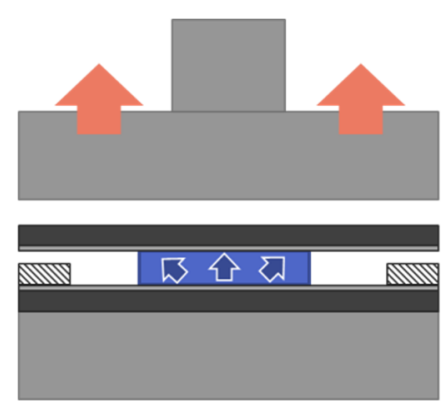

b)

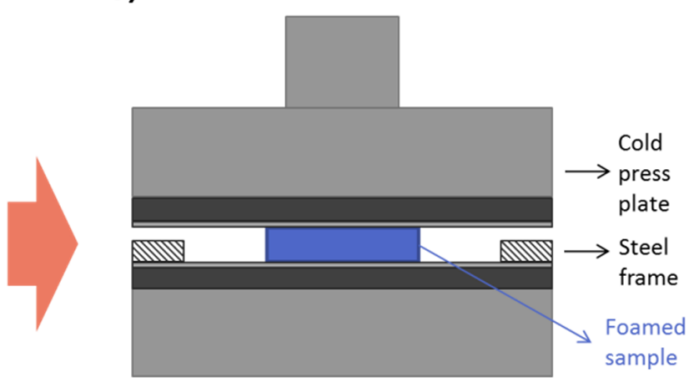

Figure S2. Schematic representation of a) release of the upper hot plate and foaming and b) cooling of the sample in the cold press plates.

This foaming procedure in the press allows producing flat samples without internal defects. Details about the foaming temperatures and times can be found in the main article.

The samples foamed in the press showed a homogeneous cellular structure through the sample thickness, once the solid skin was removed. Figure S3 shows representative micrographs of two samples (PMMA and 2\%-S) at high relative density (0.5) as an example. SEM images near the border (Figure S3.a and Figure S3.b) and in the centre of the sample (Figure S3.c and Figure S3.d) are shown to prove the homogeneity of the structure.

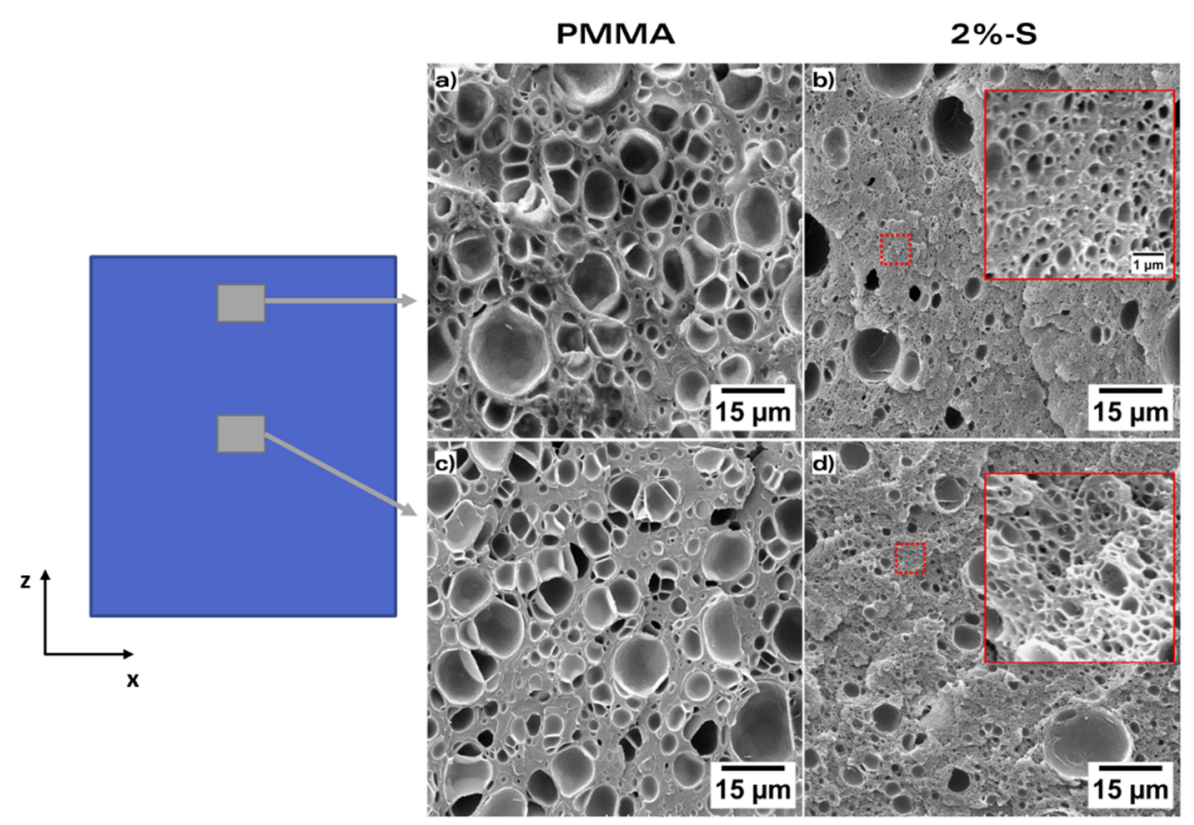

Figure S3. SEM images along sample thickness of representative materials: a) and c) PMMA (relative density around 0.5 ), and b) and d) 2\%-S (relative density around 0.5). Insert in b) and d) are a zoomed image showing the nanocellular structure. 


\section{MODELS TO PREDICT THE ELASTIC MODULUS OF THE SOLID NANOCOMPOSITES}

Several models with varying complexity and accuracy can be used to predict the elastic modulus of a nanocomposite from the properties of the matrix and the filler. The simplest analytical models are the so-called series and parallel models, also known as the Voigt and Reuss models, respectively $[4,5]$. In the Voigt model, the constituents of the composite are assumed to be strained equally:

$$
E_{n c}=V_{f} E_{f}+\left(1-V_{f}\right) E_{m}
$$

Where $E_{n c}$ is the modulus of the nanocomposite, $V_{f}$ the volume fraction of the filler and $E_{f}$ and $E_{m}$ the modulus of the filler and the matrix, respectively. On the other hand, the Reuss model assumes uniform stress in the matrix and the filler, leading to the following prediction of the elastic modulus:

$$
\frac{1}{E_{n c}}=\frac{V_{f}}{E_{f}}+\frac{1-V_{f}}{E_{m}}
$$

More sophisticated analytical models predict intermediate behaviours between these two limit cases. Consider the Paul model (equation (S3)) and the Bourkas model (equation (S4)), respectively:

$$
\begin{gathered}
E_{n c}=E_{m}\left[\frac{1+(m-1) V_{f}^{2 / 3}}{1+(m-1)\left(V_{f}^{2 / 3}-V_{f}\right)}\right] \\
E_{n c}=E_{m}\left[1+\frac{V_{f}}{\frac{1}{m-1}+V_{f}^{1 / 3}-V_{f}^{2 / 3}}\right]
\end{gathered}
$$

where $m$ is defined as $m=E_{f} / E_{m}$. Ziegel and Romanov [6,7] developed a model with two adjustable parameters, $n$ and $B$ :

$$
E_{n c}=E_{m}\left[1-\left(B V_{f}\right)^{n}\right]^{-1}
$$

These theoretical models are illustrated in Figure S4 in comparison with the measured elastic modulus values of the solid nanocomposites. Note that the modulus of the pure PMMA $\left(E_{m}\right)$ was found to be equal to $2.23 \mathrm{GPa}$. The modulus of the pure sepiolites was estimated based on data available in the literature. Some studies [8] have measured the mechanical properties of different clays, most of them montmorillonites or similar layered clays. Results indicate a strong influence of the density on the elastic modulus. In particular, based on the review of Chen [9], $E_{f}$ was taken to be equal to $30 \mathrm{GPa}$, based on the measured density of the sepiolite material $\left(\rho=2.1 \mathrm{~g} / \mathrm{cm}^{3}\right)$. For the Ziegel-Romanov equation, a logarithmic plot was used to obtain the experimental values of the constants. The fitted values for $n$ and $B$ were 0.61 and 1.29, respectively. A more accurate prediction of the effect of sepiolite content on the modulus of the nanocomposites is obtained by the Paul, Bourkas and Ziegel-Romanov intermediate models. However, none of these models predicts the maximum value of the reinforcement detected at $2 \mathrm{wt} \%$ and the stabilization of the modulus after that content.

For the solid material $2 \%-\mathrm{S}$, the model that predicts with more accuracy the elastic modulus is the Voight model. This implies that with this particle content the reinforcement obtained is the maximum possible taking into account the rule of mixtures. 


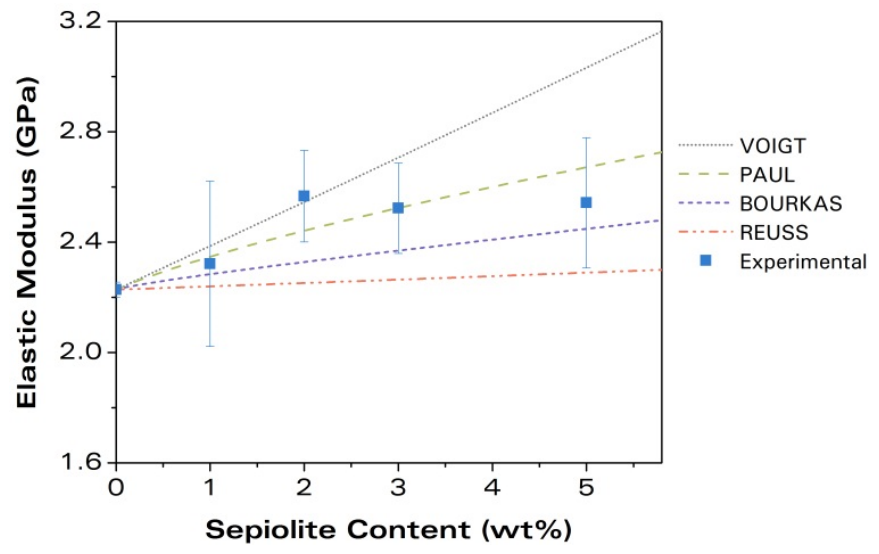

Figure S4. Predictions of the elastic modulus of the solid nanocomposites as a function of the sepiolite content by different analytical models along with the measured elastic modulus values.

\section{EFFECT OF THE BIMODAL DISTRIBUTION ON THE MECHANICAL PROPERTIES}

The cellular nanocomposites of this work possess a bimodal cell size distribution with micro- and nano-sized cells. The presence of a bimodal structure could affect the mechanical response of these materials, as the small pores surrounding the big ones can act as reinforcement. Also, it is known that the presence of nanometric pores confines the polymer chain in very thin cell walls [10] that could lead to an enhancement of the mechanical behaviour [11]. The best way to verify if any of these effects are taking place in the materials of this study is to compare their properties with materials with the same chemical composition but with a completely microcellular structure.

\subsection{Production and characterization of microcellular nanocomposites}

To produce microcellular materials based on PMMA/sepiolite nanocomposites, the processing parameters have been tuned to reduce the amount of gas uptake and prevent the sepiolites from acting as nucleating agents. Microcellular materials based on the composite 3\%-S were produced using a two-step gas dissolution foaming process with $10 \mathrm{MPa}$ of saturation pressure and $70{ }^{\circ} \mathrm{C}$ of saturation temperature. Under these conditions, the solubility of $\mathrm{CO}_{2}$ in PMMA is approximately 15 wt $\%$, whereas at $25{ }^{\circ} \mathrm{C}$ (temperature used for the production of the bimodal structures) the solubility is as high as $25 \mathrm{wt} \%$. This significant difference in solubility allows the transition from a bimodal structure with nanometric cells to a $100 \%$ microcellular material. The foaming step was performed in a hot and cold plates press as explained in the previous section, using various temperatures and times to produce materials with different densities (Table S1).

Table S1. Foaming parameters in the press for the production of microcellular nanocomposites based on 3\%-S.

\begin{tabular}{ccc}
\hline Target Density & Temperature $\left({ }^{\circ} \mathrm{C}\right)$ & Time $(\mathrm{min})$ \\
\hline Medium-High $(\sim 0.45)$ & 70 & 3 \\
Low $(\sim 0.3)$ & 100 & 1 \\
\hline
\end{tabular}


Figure S5 shows the SEM images of the microcellular materials produced with these conditions and Table S2 summarizes the main characteristics of their cellular structures. The obtained structures present a very heterogeneous structure $(S D / \phi$ greater than 1$)$ but with cells in the micrometric range and average cell sizes around 25-30 microns. Figure S5.C and Figure S5.d show that among the microcellular pores there are no nanometric cells. The anisotropy ratios are around 1.1 and the materials can be considered to have a closed cell structure.

The materials of Figure S5 will be referred from now on as "Micro" and compared with those of the main article with the same chemical composition and relative density but showing a bimodal cellular structure (samples 4, 9 and 13 in Table 3), these will be called "Bimodal".

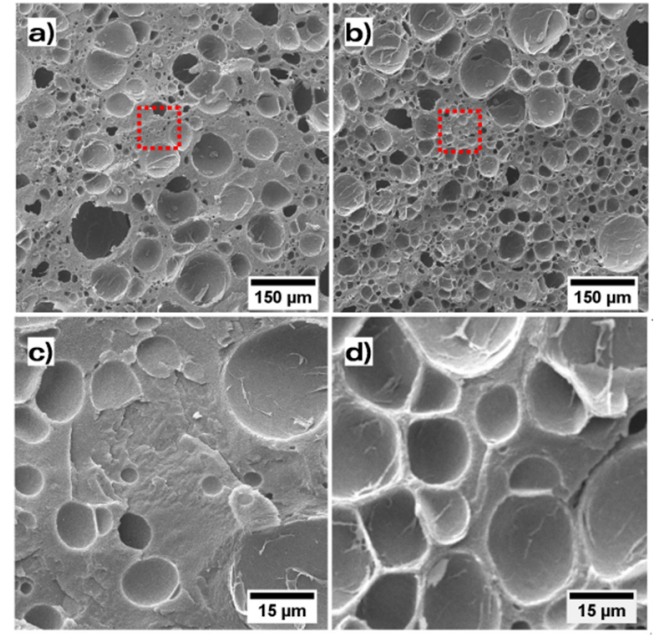

Figure S4. SEM images of the microcellular samples produced with the nanocomposite 3\%-S with different densities a) medium-high density and b) low density. The second row shows images of the same material systems at an increased magnification.

Table 3. Measured cellular structure parameters and open cell content of the microcellular samples produced with the nanocomposite 3\%-S.

\begin{tabular}{cccccccc}
\hline$\#$ & Material & $\begin{array}{c}\text { Relative } \\
\text { Density }\end{array}$ & $\begin{array}{c}\text { Cell Nucleation } \\
\text { Density } \\
(\text { nuclei/cm }\end{array}$ & $\boldsymbol{\phi}(\mu \mathrm{m})$ & SD / $\boldsymbol{\phi}$ & $\boldsymbol{A R}$ & $\begin{array}{c}\boldsymbol{O} \text { ( } \\
(\%)\end{array}$ \\
\hline M1 & $3 \%-S$ Micro & $0.46 \pm 0.02$ & $5.01 \cdot 10^{7}$ & 30 & 1.05 & $1.1 \pm 0.4$ & 9.4 \\
M2 & $3 \%-S$ Micro & $0.31 \pm 0.03$ & $1.06 \cdot 10^{8}$ & 25 & 1.10 & $1.1 \pm 0.4$ & 11.2 \\
\hline
\end{tabular}

\subsection{Uniaxial compression tests}

Figure $\mathbf{S 6}$ shows the mechanical properties of the cellular materials based on the nanocomposite $3 \%-\mathrm{S}$ in uniaxial compression as a function of relative density. It is observed that both parameters are independent of the cellular structure of the materials, as the property versus relative density trends of both the micro and the bimodal structures are similar.

This result implies that potential reinforcement of the mechanical properties of the cellular nanocomposites caused by the addition of sepiolites are not related to the bimodal cell size distribution and/or the presence of nano-sized pores. 
a)

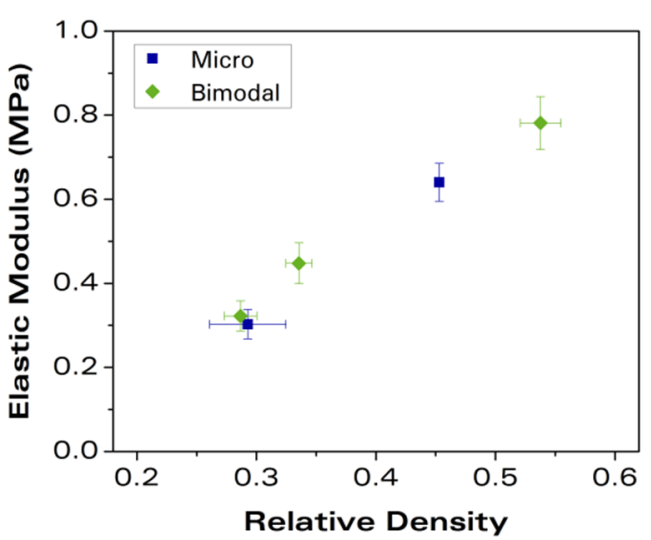

b)

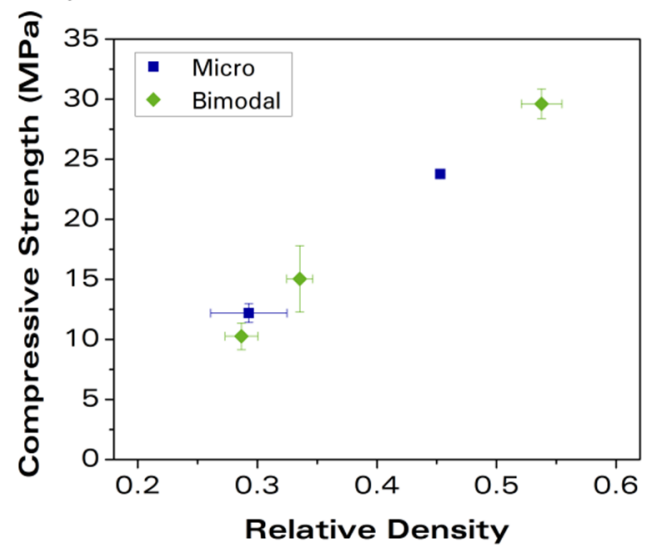

Figure S6. a) Elastic modulus and b) compressive strength of the cellular materials based on 3\%-S with a unimodal microcellular structure (Micro) and a bimodal cell size structure (Bimodal) as a function of the relative density.

\subsection{Fracture toughness}

Figure S7 shows the measured values for the fracture toughness of the cellular materials as a function of relative density. As shown in Figure $\mathbf{S 5}$, the mechanical properties in compression of the microcellular materials with an unimodal cell size distribution show the same behaviour as bimodal samples with nano-sized cells.

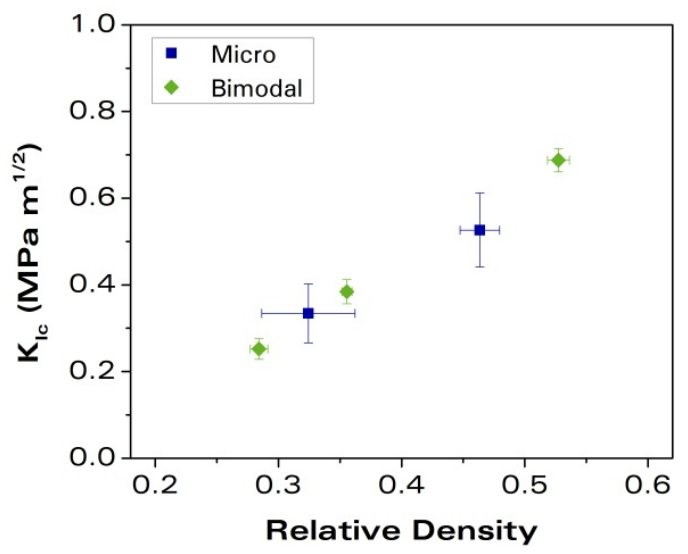

Figure S7. Fracture toughness of the cellular materials based on 3\%-S with different structures as a function of the relative density.

\section{SUPPORTING FIGURES (Figures 5, Figure 6 and Figure 11)}

The uncertainty in the trends shown in Figure 5, Figure 6 and Figure 11 as a result of the scatter in the measured properties is shown in Figure S8, S9 and S10, respectively. The error bars are computed by the following procedure. The average $n$ values used for the analysis leading to the trends shown in Figure 5, Figure 6 and Figure 11 were used to calculate maximum and minimum values of the constants $(A, B$ and $C$ ) for each system using the maximum and minimum limits of the corresponding error bars of the measured properties (see Figure 4.a, Figure 4.c and Figure 10.a). 
The observed trends discussed in the main article are not affected by the scatter in measured properties.

a)

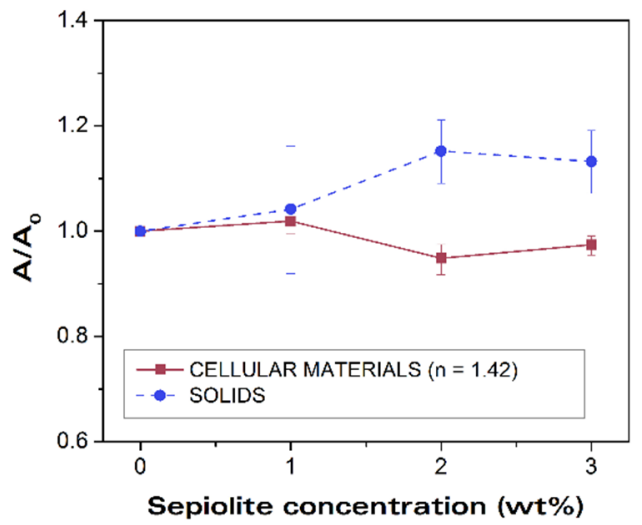

b)

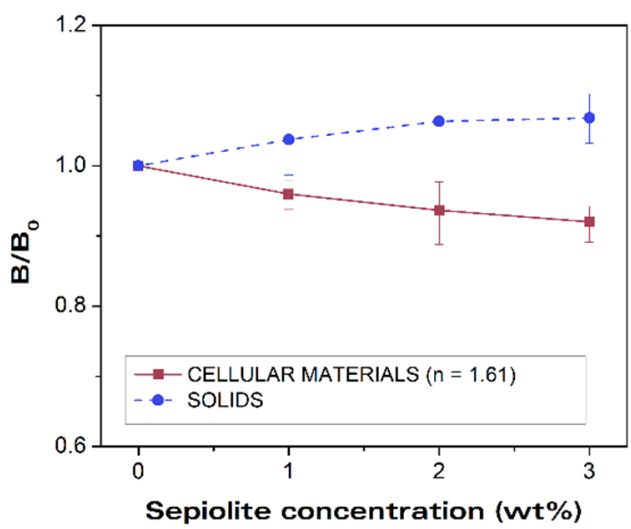

Figure S8. Figure 5 with error bars: a) $A / A_{0}$ (elastic modulus) and b) $B / B_{0}$ (compressive strength) as a function of the sepiolite concentration for the cellular materials and the solids.

a)

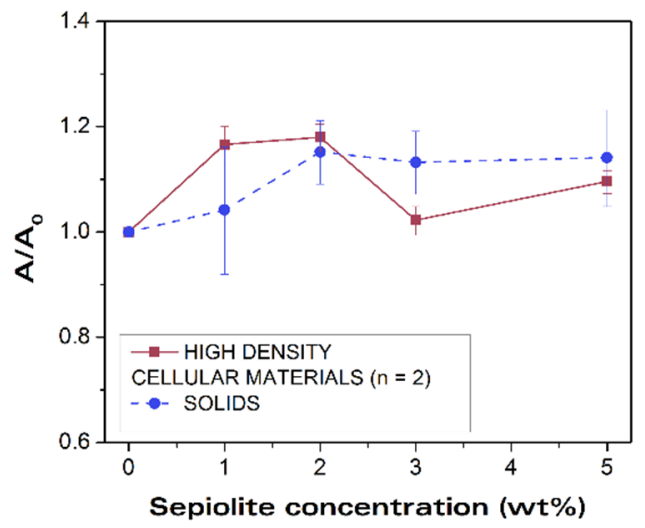

b)

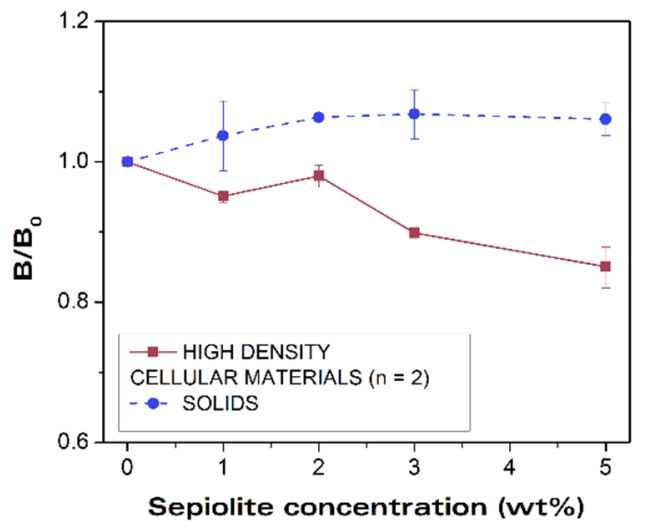

Figure S9. Figure 6 with error bars: a) $A / A_{0}$ (elastic modulus) and b) $B / B_{0}$ (compressive strength) as a function of the sepiolite concentration for the cellular materials with high relative density and the solids.

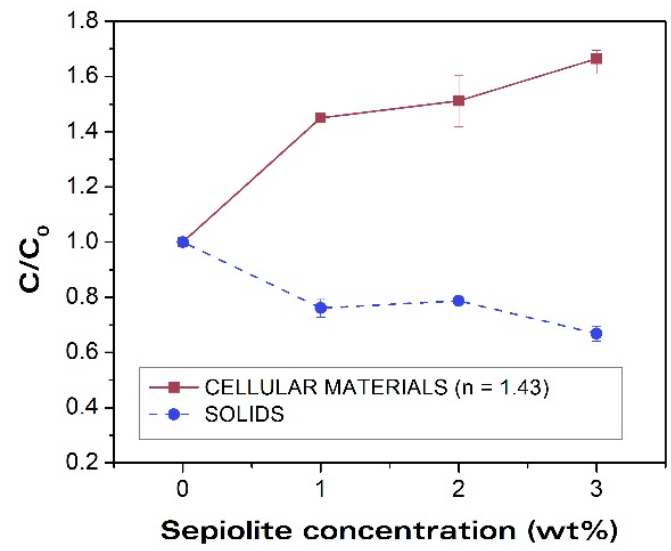

Figure S10. Figure 11 with error bars: $C / C_{0}$ (fracture toughness constants) as a function of the sepiolite concentration for the cellular materials and the solids. 


\section{MORPHOLOGY OF THE FRACTURE SURFACE}

Figure S11 shows representative SEM images of the fracture surface after the single edge notch three point bending tests. The pure PMMA and one nanocomposite (3\%-S) of high density (around $0.5)$ are selected as representative materials of the general behaviour. The cellular structure can be clearly appreciated in the SEM images of the fracture surface, indicating a brittle behaviour in these materials. This matches with the observed load versus intender displacement curves, that showed a linear trend until fracture for all the materials.

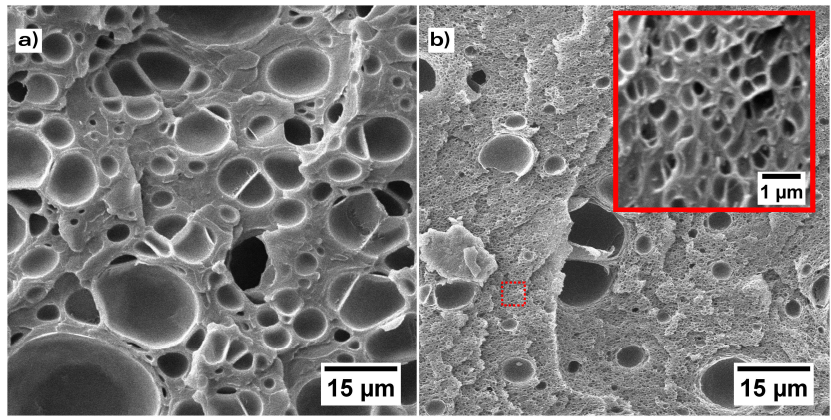

Figure S11. SEM images of the fracture surface of representative materials: a) PMMA (relative density around 0.5 ), and b) 3\%-S (relative density around 0.5 ). Insert in b) is a zoomed image showing the nanocellular structure.

\section{REFERENCES}

[1] K. Nadella, V. Kumar, W. Li, Constrained solid-state foaming of microcellular panels, Cell. Polym. 24 (2005) $71-$ 90.

[2] V. Bernardo, J. Martin-de León, E. Laguna-Gutiérrez, M.Á. Rodríguez-Pérez, PMMA-sepiolite nanocomposites as new promising materials for the production of nanocellular polymers, Eur. Polym. J. 96 (2017) 10-26. doi:10.1016/j.eurpolymj.2017.09.002.

[3] H. Guo, V. Kumar, Solid-state poly(methyl methacrylate) (PMMA) nanofoams. Part I: Low-temperature $\mathrm{CO} 2$ sorption, diffusion, and the depression in PMMA glass transition, Polymer (Guildf). 57 (2015) 157-163. doi:10.1016/j.polymer.2014.12.029.

[4] C.P. Wong, R.S. Bollampally, Thermal Conductivity, Elastic Modulus, and Coefficient of Thermal Expansion of Polymer Composites Filled with Ceramic Particles for Electronic Packaging, 74 (1999) 3396-3403.

[5] L.E. Nielsen, Generalized Equation for the Elastic Moduli of Composite Materials, J. Appl. Phys. 41 (1970) 46264627.

[6] K.D. Ziegel, A. Romanov, Modulus reinforcement in elastomer composites. I. Inorganic fillers, J. Appl. Polym. Sci. 17 (1973) 1119-1131. doi:10.1002/app.1973.070170410.

[7] K.D. Ziegel, A. Romanov, Modulus Reinforcement in Elastomer Composites . 11 . Polymeric Fillers, J. Appl. Polym. Sci. 17 (1973) 1133-1142.

[8] T. Vanorio, M. Prasad, A. Nur, Elastic properties of dry clay mineral aggregates, suspensions and sandstones, Geophys. J. 155 (2003) 319-326.

[9] B. Chen, J.R.G. Evans, Elastic moduli of clay platelets, Scr. Mater. 54 (2006) 1581-1585. doi:10.1016/j.scriptamat.2006.01.018.

[10] J. Pinto, B. Notario, R. Verdejo, M. Dumon, S. Costeux, M.A. Rodriguez-perez, Molecular confinement of solid and gaseous phases of self-standing bulk nanoporous polymers inducing enhanced and unexpected physical properties, Polymer (Guildf). 113 (2017) 27-33. doi:10.1016/j.polymer.2017.02.046.

[11] B. Notario, J. Pinto, M.A. Rodríguez-Perez, Towards a new generation of polymeric foams: PMMA nanocellular foams with enhanced physical properties, Polymer (Guildf). 63 (2015) 116-126. doi:10.1016/j.polymer.2015.03.003. 


\subsection{Modeling the heat transfer by conduction of nanocellular polymers with bimodal cellular structures}

This section contains a publication entitled "Modeling the heat transfer by conduction of nanocellular polymers with bimodal cellular structures", published in Polymer in 2018 (V. Bernardo, J. Martin-de Leon, J. Pinto, R. Verdejo, M.A. Rodriguez-Perez, Modeling the heat transfer by conduction of nanocellular polymers with bimodal cellular structures, Polymer (Guildf). 160 (2019) 126-137. doi:10.1016/j.polymer.2018.11.047.

Some of the materials produced throughout this thesis presented a bimodal cellular structure with nanometric pores (see, for instance, the materials produced in Chapter 4). In the nanocellular structure, a reduction of the gas contribution to the thermal conductivity is excepted due to the Knudsen effect, but there is currently no appropriate model to predict the thermal conductivity of a material combining micro- and nanometric cells.

In this paper, a new model to predict the heat transfer by conduction of bimodal cellular structures is developed. The model is based on a circuit analogy (series and parallel model), and it takes into consideration the volume fraction occupied by each cell size. The model differentiates between nanometric cells and micrometric cells, to account for the Knudsen effect in the first ones. Also, the structural factor modulating the contribution of the solid phase of each population of cells is studied by thermal and electrical conductivity measurements. According to our models, the conductivity of a bimodal system depends on the volume fraction occupied by the nanometric cells. Also, the parallel model predicts slightly smaller conductivities (this model minimizes the effect of the micrometric cells).

Two bimodal systems based on PMMA are used to validate the model: one with a small fraction of MAM (0.05 wt\%) and one with sepiolites. For the two systems, the models provide better estimations of the conductivity than considering the material totally micro or nanocellular or using the average cell size. Therefore, the model is validated. The results of these evaluations indicate that bimodal nanocellular materials could be interesting from a practical point of view: the microcellular pores allow reducing the density, while the nano-pores reduce the thermal conductivity through the gas phase.

Finally, the model can also be used to predict the thermal conductivity of monomodal nanocellular materials with a wide cell size distribution. In particular, we observe that the width of the distribution increases the value predicted considering only the average cell size, especially at low densities and therefore we conclude that the predictions published up to now and based on using the average cell size of the nanocellular foam, underestimate the thermal conductivity by conduction.

Figure 7.2 shows the graphical abstract of this publication that is included in the next pages of this chapter. 

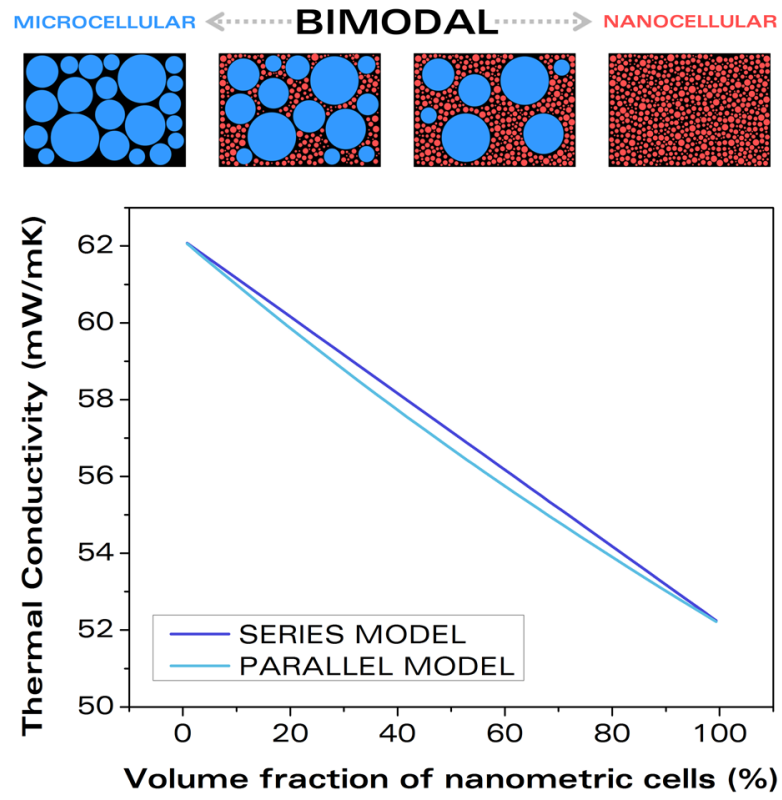

Figure 7.2. Graphical abstract of "Modeling the heat transfer by conduction of nanocellular polymers with bimodal cellular structures". 


\title{
Modeling the heat transfer by conduction of nanocellular polymers with bimodal cellular structures
}

\author{
Victoria Bernardo*1, Judith Martín-de León' ${ }^{1}$ Javier Pintoํㅜ, Raquel Verdejo², Miguel Ángel \\ Rodríguez-Pérez ${ }^{1}$ \\ 1. Cellular Materials Laboratory (CellMat), Condensed Matter Physics Department, \\ University of Valladolid, Campus Miguel Delibes, Paseo de Belén n7, 47011 Valladolid, Spain \\ 2. Institute of Polymer Science and Technology (ICTP-CSIC), Juan de la Cierva, 3, Madrid 28006, \\ Spain \\ *Corresponding author: Victoria Bernardo (vbernardo@fmc.uva.es) +34983184035
}

\begin{abstract}
Nanocellular polymers are a new generation of materials with the potential of being used as very efficient thermal insulators. It has been proved experimentally that these materials present the Knudsen effect, which strongly reduces the conductivity of the gas phase. There are theoretical equations to predict the thermal conductivity due to this Knudsen effect, but all the models consider an average cell size. In this work, we propose a model to predict the thermal conductivity due to the conduction mechanisms of nanocellular materials with bimodal cellular structures, that is, with two populations of cells, micro and nanocellular. The novelty of our work is to consider not only the average cell size, but the cell size distribution. The predictions of the model are compared with the experimental conductivity of two real bimodal systems based on poly(methyl methacrylate) (PMMA), and it is proved that this new model provides more accurate estimations of the conductivity than the models that do not consider the bimodality. Furthermore, this model could be applied to monomodal nanocellular polymers. In particular, for monomodal materials presenting a wide cell size distribution and at low densities, the model predicts important variations in comparison with the current models in the literature. This result indicates that the cell size distribution must be included in the estimations of the thermal conductivity of nanocellular polymers.
\end{abstract}

\section{KEYWORDS}

nanocellular polymer; thermal conductivity; modeling.

\section{INTRODUCTION}

Buildings represent the largest energy-consuming sector in the global economy with more than one-third of the energy expenses. Therefore, they are responsible for more than one-third of global carbon emissions [1]. With the growth of the population predicted for the next decades, the energy used in buildings is also set to increase sharply [1,2]. Most of this energy is used in conditioning indoor spaces, so its use could be drastically decreased using more efficient thermal insulation systems. 
Cellular polymers are commonly used in house insulation [3-5]. Several factors contribute to their good behavior as thermal insulators. First, the very low thermal conductivity of the gas enclosed in the cells. Second, the distribution of the gas in small cells suppresses convention. Finally, the relatively small amount of solid polymer, that also presents a not very high thermal conductivity. Some of the most common cellular polymers currently used for thermal insulation, such as expanded polystyrene (EPS) or extruded polystyrene (XPS), present thermal conductivities in the range 30-35 $\mathrm{mW} / \mathrm{mK}$ at room temperature [6]. These types of foams have air in the cells sometime after their production, and due to this, the previous values of the thermal conductivity are already within the limits of their potential, as the thermal conductivity of air at room temperature is 26 $\mathrm{mW} / \mathrm{mK}$. The thermal conductivity can be reduced by using other gases of higher molecular weight and with lower thermal conductivities that can stay in the cells of the cellular material for long times, such as HFCS or alkanes. For instance, rigid polyurethane foams foamed using cyclo-pentane can have thermal conductivities of around $21 \mathrm{~mW} / \mathrm{mK}$ just after their production and values around 25$26 \mathrm{~mW} / \mathrm{mK}$ several months after production. This is because the thermal conductivity of cyclopentane is $12 \mathrm{~mW} / \mathrm{mK}$. However, the use of these gases is in general not environmentally friendly (HFCS) or even they are a serious drawback for the flame-retardant behavior of the materials (alkanes) $[7,8]$.

So, to develop better insulating materials that are at the same time environmentally friendly, new strategies must be followed.

One interesting approach of producing materials with lower thermal conductivity is the use of nanocellular polymers [1,9-11]. As a consequence of their reduced cell size, these materials allow a significant reduction of the thermal conductivity, as high as 2.5 times for low-density materials [12]. Several authors have demonstrated the super-insulating properties of nanocellular materials. Most of the work up to know is focused on the characterization of aerogels $[13,14]$, but polymerbased nanocellular materials have also been successfully tested. Notario and coworkers [12] measured the thermal conductivity of nanocellular poly(methyl methacrylate) (PMMA) with different cell sizes, proving the strong influence of the cell size in the conductivity (Knudsen effect). Grassberger et al. [15] demonstrated the same idea in blowing agent free nanocellular PMMA. In the work of Wang et al. [16], a nanocellular polymers based on blends of low-density PMMA and thermoplastic polyurethane (TPU) was shown to present a thermal conductivity as low as 24.8 $\mathrm{mW} / \mathrm{mK}$.

There are theoretical equations to model and predict the thermal conductivity of nanocellular polymers [12,17-19]. However, none of these models take into consideration that cellular materials can present a non-uniform cellular structure, that is, in all these models only the average cell size is used. Then, the previously mentioned works are not suitable for modeling the thermal conductivity of non-uniform systems, such as bimodal cellular structures with micro and nanometric pores. Such systems could be of great interest since the presence of micrometric pores could help to reduce the density, whereas the nanometric cells will decrease the thermal conductivity.

As a consequence of the interest of bimodal structures, also in the micrometric range, there are several works dealing with the production of such materials [20,21]. For instance, Lee et al. [22] 
produced bimodal PS/silica structures using two different blowing agents, and they investigated in detail the effect of the amount of silica, blowing agent and extrusion conditions in the resultant bimodal structure. In the work of Zhang and coworkers [23], bimodal PS was also produced by an extrusion process with two blowing agents, and they proved that the bimodality enhanced the mechanical and insulation performance compared with PS cellular materials. Arora and coworkers [24] produce bimodal PS cellular materials using a gas dissolution foaming method in which the pressure was released in two steps. In the work of Zeng et al. [25], PMMA/carbon nanotube nanocomposites showed a bimodal cell size distribution due to insufficient dispersion of the particles. Regarding bimodal structures with nanometric pores, Luo and coworkers [26] proved that the addition of silica aerogel to PMMA induced the appearance of a bimodal structure with nanometric pores in the cell walls, that helped to reduce the thermal conductivity compared to the neat PMMA. In the work of Miller et al. [27], microcellular high-density polyethylene (HDPE) was produced with a unique interconnected nanoporous structure in the cell walls. Schmidt at al. [28] proved that a bimodal structure formed by nanometric pores and micrometric ones (obtained by microemulsion template) presented a thermal conductivity that was between the two limits established by the nanocellular structure (obtained by sol-gel) and a macroporous material.

Several of the previously mentioned works proved that the presence of small cells allows reducing the thermal conductivity, but none of them proposed a model to quantify the weight of the different cells in the cell size distribution. About the modeling of the thermal conductivity of bimodal structures, we have only found the recent work of Gong et al. [29]. They proposed a model to calculate the thermal conductivity of microcellular bimodal structures and validated their model using bimodal PS/multi-walled carbon nanotube cellular materials. However, this model only took into account an average cell size of for each population of cells.

In this work, we propose a new theoretical model to calculate the thermal conductivity due to the heat transfer mechanisms by conduction of nanocellular polymers with non-uniform cellular structures. In this model, the cell size of all cells is considered together with the relative volume occupied by each cell, with the aim of considering the relative contribution of each cell size to the global thermal conductivity. Experimental measurements of nanocellular polymers presenting a bimodal cellular structure confirm the validity of the proposed model.

\section{THEORETICAL BACKGROUND}

The thermal conductivity of a cellular polymer $\left(\lambda_{t}\right)$ can be calculated as the sum of four different contributions [5,30]:

$$
\lambda_{t}=\lambda_{s}+\lambda_{g}+\lambda_{r}+\lambda_{c}
$$

Where $\lambda_{s}$ is the conduction through the solid phase, $\lambda_{g}$ is the conduction across the gas phase, $\lambda_{r}$ is the thermal radiation term, and $\lambda_{c}$ represents the convection within the cells. This last term is negligible for cell sizes smaller than $2 \mathrm{~mm}[5,30,31]$. Regarding the radiation term, there are several models to justify its dependence with the cell size in the microcellular range [32,33], but it is known that the models used for microcellular polymers cannot be used for nanocellular materials. As far as the authors know, the only model dealing with the contribution of the radiation in the thermal 
conductivity of nanocellular materials is that of Wang and coworkers [19], although the calculation of the radiative contribution is purely theoretical and has not been experimentally validated. In fact, there is not yet any experimental data about how radiation propagates in a system the nanometric cells.

Nonetheless, both the microcellular and the nanocellular models predict that the contribution of the radiation becomes only relevant for low relative densities, due to a high fraction of absorbent solid present in the medium and high-density cellular materials. In particular, in the work of Wang et al. [19] it is proved that for cell sizes in the range of $200 \mathrm{~nm}$ to 10 microns and relative densities around 0.25 or greater, the radiation contribution becomes negligible.

Taking into account that the cellular materials used in this work present relative densities above 0.27 and cell sizes in the aforementioned boundaries, we have neglected in all the modeling the possible contribution of radiation. This means that the model proposed is valid for the thermal conductivity by conduction, including both the conduction through the solid and through the gas phases. The values given by the model will be equivalent to the total conductivity when the radiation contribution is negligible, and this would be the case for cellular materials with high or medium densities (higher than around 0.20) as those included in this paper.

To quantify the weight of each contribution, the relative amount of solid and gas phases should be used, that is, the relative density $\rho_{r}$ (defined as $\rho_{r}=\rho / \rho_{s}$, where $\rho_{s}$ is the density of the solid and $\rho$ is the density of the cellular material). Using this idea, the conductivity can be described as [5]:

$$
\lambda_{t}=\lambda_{s}+\lambda_{g}=g \lambda_{s}^{\prime} \rho_{r}+\lambda_{g}^{\prime}\left(1-\rho_{r}\right)
$$

Where $\lambda_{s}^{\prime}$ and $\lambda_{g}^{\prime}$ are the thermal conductivities of the solid polymer and the gas inside the cells, respectively, and $g$ is a an efficiency-structural factor proposed by Glicksman [30]. This factor has been shown to be close to 1 for microcellular materials with medium/high relative densities (0.30.6) [34] and ranging 0.8-1 for nanocellular polymers with medium/high relative densities (0.4-0.65) [12]. In the case of microcellular structures with very low densities (lower than 0.05) (i.e., when the cell walls are very thin and the cells have a polyhedral shape), this factor is $2 / 3$, and when the fraction of mass in the struts is also considered in the model, $g$ can have a minimum value of $1 / 3$ for materials with a high fraction of the solid phase in the struts [30].

In a microcellular material, $\lambda_{g}^{\prime}$ is directly the thermal conductivity of the gas inside the pores (26 $\mathrm{mW} / \mathrm{mK}$ if the gas is air at atmospheric pressure and room temperature). However, when the mean free path of the gas molecules inside the cells is comparable with the cell size, the conduction throughout the gas is significantly reduced, because the collisions among the gas molecules become less probable than the collisions with the cell walls. This effect is well-known as the Knudsen effect [12,35-38]. Once this effect is taken into account, the effective conductivity of the gas $\lambda_{g}^{\prime}$ can be described as $[36,39,40]$ :

$$
\lambda_{g}^{\prime}=\frac{\lambda_{g 0}^{\prime}}{1+2 \beta K n}
$$

Where $\lambda_{g 0}^{\prime}$ is the thermal conductivity of the gas inside the pores, $\beta$ is a factor correlating the energy transfer between gas molecules and the structure (varying from 1.5 to 2 for argon and nitrogen [40] and 1.64 being the value for air [36]), and $\mathrm{Kn}$ is the Knudsen number, defined as: 


$$
K n=\frac{l_{g}}{\phi}
$$

Where $l_{g}$ is the mean free path of the gas molecules $\left(l_{g} \approx 70 \mathrm{~nm}\right.$ for air $\left.[12,17]\right)$ and $\phi$ is the average cell size. For a cell size much larger than the mean free path, the reduction due to the Knudsen effect is not significant, but for cell sizes under the micron, there is a significant decrease of the thermal conductivity. Theoretically, the Knudsen effect is related to the rarefied gas conduction regime [36,38], which starts to play a role for Knudsen numbers higher than $0.01, K n \geq 0.01$ [41]. In other words, this effect starts to become relevant when the cell size is smaller than 100 times the mean free path, $\phi \leq 100 l_{g}$. For a mean free path of $70 \mathrm{~nm}$, this means that the Knudsen effect should be considered when calculating the thermal conductivity of systems with cell sizes smaller than 7 microns.

Combining equations (2) to (4), we lead to the following expression as a first approach to estimate the thermal conductivity by conduction in a nanocellular polymer:

$$
\lambda_{t}=g \lambda_{s}^{\prime} \rho_{r}+\frac{\lambda_{g 0}^{\prime}}{1+\frac{2 \beta l_{g}}{\phi}}\left(1-\rho_{r}\right)
$$

Figure 1 shows the predictions of equation (5) as a function of the cell size for a nanocellular polymer based on PMMA (conductivity of the solid: $211.7 \mathrm{~mW} / \mathrm{mK}$ ) and for three different relative densities. For this plot, the structural factor $g$ was considered as 1 for simplicity. A discussion about the value of $g$ is included below.

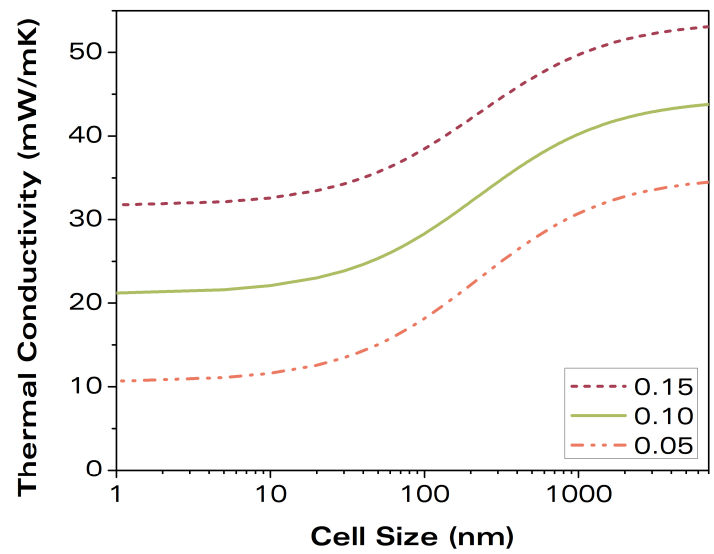

Figure 1. Theoretical effect of the cell size in the thermal conductivity by conduction of a PMMAbased nanocellular polymer, according to equation (5), for relative densities of $0.15,0.10$, and 0.05 .

This model was proved to be successful in the prediction of the thermal conductivity of nanocellular polymers [12], but it only takes into account the average cell size. Further considerations are needed to use this model to predict the thermal conductivity of bimodal systems or structures with a wide cell size distribution. Our model attempts to complete and improve the previous one to widen its range of application to systems with non-uniform cellular structures. 


\section{MODEL}

To demonstrate the basic concept of the model, we will consider a very simple bimodal system with two distinct populations of cells. This system can be seen as a two-phase system comprising micrometric and nanometric cells, and it is schematized in Figure 2.a. The cell size distribution is calculated using a correction that takes into consideration the relative volumes occupied by each type of cell (details can be found elsewhere [42] and in section 4.3). As the two populations of Figure 2.a are monodisperse, only two different cell sizes appear in the histogram.

a)
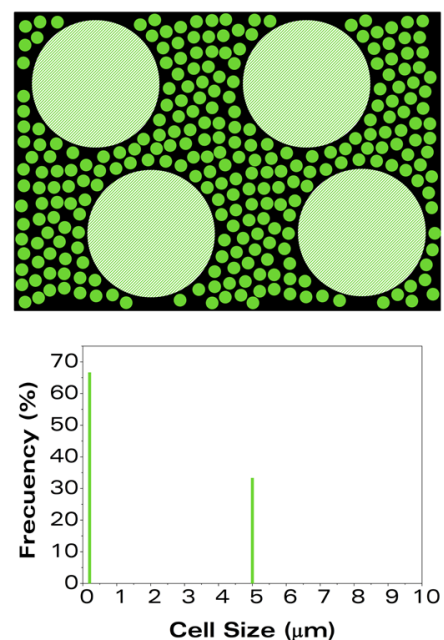

b)
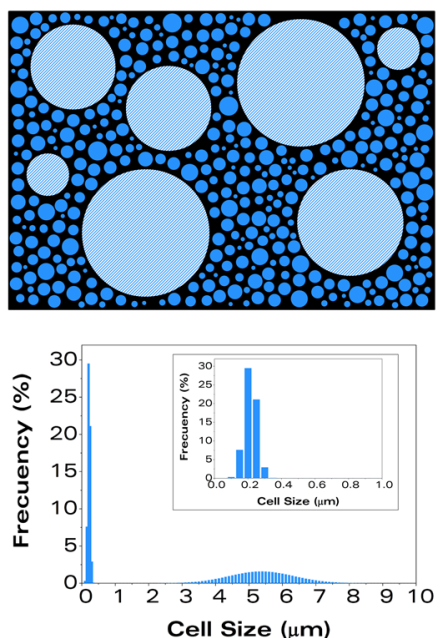

Figure 2. Schematic representation and cell size distribution (corrected with the volume) of bimodal cellular structures: a) bimodal system with a microcellular and a nanocellular population, both monodisperse, and b) bimodal system with a microcellular and a nanocellular population, with a certain width in the cell size distributions of both micro and nanometric cells.

The system of Figure 2.a has micrometric cells of 5 microns of cell size, representing more than the $30 \%$ of the volume of the sample. However, there are more than 1000 nanometric pores per microcellular one. Then, when calculating the average cell size, the high number of nanocellular pores (with a diameter of $200 \mathrm{~nm}$ ) is predominant, given an average cell size of around $205 \mathrm{~nm}$. Assuming a relative density of 0.2 , the theoretical conductivity based only on the average cell size is $52.1 \mathrm{~mW} / \mathrm{mK}$ (obtained from equation (5)). In this calculus, the polymer matrix was assumed to be PMMA with a thermal conductivity of the solid phase of $211.7 \mathrm{~mW} / \mathrm{mK}$, and the $g$ factor was considered to be equal to 1 for this initial estimation.

Two basic approximations can be used to calculate the thermal conductivity of a two-phase system like that shown in Figure 2.a using the common analogy of an electric circuit: the series and the parallel model (equation (6) and (7) respectively, where $\lambda_{i}$ represents the thermal conductivity of the $i$ phase ( $i=1$ or 2 ) and $V_{i}$ is the volume fraction of each of the components). The circuit analogy is a common way to compute the properties of two-phase systems such as a cellular polymer $[39,43]$.

$$
\lambda_{t}=\sum_{i=1,2} V_{i} \lambda_{i}
$$




$$
\frac{1}{\lambda_{t}}=\sum_{i=1,2} \frac{V_{i}}{\lambda_{i}}
$$

The series model maximizes the interaction between the two phases, whereas the parallel model minimizes the effect of the dispersed phase $[44,45]$. These models are commonly used to predict the conductivity of multi-phase systems, such as polymer composites or sandwich panels [46]. They can also be applied to systems like that schematized in Figure 2.a. For that particular system, $\lambda_{1}$ would be the thermal conductivity of a microcellular material with cell size 5 microns, $\lambda_{2}$ the thermal conductivity of a nanocellular material with a cell size of $200 \mathrm{~nm}$ and $V_{1}$ and $V_{2}$ the volume fractions occupied by each population of cells (30\% and $70 \%$ in this example). With this approach, and using for instance the series model, the theoretical prediction of the conductivity is $55.4 \mathrm{~mW} / \mathrm{mK}, 6 \%$ higher than the value calculated using only the average cell size.

Based on this simple idea, we can enlarge the model for any bimodal system in which the cell size distributions have a certain width (Figure 2.b).

Combining equation (5) with equations (6) and (7), we established the general equations for the models proposed in this work: the series model (equations (8) and (9)) and the parallel model (equations (10) and (11)). For the models, the volume fraction occupied by each class of cell size is taken into consideration, $f_{x_{i}}$ (see section 4.3 for more details about how to calculate it), and also the thermal conductivity for the corresponding cell size, $\lambda_{x_{i}}$. A distinction between micro and nanometric cells is also considered in the model. For cell sizes smaller than 7 microns [41], Knudsen correction is used for calculating the contribution of the gas phase (equations (9) and (11)). Therefore, for cell sizes higher than this threshold, no effect of the cell size is included. In addition, the structural factor $g$ in the contribution of the solid phase is assumed to be potentially different for nano $\left(g_{n}\right)$ and microcellular $\left(g_{m}\right)$ structures. This assumption is based on the intrinsic structural differences between a micrometric cell wall and a nanoporous one (with cell wall thickness in the range of $20 \mathrm{~nm}$ [47]). The reduction of the cell wall thickness to the nanoscale can induce a tortuosity effect that might reduce the $g$ factor, as reported by Notario et al. [12]. In addition, Ma et al. [48] showed that in solid films with nanometric thickness, such as the cell walls in a nanocellular polymer, the thermal conductivity is reduced when the thickness size is reduced, that is, that a strong confinement effect can lead to a reduction in the thermal conductivity. For all these reasons, we have assumed the $g$ factor being dependent on the cellular structure. This assumption has been supported with electrical conductivity measurements (see Supplementary Information). See section 5.1 for a more detailed discussion of the values of $g$.

$$
\begin{gathered}
\text { SERIES: } \boldsymbol{\lambda}_{\boldsymbol{t}}=\sum_{x_{\boldsymbol{i}}} \boldsymbol{f}_{\boldsymbol{x}_{i}} \lambda_{x_{i}} \\
\lambda_{t}=\sum_{x_{i}=0}^{7} f_{x_{i}}\left(\frac{\lambda_{g_{0}}^{\prime}\left(1-\rho_{r}\right)}{1+\frac{2 \beta l_{g}}{x_{i}}}+g_{n} \lambda_{s}^{\prime} \rho_{r}\right)+\sum_{x_{i}>7} f_{x_{i}}\left(\lambda_{g_{0}}\left(1-\rho_{r}\right)+g_{m} \lambda^{\prime} \rho_{r}\right) \\
\text { PARALLEL: } \frac{\mathbf{1}}{\lambda_{t}}=\sum_{x_{i}} \frac{\boldsymbol{f}_{x_{i}}}{\lambda_{x_{i}}}
\end{gathered}
$$




$$
\frac{1}{\lambda_{t}}=\sum_{x_{i}=0}^{7} \frac{f_{x_{i}}}{\frac{\lambda_{g 0}^{\prime}\left(1-\rho_{r}\right)}{1+\frac{2 \beta l_{g}}{x_{i}}}+g_{n} \lambda^{\prime}{ }_{s} \rho_{r}}+\sum_{x_{i}>7} \frac{f_{x_{i}}}{\lambda_{g_{0}}^{\prime}\left(1-\rho_{r}\right)+g_{m} \lambda_{s}^{\prime} \rho_{r}}
$$

In summary, the main hypothesis of the model proposed in this work to evaluate the heat transfer by conduction in a bimodal nanocellular material are the following:

- $\quad$ The structure presents a bimodal cellular structure with micro and nanometric cells characterized by a cell size distribution.

- Only conduction mechanisms are considered, so this model is valid as long as the density of the materials is high enough to neglect radiation $\left(\rho_{r}>0.25\right)$.

- The conduction through the gas phase is different for the micro and the nanometric cells, the last presenting Knudsen effect.

- $\quad$ The conduction through the solid phase is different for the micro and the nanometric cells. The differences are included in the structural factor $g$. For the microcellular population, $g_{m}$ takes a value of 1 , whereas for the nanocellular population the value, $g_{n}$, is calculated as a function of the relative density.

- The calculation of the factor $g_{n}$ is performed using $100 \%$ nanocellular materials with different densities.

- The results were supported with electrical conductivity measurements.

- Out of the density range analyzed there are not experimental evidence about the value of this factor. Then, and for illustrative purposes when the model is introduced, a value of $g=1$ was considered.

- $\quad$ Each cell size of the cell size distribution contributes differently to the total conductivity by conduction, and its contribution is given by its corresponding volume fraction.

- To add all the contributions, two approaches based on a circuit analogy have been used: series and parallel, resulting in two versions of this model.

Figure 3 shows the effect of the volume fraction of nanometric cells on the thermal conductivity due to the conduction using the series and the parallel model proposed in this work, for a bimodal system such as that shown of Figure 2.b. For this particular example, the two distributions are Gaussian functions, with an average cell size of $200 \mathrm{~nm}$ and 5 microns and width of the distributions of $40 \mathrm{~nm}$ and 1 micron, respectively. That is, the two distributions present the same ratio width/cell size $(S D / \phi=0.2)$. The total relative density was assumed to be 0.2 and the structural factor of both micro and nanometric cells are considered as 1. These values have been calculated using equations (9) and (11). In Figure 3, two additional horizontal lines are plotted together with the predictions of the model: the thermal conductivity of a nanocellular polymer with $200 \mathrm{~nm}$ of cell size (named as "NANO") and a microcellular material with 5 microns of cell size (referred as "MICRO") with the same densities. The polymer matrix was assumed to be PMMA with a thermal conductivity of the solid phase of $211.7 \mathrm{~mW} / \mathrm{mK}$ and the $g$ factors were considered equal to 1 for simplicity. It is observed that both parallel and series model moved from the microcellular behaviour when the volume of 
nanometric cells is small, to the nanocellular line for very a large volume of nanometric cells. Even at $100 \%$ of nanometric cells, the models do not cross the nanocellular prediction, since they take into account the width of the cell size distribution of the nanocells and the nanocellular line does not. Figure 3 also shows that the parallel model predicts smaller conductivities than the series one. Then, this model minimizes the effect of the micrometric cells in the bimodal structure.

a)

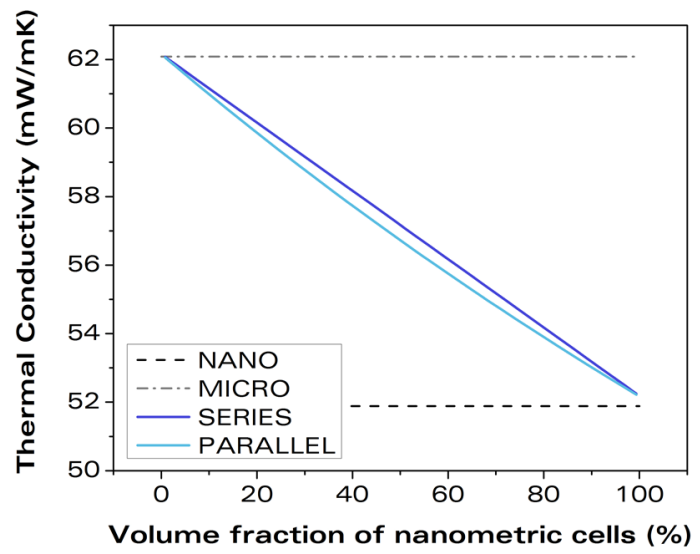

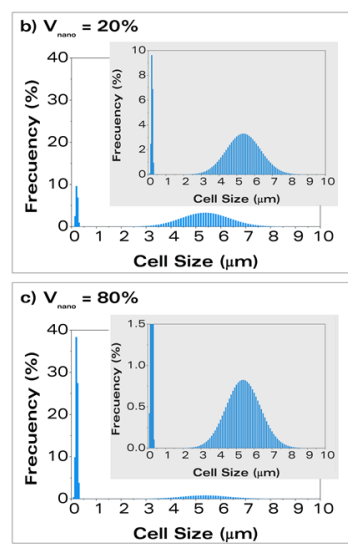

Figure 3. a) Effect of the volume fraction of nanometric cells in the thermal conductivity of a PMMA-based cellular polymer with a relative density $\rho_{r}=0.2$ with a bimodal (nano and micro) cell size distribution and examples of cell size distributions with different volume fraction of nanometric cells: b) $20 \%$ and c) $80 \%$. Insets of figures b) and c) show in detail the cell size distribution of the microcellular region.

\section{EXPERIMENTAL}

\subsection{Materials}

PMMA V825T was kindly supplied by ALTUGLAS ${ }^{\circ}$ International. Poly(methyl methacrylate)poly(butyl acrylate)-poly(methyl methacrylate) (MAM) block copolymer Nanostrength M53 was kindly supplied by Arkema Company (France). Sepiolites modified with a quaternary ammonium salt $[49,50]$ were provided by Tolsa S.A (Spain). Medical grade carbon dioxide $\left(\mathrm{CO}_{2}\right)(99.9 \%$ purity) was used as the blowing agent for the gas dissolution foaming experiments.

In this work, two different systems able to produce bimodal structures with nanometric cells are analyzed: a blend of PMMA and MAM and a blend of PMMA with sepiolites. Blends in the proportions of Table 1 were produced by extrusion using a twin-screw extruder model COLLIN TEACH-LINE ZK 25T, with L/D of 24 and screw diameter of $25 \mathrm{~mm}$, with a temperature profile set from $160^{\circ} \mathrm{C}$ to $200^{\circ} \mathrm{C}$, and the screw speed equal to $40 \mathrm{rpm}$. The extruded materials were extruded again at the same conditions for dispersing the MAM or the sepiolites homogeneously.

Solid sheets ( $4 \mathrm{~mm}$ thick) from the blends were produced by compression molding using a hot plate press provided by Remtex (Spain). The temperature set on the press was $250^{\circ} \mathrm{C}$ and processing time was 9.5 minutes, 8.5 for melting the polymer and 1 minute more for compression under pressure $(1.7 \mathrm{MPa})$. From these sheets, squares of $25 \times 25 \mathrm{~mm}^{2}$ were cut for the foaming experiments. 
As-received PMMA was also compressed into $4 \mathrm{~mm}$ thick solid sheets to produce reference monomodal nanocellular materials.

Table 1. Summary of the material systems used in this work.

\begin{tabular}{ccc}
\hline System & Second phase & $\begin{array}{c}\text { Second phase } \\
\text { amount } \\
\text { (wt\%) }\end{array}$ \\
\hline PMMA & - & - \\
PMMA/MAM & MAM Nanostrength M53 & 0.05 \\
PMMA/SEP & Sepiolite modified with a quaternary ammonium salt & 5 \\
\hline
\end{tabular}

\subsection{Foaming experiments}

Cellular materials for thermal conductivity characterization were produced using a two-step foaming process [51] in a high-pressure vessel (model PARR 4681) provided by Parr Instrument Company. Pressure is controlled via a pressure pump controller (model SFT-10) provided by Supercritical Fluid Technologies Inc. Temperature is provided by a clamp heater controlled with a CAL 3300 temperature controller. Foaming was carried out in a thermal bath with water.

Each system requires different foaming conditions, which are summarized in Table 2. Pure PMMA requires a high saturation pressure (31 $\mathrm{MPa}$ ) to produce nanocellular structures [52], whereas blends with MAM and sepiolites can produce them at a lower pressure (10 MPa). Different foaming temperatures were used with the aim of producing samples with different densities for each type of material. Saturation time was $24 \mathrm{~h}$ for all the experiments.

Table 2. Summary of the foaming experiments.

\begin{tabular}{cccccc}
\hline System & $\begin{array}{c}\text { Saturation } \\
\text { Pressure }(\mathrm{MPa})\end{array}$ & $\begin{array}{c}\text { Saturation } \\
\text { Temperature } \\
\left({ }^{\circ} \mathrm{C}\right)\end{array}$ & $\begin{array}{c}\text { Pressure } \\
\text { Drop Rate } \\
(\mathrm{MPa} / \mathrm{s})\end{array}$ & $\begin{array}{c}\text { Foaming } \\
\text { Temperatures } \\
\left({ }^{\circ} \mathrm{C}\right)\end{array}$ & $\begin{array}{c}\text { Foaming } \\
\text { Time } \\
(\mathrm{min})\end{array}$ \\
\hline PMMA & 31 & 25 & $100 \mathrm{MPa} / \mathrm{s}$ & $60 / 80 / 110$ & 1 \\
PMMA/MAM & 10 & 25 & $15 \mathrm{MPa} / \mathrm{s}$ & $80 / 100$ & 1.5 \\
PMMA/SEP & 10 & 25 & $15 \mathrm{MPa} / \mathrm{s}$ & $80 / 100$ & 1 \\
\hline
\end{tabular}

\subsection{Characterization}

The density of the solid materials $\left(\rho_{s}\right)$ was determined with a gas pycnometer (Mod. AccuPyc II 1340, Micromeritics) and the density of the cellular samples $(\rho)$ was measured using a density determination kit for an AT261 Mettler-Toledo based on Archimedes' principle. Before measuring the density, the solid skin of these foamed samples was removed out with a polisher (model LaboPOI2-LaboForce3, Struers) by removing at least $200 \mu \mathrm{m}$ of each side. Relative density was calculated as the ratio $\rho_{r}=\rho / \rho_{s}$.

The cellular structure was characterized using SEM images from an ESEM Scanning Electron Microscope (QUANTA 200 FEG). A specific software based on ImageJ/FIJI [53] was used for this purpose. Averages cell sizes and cell nucleation density (based on Kumar's theoretical approach [51]) are calculated using image analysis. The cell nucleation density of the bimodal structures needs to be carefully calculated since micro and nanometric pores cannot be quantified in the same image. A detailed explanation about this procedure is given in the Supplementary Information. 
The cell size distribution in the different cellular materials was also determined. Then, a correction that takes into account the area occupied by each class of cells is applied. This correction consists of multiplying the number of cells of a given diameter ( $n_{\text {cell } s, x}$, where $x$ is the cell diameter) times the surface of the cell (that is, times its radius square and $\pi$ ). Equation (12) [42] gives the formula to calculate the frequency relative to the surface for each cell size $x$ :

$$
\text { Frequency relative to the surface } f_{x}(x)=100 \frac{n_{\text {cells }, x} \pi\left(\frac{x}{2}\right)^{2}}{\sum_{x_{i}} n_{\text {cells }, x_{i}} \pi\left(\frac{x_{i}}{2}\right)^{2}}
$$

This correction is needed for accounting for the size of each cell and the corresponding area (or volume, as the surface ratio should be equal to the volume ratio when representative surfaces are analyzed, according to stereology $[46,47]$ ) occupied by each cell size. This is of extreme importance in bimodal cellular structures, with cells in the micro and the nanoscale, since for these systems a standard cell size distribution in which the number of cells for a given size is represented, neglects the contribution of microcells. Furthermore, the relative volume occupied by the population of nanometric cells has been calculated by measuring the area occupied by the micrometric cells (cell size higher than 1 micron) in the SEM images $A_{m}$ and the total area of the image, $A_{t}$, according to Equation (13).

$$
\text { Volume fraction nanometric cells } \mathrm{V}_{\text {nano }}(\%)=100\left(\frac{A_{t}-A_{m}}{A_{t}}\right)
$$

Based on this volume fraction, it is interesting to estimate the relative density of the cellular material without taking into account the microcellular pores. For this calculus, it will be assumed that the gas inside the pores is weightless. Then, the relative density in the nanocellular region can be calculated from the total relative density and the volume fraction of nanocellular pores according to (14).

$$
\rho_{r, \text { nano }}=\frac{\rho_{r}}{V_{\text {nano }}}
$$

Finally, the thermal conductivity of the cellular materials was determined by the Transient Plane Source (TPS) [54] technique using a thermal conductivimeter TPS $2500 \mathrm{~S}$ (Hotdisk). The TPS is a standard technique for the thermal properties characterization of different materials, including PMMA-based micro and nanocellular materials [12]. Measurements were carried out with a TPS sensor of radius $3.189 \mathrm{~mm}$. Before measuring, all the samples were dried in vacuum at $50{ }^{\circ} \mathrm{C}$ overnight to remove the possible moisture. Then, two samples of the same material and density were placed in the experimental set-up. The samples and the experimental set-up were allowed to reach an equilibrium temperature for 30 minutes before the beginning of the measurements. Samples were measured five times with a time span of $20 \mathrm{~min}$ to avoid temperature drift. The measurement time was $40 \mathrm{~s}$ for all samples, whereas the typical power was about 7-9 $\mathrm{mW}$ for the cellular samples and 19-20 $\mathrm{mW}$ for the solid materials.

All the samples for thermal conductivity measurements were analyzed using X-ray radiography to ensure their homogeneity and the lack of internal defects [12]. 


\section{RESULTS AND DISCUSSION: VALIDATION OF THE MODEL}

\subsection{Determination of the structural factor $g$ for nanocellular materials}

As aforementioned, the structural factor $g$ modulating the conductivity of the solid phase is known to be close to 1 for microcellular materials with medium high/density (0.3-0.6) [34] and ranging 0.81 for nanocellular polymers [12] with medium high/density (0.4-0.65). To determine the value of $g$ for nanocellular materials in the range of densities used in this work, the thermal conductivity of three different monomodal nanocellular materials based on PMMA was determined experimentally and compared with the theoretical predictions of the series model (equation 9) for different $g$ values (Figure 4.a). The parallel model provides very similar results. These materials based on PMMA have an average cell size of $220 \mathrm{~nm}$ [47]. It is observed that, at high relative densities, the best fitting is obtained for $g$ smaller than 0.9. Meanwhile, at a medium density, this factor is close to 0.95 , and it increases at lower densities. To determine the structural factor as a function of the relative density, a linear fit between the relative density and the $g$ factor for the three materials is calculated (Figure 4.b).
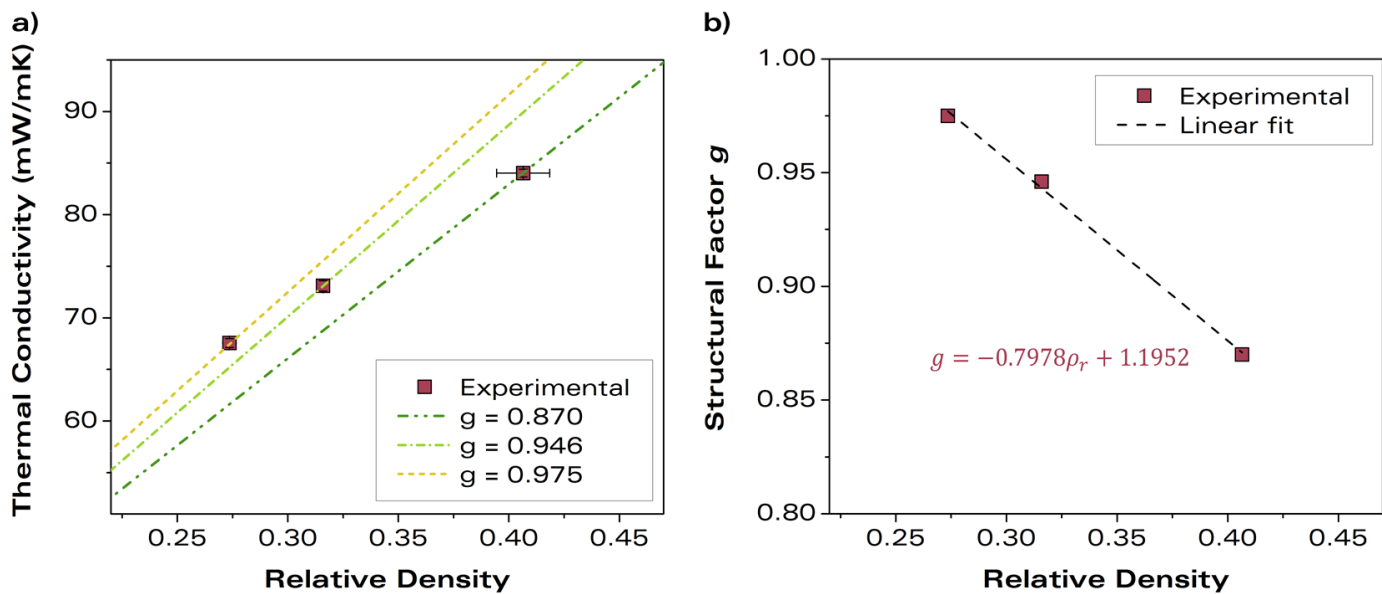

Figure 4. a) Thermal conductivity of the materials based on PMMA: experimental data points and models with different $g$ values, and b) linear fit between the structural factor $g$ and the relative density.

The structural factor $g$ is usually related with both the tortuosity of the material and the possible changes in the conductivity of the solid phase [12]. It is important to determine whether this adjustment of the $g$ factor is only related with structural issues and not with other possible effects like a radiation contribution. Regarding the model, it is also necessary to check if the variations of the $g$ factor depend on the density for the bimodal materials in the same way it does for the pure nanocellular PMMA. This idea was evaluated by studying the electrical conductivity of the samples at medium-high frequencies [55] (Supplementary Information). It was checked that this change in the $g$ factor is only related to structural modifications, and it was also proved that bimodal materials behave in the same way as the pure nanocellular PMMA (see Supplementary Information for more details). Then, it is justified to use the same $g$ values calculated for PMMA at any density and detailed in the previous paragraph when calculating the thermal conductivity of bimodal materials. 


\subsection{System 1: Bimodal micro and nanocellular PMMAMAM}

Figure 5 shows the cellular structure of the materials produced with the blend PMMA/MAM at different foaming temperatures. Bimodal structures, with micro and nanocellular pores, are observed regardless of the foaming conditions. Table 3 summarizes the main characteristic of these cellular materials. It is observed that $85 \%$ of the volume is occupied by nanometric cells, with cells ranging $260-280 \mathrm{~nm}$. Regarding the microcellular population, it is very heterogeneous, with cells of around 2 microns.

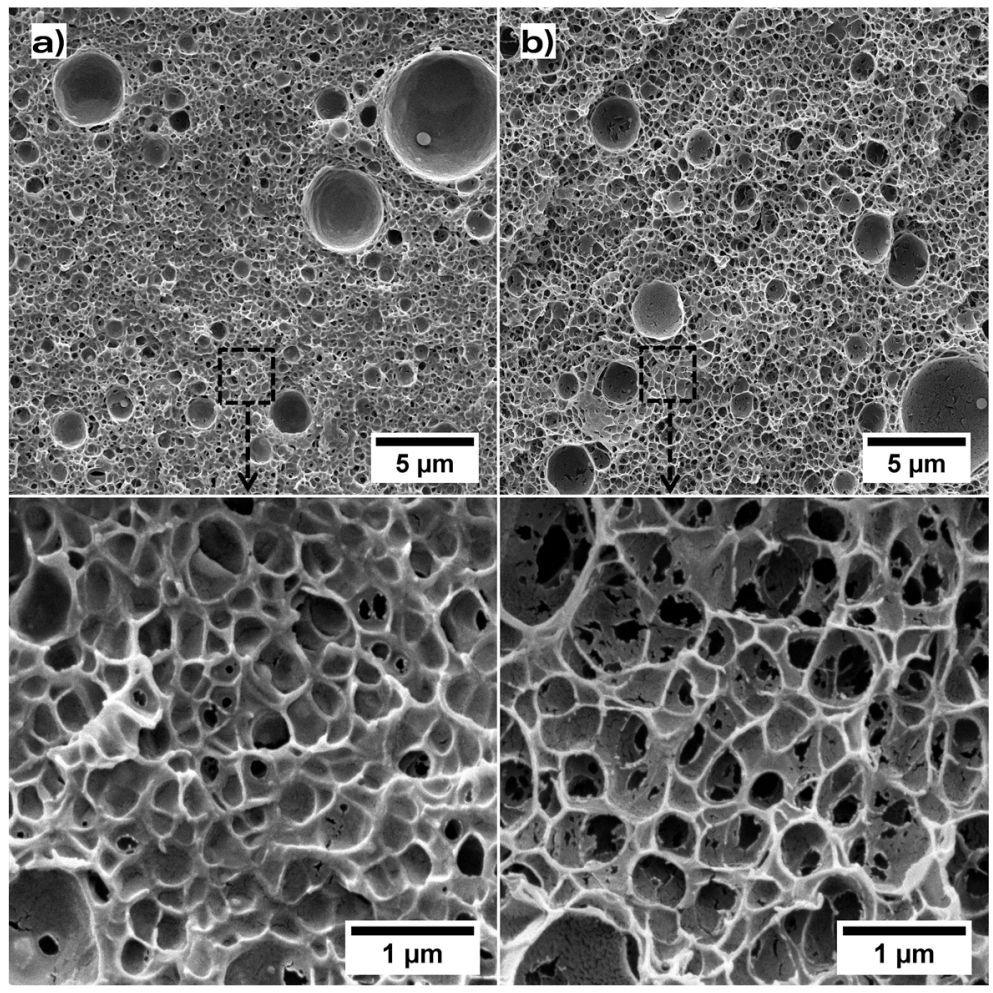

Figure 5. SEM micrographs of the bim odal cellular materials produced with the system PMMA/MAM, foamed at a) $80^{\circ} \mathrm{C}$ and b) $100^{\circ} \mathrm{C}$. The second row corresponds to zoomed images of the first row.

Table 3. Cellular structure characteristics of the samples based on PMMA/MAM.

\begin{tabular}{ccccccc}
\hline $\begin{array}{c}\text { Foaming } \\
\begin{array}{c}\text { Temperature } \\
\left({ }^{\circ} \mathrm{C}\right)\end{array}\end{array}$ & $\begin{array}{c}\text { Relative } \\
\text { Density }\end{array}$ & $\mathrm{V}_{\text {nano }}(\%)$ & $\begin{array}{c}\text { Relative } \\
\text { Density } \\
\text { NANO }\end{array}$ & $\begin{array}{c}\text { Cell Nucleation } \\
\text { Density } \\
(\text { nuclei/cm }\end{array}$ & $\begin{array}{c}\text { Cell Size } \\
\text { MICRO } \\
(\mu \mathrm{m})\end{array}$ & $\begin{array}{c}\text { Cell Size } \\
\text { NANO } \\
(\mathrm{nm})\end{array}$ \\
\hline 80 & 0.35 & 85 & 0.41 & $5.5 \cdot 10^{13}$ & $2.2 \pm 2.1$ & $258 \pm 134$ \\
100 & 0.27 & 86 & 0.32 & $4.7 \cdot 10^{13}$ & $2.1 \pm 1.7$ & $276 \pm 152$ \\
\hline
\end{tabular}

Figure 6 includes the experimental thermal conductivity of these three materials as a function of the relative density, together with the predictions of the models (series and parallel) proposed in this work. In the theoretical calculations, the structural factor in the nanocellular region, $g_{n}$, was considered to vary with density as shown in Figure 4.a and calculated according to the linear fit shown in Figure 4.b (section 5.1). The thermal conductivity of the solid PMMA/MAM material was determined to be equal to $211.3 \mathrm{~mW} / \mathrm{mK}$, which is very similar to that of the pure PMMA. To gain a better understanding of the results provided by the model, three additional theoretical estimations 
have been included in Figure 6. First, the thermal conductivity of a $100 \%$ nanocellular material (named as "NANO") with the density of the nanocellular part (equation (14)) and the cell size of the nanometric region, according to the data of Table 3. If the experimental conductivity would be the same as the theoretical one in the nanocellular region, this will imply that the microcellular pores are not contributing to the heat transfer. That is, that conduction in the gas phase is taking place throughout the nanocellular region and the micrometric pores are isolated. On the other hand, the thermal conductivity of a purely microcellular material was also calculated an included in Figure 6 (bars denoted as "MICRO"). For this calculus the relative density of the whole sample was used, so the comparison is between two systems with the same density: one microcellular and the other bimodal. In the case that the experimental conductivity would approach the "MICRO" value, this will mean that the presence of the nanocellular pores does not reduce the thermal conductivity. Finally, the conventional prediction using equation (5) with the average cell size ("AVERAGE") was also included. For this calculus, the average cell size of the cell size distribution was calculated using the standard average (without taking into account the size of the cells). Given the high number of nanometric cells, the average cell size is only slightly higher to the nanocellular cell size. Then, in this case, the "AVERAGE" prediction underestimates the real thermal conductivity, as it does not consider the significant volume occupied by the micrometric cells. In the Supplementary Information there are more details about all these theoretical estimations.

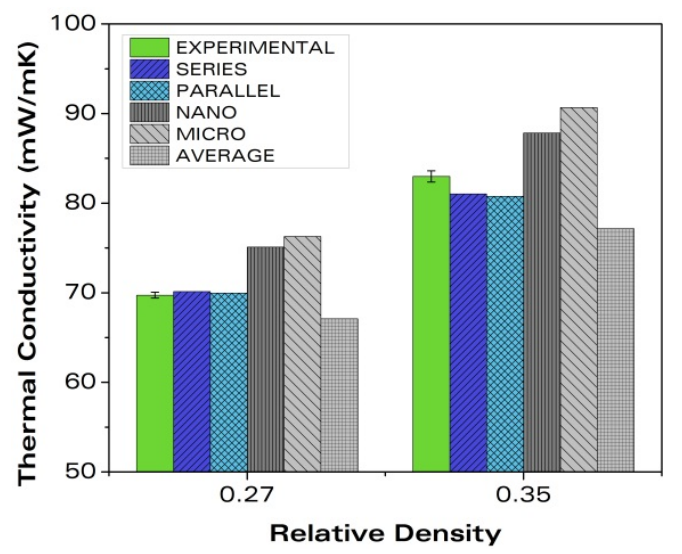

Figure 6. Thermal conductivity of the materials based on PMMA/MAM: experimental values and theoretical predictions.

It is observed that in the density range analyzed both series and parallel models provide similar predictions. Also, these predictions are close to the experimental values, with a difference of less than a $3 \%$, whereas the other predictions (of materials purely nano or microcellular) overestimate the real conductivity from a $4 \%$ to a $10 \%$. These results imply that the models proposed in this work, which take into account the contributions of the different cell sizes to the total thermal conductivity, provide the best approach to quantify the thermal conductivity by conduction of these bimodal nanocellular systems. That is, the bimodal material does not behave as a microcellular material, neither as a nanocellular material with the density of the nanocellular part. Both types of cells must be included in the theoretical calculation of the thermal conductivity, weighted with the relative volume fractions occupied by them. This is a very interesting result, showing that the presence of micrometric cells helps to reduce the conductivity by reducing the density, whereas the Knudsen effect is taking place in the nanometric cells and also contributes to decrease the conductivity. 


\subsection{System 2: Bimodal micro and nanocellular PMMAVSEP}

Figure 7 shows the cellular structure of the second type of bimodal materials analyzed in this work. It is observed that the microcellular population in these PMMA/SEP samples is larger and more heterogeneous than that of PMMA/MAM. Also, the volume fraction occupied by the nanometric cells is smaller (Table 4): $70 \%$ at medium densities and only $57 \%$ in the low-density sample. Regarding the nanocellular population, cell sizes ranging 260-300 $\mathrm{nm}$ are measured. The characteristics of the cellular structure of these materials are summarized in Table 4.

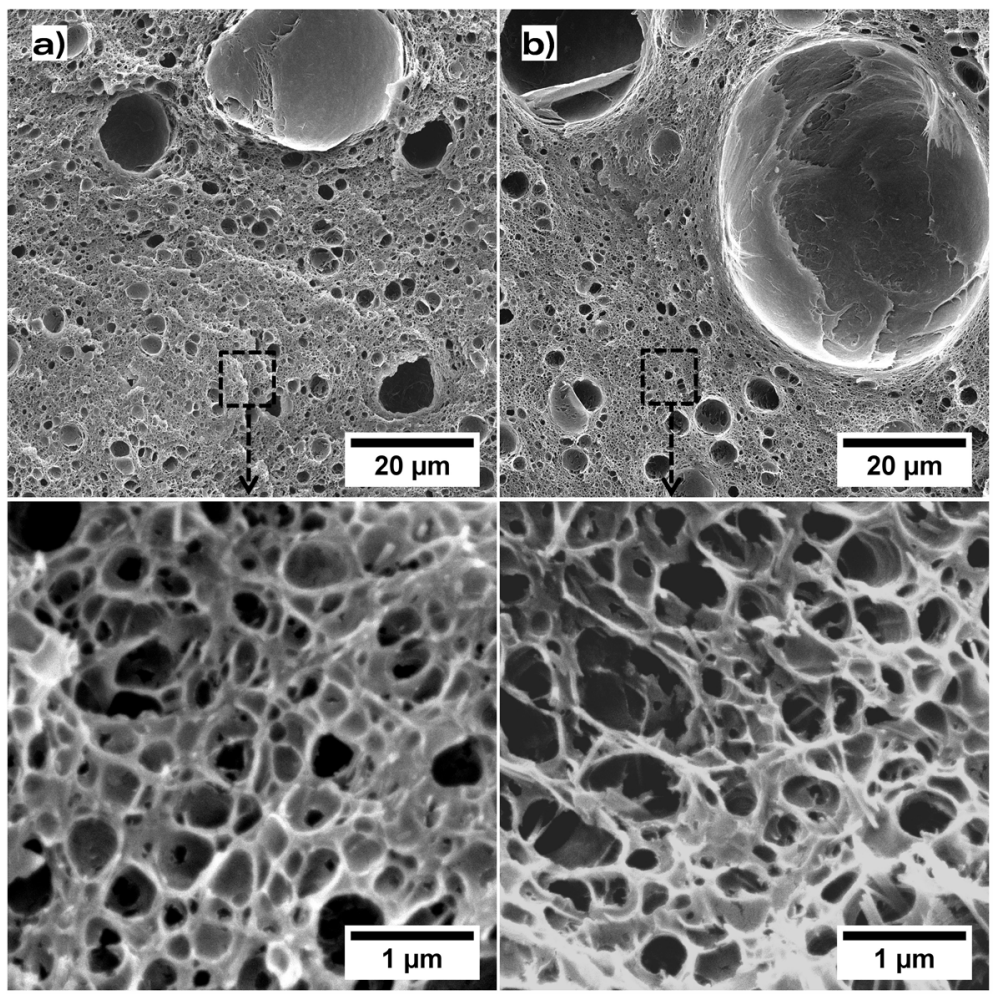

Figure 7. SEM micrographs of the bimodal cellular materials produced with the system PMMA/SEP, foamed at a) $80^{\circ} \mathrm{C}$ and b) $100^{\circ} \mathrm{C}$. The second row corresponds to zoomed images of the first row.

Table 4. Cellular structure characteristics of the samples based on PMMA/SEP.

\begin{tabular}{ccccccc}
\hline $\begin{array}{c}\text { Foaming } \\
\begin{array}{c}\text { Temperature } \\
\left({ }^{\circ} \mathrm{C}\right)\end{array}\end{array}$ & $\begin{array}{c}\text { Relative } \\
\text { Density }\end{array}$ & $\mathrm{V}_{\text {nano }}(\%)$ & $\begin{array}{c}\text { Relative } \\
\text { Density } \\
\text { NANO }\end{array}$ & $\begin{array}{c}\text { Cell Nucleation } \\
\text { Density } \\
\left.(\text { nuclei/cm })^{3}\right)\end{array}$ & $\begin{array}{c}\text { Cell Size } \\
\text { MICRO } \\
(\mu \mathrm{m})\end{array}$ & $\begin{array}{c}\text { Cell Size } \\
\text { NANO } \\
(\mathrm{nm})\end{array}$ \\
\hline 80 & 0.38 & 70 & 0.55 & $3.5 \cdot 10^{13}$ & $2.9 \pm 3.0$ & $260 \pm 140$ \\
100 & 0.29 & 57 & 0.50 & $1.6 \cdot 10^{13}$ & $2.1 \pm 1.7$ & $296 \pm 182$ \\
\hline
\end{tabular}

The experimental thermal conductivity of the samples in Figure 7 is displayed in Figure 8. These values are compared with the predictions of the models proposed in this work (series and parallel). For this system, the structural factor in the nanocellular region, $g_{n}$, was considered to vary with density as in the previous section. In this case, the solid phase (PMMA/SEP nanocomposite) presents a thermal conductivity of $229.3 \mathrm{~mW} / \mathrm{mK}$. This conductivity is higher than that of the PMMA 
or the PMMA/MAM solids due to the addition of the sepiolites. The reference estimations for a purely nanocellular material with the density of the nanocellular region ("NANO") and a completely microcellular material ("MICRO") are also included for the sake of comparison. The prediction of equation (5) calculated with the average cell size ("AVERAGE") is also plotted in Figure 8.

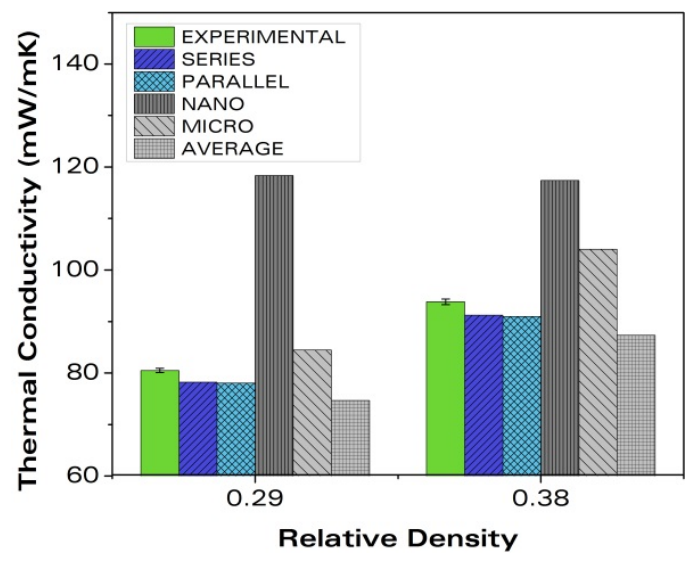

Figure 8. Thermal conductivity of the materials based on PMMA/SEP: experimental values and theoretical predictions.

Once again, the bimodal models present the best match with the experimental results, with differences of around a 3\%. Microcellular materials with the same densities would have higher conductivities, of around $5-10 \%$. In the case of the prediction for a nanocellular material with the density of the nanocellular region, the overestimations are higher than $25 \%$. The prediction with the average cell size also underestimates the conductivity in more than a $6 \%$. It is observed that the results are slightly less accurate than those of the PMMA/MAM system. To further improve the model, the conductivity of the solid polymer matrix in the nanometric cell walls including nanoparticles should be studied in more detail.

The success of the models to predict the thermal conductivity of these bimodal systems show that the assumptions made to elaborate the model are accurate and necessary to predict the thermal conductivity by conduction of these systems correctly. A further step to improve the precision of the model should be to analyze the conductivity of the solid polymer matrix over all the range of densities and cell sizes.

\section{OTHER APPLICATIONS OF THE MODEL}

Up to now, we have proved the validity of the models proposed in this work to predict the thermal conductivity of bimodal systems. However, it could also be used to evaluate the thermal conductivity of monomodal nanocellular materials with a wide cell size distribution, like the one shown in Figure 9.

Figure 10 shows the effect of the ratio width/cell size $(S D / \phi)$ for a nanocellular material with an average cell size of $200 \mathrm{~nm}$ and a relative density of 0.1 . The horizontal line marked as "NANO" represents the prediction of the thermal conductivity by conduction of this system without including the effect of the width of the cell size distribution. For low values of $S D / \phi$, up to 0.1 , both series and parallel model predict the same thermal conductivity of a model with a perfectly 
monodisperse cell size distribution. As $S D / \phi$ grows, the thermal conductivity increases, as the larger cells of the distribution start to play a role. For a value of $S D / \phi=0.5$, that is, a width of 100 $\mathrm{nm}$ with an average cell size of $200 \mathrm{~nm}$, a difference of almost $1.5 \mathrm{~mW} / \mathrm{mK}$ is predicted, that is, an increase of a $4.8 \%$ in the conductivity. Values of $S D / \phi$ of 0.5 and higher are usually detected in nanocellular materials $[47,56,57]$, so this effect is important for the accurate prediction of the thermal conductivity of nanocellular polymers.
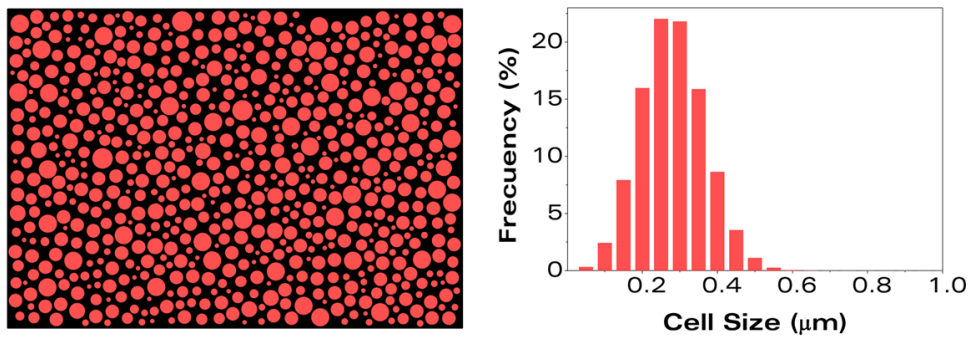

Figure 9. Schematic representation and cell size distribution (corrected with the volume) of a monomodal nanocellular system with a certain width of the cell size distribution.
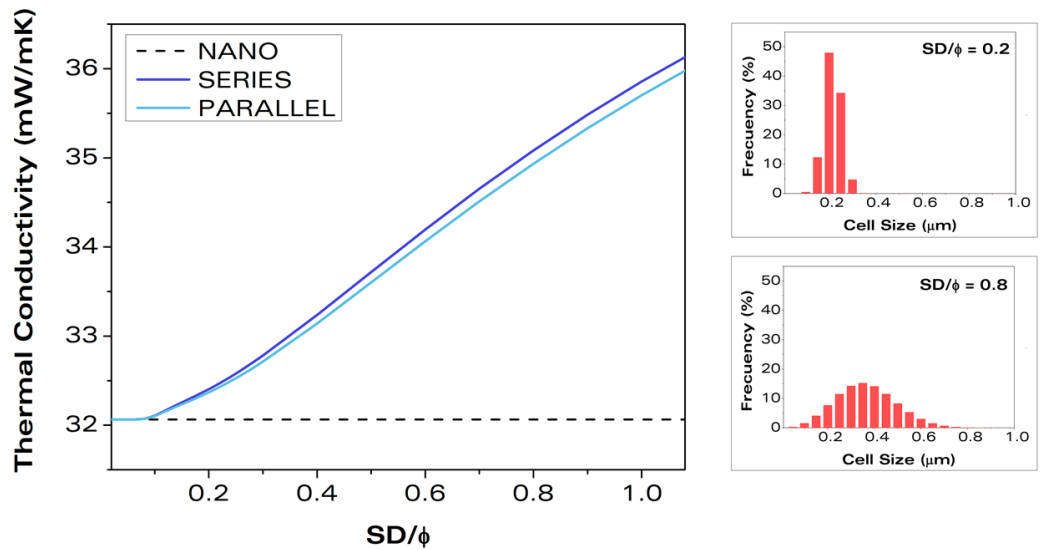

Figure 10. a) Effect of the width of the cell size distribution in the thermal conductivity of a PMMAbased nanocellular polymer with relative density 0.1 and examples of cell size distributions for different $S D / \phi$ ratios: b) $S D / \phi=0.2$ and c) $S D / \phi=0.8$.

In addition, for lower relative densities the effect of a broad cell size distribution would be even more evident, as the gas contribution is higher. Figure 11 represents the percentage of increase in the thermal conductivity by conduction between the classic equation (equation 5) with the average cell size and the model of this work including the effect of the cell size distribution, as a function of both the relative density and $S D / \phi$, in the range of low densities, for the series and the parallel models. The average cell size used in Figure 11 was $200 \mathrm{~nm}$. For instance, at a relative density of 0.05 , a system with $S D / \phi=0.5$ would have a theoretical conductivity by conduction around $8-10 \%$ higher than that predicted using only the average cell size. Therefore, this effect must be taken into consideration when predicting the thermal conductivity of low-density nanocellular materials. 
a)

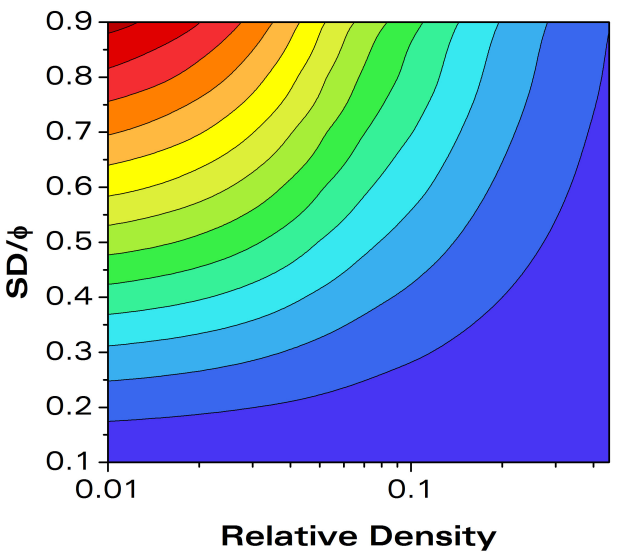

b)

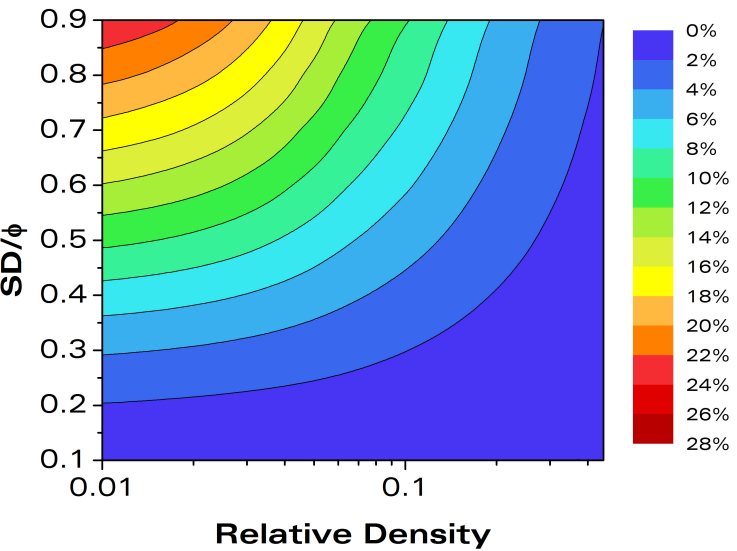

Figure 11. Color map representing the percentage of increase of thermal conductivity compared with a model that does not include the effect of the cell size distribution as a function of the width of the cell size distribution (average cell size $200 \mathrm{~nm}$ ) and the relative density: a) series model and

b) parallel model.

\section{CONCLUSIONS}

In this work, a new model to predict the heat transfer by conduction of bimodal cellular structures with micro and nanometric cell sizes is presented and validated. This model analyzes the conduction mechanisms both through the solid and gas phases and takes into account the volume occupied by each cell size and the Knudsen effect.

The model is based on a circuit analogy and has two different versions: series model, and parallel model. The model differentiates between nanometric cells, that should present Knudsen effect, and micrometric cells, in which this effect does not occur. Also, the structural factor modulating the contribution of the solid phase is also set as a variable that may change between micro and nanocellular materials. The values of these factor in the range of densities under study have been found by thermal and electrical conductivity measurements. The two models predict that the conductivity of a bimodal system would depend strongly on the volume fraction occupied by the nanometric cells. On the other hand, both series and parallel models provide very similar predictions, the parallel prediction being slightly smaller as this model minimizes the effect of the micrometric cells.

The model has been validated by comparing the predictions with the experimental conductivities of two bimodal systems based on PMMA: one with a block-copolymer (MAM) and one with nanoparticles (sepiolites). In both cases, the models proposed in this work provide better estimations of the conductivity than considering the material totally micro or nanocellular. Therefore, it is proved that the hypotheses of the model are valid and necessary to calculate the thermal conductivity of bimodal nanocellular materials. Moreover, it is shown that bimodal nanocellular materials could be interesting from a practical point of view since the presence of microcellular pores allows reducing the density and thermal conductivity by conduction through the solid phase, while nanometric cells contribute to reducing the conductivity through the gas phase. 
In addition, we propose that this model can also be used to predict the thermal conductivity of monomodal nanocellular materials with a wide cell size distribution. The model shows that the width of the distribution strongly affects the thermal conductivity, increasing the value predicted considering only the average cell size. This effect is even more relevant at low densities. Therefore, our model could also be helpful to calculate the thermal conductivity by conduction of nanocellular materials with low density and a wide cell size distribution.

\section{Acknowledgments:}

Financial assistance from MINECO, FEDER, UE (MAT2015-69234-R) and the Junta de Castile and Leon (VA011U16) are gratefully acknowledged. Financial support from FPU grant FPU14/02050 (V. Bernardo) from the Spanish Ministry of Education, Juan de la Cierva-Incorporación grant IJCI-201629992 (J. Pinto) from Spanish MINECO, and Junta of Castile and Leon grant of J. Martín-de León are gratefully acknowledged. We also want to thank Arkema for supplying the copolymer used in this research and the company Tolsa (Madrid, Spain) for supplying the sepiolites of this study.

\section{REFERENCES}

[1] International Energy Agency (IEA), Technology Roadmap. Energy efficient building envelopes, (2013). doi:10.1007/SpringerReference_7300.

[2] P.D. (2017) United Nations Department of Economic and Social Affairs, World Population Prospects: The 2017 Revision, Methodology of the United Nations Population Estimates and Projections, (2017).

[3] M.A. Rodriguez-Perez, Crosslinked polyolefin foams: Production, structure, properties, and applications, Adv. Polym. Sci. 184 (2005) 97-126. doi:10.1007/b136244.

[4] D. Eaves, Handbook of Polymer Foams, Rapra Technology, United Kingdom, 2004.

[5] L.J. Gibson, M. Ashby, Cellular solids: structure and properties, 2nd Editio, Cambridge University Press, 1997.

[6] B. Wicklein, A. Kocjan, G. Salazar-Alvarez, F. Carosio, G. Camino, M. Antonietti, L. Bergström, Thermally insulating and fire-retardant lightweight anisotropic foams based on nanocellulose and graphene oxide, Nat. Nanotechnol. 10 (2014) 277-283. doi:10.1038/nnano.2014.248.

[7] C. V. Vo, R.T. Fox, Assessment of hydrofluoropropenes as insulating blowing agents for extruded polystyrene foams, J. Cell. Plast. 49 (2013) 423-438. doi:10.1177/0021955X13488398.

[8] C. V. Vo, F. Bunge, J. Duffy, L. Hood, Advances in thermal insulation of extruded polystyrene foams, Cell. Polym. 30 (2011) 137-156.

[9] B. Notario, J. Pinto, M.A. Rodriguez-Perez, Nanoporous polymeric materials: A new class of materials with enhanced properties, Prog. Polym. Sci. 78-79 (2016) 93-139. doi:10.1016/j.pmatsci.2016.02.002.

[10] European Commission, Horizon 2020 Work Programme 2014 - 2015 Science with and for Society Revised, 2015.

[11] J. Pinto, M. Dumon, M.A. Rodriguez-Perez, Nanoporous Polymer Foams from Nanostructured Polymer Blends: Preparation, Characterization, and Properties, in: P.. Visakh, G. Markovic, D. Pasquini (Eds.), Recent Dev. Polym. Macro, Micro Nano Blends, Woodhead Publishing in Materials, 2016: pp. 237-288.

[12] B. Notario, J. Pinto, E. Solorzano, J.A. de Saja, M. Dumon, M.A. Rodriguez-Perez, Experimental validation of the Knudsen effect in nanocellular polymeric foams, Polymer (Guildf). 56 (2015) 57-67. doi:10.1016/j.polymer.2014.10.006.

[13] L.W. Hrubesh, R.W. Pekala, Thermal properties of organic and inorganic aerogels, J. Mater. Res. 9 (1994) $731-$ 738. doi:10.1557/JMR.1994.0731.

[14] X. Lu, R. Caps, J. Fricke, C.T. Alviso, R.W. Pekala, Correlation between structure and thermal conductivity of organic aerogels, J. Non. Cryst. Solids. 188 (1995) 226-234. doi:10.1016/0022-3093(95)00191-3. 
[15] L. Grassberger, K. Koch, R. Oberhoffer, A. Müller, H.F.M. Klemmer, R. Strey, Blowing agent free generation of nanoporous poly ( methylmethacrylate ) materials, Colloid Polym. Sci. 295 (2017) 379-389. doi:10.1007/s00396-017-4012-1.

[16] G. Wang, J. Zhao, L.H. Mark, G. Wang, K. Yu, C. Wang, C.B. Park, G. Zhao, Ultra-tough and super thermalinsulation nanocellular PMMA/TPU, Chem. Eng. J. 325 (2017) 632-646. doi:10.1016/j.cej.2017.05.116.

[17] C. Forest, P. Chaumont, P. Cassagnau, B. Swoboda, P. Sonntag, Polymer nano-foams for insulating applications prepared from CO 2 foaming, Prog. Polym. Sci. 41 (2015) 122-145. doi:10.1016/j.progpolymsci.2014.07.001.

[18] S.S. Sundarram, W. Li, On Thermal Conductivity of Micro- and Nanocellular Polymer Foams, Polym. Eng. Sci. 53 (2013). doi:10.1002/pen.

[19] G. Wang, C. Wang, J. Zhao, G. Wang, C.B. Park, G. Zhao, Modelling of thermal transport through a nanocellular polymer foam: Toward the generation of a new superinsulating material, Nanoscale. 9 (2017) 5996-6009. doi:10.1039/c7nr00327g.

[20] A.N. Paquet, K.W. Suh, United States Patent - FLEXIBLE BIMODAL FOAM STRUCTURES, 5,332,761, 1988

[21] A.N. Paquet, K.W. Suh, United States Patent - CARBON BLACK-CONTAINING BIMODAL FOAM STRUCTURES AND PROCESS FOR MAKING, 5,210,105, 1993

[22] K.M. Lee, E.K. Lee, S.G. Kim, C.B. Park, H.E. Naguib, Bi-cellular foam structure of polystyrene from extrusion foaming process, J. Cell. Plast. 45 (2009) 539-553. doi:10.1177/0021955X09343632.

[23] C. Zhang, B. Zhu, D. Li, L.J. Lee, Extruded polystyrene foams with bimodal cell morphology, Polymer (Guildf). 53 (2012) 2435-2442. doi:10.1016/j.polymer.2012.04.006.

[24] K.A. Arora, A.J. Lesser, T.J. McCarthy, Preparation and characterization of microcellular polystyrene foams processed in supercritical CO2, Macromolecules. 38 (1997) 446-447. doi:10.1021/ma971811z.

[25] C. Zeng, N. Hossieny, C. Zhang, B. Wang, Synthesis and processing of PMMA carbon nanotube nanocomposite foams, Polymer (Guildf). 51 (2010) 655-664. doi:10.1016/j.polymer.2009.12.032.

[26] G. Luo, X. Gu, J. Zhang, R. Zhang, Q. Shen, M. Li, L. Zhang, Microstructural, mechanical, and thermal-insulation properties of poly(methyl methacrylate)/silica aerogel bimodal cellular foams, J. Appl. Polym. Sci. 134 (2017) 1-7. doi:10.1002/app.44434.

[27] D. Miller, V. Kumar, Fabrication of Microcellular HDPE Foams in a Sub-Critical CO2 Process, Cell. Polym. 28 (2009) 25-40. doi:10.1177/026248930902800102.

[28] D. Schmidt, V.I. Raman, C. Egger, C. du Fresne, V. Schädler, Templated cross-linking reactions for designing nanoporous materials, Mater. Sci. Eng. C. 27 (2007) 1487-1490. doi:10.1016/j.msec.2006.06.028.

[29] P. Gong, G. Wang, M.P. Tran, P. Buahom, S. Zhai, G. Li, C.B. Park, Advanced bimodal polystyrene/multi-walled carbon nanotube nanocomposite foams for thermal insulation, Carbon N. Y. 120 (2017) 1-10. doi:10.1016/j.carbon.2017.05.029.

[30] N.C. Hilyard, A. Cunningham, Low density cellular plastics--Physical basis of behaviour, Chapman and Hall, London, 1994.

[31] M. Alvarez-Lainez, M.A. Rodríguez-Pérez, J.A. de Saja, Thermal Conductivity of Open-Cell Polyolefin Foams, J. Polym. Sci. Part B Polym. Phys. 46 (2008) 212-221. doi:10.1002/polb.

[32] R.J.J. Williams, C.M. Aldao, Thermal conductivity of plastic foams, Polym. Eng. Sci. 23 (1983) 293-298. doi:10.1002/pen.760230602.

[33] L.R. Glicksman, Heat transfer in foams, in: N.C. Hilyard, A. Cunningham (Eds.), Low Density Cell. Plast., Springer, Dordrecht, 1994: pp. 104-152. doi:10.1007/978-94-011-1256-7_5.

[34] M. Saadatfar, C.H. Arns, M.A. Knackstedt, T. Senden, Mechanical and transport properties of polymeric foams derived from 3D images, Colloids Surfaces A Physicochem. Eng. Asp. 263 (2005) 284-289. doi:10.1016/j.colsurfa.2004.12.040.

[35] M. Knudsen, The Kinetic Theory of Gases, Methuen, London, 1934.

[36] S. Song, M.M. Yovanovich, F.O. Goodman, Thermal Gap Conductance of Conforming Surfaces in Contact, J. Heat Transfer. 115 (1993) 533-540. doi:10.1115/1.2910719.

[37] P. Ferkl, R. Pokorný, M. Bobák, J. Kosek, Heat transfer in one-dimensional micro- and nano-cellular foams, Chem. Eng. Sci. 97 (2013) 50-58. doi:10.1016/j.ces.2013.04.018.

[38] N.G. Hadjiconstantinou, The limits of Navier-Stokes theory and kinetic extensions for describing small-scale 
gaseous hydrodynamics The limits of Navier-Stokes theory and kinetic extensions for describing small-scale gaseous hydrodynamics, Phys. Fluids. 18 (2006) 111301. doi:10.1063/1.2393436.

[39] P.G. COLLISHAW, J.R.G. EVANS, An Assessment of Expressions for the Apparent Thermal-Conductivity of Cellular Materials, J. Mater. Sci. 29 (1994) 2261-2273. doi:10.1007/BF00363413.

[40] Z. Li, C. Zhu, X. Zhao, A theoretical and numerical study on the gas-contributed thermal conductivity in aerogel, Int. J. Heat Mass Transf. 108 (2017) 1982-1990. doi:10.1016/j.ijheatmasstransfer.2017.01.051.

[41] J. Nassios, Kinetic theory of rarefied gas flows with modern applications, Aust. Math. Soc. Gaz. 40 (2013) 50.

[42] V. Bernardo, J. Martin-de León, E. Laguna-Gutiérrez, M.Á. Rodríguez-Pérez, PMMA-sepiolite nanocomposites as new promising materials for the production of nanocellular polymers, Eur. Polym. J. 96 (2017) 10-26. doi:10.1016/j.eurpolymj.2017.09.002.

[43] A.G. Leach, The thermal conductivity of foams. I: Models for heat conduction, J. Phys. D. Appl. Phys. 26 (1993) 733-739. doi:10.1088/0022-3727/26/5/003.

[44] D.M. Bigg, Thermal Conductivity of Heterophase Polymer Compositions, Adv. Polym. Sci. 119 (1995) 1-29.

[45] Z. Han, A. Fina, Thermal conductivity of carbon nanotubes and their polymer nanocomposites: A review, Prog. Polym. Sci. 36 (2011) 914-944. doi:10.1016/j.progpolymsci.2010.11.004.

[46] T. Kawasaki, S. Kawai, Thermal insulation properties of wood-based sandwich panel for use as structural insulated walls and floors, J. Wood Sci. 52 (2006) 75-83. doi:10.1007/s10086-005-0720-0.

[47] J. Martin de-Leon, V. Bernardo, M.A. Rodriguez-Perez, Low Density Nanocellular Polymers Based on PMMA Produced by Gas Dissolution Foaming: Fabrication and Cellular Structure Characterization, Polymers (Basel). 8 (2016) 1-16. doi:10.3390/polym8070265.

[48] K. Kurabayashi, M. Asheghi, M. Touzelbaev, K.E. Goodson, Measurement of the thermal conductivity anisotropy in polyimide films, IEEE J. Microelectromechanical Syst. 8 (1999) 180-191. doi:10.1109/84.767114.

[49] N. García, J. Guzman, E. Benito, A. Esteban-Cubillo, E. Aguilar, J. Santaren, P. Tiemblo, Surface Modification of Sepiolite in Aqueous Gels by Using Methoxysilanes and Its Impact on the Nanofiber Dispersion Ability, Langmuir. 27 (2011) 3952-3959. doi:10.1021/la104410r.

[50] J. Santaren, A. Alvarez, A. Esteban-Cubillo, B. Notario, D. Velasco, M.A. Rodriguez-Perez, Improving the Cellular Structure and Thermal Conductivity of PS Foams by Using Sepiolites, in: Foams2012, 2012: pp. 1-5.

[51] V. Kumar, N.P. Suh, A process for making microcellular parts, Polym. Eng. Sci. 30 (1990) 1323-1329. doi:https://doi.org/10.1002/pen.760302010.

[52] J. Pinto, M. Dumon, M. Pedros, J. Reglero, M.A. Rodriguez-Perez, Nanocellular CO2 foaming of PMMA assisted by block copolymer nanostructuration, Chem. Eng. J. 243 (2014) 428-435. doi:10.1016/j.cej.2014.01.021.

[53] J. Pinto, E. Solorzano, M.A. Rodriguez-perez, J.A. De Saja, Characterization of the cellular structure based on user-interactive image analysis procedures, J. Cell. Plast. 49 (2013) 555-575. doi:10.1177/0021955X13503847.

[54] A. International, D 5930 - 01: Standard Test Method for Thermal Conductivity of Plastics by Means of a Transient Line-Source Technique, (n.d.). doi:10.1520/D5930-09.

[55] J. Pinto, B. Notario, R. Verdejo, M. Dumon, S. Costeux, M.A. Rodriguez-perez, Molecular confinement of solid and gaseous phases of self-standing bulk nanoporous polymers inducing enhanced and unexpected physical properties, Polymer (Guildf). 113 (2017) 27-33. doi:10.1016/j.polymer.2017.02.046.

[56] C. Forest, P. Chaumont, P. Cassagnau, B. Swoboda, P. Sonntag, Nanofoaming of PMMA using a batch CO2 process: Influence of the PMMA viscoelastic behaviour, Polymer (Guildf). 77 (2015) 1-9. doi:10.1016/j.polymer.2015.09.011.

[57] V. Bernardo, J. Martin-de Leon, E. Laguna-Gutierrez, T. Catelani, J. Pinto, A. Athanassiou, M.A. Rodriguez-Perez, Understanding the role of MAM molecular weight on the production of PMMA/MAM nanocellular polymers, Polymer (Guildf). 153 (2018) 262-270. doi:10.1016/j.polymer.2018.08.022. 


\section{Supplementary Information:}

\section{Modeling the heat transfer by conduction of nanocellular polymers with bimodal cellular structures}

Victoria Bernardo*1, Judith Martin-de Leon', Javier Pinto', Raquel Verdejo², Miguel Angel Rodriguez-Perez ${ }^{1}$

1. Cellular Materials Laboratory (CellMat), Condensed Matter Physics Department, University of Valladolid, Campus Miguel Delibes, Paseo de Belén n7, 47011 Valladolid, Spain 2. Institute of Polymer Science and Technology (ICTP-CSIC), Juan de la Cierva, 3, Madrid 28006, Spain *Corresponding author: Victoria Bernardo (vbernardo@fmc.uva.es) +34 983184035

\section{CALCULATION OF THE CELL NUCLEATION DENSITY IN A BIMODAL STRUCTURE}

The cell nucleation density of the bimodal structures needs to be carefully calculated, since micro and nanometric pores cannot be quantified in the same image. The procedure we use consists on counting the number of nanometric cells $\left(n_{n}\right)$ in a small area $a_{n}$ (high magnification image, Figure S1.a). Then, we calculate the number of micrometric pores $\left(N_{m}\right)$ in a low magnification image (Figure S1.b). In this second image, the micro pores occupy a certain area $\left(A_{m}\right)$ and we know that the remaining area is occupied by the nanometric pores $\left(A_{n}\right)$. With a simple rule of three we calculate the number of nanometric pores in this remaining area $\left(N_{n}\right)$ (Figure S1.c). Then, the number of total pores in the low magnification image is the number of microcellular pores $N_{m}$ plus the number of nanometric pores $N_{n}$ in the area $A_{n}$ (Figure S1.d). Then, cell density can be calculated as usual from the number of pores and the area, and cell nucleation density is estimated from the cell density and the relative density (Figure S1.d). As a consequence of the high number of nanometric pores per microcellular one, these parameters are only slightly smaller than those obtained in the nanocellular region.

a)

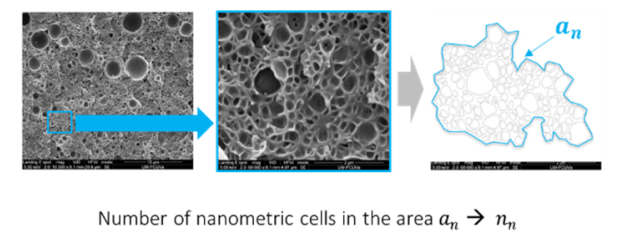

c)

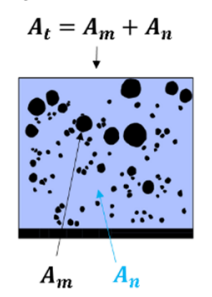

In an area $a_{n} \rightarrow n_{n}$ nanometric cells

In an area $A_{n} \rightarrow N_{n}$ nanometric cells

$$
N_{n}=\frac{A_{n} n_{n}}{a_{n}}
$$

b)

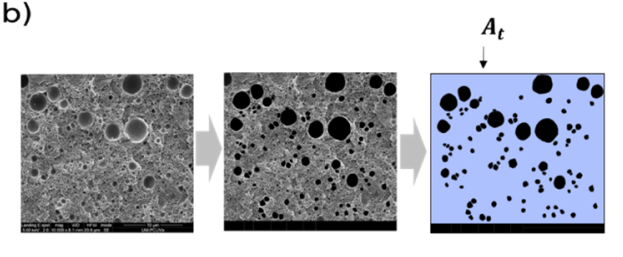

Number of micrometric cells in the total area $A_{t} \rightarrow N_{m}$

d)

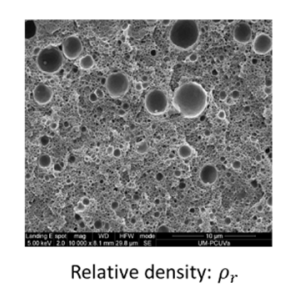

Total numer of cells in $A_{t}$ :

$\rightarrow N_{t}=N_{m}+N_{n}$

Cell Density: $N_{v}=\left(\frac{N_{t}}{A_{t}}\right)^{3 / 2}$

Cell Nucleation Density:

$$
\boldsymbol{N}_{o}=\frac{\boldsymbol{N}_{v}}{\boldsymbol{\rho}_{r}}
$$

Figure S1. Procedure to calculate the cell nucleation density in a bimodal system with micro and nanometric cells. 


\section{ON THE PREDICTIONS OF THE MODEL AND ITS IMPLICATIONS}

To evaluate the predictions of the new model proposed in this work, they were compared with different theoretical estimations using the conventional equations for microcellular and nanocellular materials (equations (S1) and (S2), respectively).

$$
\begin{gathered}
\lambda_{t}=g_{m} \lambda_{s}^{\prime} \rho_{r}+\lambda_{g 0}^{\prime}\left(1-\rho_{r}\right) \\
\lambda_{t}=g_{n} \lambda_{s}^{\prime} \rho_{r}+\frac{\lambda_{g 0}^{\prime}}{1+\frac{2 \beta l_{g}}{\phi}}\left(1-\rho_{r}\right)
\end{gathered}
$$

Where $\lambda_{g 0}^{\prime}$ is the thermal conductivity of the gas inside the pores, $\lambda_{s}^{\prime}$ is the thermal conductivity of the solid polymer, $g_{m}$ and $g_{n}$ are the structural factors for micro and nanocellular materials, $\rho_{r}$ is the relative density, $\phi$ is the cell size, $\beta$ is a factor correlating the energy transfer between gas molecules and the structure and $l_{g}$ is the mean free path of the gas molecules (see the main article for more details about the equations).

The real bimodal system is described in Figure S2.a. This system is characterized by its relative density $\rho_{r}$ and its cell size distribution. This cell size distribution consists of two distributions, micro and nanocellular, each of them with a certain width and with an average cell size, $\phi_{m}$ and $\phi_{n}$, respectively. To calculate the conductivity of such a system, two approaches can be followed. First, use the model proposed in this work. Second, simplify the real system in less complex situations and calculate the thermal conductivity in any case. These simplified models have some assumptions that can shed light into the heat transfer mechanisms involved in these kind of systems. Three different models are used to calculate the thermal conductivity and compare it with the experimental data and the predictions of the new model (Figure S2 b), c) and d)) have been used:

\section{a) NANO (Figure S2.b)}

This model attempts to isolate the effect of the nanometric cells in the bimodal cellular material. That is, it assumes that the microcellular pores are not present in the sample and calculates the thermal conductivity predicted by equation (S2) using the average cell size in the nanocellular region, $\phi_{n}$. However, it should be noticed that the presence of the microcellular pores reduces the density of the material. Then, to completely eliminate the effect of the micrometric cells, the density of the nanocellular region, $\rho_{r, \text { nano }}$, must be calculated using the following equation:

$$
\rho_{r, \text { nano }}=\frac{\rho_{r}}{V_{\text {nano }}}
$$

Where $V_{\text {nano }}$ is the volume fraction occupied by the nanometric cells.

\section{a) MICRO (Figure S2.c)}

The other extreme situation is to eliminate the effect of the nanometric cells. In this case, we assume a purely microcellular material formed by cells of the same size as the microcellular cells of the bimodal material, $\phi_{m}$. The relative density used is the density of the bimodal material and 
the thermal conductivity is calculated using equation (S1). These assumptions neglect the presence of the nanometric cells.

\section{b) AVERAGE (Figure S2.d)}

In the other two previous situations, the bimodal cellular material was assumed to behave as a pure nano or microcellular material. This last theoretical estimation takes into account the real cell size distribution, with micro and nanometric cells, but does not consider the relative volumes occupied by each population of cells. In this case, the cell size was calculated as the average cell size of all the distribution, $\phi_{\text {average }}$. Given the high number of nanometric cells in comparison with the micrometric cells, it has been observed that $\phi_{\text {average }}$ is only slightly higher than $\phi_{n}$. As the cell size is in the nanometric range, equation (S2) is used for calculating the thermal conductivity. This estimation is the usual way of calculating the thermal conductivity and does not take into consideration that the volume occupied by the micrometric cells is significant.
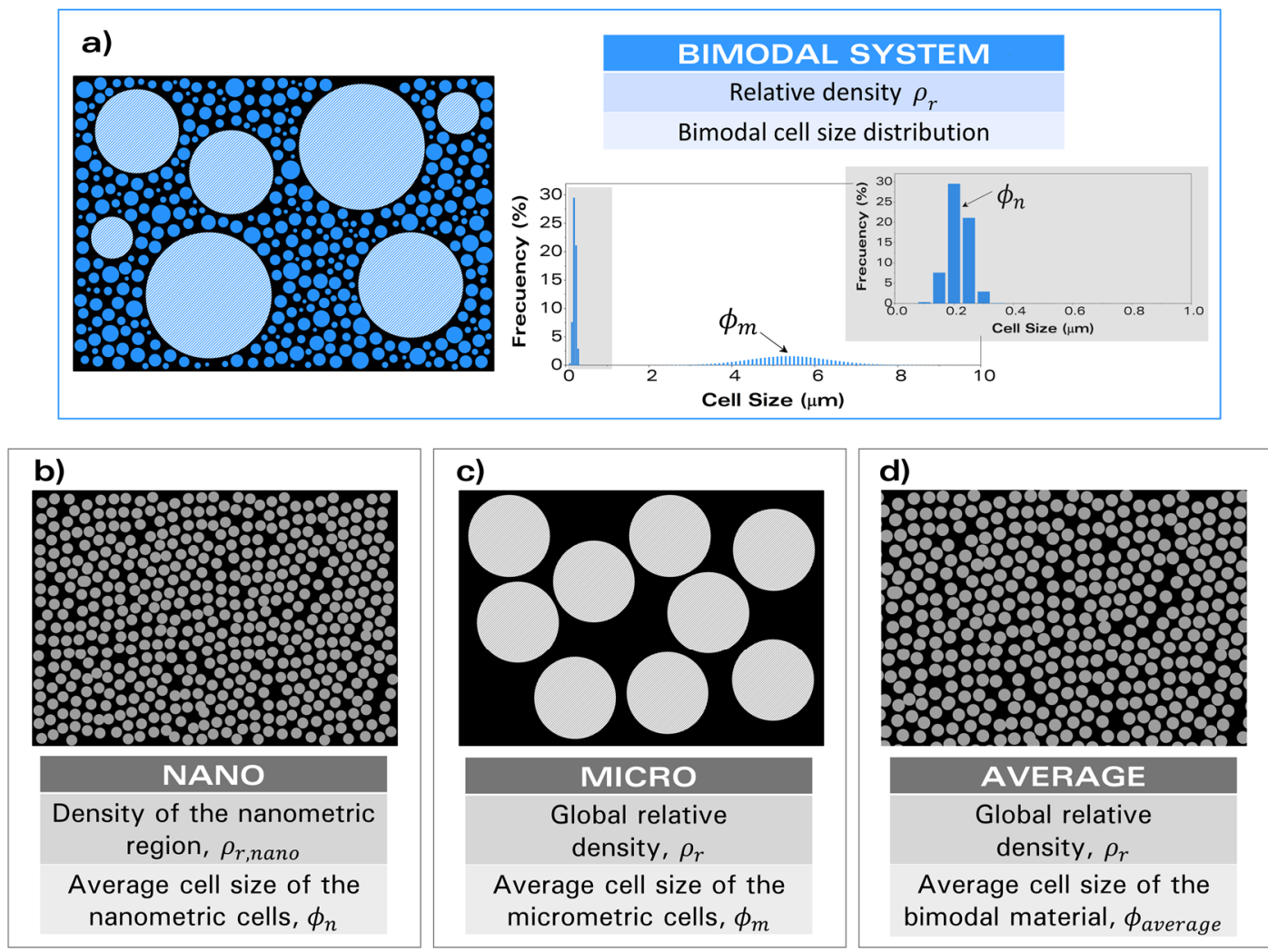

Figure S2. a) Bimodal cellular material with two populations of cells, micro and nanocellular, and simplified models to theoretically estimate the thermal conductivity: a) nano, b) micro and c) average.

Throughout the paper, it has been proved that none of the previous models describes the real situation. That is, a bimodal system does not behave as a pure nano or microcellular material. Both micro and nanometric cells play a key role in the transmission of heat by conduction through the bimodal material, and they should be taken into account by weighting their contributions with the volume fraction occupied by them. 


\section{ELECTRICAL CONDUCTIVITY MEASUREMENTS}

Measuring the electrical conductivity of a cellular material is a suitable technique to study the polymer matrix, as it only depends on the polymer itself and its structure (tortuosity of the solid phase), at least at medium-high frequencies, where there is no Maxwell Wagner Sillars (MWS) effect [1]. Therefore, measuring the electrical conductivity as a function of the density and comparing the results with the trends observed for the thermal conductivity is a good way to evaluate if the $g$ factor is solely related to the polymer matrix, and its structure or other factors not considered in the model (like radiation) are playing a role.

\subsection{Experimental}

The structural modifications observed in the thermal conductivity of nanocellular materials are analyzed by performing broadband dielectric spectroscopy (BDS) to determine the electrical conductivity [1]. These measurements were performed on an ALPHA high-resolution dielectric analyzer using the same samples used for measuring the thermal conductivity. Samples were held in the dielectric cell between two parallel gold-plated electrodes. The thickness of the samples (around $4 \mathrm{~mm}$ ) was taken as the distance between the electrodes and measured using a micrometer gauge.

The dielectric response was determined by measuring the complex capacity over a frequency range window of $10^{-1}$ to $10^{7} \mathrm{~Hz}$ at room temperature. The amplitude of the alternating current (ac) electric signal applied to the samples was $1 \mathrm{~V}$. To compare the results of the different material systems, a frequency of $10^{4} \mathrm{~Hz}$ was selected as representative.

\subsection{Results}

Figure S3 shows de electrical conductivity of the different materials used in this work, together with some previous data on micro and nanocellular samples from the work of Pinto et al. [1]. The dashed line in Figure S2 corresponds to the linear fit of the electrical conductivity of the microcellular materials as a function of the relative density. It is observed that for relative densities lower than 0.3 , the electrical conductivity of the samples of this work follows the trend line of the microcellular materials. Reglero-Ruiz and coworkers determined a structural factor of $g=1$ for microcellular samples [2]. Then, it is proved that at low density, nanocellular PMMA materials and PMMA-based bimodal systems show a structural factor close to 1 . As density increases from 0.27 , the experimental data points of the electrical conductivity of the materials with nanometric does not follow the trend of the microcellular materials. That is, the electrical conductivity is smaller than it should be, confirming the result that $g$ values smaller than 1 should be used for higher densities. Also, the higher the density, the greater the difference with the microcellular line, and thus the smaller the $g$ value, as already commented in section 5.1. Therefore, electrical conductivity measurements confirm the trends observed in the thermal conductivity and support the hypothesis of varying the structural factor with the density. 


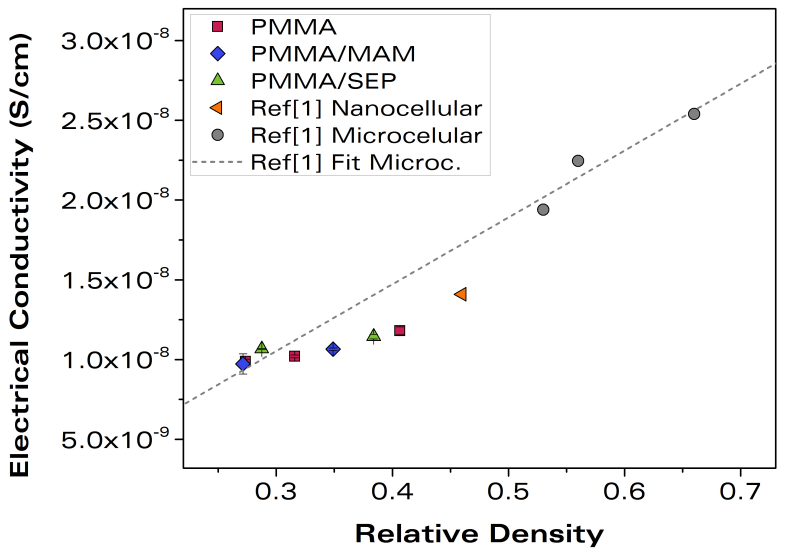

Figure S3. The electrical conductivity of the different material systems used in this work and literature data from [1].

These results confirm that the change in the $g$ factor is related with the polymer matrix and its structure (tortuosity) in the cellular material, and not with other possible effects.

\section{REFERENCES}

[1] J. Pinto, B. Notario, R. Verdejo, M. Dumon, S. Costeux, M.A. Rodriguez-perez, Molecular confinement of solid and gaseous phases of self-standing bulk nanoporous polymers inducing enhanced and unexpected physical properties, Polymer (Guildf). 113 (2017) 27-33. doi:10.1016/j.polymer.2017.02.046.

[2] J.A. Reglero Ruiz, C. Saiz-Arroyo, M. Dumon, M.A. Rodríguez-Perez, L. Gonzalez, Production, cellular structure and thermal conductivity of microcellular (methyl methacrylate)-(butyl acrylate)-(methyl methacrylate) triblock copolymers, Polym. Int. 60 (2011) 146-152. doi:10.1002/pi.2931. 
Chapter 8.

\section{Conclusions and Future Work}





\section{Chapter 8. Conclusions and Future Work}

\subsection{Conclusions}

The scientific papers presented in this thesis have allowed reaching several important conclusions relevant in the field of nanocellular polymers. The main conclusions of each topic are summarized in the following paragraphs:

\subsubsection{Fabrication of PMMA/Sepiolites nanocellular polymers}

About the surface modification of the particles:

- The addition of $0.5 \mathrm{wt} \%$ of sepiolites modified with a quaternary ammonium salt (S-QAS) allows obtaining nanometric cells in PMMA. On the other hand, the addition of natural sepiolites (non-modified) and sepiolites modified with a silane in the same concentration (0.5 wt\%) do not produce any nucleating effect in PMMA (Chapter 4, section 4.2).

- A similar dispersion of the particles is observed in SEM for the different surface modifications, so we conclude that the interaction of the quaternary ammonium salt with the $\mathrm{CO}_{2}$ is responsible for promoting the nucleation in the composites with the sepiolites modified with this salt (Chapter 4, section 4.2).

- The structures produced with the sepiolites modified with this salt are bimodal. As a result of the well-dispersed sepiolites, nanometric pores appear, whereas the presence of micron-sized aggregates of the particles causes the appearance of microcellular pores.

- The higher the amount of quaternary ammonium salt, the better the dispersion in the PMMA matrix for a particle content of $1.5 \mathrm{wt} \%$ (Chapter 4, section 4.3). As a result, higher salt contents lead to greater nucleating effects. Particularly, nucleation is almost doubled (from 5 to $9 \cdot 10^{13}$ nuclei $/ \mathrm{cm}^{3}$ ) when the salt content increases from $9.5 \mathrm{wt} \%$ to $20.5 \mathrm{wt} \%$. Also, the fraction of micrometric cells is reduced from $88 \%$ to $79 \%$ for the highest salt content. Further, the sole addition of the quaternary ammonium salt also causes some modifications in the cellular structure of PMMA, increasing the nucleation in one order of magnitude, although it does not induce the presence of nanometric pores.

- None of the sepiolite particles used was detected to absorb $\mathrm{CO}_{2}$.

About the concentration of sepiolites:

- The increase of the sepiolite S-QAS concentration from 0.5 to $10 \mathrm{wt} \%$ increases the nucleation density from $10^{13}$ nuclei/ $/ \mathrm{cm}^{3}$ to more than $10^{14}$ nuclei/ $\mathrm{cm}^{3}$, whereas cell size is reduced from around 500 to less than $200 \mathrm{~nm}$ (see for instance Chapter 6, section 6.3).

- Bimodal structures are found at every particle concentration, but there is a dependency on the amount of particles. At very small particle amounts ( $0.5 \mathrm{wt} \%$ and $1 \mathrm{wt} \%)$ the fraction of nanometric pores is low (50-60\%). At medium contents of sepiolites ( $1.5 \mathrm{wt} \%$ to $3 \mathrm{wt} \%$ ), the fraction of nanometric pores ranges from 70 to $90 \%$, so particle dispersion is slightly improved. However, when particle content increases further, the fraction of nanometric 
pores is reduced. At concentrations of $5 \mathrm{wt} \%$, it is around $60-70 \%$, whereas at the highest particle concentration investigated, $10 \mathrm{wt} \%$, the nanocellular population counts only for a volume fraction ranging from 50 to $60 \%$. We attribute this effect to a poorer dispersion of the sepiolites at high particle concentrations.

About the saturation pressure:

- In the range from 10 to $30 \mathrm{MPa}$ of saturation pressure, the nucleation in the PMMA/Sepiolite nanocomposites is independent of the saturation pressure (Chapter 4, section 4.2).

- At $6 \mathrm{MPa}$, nucleation is observed to be slightly smaller than in the range from 10 to $30 \mathrm{MPa}$ at the same foaming conditions, so slightly higher cell sizes are obtained (Chapter 6 , section 6.3). Particularly, for a particle content of $1.5 \mathrm{wt} \%$, cell size in the nanocellular region is around $400 \mathrm{~nm}$ at $6 \mathrm{MPa}$, whereas at $10 \mathrm{MPa}$ the cell size is approximately $300 \mathrm{~nm}$.

- However, over the whole range of pressures (from $6 \mathrm{MPa}$ to $30 \mathrm{MPa}$ ) the nucleation in the PMMA/Sepiolites is much higher than in the pure PMMA, so heterogeneous nucleation in the sepiolites is dominating the nucleation process within this range of pressures. Therefore, it is possible to produce these materials in a wide range of pressures.

About the foaming conditions:

- Increasing foaming temperature from 80 to $110^{\circ} \mathrm{C}$ allows a relative density reduction from 0.27 to $0.15,0.18$ and 0.21 for the samples with $0.5,1$ and $1.5 \mathrm{wt} \%$ of S-QAS, respectively (Chapter 4, section 4.2). However, this density reduction is at the expenses of increasing the cell size. For instance, for a particle content of $1.5 \mathrm{wt} \%$, the cell size increases from $300 \mathrm{~nm}$ to almost $500 \mathrm{~nm}$ when the foaming temperature goes from $80^{\circ} \mathrm{C}$ to $110^{\circ} \mathrm{C}$. The cell nucleation density is also observed to be reduced, so we concluded that the cell size increases due to coalescence. The presence of the particles can promote cell wall rupture in these systems.

- Foaming in a hot press allows producing flat samples suitable for mechanical characterization (Chapter 7, section 7.2), but the structures obtained are in general less homogeneous, and the nucleation densities are smaller than those obtained in a thermal bath, maybe due to a poorer heat transfer. For instance, for a particle content of $1 \mathrm{wt} \%$, nucleation in the thermal bath is $3 \cdot 10^{13}$ nuclei $/ \mathrm{cm}^{3}$ and the cell size in the nanocellular region is $395 \mathrm{~nm}$, whereas in the hot press the nucleation is $1 \cdot 10^{13}$ and the cell size is 460 $\mathrm{nm}$.

About the anisotropy:

- The production of solid filaments in an extruder allows obtaining aligned sepiolites in the solid precursors. The presence of oriented particles induces coalescence during foaming in the extrusion direction, and as a result, the cellular structures produced with these materials present anisotropic cellular structures (Chapter 4, section 4.3).

- Higher particle contents allow reaching higher anisotropy ratios (from 1.38 to 2.15 for materials with 1.5 to $10 \mathrm{wt} \%$ of S-QAS) (Chapter 4, section 4.3). 
The investigations on this topic and the conclusions summarized here fulfill the objectives specified in Figure 1.7 (Chapter 1) for the PMMA/sepiolites systems. First of all, nanocellular polymers based on PMMA/sepiolite blends have been produced for the first time, and the effect of the surface modification and the concentration of sepiolites has been investigated and understood. Moreover, the influence of the processing parameters was also analyzed, and it was possible to produce anisotropic nanocellular polymers thanks to the alignment of the sepiolites. Figure 8.1 summarizes all the results about the fabrication of PMMA/Sepiolites nanocellular polymers that can be found in the papers of Chapter 4 (chapter section included in the legend). Also, the materials based on these systems used in the papers of Chapter 6 and Chapter 7 have been included in this graph. A wide range of cell sizes, relative densities, and cell nucleation densities have been obtained with these systems. Cell sizes from 200 to $800 \mathrm{~nm}$ with relative densities ranging from 0.15 to 0.5 have been produced (Figure 8.1.a), whereas cell nucleation densities in the range from $10^{13}$ to $3 \cdot 10^{14}$ nuclei/ $\mathrm{cm}^{3}$ have been achieved (Figure 8.1.b).

Moreover, these PMMA/Sepiolites systems allow obtaining nanocellular polymers in a wide range of pressures, from 6 to $30 \mathrm{MPa}$, and more specifically, at very low pressures (6 MPa) and using room temperature as saturation temperature (Chapter 6, section 6.3).

a)

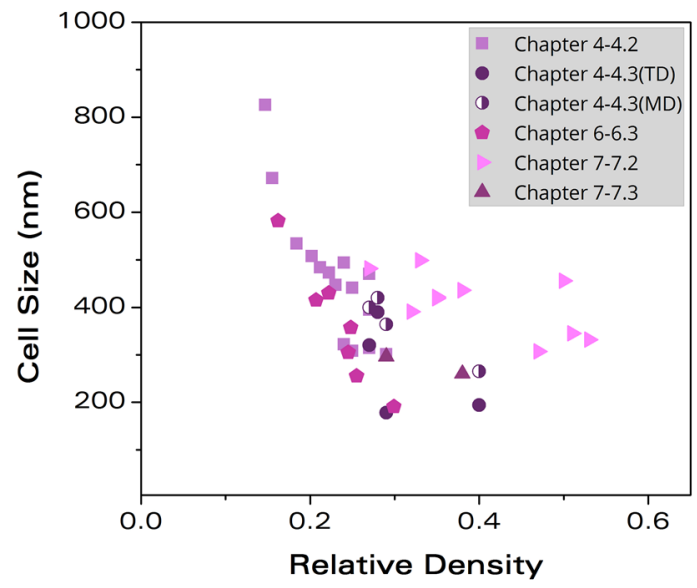

b)

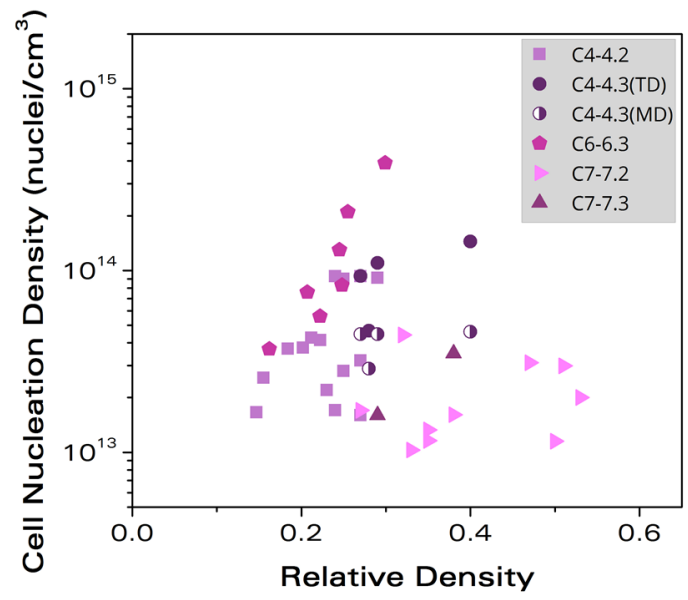

Figure 8.1. a) Cell size as a function of the relative density and b) cell nucleation density as a function of the relative density for the materials based on PMMA/Sepiolites. All these materials present bimodal structures with micrometric pores, but the cell size (Figure 8.1.a) corresponds to the nanocellular part, whereas the cell nucleation density (Figure 8.1.b) is that on the complete

structure. In the systems presenting anisotropic structures, the structures of both planes (machine direction (MD) and traverse direction (TD)) are presented.

\subsubsection{Fabrication of PMMA/MAM nanocellular polymers}

About the molecular weight of MAM:

- Increasing the molecular weight of MAM at a fixed PBA ratio (around a $50 \mathrm{wt} \%$ ) results in an increase of the micelle density in the solid PMMA/MAM blends at any MAM concentration (from 0.1 to $10 \mathrm{wt} \%$ ). The micelle density is a result of the dispersion of the MAM in the PMMA during the extrusion process and the later self-assembly of the 
copolymer molecules to form the micelles. The higher the molecular weight, the higher the viscosity, and thus, the smaller the micelles and the higher the micelle density. For instance, at $10 \mathrm{wt} \%$ of MAM, increasing molecular weight from 46 to $128 \mathrm{~kg} / \mathrm{mol}$ allows increasing the micelle density from 2 to $8 \cdot 10^{14}$ micelles $/ \mathrm{cm}^{3}$ (Chapter 5 , section 5.2). At a smaller MAM concentration ( $0.5 \mathrm{wt} \%$ of MAM), the same change in molecular weight results in an increase of the micelle density from 2 to $8 \cdot 10^{13}$ micelles $/ \mathrm{cm}^{3}$ (Chapter 5 , section 5.3).

- As a consequence of the micelle density, higher MAM molecular weights produce structures with higher nucleation density (i.e., the nanostructuration controls the nucleation). At $10 \mathrm{wt} \%$ of MAM, nucleation density and micelle density are good correlated (Chapter 5, section 5.2).

- The intermicelle distance controls the cell size, because the nucleation takes places within the micelle, and the space to grow is just the distance between micelles. Thus, at lower molecular weights, the intermicelle distance is higher, and so is the cell size. At $10 \mathrm{wt} \%$ of MAM, increasing molecular weight from 46 to $128 \mathrm{~kg} / \mathrm{mol}$ allows decreasing the cell size from 200 to $120 \mathrm{~nm}$ (Chapter 5, section 5.2).

- The presence of micelles is a limiting factor for the expansion in these materials. The micelles are restricted to grow spherically, and they grow until a minimum cell wall thickness is reached, so at that moment the expansion stops.

- Lower MAM molecular weights allow reaching higher expansions because the mechanisms explained above. At $10 \mathrm{wt} \%$ of MAM, increasing molecular weight from 46 to $128 \mathrm{~kg} / \mathrm{mol}$ allows decreasing the relative density from 0.57 to 0.37 using the same saturation and foaming conditions (Chapter 5, section 5.2).

- The absorption of $\mathrm{CO}_{2}$ is enhanced when MAM is added, but no effect of the molecular weight was detected.

About MAM concentration:

- Reducing the amount of copolymer (from $10 \mathrm{wt} \%$ to $0.1 \mathrm{wt} \%$ ) leads to a decrease of the micelle density at any MAM molecular weight. For instance, for the MAM with the highest molecular weight, the micelle density is reduced from $8 \cdot 10^{14}$ to $4 \cdot 10^{12}$ micelles $/ \mathrm{cm}^{3}$ when the MAM concentration is reduced from $10 \mathrm{wt} \%$ to $0.1 \mathrm{wt} \%$ (Chapter 5 , section 5.3).

- As a result, a decrease in the concentration of MAM causes a reduction of the nucleation density and an increase of the cell size. Following the example above, the cell nucleation density with that copolymer is reduced from 9 to $2 \cdot 10^{14}$ nuclei/ $/ \mathrm{cm}^{3}$ for MAM contents ranging $10 \mathrm{wt} \%$ to $0.1 \mathrm{wt} \%$, whereas cell size increases from 120 to $260 \mathrm{~nm}$ (Chapter 5 , section 5.3).

- In the systems with very low MAM contents ( 0.5 and $0.1 \mathrm{wt} \%$ ), nucleation can also take place in aggrupations of MAM molecules that are not forming a micelle. This is supported by the nucleation density being higher than micelle density in these materials (Chapter 5 , section 5.3).

- The relative density can be reduced by decreasing the amount of MAM. This is possible because nucleation is no longer occurring in the micelles, but in some MAM-rich dispersed domains, so the organization of the molecules is not restricting the growth. As a result, cells can grow in any shape, and the relative density is reduced by reducing the fraction of mass 
in the struts. With the same MAM copolymer of the previous examples (highest molecular weight), relative density is reduced from 0.57 to 0.29 due to the reduction of the amount of MAM from 10 to $0.1 \mathrm{wt} \%$ (Chapter 5, section 5.3).

- Very low MAM fractions (0.05 wt\%) lead to bimodal cellular structures (Chapter 7, section 7.3). We hypothesize that this is due to an insufficient amount of MAM that cannot be uniformly distributed in the PMMA matrix. As a result, in the regions where there are no MAM molecules, the nucleation is controlled by the PMMA matrix, and micrometric cells appear.

About the effect of the foaming temperature:

- Foaming temperature does not affect nucleation at any MAM concentration and molecular weight (Chapter 5, section 5.3).

- An increase of the foaming temperature in systems with high MAM content does not produce any effect because the micelle geometry restricts cell growth (Chapter 5, section 5.2).

- However, at low MAM concentrations, increasing the foaming temperature from 60 to 100 ${ }^{\circ} \mathrm{C}$ promotes cell growth and a reduction of the relative density. For the sample with 0.1 $w t \%$ of the MAM copolymer with an intermediate molecular weight, increasing foaming temperature reduces density from 0.42 to 0.23 . Again, this is due to the nucleation taking place in aggrupations of MAM molecules instead of in the micelles. This strategy allows obtaining low relative density (0.23) nanocellular polymers (cell size $350 \mathrm{~nm}$ ) using PMMA/MAM blends (Chapter 5, section 5.3).

About the effect of the saturation pressure:

- At low saturation pressure (6 $\mathrm{MPa}$ ) nanocellular polymers based on PMMA/MAM can be still obtained using low (0.1 wt \%) and high (10 wt \%) MAM concentrations (Chapter 6, section 6.3). In general, the reduction in the saturation pressure from 10 to $6 \mathrm{MPa}$ does not have any effect in the nucleation. However, for the copolymer with the lowest molecular weight at small contents $(0.1 \mathrm{wt} \%)$, the reduction in the saturation pressure increases the cell size from 650 to $870 \mathrm{~nm}$. In this particular material, all the nucleation takes place in MAM domains (there are not micelles), and for this reason, the saturation pressure has a more significant effect.

The research about the use of PMMA/MAM blends and the conclusions summarized here fulfill the objectives specified in Figure 1.7 (Chapter 1) for these systems. The influence of the MAM molecular weight and concentration has been investigated. Further, the mechanisms limiting the expansion in these PMMA/MAM blends have been identified and finally overcome by producing low-density nanocellular polymers with this approach for the first time. Figure 8.2 summarizes all the results about the fabrication of PMMA/MAM nanocellular polymers that can be found in the publications of Chapter 5 (chapter section included in the legend). The materials based on PMMA/MAM of Chapter 6 and Chapter 7 have also been included in this plot. Cell sizes from 120 to $800 \mathrm{~nm}$ with relative densities ranging 0.17 to 0.6 have been produced (Figure 8.1.a), whereas cell nucleation densities from $10^{13}$ to $10^{15}$ nuclei/ $/ \mathrm{cm}^{3}$ have been reached (Figure 8.1.b). 
Furthermore, these PMMA/MAM systems allows obtaining nanocellular polymers in a wide range of pressures, from 6 to $30 \mathrm{MPa}$, and more specifically, at very low pressures ( $6 \mathrm{MPa}$ ) and using room temperature as saturation temperature (Chapter 6, section 6.3).

a)

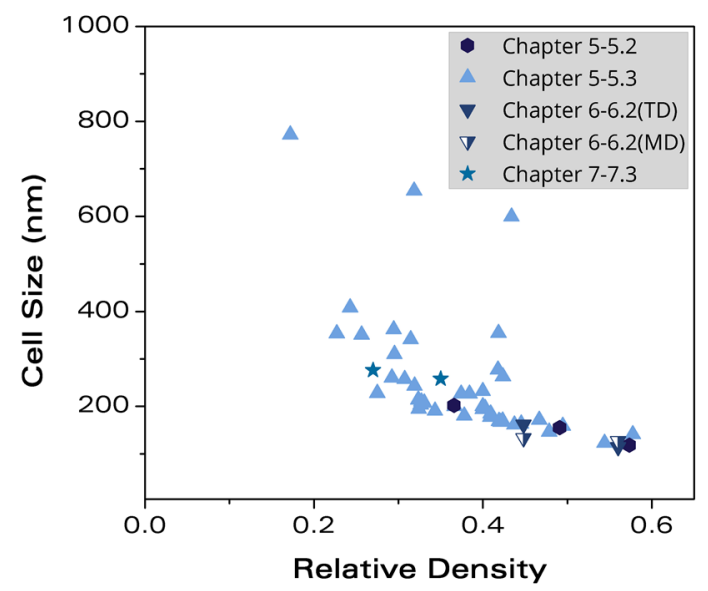

b)

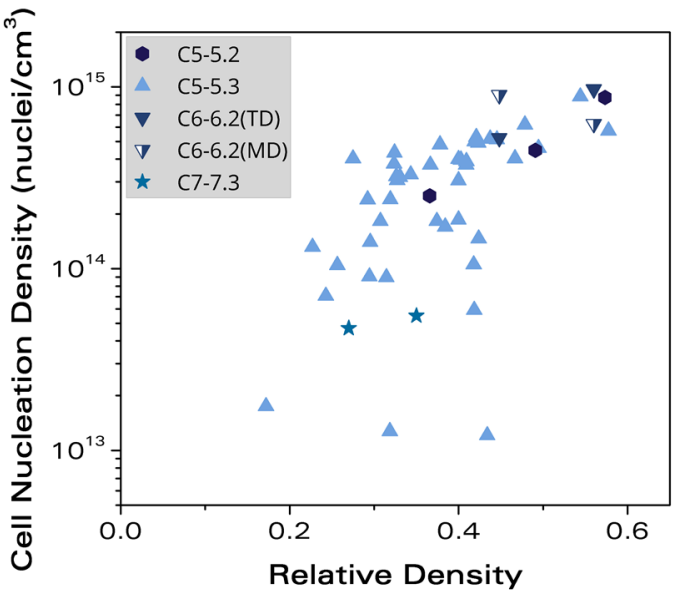

Figure 8.2. a) Cell size as a function of the relative density and b) cell nucleation density as a function of the relative density for the materials based on PMMA/MAM. In the systems presenting anisotropic structures, the structures of both planes (machine direction (MD) and traverse direction (TD)) are presented.

\subsubsection{Fabrication of PMMAVTPU nanocellular polymers}

About the addition of TPU:

- PMMA and TPU are immiscible. As a result, the addition of $2 \mathrm{wt} \%$ of TPU to PMMA results in the formation of nanometric TPU domains well dispersed in the PMMA matrix. Volumetric domain density is about $10^{13}$ domains $/ \mathrm{cm}^{3}$, whereas the domain size is around $90 \mathrm{~nm}$ (Chapter 5, section 5.4).

- The PMMA/TPU foamed samples present a gradient cellular structure, with a homogeneous nanocellular core in the center of the sample (roughly a $16 \%$ of the total volume of the sample), and a transition to a microcellular structure in the border. This effect was not observed in other filament samples prepared with other nucleating agents, as those foamed in Chapter 4 (section 4.3) or Chapter 6 (section 6.2).

- In the nanocellular core, TPU acts as an efficient nucleating agent for producing nanocellular PMMA by increasing the nucleation density in three orders of magnitude at $15 \mathrm{MPa}$ of saturation pressure. The nucleation density is similar to the volumetric TPU domain density, so the TPU nanostructuration controls the nucleation. The cell size obtained in the nanocellular core at these conditions is $400 \mathrm{~nm}$ (Chapter 5, section 5.4).

- There is a density gradient in the samples, the nanocellular core being denser than the outer transition region. The difference in density between the nanocellular core and the complete sample is around $10-20 \%$ (Chapter 5, section 5.4). 
About the saturation pressure:

- Saturation pressure has a significant effect on the nucleation: reducing the pressure below $10 \mathrm{MPa}$ causes that the structure is no longer nanocellular, but microcellular and heterogeneous. Increasing the saturation pressure from 10 to $20 \mathrm{MPa}$ slightly increases the cell density in the PMMA/TPU samples, both in the nanocellular core and in the microcellular transition region (Chapter 5 , section 5.4).

- Then, the nucleation in the TPU domains is not predominant at any condition but depends on the saturation pressure. Therefore, PMMA/TPU is a more complex system than the other two analyzed so far, because the behavior is not only controlled by the polymeric matrix morphology.

- This dependence of the nucleation with the saturation pressure explains the presence of a gradient structure in the PMMA/TPU nanocellular samples. Between the release of pressure and the foaming step there is a time interval of 2 minutes, and during this time some gas is diffusing out the sample. Therefore, in the PMMA/TPU samples, there is a pressure gradient when the foaming starts. As the nucleation in the TPU phase is not predominant at every pressure, only in the region with constant pressure there is a homogeneous structure, whereas the pressure gradient in the edges results in gradient nucleation, causing a graded cellular structure.

- This explanation is in agreement with our previous results with other filaments based on PMMA/Sepiolites (Chapter 4, section 4.3) and PMMA/MAM and PMMA/MAM/Sepiolites (Chapter 6, section 6.2) that did not present such graded structure, because in those blends nucleation is predominant even at low pressures (Chapter 6 , section 6.3).

About the foaming parameters:

- Foaming temperature does not seem to have a significant effect on the nucleation process in the core of the samples, but at $100^{\circ} \mathrm{C}$ the nanocellular core occupies a higher fraction of the sample.

- At $90^{\circ} \mathrm{C}$, an increase in the foaming time from 0.5 to 2 minutes causes a significant reduction of the relative density (from 0.30 to 0.16 in the core), but at the same time the cell size increases from 350 to $480 \mathrm{~nm}$ because of cell coalescence (Chapter 5, section 5.4).

- At $100{ }^{\circ} \mathrm{C}$, a similar effect is observed between 0.5 and 1 minute, but at 2 minutes the density is no longer reduced and the cell size keeps increasing (Chapter 5 , section 5.4).

- Thus, a precise adjustment of the foaming parameters is critical to control the structure and density of these PMMA/TPU materials.

The objectives set in Figure 1.7 (Chapter 1) for the study of PMMA/TPU systems have been achieved with the results summarized here. The effect of the addition of TPU has been evaluated, and the influence of the processing parameters has been investigated as well. It was possible to produced graded nanocellular polymers thanks to the addition of TPU and its pressure-dependent nucleation. Also, low-density graded nanocellular polymers (relative density $0.16-0.3$ and cell sizes from 310 to $480 \mathrm{~nm}$ in the nanocellular core) have been obtained. Figure 8.3 collects the results obtained with the PMMA/TPU system (publication in Chapter 5, chapter section included in the legend of Figure 8.3). 
As a general remark, the combination of a low viscosity PMMA matrix with TPU seems to be a promising route towards low-density nanocellular polymers, but several issues need to be yet overcome to take advantage of this strategy.

a)

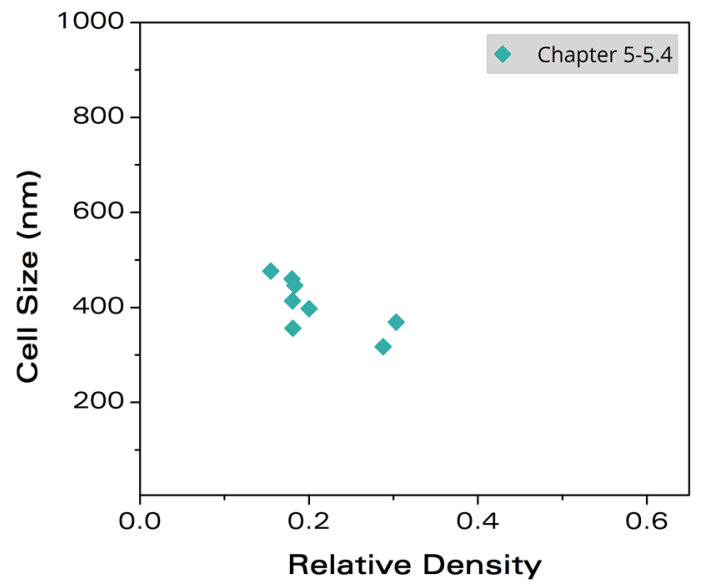

b)

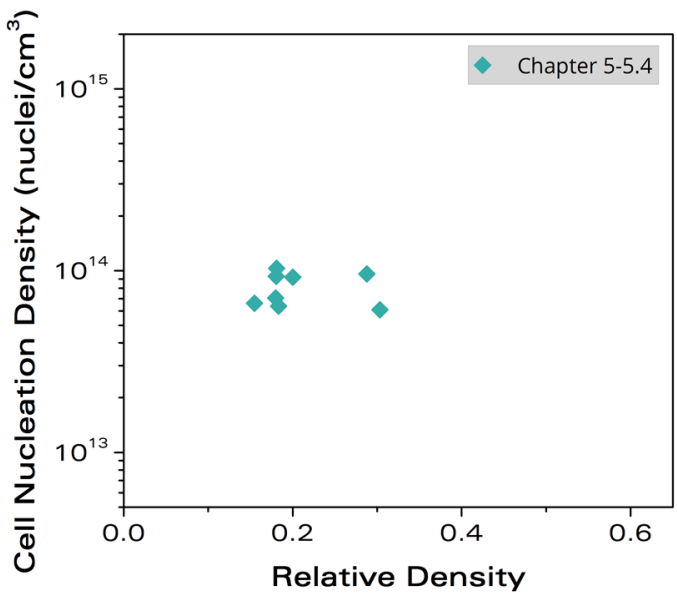

Figure 8.3. a) Cell size as a function of the relative density and b) cell nucleation density as a function of the relative density for the materials based on PMMA/TPU. All these materials present a gradient cellular structure with a homogeneous nanocellular core; the parameters presented in

Figure 8.3 corresponds to the nanocellular core.

\subsubsection{Fabrication of PMMA/MAM/Sepiolites nanocellular polymers}

About the nucleation on each phase:

- At low MAM content (1 wt $\%)$, the addition of $1.5 \mathrm{wt} \%$ of sepiolites reduces the nucleation density. From the other point of view, in a system with $1.5 \mathrm{wt} \%$ of particles, the addition of $1 \mathrm{wt} \%$ of MAM increases the nucleation. That is, an intermediate behavior between the effects of the two additives isolated is observed in the tri-phasic system, meaning that none of the nucleants dominates at these concentrations and conditions (Chapter 6, section 6.2).

- At high MAM content (10 wt $\%$ ) with $1.5 \mathrm{wt} \%$ of sepiolites, the nucleation is controlled by the MAM phase. The high density of nanometric MAM micelles is controlling the nucleation, and at the same time limits the expansion (Chapter 6, section 6.2).

About the bimodality:

- The addition of MAM reduces the fraction of micrometric cells present in the systems with sepiolites. In particular, in the sample with $10 \mathrm{wt} \%$ of MAM and $1.5 \mathrm{wt} \%$ of sepiolites, the amount of micron-sized pores is almost eliminated (Chapter 6, section 6.2).

About the anisotropy:

- At low MAM content (1 wt\%) the addition of sepiolites aligned in the extrusion direction induces the formation of anisotropic cells in that direction. Anisotropic ratios of 1.48 are obtained. However, the anisotropy is smaller than that obtained with solely the sepiolites (anisotropy ratio equal to 1.88) (Chapter 6, section 6.2). 
- At high MAM content (10 wt\%), the alignment of the micelles in the extrusion direction already caused some anisotropy in the structure (anisotropy ratio equal to 1.71), but the addition of sepiolites oriented in the same direction promotes this effect, and anisotropy ratios as high as 2.77 are obtained (Chapter 6, section 6.2).

The analysis of PMMA/MAM/sepiolite systems fulfill the objectives established in Figure 1.7 (Chapter 1). The effect of the addition of sepiolites in the nucleation of a PMMA/MAM matrix has been analyzed. Also, highly anisotropic nanocellular materials (cell sizes 100-200 nm and anisotropy ratio higher than 2.7) have been produced. Figure 8.4 collects the results obtained with these systems (publication in Chapter 6, chapter section included in the legend).

a)

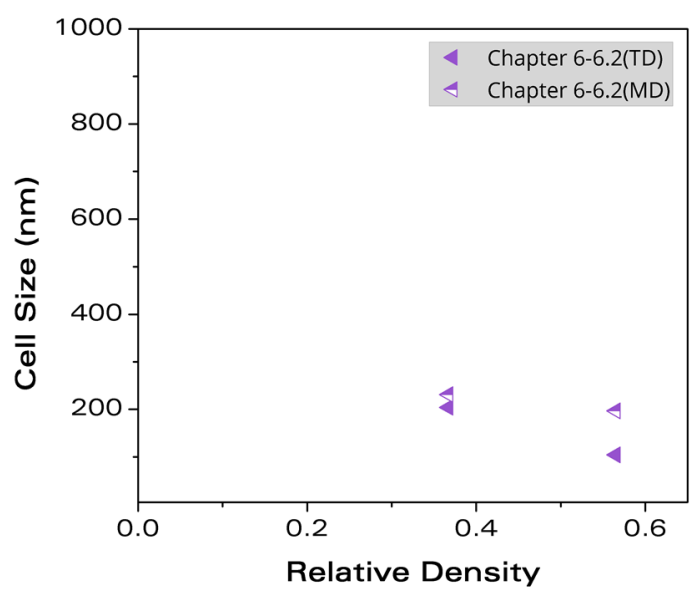

b)

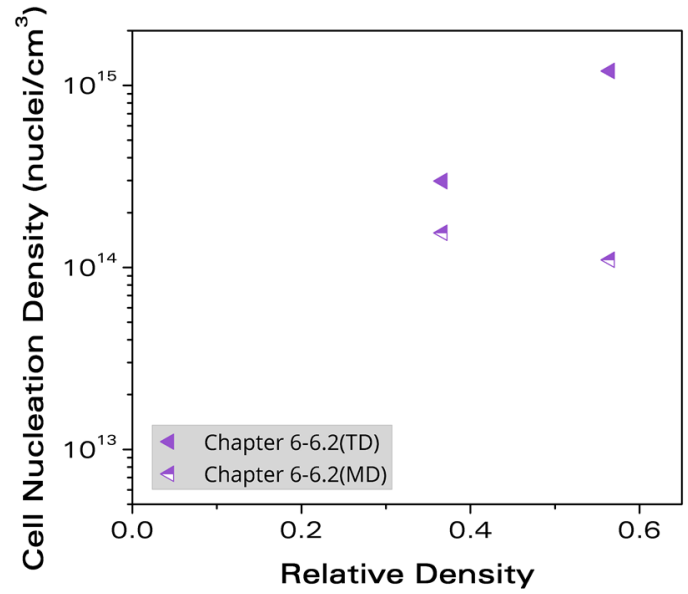

Figure 8.4. a) Cell size as a function of the relative density and b) cell nucleation density as a function of the relative density for the materials based on PMMA/MAM/sepiolites. For the materials with bimodal structures with micrometric pores, the cell size (Figure 8.4.a) correspond to the nanocellular region. The structures of both planes (machine direction (MD) and traverse direction (TD)) are presented.

\subsubsection{Fabrication: an overview}

Figure 8.5 shows a general overview of all the materials produced in this thesis (Chapter 4, Chapter 5 and Chapter 6). A wide range of cell sizes is covered thanks to the different approaches used (Figure 8.5.a). PMMA/MAM systems allow producing the lowest cell sizes, whereas PMMA/TPU is the material with the smallest relative density. On the other hand, PMMA/Sepiolites lead to bimodal materials and in some cases highly anisotropic nanocellular structures. Nanocellular polymers with cell sizes from 100 to $800 \mathrm{~nm}$ and relative densities between 0.15 and 0.6 have been obtained throughout this thesis. Regarding the cell nucleation density (Figure 8.5.b), materials with nucleation densities in the range from $10^{13}$ nuclei/ $\mathrm{cm}^{3}$ to $10^{15}$ nuclei/ $/ \mathrm{cm}^{3}$ have been produced. Regarding the nucleation efficiency, MAM is the nucleating agent that allows reaching the highest nucleation densities, especially at high MAM contents, whereas low concentration of sepiolites and foaming in the hot press produce the lowest nucleation densities.

Note that all of these materials can be produced at low pressures (10 MPa) and room temperature as saturation conditions, and most of them (except those based on PMMA/TPU) can be produced 
at a very low pressure (6 MPa), which is the pressure of the gas bottle. That is, most of the nanocellular polymers of this research can be produced without the need for a pressure pump or a heating/cooling system during the saturation stage.

a)
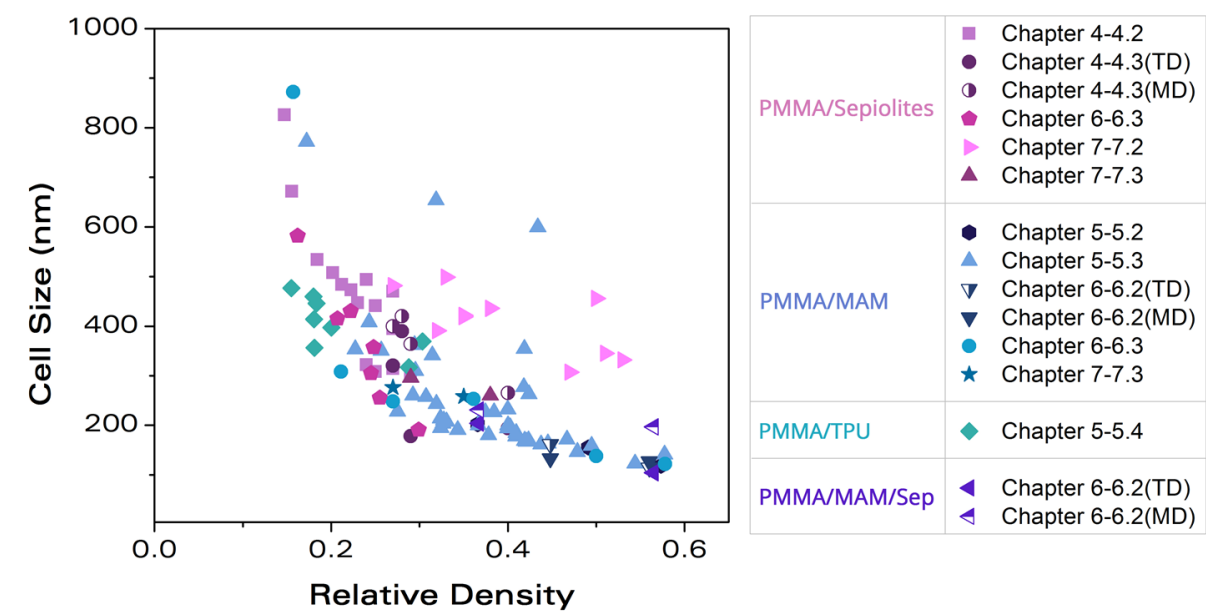

b)
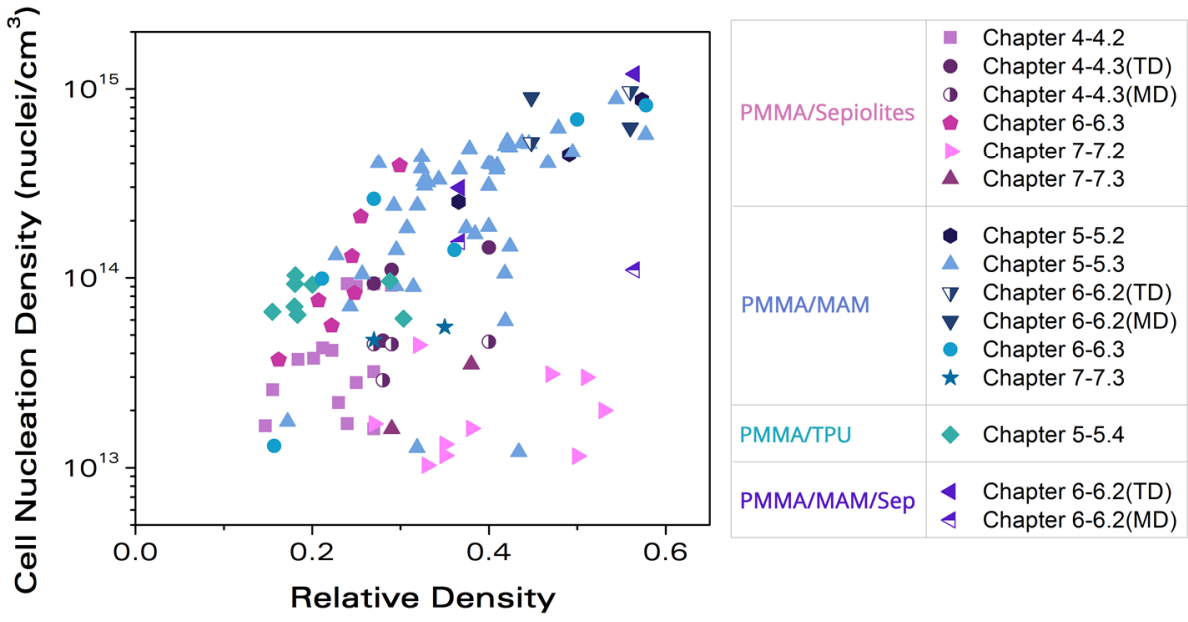

Figure 8.5. a) Cell size as a function of the relative density and b) cell nucleation density as a function of the relative density for all the materials in this thesis. In those materials with bimodal structures, the cell size (Figure 8.5.a) corresponds to the nanocellular part, whereas the cell nucleation density (Figure 8.5.b) is that on the complete structure. In the systems presenting anisotropic structures, the structures of both planes (machine direction (MD) and traverse direction (TD)) are presented. In the systems with a gradient structure (PMMA/TPU), the parameters correspond to the homogeneous nanocellular core.

\subsubsection{Properties of nanocellular polymers}

About the mechanical properties of PMMA/Sepiolites (Chapter 7, section 7.2):

- The addition of sepiolites (from 1 to $5 \mathrm{wt} \%$ ) to the solid PMMA produces an improvement in the elastic modulus and the compressive strength. However, the fracture toughness of 
the nanocomposites is significantly reduced compared to the pure PMMA due to the presence of micron-sized aggregates.

- In the nanocellular composites with a bimodal cellular structure, the relative mechanical properties in compression (that is, the elastic modulus and the compressive strength) seem to be unaltered by the presence of the particles in average (in the density range from 0.25 to 0.5 ) compared to a pure PMMA with a microcellular structure. However, at a high relative density (0.5), the relative modulus of the nanocomposites is higher than that of the pure PMMA for the nanocomposites with $1 \mathrm{wt} \%$ and $2 \mathrm{wt} \%$ of particles. For instance, an $18 \%$ enhancement of the modulus by the addition of $2 \mathrm{wt} \%$ sepiolites is observed. That is, the modulus is enhanced more than the reinforcement of the solid.

- The fracture toughness in the cellular nanocomposites is the same as that of the pure microcellular PMMA, that is, the decrease in toughness observed in the solids is not detected in the cellular materials. Thus, the relative toughness is higher in the samples with sepiolites over all the density. For instance, for the material with $3 \mathrm{wt} \%$ of sepiolites, the relative fracture toughness is higher than in the pure PMMA by more than $60 \%$.

- These enhancements in the relative properties are not a consequence of the nanometric pores of the bimodal systems, because microcellular PMMA/Sepiolites materials behave the same way.

- Therefore, the improvements are related to a synergy between the nanoparticles and the foaming process. On the one hand, foaming enhances the dispersion of the sepiolites (the number of large particle aggregates is reduced), and on the other hand, the micron-sized aggregates are placed inside the microcellular pores, so its adverse effect in the properties is somehow hidden.

About the thermal conductivity of bimodal nanocellular polymers (Chapter 7, section 7.3):

- A model to determine the thermal conductivity by conduction of nanocellular polymers with a bimodal cell size distribution is developed. This model takes into account the area fraction occupied by each cell size. For the cells in the nanometric range, the heat transfer by conduction is modeled taking into account the Knudsen effect (gas phase) and the variations with density in the structural factor (solid phase).

- This model provides accurate predictions of the conductivity of real bimodal systems based on PMMA/Sepiolites and PMMA/MAM (very low MAM fraction, $0.05 \mathrm{wt} \%$ ). The conductivity is intermediate between those of a purely micro- or nanocellular polymer. So it is necessary to consider the sizes of all the cells (and the volume they represent) to have a good estimation of the heat transfer by conduction in these systems.

- Moreover, this model can be applied to monomodal nanocellular polymers with a wide distribution of the cell size to take into account all the range of cell sizes. In fact, this model predicts significant variations of the conductivity once the cell size distribution is considered, especially for low relative densities and wide cell size distributions. It is demonstrated that the presence of a wide cell size distribution increases the thermal conductivity. 


\subsubsection{The last objective: understanding the heterogeneous nucleation mechanisms, advantages, and limitations}

One of the main goals of this research was "to achieve a deep understanding of the mechanisms involved in the formation of the cellular structure"(Chapter 1). That is, to gain knowledge about the physics involved in the formation of nanocellular polymers via a heterogeneous nucleation approach, with the aim of being able to control the process and identify its main advantages and limitations. From all the previously listed conclusions, some general remarks about the foaming behavior of these systems can be extracted:

* The addition of needle-like sepiolites is a promising strategy to produce nanocellular polymers. The dispersion of the particles in the polymer matrix, together with the surface modification of the nanoclay, are key aspects that control the nucleation efficiency. Ideally dispersed particles would produce very homogeneous nanocellular polymers with high nucleation ratios at low particle contents. The nucleation in the sepiolite nanoparticles predominates over a wide range of pressures.

* However, the rigid character of this additive combined with its needle-shape causes cell wall ruptures in the polymer-particle interface at high expansion ratios. Nevertheless, this effect can be exploited by aligning the nanoparticles in a given direction and selecting the direction of the cell coalescence. As a result, very anisotropic nanocellular structures can be obtained.

* The molecular weight of MAM is a tool to control the nanostructuration of the PMMA/MAM blend, and thus the cellular structure.

* The presence of nanometric micelles is a limiting factor in the expansion due to the organization of the molecules around the micelle and the spherical geometry they impose. However, once this limitation is identified, it can be overcome by changing the nucleation from the micelles to MAM-rich domains without structure. This can be done by reducing the concentration of MAM. This way, low relative densities can be achieved.

* PMMA/TPU immiscible blends are new promising materials to obtain low-density nanocellular polymers. However, the nucleation in the TPU phase is not predominant at any pressure. Using a PMMA matrix with a low viscosity seems to be adequate, but the foaming conditions affect significantly to the cellular structure, and, due to this, this system is more complicated because small variations in the process conditions could result in modifications of the cellular structure. In addition, the samples obtained are not homogeneous, but they present a gradient cellular structure with nanometric cells only in the central area of the foamed samples.

* Combining two effective nucleating agents such as MAM and sepiolites can lead to intermediate structures if the concentration of the two additives is low and to materials with very high anisotropy ratios, by adequately combining in just one direction the coalescence mechanisms associated to the two additives.

It is clear that the use of heterogeneous nucleation to produce nanocellular polymers present some strong points in comparison to the homogeneous approach. In particular, some of the most relevant advantages of the heterogeneous nucleation mechanism identified throughout this thesis are: 
Nanocellular polymers can be produced at mild processing conditions (saturation at room temperature $\left(25^{\circ} \mathrm{C}\right)$ and low-medium pressures (from $\left.6 \mathrm{MPa}\right)$ ).

$\checkmark$ The processing window for fabricating these materials is in general wide, because the nucleating agent controls the nucleation, and therefore variations in the saturation conditions do not affect the resultant cellular structures, i.e., the process is more robust, and more reproducible.

$\checkmark$ The nucleating agent controls the cellular structure, so a wide variety of morphologies can be obtained at the same conditions just by tuning the amount and/or type of the nucleants.

$\checkmark$ The addition of nanoparticles or the production of nanostructured polymer blends can yield to other improvements in the nanocellular samples, such as enhanced mechanical properties or modified toughness.

Nevertheless, this strategy also presents some drawbacks, at least with the materials and technologies available today. Some of the current limitations of the heterogeneous nucleation approach are:

* Obtaining very low cell sizes (under $50 \mathrm{~nm}$ ) seems to be complicated due to the size of the nucleating agents in that order of magnitude.

* Even if such cell sizes could be achieved, it is possible that transparent nanocellular polymers with additives cannot be produced, because the nucleating agent might disperse the light and avoid the transparency.

* The presence of the additives can also affect negatively to other properties (for instance, some nanoparticles increase the thermal conductivity).

Despite the drawbacks above, the heterogeneous nucleation strategy is nowadays one of the most promising route towards the industrial production of nanocellular polymers. The possibility of using mild processing conditions is the critical aspect that makes heterogeneous systems the most likely candidates for the future scale-up of the gas dissolution foaming process. Continuous approaches such as extrusion foaming could also be most easily implemented in heterogeneous systems. For all these reasons, the development of nanocellular polymers with this approach will continue to be on the spotlight in the coming years.

\subsection{Fabrication of nanocellular polymers: state of the art after this thesis}

Figure 8.6 presents a cell size - relative density map with the main results obtained so far using the heterogeneous nucleation route, including the results from the literature (references [1-32]). Note that some of the literature data included in this plot might correspond to 2D values of the cell size, whereas the data points for this thesis are real 3D values. The literature data are presented in Figure 8.6 and the next figures as extracted from the corresponding paper.

To have a better look into the results, Figure 8.7 presents the same results divided into the two approaches within the heterogeneous nucleation strategy: nanoparticles (Figure 8.7.a) and nanostructured polymer blends (Figure 8.7.b). The results obtained with the tri-phasic blends in this thesis are included in both graphs. Note that with the materials produced in this thesis a wide range of cell sizes and relative densities can be covered. 


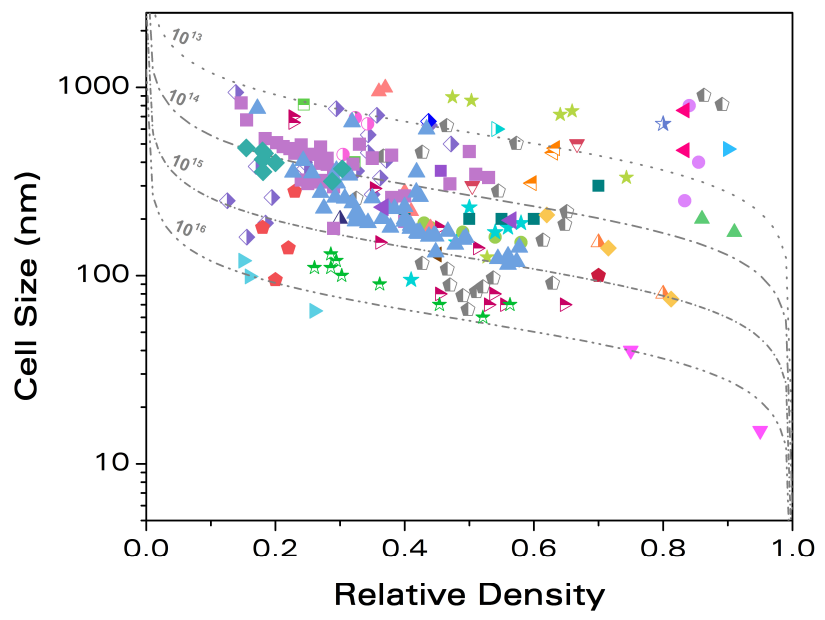

- PLA+O-MMT - [1] PS-PFDA - [9]

$\triangle \quad$ PLA+O-MMT - [2] $\quad \nabla$ PMMA-PFMA - [10]

- HDPE+O-MMT - [13] $\bigcirc \quad$ PMMA+MAM - [11]

PP+MWCNT - [24] $\triangle$ PMMA+MAM - [12]

$4 \mathrm{PC}+\mathrm{SiO} 2-[27] \quad \mathrm{MAM}-[12]$

* $\mathrm{PC}+\mathrm{O}-\mathrm{FH}-[28] \quad \star \quad \mathrm{PMMA}+\mathrm{MAM}-[14]$

- $\mathrm{PMMA}+\mathrm{SIO} 2-[29] \quad \mathrm{PMMA}+\mathrm{MAM}-[15]$

$\rightarrow$ PMMA+POSS - [29] $\backslash$ ABS - [16]

$\triangle$ SAN+POSS-[29] $\triangle$ PEEK+PEI - [18]

$\rightarrow$ SAN+O-MMT - [30] $\$ PMMA+TPU - [23]

* PMMA+ZnO-[31] $\rightarrow$ PMMA+MAM-[25]

- $\mathrm{PMMA}+\mathrm{SiO} 2-[32] \star \mathrm{PMMA}+\mathrm{MAM}-[26]$

(1) $\mathrm{PS}+\mathrm{SiO} 2$ - [32]

- PMMA+OMS - [3]

1) PEI+POSS - [6]

$\rightarrow$ PMMA+O-MMT - [4]

b $\mathrm{PC}+\mathrm{MWCNT}-[5]$

PMMA/Sep (this work)

PMMA/MAM (this work)

PMMA/TPU (this work)

PMMA/MAM/Sep (this work)

Figure 8.6. Cell size - relative density map summarizing the main results of the production of nanocellular polymers using a heterogeneous nucleation approach, including the results of this thesis. Discontinuous lines represent curves of constant cell nucleation density (from $10^{13}$ to $10^{16}$ nuclei/ $\mathrm{cm}^{3}$ ) according to the theoretical prediction of equation (2.3).

a)

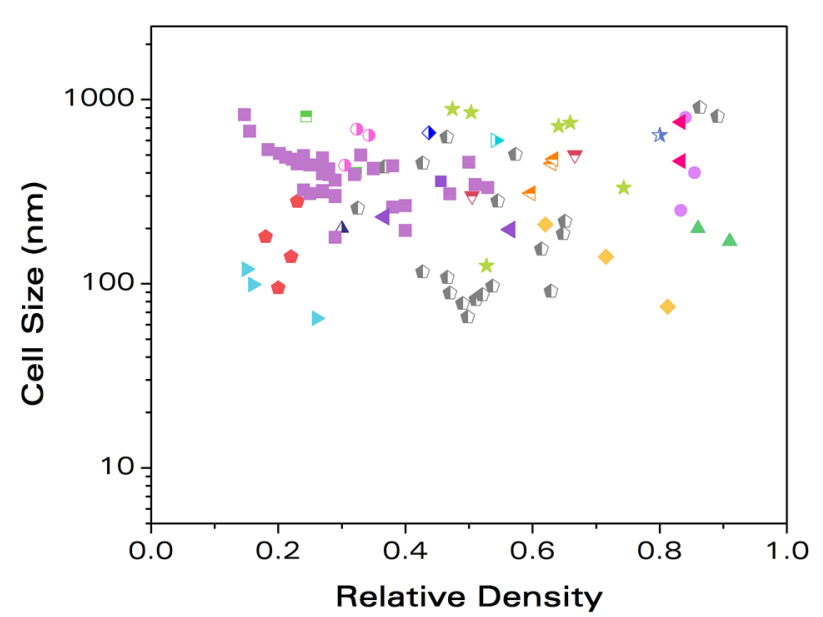

- PLA+O-MMT - [1]

$\triangle \quad$ PLA+O-MMT - [2]

- HDPE+O-MMT - [13]

- PP+MWCNT - [24]

$4 \mathrm{PC}+\mathrm{SiO} 2-[27]$

* $\mathrm{PC}+\mathrm{O}-\mathrm{FH}-[28]$

- PMMA+SiO2 - [29]

> PMMA+POSS - [29]

a SAN+POSS - [29]

$\nabla$ SAN+O-MMT - [30]

* $\mathrm{PMMA}+\mathrm{ZnO}-[31]$

- PMMA+SIO2 - [32]

(1) $\mathrm{PS}+\mathrm{SiO} 2-[32]$

- PMMA+OMS - [3]

- PEI+POSS - [6]

4 PMMA+O-MMT - [4]

1) $\mathrm{PC}+\mathrm{MWCNT}-[5]$

PMMA+SEP (this work)

PMMA+MAM+SEP (this work)

b)

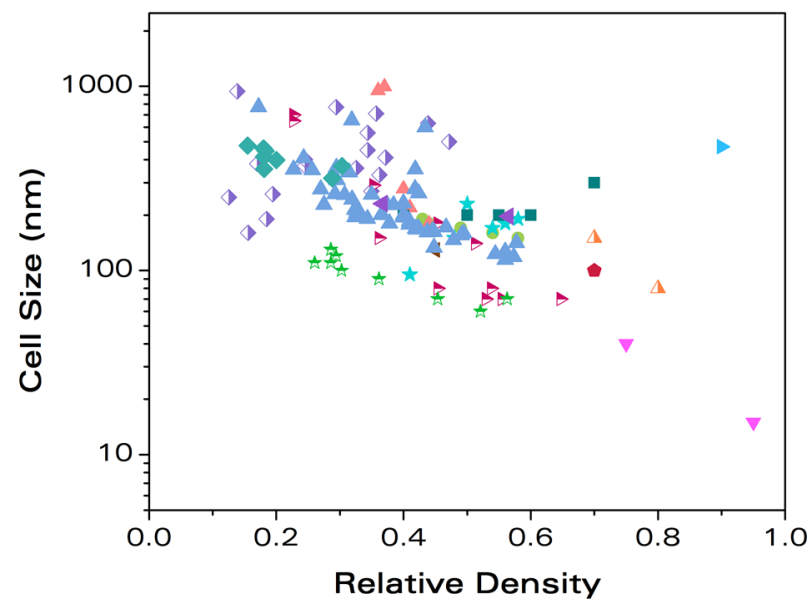

PS-PFDA - [9]

$\checkmark$ PMMA-PFMA - [10]

- PMMA+MAM - [11]

- PMMA+MAM - [12]

4 MAM - [12]

* PMMA+MAM - [14]

- PMMA+MAM - [15]

- ABS - [16]

1 PEEK+PEI - [18]

\ PMMA+TPU - [23]

- PMMA+MAM - [25]

t PMMA+MAM - [26]

PMMA+MAM (this work)

PMMA+TPU (this work)

PMMA+MAM+SEP (this work)

Relative Density

Figure 8.7. Cell size - relative density map summarizing the main results of the production of nanocellular polymers using the two strategies in the heterogeneous nucleation approach: a) nanoparticles, and b) nanostructured polymer blends. 
For the PMMA/MAM blends, the results of this work provide the lowest relative densities ever achieved in the literature using MAM as the nucleating agent. With the systems based on PMMA/Sepiolites and PMMA/TPU, it was possible to reach the lowest relative densities in the literature (around 0.15), but with higher cell sizes than those obtained with $\mathrm{PMMA} \mathrm{SiO}_{2}$ and PMMA+POSS [29], and PMMA+TPU [23]. However, recall that the materials of Costeux et al. with nanoparticles [29] were produced at very high pressures (30 MPa), and also the cell size in that paper was determined as a 2D value. The results of Wang with PMMA/TPU [23] were obtained using medium pressures, but an extra cooling step (under $0^{\circ} \mathrm{C}$ ) before the pressure release was applied. As a counterpart, most of the materials in this work were produced at low/medium pressure (6-10 $\mathrm{MPa}$ ) and using a regular two-step foaming procedure.

Finally, the results obtained in the papers of this thesis and the saturation conditions needed to produce these materials are compared with the most relevant results obtained in the literature, both with heterogeneous systems and the other approach, that is, the homogeneous nucleation methodology. Figure 8.8.a shows a 3D plot relating the cell size with the saturation pressure and temperature for various works from the literature and the papers of this thesis. In this case, only systems based on PMMA are included to make a fair comparison among the results (see Chapter 2 for a general overview of the processing conditions used for different polymer matrices). The homogeneous systems based on PMMA in Figure 8.8 were extracted from references [33-38]. 2D projections of Figure 8.8.a have been included for clarification. Figure 8.8.b and Figure 8.8.a show the cell size versus the saturation pressure and temperature, respectively, and Figure 8.8.c shows the saturation pressure - saturation temperature graph.

The materials of this work were produced mainly at low pressure (6-10 MPa), but it was also possible to produce them at higher pressure (from 15 to $30 \mathrm{MPa}$ ) (Figure 8.8.b). Regarding temperature, all the samples of this thesis were obtained with saturation at room temperature (Figure 8.8.c). Thus, the processing window to produce these materials can be considered as mild-processing conditions, that however provide promising results (Figure 8.8.d).

To take into account both saturation parameters (pressure and temperature), the amount of $\mathrm{CO}_{2}$ uptake (that is, the solubility) can be used as a reference. Figure 8.9.a presents a 3D plot of the cell size, the relative density and the solubility for the different PMMA-based systems included in the previous figure. The solubility data were extracted from the respective paper when specified. Otherwise, it was interpolated from other available data in the literature. 2D plots are presented together with the 3D graph for clarification: Figure 8.9.b and Figure 8.9.c show the relative density and the cell size as a function of the amount of gas uptake, respectively, while Figure 8.9.d presents a cell size - relative density map. The range of solubilities covered in this work goes from $22 \mathrm{wt} \%$ to around $30 \mathrm{wt} \%$, so the materials and production routes developed throughout this thesis allow obtaining nanocellular structures in a wide range of cell sizes and relative densities without needing demanding saturation conditions. The best results regarding cell size - relative density in the literature were obtained at solubilities higher than those used with the systems produced in this work. 


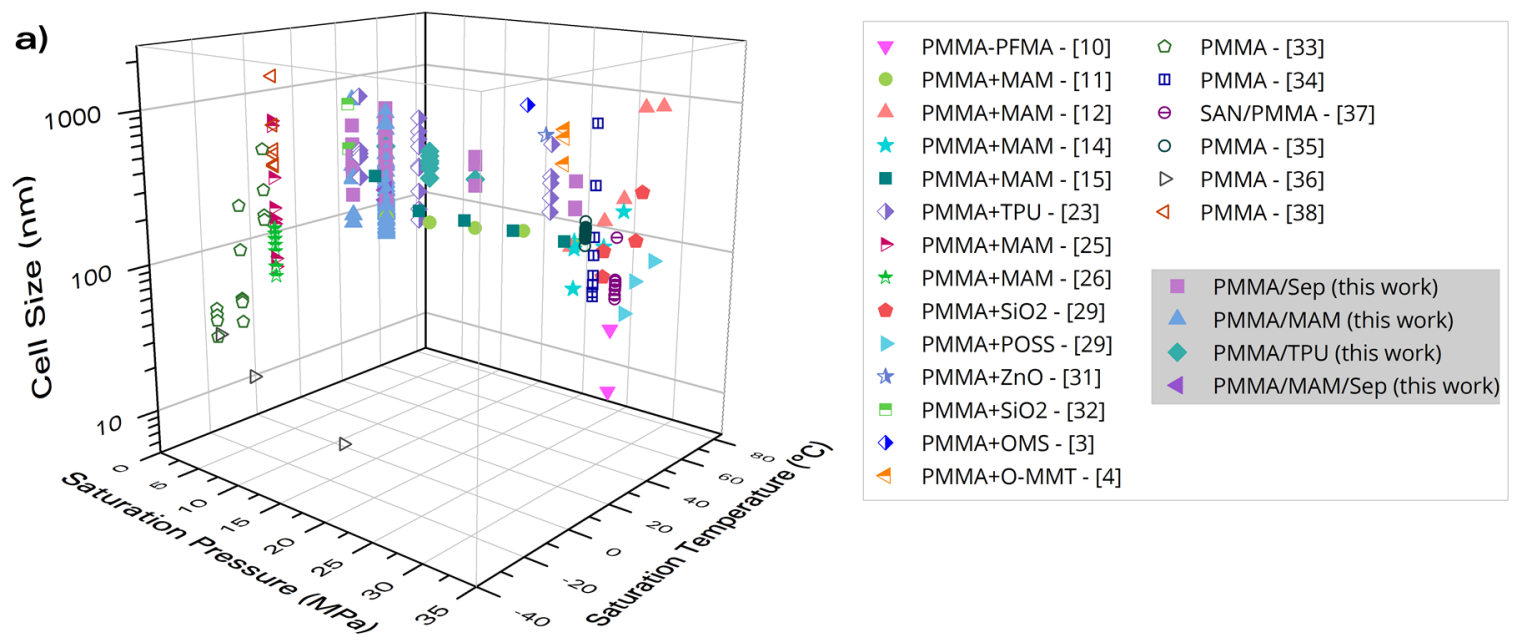

b)

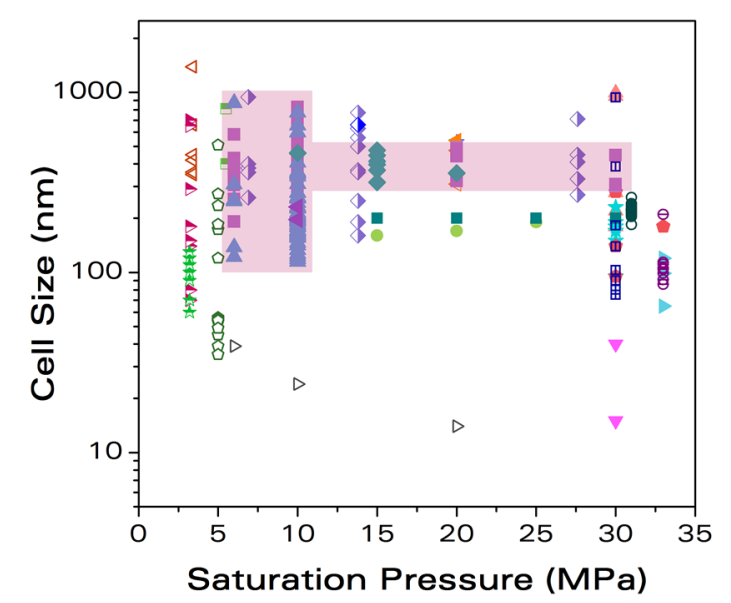

c)

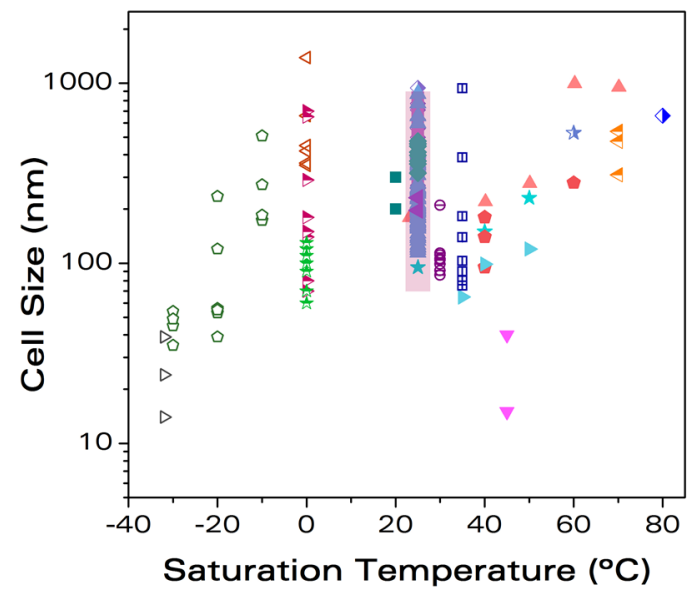

d)

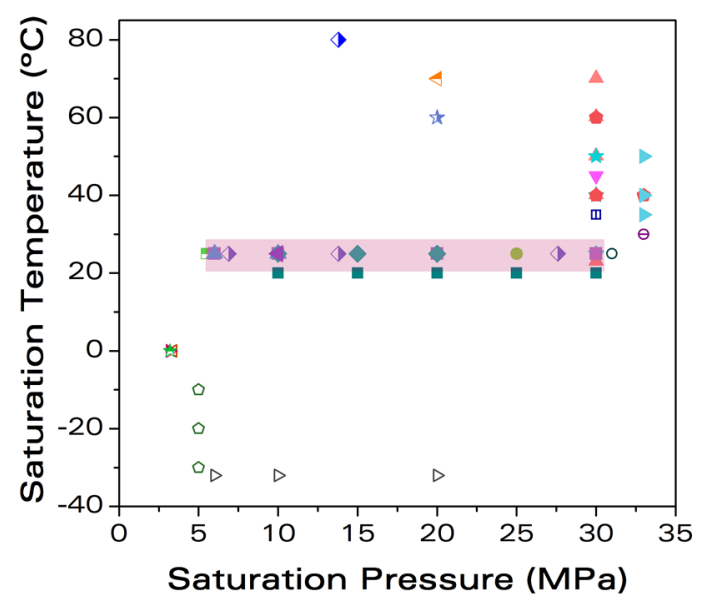

This work

Figure 8.8. a) Cell size - saturation temperature - saturation pressure 3D map for different systems based on PMMA and the materials produced in this thesis, and 2D projections: $b$ ) cell size - saturation pressure, c) cell size - saturation temperature, and c) saturation temperature saturation pressure (results of this work shaded in pink). 
a)

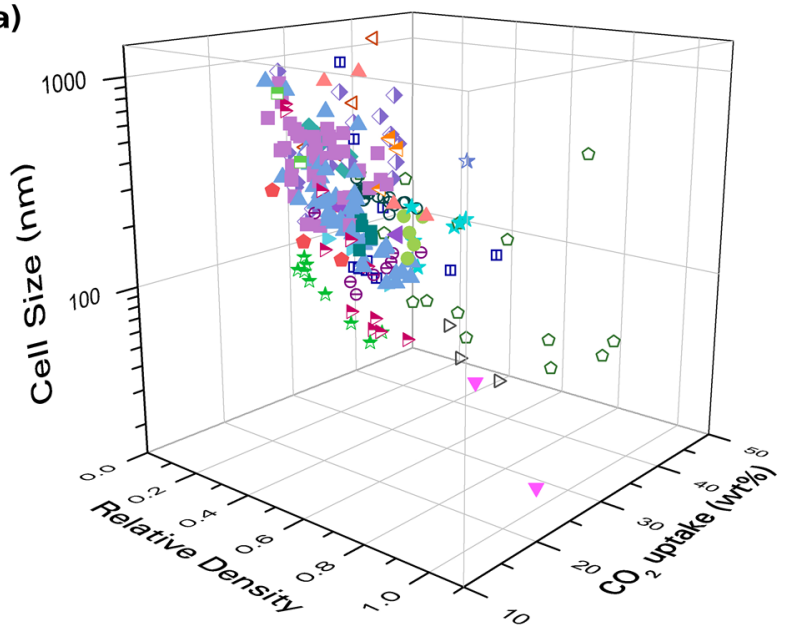

PMMA-PFMA - [10]

PMMA+MAM - [11]

PMMA+MAM - [12]

PMMA+MAM - [14]

PMMA+MAM - [15]

PMMA+TPU - [23]

PMMA+MAM - [26]

$\rightarrow$ PMMA+MAM - [25]

- PMMA+SiO2 - [29]

PMMA+POSS - [29]

$P M M A+Z n O-[31]$

$\mathrm{PMMA}+\mathrm{SiO} 2$ - [32]

PMMA+O-MMT - [4]
- PMMA - [33]

PMMA - [34]

- PMMA - [35]

$D$ PMMA - [36]

$\ominus$ SAN/PMMA - [37]

$\triangleleft$ PMMA - [38]

PMMA/Sep (this work)

PMMA/MAM (this work)

PMMA/TPU (this work)

PMMA/MAM/Sep (this work) b)

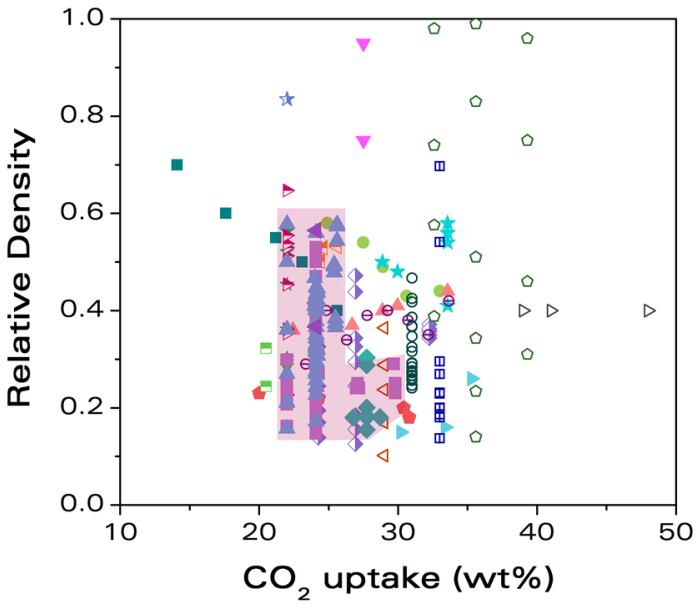

c)

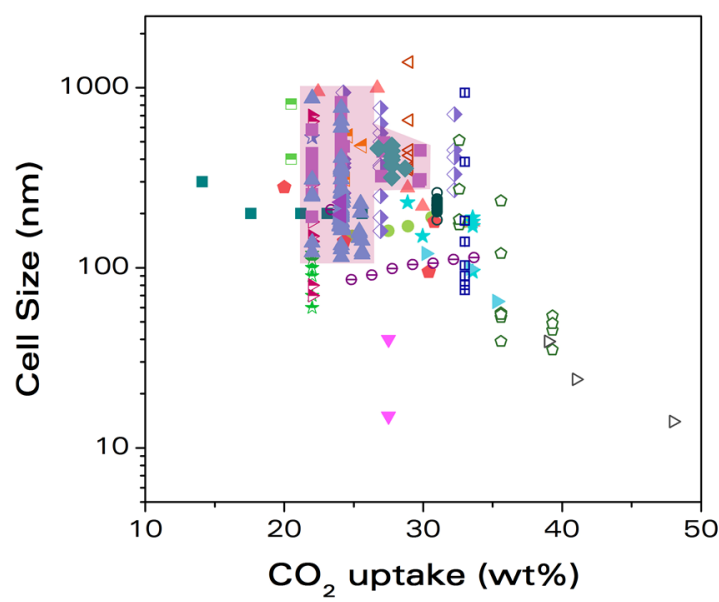

d)

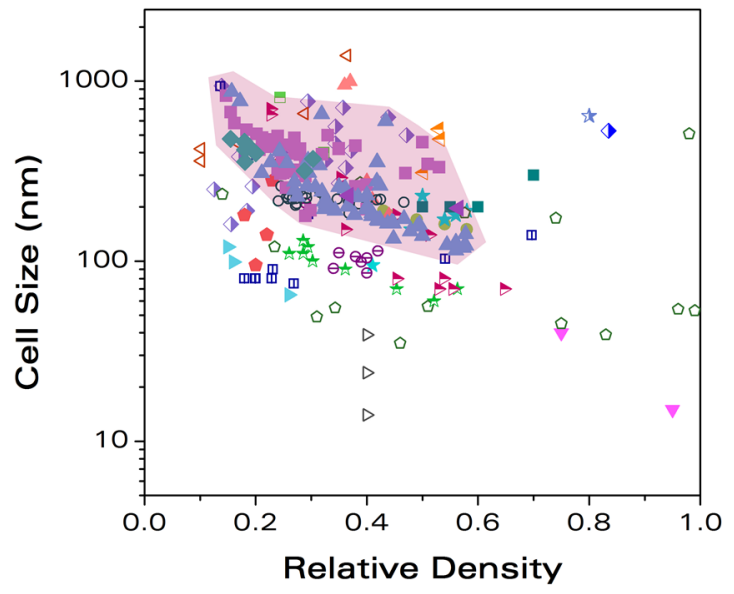

This work

Figure 8.9. a) Cell size - relative density - $\mathrm{CO}_{2}$ uptake 3D map for PMMA-based systems and the materials of this work, and 2D projections: b) relative density $-\mathrm{CO}_{2}$ uptake, c) cell size $-\mathrm{CO}_{2}$ uptake, and d) cell size - relative density (results of this work shaded in pink). 


\subsection{Future work}

The present work is the third thesis about nanocellular polymers in CellMat Laboratory. As nanocellular polymers are one of the main research topics in CellMat [39], it is expectable that the knowledge gained with the development of this thesis would be a starting point for future research in this area. In particular, some aspects only superficially treated in this work could be investigated in more detail in future research activities. The following list includes some of these topics that could be studied in more detail in the coming investigations:

- Effect of the viscosity of the PMMA matrix: The way towards low-density nanocellular materials would require further optimization of the PMMA matrix. The same formulations developed in this thesis could be produced with different PMMA matrices with the aim of correlating the viscosity of the PMMA with the dispersion of the nucleating agents and lately the cellular structure and density of the nanocellular polymers. Some preliminary results obtained in the last stages of this thesis indicate that the influence of the matrix is critical. Blends of more than one PMMA grade could also be studied with the aim of optimizing the expansion capability of the systems. Also, some preliminary studies conducted at the end of this work suggest that this could be an interesting research line.

- Effect of the extrusion parameters in the dispersion of the nucleating species: It is clear that the dispersion of the sepiolites can be further improved, and this could be investigated by making a systematic study of the extrusion parameters. Also, the nanostructuration in the PMMA/MAM and the PMMA/TPU samples depends on the screw speed during the extrusion, so it could be optimized to obtain the maximum number of nucleation points with the minimum amount of additive. This could allow increasing the cell nucleation density.

- Investigating TPU as a promising nucleating agent: The results obtained so far indicate that TPU has a strong potential to become a good nucleating agent in PMMA, but further studies are needed. To begin with, different TPU grades covering a range of viscosities and crystallinities could be tested. The concentration of TPU can also be analyzed. Also, the viscosity of the PMMA matrix and the extrusion conditions could be optimized. Another interesting idea could the use of the opposite blends, TPU/PMMA, where PMMA is the nucleating agent, with the aim of producing flexible nanocellular polymers.

- The limits of the heterogeneous nucleation efficiency - low-pressure production: The saturation pressure could be reduced to investigate the limits of the efficiency of the different nucleating agents, although this would compromise the saturation times. In this sense, smaller samples could be helpful.

- The other limit - low-temperature production: It would also be interesting to investigate the limits in the high solubility range, for instance by strongly reducing the saturation temperature. Apart from the academic relevance, from a technological point of view, it would be interesting to know if very small cell sizes can be obtained even though there are nucleating species of higher size. Extremely small cell sizes could lead to interesting properties (such as transparency and very low heat transfer by conduction through the gas phase), whereas the nucleating species could be used to control the physical 
properties (such as the mechanical performance or the heat transfer through the solid or by radiation).

- New nucleating species. Other nanoparticles and polymers can be tested to evaluate their effects in the nucleation process of PMMA. For instance, immiscible PMMA/PS blends could be investigated. Also, nanoparticles that absorb infrared radiation, such as carbon nanotubes or graphene, would be very interesting, since they would allow reducing the conductivity by decreasing the conduction through the radiation mechanism.

- Structure-property characterization:There is still a need for a detailed characterization of the properties of nanocellular polymers in a wide range of cell sizes. Thermal properties and mechanical properties could be measured to establish the structure-property relationships and the influence of the nucleating species in the performance of these materials. Another area of interest would be analyzing the effect of anisotropy on the physical properties of nanocellular polymers. Some of the systems developed in this thesis could be very useful for this purpose.

- Modeling. The research work conducted in this thesis has allowed improving the models to predict the thermal conductivity of nanocellular polymers by introducing in the model the effect of having a cell size distribution. However, there is still a need to understand the heat conduction by radiation in these materials. Both experimental work and modeling work on this topic would be of great interest.

- The scale-up: One important step would be producing these systems using scalable-up production routes. One possible way could be the extrusion route, using a tandem extrusion line with a gas injection system. This is a real possibility since the pressures and temperatures used in this work allow to produce these materials in the range of processing conditions used in this technology. In this sense, it would also interesting testing some of the formulations developed in this thesis using the one-step gas dissolution foaming, which can simulate in a better way the behavior of the material in the die on an extrusion machine. Similarly, injection foaming can also be an alternative to produce nanocellular parts. All these methods and others could be evaluated to identify the best alternative for the future industrial production of nanocellular polymers.

\subsection{References}

[1] Y. Fujimoto, S.S. Ray, M. Okamoto, A. Ogami, K. Yamada, K. Ueda, Well-Controlled Biodegradable Nanocomposite Foams: From Microcellular to Nanocellular, Macromol. Rapid Commun. 24 (2003) 457-461. doi:10.1002/marc.200390068.

[2] Y. Ema, M. Ikeya, M. Okamoto, Foam processing and cellular structure of polylactide-based nanocomposites, Polymer (Guildf). 47 (2006) 5350-5359. doi:10.1016/j.polymer.2006.05.050.

[3] J. Yang, L. Huang, Y. Zhang, F. Chen, P. Fan, M. Zhong, S. Yeh, A new promising nucleating agent for polymer foaming: Applications of ordered mesoporous silica particles in polymethyl methacrylate supercritical carbon dioxide microcellular foaming, Ind. Eng. Chem. Res. 52 (2013) 14169-14178. doi:10.1021/ie4018447.

[4] V. Realinho, M. Antunes, A.B. Martínez, J.I. Velasco, Influence of nanoclay concentration on the CO2 diffusion and physical properties of PMMA montmorillonite microcellular foams, Ind. Eng. Chem. Res. 50 (2011) 1381913824. doi:10.1021/ie201532h.

[5] L. Monnereau, L. Urbanczyk, J.M. Thomassin, M. Alexandre, C. Jérôme, I. Huynen, C. Bailly, C. Detrembleur, Supercritical CO2 and polycarbonate based nanocomposites: A critical issue for foaming, Polymer (Guildf). 55 
(2014) 2422-2431. doi:10.1016/j.polymer.2014.03.035.

[6] H. Yu, Y. Lei, X. Yu, X. Wang, T. Liu, S. Luo, Solid-state polyetherimide (PEI) nanofoams: the influence of the compatibility of nucleation agent on the cellular morphology, J. Polym. Res. 23 (2016) 121. doi:10.1007/s10965-016-1009-2.

[7] H. Yokoyama, L. Li, T. Nemoto, K. Sugiyama, Tunable nanocellular polymeric monoliths using fluorinated block copolymer templates and supercritical carbon dioxide, Adv. Mater. 16 (2004) 1542-1546. doi:10.1002/adma.200400072.

[8] H. Yokoyama, K. Sugiyama, Nanocellular structures in block copolymers with CO2-philic blocks using CO2 as a blowing agent: Crossover from micro- to nanocellular structures with depressurization temperature, Macromolecules. 38 (2005) 10516-10522. doi:10.1021/ma051757j.

[9] J.A. Reglero-Ruiz, E. Cloutet, M. Dumon, Investigation of the Nanocellular Foaming of Polystyrene in Supercritical CO2 by Adding a CO2-Philic Perfluorinated Block Copolymer, J. Appl. Polym. Sci. 121 (2012) 3845. doi:10.1002/app.

[10] C. Dutriez, K. Satoh, M. Kamigaito, H. Yokoyama, Nanocellular foaming of fluorine containing block copolymers in carbon dioxide: The role of glass transition in carbon dioxide, RSC Adv. 2 (2012) 2821-2827. doi:10.1039/c2ra01268e.

[11] J. Pinto, M. Dumon, M. Pedros, J. Reglero, M.A. Rodriguez-Perez, Nanocellular CO2 foaming of PMMA assisted by block copolymer nanostructuration, Chem. Eng. J. 243 (2014) 428-435. doi:10.1016/j.cej.2014.01.021.

[12] J. Pinto, J.A. Reglero-Ruiz, M. Dumon, M.A. Rodriguez-Perez, Temperature influence and CO2 transport in foaming processes of poly(methyl methacrylate)-block copolymer nanocellular and microcellular foams, J. Supercrit. Fluids. 94 (2014) 198-205. doi:10.1016/j.supflu.2014.07.021.

[13] Y.H. Lee, C.B. Park, K.H. Wang, HDPE-Clay Nanocomposite Foams Blown with Supercritical CO2, J. Cell. Plast. 41 (2005) 487-502. doi:10.1177/0021955X05056964.

[14] J. Pinto, M. Dumon, M.A. Rodriguez-Perez, R. Garcia, C. Dietz, Block Copolymers Self-Assembly Allows Obtaining Tunable Micro or Nanoporous Membranes or Depth Filters Based on PMMA; Fabrication Method and Nanostructures, J. Phys. Chem. C. 118 (2014) 4656-4663. doi:10.1021/jp409803u.

[15] J.A. Reglero Ruiz, M. Dumon, J. Pinto, M.A. Rodriguez-Perez, Low-density nanocellular foams produced by high-pressure carbon dioxide, Macromol. Mater. Eng. 296 (2011) 752-759. doi:10.1002/mame.201000346.

[16] A.V. Nawaby, Y.P. Handa, X. Liao, Y. Yoshitaka, M. Tomohiro, Polymer-CO2 systems exhibiting retrograde behavior and formation of nanofoams, Polym. Int. 56 (2007) 67-73. doi:10.1002/pi.2112.

[17] T. Otsuka, K. Taki, M. Ohshima, Nanocellular foams of PS/PMMA polymer blends, Macromol. Mater. Eng. 293 (2008) 78-82. doi:10.1002/mame.200700257.

[18] T. Nemoto, J. Takagi, M. Ohshima, Nanocellular Foams-Cell Structure Difference Between Immiscible and Miscible PEEK/PEI Polymer Blends, Polym. Eng. Sci. 50 (2010) 2408-2416. doi:10.1002/pen.

[19] D. Bao, X. Liao, T. He, Q. Yang, G. Li, Preparation of nanocellular foams from polycarbonate/poly(lactic acid) blend by using supercritical carbon dioxide, J. Polym. Res. 20 (2013). doi:10.1007/s10965-013-0290-6.

[20] T. Nemoto, J. Takagi, M. Ohshima, Nanoscale cellular foams from a poly(propylene)-rubber blend, Macromol. Mater. Eng. 293 (2008) 991-998. doi:10.1002/mame.200800184.

[21] T. Nemoto, J. Takagi, M. Ohshima, Control of bubble size and location in nano-/microscale cellular poly(propylene)/rubber blend foams, Macromol. Mater. Eng. 293 (2008) 574-580. doi:10.1002/mame.200800015.

[22] R.W.B. Sharudin, M. Ohshima, CO2-induced mechanical reinforcement of polyolefin-based nanocellular foams, Macromol. Mater. Eng. 296 (2011) 1046-1054. doi:10.1002/mame.201100085.

[23] G. Wang, J. Zhao, L.H. Mark, G. Wang, K. Yu, C. Wang, C.B. Park, G. Zhao, Ultra-tough and super thermalinsulation nanocellular PMMA/TPU, Chem. Eng. J. 325 (2017) 632-646. doi:10.1016/j.cej.2017.05.116.

[24] A. Ameli, M. Nofar, C.B. Park, Polypropylene/carbon nanotube nano/microcellular structures with high dielectric permittivity, low dielectric loss, and low percolation threshold, Carbon N. Y. 71 (2014) 206-207. doi:10.1016/j.carbon.2014.01.031.

[25] C. Forest, P. Chaumont, P. Cassagnau, B. Swoboda, P. Sonntag, CO2 nano-foaming of nanostructured PMMA, Polymer (Guildf). 58 (2015) 76-87. doi:10.1016/j.polymer.2014.12.048.

[26] C. Forest, P. Chaumont, P. Cassagnau, B. Swoboda, P. Sonntag, Nanofoaming of PMMA using a batch CO2 process: Influence of the PMMA viscoelastic behaviour, Polymer (Guildf). 77 (2015) 1-9. 
doi:10.1016/j.polymer.2015.09.011.

[27] W. Zhai, J. Yu, L. Wu, W. Ma, J. He, Heterogeneous nucleation uniformizing cell size distribution in microcellular nanocomposites foams, Polymer (Guildf). 47 (2006) 7580-7589. doi:10.1016/j.polymer.2006.08.034.

[28] Y. Ito, M. Yamashita, M. Okamoto, Foam Processing and Cellular Structure of Polycarbonate-Based Nanocomposites, 291 (2006) 773-783. doi:10.1002/mame.200600075.

[29] S. Costeux, L. Zhu, Low density thermoplastic nanofoams nucleated by nanoparticles, Polymer (Guildf). 54 (2013) 2785-2795. doi:10.1016/j.polymer.2013.03.052.

[30] L. Urbanczyk, C. Calberg, C. Detrembleur, C. Jérôme, M. Alexandre, Batch foaming of SAN/clay nanocomposites with scCO2: A very tunable way of controlling the cellular morphology, Polymer (Guildf). 51 (2010) 3520-3531. doi:10.1016/j.polymer.2010.05.037.

[31] J. Pinto, D. Morselli, V. Bernardo, B. Notario, D. Fragouli, M.A. Rodriguez-Perez, A. Athanassiou, Nanoporous PMMA foams with templated pore size obtained by localized in situ synthesis of nanoparticles and CO2 foaming, Polymer (Guildf). 124 (2017) 176-185. doi:10.1016/j.polymer.2017.07.067.

[32] S. Liu, B. Zoetebier, L. Hulsman, Y. Zhang, J. Duvigneau, G.J. Vancso, Nanocellular polymer foams nucleated by core-shell nanoparticles, Polymer (Guildf). 104 (2016). doi:10.1016/j.polymer.2016.09.016.

[33] H. Guo, A. Nicolae, V. Kumar, Solid-state poly(methyl methacrylate) (PMMA) nanofoams. Part II: Lowtemperature solid-state process space using CO2 and the resulting morphologies, Polymer (Guildf). 70 (2015) 231-241. doi:10.1016/j.polymer.2015.06.031.

[34] S. Costeux, I. Khan, S.P. Bunker, H.K. Jeon, Experimental study and modeling of nanofoams formation from single phase acrylic copolymers, J. Cell. Plast. 51 (2015) 197-221. doi:10.1177/0021955X14531972.

[35] J. Martin de-Leon, V. Bernardo, M.A. Rodriguez-Perez, Low Density Nanocellular Polymers Based on PMMA Produced by Gas Dissolution Foaming: Fabrication and Cellular Structure Characterization, Polymers (Basel). 8 (2016) 1-16. doi:10.3390/polym8070265.

[36] J. Martin-de Leon, V. Bernardo, M.A. Rodriguez-Perez, Key Production Parameters to Obtain Transparent Nanocellular PMMA, Macromol. Mater. Eng. 1700343 (2017) 1-5. doi:10.1002/mame.201700343.

[37] S. Costeux, S.P. Bunker, Homogeneous nanocellular foams from styrenic-acrylic polymer blends, J. Mater. Res. 17 (2013) 2351. doi:10.1557/jmr.2013.100.

[38] Y.P. Handa, Z. Zhang, A New Technique for Measuring Retrograde Vitrification in Polymer-Gas Systems and for Making Ultramicrocellular, J. Polym. Sci. Part B Polym. Phys. 38 (2000) 716-725. doi:10.1002/(SICI)10990488(20000301)38:5<716::AID-POLB9>3.0.CO;2-N.

[39] CellMat Laboratory Webpage, Accesed April 2019. (n.d.). http://cellmat.es/. 
